

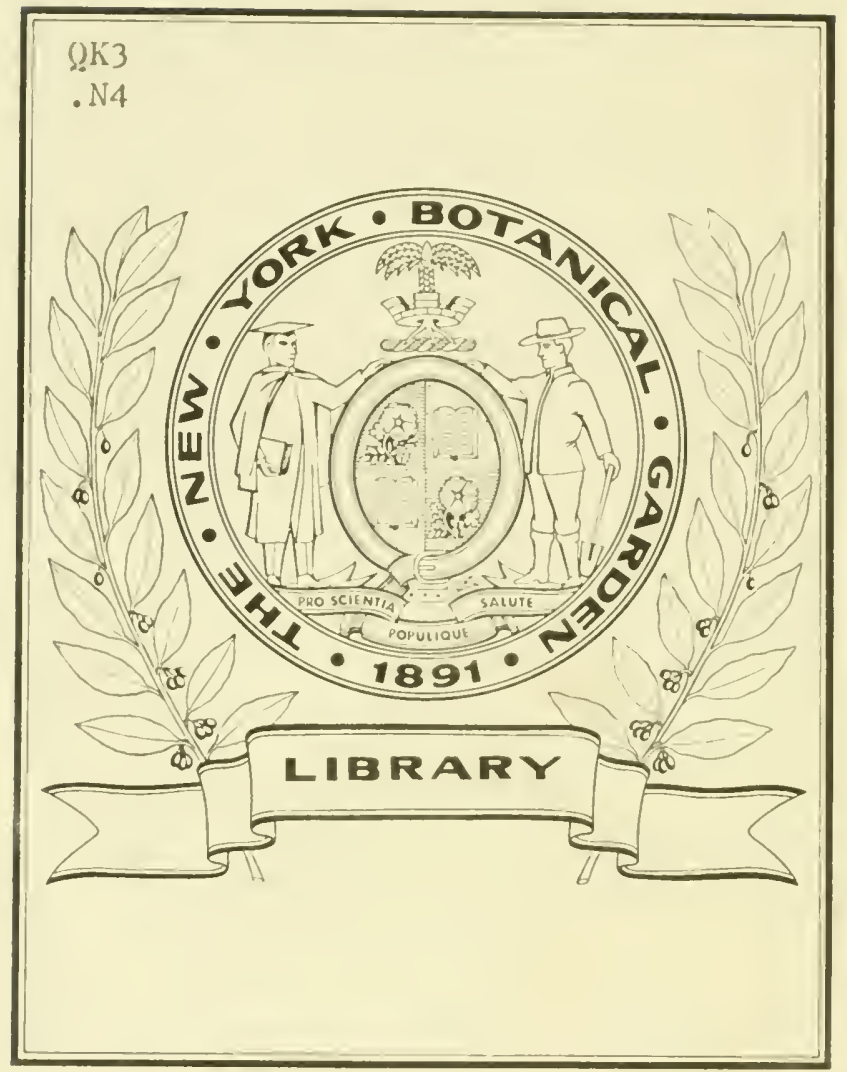










\author{
MEMOIRS \\ OF THE \\ New York Botanical Garden \\ VOL. VI \\ PAPERS \\ PRESENTED AT THE \\ Celebration of the Twentieth Anniversary \\ or \\ The New York Botanical Garden
}

September 6 9, 1915

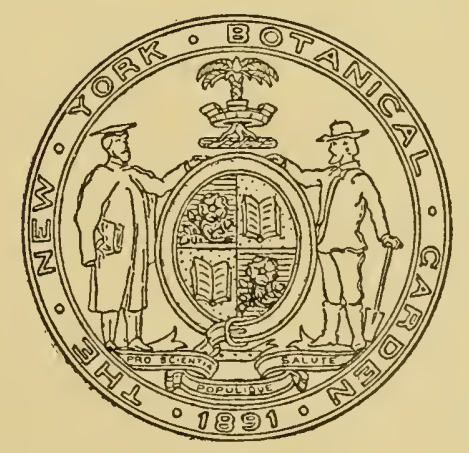

ISSUED A ugust 31, 1916 



\title{
PAPERS
}

PRESENTED AT THE

\section{Celebration of the Twentieth Anniversary \\ OF \\ The New York Botanical Garden}

September 6 9, I9I5

\author{
Published by the Aid of the \\ DAVID LYDIG FUND \\ Bequeathed by Charles P. Daly
}

NEW YORK

r916 
.04

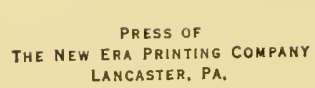




\section{PREFACE}

The papers herewith published are arranged essentially in the order of their presentation as indicated in the general account of the Twentieth Anniversary Celebration published in the Journal of The New York Botanical Garden for October, I9I5. Three of the papers presented are here omitted for the reason that they have been, in substance, already published elsewhere in accordance with prior engagements. " Collybia in North America," by W. A. Murrill, was essentially a summary, along statistical and geographic lines, of the monograph of the genus Gymnopus (Collybia) which subsequently appeared in the North American Flora (9: $352-374.7$ Je I9r6). The main facts of the paper by R. S. Williams on "Philippine Island mosses collected by J. B. Leiberg" are to be found in a paper entitled "Mosses of the Philippine and Hawaiian Islands collected by the late John B. Leiberg," published in the Bulletin of the Torrey Botanical Club $(42: 57 \mathrm{I}-577$. I3 $\mathrm{N}$ 1915). Likewise, the substance of the paper by B. O. Dodge on the "Influence of the host on the morphology of the roestelia," appeared in the Bulletin of the Torrey Botanical Club (42: 519542. pl. 28, 29. $5 \mathrm{~N}$ I9I5) under the title, "The effect of the host on the morphology of certain species of Gymnosporangium." Six other papers actually read are omitted because of obligations to publish elsewhere, or because they were considered by their authors to be too incomplete or preliminary to justify publication at the present time, or for other reasons. Of the papers read by title, only one (that by W. J. Beal) is included in the present volume.

Marshall A. Howe, Editor 



\section{CONTENTS}

Thompson, W. Gilman. Address of welcome............. I

MacDougal, D. T. The mechanism and conditions of growth

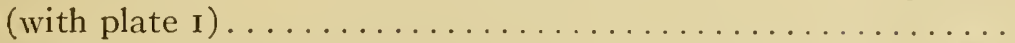

Thompson, W. P., and BaIley, I. W. Are Tetracentron, Trochodendron, and Drimys specialized or primitive types? (with

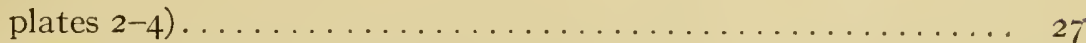

Chivers, Arthur H. Directing factors in the teaching of botany. . 33

Barnhart, John Hendley. Segregation of genera in Lentibu-

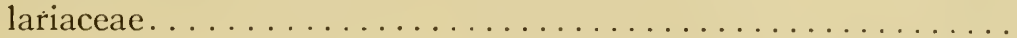

Call, Richard Ellsworth, Observations on the flora of Mammoth Cave, Kentucky......................... 65

Yampolsky, Cecil. Observations on inheritance of sex-ratios in

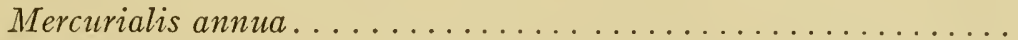

Humphreys, Edwin W. Triassic p'ants from Sonora, Mexico, including a Neocalamites not previously reported from North

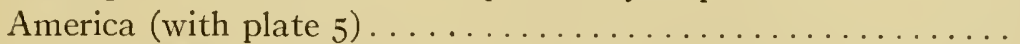

TAYlor, Norman. A white-cedar swamp at Merrick, Long Island, and its significance (with plates $6-10) \ldots \ldots \ldots \ldots \ldots . . . . . .$.

Blakeslee, Albert F. Inheritable variations in the yellow daisy (Rudbeckia hirta) .......................... 89

HARPER, R. A. On the nature of types in Pediastrum........ 9I

Howe, Marshall Avery, and Hoyt, William Dana. Notes on some marine algae from the vicinity of Beaufort, North Carolina (with plates II II 5 ......................... I05

Levine, Michael. Somatic and reduction divisions in certain species of Drosera (with plates I6-19) . ............ I25

Shaw, Harry B. Self, close and cross fertilization of beets (with

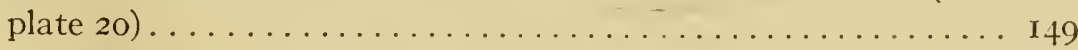

Gager, C. Stuart. Present status of the problem of the effect of radium rays on plant life...................... I5

SinNotT, Edmund W. Endemism as a criterion of antiquity among plants................................ I6r

Graves, Arthur H. A botanical trip to North Wales in June.... I67

Orton, C. R. North American species of Allodus........... 173 Atkinson, Geo. F. The development of Lepiota cristata and L. seminuda (with plates $2 \mathrm{I}-26$ ) . . . . . . . . . . . . . 209

HARris, J. ARThUR. A tetracotyledonous race of Phaseolus vulgaris. 229 
KeRN, FrdNk D. Japanese species of Gymnosporangium....... 245

FARr, Clifford HARrisos. Cytokinesis of the pollen-mother-cells of certain dicotyledons (with plates $27-29$ ) . . . . . . . 253

Lipmax, Chas. B. Plant ecology and the new soil fertility...... 319 Graves, Arthur H. Chemotropic reactions in Rhizopus nigricans. 323 Stout, A. B. Self- and cross-pollinations in Cichorium Intybus with reference to sterility (with plate 30 ) .................. 333

Norton, J. B. S. Variation in Tithymalopsis............. 455

Farwell, Oliver Atrins. The genus Hippochaete in North America, north of Mexico................. 46I

Hollick, Arthur. A fossil fern monstrosity (with plates 3I, 32) .473 -Small, John K. Recent exploration in southern Florida . . . . . . 475 Rydberg, P. A. Vegetative life zones of the Rocky Mountain region............................ 477

SEAVER, Fred J. Bermuda fungi................ 5 OI

BEAL, IV. J. Some things learned in managing a botanic garden. . $5^{\mathrm{I}} 3$ KELLERMAN, KARL F. Cooperation in the investigation and control of plant diseases. . . . . . . . . . . . . . . 517

Black, Caroline A. The nature of the inflorescence and fruit of Pyrus Malus (with plates $33-40$ ) . . . . . . . . . . . . 519

Taubenhaus, J. J. A contribution to our knowledge of silver scurf (Spondylocladium atrovirens Harz) of the white potato (with plates $4 \mathrm{I}-43$. . . . . . . . . . . . . . 549

Lloyd, Francis E. The embryo-sac and pollen grain as colloidal

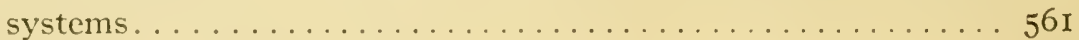

Britton, N. L. The vegetation of Anegada............ 565 


\title{
ADDRESS OF WELCOME
}

\author{
W. Gilman Thompson
}

President, Board of Managers, The New York Botanical Garden

\section{Ladies and Gentlemen:}

On behalf of the Board of Managers of The New York Botanical Garden, I extend to you a most cordial welcome to the celebration of the twentieth anniversary of the establishment of the Garden. The attendance here of so many guests, representatives of distinguished scientific and educational organizations in many parts of the country, is in itself a gratifying reward for the labor and study expended in the development of the Garden, and will doubtless bring the stimulus of great encouragement to the energies of its Staff. In these troublous times, when so large a part of the world seems bent upon its own mad destruction, it is wholesome to turn to constructive processes, and to a peaceful science based upon the phenomena of growth.

As a matter of local interest, too, it is interesting that in the midst of a great city characterized particularly by the hurry and bustle of strife (not to say by noise!) there should be found a garden of beauty and peace, where one may commune with a lotus from the Ganges, an orchid from the scenes of the Amazon, or a pine from a far-off Himalayan mountainside. During the past score of years, nothing of greater importance has occurred in the phenomenal expansion of the City than the rescue and redemption of the Garden land, so that, including a recent acquisition, there are now nearly 400 acres constituting a permanent garden and lying within what has become a prominent residential center of Greater New York.

If our eminent Director could have been called as consulting botanist in paleozoic days, I doubt whether he could have suggested a more ideal site for a botanical garden than that which nature kindly offered to the Board of Managers twenty years ago, 
with its river and falls and ponds, its ravine and marshes and swales and twenty acres of hemlock forest, affording scenes as wild and picturesque, almost, as the Adirondacks.

But it is not natural beauty alone which we celebrate here, for during its comparatively short life the Garden has won cqual rank as one of a quartette of educational and scientific institutions established through private munificence in coöperation with the City's funds for construction and maintenance-the other three being the Ancrican Museum of Natural History, the Metropolitan Museum of Art, and the Zoölogical Park. Like these kindred institutions, the Garden, in addition to the educational facilities offered to specialists and to the general public, affords opportunities for instruction through lectures, demonstrations, and excursions through its grounds, muscum, and greenhouses to public school teachers and tens of thousands of school children. Like these institutions also, it reaches out to other countries all over the world and upwards of a hundred expeditions have been sent out in this country and abroad to gather material for its collections and research. The constantly increasing number of those whose generosity has led to the contribution of valuable collections or of funds for special collections or expeditions is a source of great gratification to the Managers, indicating as it does, substantial appreciation of the aims which it has been their endeavor to accomplish.

The work of a great botanic garden is far wider than the mere maintenance of a store-house for collections. In addition, it comes under three divisions, that of research in pure science for the advancement of botanical knowledge, second, that of education of all classes of the community, from school children upward, and finally there is the aesthetic field, which, like that of a muscum of art, should not alone afford gratification to the love of beaty and form, but which should be suggestive for imitation elsewhere. In other words, the general effects of form and color to be derived from appropriate grouping or mass planting may he produced upon a large scale, combined with reference to environnent, seasonal conditions, etc. This latter phase of the Garden's work has been left, in great part, until now, lut the Ifo acres of additional land lately secured, suggests its practicability and a special fund is being raised for its accomplishment. 
The Garden, it should be remembered, was begun by the redemption, twenty years ago, of what was literally a goat pasture and the recedence of that valuable domestic animal was necessarily followed for several years by gradual substitution of his customary articles of diet by a more varied flora. The early work of the Garden, concerned as it was with the construction of new buildings, grading, planting, and road-making, could not be expected to include at once all those features of adornment which should be the outcome of prolonged study. Moreover, within the period of years which we are celebrating, there has been a remarkable development of intelligent interest in private gardens, whose owners constantly are seeking practical illustrations as guides for their own work. Two decades ago how few reliable books existed upon aesthetic gardening, compared with the numerous practical treatises obtainable today! Garden clubs are springing up like mushrooms (although, let us hope, with more substantial basis!), and the florists are offering a range of selection in variety and form and color of garden plants quite unimagined twenty years ago. There is, therefore, an opportunity for a botanical garden to furnish object lessons in planting, in grouping and outdoor arrangement of flowers which may serve as public standards, just as art museums furnish standards for art. A very useful and popular innovation has been introduced here in the spring and autumn inspections of the grounds to which the public are especially invited, which consists of practical demonstrations by the gardeners of the processes of planting and transplanting.

Of the purely scientific achievements of the Garden during the past twenty years, a layman may not presume to speak before an audience so proficient in botanical lore, but the Managers are most appreciative of the earnestness and devotion to their work of the entire Garden Scientific Staff. I cannot conclude these remarks, however, without expressing the feeling that this celebration of the Garden is in reality a celebration of its Directorin-Chief. His scientific attainments are well known to you all, but his untiring energy, admirable judgment, and genius for organization can only fully be appreciated by those of us who have worked in coöperation with him for the past twenty years, and who have learned to regard the Garden and "Britton" as synonymous botanical terms! 
A glance at the list of scientific papers to be presented by our guests at this anniversary celebration bespeaks their appreciation and good will, as it also constitutes a notable event in the botanical history of this country.

Once more I bid you cordially welcome, and in the phraseology of those unique gardeners, the Japanese, "the honorable Garden is yours." 


\title{
THE MECHANISM AND CONDITIONS OF GROWTH
}

\author{
D. T. MacDougal \\ Carnegie Institution of Washington
}

(WITH PLATE I)

One of the most important characteristics of the activities of living matter is that external substances pass into it more or less constantly, thus adding to its bulk, and the introduced material is ultimately partly burned and its energy rendered available, while some of it is converted into constituents of the colloidal protoplast and its envelope, increasing their mass, the accretion being followed by changes in arrangement and structure which find external expression in alterations in form and size. Such increases are accompanied and made possible mechanically by differentiations into tissues or specialized tracts.

The general external features of growth are of the most obvious kind. When, however, we set ourselves the task of determining the conditions under which it proceeds, of analyzing the contributory factors, and of measuring their relative influence on its rate and course, technical difficulties of a very refractory kind are encountered. The elements and their compounds necessary for growth are in the main known to us, and also the fact that water is of an importance in the process corresponding to its high proportion in protoplasm.

The purpose of the present paper is not to discuss these features of the matter, but rather to present the results of some experimentation which seems to have important bearing upon the main problems of growth. In any picture we may draw of the irreversible accretions to living matter and its accessory and enveloping structures, attention may well be centered upon the origination of the material to be used. The greater amount of growth is accomplished in the higher plants by material which has accumulated in storage tracts or is being formed by photosynthesis or otherwise, and this material must be diffused a 
distance varying from that of a fraction of the radius of a cell to many meters to the protoplasts which are to make use of it. The origination or the hydrolyzation of this material is a chenical process, and the rate or velocity at which it takes place is one which may be assumed to bear the relation to temperature by which it doubles or accelerates even faster for every rise of 10 degrees $\mathrm{C}$.

Diffusion is much less affected by temperature, hence the rate and amount of translocation is much less affected by temperature. When the dissolved food reaches the membrane or the periphery of a protoplast it is then in a position of being about to become part of the integral substance of bodies of widely different composition, and it must therefore be taken for granted that for the growth of different organs, tissues, or protoplastic members, the food-material must be converted into "building material."

This building material must be of a highly specific character, and that such special stuffs are formed in the growth and development of the complex plant is the conclusion to which all morphogenic experiments converge during the last decade. Non-development under conditions inhibiting the construction of "formative stuffs" is now well exemplified by a score of investigations, the latest arailable results being those of my own in which the form of the polymorphous leaf of Neobeckia might be attributed to special materials. ${ }^{1}$ The induction or inhibition of flower formation, fruit-development, tuberization, spore-formation, conjugation, etc., in plants from the algae to the Compositae by variation of external conditions is a matter of the commonest observation and in every analyzed instance has yielded the single conclusion that such action is through the formation or lack of formation of special building materials.

The initiatory stage of the supplying of food to a growing part of a plant may or may not be a chemical change, the second link is one of diffusion or osmosis, and the third must inevitably be one of chemical change as a consequence of which temperature plays the dominating rôle, affecting not only the rate at which such changes take place, but also to a lesser extent the permeability of membranes and the hydratation capacity of the colloids

s Macl)ongal, 1). T. The determmative action of environic factors upen veobekia aquatica crecenc. Filera $106: 265-280$. 1914. 
concerned. No other single agency or external force acting upon an adequate food-supply may exert so wide a range of effects, upon the processes necessary in the adduction and formation of building material necessary for growth.

In the incorporation of this material, however, some energetics are involved in which light also may play a part. Turgidity and its resultant pressure-effects, hydratation capacity and its resultant swelling in the cell colloids, while modified by temperature, are also highly respondent to the acidity and alkalinity of the solutions which penetrate them, in consequence of which light, as will be shown later, may play a more important rôle than in other phases of growth. This form of energy, especially in the shorter wave lengths, may neutralize or coagulate protoplastic colloids, especially in the minute plants and it is probable that the efficiency of this agency in sterilization is because of this action. Its partial action would decrease hydratation capacity and thus tend to lessen growth.

The author carried out some extensive experiments upon the course of growth and development of plants in darkness, previous to 1904 , and in connection with this study of the features of enlargement and differentiation of shoots uninfluenced by growth obtained some insight into the positive effects of light on growth. The results of this work carried on at The New York Botanical Garden, I899-I904, showed that the total amount of growth accomplished by individual plants of a hundred species selected for the experiments might be more or less in any given dimension in darkness than in light, that the rate of growth might be affected in a similar manner and, that the effect of light on growth was not invariable. This rendered unsafe at once the trite conclusion that "light retards growth," current from the time of Sachs to the present day and still repeated in text-books and lectures.

My own results ${ }^{1}$ on the matter were presented only in a generalized way, and their validity was not considered by authors of text-books and reviewers, including Barnes, Jost, and others.

Blaauw, ${ }^{2}$ a Dutch investigator, has recently studied the question

${ }^{1}$ MacDougal, D. T. Influence of light and darkness on growth and development. Mem. N. Y. Bot. Garden 2: 307, 308. I903. Also, Light and the rate of growth in plants. Science II. $4 \mathrm{I}: 467-469$. I9I5.

${ }^{2}$ Blaauw, A. H. Licht und Wachstum. Zeitsch. Bot. 6: 641-703. I914. Also, $7: 465-532$. 1915 . 
anew, and his fortunate choice of material in the delicate sporangiophores of Phycomyces, and the availability of apparatus for temperature regulation, and of measurable sources of light made it possible to secure data upon which some conclusions as to beginning and following effects of illumination on growth, and the influence of exposures of varying length and to a series of intensities might be reached. Later, similar studies were made of Helianthus globosus. The behavior of the two plants included some striking dissimilarities. The illumination of Phycomyces results in an immediate acceleration, while in Helianthus the primary effect is a retardation. The course of growth in Phycomyces includes a primary acceleration, then retardation with a final rising rate. Helianthus is first checked, then shows an acceleration, which slackens gradually to the original course.

Vogt $\mathrm{t}^{1}$ has also made some measurements of the growth of the colcoptile of Avena sativa, well controlled as to temperature and light, in which it was found that the illumination of a plant (not etiolated) is soon followed by an acceleration of growth, the duration of which depends upon the intensity of the light. The rate now falls off for a period, then rises to or above the normal.

If these be taken in connection with my own findings of the behavior of a plant deprived of illumination, viz: "In one series, however, the peduncles and scapes of Arisaema nearing the end of their period of elongation showed an initial acceleration when light was totally excluded from the plants. This acceleration reached its maximum in twenty-four hours then decreased to a minimum equivalent to the original rate in about four times this period," adequate ground will be found for the conclusion that the reaction of plants in growth to light is due directly or indirectly to physico-chemical changes effected by light-energy.

Opportunity for reconsideration of the general problems of growth developed at the Desert Laboratory two years ago and a series of experimental observations was planned to make an analysis of some of its phases. It was found that the various instruments used in measuring growth, inclusive of several types of auxanometers, balances, recorders, horizontal and traversing microscopes are in their diversity both adecjuate and precise to

${ }_{1}^{1}$ Vogt, E. Über den Einfluss des Lichts auf das Wachstum der Koleoptile von Avena saliva. Zeitsch. Bot. 7: 193-270. 1915. 
such a degree as to have solved most of the mechanical difficulties so far as apparatus was concerned. The results presented in the present paper were obtained by the use of a horizontal microscope and by a number of auxanometers of the type described in $1901{ }^{1}$ Various types of levers and supports were made to fit special preparations of plants (PLATE I).

Nearly all studies of growth have been made on seedlings or on the tender and slender parts of young shoots, or on minute structures such as the sporangiophores of fungi in which it had been practically impossible to make any reliable determinations of the constituency or physical condition of the growing structure, or of its direct reactions.

The choice of material therefore assumed a major importance in any possible advance that might be made in an investigation of the matter. A review of the plants available at the Desert Laboratory made it apparent that the platyopuntias offered certain features by reason of which it might be possible to secure measurements capable of correction and analysis to a degree not attainable with any other material. The flattened mature joints of these plants have an elongated oval outline with a length of Io to $20 \mathrm{~cm}$., a width of 8 to $20 \mathrm{~cm}$. and a thickness of $\mathrm{I}$ to $3 \mathrm{~cm}$.

A new joint first emerges as a bud thickly sheathed with ephemeral leaves from one of the distal areolae of an old joint, in March to May in the Tucson vicinity. By the time a length of $2 \mathrm{~cm}$. is reached, both lateral and longitudinal expansion assume proportions which are maintained until maturity is reached and it is at this time that it is profitable to bring the apex of the bud in bearing upon the lever of an auxanometer. The alterations in length and width which ordinarily ensue may be illustrated by the following measurements made with a ruler on a new joint arising from an old one into which the bulb of a mercurial thermometer had been thrust.

\begin{tabular}{|c|c|c|c|c|c|}
\hline & & Length & Width & Joint & Air \\
\hline March & $15-3$ & P.M. . . 3.4 & 2.4 & $85^{\circ} \mathrm{F}$. & $83^{\circ} \mathrm{F}$ \\
\hline “ & I6- $4: 30$ & " $\quad \ldots 3.8$ & 2.8 & $97 "$ & \\
\hline “ & 19 - $2: 30$ & noon $\ldots .4 .9$ & 3.I & 65 “ & 67 “ \\
\hline " & $24-3: 30$ & P.M. . . 5.6.6 & 4.0 & 88 “ & 83 “ \\
\hline
\end{tabular}
York.

${ }^{1}$ MacDougal, D. T. Practical textbook of plant physiology, p. 29I. I90I. New

${ }^{2}$ Leaves cut off. 
A preparation suitable for such work consists of a rooted joint separated from a plant in the previous season, and fixed rigidly in a setting of plaster in a metal disk with the roots imbedded in soil or depending in water. Although water-culture scems anomalous for cacti, yet preparations showed normal activity throughout a growing season with the roots immersed in ordinary water from a shallow well.

Such joints offer the advantage of being mechanically firm enough to support a lever counterweighted to give a bearing which will allow the minute change in length to be recorded, and by occasional adjustments of the instruments the course of growth of a joint may be followed from the bud to approximate maturity, a development which extends over two or three months.

The use of the opuntias as material for the study of growth might raise objections based upon the obscure and possibly complex morphogeny of these plants. Such oljections would have no real weight. A joint supposedly consists of a number of internodes which mature as one in a developmental period of several weeks. These structures are in effect thick disks of plasmatic colloids enclosed in a distensible epidermal membrane, and traversed by a fibro-vascular system of cellulose also capable of extension. Carbohydrates are formed within this system by photosynthesis and the catabolic or respiratory action is one by which a high proportion of acids is accumulated at low temperatures and in darkness. Water is drawn into the disk through basal connections, and some is lost through the stomatal openings in a characteristic manner.

The opportunities for an analytical study of growth in such plants were enhanced by the fact that the general course of water loss had been determined by workers at the Desert Laboratory in previously completed studies and that the daily and scasonal variations in acidity had been followed in hundreds of instances in certain species by Dr. H. M. Richards and by Dr. H. A. Spoehr, while some measurements of the hydratation capacity or swelling power had been made in I9It by Mr. E. R. Long.

Olsservations on the growth of a joint might therefore be carried through several weeks and the daily and ontogenetic rariations correlated with acidity, turgidity, hydratation, and transpiration conditions exhibited by controls and material previously examined. 
It is believed that no such previous relation between the actual growth phenomena and internal conditions had ever before been achieved in studies on this general subject.

In addition to such determinations of the physical conditions of the disks, the results of some measurements begun in I9I I upon the general alterations in form and size of the joints were also available. These show that while the main growth is accomplished during the initial season of enlargement, yet some distinct variations in size ensue during the second season. The dimensions of some joints of Opuntia discata at Tucson in the warm arid climate of the Desert Laboratory and at Carmel in a cool equable climate are given below:

Measurement of joInts of Opuntia discata:

No. I. (Tucson)

\begin{tabular}{|c|c|c|}
\hline & Width & Length \\
\hline May & $9,1912 \ldots \ldots \ldots \ldots \ldots 6.5 \mathrm{~cm}$ & $7.0 \mathrm{~cm}$ \\
\hline May & I 8, I91 $2 \ldots \ldots \ldots \ldots \ldots$ I 1.5 & 12.3 \\
\hline May & $29,1912 \ldots \ldots \ldots \ldots \ldots \ldots$ I3.4 & I 4.6 \\
\hline June & 9, I9I $2 \ldots \ldots \ldots \ldots \ldots$ I 4.0 & I 5.0 \\
\hline Sept. 2 & $24,1912 \ldots \ldots \ldots \ldots \ldots$ I9.8 & 20.2 \\
\hline March & $9,1913 \ldots \ldots \ldots \ldots \ldots .6$ & 20.2 \\
\hline May & $9,1913 \ldots \ldots \ldots \ldots \ldots$ & I9.6 \\
\hline June & $18,1913 \ldots \ldots \ldots \ldots \ldots 20.0$ & I9.8 \\
\hline April & $3,191+\ldots \ldots \ldots \ldots \ldots .20 .0$ & 20.0 \\
\hline & No.2. $\quad($ Tucson $)$ & \\
\hline May & 9, І9г $2 \ldots \ldots \ldots \ldots \ldots$ го. 8 & I2.0 \\
\hline May & IS, I9I $\ldots \ldots \ldots \ldots \ldots \ldots$ If.I & I $5 . \mathrm{I}$ \\
\hline May & 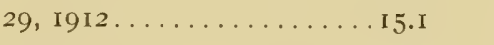 & 17.2 \\
\hline June & 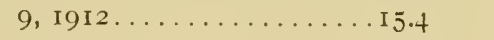 & 17.2 \\
\hline Sept. 2 & $24,1912 \ldots \ldots \ldots \ldots \ldots \ldots .5$ & 20.0 \\
\hline March & 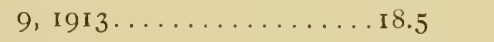 & 20.6 \\
\hline May & $9,1913 \ldots \ldots \ldots \ldots \ldots .4$ & 20.8 \\
\hline June & I 8, I913 $3 \ldots \ldots \ldots \ldots \ldots .2$ & 20.0 \\
\hline April & $3,1914 \ldots \ldots \ldots \ldots \ldots 2 \mathrm{I} .2$ & 18.0 \\
\hline & No.3. (Tucson) & \\
\hline May & 9, I9I2 $\ldots \ldots \ldots \ldots \ldots 6.0$ & 7.0 \\
\hline May & I 8, I9I $2 \ldots \ldots \ldots \ldots \ldots .9$ & I I.O \\
\hline May & 29, I9I2 $\ldots \ldots \ldots \ldots \ldots \ldots$ II.2 & 13.2 \\
\hline June & 9, I9I $2 \ldots \ldots \ldots \ldots \ldots$ I I.8 & 13.2 \\
\hline Sept. 2 & $24,1912 \ldots \ldots \ldots \ldots \ldots \ldots \ldots .2$ & I 6.8 \\
\hline March & 9, I913........... & 17.2 \\
\hline May & 9, I9I $3 \ldots \ldots \ldots \ldots \ldots \ldots .2$ & 17.0 \\
\hline June & I 8, I913 $\ldots \ldots \ldots \ldots \ldots \ldots$ I 5.3 & 17.0 \\
\hline April & $3,191+\ldots \ldots \ldots \ldots \ldots \ldots$ I 6.2 & I 7.2 \\
\hline
\end{tabular}


No. 4. (Carmel)

\begin{tabular}{|c|c|c|}
\hline May & $3,1912 \ldots \ldots \ldots \ldots \ldots, 3.8$ & 5.5 \\
\hline June & $17,1912 \ldots \ldots \ldots \ldots \ldots .2$ & 10.3 \\
\hline July & $12,1912 \ldots \ldots \ldots \ldots \ldots \ldots 6.2$ & IO.O \\
\hline Aug. & II, I9I2 . . . . . . . 6.2 & IO. I \\
\hline April & 9, 1913.......... 6.5 & 10.5 \\
\hline May & $13,1913 \ldots \ldots \ldots \ldots \ldots, 6.5$ & 10.5 \\
\hline July & 7, I913 $\ldots \ldots \ldots \ldots \ldots, 6.4$ & 10.4 \\
\hline Aug. & $20,1913 \ldots \ldots \ldots \ldots \ldots .6 .3$ & 10.2 \\
\hline \multicolumn{3}{|c|}{ No. 5. (Carmel) } \\
\hline May & $3,1912 \ldots \ldots \ldots \ldots \ldots \ldots$ 3.I & 5.2 \\
\hline June & $17,1912 \ldots \ldots \ldots \ldots \ldots, 8.0$ & 12.8 \\
\hline July & 12, 1912 $\ldots \ldots \ldots \ldots \ldots, 8.3$ & 13.2 \\
\hline Aug. & II $, 1912 \ldots \ldots \ldots \ldots \ldots, 8.2$ & $13 \cdot 5$ \\
\hline Sept. & $9,1912 \ldots \ldots \ldots \ldots \ldots .8 .5$ & I3.4 \\
\hline April & $9,1913 \ldots \ldots \ldots \ldots \ldots .8$ & I 4.0 \\
\hline May & $13,1913 \ldots \ldots \ldots \ldots \ldots, 8.8$ & 14.0 \\
\hline July & $7,1913 \ldots \ldots \ldots \ldots \ldots, 8.8$ & $13 \cdot 4$ \\
\hline Aug. & $20,1913 \ldots \ldots \ldots \ldots \ldots \ldots$ & I 3.0 \\
\hline \multicolumn{3}{|c|}{ No. \&. $\quad($ Carmel $)$} \\
\hline May & 4, I9I2,............. 6.3 & $7 \cdot I$ \\
\hline June & I6, I9I $2 \ldots \ldots \ldots \ldots \ldots$ I 4.0 & $17 \cdot 3$ \\
\hline July & 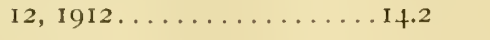 & I 8.1 \\
\hline Aug. & II, I9I $2 \ldots \ldots \ldots \ldots \ldots$ I 4.3 & 18.0 \\
\hline Sept. & $9,1912 \ldots \ldots \ldots \ldots \ldots \ldots \ldots$ & I 8.0 \\
\hline April & 9, I9I $3 \ldots \ldots \ldots \ldots \ldots$ I5.4 & 18.3 \\
\hline May & I3, I9I3 $\ldots \ldots \ldots \ldots \ldots$ I5.t & 18.3 \\
\hline July & 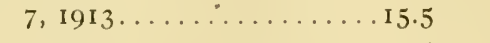 & I 8.6 \\
\hline Aug. & $20,1913 \ldots \ldots \ldots \ldots \ldots \ldots$ I 5.5 & 18.5 \\
\hline \multicolumn{3}{|c|}{$\begin{array}{c}\text { No. I2. (Carmel) } \\
\text { (Mature) }\end{array}$} \\
\hline Aug. & $4,1911 \ldots \ldots \ldots \ldots \ldots \ldots \ldots \ldots$ & 16. I \\
\hline May & $3,1912 \ldots \ldots \ldots \ldots \ldots \ldots \ldots$ & 16.8 \\
\hline June & $16,1912 \ldots \ldots \ldots \ldots \ldots \ldots \ldots$ & 16.8 \\
\hline July & I 2, I9I $2 \ldots \ldots \ldots \ldots \ldots$ I 3.6 & 16.8 \\
\hline Aug. & 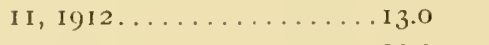 & 16.8 \\
\hline Sept. & 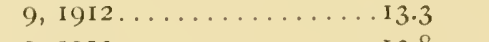 & 16.6 \\
\hline April & 9, 19I3 $\ldots \ldots \ldots \ldots \ldots \ldots$ I 3.8 & 17.0 \\
\hline May & 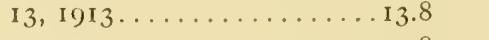 & 17.1 \\
\hline July & $7,1913 \ldots \ldots \ldots \ldots \ldots \ldots$ & 16.8 \\
\hline Aug. & $20,1913 \ldots \ldots \ldots \ldots \ldots \ldots$ & 16.8 \\
\hline
\end{tabular}

The preceding tables convey the general features of development of the joints, both in the semi-aricl subtropical climate under which the plants habitually thrive and in the cooler equable climate of Carmel. It is to be seen that the rate and total growth of the joints is much greater in Tucson with its higher number of 
auxo-thermal units, and that the enlargement is halting and irregular, in some instances actual decrease of length and width being apparent (see measurements in bold face type); and that such shrinkage was not an error was amply attested by the auxanometric data to be given below.

Many of the series of measurements of the growth of a single bud extended over a hundred days. It was necessary to secure rigid and secure mountings for plants which were to be kept under observation so long. Preliminary arrangements for the experiments to be carried out in I9I 5 were made by making cuttings of old joints of sound healthy plants. After the wounded surface at the bases had healed, some of the joints were put in an equable low temperature dark room until needed: others were set in pots of sandy soil and others were set in dishes as water cultures. The beginning stages of development were anticipated by cutting a slot in a metal plate or disk through which the basal part of a joint might be passed so that a small segment including the calloused surface and roots, if formed, projected clear of the disk. The joint of the cactus would now be securely fastened in place in the disk by a setting of plaster. After this had become firm, the preparation was firmly clamped to the top of an earthenware pot or dish in such manner as to eliminate all possibility of any vertical motion. The bud would be arranged to bear against the lower side of a counterweighted auxanometer lever. This instrument was likewise clamped to its base in such a manner as to eliminate errors which might be caused by irregular movements. The auxanometers consisted essentially of recording drums revolving daily or weekly, on which pens traced the movements of improvised levers. These levers were arranged as simple or compound, according to the needs of the experiment. The growth of a joint from the initial $2 \mathrm{~cm}$. to $\mathrm{I} 2-15 \mathrm{~cm}$. necessitated periodical adjustment of the instrument. This was generally done by blocking it up on its base and then securing by heavy steel clamps (FIG. I).

Since some of the factors which would operate to cause changes in external dimensions would also be operative in mature joints, a number of these were mounted as above and put in contact with auxanometric levers. Modification and control of the conditions prevalent at Tucson were obtained by dark rooms, glass houses, 
etc. The course of growth of joints Nos. I, 2, and 3 at Tucson and of Nos. 4, 5, 8, and I 2 at Carmel illustrate the widely ranging intensitics of environmental conditions at the first-named place and the equable climate of the second.

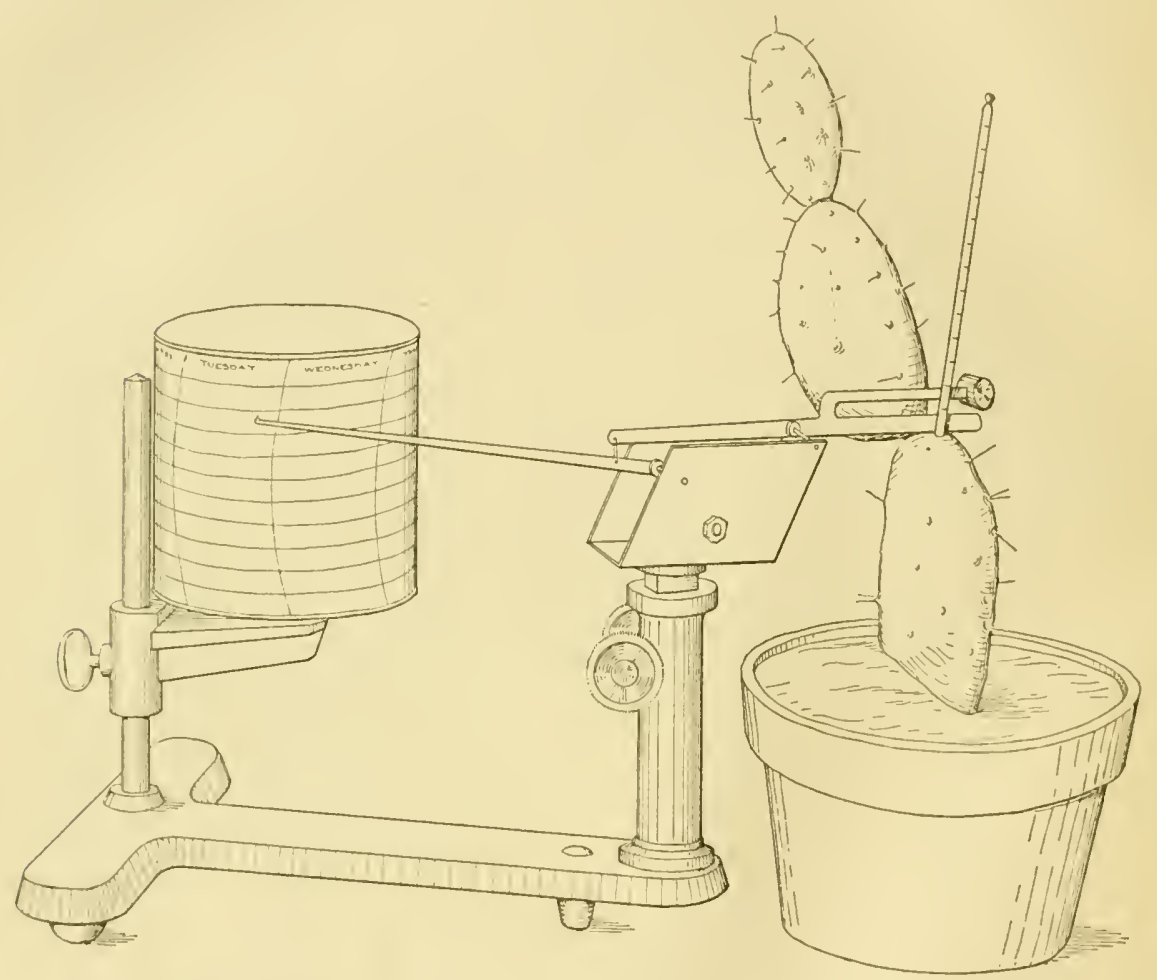

FIG. I. Measurement of variations in length of mature joint of Opuntia with precision auxograph. The mercurial thermometer may be read at convenient intervals for actual temperature of the joint while air temperatures are recorded by a thermograph.

The record of No. 5 (Opuntia Blakeana) of the auxanometric series may be used as a guide to the discussion of the growth phenomena of a llat joint of opuntia. This joint was put in hearing with an auxanometer lever on March 27, 1915, when its length was $17 \mathrm{~mm}$. With the exception of brief intervals necessary for readjustment of instruments, the history of the developmental enlargement of this joint to ten times this length was completely recorded for a period of 63 days. At the end of this period the net increase in length became very small and the variations in length were of the type clisplayed by a mature joint. 
The measurements of mature joints which had been made by rulers, calipers, horizontal microscopes, etc., showed that changes in dimension of some amplitude due to the amount of the water balance occurred in these plants. The known factors to which such changes might be due were the water supply, transpiration, temperature, variations in acidity, etc., all of which would affect the growth of young joints.

It was important therefore that the general nature of the changes be made out and the parts played by the contributory factors analyzed. In accordance with this requirement the mature joint bearing the new bud (No. 5) was fixed firmly in plaster with its root-bearing base immersed in a vessel of water on March 4,

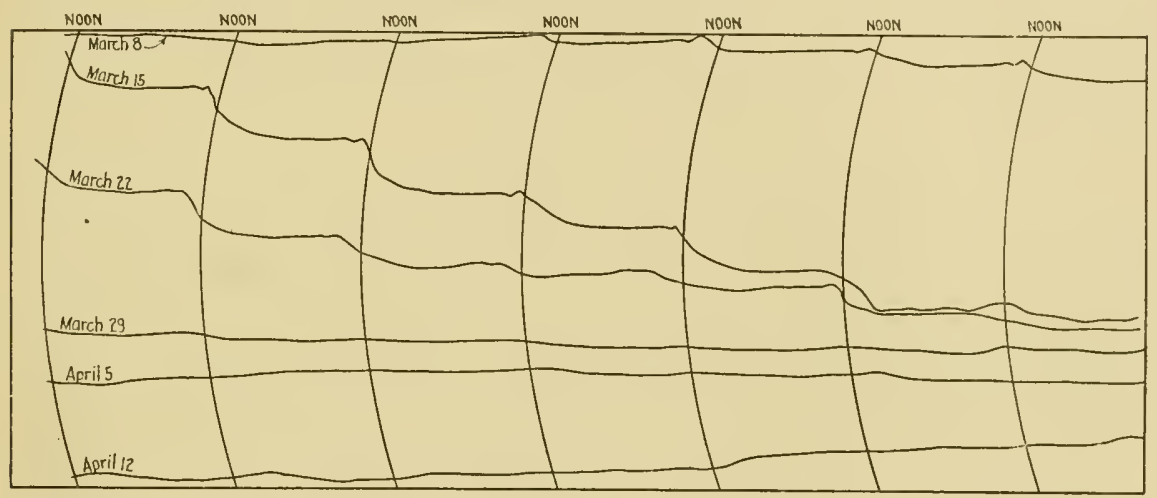

FIG. 2. Auxographic tracings of the variations in lengtly of mature joint of Opuntia Blakeana, No. 5, preceding the development of the new joint and during the earlier part of its growth, $\times 8 \frac{1}{5}$. Elongation produced a downward movement of the pen. The record is complete for 42 days, starting in a period of equalizing daily variations, including a period of enlargement and ending in a stage of decreasing length.

1915. An auxanometer lever was put in contact with a space between two areolae on the apical margin and the features of changes in volume are well shown by tracings of the actual record given in FIG. 2, the actual elongation being magnified twenty times and denoted by downward movement of the pen. The old joint had suffered the usual winter depletion of water as it stood in the open, and its transferral to the experimental setting duplicated the conditions under which it would have begun to take up water more rapidly from the moist soil. The increase of the water-balance began to be manifest on the eighth day after the experiment was begun (see uppermost tracing in FIG. 2) and 
reached its general maximum in seventeen days. The accumulation of such a balance was accompanied by an actual increase of $5 \mathrm{~mm}$. in length, which would be about .4 per cent. of its initial full length. This upward thrust of the mature joint would of course carry the young bud, the growth of which was measured, and would constitute about .3 per cent. of the upward movement of its apex.

The most obvious and prevalent feature of the expansion of the old joint was the fact that the greater part of this occurred between II A.M. and 2 P.M. daily. Diminished elongation or actual shortening followed soon after 2 P.M. Both the mature and the young joint stood plane in the meridian and during the period of most rapid elongation presented their margins to the source of light. The preparation was accidentally placed where the shadow of a door frame $20 \mathrm{~cm}$. in width and $\mathrm{I} I 0 \mathrm{~cm}$. distant passed across it between 9 and Io A.M.

The principal daily variations are illustrated by the tracings March 8-15, and March $15^{-22}$. If the records of March 9, Io and I I be consiclered, it will be seen that the course of variation was such that the length of the old joint remained unchanged through a night with the temperature ranging from 50 down to $47^{\circ} \mathrm{F}$. A rise in temperature of the air from the last named figure to $63^{\circ} \mathrm{F}$. at 4 P.MI. was accompanied by the following changes: a slow decrease in length continued from the previous night until ro A.M., broken by an elongating action while under the passing shadow at 9 A.M. A positive elongation at $55^{\circ} \mathrm{F}$. began at I I A.M., and was marked in character until I P.M., when it checked, although the temperature was still rising to favorable intensities for absorption, reaching $63^{\circ} \mathrm{F}$. at 4 P.M. Before this, however, shortening had begun and continued on through the night with repetition on the following days. This is still more marked in the record of March $15^{-20}$. The momentary elongation due to shadling was displayed at 9 A.M. Shortening or a very slow increase set in at 2 P.M. and lasted until I I A.M. Two or three hours of lengthening ensued, then cessation of expansion, complete or nearly so. On Narch 20 th the preparation was set in the open at 8 A.M., the illumination being more intense than in the greenhouse. Elongation began at once and ran five hours, ending suddenly at I P.M. and decrease set in 
which conformed in its general aspects to the behavior of the previous period.

The daily increase in length amounted to $.6 \mathrm{~mm}$. as a maximum and, as the longitudinal dimension of the joint free of the support was $15 \mathrm{~cm}$., the coefficient of expansion was I in 250 or 4 per cent. On Wednesday, March I7, this increase began at Io A.M. at $63^{\circ} \mathrm{F}$. and the expansion followed while the temperature rose to $72^{\circ} \mathrm{F}$. during the next three hours. Some expansion continued with a fall of $2^{\circ} \mathrm{F}$. during the next 4 hours. It is evident, however, that the decreasing expansion is not to be attributed chiefly or solely to the temperature relation. This is also supported by the fact that on the following day the increase of a total amplitude of about $.4 \mathrm{~mm}$. began at Io A.M. at $60^{\circ} \mathrm{F}$. and went forward rapidly until 3 P.M., the sky having become overclouded at noon, and continued to increase until midnight under the equalized conditions. The temperature remained between $69^{\circ}$ and $70^{\circ}$ from noon until 6 P.M. and had fallen to $62^{\circ} \mathrm{F}$. by midnight.

That the enlargement in question was not entirely growth, was evidenced by the fact that before the close of the observations on June I a large part of the total increase noted above $(2 \mathrm{~mm}$.) had been lost by shrinkage, and the inevitable loss of water during the remainder of the season would probably result in changes similar to those shown by Nos. 2 and 3. (Tucson, I9I3-I9I4.)

It would appear that the alterations noted above are reversible in greater part and must therefore be attributable to osmotic action and hydratation.

Not the least remarkable aspect of the matter, however, is the fact that the growth enlargement of joints follows a course fairly parallel to that described.

The bud of No. 5, for example, began to accelerate at 9 A.M., April 3, temperature $65^{\circ} \mathrm{F}$, and followed the rise until 3 P.M. and then slackened (temperature $75^{\circ} \mathrm{F}$.), although the temperature continued at this intensity for at least an hour longer. From 6 P.M. until 8 A.M. the rate was a straight line and parallel to the temperature record. Acceleration from here lagged, repeating the events of the previous day. (FIG. 3.)

The record of April 6 illustrates another phase. The old joint was undergoing continuous shortening at a fairly uniform rate. Temperature rose from $60^{\circ}$ at 6 A.M. to $66^{\circ}$ at I I A.M., varying 
between the two figures until 6 P.M., the rate of growth being a straight line record.

The major part of the growth enlargement being accomplished, the newly matured joint began to exhibit the daily variations hitherto displayed by the mature joint. Increase in length in progress at daylight was slightly accelerated at about 8 A.M. and continued with the rising temperature (May I $-68^{\circ} \mathrm{F},-76^{\circ} \mathrm{F}$. until 2:30 P.M.) then slackened, although the temperature kept up to $78^{\circ}$ F. at 8 P.M. By + P.M. a shrinkage began which

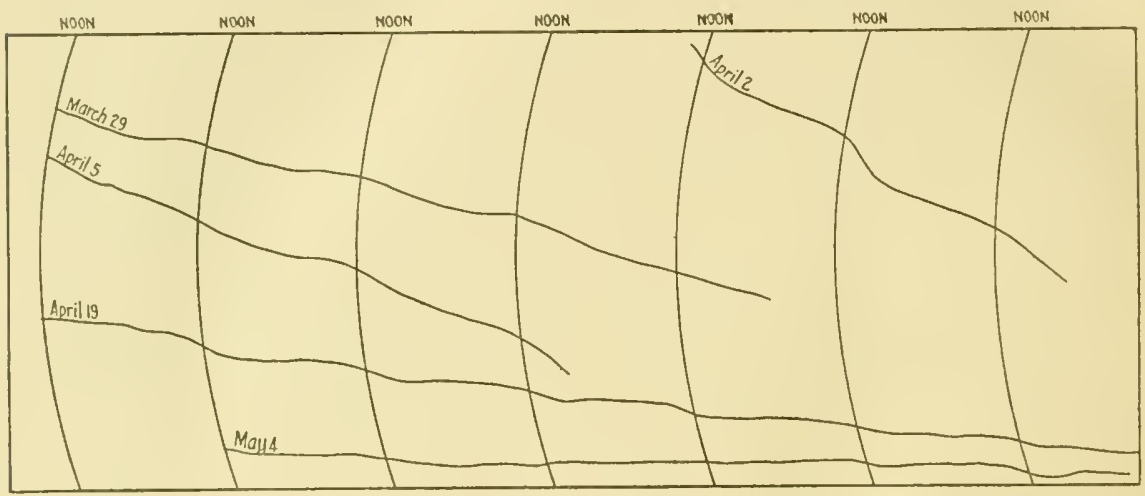

FIG. 3. Auxographic tracings of growth of joint No. 5, of Opuntia Blakeana, X I ${ }^{7}$. Downward movement denotes clongation. The date of beginning of each partial record is given. Thus the record of beginning April 2 extends to the crening of April + . The record for the entire week beginning April is is given.

continued until about midnight, when with a temperature now falling to $70^{\circ} \mathrm{F}$, at $7 \mathrm{~A} . \mathrm{M}$., elongation began, and continued as on the previous day, until mid-afternoon. A behavior of a modified type was presented by the growth of the young bud of Opuntia Blakeana No. I3, a joint which had been rooted in sand and covered with a screen of glass $\left(G_{55} \mathrm{~A}_{62}\right)$, which transmits only the violet rays and the longer red waves, from Norember until it began to develop a bud late in March, I9I5.

April 9, 1915, it was removed to the greenhouse and put in contact with an auxanometer in which the compound lever magnified the motion by 23. From the first the rate of growth was accelerated, beginning at about 9 A.M. and continued at a high rate until about + P.MI. or later. Slackening then occurred and the actual rate decreased until about $8 \mathrm{~A} . \mathrm{M}$. This last-named 
retardation effect became more accentuated with the development of the joint until an actual cessation of growth occurred on the night of May 9 and Io. The retarding conditions from this time became accentuated so that on May i I actual shortening was displayed, and the remainder of the period of observation was made up alternating daylight-elongating phases and nocturnalshortening phases (FIG. 4).

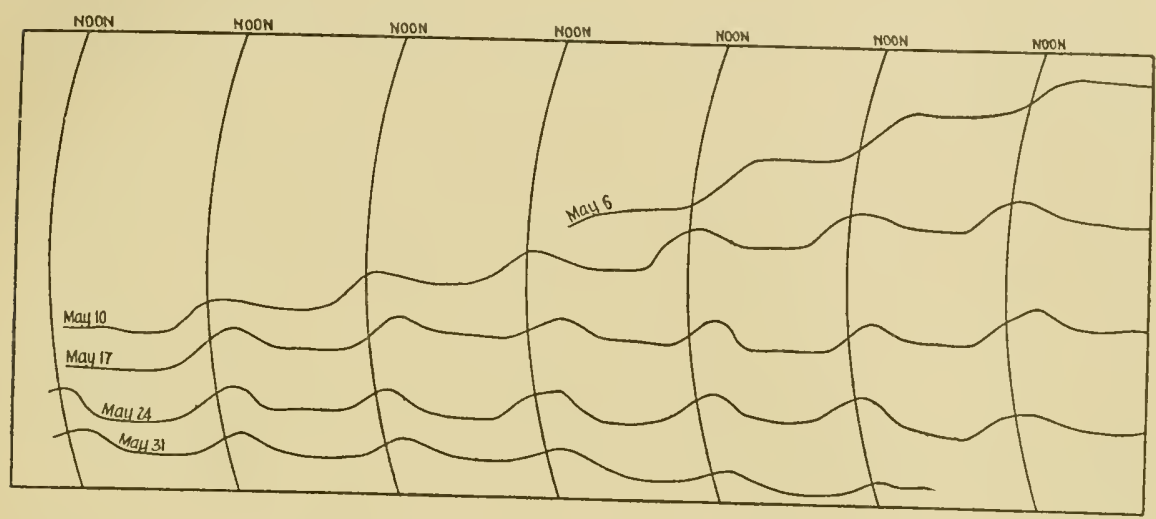

FIG. 4. Auxographic tracing of growth and variations in length of Opuntia Blakeana, No. 13 , for the period month beginning May 6, and ending June 5, I916. Elongation is denoted by upward movement of the pen and the actual change in length is multiplied $9 \frac{3}{7}$ times.

At the time of maximum rate of elongation the daily increase was equivalent to nearly I $\mathrm{mm}$. In the period following, when the daily increase ceasing in mid-afternoon was followed by a decrease in length, the elongation amounted to $.5 \mathrm{~mm}$. daily, and would be followed by a shortening of $.3 \mathrm{~mm}$., leaving a net total growth daily of $.2 \mathrm{~mm}$. This net accretion diminishes with the approaching maturity of the joint. This last-named record was taken during the high temperatures of May.

The three types of change in volume illustrated by these measurements agree in that accelerating elongation coincides with the duration and increasing intensity of illumination in the forenoon and that the continued rise in temperature (within the tonic range) and of the illumination is accompanied by a retardation or a shrinkage in the afternoon.

If we consider the known possibilities in the way of change of volume attention would naturally be turned first to water-loss. 
Thus it might be supposed that the transpiration loss might reach an amount in the afternoon which would result in a condition analogous to wilting. Extensive measurements, however, have shown that the maximum transpiration of these cacti within the ranges of temperature $60-80^{\circ} \mathrm{F}$. occurs during the night period and that it comes down to a minimum during the forenoon at about the time elongation begins to accelerate, and that it does not rise materially until the end of the daylight period.

That the water-balance is actually decreased at night and increased by day has been found by Mrs. E. B. Shreve, who says of a cylindropuntia, " "It was found, under conditions of average transpiration, such as occur in the greenhouse in summer, that the water intake at night is less than the outgo, while during the day the intake is greater than or at least equal to the outgo. ... An examination of the water-content of stems from plants in the open and from the greenhouse showed that the highest water-content is at 5 P.M. after the close of a bright day, and the lowest just before daylight the next morning, with an intermediate amount at noon."

Next there is the swelling capacity of the material of the joints to be considered, with especial relation to the decreasing acidity. It has been well established by the work of Spoehr, Richards, ${ }^{2}$ and Long that the acidity of the sap of these cactus joints decreases steadily throughout the day and reaches its minimum at a varying time late in the afternoon-about two hours after the rate of growth manifests such a remarkable decrease. According to Long's results, ${ }^{3}$ the hydratation capacity of separated living sections increases with the decrease of the acidity during the day, being at its greatest at 5:30 P.M. It is evident therefore that growth elongations do not follow a course parallel to the capacity for distention, whether this be caused by swelling (hydratation) or osmosis and resultant turgidity. The rate of growth is at a minimum or approaching it at a time when the capacity for the tissues for taking up water is greatest, and when they actually contain the highest proportion. Growth in these cacti therefore

1 Rep. Dept. Bot. Rescarch, Carnegie Inst. of Washington, 98, 99. 1915.

${ }^{2}$ Richards, II, M. Acidity and gas interchange in cacti. Publ. Carnegie Inst. of Washington, 110. 209. 1915 .

${ }^{3}$ Long, E. R. Growth and colloid hydratation in cacti. Bot. Craz. 59: $49 \mathrm{I}-497$. 1915. 
is not primarily determined by water-conditions as affected by light either directly, or indirectly by variations of the acidity. Irreversible changes in form and size are intimately and primarily dependent upon the amount and availability of the substances which for lack of a more definitive term may be designated as "building material," and upon its use by respiratory action, as is well evidenced by the fact that the process sustains an intimate relation to temperature, so that great variations in the rate are induced by temperature changes so small as 2 or 3 degrees F. The facts to be taken in to account justify the assumption that the actual building material is derived from accumulated food in a hydrolized condition for example, the velocity of the chemical changes depending directly upon the temperature.

This assumption harmonizes with the repeated observation that growth at the higher temperatures proceeds at rates which soon fall off. If growth took place at a rate governed by the adduction of plastic material no such abrupt acceleration would be possible, while as a matter of fact the rate rises suddenly after a mode similar to the increase in reaction velocities. ${ }^{1}$

Accelerations in rate of growth may be capable of interpretation upon this basis but reaction velocity alone as governed by temperature does not afford an adequate explanation of the slackening and cessation of growth under favorable temperature conditions.

If reaction velocity may not be held to account for a decrease in rate, attention would naturally be turned next to the size of the supply of material and its availability for construction purposes.

The analyses of Richards, Spoehr, and Long show that owing to the type of respiration prevalent in these plants, organic acids accumulate in the cells during the night to a concentration of $\mathrm{N} / 20$ to $\mathrm{N} / \mathrm{IO}$, and their disintegration begins with the dawn and continues throughout the day so that these substances are present in minimum quantity by 4 P.M. The breaking down of these acids includes a web of processes not capable of ready description, but which does not yield substances capable of being used as building material by the plant.

On the other hand, these acids are the partially oxidized waste

${ }^{1}$ For recent measurements, see Lehenbauer, P. A. Growth of maize seedlings in relation to temperature. Physiological Researches I: $247-288$. I9I. 
products of incomplete respiration, and their presence operates to prevent the respiration and use of the sugars as a source of energy and as building material. The slow growth at night may therefore be attributed mainly to high acidity impeding respiration and the higher rate of water-loss would also tend to lessen the possibilities of increase in length and thickness.

The disintegrating action of light on these acids would at some time toward midday bring the acidity down to concentration where its impeding effect on respiration would be largely cancelled and growth would then go on at a rapidly accelerating rate until the supply of accumulating sugars was used up. Such exhaustion of the food-material might occur at any time, but in the cacti generally comes at Tucson two or three hours after midday, after which time construction would be largely from sugars diffusing directly from the photosynthetic tracts. The general features of the daily course of growth show some precession with the adrance of the seasons and the higher temperature and light maxima at Tucson. The auxographs of Opuntia discata made at Carmel under equable conditions also harmonize with the conclusions given above.

The above explanation scems to account in an adecuate manner for the irreversible changes taking place in the growing plant, whether illustrated by the growing bud or by the large joint in its second year and clesignated as "mature" though still capable of some growth. It is evident that coincident with growth and extending throughout the active existence of the stem a scries of reversible changes in size takes place. This is most noticeably exemplified by the case of Opuntia Blakeana No. I3, which had been suljected to light rays of wave length below $.52 \mathrm{mu}$ for four months before growth began. This plant showed extremely rapid accelerations of growth in the forenoon and abrupt slackenings at midclay, which soon ran into shrinkages in length as if the hydratation capacity had been altered, following the failure of the supply of building material (FIG. 4).

This superposition of reversible and irreversible changes makes our problem complex, but by no means insoluble. Furthermore, it is reasonably certain that the two types of change ensue in the thin leaf of wheat and in stems as well as in the cacti used in our experiments, this matcrial, however, offering phenomena in which the phases are thrown into high relief. 
It will be best to take up this phase of the matter at the time of day when growth has come down to a low rate in the afternoon.

If it be assumed that a slackening does ensue by reason of the practical exhaustion of the reserve supply of material it would then be seen at once that construction might proceed only at the expense of photosynthetic products diffusing directly from the chlorophyllous layer to the enlarging tracts. The disproportion of the growing mass to the chlorophyll layer in a cactus joint is so great that it might readily be seen that growth may not be supported for any extencled period or to any great extent at the expense of coincident photosynthesis. It has long been known that rapidly extending organs such as leaves may not be built up by material derived from their own reducing processes.

The enlargement of a joint having been carried through the earlier part of the day by actual construction and continued late in the afternoon by increased swelling power of the deacidified tissues, would decrease and come to zero with the falling temperature of evening, and this effect may even be carried so far that the capacity of the colloids might be reduced below the amount acquired at the high afternoon temperatures and some water might be actually extruded. So much for the direct temperature effects. The indirect effects may be quite as large or important. The absence of light and the failure of its disintegrating effects, together with the low temperature, would result in an increased accumulation of acids reaching a maximum at daybreak, and this increase would also lessen water-holding capacity and osmotic pressure with the result that all forms of distensive action would be lessened, cancelled or reversed, tending to check elongation or to produce actual shortening. This ready yielding of water resultant from the above action would, it seems, facilitate waterloss to some extent, and that it does so is suggested by the apparent coincidence of low hydratation capacity and high transpiration rate. It may be well to emphasize the fact that a joint of a cactus, a simple stem, or the still more rudimentary Phycomyces sporangiophores are not homogeneous as to chemical composition or simple as to mechanical qualities. The agents affecting hydratation may not cause identical effects in cell-wall, in protoplast, and in accessory slimes or mucilages. When such dissimilarly reacting elements are mechanically bound together as in the stem, the resultant change in volume may not be easily analyzed. 
In recapitulation it is to be said that the auxographic record of a plant is a resultant of its reversible and irreversible changes in form.

The permanent changes in the cactus dependent largely on its type of respiration take place in the day time when the accumulated acids are disintegrated by the action of light, and growth continues at the expense of the available sugars until the balance or supply is reduced to a minimum. Reversible changes in form rest upon water-holding capacity and the distensive action of osmotic and hydration pressure. Temporary enlargements cumulate with decreasing acidity and decreases or shrinkages follow falling temperatures and heightened acidity, being coincident in some cases with maximum transpiration. With this interpretation of the auxographic record accepted, it is now possible to proceed with a general summary of the relation of temperature and light to the processes under discussion. The facts already presented tend to show that temperature influences the diffusion of food-material at a low simple ratio, that food-formation, hycholysis, and the formation of building material take place under van't Hoff's law, and as temperature also affects osmotic pressure, permeability, and hydratation capacity, it is the doninating agency in determining the course, rate, and consequently the final amount of growth. It may have supra-optimal, as well as minimum effects.

Light, especially the shorter wave-lengths, exerts a neutralizing or coagulatory action on many of the colloids of the protoplast, but as such radliations have the least penetrating power, this action is most marked in the minute organisms, or in those with translucent membranes or outer integuments. It is in accord with these facts that the action of enzymes may be retarded by light of certain wave-length and intensity, and also that stems developing in the illumination of a mercury vapor are lamp show grotesque departures from the normal form. There seems to be a marked specificity of the wave-kength upon the relative development of various tracts, but these morphogenic effects may be dealt with in another paper. How far "permeability" as dependent upon the relations of disperse phase and disperse medium of protoplasm may be affected by light is not yet clear. It is clear however that the disintegration of clogging or smothering 
acids which retard respiration and growth and lessen hydratation capacity is a process which may affect the rate and amount of growth in a very important manner.

Since these various effects may be widely variant with the mechanical structure and composition of the plant there is the amplest confirmation of my own generalization made fourteen years since that the "action of light upon grow th is not invariable." The most recent confirmation of this conclusion is that of Blaauw, who finds important differences in the "photo-growth reactions" of the sporangiophores of Phycomyces and of hypocotyls of Helianthus. The considerations presented in the foregoing paper would make a similarity of response between two organs of such unlike structure highly improbable.

The more important suggestions, inferences, and conclusions arising from the work described above may be briefly re-stated as follows:

I. The joints or segments of platyopuntias accomplish nearly all their total enlargement during sixty to one hundred days of the initial season in the Tucson climate. Enlargement and secondary growth may take place as determined by branching and environic factors, in succeeding seasons.

2. The changes in volume of joints in the second or succeeding seasons include daily reversible alterations amounting to $\mathrm{I} / 250$ of the total length.

3. Reversible enlargement begins in mid-forenoon and continues until afternoon, when contraction ensues and with various modifications may continue until the following morning, daily.

4. Reversible daily elongations of $6 \mathrm{~mm}$. were recorded and irreversible growth elongations of ten to twenty times this amount were recorded.

5. Elongation takes place during the daylight period, accompanied by decreasing acidity and lessened transpiration. The maximum rate occurs about mid-day. Decrease in rate takes place after mid-day, while the air temperature is still of optimal intensity and the plant has the highest water content.

6. Reversible changes in mature joints synchronize with growth of young joints, but the extent to which the reversible changes enter into or accompany growth has not yet been determined.

7. The general features of the daily growth record suggest that 
enlargement takes place after smothering or clogging acids have been broken down and that it ceases when the supply of "building material " is reduced to a minimum.

8. The action of light on growth has been considered only with reference to its disintegrating effects on acids, and as affecting transpiration and air-temperature. The direct action of light on protoplasts and on body temperatures will be discussed in a later paper.

\section{Explanation of plate I}

Group of auxographs recording variations in volume of Opuntia discata. A joint of this plant growing as a water culture at the left. Desert Laboratory. 


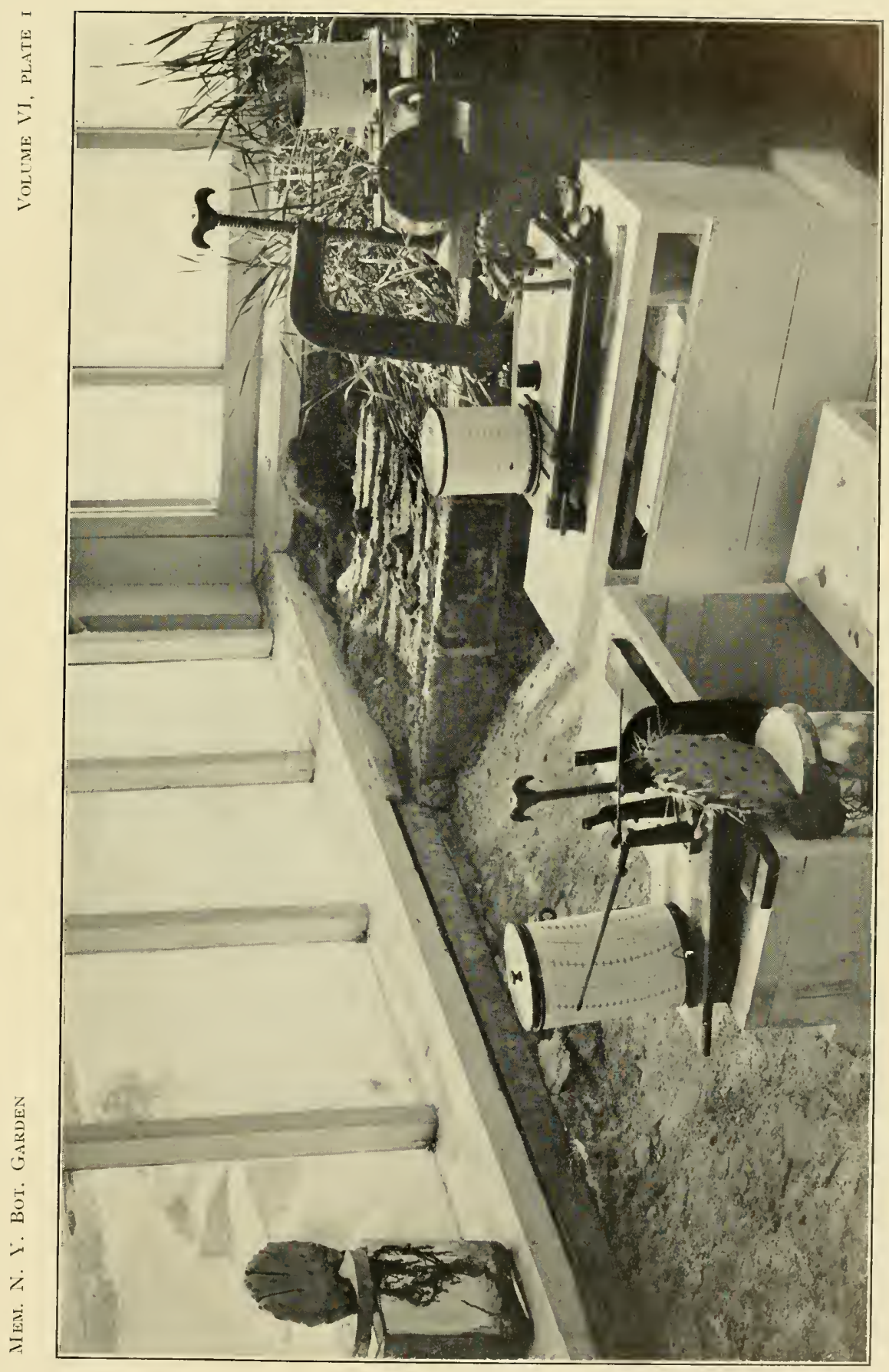

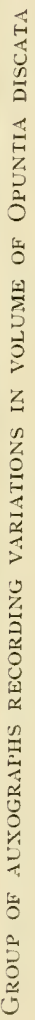





\title{
ARE TETRACENTRON, TROCHODENDRON, AND DRIMYS SPECIALIZED OR PRIMITIVE TYPES?
}

\author{
W. P. Thompson and I. W. Bailey \\ University of Saskatchewan \\ Bussey Institution, Harvard University
}

(WITH PLATES 2-4)

The presence of vessels in the xylem of Angiosperms and their absence in that of the Gymnosperms is one of the striking differences between these two great groups of plants. The taxonomic significance of the absence of vessels in Gymnosperms is likely to be emphasized by the work of Lignier and Tison upon Welwitschia, and that of Thompson upon Gnetum, which indicates that the Gnetales belong in the former rather than in the later group. This raises the question, are there, among living Angiosperms, forms that have retained the primitive, Gymnosperm vesselless type of structure?

Among the Ranales there are four well-established genera, Tetracentron, Trochodendron, Drimys, and Zygogynum, that, owing to the simplicity of their xylem, have been compared with the Conifers. In I $8+2$ Goeppert noted the absence of vessels in the xylem of Drimys, and his observation has since been confirmed by a number of botanists, notably by Solereder and Van Tieghem. Absence of vessels has also been recorded in Tetracentron, Trochodendron, and Zygogynum by Eichler, Harms, Van Tieghem, Solereder, and others. Opposed to the observations of these investigators are the statements of Parmentier, that vessels occur in Trochodendron and two species of Drimys. However, it has subsequently been shown by Van Tieghem that Parmentier's socalled Drimys Muelleri and $D$. vascularis were wrongly identified, and undoubtedly do not belong in the genus Drimys.

More recently, Holden ${ }^{1}$ has advanced the idea that the Magnoliaceae are forms that have become specialized through reduction, and, therefore, are not primitive as has been considered probable by a number of botanists and geologists.

${ }^{1}$ Holden, R. Reduction and reversion in North American Salicales. Ann. Bot. 26: I7I. I9I2. 
The evidence, adranced in faror of this view, may be bricfly summarized as follows: Diffuse ${ }^{1}$ wood-parenchyma is primitive, since it occurs in many Gymnosperms and in the Casuarinaceae, Fagaceae, Betulaceae, Juglandaceae, and Rosaceae. Vasicentric ${ }^{2}$ mood-parenchyma is a derived and more recent type, since it occurs in the highest Angiosperms, the Oleaceae, Ulmaceae, Leguminosae, Compositae, etc. In the Salicaceae and Magnoliaceae the parenchyma is usually terminal, ${ }^{3}$ but may be vasicentric in roots, young stems, and traumatic tissue. Interpreted in the light of the "laws of recapitulation, reversion, and retention," these facts show terminal wood-parenchyma to have been derived from vasicentric. Therefore, the Salicaceae and Magnoliaceae are specialized families that have originated by "reduction" from adranced types of Angiosperms.

There are, however, important objections to this type of reasoning. Even if it be admitted that laws of recapitulation, reversion, and retention can be formulated, it is extremely difficult to apply them logically in phylogenetic discussions, since frequently no reliable evidence is available to show whether a given character in a given region is cenogenetic or truly palingenetic. This would be very likely to be the case in clealing with parenchyma, cells that function in storage and other physiological processes, and are particularly sensitive to the effects of environment. Furthermore, it is by no means certain that, because a selected character is "progressive" or "regressive," a group of plants, the sums of all characters, are moving in a similar direction. Thus, even if it be granted that the simple flowers of the Amentiferae are primitive (not reduced, as is held to be the case by many botanists), and that the Magnoliaceae formerly possessed vasicentric wood-parenchyma, it does not necessarily follow that all characters in the former group are primitive and that Tetracentron and Drimy's once possesserl vessels and have lost them.

In view of these facts, the writers decided to study the Magnoliaceac and allied families in the endearor to secure evidence that might indicate whether these families have become specialized through reluction or have retained a number of truly primitive characters. In the following pages are summarized the results

\footnotetext{
I Scattererl among the tracheids or filer tracheids.

2 Clustcrerl about the vessels.

${ }^{3}$ Confined to the end of the year's growth.
} 
of our observations upon the xylem of Tetracentron, Trochodendron, and Drimys.

FIG. I is a photomicrograph of a transverse section of a two year old stem of Ginkgo biloba L., and illustrates the typical resselless xylem of Gymnosperms, which is in marked contrast to that of the Angiosperms, shown in FIG. 5, a transverse section of a young stem of Schizandra chinensis Koch. This difference in xylem structure is clearly illustrated in FIGs. 6 and Io, more highly magnified transverse sections of Pinus palustris Mill. and Swieteria Mahagoni Jacq.

FIG. 4 is a photomicrograph of a transverse section of a young stem of Tetracentron sinense Oliver. The xylem of the central cylinder and leaf traces is composed of radial rows of tracheids, and vessels are entirely absent. Similar xylem, which is even more typically coniferous, is shown in FIG. 2, a cross section of a young root of the same species.

FIG. 3 illustrates the characteristically coniferous structure of a seven year old stem of Trochodendron aralioides Sieb. \& Zucc. and FIG. 7 shows, under higher magnification, part of an annual ring of the mature wood of this species. The differentiation of the xylem into thin-walled "spring" tracheids and thick-walled "summer" tracheids closely resembles that of many Conifers (compare FIG. 6).

The entire absence of vessels in Tetracentron and Trochodendron, in regions ${ }^{1}$ that are supposed to be conservative of ancestral characters, is clearly illustrated in FIGS. $2,3,4,8$, I I, I2. In fact, the writers have been unable to find vessels or vestiges of vessels in Tetracentron, Trochodendron, Drimys Winteri Forst., $D$. colorata Raoul, and $D$. axillaris Forst.

Not only are vessels absent in the xylem of these plants, but the tracheids are typically coniferous in form, structure, and general arrangement. Thus the bordered pits, as in the case of the Gymnosperms, vary considerably in form and arrangement. Scattered circular pits, the commonest coniferous type, occur in the thick-walled tracheids of the summerwood of Tetracentron and Trochodendron, and in many of the tracheids of Drimys. In the large thin-walled spring tracheids of the former genera and in the tracheids of certain species of Drimys the bordered pits

\footnotetext{
¿ Root, seedling, young stem, node, leaf, etc.
} 
are crowded and much elongated (FIG. I4) resembling those which occur in a number of extinct Conifers, $c$. g., Xenoxylon latiporosum (Cram.) Gothan. Multiseriate pitting of the araucarian type of arrangement occurs in Drimys axillaris and $D$. coloratu, particularly in the wood of the roots. Araucarian pitting also occurs in Tetracentron, in large, short tracheids that are to be found just below the nodes. These tracheids (FIGS. I5 and I6) unlike the majority of the tracheids, are abundantly pitted on their tangential as well as their radial walls, and appear to function in facilitating a rapid raclial flow of water to the "entering" traces of the leaves and rootlets.

Particularly significant, however, is the distribution of woodparenchyma in Tetracentron, Trochodendron, and Drimys. In the first two genera and in Drimys Winteri it is diffuse. In Tetracentron and Trochodendron the parenchyma is abundant and scattered throughout the thick-walled tracheids of the summerwood (FIGS. 7 and I3), whereas in Drimys Winteri it is usually much reduced in amount. In Drimys colorata (FIG. 9) and $D$. axillaris diffuse parenchyma with transitions to terminal and banded types occurs in the stem and root.

If these facts are interpreted from the point of view of the socalled laws of recapitulation, reversion, and retention, and Holden's hypothesis in regard to the taxonomic and phylogenetic significance of the distribution of wood-parenchyma, it is evident that Tetracentron, Trochodendron, and Drimy's must be considered to be primitive types of Angiosperms, since they possess diffuse parenchyma and do not show restiges of ressels in the root, seedling, node, leaf, and other supposedly conservative regions.

There seems to be no evidence, therefore, to indicate that Tetracentron, Trochodendron, and Drimys once possessed ressels and have lost them. In fact, all the evidence at hand seems to indicate that these genera have retained a number of ancestral Gymnosperm characters. As will be shown in a subsequent paper, the Nagnoliaceae and allied families are extremely variable in their external and internal characters, and show numerous transitions from apparently primitive to advanced and highly specialized types of structures. This is true of the flower, leaf, node, xylem, phloem, cortex, etc. It appears, accordingly, to be highly improbable that the members of this group are forms that 
have been "reduced" from advanced and more complex types of Angiosperms.

\section{SUMMARY AND CONCLUSIONS}

Vessels are entirely absent in the secondary xylem of Tetracentron, Trochodendron, Drimys colorata, D. axillaris, and D. Winteri.

Vestiges of vessels do not occur in the root, seedling, young stem, node, petiole, traumatic tissue, and other regions that have been considered to be retentive of ancestral characters.

The form, structure, and arrangement of the tracheids of the xylem closely resembles that of the Gymnosperms and there seems to be no valid reason for not considering the three genera primitive as far as their xylem structure is concerned.

The wood-parenchyma is diffuse in Tetracentron, Trochodendron, and Drimys Winteri. In D. colorata and $D$. axillaris it shows transitions from diffuse to banded and terminal.

The distribution of parenchyma in these three genera makes it seem improbable that the terminal parenchyma of the Magnoliaceae originated through reduction from the vasicentric condition.

There appears to be no reliable evidence to indicate that the Magnoliaceae and allied families are forms that have become highly specialized through reduction from advanced types of Angiosperms.

In conclusion the writers wish to express to Mr. E. H. Wilson their sincere thanks for material of Trochodendron aralioides, and to Professors A. J. Eames and E. W. Sinnott for material of Drimys colorata and $D$. axillaris.

\section{Explanation of plates 2-4}

FIG. I. Ginkgo biloba, transverse section of two year old stem, $\times 13$.

FIG. 2. Tetracentron sinense, transverse section of four year old root, $X$ i 8 .

FIG. 3. Trochodendron aralioides, transverse section of seven year old stem, $X$ I I.

FIG. 4. Tetracentron sinense, transverse section through nodal region of a young stem, $\times 23$.

FIG. 5. Schizandra chinensis, transverse section of young stem, $X$ I6.

FIG. 6. Pinus palustris, transverse section of mature wood, $\times 50$.

FIG. 7. Trochodendron aralioides, transverse section of mature wood, $\times$ to.

FIG. 8. Trochodendron aralioides, transverse section of seedling stem, $\times 60$.

FIG. 9. Drimys colorata, transverse section of stem, $X$ I IO.

FIG. Io. Swietenia Mahagoni, transverse section of mature wood, $\times 30$.

FIG. II. Tetracentron sinense, transverse section of petiole, $\times 20$.

FIG. I2. Trochodendron aralioides, transverse section at base of leaf, $\times 25$. 
FIG. 13. Trochodendron aralioides, longitudinal radial section through summerwood, showing diffuse parenchyma, $\times 300$.

FIG. I4. Trochodendron aralioides, longitudinal radial section through the springwood and a small portion of the summer-wood, $\times 250$.

FIG. I5. Tetracentron sinense, longitudinal tangential section of stem, showing lateral leaf-trace and sulbtending tracheids, $\times 45$.

FIG. 16. Tetracentron sinense, longitudinal tangential section through the short tracheids below entering leaf-trace, $\times 100$.

FIG. 17. Tetracentron sinense, transverse section of phloem, showing two companion cells, $\times 600$. 


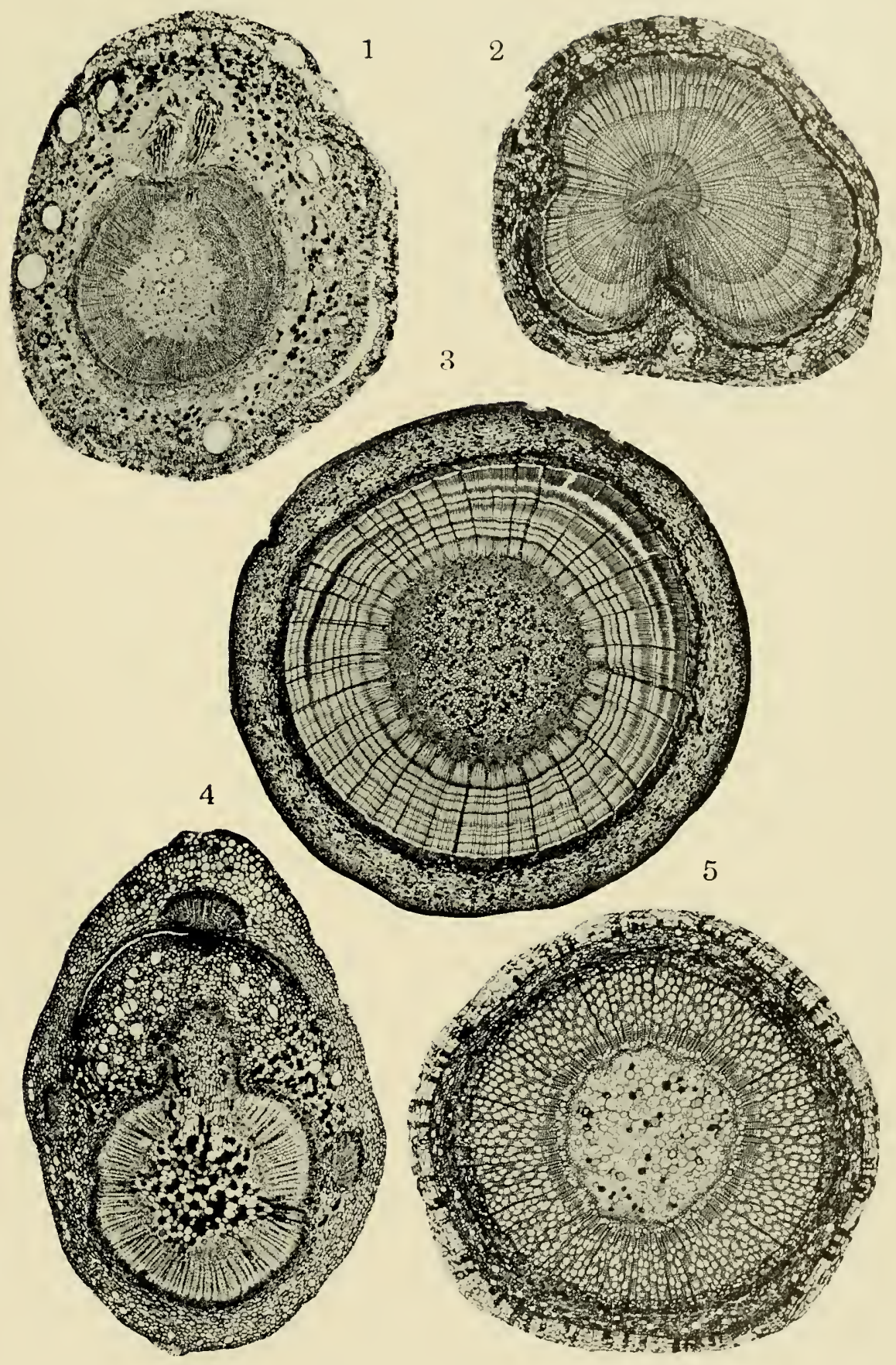

ThOMPSON AND BaIley: TetraCENTRON, EtC. 


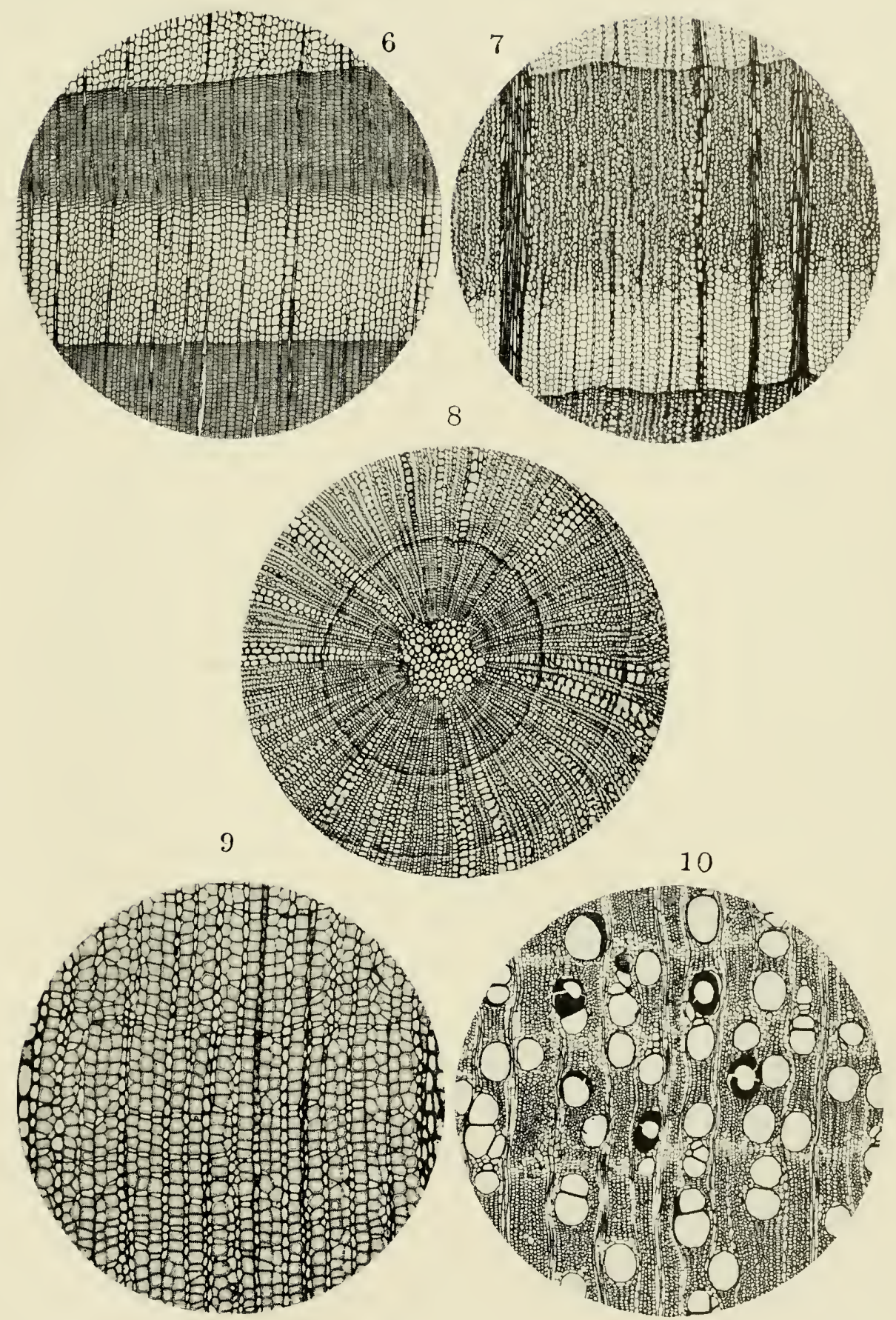

ThOMPSON AND BaIley: TETRACENTRON, EtC. 


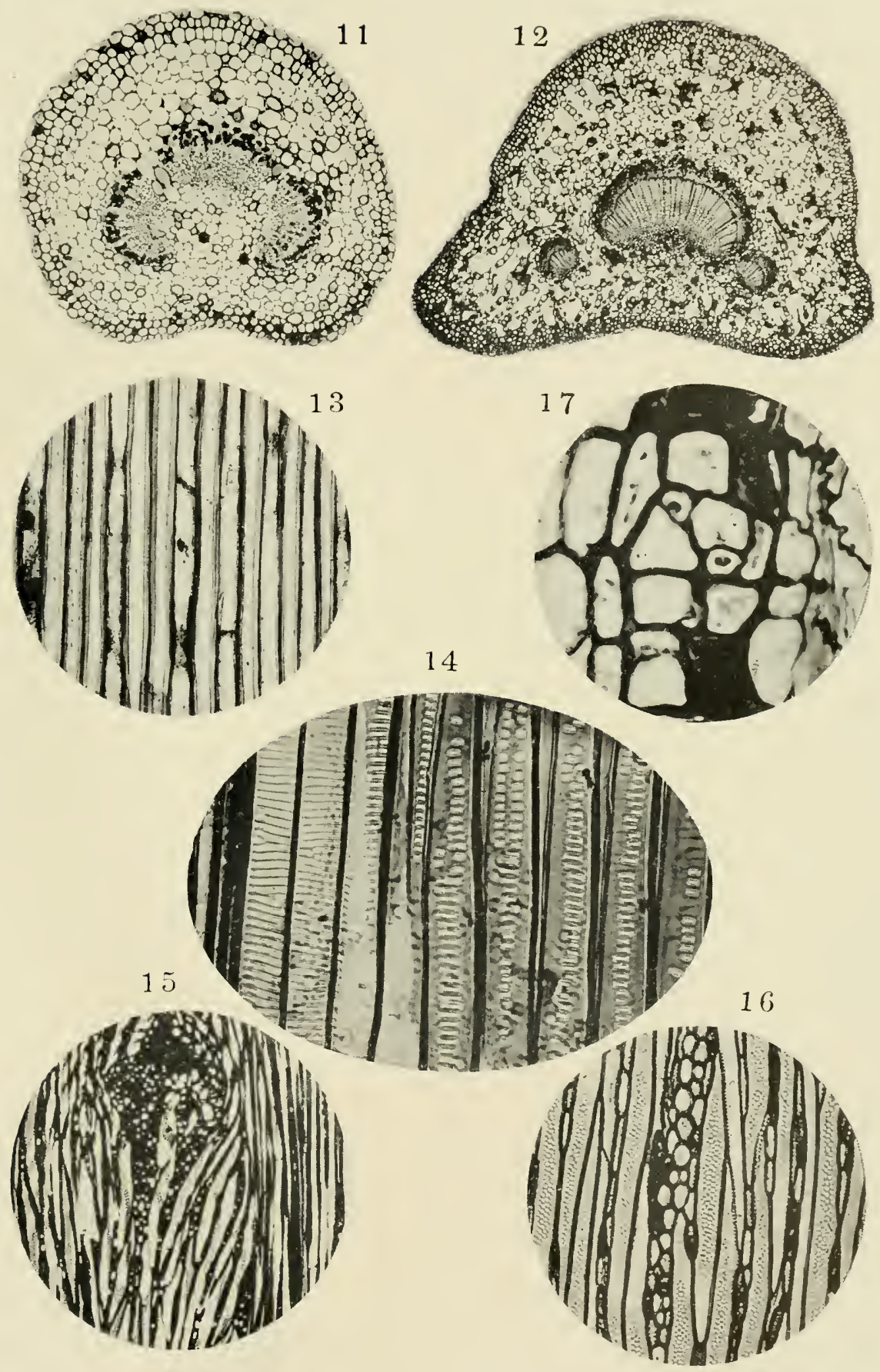

THOMPSON AND BAILEX: TETRACENTRON, ETC. 



\title{
DIRECTING FACTORS IN THE TEACHING OF BOTANY
}

\author{
Arthur H. Chivers \\ Dartmouth College
}

In studying the program for this anniversary it has occurred to me that the subject I have chosen may seem somewhat out of place in these meetings, since it savors of pedagogy, and offers no indication of research into the field of botany. It is my intention, however, to avoid an extended philosophical discussion, to which my subject might easily lead, and to speak as briefly as possible of the problems which have impressed me very deeply during my career as a teacher of college botany, and of certain possible factors which may serve as guides in the solution of these problems. And I have ventured this with greater courage since I believe that they are problems, in the nature of real dangers, which concern us all, whether we are at work in the direction and maintenance of a botanical garden, or in the teaching of botany in our public schools, colleges, and universities, or in the various branches of applied botany.

The greatest problem which endangers botany today is the tendency to commercialize its product. We hear a great deal of talk to the effect that this is an extremely practical age in which we are living. If any one doubts this statement let him teach in an American college for a sufficient length of time to learn the attitude of the typical undergraduate student. Nowhere do we feel the tremendous pressure away from the theoretical and toward the utilitarian more than in our colleges, and especially is this true in those institutions which are able to attract students into continuous courses of study through well-equipped affiliated schools of a graduate nature. The results obtained in the botanical department of one of our well-known New England colleges during the last nine years may be cited as evidence for the truth of my statement. During this period more than twenty-five 
hundred men completed the beginning course in botany. Of those who continued the work in the higher courses by far the largest number entered schools of sanitary enginecring, agriculture, landscape architecture, and forestry, while those contented to continue in purely botanical work were few indeed. It is probably not far from the truth to say that 99 per cent. of the men who completed the work of the department during those nine years represented a commercialized product.

From this eagerness of the undergraduate to turn botanical training into dollars and cents has come a constant pressure to shift our standard, and to revise our courses, introducing the practical as we chose to call it, and thus making our courses interesting. Nuch of our college work, therefore, has become an hotchpotch of commercial, and a smattering of foundational, botany.

As a guiding factor to this tendency I would make an appeal for a strong and vigorous training in scientific botany in our colleges. During the last few years, for reasons already indicated, I have experienced a strong and growing pressure to introduce more and more work of a practical nature into the beginning courses, but thus far at least I have persistently held to my idea of what a foundational course ought to be, namely; a thorough training in the morphology of as many representatives as possible from the great groups of plants, together with a limited discussion of their economic importance and their physiology. There is no more excellent road for the beginner to a good knowledge of the seed plants than the complete mastery of such a text as Gray's Structural Botany, followed by a thorough drill in analysis.

Let no one suppose that I am inclined to discourage the prospective landscape architect, or the scientific agriculturalist, or the sanitary engineer, or that I do not appreciate the splendid work which the various branches of applied botany have accomplished in recent years. But $I$ do insist that men so trained are not in any way to be classified as botanists, that their work is not botany, and that the science must be protected against the tremendous pressure of the college student who is all too willing to plunge directly into commercial botany, before any adequate foundation has been laicl.

The second problem to which botanists should derote greater 
attention is the teaching in our public schools. Too long the theory has been held by those responsible for such work, that any teacher not otherwise fully occupied should be capable of handling the botany. The high school of one of our well-known New England cities recently handed over the botany and zoölogy to a classmate of mine who, during his college course, had received no training in these sciences. His inquiries regarding the best method for preparing himself, in two months, to teach these subjects, were to me no less than pathetic. I have no doubt that on inspection we might find many teachers explaining the anatomy of the dandelion head as that of a single flower, and the columella of bread mold as arising from a cross wall, which, by a process of bulging, arrives at its final position in the sporangium.

That the teaching of botany of the present day is of a better character than formerly we are all willing to admit, but there is still some opportunity for improvement in some of our schools, and great need for improvement in others. Greater care and wisdom must be exercised in the appointment of teachers, and just as far as possible those should be chosen who not only have mastered the elements of botany, but have, by virtue of a broad and deep training, an appreciation for more of the subject than the mere minimum requirement of the class room.

The third problem which botany has been obliged to face in the last few years is that of nature study. Every one must be aware that the science has suffered at the hands of those who have pleased to popularize botany at any cost, and at times even to sacrifice truth. As a result the ugly but somewhat merited name of nature-faker has arisen. Teachers of the general public and of students in our public schools have deceived themselves in the thought that knowledge is to be acquired by play, not work; that the child who makes a conventionalized drawing of a butterfly is mastering a lesson in zoölogy, when in reality he is receiving instruction in art or free-hand drawing; that the boys and girls who plant beet seeds in the school garden are acquiring botanical knowledge at the same time that they are receiving an elementary lesson in agriculture.

I believe the botanical garden and museum, if wisely directed and carefully arranged, may have a strong correcting influence upon those who tend to misinterpret, wilfully or otherwise, natural 
laws. Nature if left to itself provides for us a botanical garden but with a very awkward arrangement. She seldom classifies, points out or directs. People look with satisfaction on a host of varied plants of which such a natural garden is made up, but with enjoyment only. No information is offered and little or no accurate knowledge is obtained. You who are able to present to the general public such an extraordinary garden, in which the visitors young and old alike are made acquainted with a most remarkable collection of plants, should consider yourselves as foremost among the teachers of botany, and your effort represents no small directing factor in the dissemination of accurate information about plants.

In passing I feel that I must call the attention of those concerned to the fact that many of my students have spoken with peculiar interest of their visits to the New York botanical and zoölogical gardens. To be sure, weird plants and animals have often been described to me-products of a fading memory and active imagination-but they are none the less indicative of the real interest excited in the visitor.

Finally, the methods employed in, and the conditions attendant upon, graduate instruction and research present real problems, and, in order that we may properly train the interested student in advanced work so that we may have a steady procession of competent botanists, and thus assure ourselves of the permanency of the science, I believe we must turn more attention toward these problems. I have time only to mention them here.

The graduate student is peculiarly sensitive to the conditions attendant upon his work. A spirit of harmony among the members of the department in which he labors inspires him with confidence and enthusiasm, while on the other hand the evil effects of contention and ultra-individualism are sooner or later to be reflected in the graduate product.

There is need for a greater spirit of coöperation among investigators. We are too prone to look with pity from our field of activity over to those who may be working as fertile a soil but with different results.

There is need also for more thorough organization in botanical research. Probably no one of us has escaped the experience of reading articles from the pen of another author, which contain 
results identical with our own. Two have devoted their attention to one problem. The time of one has been almost or entirely wasted, and his work has been discounted. There is no doubt that some of this confusion may be assigned to plagiarism, but by far the greater part is due to a lack of intelligent organization among researchers. Many of us have come to look with suspicion upon our neighbor, and to conceal our product until we are entirely certain that no man can borrow it. Of what advantage it would be to the science if each and every person engaged in botanical research could have access to some common source of information which should indicate the field of activities of the individual. Then theft would be in the nature of an inexcusable misdemeanor, and our attitude one toward another would rapidly change.

In concluding I may say that I am convinced that botany is on trial at the present time in our educational system. It is a comparatively young subject and has not as yet arrived at a well-developed stature. Whether or not it will succeed is open to serious question. IVe are told by some that botany will prosper in so far as it is able to show its relation to the various branches of industry. On the contrary I believe it will fail if this be our shibboleth. The success of any subject cannot be measured by the number of dollars and cents it can earn.

IVe have seen in recent years the decline of the study of Greek and Latin, the reason most frequently given being that these subjects have had no relation to the practical affairs of life. This fallen position I venture to say is not permanent, and if we will look into the future beyond this money-getting age we shall find Greek and Latin restored to their proper position in our educational system. The restoration will be not on account of their commercial value, but their importance per se.

It seems highly possible that botany may experience a similar downfall unless those who have the interests of the science at heart are willing to devote time and attention sufficient to guide its progress. I believe the most potent guiding factors are those which I have already attempted to point out: intelligent and accurate instruction in our public schools; well-equipped botanical gardens and museums; strong courses in foundational botany in our colleges; a hearty spirit of coöperation in our graduate departments; thorough organization in the field of research. 



\title{
SEGREGATION OF GENERA IN LENTIBULARIACEAE
}

\author{
JoHN HENDLEY BARNHART \\ The New York Botanical Garden
}

The true bladderworts seem to have been overlooked by the earlier botanists. All are small herbs; the European ones are aquatics (a sadly neglected class of plants); and none are of the slightest economic importance. Their discovery may be placed with much definiteness in the last quarter of the sixteenth century, for the species now. known as Utricularia vulgaris was described and illustrated in the German edition of Lobel's herbal, in I 58I, although it was not mentioned in the Latin edition published five years earlier, in 1576 . It may be remarked in passing that Lobel's crude wood-cut of $\mathrm{I} 58 \mathrm{I}$ is an excellent habit-sketch of the plant; better, in fact, than any known to me in the numerous elaborately illustrated works of the three following centuries. Six years later, in 1587 , was published the name Lentibularia of Gesner, derived from the lentil-like bladders overlooked by Lobel.

During the next century and a half the genus received scant attention. A second European species, now known as Utricularia minor, was distinguished, and Linnaeus, at the end of this period, in 1737 , changed the name of the genus to Utricularia; but in I753, when he first used uniformly binary names, he recognized only seven species. These agreed in having two stamens, a single pistil, a two-parted calyx, a gamopetalous corolla with a palate and spur, a one-celled ovary and capsule, and a free-central placenta. And from that day to this, nearly every botanical taxonomist has referred to Utricularia all plants possessing the characters just mentioned, no matter how diverse they might be in other respects nor how incongruous the result.

When I began to devote particular attention to this group of plants, some years ago, it was soon manifest to me that their classification was in the utmost confusion. Herbarium material 
is often fragmentary, and no real progress was made until it was discorered that certain of the more persistent structures could be clearly correlated with the more delicate ones; so that, for instance, it became possible in the absence of corollas to identify material which without such correlation was not determinable. In my arrangement of these plants I have emphasized what might be termed "vegetative" parts of the inflorescence, but this is because the characters drawn from these are readily demonstrable, while correlated characters drawn from the flowers and fruit are just as striking but more difficult to utilize in the study of herbarium material. The characteristic corolla-forms, too, are complicated, and of ten when the type is recognizable at a glance, verbal description proves very elusive, and can not be succinct.

If my efforts shall aid in bringing order out of the present chaos, it makes little difference to me what rank, whether generic or subgeneric, is accorded to the groups I have come to recognize as natural ones. For me the current genus Utricularia comprises more than a dozen perfectly well-defined genera; but my aim is to show that the groups exist in nature, not to quarrel with anyone about what they shall be called.

A few words may not be out of place concerning those genera of Lentibulariaceae that have hitherto been distinguished from Utricularia. The most unrelated of these is Pinguicula. The European species of the two genera are so different in appearance that their affinity does not seem to have been recognized until they were brought together in the Linnaean artificial system; then it became evident that the characters possessed by them in common were not purely accidental, but of a fundamental nature. Extension of our knowledge of the species of the world, however, has in so far broken down the distinctions between Pinguicula and the rest of the family, that I know of only two characters that can be depended upon to distinguish this genus from the others. One of these, purely regetative, is the possession of true roots, not otherwise known in the Lentibulariaceae; in the other genera, however, other organs, sometimes leaves, sometimes stems, mimic roots so successfully that it is not always easy to prove that they are not what they seem. The other definite character of Pinguicula, while it is found in the inflorescence, does not resicle in either the flower or the fruit, but in the fact that the scapes are always 
one-flowered (except in the rare cases of forking) and are truly simple, being quite devoid of bracts; while in the other genera the compound nature of the scape is always indicated by the presence of at least one bract, even when there is only a single flower.

The species of Pinguicula are remarkably uniform in habit. Four very distinct types of corolla are to be found, and their recognition furnishes an unquestionably natural method for the arrangement of the species; for the present, however, even the iconoclastic treatment here adopted leaves the genus Pinguicula undisturbed.

The genus Genlisea differs from Utricularia as commonly accepted in having the calyx 5-lobed instead of 2-lobed. Each plant bears leaves of three kinds: ordinary foliage-leaves, rootlike subterranean ones, and ascidia of a peculiar type entirely different from any of the bladders found in other genera.

Polypomploolyx is the name that has been most commonly applied to a small Australian genus characterized by four calyxlobes. Two of these are antero-posterior, and are undoubtedly true calyx-lobes; the two others are lateral and internal, and more or less petaloid, and should perhaps be regarded morphologically rather as specialized appendages of the calyx than as true lobes. The genus is here called Cosmiza, a prior name applied by Rafinesque to one of its species, although he knew nothing of the peculiar calyx which furnishes the most distinctive generic character.

The genus Biovularia is based upon a minute plant collected many years ago in Cuba by Charles Wright, and is characterized by two ovules, only one maturing, instead of the usually numerous ovules and seeds of other Lentibulariaceae. It is an instance, it is true, of extreme reduction, and may well be recognized as a valid genus; but its relationship is extremely close with certain species of the genus Utricularia as here restricted, and it is far less entitled to recognition than any of the other segregates here distinguished.

After excluding Pinguicula, Genlisea, Cosmiza, and Biovularia, there is left in the family a vast assemblage of heterogeneous elements hitherto retained in a single genus, Utricularia, which it is here proposed to dismember. The collective genus may be distinguished from the others by the combination of the following 
characters: a compound (bracteate) inflorescence, several or usually numerous orules and sceds, and a persistent 2-parted calyx, so deeply parted that the lobes are often referred to in descriptive works as sepals. In all other characters, such as habit, foliage, inflorescence, corollas, anthers, fruits, and seeds, the utmost diversity prevails.

In segregation, the most useful characters are to be derived from those structures which may be termed collectively the vegetative appendages of the scape, all of them reduced foliar organs, and may be distinguished as scales, bracts, and bractlets. Of these, the bracts alone are invariably present, and of these there is sometimes only one. Each pedicel is axillary to a bract, although when there is only a single flower its pedicel commonly appears like a prolongation of the main axis of the scape, and the rudimentary tip of the latter looks as if it were opposite to the single bract.

The bracts may be either basifixed or basisolute. In the latter case the bract is produced below the point of insertion into a free lobe, more or less similar to and sometimes almost as large as the portion above the point of insertion. At first sight this character, so striking and not known to me outside of this family of plants, ${ }^{1}$ would appear to be of primary importance in any scheme of classification; but the Lentibulariaceae appear to have developed three very distinct types of basisolute bracts, and I have come to regard the structure of the bract as less fundamental than the presence or absence of bractlets.

In one type of basisolute bracts the free base is relatively short, and may be compared to an auriculate base with the auricles meeting below and fused along the line of contact; this type occurs in Meloneura, Pelidnia, and Pleiochasia, and basisolute bractlets always accompany the bracts. In the second type the bracts are almost exactly peltate, the point of insertion being near the middle; it occurs in Avesicaria and Setiscapella, and there are no bractlets. In the third type the free portion consists of a more or less membranous outgrowth, of irregular shape, extending downward like an apron from the transverse line of insertion of the bract; this occurs only in Vesiculina, and while it appears to

\footnotetext{
${ }^{1} \mathrm{~A}$ very similar structure has been described as occurring in Lilunthus, a South African genus of Liliaceae.
} 
be uniformly present in some species and absent in others, there are species in which the free basal portion may be dereloped or not, even in the case of two bracts on the same scape. It is evident, therefore, that this third type of free base is of little taxonomic significance.

The bractlets, when present, are always two to each pedicel, opposite to each other, and lateral with respect to the median bract. In Aranella they are borne distinctly above the base of the very short pedicel, but distinctly below the calyx, and simulate a pair of lateral exterior sepals. In all the other genera in which they occur they are at the base of the pedicel. In most cases they are inserted just above the bract, and more or less enfolded by its base; but in at least one genus they are inserted on the same line with the bract and are commonly more or less coherent with it. There results a single three-lobed bract, but the bractlets always manifest their presence as distinct lateral lobes, and I have never experienced any difficulty in deciding whether a bract was actually without bractlets or had bractlets adnate to it.

Below the lowest bract the scape may be naked, that is, wholly destitute of foliar organs, or may bear appendages for which the word "scale" is in use, and is ordinarily appropriate. In some cases the scales resemble the bracts so closely that one might suppose them to be merely bracts in whose axils the pedicels had failed to develop, but frequently there is a marked contrast between the bracts and the scales. For instance, in Aranella the bracts are basifixed while some or all of the scales are peltate. In many species of Utricularia the so-called scales are developed into large hollow floats, verticillate or subverticillate; indeed, these conspicuous organs suggest themselves at once as a possible basis for generic segregation. A study of the species bearing them shows, however, that they differ from each other more widely than from some of the species without floats, and if the ampulla-bearing species are to be separated from Utricularia, a philosophic treatment will require that they be distributed into several genera rather than kept in one.

The calyx-lobes are usually nearly equal, the most marked inequality occurring in Meloneura, where the upper lobe is much larger and is adnate to the base of the ovary. In texture they are commonly herbaceous, but may be scarious, foliaceous, or even 
petaloid. They may be but slightly enlarged and spreading under the capsule or appressed to it, or markedly accrescent and completely enclosing it, or even extending far beyond it like a pair of valves.

The corolla is always strongly two-lipped, and spurred or rarely only saccate at the base of the lower lip, but otherwise show's great diversity. Each genus possesses its own characteristic type of corolla, easily recognized at a glance when one has become familiar with it, but sometimes difficult to define in words. The palate is very different in different genera; two-lobed in some, nearly hemispheric in others, helmet-shaped in Stomoisia; in Calpidisca the limb is strongly reflexed from the aperture of the spur, the palate consisting of a more or less thickened and sometimes toothed ring along the line of reflexion; in Vesiculina the palate is a prominent and divergently two-lobed sac involving essentially the whole of the two lateral lobes of the lower lip; in Lecticula the palate is nearly obsolete and the corolla is almost that of Pinguicula.

One of the noteworthy family characters commonly assigned to the Lentibulariaceae is the possession of one-celled anthers. It is probably true that the anthers are never two-celled with the cells collateral, as is commonly the case in related plants; but throughout the group with bractlets, the anthers are always more or less strongly transiersely constricted and consequently partially if not completely vertically two-celled. This anther-structure deserves special study, particularly from the standpoint of its developmental history. So, too, does the very peculiar antherstructure of a small group of South American species, here referred provisionally to Calpidisca, but probably worthy of generic rank when better understood. In these, there is developed at the summit of the filament a broad horseshoe-shaped membrane, called for want of a better term a "connective," bearing on its inner edge two anther-cells, or perhaps a single strongly constricted one.

The ovary, placenta, and stigma are very similar throughout the family. So also is the capsule, although the method of dehiscence may prove of some value in classification when known for all species. The seeds present great variations, but these are chiefly in the form and markings of the outermost seed-coat. 
Seed-characters have been made use of in so far as present knowledge permits, in the classification here proposed; but no genus has been based exclusively, or even primarily, upon seed-characters, for these differ too strikingly in the case of some plants evidently very closely related. As an example may be mentioned the genus Meloneura, where one species has the seeds with a tuft of simple hairs at each end, while those of the other species bear scattered "glochidiate" (anchor-shaped) hairs, giving the seed an appearance much like the statoblast of the fresh-water bryozoan Cristatella.

In Small's "Flora of Miami" and in the second edition of Britton \& Brown's "Illustrated flora," both published in I9I3, my views upon generic segregation in this family were presented to the botanical public as clearly as the limited scope of those works would permit; but those views were not based upon a study of North American species only, and it has seemed desirable to place on record at least an outline of my more or less tentative scheme of classification for the entire family. I have therefore prepared the present discussion, and append diagnoses of each of the sixteen genera I am now prepared to recognize, with brief notes upon each genus, and a generic key.

\section{CONSPECTUS LENTIBULARIACEARUM}

\section{LENTIBULARIACEAE}

Herbae annuae vel perennes, aquaticae vel terrestres, plerumque hydrophilae. Folia alterna vel conferta vel rosulata, integra vel dissecta, saepe radiciformia, interdum nulla. Inflorescentia scaposa, raro ramosa. Flores solitarii vel racemosi, interdum subspicati, monoclini, zygomorphi. Calyx inferior, gamosepalus, 2-5-lobatus, persistens. Corolla hypogyna, gamopetala, antice calcarata; limbus interdum subaequaliter 5 -lobatus, sed saepissime valde 2-labiatus; labium superius vero ex 2, inferius ex 3 lobis coalitis formatum. Androecium staminibus 2 distinctis ad basin corollae tubi insertis; filamenta plerumque arcuata, saepe praeterea contorta; antherae uniloculares. Gynoecium ovario solitario uniloculare superiore; placenta libera centralis e basi enata; ovula plerumque numerosa raro tantummodo 2; stylus plerumque brevis crassusque, saepe subobsoletus; stigma valde bilabiatum, 
labio anteriore lamelliforme, posteriore multo minore vel obsoleto. Fructus capsularis, plerumque multiseminatus, irregulariter dehiscens vel valvatus vel indehiscens. Semina exendospermica; embryo saepissime haud plane differentiatus.

1. Pinguicula L. Sp. Pl. I7. I753. Herbae scaposae terrestres, radicibus fibrosis. Folia rosulata; ascidia nulla. Scapus nudus, uniflorus, circinatus. Calyx 5-lobatus, plus minus 2-labiatus; labium superius 3-lobatum, inferius 2-lobatum. Corolla 5-lobata, plus minus 2-labiata; labium superius 2-lobatum, inferius 3lobatum; tubus infra saccatus atque in calcar nectariferum contractus. Antherae suloglobosae. Capsula bivalvata. Semina numerosa, oblonga, reticulata.
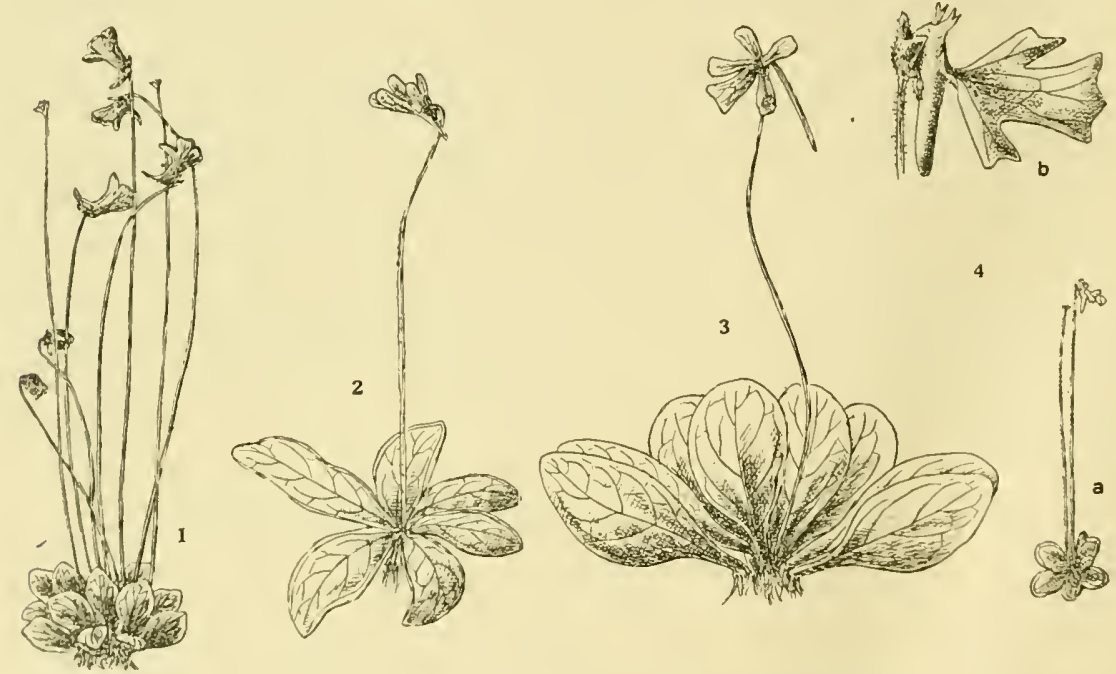

I. Pinguicula subg. Isoloba. P. pumila Michx. Plant, half natural size.

2. Pinguicula subg. Pionopirllum. P. vulgaris L. Plant, half natural size.

3. Pixguicula subg. Orcheosantuus. P. caudata Schlecht. Plant, half natura size.

4. Pinglicula subg. Teminoceras. P. crenatzloba A. DC. a. Plant, half natural size. b. Flower, $\times 3 \frac{1}{2}$.

Species typica, Pinguicula vulgaris L.

About 30 species, widely distributed throughout the northern hemisphere, especially in America, and ranging southward along the Andes to Patagonia.

${ }^{1} \mathrm{All}$ of the figures used to illustrate this paper are from drawings made severil years ago uncler my dircetion by Mr. Auguste Francois Théodore Victor Mariolle, botanical artist for the university of Marseilles, 1892-1901, and for the New York Botanical Critrden, I90I-I I. 
Four marked corolla-types may serve to distinguish as many subgenera, or perhaps genera. Of these, the most distinct is Temnoceras.

A. Isoloba (Raf. pro gen.). Corollae lobi subaequales et subaequaliter divergentes; calcar abrupte contractum et cum tubo angulum validum formans.

B. Pionophyllum A.DC. Corollae limbus obliquus; lobi 2 superiores erectiores et plus minus coaliti, 3 inferiores explanati et plus minus coaliti; tubus in calcar gradatim transiens.

C. Orcheosanthus A.DC. Corolla profunde 5-partita itaque tubo subnullo; calcar pendens, lineare.

D. Temnoceras (subgen. nov.). Corolla profunde bilabiata; labium superius bidentatum, inferius divergente trilobatum; calcar subcylindricum.

Isoloba comprises 4 species in the southeastern United States, and about 6 in tropical America; there is only one in the Old IVorld, the little-known P. lusitanica L. The subgenus Brandonia differs only by its yellow corollas, and seems unworthy of taxonomic recognition. Some of the species of Isoloba have a prominent acicular or even clavate palate, included in the throat, but in other species the palate is much less distinct, while in some it is essentially obsolete.

Pionophyllum comprises about I5 species, mostly European, some of them ranging to the mountains of central Asia and northern Africa, or to the northern parts of North America; while a few are found in tropical America, and one as far south as Patagonia.

Orcheosanthus includes about 6 species, apparently, but future study may show that the number is less, or that the fragmentary material now preserved in herbaria represents a much larger number. The range of variation is enormous, but how much is seasonal, how much individual, and how much of taxonomic importance, is at present mere guesswork. The group is wholly confined to Mexico.

Temnoceras is based upon a single described species, a small one of Mexico and Central America, Pinguicula crenatiloba. Probably it will eventually be segregated into several species, but the material now available is insufficient to accomplish this in a satisfactory manner. The corolla-sinus is so deep that it extends beyond the corolla-base and the lower lip is connected with the upper one only by the spur; hence the name, which signifies cleft spur. 
2. Genlisea St. Hil. V'oy. Distr. Diam. 2: 428. I833. Herbac scaposac terrestres, radicibus veris nullis. Folia suprema aeria, rosulata, laminis expansis, infima subterranea, radiciformia, intermedia ascidia formantia. Ascidia pedunculata, bullata, rostrata tubo cylindrico, laminis 2 divergentibus contortis terminato, intus elaborate armata. Scapus squamatus, bracteatus, uniflorus vel pluriflorus; squamae et bracteae consimiles, basifixae; bracteolae ad basin petioli 2, basifixae. Calyx 5-partitus; lobi subaequales, sub capsula patuli. Corolla 2-labiata; labium superius subintegrum, inferius 3-lobatum. Antherae subglobosae vel oblongae. Capsula globosa, saepe manifeste circumscissa.

Species typica, Genlisea aurea St. Hil.
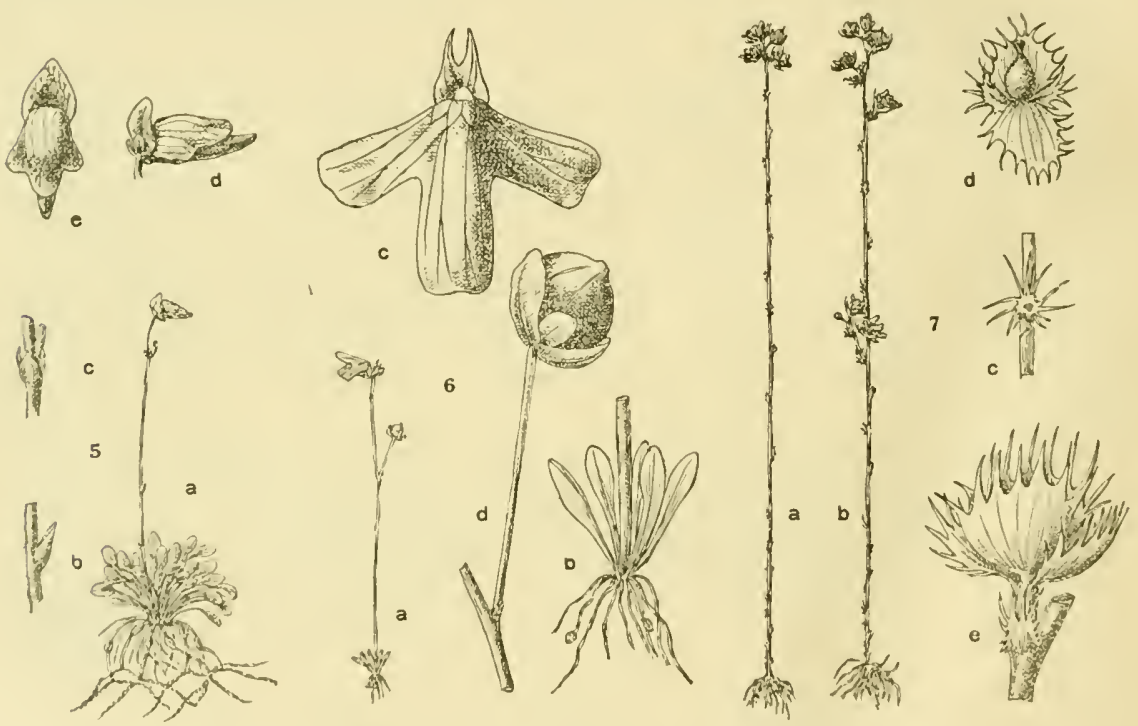

5. Genlisen. G. filiformis St. Hil. a. Plant, half natural size. $b$. Scale, $\times 3 \frac{1}{2}$. c. Bract and bractlets, $\times 3 \frac{1}{2}$. d. Flower, $\times 2$. e. Corolla, $\times 2$.

6. Cosmiza. C. multifida (R. Br.) Barnh. a. l'lant, half natural size. $b$. Base of plant, $\times 2 \frac{1}{2}$. c. Corolla, $\times 2 \frac{1}{2}$. d. Fruit, $\times 3 \frac{1}{2}$.

7. Aranelda. A. fimbriata (H.B.K.) Barnh. $a, b$. Plants, half natural size. c. Scale, $x 8$. d. Flower, with corolla and stamens removed, $X+$. e. Bract, bractlets, and caly $x, \times 8$.

About I 5 species, of which 3 are African, I occurs only in Cuba (where it has never been collected since its discovery by Charles Wright many years ago), and the remainder are South American (Brazil and Guiana).

In a few species (including the type species) the corolla is 
xanthic, in most it is cyanic. The spur is either conic or cylindric, acute or obtuse; it is usually parallel with the lower lip, but in one or two species is pendent.

3. Cosmiza Raf. Fl. Tellur. 4: I Io. I838. (Polypompholyx Lehm. F I 844; Tetralobus DC. Mr I844). Herbae scaposae terrestres, radicibus veris nullis. Folia suprema aeria, rosulata, laminis expansis, infima subterranea, radiciformia, intermedia ascidia formantia. Ascidia pedunculata, bullata, erostrata. Scapus esquamatus, bracteatus, uniflorus vel pluriflorus; bracteae basifixae, minutae; bracteolae 2, consimiles. Calyx 4-partitus, vel forsitan potius 2-partitus cum 2 appendiculis lateralibus interioribus sepaliformibus, sub capsula patulus. Corolla profunde 2-labiata; labium superius parvum, inferius amplum, valde a calcaris apertura reflexum; calcar conicum. Antherae subdiscoideae. Capsula globosa.

Species typica, Cosmiza multifida comb. nov. (Utricularia multifida R. Br.; Cosmiza coccinea Raf.).

This curious genus is limited to western and southern Australia and Tasmania. Australian botanists recognize only 2 species; but the synonymy is large, and if there are actually only 2 valid species they are both astonishingly variable. Careful field-study is much needed; in default of this, I would estimate the probable number of valid species represented in herbaria as 5 or 6 .

4. Aranella Barnh. in Small, Fl. Miami I7I. I9I3. Herbae scaposae terrestres, radicibus veris nullis. Folia rosulata, linearia, saepe fugacia; ascidia nulla (?). Scapus squamatus, bracteatus, uniflorus vel pluriflorus; squamae scariosae, fimbriatae, plerumque peltatae; bracteae consimiles, sed basifixae; bracteolae 2, valde majores, fimbriatae, supra basin pedicelli brevis et prope florem, calyci lobos 2 laterales exteriores simulantes. Calyx genuinus 2-partitus; lobi fimbriati. Corolla valde 2-labiata; labii utrique parvi; calcar conicum, cum labio inferiore parallellum. Antherae sublobatae. Capsula subglobosa.

Species typica, Aranella fimbriata (H. B. K.) Barnh. (Utricularia fimbriata H. B. K.).

This genus is monotypic, the single described species widely distributed in tropical and subtropical America. In size, number of flowers, and number and cutting of the scales, it is variable, and it may be possible to recognize eventually several species. By the blunder of a careless worker nearly 80 years ago, this plant was erroneously referred to the very different genus here called 
Cosmiza; the error has been perpetuated in German botanical literature, and even in Engler \& Prantl's Natürlichen Pflanzenfamilien, in I893, the calyx and bracts of this species (as Polypompholy: laciniata) are figured to illustrate the 4-parted calyx of the Australian genus.

5. Meloneura Raf. F1. Tellur. 4: I09. I 838. (Diurospermum Edgew. I \&+8; Utricularia \$ Phyllaria S. Kurz. I874.) Herbac scaposae terrestres, stolonibus foliatis a basi scapi radiantibus, radicibus veris nullis. Folia difformia, alia aeria laminis expansis, alia subterranea, radiciformia et ascidiifera. Scapus esquamatus, bracteatus, I-5-florus; bracteae basisolutae; bracteolae 2, consimiles. Calyx 2-partitus; lobus superior multo major, ejus basi ad basin orarii adnata, inferior maturitate reflexus. Corolla cyanica, valde 2-labiata; labium superius minimum, inferius amplum, subplanum; palatum tantum convexitas; calcar tenue, pendens. Antherae bilobatae. Capsula globosa. Semina appendiculata.

Species typica, Meloneura striatula comb. nov. (Utricularia striatula Smith; Meloneura purpurea Raf.).

A small genus of about 6 species, confined to the tropics of the Old World. One of the most distinct of the genera here recognized; indeed, a synthetic type of mind is required to refer these plants to Utricularia.

6. Pelidnia gen. nov. (? Meiomula Raf. I 838.) Herbae scaposae terrestres, ramulis brevibus radiciformibus et stolonibus tenuibus foliatis a basi scapi radiantibus, radicibus veris nullis. Folia difformia, alia acria, rosulata, laminis expansis, alia subterranea, radiciformia, ascidiifera. Ascidia utriculiformia, cum proboscide unica plana glandulare. Scapus simplex vel saepe ramosus, squamatus (vel in specie unica esquamatus?), bracteatus, Imultiflorus; squamae mediofixae, extremo utroque acutae; bracteae basisolutae; bracteolae consimiles sed minores. Calyx 2-partitus; lobi herbacei, concavi, subaequales, sub capsula patuli. Corolla cyanica, siccatione nigricans, 2-labiata; labium superius parvum, inferius magno latius, valde a basi calcaris reflexum; calcar prope basim late conicum, ad labium inferius non approximatum. Antherae bilobatae. Capsula subglobosa, stylo persistente rostrata, longitudine fissuris dehiscens, valvulorum extremitatibus semper conjunctis. Semina polygonalia, reticulata.

Species typica, Pelidnia caerulea comb. nov. (Utricularia caerulea L.).

Unfortunately, it is essential, in typifying this genus by $U$. caerulea, to explain what is intended, as that name was applied 
by Linnaeus to three different species, of which only one belongs to the present genus. These three species were as follows:

I. A plant in Hermann's herbarium, from Ceylon, apparently the only actual specimen of $U$. caerulea ever seen by Linnaeus before 1753 . The specimen is still in existence, at the British Museum (Nat. Hist.), and is here accepted as the type of the Linnaean species, and of the present genus. This species has been most generally known as $U$. racemosa Wall.
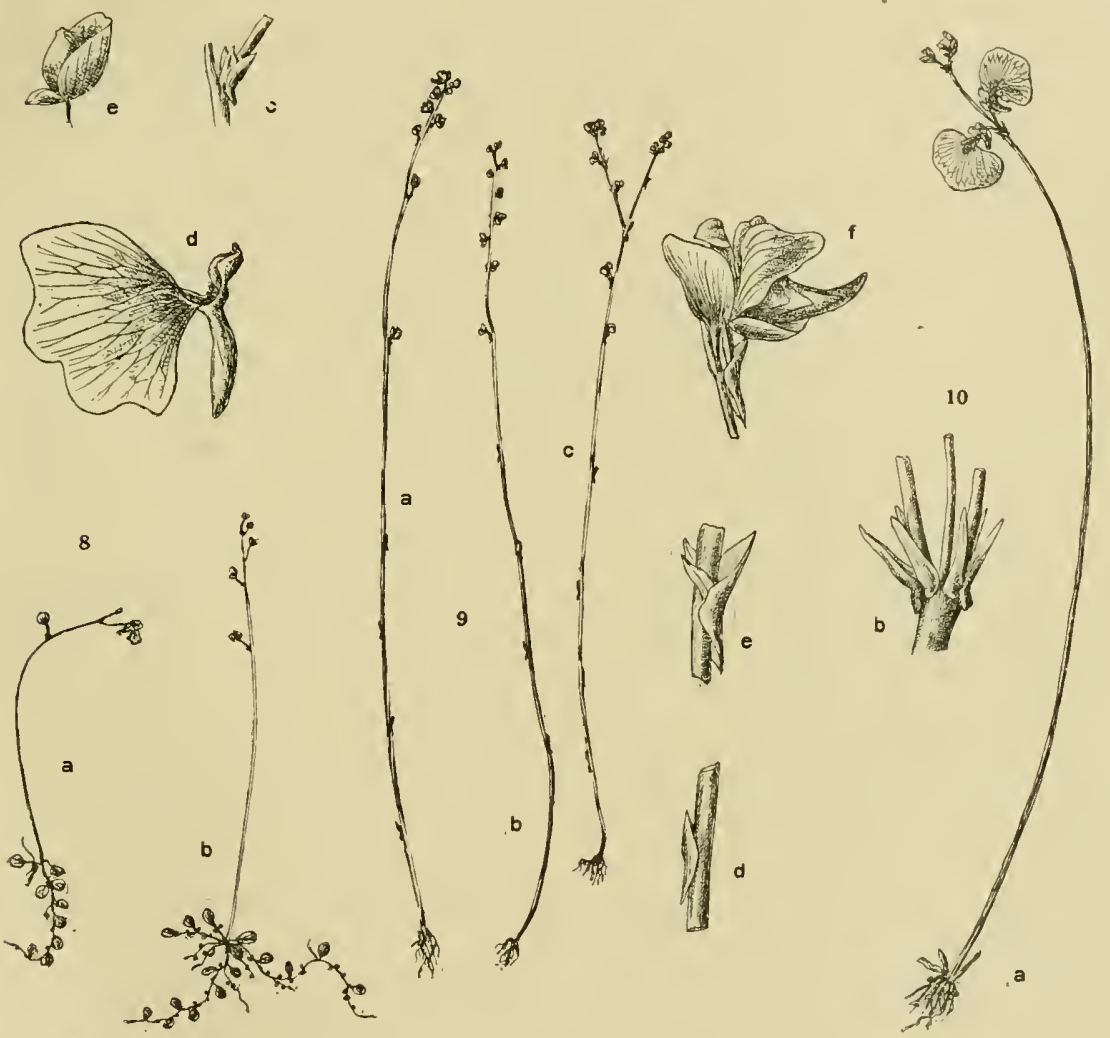

8. Meloneura. $M$. striatula (Sm.) Barnh. $a, b$. Plants, half natural size. $c$. Bract and bractlets, $\times 8$. d. Corolla, $\times 3 \frac{1}{2}$. e. Fruit, $\times 3 \frac{1}{2}$.

9. Pelidnia. P. caerulea (L.) Barnh. $a, b, c$. Plants, half natural size. $d$. Scale, $\times 3 \frac{1}{2}, e$. Bract and bractlets, $\times 3 \frac{1}{2}$. f. Flower, $\times 3 \frac{1}{2}$.

io. Pleiochasia. $P$. dichotoma (Labill.) Barnh. $a$. Plant, half natural size. b. Bracts and bractlets, $\times 4$.

2. A plant illustrated by Rheede, and confused with the preceding by Linnaeus, who cited Rheede's illustration under $U$. 
caerulea in I753. This species is commonly and correctly known as $U$. reticulata Smith; in the present treatment a Stomoisia.

3. A plant collected in India by Koenig, and placed by Linnaeus in his herbarium to represent $U$. caerulea. It is the only specimen of $U$. caerulea in the Linnaean herbarium, but it was not collected until long after I753, so can not by any possibility be regarded as the type of the species. It is entirely different from both of the preceding, although belonging in Stomoisia as here defined. When Oliver monographed the Indian species of Utricularia, in I 859, he deliberately selected this Linnaean herbarium specimen as the type of $U$. caerulea. He knew that it was not the original $U$. caerulea of $I 753$, but believed that it represented a species otherwise nameless, so instead of proposing a new name he quite unwarrantably limited the Linnaean name to the wrong plant, and as "U. caerulea L." the species has been known ever since; owing, in part, to the weight of Oliver's "authority," and in part to the fact that no critical monographer has since reviewed the Indian species. The oldest name of this species, overlooked both by Oliver and the "Index kewensis," is Utricularia parviflora Buchanan, published by Smith in I808, in his remarks upon the three plants confused by Linnaeus under $U$. caerulea, at the same time that he published $U$. reticulata! Smith discussed the whole problem fully and wisely, and solved it correctly; it remained for one of his fellow-countrymen, $5^{0}$ years later, to go over the ground independently and come to an erroneous decision that introduced a regrettable element of confusion, and has resulted in the misinterpretation of the Linnacan name for another half century.

About 5 species of Pelidnia have been described, all from tropical Asia and Australia; another, apparently not yet described or named, occurs in tropical Africa. Most if not all of the species turn blue-black in drying, and this has suggested the name Pelidnia, from a Greek adjective signifying livid. Meionula of Rafinesque was based upon $U$. minutissima V'ahl, a doubtful species, probably belonging to the genus Pelidnia as here defined, but it has seemed better to give the genus a new name than to use for it one of doubtful applicability.

7. Pleiochasia (Kam.) gen. nov. (Utricularia \$ Pleiochasia Kam. I893.) Herlbae scaposae terrestres, radicibus veris nullis. 
Folia suprema aeria, rosulata, laminis expansis, infima subterranea, radiciformia, intermedia etiam radiciformia, sed ascidiifera. Ascidia compresso-ovoidea, margine dorsale in rostro terminante, margine ventrale carinata. Scapus esquamatus, bracteatus, I-4florus; bracteae oppositae vel verticillatae, basisolutae; bracteolae 2, consimiles. Calyx 2-partitus; lobi herbacei, concavi, subaequales, capsulam amplectentes sed non excedentes. Corolla cyanica, valde 2-labiata; labium superius parvum, inferius amplum, expansum, planum vel parum reflexum; palatum parvum, dentatum; calcar cylindricum obtusum. Capsula subglobosa, stylo persistente brevirostrata.

Species typica, Pleiochasia dichotoma comb. nov. (Utricularia dichotoma Labill.).

This genus, as here defined, comprises about 20 species, all natives of Australia or New Zealand. It is undoubtedly a natural group, but contains rather diverse elements; so much so that Kamienski, when he proposed the section Pleiochasia, proposed another section (Macroceras) here provisionally combined with it. Most of the species are poorly represented in European and American herbaria, and a careful study of the group might result in the segregation of other genera from this one.

8. Orchyllium gen. nov. Herbae scaposae epiphyticae vel terrestres, ramulis brevibus radiciformibus et stolonibus foliatis a basi scapi radiantibus, radicibus veris nullis. Folia difformia, alia aeria, laminis expansis, alia subterranea, radiciformia, ascidiifera. Ascidia minuta, ovoidea, ore prope basin, saepe cum projectionibus duobus pediculum utrimque praeterientibus. Scapus squamatus, bracteatus, I-multiflorus; squamae plures, basifixae, saepe foliaceae; bracteae basifixae, saepe subfoliaceae; bracteolae consimiles. Calyx 2-partitus; lobi plani, ad basin saepe truncati vel cordati, tenuiter venosi, virides vel plus minus petaloidei, accrescente valvati et conjuncte adpressi et capsulam includen tes. Corolla cyanica, valde 2-labiata; labium superius amplum, subplanum, inferius amplum, plerumque carinatum in lineam mediam; calcar ad basin saccatum, distaliter tenuius, saepe sursum curvatum. Antherae valde bilobatae.

Species typica, Orchyllium alpinum comb. nov. (Utricularia alpina Jacq.).

This genus comprises about Io or I2 species, several of them among the largest in the family, natives of the American tropics. Owing to their epiphytic habit and orchid-like appearance (whence the name Orchyllium), they are often grown with orchids, and have 
been repeatedly introduced into cultivation; yet no one seems to have given critical study even to these cultivated plants.

The African analogues of Orchyllium are confined to the mountains of the mainland and islands of the gulf of Guinea; two species, Utricularia Mannii Oliver and $U$. bryophila Ridley, have been described, and both are recognized in the "Flora of tropical Africa," but they are probably not distinct. All the material of both so-called species in the herbaria of the world could probably be mounted on a single sheet of standard size without overlapping. Enough is known of this group to indicate a valid genus, but not enough to characterize it properly; for the present it is referred here, but no attempt has been made to include it in the characterization of the genus Orchyllium.

9. Stomoisia Raf. Fl. Tellur. 4: 108. I838. (? Trixapias Raf. I 838; ? Askofake Raf. I838; Nelipus Raf. I838; Enskide Raf. I 838; Personula Raf. I 838.) Herbae scaposae terrestres, ramulis brevibus radiciformibus et stolonibus tenerrimis foliatis a basi scapi radiantibus, radicibus veris nullis. Folia difformia, alia erecta et viridia, linearia vel sublinearia, alia subterranea et radiciformia, ascidiifera. Ascidia minuta, valde reducta, rostrata. Scapus erectus vel flexuosus vel tortilis, squamatus, bracteatus, I-multiflorus; squamae basifixae; bracteae basifixae; bracteolae consimiles sed angustiores interdum filiformes. Calyx 2-partitus; lobi tenues, venosi, superior plerumque major, capsulam arcte amplectentes, saepe accrescente valvati. Corolla xanthica vel cyanica, profunde 2-labiata; labium superius distincte unguiculatum, inferius galeatum, cum margine plus minus expanso; palatum praeter galeam nullum; calcar conicum, pendens. Antherac bilobatae. Capsula subglobosa, stylo persistente rostrata, calycis lobis arcte inclusa. Semina suloglobosa vel prismatica, arcolata vel reticulata.

Species typica, Stomoisia cormuta (Michx.) Raf. (Utricularia cormuta Michx.).

This genus, of about 50 or more species, is widely distributed in southern Asia, in Africa and Australia, and in eastern North and South America; it is lacking in Europe, northern Asia, and throughout the Andean region. With the exception of Utricularia and perhaps Calpidisca, it is the largest genus of the family. It is strikingly characteristic in habit, and usually readlily recognizable at a glance. Most of the species have yellow corollas, strongly laterally compressed, and the galeate lower lip is a prominent feature in all. 
10. Calpidisca gen. nov. Herbae scaposae terrestres, ramulis brevibus radiciformibus et stolonibus tenerrimis foliatis a basi scapi radiantibus, radicibus veris nullis. Folia difformia, alia erecta et viridia, alia subterranea et radiciformia, ascidiifera. Ascidia urceolata, margine plus minus bilabiato et fimbriato.
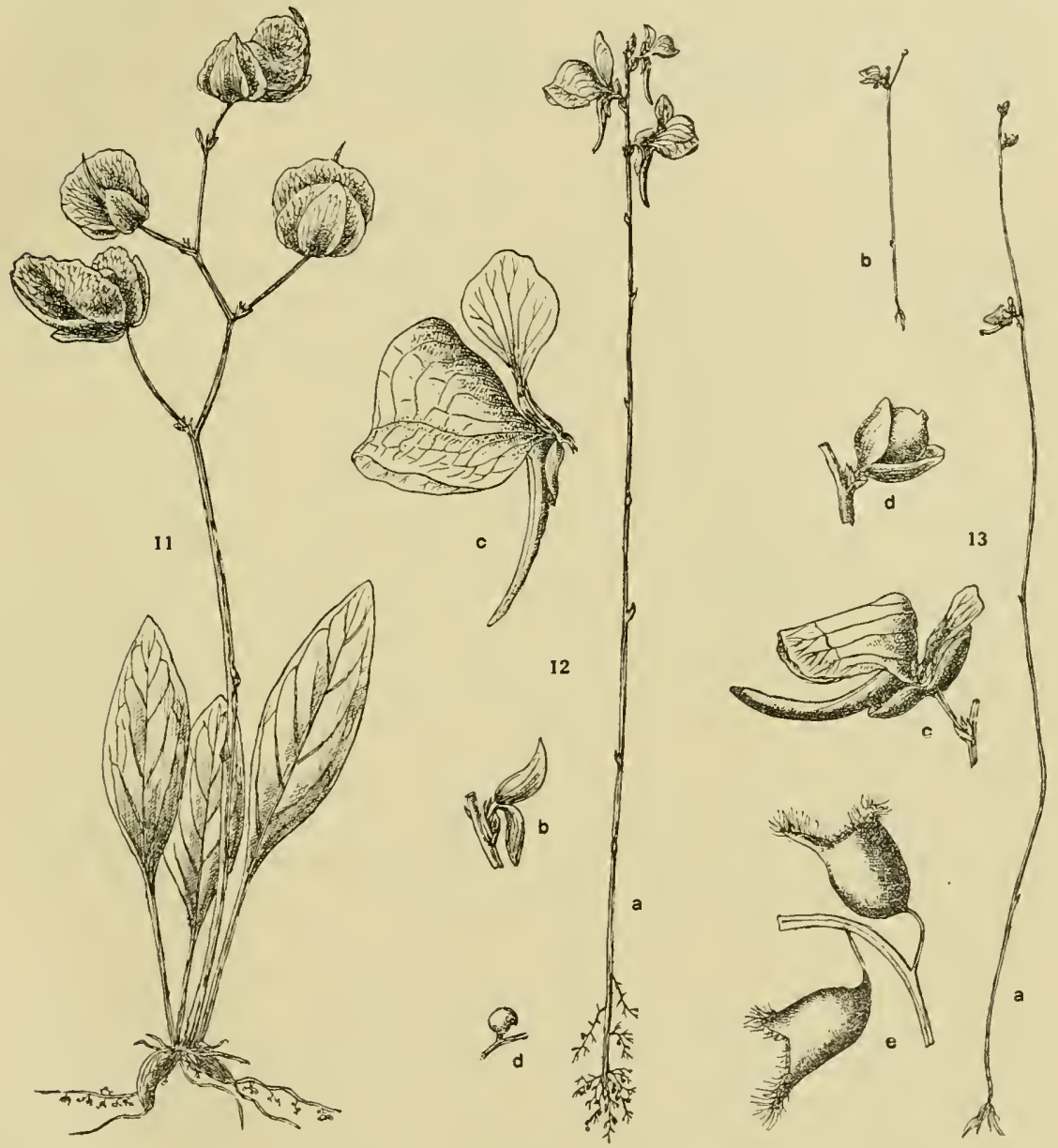

I I. Orchyllium. O. alpinum (Jacq.) Barnh. Plant, half natural size.

12. Stomoisia. S. cormuta (Michx.) Raf. a. Plant, half natural size. b. Bract, bractlets, and calyx, $\times \mathrm{I}_{2}^{\frac{1}{2}}$. c. Flower, $\times 2 . \quad d$. Bladder, $\times$ iо.

I3. Calpidisca. $C$. denticulata (Benj.) Barnh. $a, b$. Plants, half natural size. c. Flower, $\times 3 \frac{1}{2}$. d. Fruit, $\times 3 \frac{1}{2}$. e. Bladders, $\times$ io.

Scapus interdum ramosus, squamatus, bracteatus, I-multiflorus; squamae basifixae; bracteae basifixae; bracteolae consimiles, saepe 
ad bracteam adnatae, itaque bracteam tripartitam vel trifidam vel divergente tridentatum formantes. Calyx 2-partitus; lobi concavi, ad capsulam non adpressi. Corolla cyanica, profunde 2-labiata, marcescens et persistens; labium superius exunguiculatum, inferius cum limbo a margine calcaris oris abrupte reflexo; palatum, margine crasso calcaris oris excepto, nullum; calcar cum limbo parallelum vel breve et saccatum. Antherae bilobatae. Capsula globosa, stylo persistente rostrata.

Species typica, Calpidisca capensis comb. nov. (Utricularia capensis Spr.)

There are about 60 species of this genus, mostly confined to tropical regions and extratropical South Africa. In many of the species the leaves and bladders are evanescent, disappearing before the flowers are developed; indeed, in some of the species the leaves and bladders are quite unknown. In all species in which the bladders are known, they are distinctly urceolate, and the name Calpidisca is derived from two Greek words meaning urn and disc. A considerable proportion of the described species, especially the American ones, have been collected only once or twice, and the group needs much critical study. This is particularly true of several Brazilian species with hippocrepiform connectives, otherwise more or less intermediate between $\mathrm{Cal}$ pidisca and Orchyllium, and doubtless eventually deserving generic segregation.

The type species and several related ones were beautifully figured in the 28th volume of "Hooker's Icones plantarum" ( $p l .2793-2797)$; the illustration presented herewith is of a Mexican species, Calpidisca denticulata comb. nov. (Utricularia denticulata Benj.).

11. Avesicaria (Kam.) gen. nov. (Utricularia \$ Avesicaria Kam. I893.) Herbae scaposae aquaticae, ad rupes in aquo fluitante per tenacula radiciformia adhaerentes, radicibus veris nullis. Scapus squamatus, bracteatus, 2-multiflorus; squanae peltatae, saepe cum ramis tenuibus natantibus axillaribus, folia tenuiter dissecta ferentibus; bracteae peltatae; bracteolae nullae. Calyx 2-partitus; lobi concavi, basin capsulac amplectentes. Corolla valde 2 -labiata; palatum semilunare, ad basin labii inferii; calcar saccatum. Placenta hemisphaerica, superficiei anteriore convexa ovulifera. Capsula subglobosa, stylo persistente apiculata.

Species typica, Avesicaria neottioides comb. nov. (Utricularia neottioides St. Hil. \& Girard). 
Several species constitute this genus, all in Brazil, except one in tropical Africa. Its habit is the most noteworthy characteristic separating it from Setiscapella, although the corolla and placenta are very different, if the published descriptions are to be trusted.
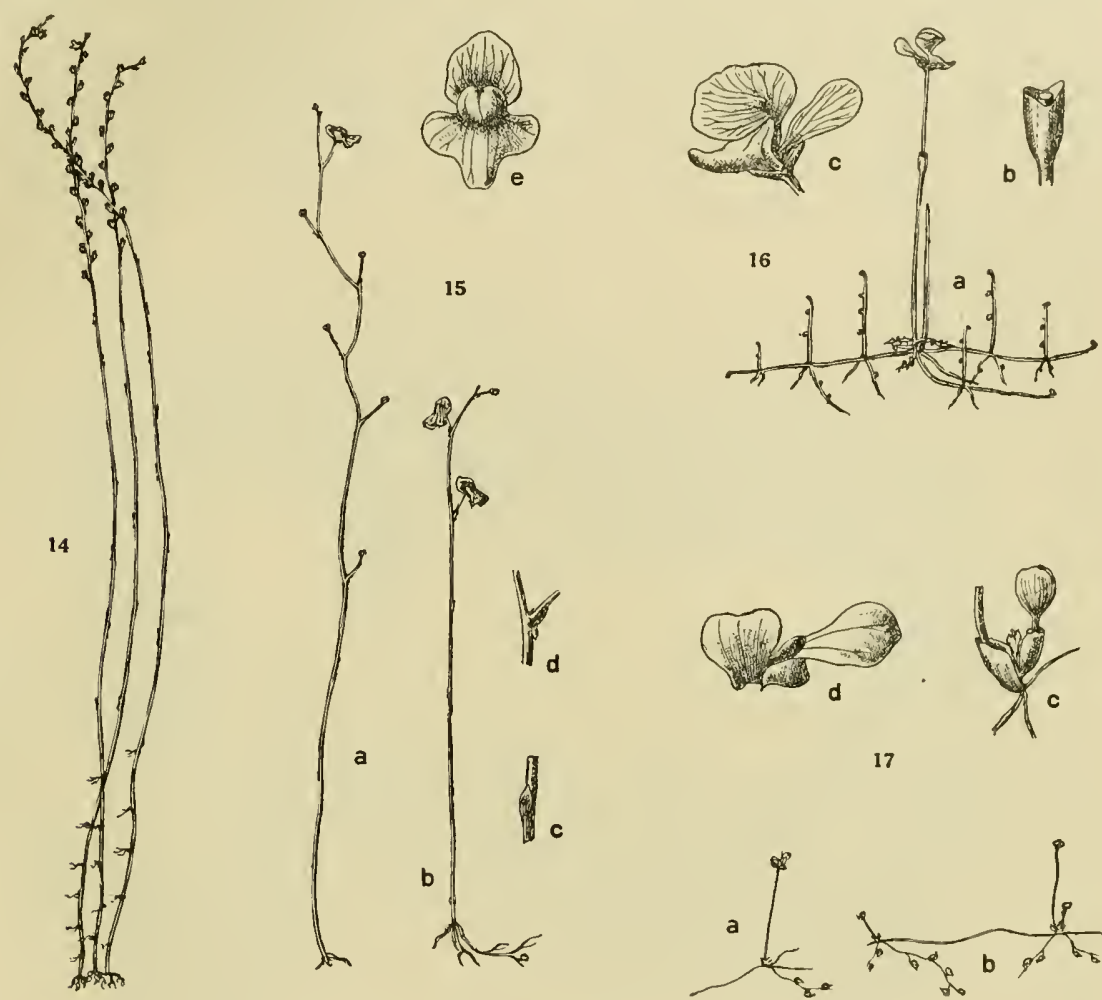

4. Avesicaria. A. sp. ${ }^{1}$ Plant, half natural size.

15. Setiscapella. S. subulata (L.) Barnh. $a, b$. Plants, half natural size. $c$. Scale, $\times 4$. d. Bract, $\times 4$. e. Corolla, $\times_{4}$.

16. Lecticula. L. resupinata (B. D. Greene) Barnh. a. Plant, half natural size. b. Bract, $\times$ 4. c. Flower, $\times 1 \frac{1}{2}$.

I7. Biovularia. $B$. olivacea (Wright) Kam. $a, b$. Plants, $\times 1 \frac{1}{2}$. c. Base of scape, showing bracts and buds, $X$ ro. $d$. Corolla, split open on one side, $\times 8$.

12. Setiscapella Barnh. in Small, Fl. Miami i7o. 26 Ap I9I3; in Britt. \& Brown, Ill. Fl. ed. 2. 3: 230. 7 Je I9I3. Herbae scaposae terrestres, ramulis brevibus radiciformibus a basi scapi radiantibus, radicibus veris nullis. Folia difformia, alia erecta

1 The species illustrated is in various herbaria under the manuscript name Utricularia Glaziouana Kam., and has been mentioned in print as U. Glazioviana Warm. (Mém. Soc. Bot. Fr. 3: 5I2), but I am not aware that any description of it has been published. 
et viridia, saepissime evanescentia, alia subterranea et radiciformia, ascidiifera. Asciclia minuta, apice 2-cornuta. Scapus squamatus, bracteatus, I-multiflorus, saepissime maturitate anfractus; squamae et bracteae peltatae, scariosae; bracteolae nullae. Calyx 2-partitus; lobi scariosi, valde longitudinaliter pluri-costati sub capsula patuli vel basin capsulae amplectentes. Corolla xanthica, valde 2-labiata; labium superius subplanum amplum, inferius amplum, plerumque valde divergenterque lobatum; palatum saepissime prominens et 2-lobatum; calcar ad basin conicum, distaliter tenue, vel omnino saccatum. Antherae subglobosae. Capsula globosa, stylo persistente apiculata. Semina prismatica, reticulata.

Species typica, Setiscapella subulata (L.) Barnh. (Utricularia subulata L.).

Of the dozen species comprising this genus, nearly all are American, but one occurs in Africa, and at least two in the Himalayas. Its wiry, zig-zag scapes, peltate scales and bracts, and scarious calyx-lobes are very characteristic. In most of the species leaves and bladders are rarely seen.

13. Lecticula Barnh. in Small, Fl. Miami izo. 26 Ap I9I3; in Britt. \& Brown, Ill. Fl. ed. 2. 3: 230. 7 Je I9I3. Herbae scaposae, ramulis radiciformibus foliatis normaliter submersis, radicibus veris nullis. Folia alterna, saepissime 3-partita; lobus medius erectus; lobi laterales capillares radiciformesque, ascidiiferi. Ascidia minuta, rostrata. Scapus semper I-florus, pedicello con scapo continuo; squamae verae nullae; bractea solitaria, basifixa, squamam simulans amplexicaulis tubularisque, margine libero truncato, plus minus 2-inciso; bracteolae nullae. Calyx 2-partitus; lobi concavi, herbacei, ad capsulam adpressi. Corolla valde 2labiata; labii subintegri; palatum tantum convexitas; calcar subconicum, obtusum. Antherae subglohosae. Capsula globosa.

Species typica, Lecticula resupinata (B. D. Greene) Barnh. (Utricularia resupinata B. D. Greene).

Besides the type species, which occurs locally throughout the eastern parts of Canada and the United States, only one other has been described, Lecticula Spruceana comb. nov. (Utricularia Spruceana Benth.), a native of eastern Brazil.

14. Biovularia Kam. Zap. Novoross. Obtsch. Est. 15': 204. I890. Herbae minutae aquaticae. Folia alterna, capillariter partita, ascidiifera. Ascidia birostrata. Scapus esquamatus, bracteatus, I-3-florus; bractea inlima ad caulem proxima; bracteae basifixae; bracteolae nullae. Calyx 2-lobatus; lobi subacquales. 
Corolla xanthica, hyalina, valde 2 -labiata; labia integra; palatum tantum convexitas; calcar saccatum. Antherae subglobosae. Ovarium 2-ovulatum. Capsula (achenium) globosa, I-seminata, indehiscens.

Species typica, Biovularia olivacea (IVright) Kam. (Utricularia olivacea Wright).

The minute plants upon which Kamienski based this genus were collected in Cuba by Charles Wright many years ago. The

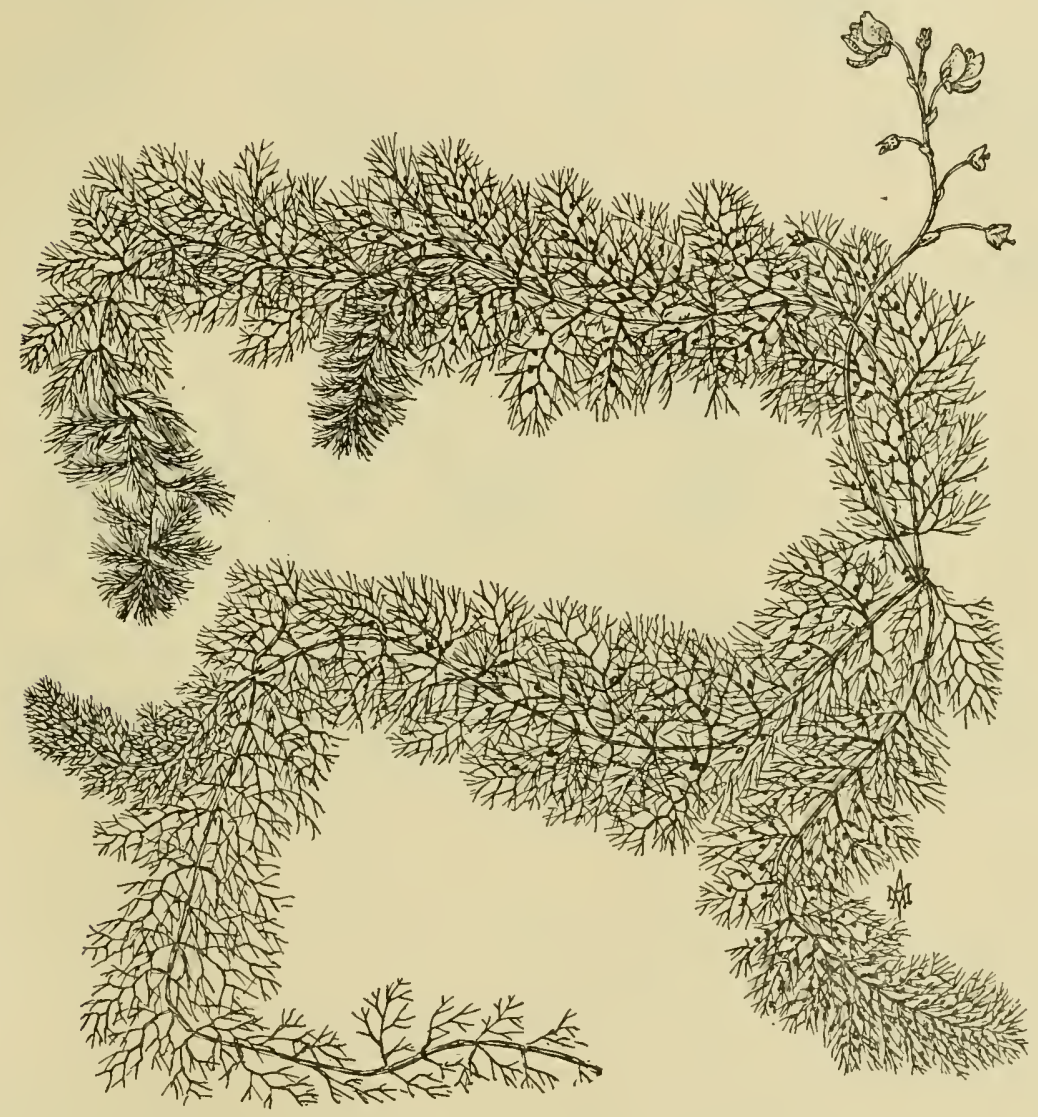

i8. Utricularia. U. macrorhiza LeConte. Plant, one third natural size.

species has not been rediscovered in Cuba, but that since described from Brazil by Warming as Utricularia minima is either identical or very closely related. There are few smaller flowering plants.

The African species called Biovularia cymbantha by Kamienski has nothing to do with this genus; it is a true Utricularia. 
15. Utricularia L. Sp. Pl. I8. I753. (Lentibularia Hill, I756; Xananthes Raf. I838; IIamulia Raf. I838; Lepiactis Raf. I838; Megozipa Raf. I838; Trilobulina Raf. I838; Plesisa Raf. I838; Plectoma Raf. I838.) Herbae aquaticac, caulibus submersis foliosis, radicibus nullis. Folia alterna, dissecta, interdum radiciformia, sessilia et profunde 2-8-partita, itaque simulate
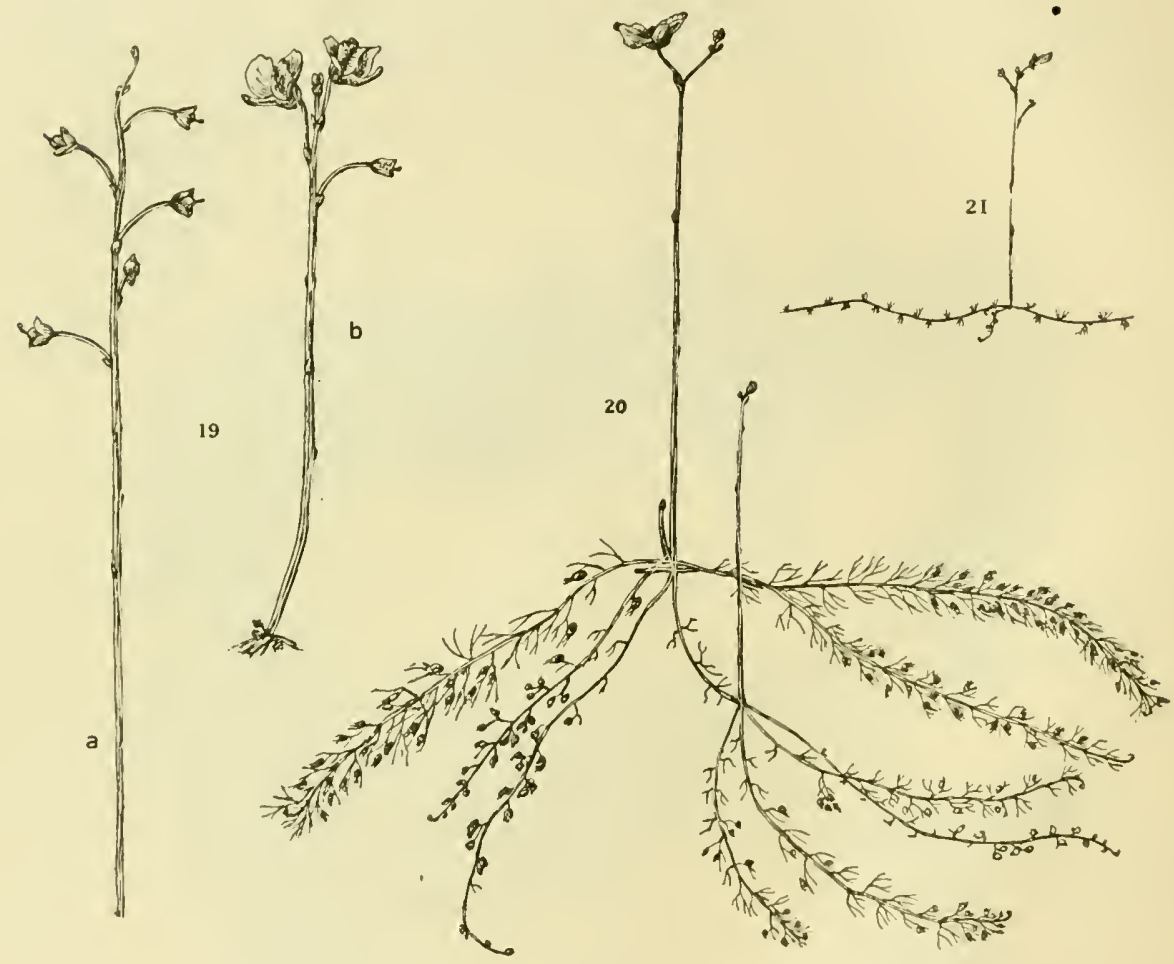

I9. Utricularia. U. macrorhiza LeConte. a. Scape, with flowers, half natural size. $b$. Scape, with fruit, half natural size.

20. Utricularia. U. pumila Walt. Plant, half natural size.

2 I. Utricularia. U. minor L. Plant, half natural size.

opposita vel verticillata; segmenti dichotome vel pinnate dissecti, aliquot vel omnes ascidiiferi. Ascidia 2-rostrata, rostris saepe setiformibus et plus minus dissectis. Scapus squamatus vel esquamatus, I-nultiflorus; squamae alternac, basifixae, vel interdum subverticillatae vel verticillatae et ampulliformae; bracteae basifixac, interdum auriculatae; bracteolae nullae. Calyx 2-partitus; lobi concavi, herbacei. Corolla valde 2 -labiata; palatum sacpissime prominens, 2-lobatum; calcar subconicum vel saccatum. 
Antherae subglobosae. Capsula globosa. Semina plus minus peltata, margine alata vel non alata.

Species typica, Utricularia vulgaris L.

In the present revision about 75 species are left in Utricularia, and the genus as here defined is of world-wide distribution, one or more species being found in almost every region where quiet freshwater conditions occur, except in certain oceanic islands. Six or eight subgenera might be distinguished, and some of these even-

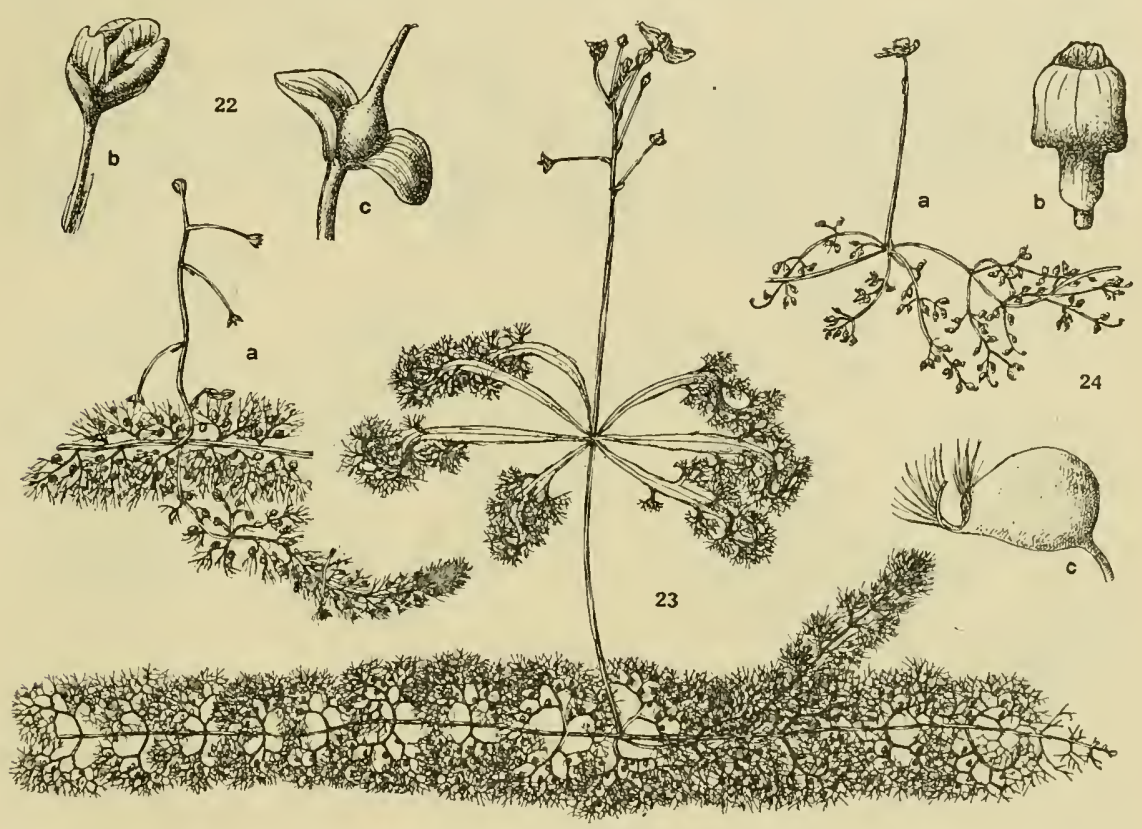

22. Utricularia. $U$. hydrocarpa Vahl. $a$. Plant, half natural size. $b$. Flower, with bract, $\times 3 \frac{1}{2}$. c. Fruit, $\times 3 \frac{1}{2}$.

23. Utricularia. $U$. inflata Walt. Plant, one fourth natural size.

24. Vesiculina subg. Hydrion. V. cucullata (St. Hil.) Barnh. a. Plant, half natural size. $b$. Corolla, $\times 2 \frac{1}{2}$. c. Bladder, $\times 8$.

tually will deserve recognition as genera. The most noteworthy, perhaps, is Akentra Benj., with two species, one in tropical America, the other in tropical Africa; it is not spurless, as supposed by the author of the name, but enough is known of it to show the incongruity of its position in Utricularia. The other ampulla-bearing species represent several good subgenera, if not genera; and the long-styled, red-flowered species of tropical America may deserve generic recognition. But the treatment of these groups is deferred until another time. 
16. Vesiculina Raf. Fl. Tellur. 4: I09. 1838. Herbac aquaticae, caulibus submersis, verticillate ramosis, ramis verticillate vel opposite decompositis. Folia vera nulla. Ascidia terminalia ad ramulos, ore nuda vel cum solitaria media pubescente proboscide. Scapus esquamatus, bracteatus, I-4-florus; bracteae hasifixae vel simulate basisolutae; bracteolae nullae. Calyx

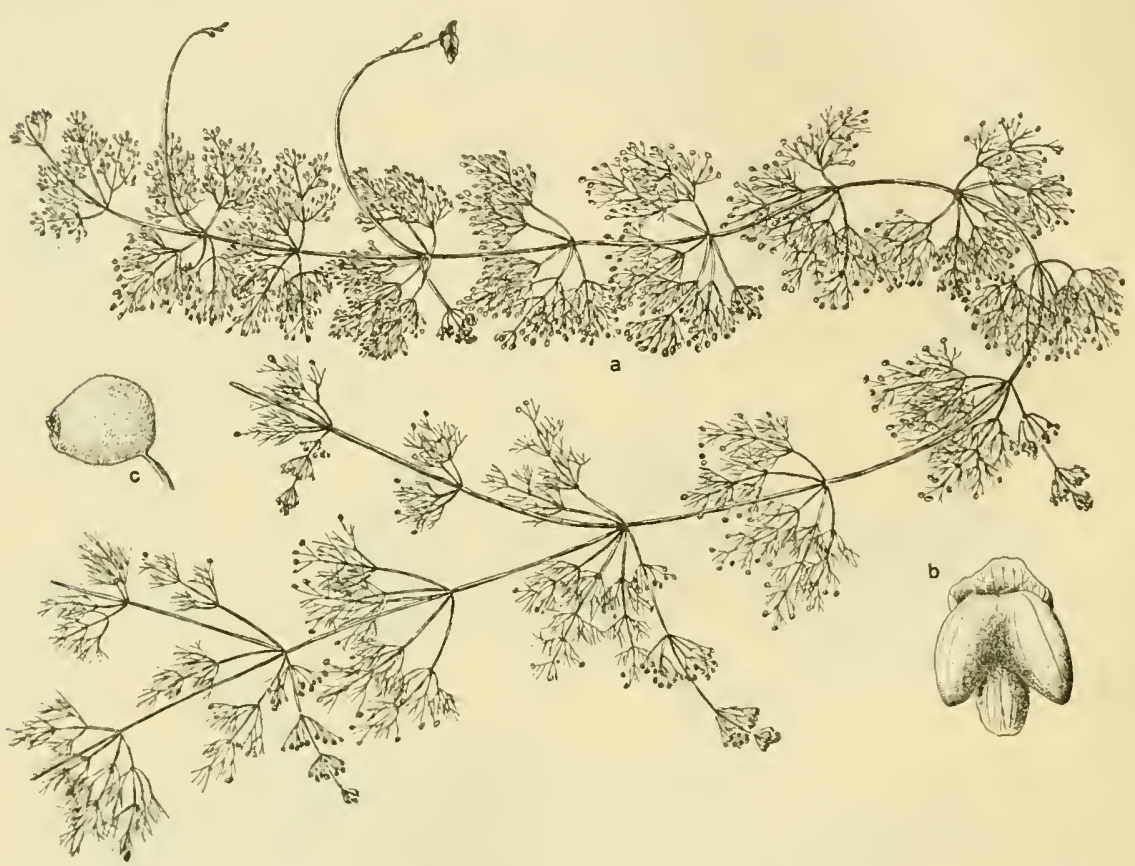

25. Vesiculixa subgen. Pemphigina. Ir. purpurea (IValt.) Raf. $a$. Plant, half natural size, $b$. Corolla, $\times 2$. c. Bladder, $\times 8$.

2-partitus; lobi concavi, herbacei. Corolla cyanica, valde 2labiata; labium superius non lobatum, inferius 3 -lobatum, lobis lateralilus saccatis et palatum prominentem 2-lobatum formantibus, lobo medio plano, inconspicuo. Antherae subglobosae. Capsula globosa. Semina tuberculata.

Species typica, Vesiculina purpurea (Walt.) Raf. (Vesiculina saccata Raf.; Utricularia saccata Le Conte; U. purpurea Walt.).

Superficially bearing a close resemblance to Utricularia, this group of species is really very distinct. The verticillate branches, terminal bladders, and prominent palate involving both lateral lobes of the lower lip of the corolla, are peculiarities not found elsewhere in the family. Two sulggenera may be recognized, as follows: 
A. Pemphigina subgen. nov. Corollae labia lata; ascidii os nudum.

B. Hydrion subgen. nov. Corollae labia angusta; ascidii os proboscidiferum.

The genus, of about 8 species, is known certainly from the New I orld only; but it is not unlikely that Utricularia tubulata F. Muell., of Australia, will be found to belong here.

Vesiculina, as published by Rafinesque, was a very unnatural grouping of diverse elements, and it is only by accepting the first species named by him as the type of his genus that his name can be made use of here. Pemphigina is the typical subgenus, with the same type species as Vesiculina; the type of the subgenus Hydrion is Vesiculina cucullata comb. nov. (Utricularia cucullata St. Hil.).

\section{Genera Excludenda}

Micranthemum Michx. was considered by St. Hilaire \& Girard (I 838 ) to be intermediate between Lentibulariaceae and Scrophulariaceae. No one has ever definitely referred it to the former family, and it is now universally placed in the latter.

Benjaminia Mart. (Quinquelobus Benj.) was proposed in 1847 as a new genus of Lentibulariaceae. It was short-lived, however, for a year and a half later Bentham called attention (Lond. Jour. Bot. 7: 567 ) to the fact that it was a mixture of three genera belonging to two families, and that no portion of the mixture belonged in the Lentibulariaceae. The type species is probably referable to Myriophyllum.

Byblis Salisb. was referred to the Droseraceae when first described (I 808), and left there by all subsequent authors for nearly a century. In I90I, F. X. Lang published a study of the Droseraceae, definitely excluding Byblis from that family, and suggesting (owing to a similarity of certain epidermal appendages to those of Pinguicula!) a possible relationship to Lentibulariaceae. Following up this suggestion, Engler, in the third edition of his "Syllabus" (I903) and in succeeding editions, has definitely referred Byblis to Lentibulariaceae, creating for it a subfamily Byblidoideae, differing from the rest of the family in all its essential characters. The genus appears to me to be as closely related to twenty or more other families as to Lentibulariaceae; it is probably worthy of recognition as the type of a distinct family, related (as suggested by Diels, in I906, in his monograph of the Droseraceae for Engler's "Pflanzenreich") to the Pittosporaceae, and very far indeed removed from the Lentibulariaceae. 


\section{Clavis analytica geNerum Lentibulariacearum}

Scapus ebracteatus; id est, inflorescentia simplex.

Scapus bracteatus; id est, inflorescentia composita.

I. Pinglicula.

Calyx 5-partitus.

2. Genlisea.

Calyx 4 -partitus.

Calyx 2-partitus.

3. Cosmiza.

Bracteolac 2, interdum plus minus cum bractea coalitac.

Bracteolae supra basin pedicelli, sepala lateralia exteriores simulantes.

Bracteolae ad basin pedicelli.

Calycis lobi valde inaequales, superior major et ad ovarium adnatus; bracteae et bracteolae basisolutae.

Calycis lobi subaequales, liberi.

Bracteae et bracteolae basisolutae.

Bracteae alternae; squamae plures.

Bracteae oppositae vel verticillatae; squamae nullae.

Bracteae et bracteolae basifixae.

Calycis lobi scariosi vel foliosi vel petaloidei, capsulam amplectentes; ascidii ovoidei, rostrati.

Corollae labia subplana; palatum prominens.

Corollae labium inferius galeatum; palatum practer galeam nullum.

Calycis lobi herbacei, capsulam non amplectentes; corollae labium inferius a margine calcaris oris abrupte rcflexum; ascidii urceolati, plus minus bilabiati.

4. Aranella.

5. Meloneura.

6. Pelidnia.

7. Pleiochasia.

8. Orchillium.

9. Stomoisia.

Bracteolae nullae.

Corollae labium inferius cum lobis lateralibus non saccatis vel nullis; rami alterni.

Bracteae squamaeque basisolutae vel peltatae.

Plantae aquaticae, ad rupes per tenacula adhaerentes; placenta hemisphaerica.

Plantae terrestres; placenta subglobosa.

Bracteae basifixae; squamae basifixae vel nullae.

Bracteae tubulares; flos solitarius.

Bracteae planae vel concavae; flores saepissime plures.

Ovula 2; semen I.

Ovula et semina pluria, sacpissime numerosa.

I1. Avesicaria.

12. Setiscapella.

13. Lecticlla.

if. Biovularia.

I5. UtRICULARIA.

Corollae labium inferius cum lobis lateralibus saccatis; rami oppositi vel verticillati.

16. VESICULINA. 


\title{
OBSERVATIONS ON THE FLORA OF MAMMOTH CAVE, KENTUCKY ${ }^{1}$
}

\author{
Richard Ellsworth Call \\ DeWitt Clinton High School, New York City
}

In presenting these notes it is desired that they be considered only a preliminary account of the plants of the great underground world of Kentucky.

Packard, Putnam, and Hubbard, and later Eigenmann, who has almost compelled us to believe that the blind fishes really see, have well presented the animal side of the Cavern's life. Your relator has added some twenty additional species, mostly new, described by specialists and to be found in the accompanying bibliography. ${ }^{2}$

Thanks to the painstaking interest of Dr. Roland Thaxter, his careful study of the more difficult cryptogamic material collected by me has added very much to our knowledge of cave forms.

Mammoth Cave underlies some 2,500 square acres of region and the avenues that have been mapped extend over a distance of more than 160 miles. This great distance is disposed in three vertical series or layers, determined by the drainage levels of former geological times. From the surface to a depth of some 225 feet below it these connecting avenues occur. Its greatest depth is determined by the present level of the Green River on the left bank of which the cave is situated. The depth of the cañon of Green River marks the extreme depth of the care.

It is, of course, to be fully understood that the total absence of light precludes the possibility of chemic or actinic rays, and therefore all plant forms that possess chloroplasts are absent. The flora is entirely saprophytic.

${ }^{1}$ Abstract.

${ }^{2}$ Call, R. Ellsworth. Note on the flora of Mammoth Cave, Kentucky. Jour. Cincinnati Soc. Nat. Hist. I 9: 79-80. Mr I897.

Call, R. Ellsworth. Some notes on the flora and fauna of Mammoth Cave. Am. Naturalist 3I: 377-392. pl. IO-II. My I897.

Hovey, Horace C., \& Call, Ellsworth R. The Mammoth Cave of Kentucky. 8vo, cloth, Louisville, I897. John P. Morton \& Co. A completely revised and better illustrated edition appeared in I9I2.

Hovey, Horace C., \& Call, Richard Ellsworth. Bibliographie chronologique and analytique de Mammoth Cave, Kentucky (États-Unis d' Amérique). Spelunca Bulletin et Mémoires de la Société de Spéléologie 9: I9I-237. J1 I9I 4. 
The distribution of the plant forms is exceedingly interesting. It seems to be determined by the accidents of visitation. These may be classified somewhat as following: (a) Visitors carrying spores on clothing or on staffs and other impedimenta. (b) By the very few cave insects that travel widely, such as Anophthalmus. (c) By the bats, which enter by the hundreds of thousands in the late fall for hibernation purposes. (d) By the migrations of the blind rat, Neotoma.

The first of these causes relates only to the distribution along such avenues as are exhibited to visitors and is, therefore, of very definite application. The others are all of indefinite operation, may be continuous or discontinuous and are by no means constant. It is well to keep these facts in mind as aiding to explain certain fitful seasons of abundance or scarcity. All but two of the plants, Mucor Mucedo and Laboulbenia subterranea have been found only along the paths frequented by sight-seers. This Mucor occurs wherever there is sufficient moisture and food supply. The second form has been found thus far only on dead Anophthalmi, the blind cave beetle. This is a most instructive fact and seems to justify the conclusion that prior to the advent of man the cave was practically devoid of plant life.

There are no representatives of the rusts, smuts, and mildews among the forms discovered. These forms are entirely parasitic on the higher forms of plants, the chlorophyll-bearing species. No plant containing a single chloroplast has been discovered over a study period of some five years. Diatoms alone have been discovered in the plankton of Echo River and the Dead Sea. Nor did the microscope reveal a single pyrenoid in the only diatom represented-a transparent Navicula for which I have not found a specific name. Many specimens were examined.

The underground rivers and smaller streams are fed by "sinks" or depressions of sometimes very great extent. They are caused by the solution of the underlying St. Louis oölitic limestone and the falling in of the superposed Chester sandstone-which together constitute the simple geology of the region. These sinks are mentioned thus particularly because, $(a)$ In the waters that pass through them to the cave many fungus spores must enter, and (b) It would seem to explain the presence of Navicula in the plankton.

At the several lunching stations food in abundance occurs on 
the rejectamenta which is often covered with certain low forms of saprophytic plants. No less than six forms, distributed in as many genera, are found in Washington Hall alone-the usual luncheon stations for parties on the Long Route. These occur indifferently on fragments of ham, chicken bones, and beef, while the plant-using varieties are found on the fragments of bread and other cereal products. For many years past the cave rats and certain insects visit this section, attracted by the richness of the food supply; this has caused this particular locality to become a center of distribution for these plant forms. But, it is to be noted, without exception all are plants of the outer world and none are distinctively of cavernicolous origin. The introduction by means of lunch baskets, clothing, staffs, timbers, etc., is ton obvious to need mention.

Briefly stated, the following conclusions have been reached regarding the Cave's flora. (a) Only two forms are to be regarded as strictly cavernicolous. They are particularized below. (b) Many are curiously modified both in habit and appearance by peculiar conditions of environment, though the conditions are very stable. (c) There are no seasonal or sporadic exhibitions of plant life. The uniform temperature, of about 54 degrees F. and the abundant supply of moisture are stable conditions: to these the plant life is now well adjusted. (d) All the plants except Coprinus micaceus, Fomes applanatus, and Rhizomorpha molinaris are microscopic. (e) All are saprophytes, two being sarcophytes.

The following annotated list comprises all that is known of the species inhabiting the cave. The list includes 13 genera and I 5 species.

Coprinus micaceus Bull.

River Hall and on the shore of the Dead Sea only. Groups of several individuals have been taken along River Hall, near the boat landing, and at the Cascades near the River Styx. A new fly, Limosina stygia Coq. was discovered by the author in a cluster taken on the River Styx. The toadstool is very often found deliquesced.

Fomes applanatus Pers.

Found in the Labyrinth, attached to old timbers and curiously modified into cylindrical and ram's-horn-like objects, some of them more than ten inches in length. Introduced from without the cave. 
RHIZOMORPIA MOLINARIS Pers.

In the Mammoth Dome, on old timbers. A very peculiarly modified species, some specimens being many-branched, others cylindrical, and often ten inches in length. A large mass of these plants on being accidentally shaken exhibited brilliant phosphoresence.

Cyathus vernicosus (Bull.) DC.

A "bird's nest" fungus common on old timbers in the Nammoth Dome has been identified as being this cosmopolitan form. It appears to be a poorly developed visitor from the outer world.

MUCOR MUCEDO L.

Growing abundantly and sometimes covering areas of thirty square feet and hanging in great festoons at the Steeps of Time, River Hall, and on the timbers around the Bottomless Pit. Microascus LONGiRostris Zukal.

On rejectamenta in Washington Hall and also in Audubon Avenue.

Zasmidium CELlare Fr.

At the top of the Corkscrew, in the Main Cave, on the head of an old barrel, which it entirely covered with a dense brown coating. Probably introduced from without, with the host.

Grinonscus setosus Eidam.

On sticks, bread, etc., in Washington Hall. This locality is the Cave's dining room.

SPOROTRICIIUM DENSUM Link.

SPOROTRICHUM FLAYISSIMUM Link.

Both species occurred on dead beetles (Anophthalmus) in Washington Hall.

LABOULBENIA SUBTERRANEA Thaxter.

Found only on dead Anophthalmi, particularly in the neighborhood of Annette's Dome.

LABOULBENIA SP.

Numerous specimens on the dung of bats in Audubon Ave. and Rafinesque Hall.

Cominasia sp.

Paptlogporat sp.

BOUDIERA sp.

The paucity of material precludes any specific reference of these three forms. 


\title{
OBSERVATIONS ON INHERITANCE OF SEX-RATIOS IN MERCURIALIS ANNUA
}

\author{
Cecil Yampolsky \\ Columbia University
}

The discovery of the sex-chromosomes (so-called) in animals has led to a wide acceptance of the doctrine that sex is inherited in the ordinary Mendelian fashion. Using the Mendelian terminology, one or the other of the two sexes is heterozygous for the sex factor. Assuming that the male is heterozygous for the sex factor, a female results from the union of any egg with a female sperm; a male results from the union of any egg with a male sperm. If the female is heterozygous for the sex factor a female results from the union of a female egg with any sperm; a male results from the union of a male egg with any sperm. The question as to when sex is determined receives its answer under the above hypothesis. Haecker's classification of the time when sex may be determined-progamy, syngamy, or epigamyresolves itself into one group, namely, syngamy.

So far, cytological evidence for the existence of a hetero- or sex-chromosome in dioecious plants is lacking and the assumption that one or the other of the sexes in dioecious plants produces two kinds of germ cells is based only on indirect evidence in experimental breeding. Correns and Bateson working almost simultaneously on Bryonia dioica and Bryonia alba, two species of the genus Bryonia, the former of which is dioecious, the latter monoecious and both of which cross readily, arrived at opposite conclusions. Correns concludes that it is the male of Bryonia dioica that has two kinds of pollen, male and female, while Bateson concludes that the female of Bryonia dioica bears two kinds of eggs, male and female. The following are the results of the crossings of Bryonia dioica with Bryonia alba which Correns and Bateson secured: 
B. alba selfed $=$ all $\Varangle$

B. dioica o $\times B$. alba $\sigma^{7}=\mathrm{F}_{1}$ all females.

B. alba \& $\times$ B. dioica $\sigma^{7}=\mathrm{F}_{1} 50 \%$ males $+50 \%$ females.

$B$. dioica ㅇ $\times B$. dioica $\sigma^{7}=50 \%$ males $+50 \%$ females.

The hybrids produced are sterile.

Correns's interpretation of his results is represented as follows:

B. dioica of has gametic constitution 우 우

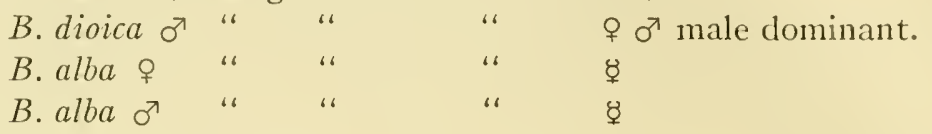

Bateson's objection to the above schematic representation of Correns is that it ignores entirely any degree of maleness in the pollen of Bryonia alba in contrast to the dominance of maleness in $B$. dioica male.

Bateson's interpretation of his results is represented as follows:
B. dioica $q$ has egg cells $q$ and $\sigma^{x}$
B. dioica ơ " pollen all ơ
B. alba has egg cells o and $\sigma^{7}$ and pollen all $q$

Strasburger, following Noll, has proposed the conception that in dioecious plants the female has egg cells with only female tendencies. The male gametes are of two strengths-strong and weak. The assumption is made that the weaker of the two kinds of male gametes in fertilization is weaker than the female gamete and hence a female plant results; the fertilization of the egg of a female plant by a strong male gamete results in a male plant. Strasburger arrived at the above conclusions from an extended study on dioccious forms. His conceptions were strengthened by the behavior of his cultures of male and female plants of $\mathrm{Mer}$ curialis anmua. 'The interesting observations of Krüger's in 1908 who reports that his so-called parthenogenetically produced seeds on female plants of Mercurialis anmua, upon germination produced only female plants, were a confirmation of Strasburger's earlier observations on the same form. The further confirmation of these results by Bitter in 1909, who reports that the seed of his self-fertilized female plants of Mercurialis amma produced 723 female and 2 m male plants left no room for doubt as to the behavior of these female plants. 
Mercurialis annua, an annual weed, is described as occurring in three forms - female, male, and hermaphrodite. Some female plants, it has been established, produce a few male flowers and are self-fertile. Some male plants occasionally produce a few female flowers and they are self-fertile. The pollen from a male plant upon a female produces seeds readily and in abundance. The interesting observations recorded show that the seeds from the selfed females produce exclusively or almost exclusively female offspring; the seeds from selfed male plants produce exclusively male plants (Strasburger); the seeds from the cross pollinated plants produce approximately a fifty to fifty ratio of males and females. Mercurialis then records the so-called gametic constitution of its sexual cells directly in self fertilization. The male cannot be regarded as heterozygous for sex in Correns's words since the offspring produced from its selfed seed are only males, nor can the female be heterozygous for sex as Bateson assumes since the offspring produced from selfed seed are only females. Strasburger assumes that in the case of the approximately half and half production of males and females in the crosspollinated plants of Mercurialis annua it is the male plant that determines the result. He interprets the phenomena of seed from selfed female plants which give rise to females and seeds from selfed male plants that give rise to male plants as evidence of the well-known breeding fact that "like tends to beget like."

The present work was begun in February, I9I4, and this communication deals primarily with female cultures of Mercurialis annua. A single vigorously growing female plant had produced in January, I914, 42 seeds. By April, I914, the plant had produced 24 more seeds. The first lot of seeds was sown, 36 germinated, and 36 plants were raised to maturity, all of which were females. The second lot of seeds gave it plants, all of which were females. Records of all these plants have been kept and at the present time offspring up to the fifth generation have been secured. I have made the following grouping of the plants under my observation:

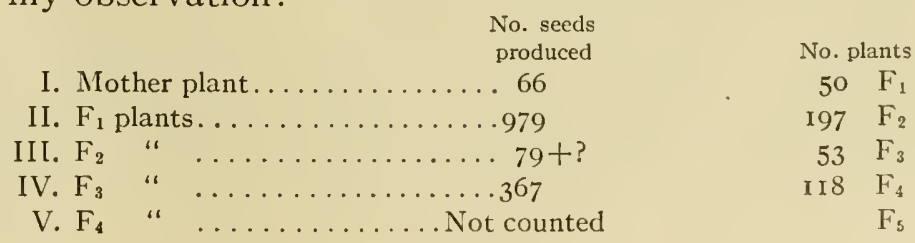


A total of I49I seeds were sown, and they produced 48 plants, all of which were females. The relatively low percentage of germination of seed in Mercurialis anmua is present in all cultures of males, females, and hermaphrodites and cross-pollinated seed. The seeds upon ripening are of ten lost because of the sudden bursting of the seed capsule and the discharge of the seeds from them. To prevent such loss the seeds were collected before they became too ripe. Many of the seeds did not mature, these later proving to be unviable. The fluctuation in the number of seeds produced by the separate females presents a wide variation. Some plants have produced as low as one seed, whereas one of the females has produced 230 seeds. Twelve females produced notseeds.

My first male plants were secured from the Brooklyn Botanic Garden in November, I9I4. Twelve plants in all were placed among an equal number of females and permitted to cross freely. Seeds set very profusely and several thousands were collected.

In May, I9I5, the above seeds were sown in the experimental plot of The New York Botanical Garden. Both male and female plants in about equal numbers were produced. Over 7 oo male plants were labelled and watched throughout the summer and fall. The seeds from them are now being grown and the results will be reported later. The males in general produce relatively few seeds as compared with the females and more striking still is the fact that less than io percent of all the males produced any seed at all.

The results so far secured confirm Strasburger's and bring out very strongly the fact that there is a decided difference in the seed production of such isolated individual plants. Strasburger only indirectly called attention to the fact by giving the numbers of seeds produced by each of his plants. The maximum number produced by females under my observation was 230 seeds; the maximum number produced by a male plant under my observation was 47 secols.

In the January, I9I6, "Proceedings of the National Academy of Sciences" Goldschmidt reports in a preliminary paper upon the sex-ratio in crosses between European and Japanese races of Gypsy moths (Limantria dispar). He gets various gradation in his sexes mlike the well-known gynandromorphs. His indivicluals do not represent a mixture of the characters of the two 
sexes but a definite point between the extremes of femaleness and maleness. He gets females which show feathered antennae of medium size (feathered antennae are a male character), but which are otherwise normal in appearance except that they produce fewer eggs which are fertilized normally. He gets females which have gone a step further towards maleness in the appearance of male wing pigmentation and so on progressively until a female becomes a male. With the increasing tendency towards maleness there is a loss in the power of the female to lay eggs and examination reveals the transition of ovaries into testes.

In his male cultures he has secured stages in transition beginning with a pure male up to a 75 percent female, while in his female cultures he has secured what he calls "female males," which can be regarded as the limit of the male extreme. Goldschmidt proposes the term "intersexes" for these individuals. Any one of the above individuals, Goldschmidt claims, can be secured at will by crossing certain strains.

The striking parallelism in the behavior of Goldschmidt's cultures of females and my cultures of females in Mercurialis anmua is significant. Potentially Goldschmidt's female "intersexes" may be regarded as functional. It is merely a matter of environment that prevents their functioning. The females of Mercurialis are self-fertile and produce seed. The female plant that produces one seed on self-fertilization is more a female than the one that produces 230 seeds upon self-fertilization. The female cultures of Mercurialis anmua may be regarded as exhibiting transition stages from femaleness towards maleness.

Correns's work on gynodioecious plants is in teresting in the above connection. Plantago lanceolata exhibits various gradations in forms between the hermaphrodite and female. Correns finds that the stronger the female tendency is present in a female plant the weaker will be the influence of the hermaphrodite upon that plant when they are crossed. The offspring resulting from his cross will be females in over 90 percent of the plants. If, however, the female plant used tends in the direction of the hermaphrodite, that is to say, it produces a few anthers, the hermaphrodite will influence the offspring so that there will be a dimunition in the number of females and an increase in the number of hermaphrodites. 
Correns and Bateson's results on Bryonia dioica and B. alba in the light of their interpretations would establish that one or the other of the sexes of Bryonia dioica has two kinds of gametes. The work on Mercurialis annua appears to negative the above assumptions. Mercurialis does this by recording its own so-called gametic constitution in the selfed males and selfed females.

The present work was begun in February, I9I4, under the direction of Professor R. A. Harper. 


\title{
TRIASSIC PLANTS FROM SONORA, MEXICO, IN- CLUDING A NEOCALAMITES NOT PREVIOUSLY REPORTED FROM NORTH AMERICA
}

\author{
Edwin W. Humphreys \\ The New York Botanical Garden
}

(WITH PLATE 5)

The collection on which this article is based is a very small one in regard to the number of both specimens and species. Inasmuch, however, as our knowledge of the Triassic flora of North America is comparatively limited, and as the collection contains at least one well-defined species which apparently has not been heretofore reported from North America and others whose range it extends, it is of some interest. It was made a number of years ago by Mr. Benjamin F. Hill in the Santa Clara Coal Field, Sonora, Mexico, and was presented to The New York Botanical Garden by Professor James F. Kemp.

Although many of the specimens are very fragmentary and the identification of these is more or less unsatisfactory and incomplete, they are on the whole well preserved in a hard bluish-gray shale and there seems to be every indication that more extensive collecting in this region would add much to our knowledge of the flora that flourished in North America during Triassic time.

At least two other collections of Triassic plants from this same general region have been described: the one by Newberry, ${ }^{1}$ from Abiquiu, New Mexico, and Los Bronces and the Yaki River in Sonora, Mexico; the other by Fontaine and Knowlton ${ }^{2}$ from Abiquiu, New Mexico. As indicated later, some of the plants of the collection under discussion are apparently the same as those

\footnotetext{
${ }^{1}$ Report of the exploring expedition from Santa Fé, New Mexico, to the junction of the Grand and Green rivers of the Great Colorado of the West, in I859, under the command of Capt. J. N. Macomb: with a geological report by Prof. J. S. Newberry, geologist of the expedition. Washington, I876. (Fossil Plants, pp. I 4 I-I 48. pl. 4-8.)

${ }^{2}$ Proc. U. S. Nat. Mus. 13: 28I-285. pl. 22-26. 1890.
} 
described by the authors mentioned. The following are the species:

\section{PTERIDOPHYTA}

\section{Order Filicales}

Pecopteris Bullata Bunbury, Quart. Jour. Gcol. Soc. London, 3: 28I. pl. II.f. I, Ia, Ib, Ic. I 847

Mertensides bullatus (Bunbury) Fontaine, Mon. U. S. Geol. Surv. 6:35.pl. I5.f. 2-5; pl. I6.f. I-3; pl. I7.f. I, 2; pl. I8.f. I, 2; pl. I9.f. I. I 883 .

This species is by far the most numerous of the forms in the collection. It is well preserved and there is no cloubt as to its being identical with that recorded by Newberry from Sonora, Mexico. The specimens show both sterile and fertile fronds. Fontaine considers Bunbury's species as belonging to his genus Jertensides but as the specimen in hand agrees perfectly with that figured by Bunbury and by Newberry, while its agreement with the genus Mertensides does not seem to be so close, the name used by Bunbury is here retained.

Asterocarpus falcatus (Emmons) Fontaine; Ward, Twenticth

Ann. Rep. U. S. Geol. Surv. 2: 237. pl. 22.f. 3. 1900

Pecopteris falcatus Emmons, Geol. Rep. Midland Counties, N. C. 327. pl. 4.f. g. $\quad$ I 856 .

Though well characterized only a single pinnule represents this species.

Asterocarpus virginiensis Fontaine, Mon. U. S. Geol. Surv.

$$
\begin{gathered}
\text { 6: +1. pl. I9.f. 2-5; pl. 20.f. I, 3; pl. } 21 . f .1,2 ; \text { pl. } 22 . \\
\text { f. I, 3; pl. 23.f. I-4; pl. 24.f. I, 2. I } 883
\end{gathered}
$$

This species is well represented in the collection. Though the finer nervation is not so well preserved as one might wish, the outline and the coarser nervation leave little to be desired.

\section{MACROTAENIOPTERIS SP.?}

This is a very fragmentary specimen, and for this reason it is not considered advisable to attempt to identify it specifically. It is, however, closely related to Macrotaeniopteris magnifolia 
(Rogers) Schimper, which has been reported from Sonora, Mexico, by Newberry.

\section{Order Equisetales}

Neocalanites Carrerei (Zeiller) Halle, Kgl. Svensk. Vet.-Akad. Handl. 43: 6. 1908

Schizoneura Carrerei Zeiller, Fl. Foss. des Gîtes de Charbon du Tonkin, 137-I43. pl. 36.f. I, 2; pl. 37.f. I; pl. 38.f. I-8. 1903.

This specimen though somewhat smaller is apparently identical with that figured by Zeiller on $p l .37 . f$. I. So far as the writer is aware this species has not heretofore been reported from North America.

\section{SPERMATOPHYTA}

\section{Order Cycadales}

Zamites Powelli Fontaine; Fontaine \& Knowlton, Proc. U. S. Nat. Mus. 13: 284. pls. 25, 26. I 890

While not as complete as might be desired, there is enough of the plant preserved to show its identity with Fontaine's species from Abiquiu, New Mexico.

Otozamites Macombir Newberry (?), Rep. Macomb Expl. Exped. I+1.pl.4.f. I, 2; pl.6.f.5, 5a. I876

This identification can hardly be used as the basis of any conclusions in regard to the geology or paleobotany of the horizon in which the specimen was found as it is too fragmentary to permit of much more than an exceedingly provisional identification.

\section{ZAMites (OTOZAMites ?) sp.?}

The remains of this plant are in so fragmentary a condition that assignment to any particular species is precluded.

\section{Crcadeomyelon (?) sp.?}

The fragment included in this genus is so poorly preserved that it would not be worthy of notice were it not for the fact that it represents a distinct plant differing from any of the others in the collection. 
78 MEMOIRS OF THE NEW YORK BOTANICAL GARDEN

\section{Order Coniferales}

Palissya sp.?

This fragment of what appears to be the remains of a leafy coniferous branch resembles very closely forms referred to the above genus and to Walchia. As the greater resemblance is, however, to the former, it is here included therein.

\section{Explanation of plate 5}

Neocalamites Carrerei (Zciller) Halle; from Santa Clara Coal Ficld, Sonora, Mexico. Natural size. 


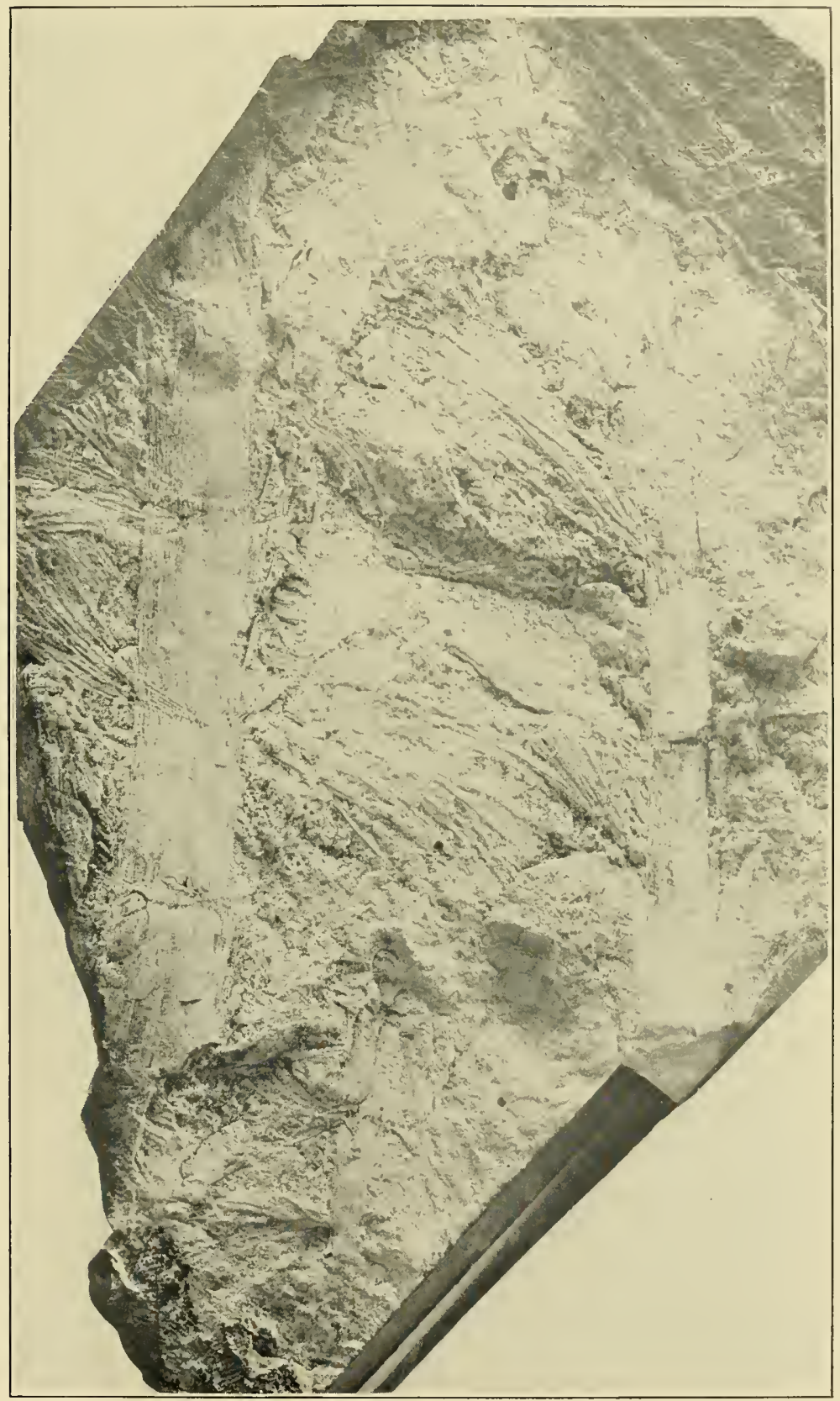

Neocalamites Carrerei (Zeiller) Halle 



\title{
A WHITE-CEDAR SWAMP AT MERRICK, LONG ISLAND, AND ITS SIGNIFICANCE ${ }^{1}$
}

\author{
Norman TAYLOR \\ Brooklyn Botanic Garden
}

(With plates 6-Io)

The white cedar (Chamaecyparis thyoides) is sufficiently scarce near New York City to make a grove of several hundred acres a spot of peculiar interest. About twenty-five miles from the City, at Merrick, on the south shore of Long Island, there is a cedar swamp more than a mile long and varying in width from a few yards to nearly half a mile. The same swamp has been noted by Miss Mulford (12), Nichols (14), Bicknell (15), and Harper (13).

The general range of the species as given in the manuals is (doubtfully indigenous in Nova Scotia) from southern Maine south along the coast to western Mississippi. All of the stations for it on Long Island are on the coastal plain except those near Riverhead, where it is found between the Harbor Hill and Ronkonkoma moraines. These stations near Riverhead are mostly scattered trees, there being no grove of any considerable area. Not only is this cedar swamp at Merrick the largest on Long Island, but so far as the general distribution of the species is concerned, it is the extreme northern outpost on the coastal plain of any considerable grove, the other cedar swamps on the island being much smaller. For this reason the occurrence of Chamaecyparis at Merrick and its behavior is of special interest. Chamaecyparis thyoides occurs in the area of which New York is the center, either on the coastal plain, or in the glaciated region, not in the intervening territory $(7,11,19,22,24)$. In the glaciated area it is scattered through southern and eastern Connecticut, northern New Jersey and in Westchester, Putnam, and Orange counties on the mainland of New York, and is nearly always found in glacial pot-holes, or morainal depressions. On the coastal plain it is

${ }^{1}$ Brooklyn Botanic Garden Contributions No. I4. 
usually found along slow-moving streams in typically swampy areas. But there are many such areas on the coastal plain of Long Island where the species might be expected, notably near Babylon (16) and along the Connecticut (Carman's) River from Japhank to South Haven. But it has never been found at these and several other likely localities. Just what the factors controlling the appearance of the species on Long Island are, it is impossible to say.

The swamp at Merrick stretches from about three quarters of a mile north of the Long Island Railroad, along the banks of a stream to the salt marshes, which are about three quarters of a mile south of the railroad. The best present development of the swamp is at the northern end, on the property of Harold Bunker, Esq., who has carefully protected the existing grove. A goodsized pond, caused by the damming of the stream about a hundred years ago, divides this northern part of the cedar swamp. All of the region now occupied by the pond was once covered by white cedar trees, submerged stumps of which may still be seen in the clear water. PLATE 6 shows the present general aspect of the region, and PLATES 7 and 8 the upper ends of the pond and the growth of cedars beyond. These trees mark the northern limit of the grove. To the southward the swamp has suffered much from fire and from the pumping operations of the City, a reservoir having been made just north of the railroad, thereby clearing the trees from this area. To the south of the railroad the cedar trees stretch uninterruptedly to the salt marshes near which there is a conspicuous fringe of dying and dead trees.

One of the most characteristic plants of the undergrowth in white-cedar swamps is Rhododendron maximum (19, 22), and, in the south, Magnolia. Neither of these are found in the swamp at Merrick, and indeed the character of the undergrowth there is such that several interesting problems are suggested by a study of the floristic content of the whole swamp).

The commonest tree, besides the Chamaecyparis, is Acer carolinianum, if this be not a mere form of A. rubrum. Morescattered, and much less common are Nyssa syliatica, Quercus rubra, and strangely conough, Sassafras, which is very plentiful in the dry reaches of the adjacent coastal plain scrub, but secms perfectly at home also in the deep shade of this moist forest. See PLATE 9 for general aspect of the interior of the swamp. 
But it is the character and composition of the undergrowth that is of chief interest. With Rhododendron and Magnolia lacking, the dominant undergrowth is as follows:

\section{WOODY PLANTS}

Clethra alnifolia

Gaylussacia frondosa

Alnus rugosa

Azalea nudiflora

Azalea viscosa

Benzoin aestivale

Hamamelis virginiana

Viburnum dentatum (rare)

Eubotrys racemosa

Toxicodendron Vernix (rare)

Sambucus canadensis

Aronia atropurpurea
Aronia arbutifolia

Nemopanthus mucronata

Ilex laevigata

Ilex glabra

Ilex verticillata

Vaccinium atrococcum

Vaccinium atlanticum

Rubus hispidus

Vitis aestivalis

Toxicodendron radicans

Smilax rotundifolia

Parthenocissus quinquefolia

\section{Herbaceous plants}

Dryopteris simulata

Woodwardia areolata

Woodwardia virginica ${ }^{1}$

Spathyema foetida

Arisaema triphyllum

Carex Collinsii ${ }^{2}$

Carex Howei

Unifolium canadense
Viola pallens

Viola papilionacea

Trientalis americana

Panicularia obtusa

Lilium canadense

Vagnera racemosa

Triadenum virginicum

Mitchella repens

The list is doubtless not complete but it serves as a guide to the most characteristic and commonest species in the swamp, which seems to have reached its climax or ultimate development, there being practically no open places in it, and being apparently farthest removed from the open-water, initial stages of whitecedar swamps described from near Woods Hole (9).

The odd feature of this aggregation of plants is that a comparatively cool habitat, many degrees cooler than the hot coastal gravels of the adjacent region, is here conditioned by the stream, and by three southern trees that are much nearer their northern

${ }^{1}$ The three ferns reported by Mrs. Britton and Miss Mulford (I2).

${ }^{2}$ Carices kindly determined by Mr. K. K. Mackenzie. 
than their southern limits. The shade and consequent coolness are mostly caused by the dominant Chamaecyparis, and the slightly less common Acer carolinianum and Nyssa, all of which are here near their northern limits, two of them being known only from Maine, the other from southern Massachusetts, southward.

An analysis of the woody undergrowth shows the same characteristic. Seventy-six per cent of the shrubs and vines at the Merrick swamp are of southern rather than northern affinities. Similar figures for the cedar swamps in Connecticut (22) show 68 per cent of the woody plants as southern and in the pine-barrens 77 per cent (19). How accurately these figures represent the dropping out of southern woody species as we come northward no one can say, but at least they indicate the general tendency of the white cedar to be associated with typically southern woody plants and to lose some of these, but not many, as it occurs northward. We have then a cool, almost coniferous-bog condition of the north, on a hot coastal plain, caused mostly by southern trees and shrubs, all of which are much nearer their northern edges of distribution than their southern.

This raises at once the question as to what is the character of the herbaceous regetation occurring in the swamp. An analysis of the above list shows that 77 per cent of the herbaceous vegetation is northern rather than southern. Similar figures from Connecticut show about 70 per cent of northern herbs. We have in this a really remarkable condition, some of which may be due to historical factors. Here, in a locally cool region, we find an aggregation of northern herbs vastly in excess of the percentage of such herbs in the surrounding region and their occurrence conditioned by the shade provided by predominately southern woody plants.

The mixture of these northern and southern elements in one swamp, which is, as shown above, not peculiar in this respect, is an excellent, if rather concentrated example of the distribution of the Long Island flora generally. The great majority of species on the coastal plain are southern, many of them reaching their northern distribution outposts on the island. Along the morainal ridge and north of it, however, the species are more northern in character. Nore or less of a tension zone exists between these two elements. But in this cedar swamp there is no evidence of a 
tension zone, for here, crowded in a small area, are two groups of species, three quarters of the woody plants of which are southern and three quarters of the herbaceous plants northern.

The conviction that these cool-atmosphere, typically northern herbaceous species are found in the cedar swamp merely because the environment is favorable and not as the result of some far reaching, almost catastrophic agency, seems inevitable. That the large percentage of herbs should be northern and that an equally large percentage of woody plants should be southern, does no violence either to the theory of Sinnott and Bailey as to the origin of herbaceous angiosperms, or to the observed ratios of growth-forms as worked out by Raunkiaer. The chief significance would seem to lie in the fact that the occurrence of these northern herbs at this point, and probably at other shaded swamps on the island, is conditioned by a group of southern woody species, which have failed to bring with them from the south the herbs with which they are there associated. And just because these southern woody plants have created a favorable habitat we find in their shade a growth of northern herbs, which, needing such conditions, are likely to occur there and nowhere else. This looks like a commonplace way of accounting for the mingling of two such diametrically opposed elements in the same swamp, but Chamaecyparis swamps further south seem to indicate that the southerly range of a number of northern herbs is conditioned by the occurrence of these swamps. Upon this conception the distribution of the tree is of less significance than is the fact that its occurrence postulates conditions favorable for the growth of herbs that would not be there if the Chamaecyparis was lacking. And the white cedar does, to a peculiar degree, make unusual conditions on the coastal plain, the dense cool shade being in such marked contrast to the surrounding region.

\section{ThE WhITE CEDAR AND THE SALT MARshes AT MERRICK}

Near the lower end of the cedar swamp, the trees begin to thin out, both as to frequency of occurrence and size, and immediately facing the salt marsh there is a large area made up of dying or wholly dead Chamaecyparis trees. See PLATE IO. Facing these is the salt marsh, which is nearly two miles wide. There is one good-sized tidal stream in it having near its upper 
limit, which is near the clead cedar trees, a rise and fall of about IS inches. Occasional special high tides flood the lower stretches of the cedar swamp and it is this that kills off the cedar. For this tree is not a salt tolerant, while Nyssa and Quercus stellata, inveterate inhabitants of the edges of most Long Island salt marshes, flourish among the dead evergreens.

It has recently been suggested by a geologist (23) that if along the edges of salt marshes there were to be found a well-marked zone of regetation that seemed to be putting up a losing fight against sea water, it would be excellent evidence that coastal subsidence was well marked in the region. The reasoning seems to be sound, especially for trees that are not good salt tolerants. It is unlikely that such trees would become established if the amount of salt water had in the past been unfarorable, but once having reached maturity in a given situation, the question of the cause of their death seems to force on one the necessity of accounting for the obviously recent encroachment of the salt water. Such seems to be the case at Merrick as PLATE Io shows.

Local conditions here made it easy to study the probable development of the whole salt marsh. Extending out into the marsh, just west of the area below the cedar swamp, is a long promontory of higher land that reaches for nearly a mile towards the bay. This lobe of drier land maintains a flora much like that of the upland region of the coastal plain, except that the red cedar, Juniperus virginiana, is the dominant tree. With scattered plants of Quercus stellata, Acer carolinianum in lower parts, Myrica carolinensis, Rhus copallina, a Vaccinium or two, and Rosa carolina, the bushes often tangled all together by Smilax glauca, we pass by easy and rapid stages through thickets of Baccharis and Iva to the open salt marsh which is guite bare of woody regetation. All these types may be found within twentyfive feet of one another. The surface evidence of coastal subsidence here is not convincing, for while this edge of the lobe of higher land is much nearer the bay, no fringe of dead or dying plants is to be found as in the case of the white cedar. The reason too is obvious, as all the species above mentioned as inhabiting the edges of the drier land, are good salt tolerants and not likely to be affected by occasional inundations of sea water.

It is unnecessary to review here all the pros and cons of the 
question of coastal subsidence, ancient and modern. That there has been such, both ancient and recent, seems quite clear not only on the evidence of older writers $(1,2,3,4,18,20,21)$ but on evidence collected at pits dug in the marsh at Merrick in I9I5. If the whole region has been sinking we should expect to find vegetable remains indicating a different type of flora on the area now overlaid by the marsh. And if these vegetable remains are not fossilized the presumption is that they are all postglacial and not to be confused with glacial or interglacial material (10). Such vegetable remains would seem like mute evidence of subsidence. With these points in mind, four pits were dug in the marsh situated as follows:

I. Nearly two miles from the white-cedar trees, the surface vegetation on the marsh where the pit was dug being made up of,

Spartina cynosuroides

Spartina patens

Distichlis spicata

Salicornia europaea

which should be evidence enough that it is near the outpost of salt-marsh vegetation. It is within a few hundred yards of the bay. The first two feet of digging was through solid turf of Spartina cynosuroides, and its roots. At three feet and five feet partly decomposed remains of the same grass, all enveloped in foul-smelling black ooze, was found. It was not possible to get down lower than this, the digger being unable to get footing as the water rose. All of the remains here point to the region having been salt marsh far back in the history of the region. This is what we should expect, for if the region has been sinking, presumably this seaward edge would show merely a repetition of previously existing salt-marsh flora, which is exactly what our evidence points to. Just how far back it has been in this condition it is impossible to say, as guesses have varied from a few inches to a foot or more a century as normal subsidence $(1,5,18)$.

II. About Ioo yards seaward of the extremity of the lobe of higher land. Surface vegetation at the point where the pit was dug consisted mostly of the following:
Limonium carolinianum
Solidago sempervirens
Tissa marina
Salicornia europaea
Plantago major halophila
Plantago maritima
Juncus Gerardi 
For the first i 8 inches the turf formed an exclusive and very tough mat, just beneath which were found a large quantity of clam shells, emphatically not a kitchen midden. These have been identified as Venus mercenaria which is "common in shallow water on muddy bottoms in the bays and estuaries about Long Island." Below the clam shells apparently pure beach sand and gravel were found with very few traces of regetable remains. Here the inference that we have to do merely with a recently sunken beach whose clam strewn shore has been covered by "salt hay" seems clear enough.

III. Within one half mile of the edge of the cedar swamp and about roo feet from the tidal stream, which seems from the general configuration of the land to have always been the natural drainage of the stream now flowing through the cedar swamp. The surface of the ground where the pit was dug was covered principally by the following:

$\begin{array}{ll}\text { Spartina patens } & \text { Atriplex hastata } \\ \text { Distichlis spicata } & \text { Agalinis maritima } \\ \text { Plantago maritima } & \text { Limonium carolinianum } \\ \text { Sabbatia stellaris } & \text { Solidago sempervirens }\end{array}$

For the first is inches, as in the other pits, the turf was nearly exclusive, but below we find an entirely new condition indicated. Large quantities of twigs, sticks, wood, bark, leaves, half a hickory mut, and other remains indicating regetation decidedly not of the salt-marsh type were abundant, mixed with fine clean sand and gravel. There is an almost startling change between the salt marsh surface and this evidently upland regetation, now buried. None of the remains could be definitely identified as those of Chamaecyparis.

IV. Surface covering the same as at the third pit, except for the arldition of Sanguisorba canadensis and a few other swamp plants. This station is just outsicle the zone of dead cedar trees (see P'ATE, 1O) and the character of the remains practically the same as in III, except that definitely identifiable Chamaecyparis remains are fairly common.

What can all this point to but the gradual dying out of the cedar and its replacement ly salt marsh? The phenomenon has been mentioned so many times hefore that there seems hardly any

1 Kindly iclentifuel for me ly .Mr. G. P'. Engelhardt of the Brosklyn Muscum. 
warrant for bringing it up again (17). In the case of the seaward end of the marsh we find merely a repetition of what has probably been always salt marsh. Nearer the present cedar swamp we find evidences of buried cedars, now more than two miles from the bay, and covered by typical salt-marsh flora. In the intervening region off the line of the probable drainage of the old fresh-water stream, now tidal, we find remains of a vegetation almost exactly like that now found on the lobe of drier land that extends out into the marsh. Here, again, this is now covered exclusively by typical salt-marsh-flora.

The evidence of costal subsidence thus seems entirely conclusive. While no new facts in connection with that controversy have been stated, with the possible exception of the record of the dead zone of cedar trees, it is surely of significance to find such evidence so far back from any barrier beach or other possible regulator of exceptional tides, which has been suggested as a possible alternative to recent subsidence.

The cedar swamp at Merrick, then, is of interest (a) because it is probably the most northerly grove on the coastal plain of anything like that size; $(b)$ the character of its undergrowth; (c) the evidence of coastal subsidence suggested near the transition between the grove and open salt marsh, by the large number of dead and dying trees.

\section{Bibliography}

I. Cook, G. H. On a subsidence of the land on the seacoast of New Jersey and Long Island. Am. Jour. Sci. II. 24: 34I-355. I 857 .

2. - Geology of the county of Cape May (N. J.), 62 and 39. I 857 .

3. Lewis, E., Jr. Evidences of coast depression along the shores of Long Island. Am. Nat. 2: 334-336. I 868.

4. - Ups and downs of the Long Island coast. Pop. Sci. Monthly ro: $434-446$. I 877 .

5. Shaler, N. S. Sea-coast swamps of the eastern United States. Ann. Rep. U. S. Geol. Surv. 6: 359-398. I 884.

6. Hollick, A. Plant distribution as a factor in the interpretation of geological phenomena, with special reference to Long Island and vicinity. Trans. N. Y. Acad. Sci. I2: 1 89-202. I893.

7. Gifford, J. Distribution of the white cedar in New Jersey. Gard. \& Forest 9:63. $\quad$ I 896. 
8. Knowlton, F. H. Catalog of Cretaceous and Tertiary plants of North America. Bull. U. S. Geol. Surv. I52:- I 898.

9. Shaw, C. H. The development of vegetation in the morainal depressions of the vicinity of Woods Hole. Bot. Gaz. 33: 437. 1902.

Io. Berry, E. W. Paleobotanical notes. Bot. Gaz. 39: 232. 1905.

I I. Harper, R. M. The coastal plain plants of New England, their history and distribution. Rhodora 7:69-80. 1905;8: 27-30. I906.

I2. (Anon.) Field meetings of the Torrey Club. (May 30, 1906.) Torreya 6: 130. 1906.

I3. Harper, R. M. A Long Island cedar swamp. Torreya 7: 198-200. 1907 .

I4. Nichols, J. T. New station for Chamaecyparis on Long Island, New York. Rhodora 9:74. I907.

I5. Bicknell, E. P. The white cedar in western Long Island. Torreya 8: $27,28 . \quad 1908$.

I6. Harper, R. M. The pine-barrens of Babylon and Islip, Long Island. Torreya 8: I-9. I908.

I 7. Bartlett, H. H. The submarine Chamaecyparis bog at Woods Hole, Massachusetts. Rhodora II:221-235. 1909.

I8. Davis, C. A. \& Bastin, E. S. Peat deposits of Maine. Bull. U. S. Geol. Surv. 376: 19, 20. I909.

19. Stone, W. Plants of southern New Jersey with special reference to the flora of the pine-barrens. Ann. Rep. N. J. State Mus. I9I0: 70, I5I. I9I2.

20. Clarke, J. M. [Review of D. W. Johnson's] Fixité de la côte atlantique de l'Amérique du Nord. Science II. 38: 26. I9I3.

21. Johnson, D. W. Botanical phenomena and the problem of recent coastal subsidence. Bot. Gaz. 56: 449-468. I9I3.

22. Nichols, G. E. Vegetation of Connecticut. Torreya I3: 89-II2. I913. Bull. Torrey Club 42: I69-2I7. I9I5.

23. Fuller, M. L. Geology of Long Island, New York. Prof. Paper U. S. Geol. Surv. 82: 212-216. I9I4.

24. Taylor, N. Flora of the vicinity of New York: A contribution to plant geography. Mem. N. Y. Bot. Gard. 5: 4, I I, 7t and pl. 6. I9I 5 .

Explanation of plates 6-10

PLATES 6-8

Bunker's Ponrl, Merrick, Long 1sland, New York, showing upper end of white-cedar swamp.

Plate 9

Interior of white-celar swamp be!ow Bunker's Pond, Merrick, Long Island, New York.

Plite 10

Contact of white-cedar swamp and salt marsh, Merrick, Long Island, New York. 


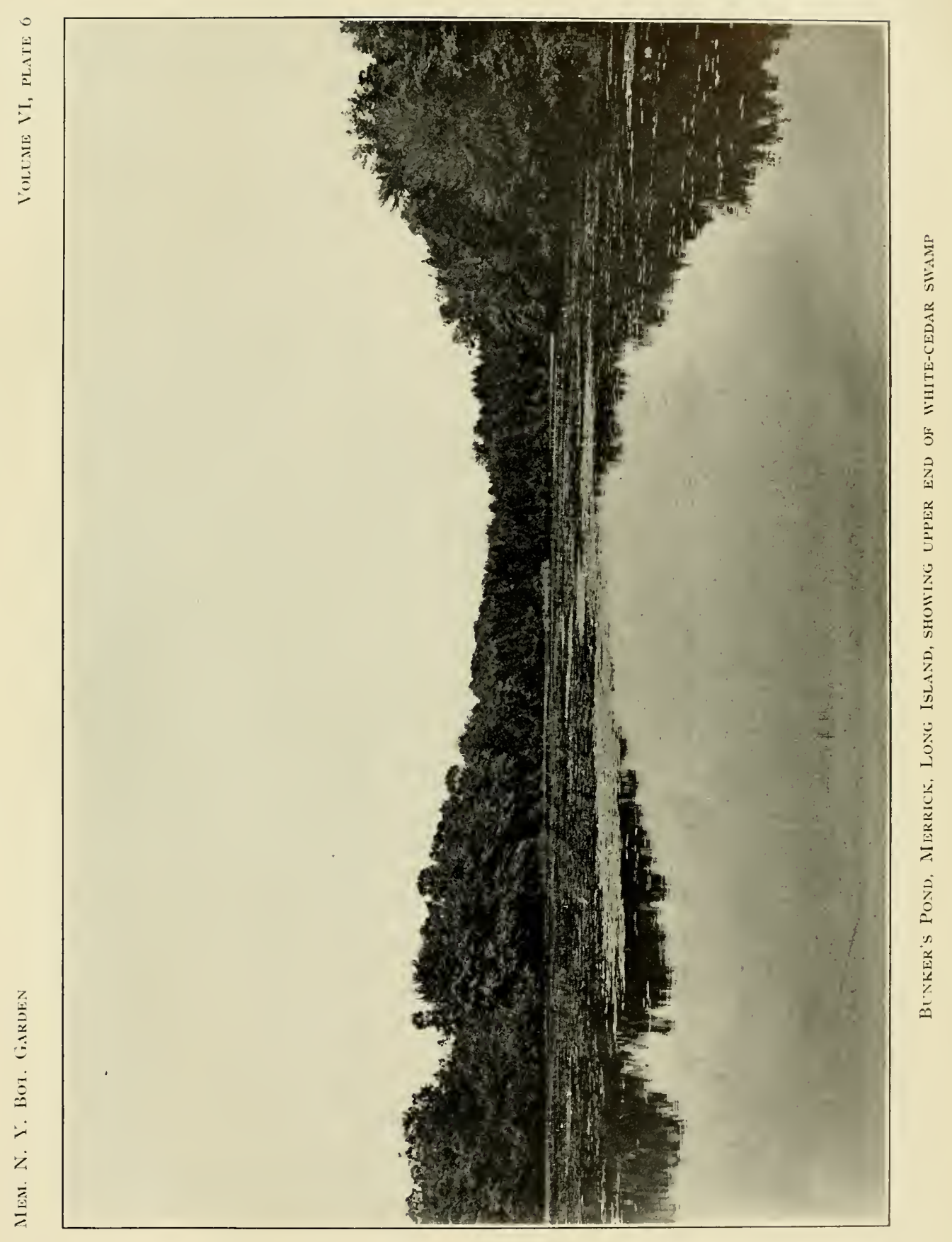





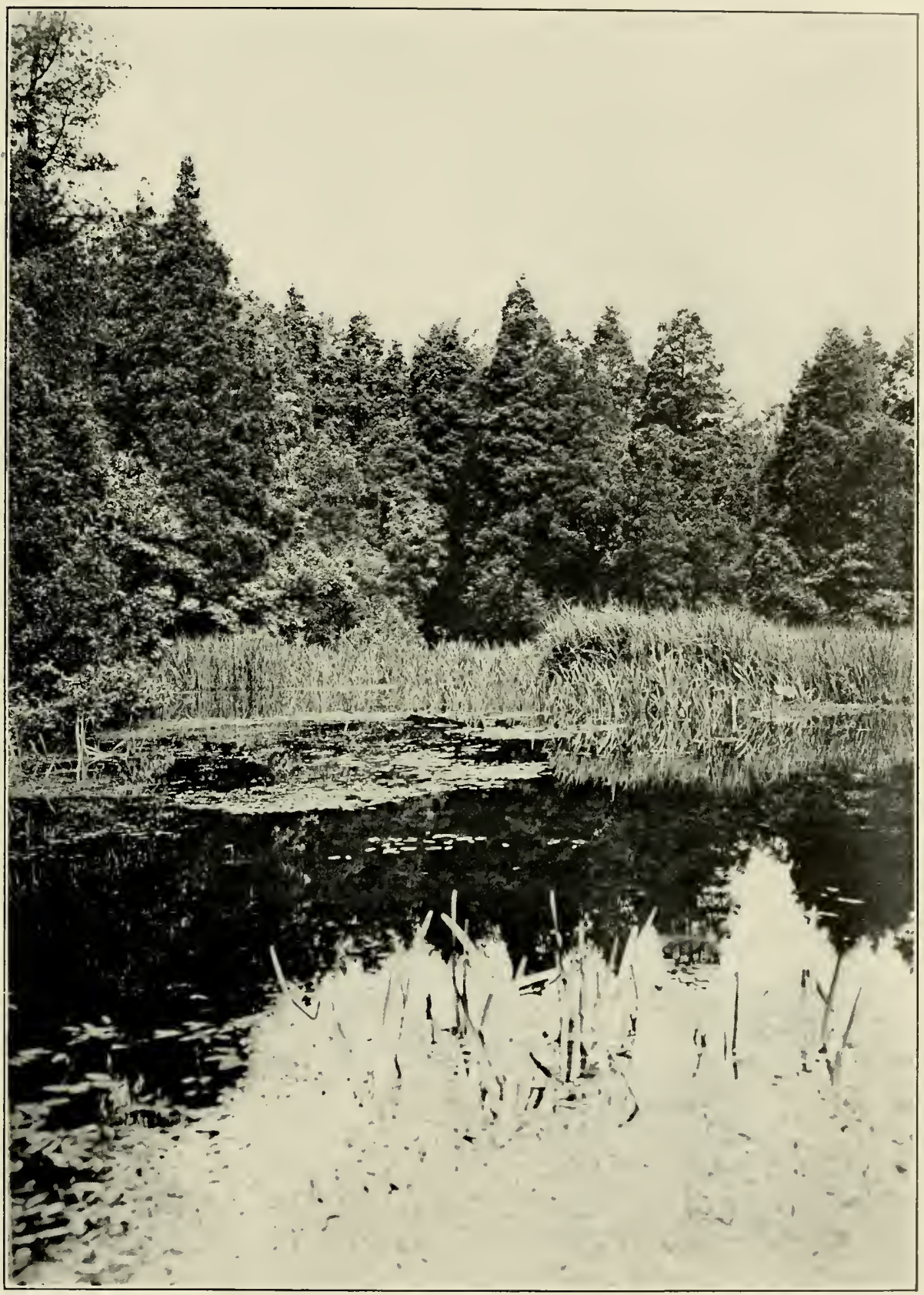

BUNKER'S POND, MERRICK, LONG ISLAND, SHOWING UPPER END OF WHITE-CEDAR SWAMP 



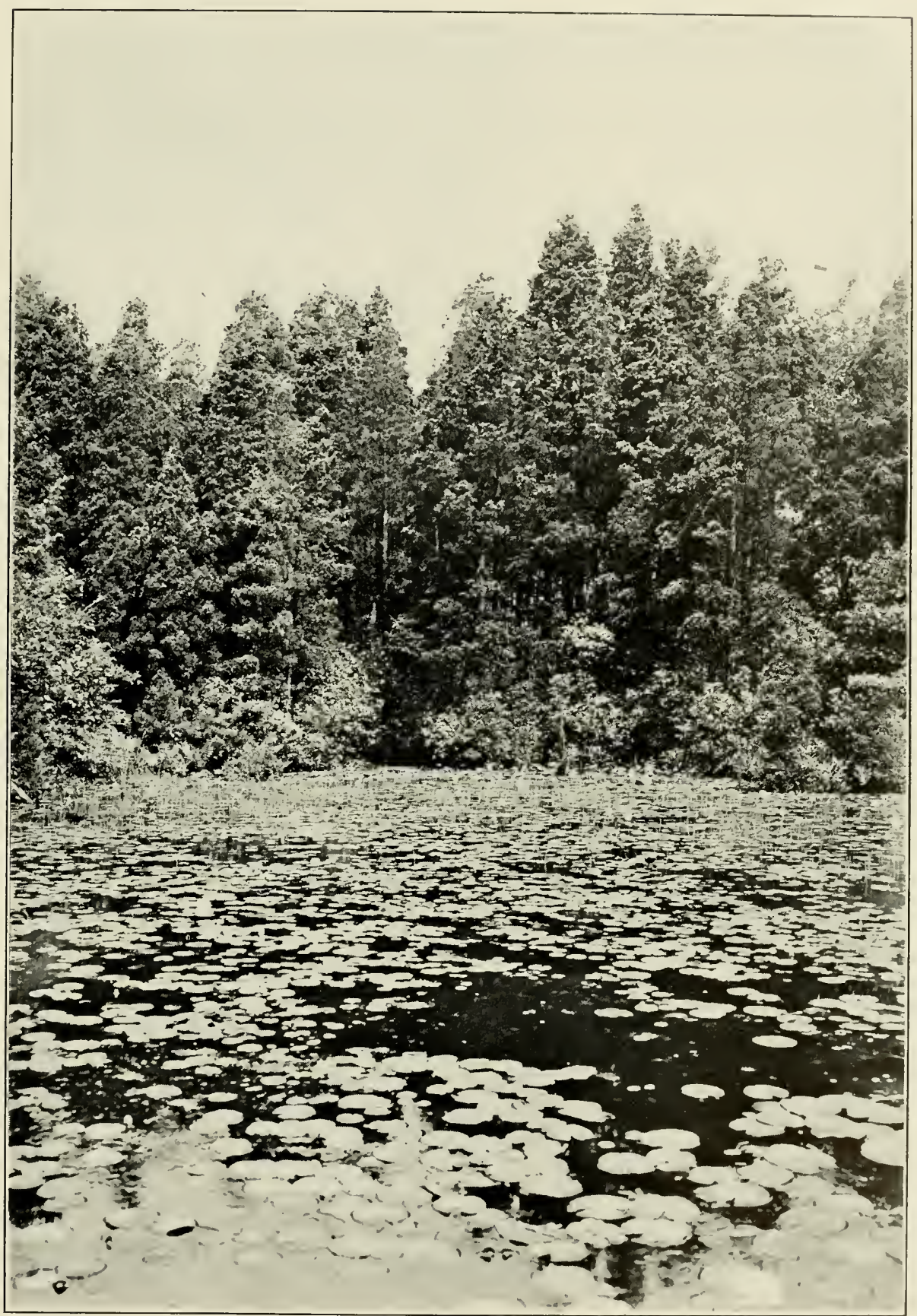

BUNGER'S POND, MERRICK, LONG ISLAND, SHOWING UPPER END OF WHITE-CEDAR SWAMP 



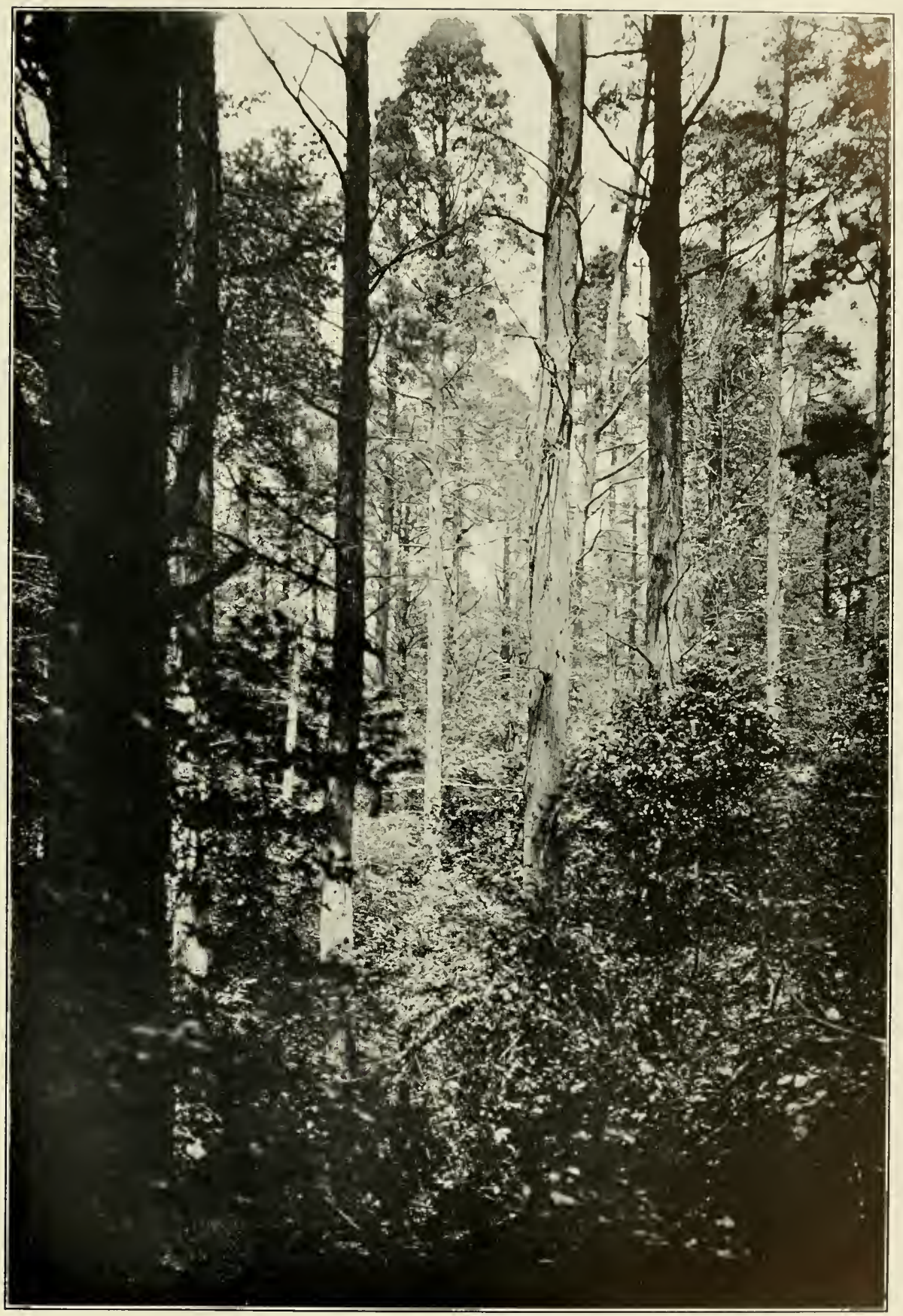

INTERIOR OF WHITE-CEDAR SWAMP BELOW BUNKER'S POND, MERRICK, LONG ISLAND 



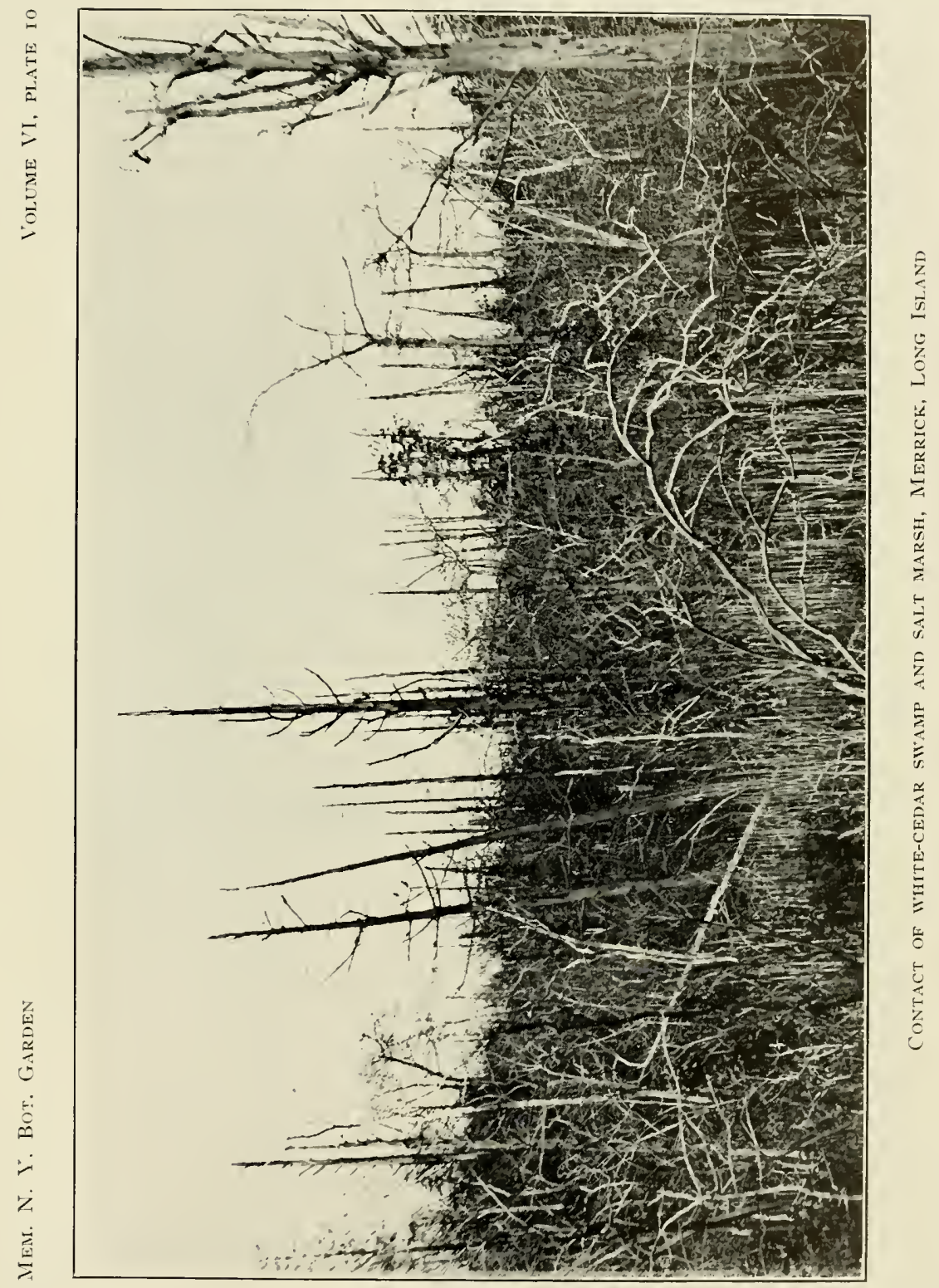





\title{
INHERITABLE VARIATIONS IN THE YELLOW DAISY (RUDBECKIA HIRTA) $)^{1}$
}

\author{
Albert F. Blakeslee
}

\author{
Station for Experimental Evolution
}

Variations in the following characters have been found in the wild yellow daisy: absence of rays and their presence in rather definite numbers from 8 to 30 and to perfectly double forms; width of rays; diameter of head from I to $5 \frac{1}{2}$ inches; color of rays from pale straw color to deep orange; relative intensity of color in inner half of ray forming a lighter or darker ring; different intensities of mahogany color at base of ray on upper side; mahogany on under side of ray; constriction of ray at tip, at middle, or at base-those constricted at tip, either rolled in or rolled out to give the "cactus" type seen in dahlias-those constricted at base without change in color or characterized by lighter color or by presence of black pigment on constricted areas; transformation of rays into tubes giving "quilled" type; the position of rays, bending upward, horizontal, reflexed, straight or variously twisted; the shape and size of disk; the color of disk from yellowish green through several grades of purple to almost black; vegetative characters such as height, branching, size and shape of leaf, fasciations, etc.

Evidence from the distribution of the variants in nature and from their reappearance in sowings from open-pollinated heads shows that most, if not all, these variations are inherited. The basal splash of mahogany on the ray seems to be inherited as a simple Mendelian dominant, while another red blotching is inherited as a recessive. Other characters are being investigated.

${ }^{1}$ Abstract. The paper was illustrated by living specimens. 



\title{
ON THE NATURE OF TYPES IN PEDIASTRUM
}

\author{
R. A. Harper \\ Columbia University
}

The Pediastrum group has been perhaps as much as any other in the plant kingdom the subject of divergent judgments as to the number and characterization of its species. Its sharp delimitation from all other genera by the form and life history of the colony and the obvious subdivisions which are suggested by the lobing of the cells were early recognized, but the wide range of variation in cell proportions, number, and arrangement in the colonies, has led to the most diverse opinions as to the number of species which should be recognized. Nitardy's (6) summary of the literature brings out very adequately these divergent views as to what should constitute specific characters in the group.

Pediastrum is also interesting as a type in which the beginnings of cell differentiation in a coenobic colony are clearly shown. In the common species, P. Boryanum, the cells of the outer series are each provided with a pair of conspicuous spine-like lobes. In some other species the difference between the cells is less marked. We have thus before us incipient stages of differentiation in structure and an approach to a typical metaphytic habit.

As Meyen (3) observed, the specific organization of the colonies of Pediastrum, as shown in the arrangement of its cells, is most mathematically definite in general plan but shows an almost infinite degree of fluctuating variation in its details. As noted by Naegeli, ( 4 and 5 ), Al. Braun (1) and others, the most common form of the I6-celled colony of $P$. Boryanum shows one cell in the center with five cells around it and ten in the outer circle. The cells are really as nearly as possible in groups of three, which is the most compact arrangement they can assume. At all points of contact, we find three walls converging to a point as in a typical foam structure with one layer of vesicles. Less commonly, as Naegeli and Braun also observed, there is a central group of 4,5 or 6 cells with I2, I I or Io cells respectively in the 
outer series, still other arrangements are also found. Braun notes more specifically the possible variations in the inner group, which, howerer, need not concern us here.

In my study of the colonies of Pediastrum all the measurements of angles, arcs, etc., were made on photomicrographs such as are reproduced in the figures. The photographs were from four to ten $\mathrm{cm}$. in diameter in the material here discussed. The magnifications are given in connection with the figures. In some cases the original print as taken was enlarged by rephotographing it in order to make it easier to measure the angles. This was done in the case of both FIGURES I $a$ and $2 a$.

The difficulties in the way of measuring the angles in such small figures are, of course, very great. A transparent xylonite protractor with radii from the center marking the angles of $120^{\circ}$ was used and the angles were read by laying on a ruler. All three angles about a point of intersection of the cell walls were read with a single placing of the protractor so that the sum of the angles about such a point was always made $360^{\circ}$, a result which, of course, would not be achieved if the protractor was placed anew for each of the angles to be measured. No claim can be made for great accuracy in the measurements. The breadth and frequently the vagueness in the outline of the cell walls in the photographs precluded the possibility of getting a high degree of consistency in the measurements even when repeated many times. There is no question, however, that much more accurate results can be obtained by measuring photographs than by attempting to measure the angles directly on the organism under the microscope. And the data obtained are certainly convincing on the general point that where, as is so regularly the case in the I 6-celled colonies, the cells in their contacts form groups of three, the angles of intersection of their walls fluctuate about $120^{\circ}$ with deriations which correlate directly with the number of cells in the colony, their inherited form, etc. The measurement of the angle which each cell of the colony subtends could be made with greater accuracy.

The colonies of Pediastrum tend to conform to the principle of least surfaces both in the shape of their cells and in the form of the group as a whole. Each cell tends to become as nearly spherical as is consistent with its inherited form tendencies and 
its adhesion to the adjacent cells. The colony as a whole also tends to become as nearly circular in outline as is possible with the number of cells of which it is composed and their individually inherited forms. That is, the cells are arranged as compactly as possible under the given conditions.

That the organization of the colony is in conformity with the principle of least surfaces is obvious from inspection and can be illustrated statistically as will be shown more fully elsewhere. The common arrangement of the cells in each case approximates that of the most nearly corresponding one of the series of groups of circles consisting of $7,19,37,61$, etc., which may be called the least surface groups. In such groups the circles are in concentric series and as compactly placed as possible. The diameters of such groups form the series $3,5,7,9$, I I, etc., and each successively larger group differs from the last by one additional peripheral series, the numbers of circles in the successive peripheral series being $6,12,18,24$, etc.

The i6-celled colony, for example, is nearest to the group of nineteen circles which consists of series of six and twelve concentrically placed about a central circle, while the colony of Pediastrum consists of five and ten cells concentrically placed about a central cell.

In view of the deeply lobed and highly irregular contours of the cells in most species of Pediastrum, it seems perhaps quite contrary to fact to speak of them as illustrating the principle of least surfaces. Still, there can be no doubt that this adult form of the cells, their anomogeneity, as Rhumbler (7) would call it, does not prevent their grouping and the angles of intersection of their walls when in contact from showing a marked tendency to approximate a least surface configuration.

The lobed form produces in many species intercellular spaces bounded by curves re-entering the cell bodies and is a very characteristic structural feature of the cells, but it is not in conflict with the general tendency of the colony to assume a rounded or slightly oval form. I have already noted elsewhere (2) that there can be no question that this lobed form is inherited by the cells as individuals since it is assumed by cells which are practically free from tissue continuity and the ordinary environmental adhesions to which they are subjected in the colonies. 
It is to be remembered also that, as was observed by the early students of the group, each cell starts its derelopment as a rounded or slightly ovoid ciliated swarmspore and that the organization of the colony is achieved by the cells while they have this form. So far as their surface tension relations are concerned they behave as mere viscid droplets of jelly-like material, both in the form which they assume and the form relations into which they enter with each other. The colony as it first appears in the vesicle from the mother cell is a plate of rounded or ovoid bodies. The more or less lobed form of the cells is wholly a result of their growth; though it appears immediately on the cessation of the swarming movement or even before movement has entirely ceased, so that very young colonies are quite exact miniatures of the mature ones.

The swarmspores are practically globular or oval plastic bodies and the problem of their combination to form a flat plate in which they shall have the characteristic arrangement found in the adult colony is essentially that of combining sixteen such units into a
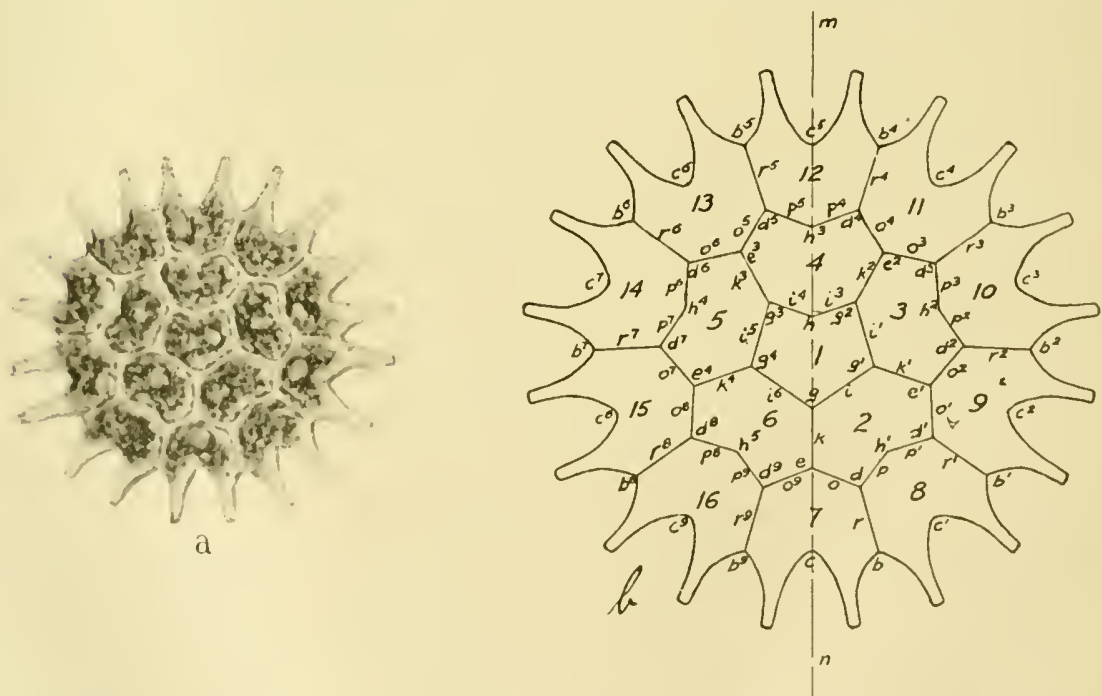

FIG. Ia. Pediastrum Boryanum, sixteen-celled colony, $\times$ about 6oo. The original enlarged about one half in reproduction.

$b$. Diagram showing the cell relations in such a colony. Dimensions obtained by averaging the corresponding sides and angles right and left of the axis $m-n$, except in case of the angles markerl by an asterisk in the table, page 98. The climensions of the cells in the diagran were measured on a photographic enlargement about twice the diameter of figure $a$. The diagram has been reduced about one fourth in reproduction. 
figure as nearly as possible like the more stable least surface configuration which can be formed with nineteen such units. The adhesion between the walls of the different cells acts in the case of the whole colony quite as the molecular forces are supposed to operate in producing surface tension.

We may take the r6-celled colony of $P$. Boryanum, which is commonly figured in textbooks, to illustrate the principles of organization common to the whole group. For convenience we may number the series of cells in the colony from the center outward. The central region of the colony may, as noted, show a central group of three or four cells or a single cell. We may number this central group or single cell $\mathbf{I}$, the next outer series 2, etc. We may also number the cells beginning with the central one, as shown in FIGURE $\mathrm{I} b$. As there are in this case twice as many cells in the outer series as in the next inner series (5), and the cells are equal in size, it follows that two of the outer cells subtend in general the same arc as one cell of the inner series, that is, $72^{\circ}$. Five of the outer third series stand radially outward from the five cells of the second or inner series and five cells are inserted with their middle points opposite the points of contact between the cell walls of the second series.

In the common type of this species three cell walls meet at a point throughout the whole colony. The alternate cells of the outer series 3 are in contact with three or four cells respectively. The cells of series 2 are each surrounded by six cells and the central pentagonal cell by five cells.

Each cell of series 2 shows a slight re-entering angle on its peripheral surface, indicating its tendency to become bilobed like the peripheral cells. The central cell also shows such a reentering angle whose vertex is on a straight line through the center of the colony and the surface of contact of cells 2 and 6 . It is obvious that the colony is bilaterally rather than radially symmetrical with this line for its axis of symmetry.

If the cells were spherical in shape, and were nineteen instead of sixteen in number, we should get the simple configuration of a least surface group which represents the maximum of compactness and stability. In a colony of sixteen instead of nineteen cells which as in Pediastrum arises as a group of free-swimming swarmspores it is obvious that only the most favorable conditions with 
the least possible disturbance in the swarming period will permit the achievement of anything like a symmetrical arrangement. I have already (2) indicated the method by which the configuration of the colonies is determined and shall describe elsewhere the stages in their development with the evidence that the two-lobed form of the cells is a character which is inherited by the cells and comes to expression in some degree at least quite independently of their position in the colony.

We are concerned now with the question as to the relation of this more or less symmetrical organization of the colonies as we find them to the physical principles illustrated in the formation of least surface groups. It is obvious that the visible space relations of the cells to each other and to the organization of the whole are simple and easily ascertainable. A drawing which represents as far as possible a full expression of the tendencies which can be discovered in the actual colonies is shown in FIGURE $\mathrm{x} b$.

I have aimed in this diagram to eliminate all the irregularities in position, size of cells, angles, etc., seen in the actual colony. IVe can approximate such an ideal figure by taking the average of the corresponding lines and angles right and left of the median axis as they are found in a specimen selected for its regularity. The dimensions of the lines and angles in this figure are obtained by averaging those in the colony shown in FIGURE $\mathrm{I} a$.

The fluctuations in any particular dimension vary rather symmetrically about a mode common to the whole group and to a considerable degree balance each other. Figures of aberrant individuals and statistical data as to the fluctuating variability in the group will be published elsewhere.

As was noted by Braun (1) the least surface grouping to which the sixteen-celled colony tends to conform is that of nineteen circles forming two series concentric about a central circle. If these circles are flattened against each other we have the familiar honeycomb configuration in which all boundaries meet in threes and each included angle is $120^{\circ}$.

The conspicuous feature of the sixteen-celled group is that while showing a concentric arrangement of the cells it is also bilaterally symmetrical, its axis bisecting cells $1,4,7$, and 12 and passing through the surface of contact of cells 2 and 6. Except for the slight reëntering angle on the sicle toward cell 4 the central cell is a pentagon lounded by the bases of the five cells of series 2 . 
The three angles about the points of intersection of the contact surfaces of each group of three cells tend to equal $120^{\circ}$ each, but with marked deviations owing to the number and inherited form of the cells. For example, the interior angles of the central cell at points $g^{2}$ and $g^{3}$ are smaller than the adjacent interior angles of cells 3,4 , and 5 . This is due to the tendency in the central cell to assume a two-lobed form and for the same reason the interior angles of cell 4 at these same points $g^{2}$ and $g^{3}$ are respectively larger than the adjacent angles of cells 3 and 5 . The exact value of such differences cannot be determined without a knowledge of the strength of the tendency in the cells toward the bilobed form. I have made the values of the three angles $87.2^{\circ}$, $134^{\circ}$ and $138^{\circ}$ respectively by taking the average of the corresponding pairs as the bilateral symmetry of the colony requires.

Correlated with this tendency of the cells to become bi-lobed the interior angles of cells $2,3,4,5$, and 6 at the points $d, d^{1}, d^{2}$, etc., are smaller than the adjacent angles of cells 7,8 , 9, Io, etc., the differences here being about $20^{\circ}$.

In the diagram the lobed form of the outer surfaces of the cells is merely sketched in free-hand. These cells represent most nearly the inherited form tendencies of the individual since from their peripheral position they have the largest proportion of free surface and the fullest opportunity to bring to expression those inherited tendencies which are not dependent upon contact with or pressure from adjacent cells. The lobes of these peripheral cells are longer but even in P. Boryanum the cells of series 2 and the central cell show clearly enough the tendency to the bilobed form. The influence of internal environment in modifying inherited form is especially well illustrated in such a case as this.

The dimensions of the cells and their interior angles in the photograph and in the diagram are given in the following table. In each case the sides and angles are taken in order beginning on the axis of the colony. The most marked asymmetry in this colony is in the region of cell 4 , especially about the point $e^{3}$ and I have given arbitrary values to certain angles such as will conform to the requirements of the general radial symmetry of the colony. The four cases in which these arbitrary values have been assigned are indicated by asterisks in the table. The area of cell 5 in optical section as shown in the photograph is greater than that of cell 4 , 
but I have made cell 4 larger in the diagram. It is of course only in very regular colonies that the averages of the single right and left pairs of angles and sides will give a figure approximating the typical surface tension configuration.

\section{Sixteen-celled colony of Pediastrum Boryanum}

Central cell I.

\section{Interior angles and sides of cells}

Angles:

$$
\text { In colony. }
$$

In diagram.

$$
\begin{array}{rlrl}
i g i^{6} & = & & \text { I I I }^{\circ} \\
i g^{1} i^{1}=\operatorname{II} 3.5^{\circ}+i^{5} g^{4} i^{6}=\mathrm{IO} 2.5^{\circ}=2 \mathrm{I}^{\circ} \div 2= & \text { I } 8^{\circ} \\
i^{1} g^{2} i^{3}=8 \mathrm{I}^{\circ}+i^{4} g^{3} i^{5}=93.5^{\circ}=\mathrm{I} 7+.5^{\circ} \div 2= & 87.2^{\circ}
\end{array}
$$

Sides:

$$
\begin{array}{rlr}
i & =9.5 \mathrm{~mm} .+i^{6}=10.5 \mathrm{~mm} .=20 \div 2= & \text { I } 0 \mathrm{~mm} \\
i^{1} & =9.25 \mathrm{~mm} .+i^{5}=8.75 \mathrm{~mm} .=18 \div 2= & 9 \mathrm{~mm}
\end{array}
$$

Cells 2-6.

Angles:

$$
\begin{aligned}
& k g i^{6}=\mathrm{I} 2 \mathrm{I}^{\circ}+k g i=\mathrm{I} 28^{\circ}=249^{\circ} \div 2= \\
& 12+\cdot 5^{\circ} \\
& i g^{1} k^{1}=\mathrm{I} 25^{\circ}+k^{1} g^{1} i^{1}=\mathrm{I} 2 \mathrm{I}^{\circ}+i^{6} g^{4} k^{4}=\mathrm{I} 29^{\circ}+ \\
& i^{5} g^{4} k^{4}=129^{\circ}=504^{\circ} \div 4= \\
& i^{1} g^{2} k^{2}=\mathrm{I} 36^{\circ}+i^{5} g^{3} k^{3}=\mathrm{I} 32^{\circ}=268^{\circ} \div 2= \\
& i^{3} g^{2} k^{2}=\mathrm{I} 42^{\circ}+i^{4} g^{3} k^{3}=\mathrm{I} 34^{\circ}=276^{\circ} \div 2= \\
& 126^{\circ} \\
& 134^{\circ} \\
& 138^{\circ} \\
& o^{9} e k=\mathrm{II} 5^{\circ}+o e k=108.5^{\circ}+o^{1} e^{1} k^{1}=\mathrm{I09.5}+ \\
& o^{2} e^{1} k^{1}=106^{\circ}+o^{7} e^{4} k^{4}=119^{\circ}+o^{8} e^{4} k^{4}=109^{\circ} \\
& =667^{\circ} \div 6= \\
& \text { I I I }^{\circ} \\
& k^{2} e^{2} o^{3}=120^{\circ}+k^{3} e^{3} o^{6}=95^{\circ}=215^{\circ} \div 2=\quad 107^{\circ} \\
& k^{2} e^{2} o^{4}=\mathrm{IO} 8^{\circ}+k^{3} e^{3} o^{5}=\mathrm{II} 6^{\circ}=224^{\circ} \div 2=\mathrm{II} 2^{\circ} * 120^{\circ} \\
& o d p=109^{\circ}+o^{1} d^{1} p^{1}=113^{\circ}+o^{2} d^{2} p^{2}=102^{\circ}+ \\
& o^{7} d^{7} p^{7}=97^{\circ}+o^{9} d^{8} p^{8}=107^{\circ}+o^{9} d^{9} p^{9}=109^{\circ}+ \\
& o^{3} d^{3} p^{3}=100^{\circ}+o^{6} d^{6} p^{6}=112^{\circ}=849^{\circ} \div 8 \quad 106^{\circ} \\
& o^{4} d^{4} p^{4}=104^{\circ}+o^{5} d^{5} p^{5}=\mathrm{II} 4^{\circ}=218 \div 2=109^{*} 100^{\circ}
\end{aligned}
$$

Sides:

$$
\begin{aligned}
k & =8 \mathrm{~mm} .+k^{1}=9 \mathrm{~mm} .+k^{2}=6.5 \mathrm{~mm} .+ \\
k^{3} & =8.5 \mathrm{~mm} .+k^{1}=8 \mathrm{~mm} .=40.0 \div 5= \\
o & =7.5 \mathrm{~mm} .+o^{1}=6 \mathrm{~mm} .+o^{2}=6.5 \mathrm{~mm} .+ \\
o^{3} & =7 \mathrm{~mm} .+o^{4}=7 \mathrm{~mm} .+o^{5}=+1 \mathrm{~mm} .+ \\
o^{6} & =8 \mathrm{~mm} .+o^{7}=7 \mathrm{~mm} .+o^{8}=7 \mathrm{~mm} .+ \\
o^{9} & =6 \mathrm{~mm} .=66 \div 10=
\end{aligned}
$$


Cells 7-16.

Angles:

$$
\begin{aligned}
& o^{9} e o=136.5^{\circ}+o^{1} e^{1} d^{2}=14+.5^{\circ}+ \\
& 0^{7} e^{4} o^{8}=132^{\circ}=413^{\circ} \div 3=137^{\circ} \\
& o^{3} e^{2} o^{4}=132^{\circ}+o^{5} e^{3} o^{6}=149=281^{\circ} \div 2=140^{\circ *} \mathrm{I} 33^{\circ} \\
& o d r=125^{\circ}+o^{1} d^{1} r^{1}=127^{\circ}+o^{2} d^{2} r^{2}=\mathrm{I} 27^{\circ}+ \\
& o^{7} d^{7} r^{7}=134^{\circ}+o^{8} d^{8} r^{8}=125^{\circ}+o^{9} d^{9} r^{9}= \\
& \mathrm{I} 22^{\circ}=760 \div 6= \\
& 126^{\circ} \\
& p d r=\mathrm{I} 26^{\circ}+p^{1} d^{1} r^{1}=120^{\circ}+p^{2} d^{2} r^{2}=13 \mathrm{I}^{\circ}+ \\
& p^{7} d^{7} r^{7}=129^{\circ}+p^{8} d^{8} r^{8}=\mathrm{I} 28^{\circ}+p^{9} d^{9} r^{9}= \\
& 129^{\circ}=763^{\circ} \div 6= \\
& p^{3} d^{3} r^{3}=122^{\circ}+p^{6} d^{6} r^{6}=125^{\circ}=247^{\circ} \div 2=123^{\circ} \\
& o^{3} d^{3} r^{3}=\mathrm{I} 38^{\circ}+o^{6} d^{6} r^{6}=\mathrm{I} 23^{\circ}=261^{\circ} \div 2=\quad \mathrm{I} 30^{\circ} \\
& o^{4} d^{4} r^{4}=120^{\circ}+o^{5} d^{5} r^{5}=126^{\circ}=246^{\circ} \div 2=123^{\circ *} \\
& 131^{\circ} \\
& p^{4} d^{4} r^{4}=\mathrm{I} 36^{\circ}+p^{5} d^{5} r^{5}=\mathrm{I} 20^{\circ}=256 \div 2=\quad \mathrm{I} 28^{\circ}
\end{aligned}
$$

Sides:

$$
\begin{aligned}
r & =9 \mathrm{~mm} .+r^{1}=9.5 \mathrm{~mm} .+r^{2}=9 \mathrm{~mm} .+ \\
r^{3} & =8.5 \mathrm{~mm} .+r^{4}=8.5 \mathrm{~mm} .+r^{5}=9.5 \mathrm{~mm} .+ \\
r^{6} & =8.5 \mathrm{~mm} .+r^{7}=7 \mathrm{~mm} .+r^{8}=9 \mathrm{~mm} .+ \\
r^{9} & =9 \mathrm{~mm} .=87.5 \div \mathrm{IO}=
\end{aligned}
$$

$8.7 \mathrm{~mm}$.

Similarly, FIGURE $2 b$ may be considered as representing the type of cell configuration found most commonly in the eight-celled colonies of P. Boryanum (FIG. 2a). The eight-celled, like the sixteen-celled group, is in unstable equilibrium, owing to the number of its cells (eight instead of seven). A group of seven spheres, six around a central one, gives a much higher degree of compactness and a more stable intercellular equilibrium than can be achieved in a plate made of eight spheres. There is a considerable tendency for one of the cells to slip out of the concentric system. In the colony represented in FIGURE $2 c$, two of the cells are so displaced.

The grouping of the cells in such an eight-celled colony shows a fine series of adjustments between mutual pressure, adhesion, surface tension and the inherited form tendencies of the cells in a system which is numerically disharmonic from the standpoint of the principle of least surfaces.

In the more typical colonies, such as the one shown in FIGURE $2 a$, the outer series of six cells forms in reality three pairs of spatially 
similar figures, 6 and 3,5 and 8,4 and 7 , but with their sides in the same order. They can he conformably superimposed if they are first rotated through $180^{\circ}$ on the median axis of the colony, which is a line de through the surfaces of contact between cells 6 and 7 and 3 and 4 , and then again rotated through $180^{\circ}$ on an axis at right angles to this median axis of the colony.
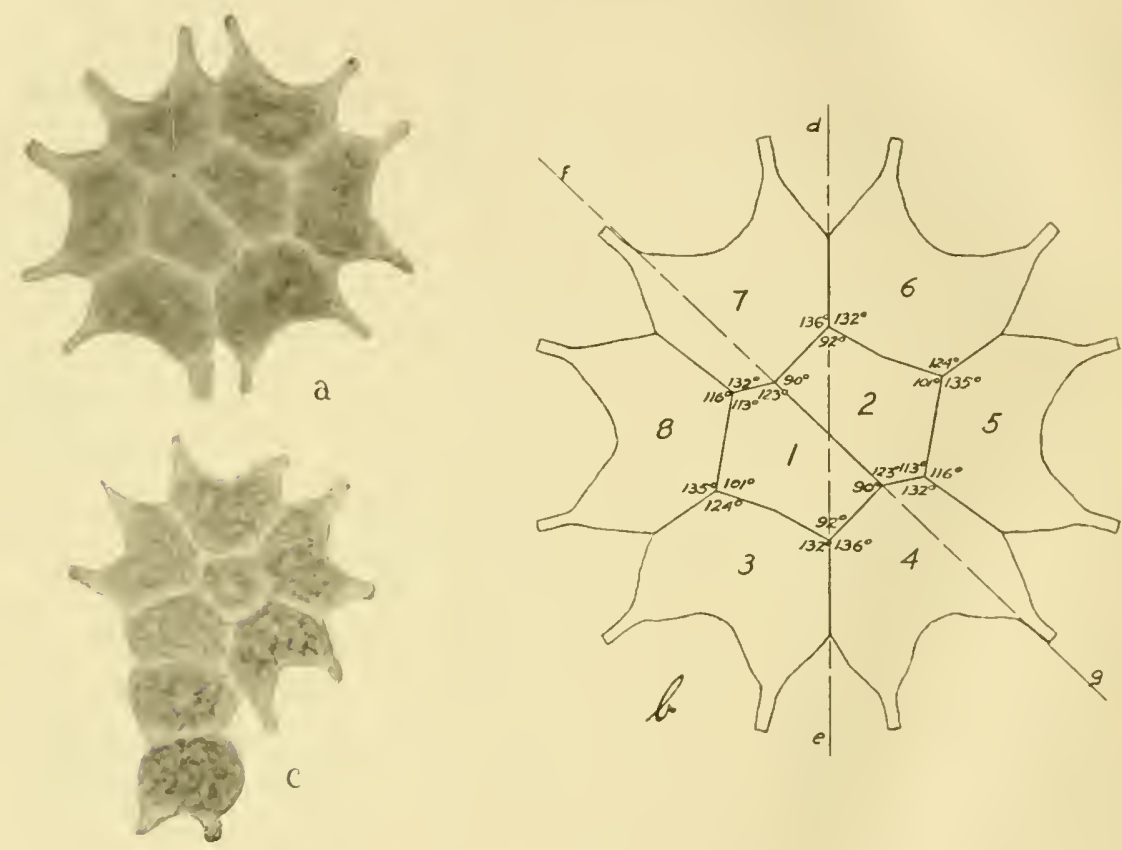

FIG. 2a. Pediastrum Boryanum, cight-celled colony; $X$ about 750 . Original print cnlarged about one half in reproduction.

$b$. Diagram showing the symmetry relations in such a colony. The climensions of the cclls were measured on a photographic cnlargement about twice the diameter of figure $a$, and the average was taken of the corresponding sides and angles about the axes de and $\mathrm{fg}$. The diagram has been reduccel about one fourth in reprocluction.

c. Irregular cight-cellerl colony of the same species. Two cells not in concentric order. $\times$ alout 750 .

If the colony is split along its median axis and one half rotated through $\mathrm{I} 80^{\circ}$ on a median line, cutting the axis at right angles, it wili he bilaterally symmetrical, so far as its outer series of cells is concerned, though its general radial symmetry will have been much disturbed and the two inner cells are divided unequally. These two central cells are in their outlines equal polygons and 
with their corresponding sides in the same order. If the colony is divided along the line $f g$, which is in the surface of contact of the central cells, and one half is rotated through $\mathrm{I} 80^{\circ}$ on a median line at right angles to the line $f g$, the two central cells form a bilaterally symmetrical figure but two of the outer cells are divided unequally.

The area of each of the central cells I and 2, as seen in the figure, appears smaller than that of those in the peripheral series. It is quite possible, however, that the central cells are proportionally thicker than the peripheral cells. It is not easy to get exact evidence by measurement as to the thickness of the colonies at different levels as seen in edge view. The cell bodies appear, however, to thin out toward the margin of the colony.

These two examples may suffice to illustrate the possibility of recognizing what may perhaps be regarded as biological form types of a group of related but fluctuatingly variable individuals. The configurations shown in the diagrams (FIGS. I $b$ and $2 b$ ) represent only the eight- and sixteen-celled colonies. The species has $8,16,32,64$, and even I28-celled colonies and for each different number of cells the configuration presents new problems of equilibrium and surface tension relations.

The configurations shown in these diagrams are, so far as my observation goes, strictly ideal and while the form relations involved are relatively simple as compared with the complexity found in the higher plants it is certainly doubtful whether such perfect regularity and equality of corresponding spatial elements (lines and angles) could ever be a common occurrence in nature.

Such a figure does not, of course, represent the average individual of a population, judged by degree of deviation from perfect regularity. All these form elements, lines and angles, fluctuate rather symmetrically about their modes and these modes are approximately the line and angular dimensions of the perfectly regular colony. It is the exceptional rather than the average individual that approximates simultaneously in all elements this standard of perfect symmetry. The average individual will naturally fall below the specially favored one in its approach to an ideal standard, determined in terms of the surface tension relations here involved.

While these figures, so far as form relations and cell arrangement are concerned, may be considered as form types of sixteen- 
and eight-celled colonies of $P$. Boryanum, such form relations cannot, of course, be taken as giving any full expression of the constitution of a true biological type for the species. Such a type must represent many other characteristics of function and life history. It is interesting, however, to note that the form of the cells and their arrangement in more or less regular concentric series which results in a plate-shaped colony have been regarded by the critical students of the genus from the earliest times as the most reliable diagnostic characteristics both for the genus and the species, the form of the colonies and the arrangement of the cells being the basis of the genus and the inherited form of the cells the basis for the delimitation of species. The configuration in such a diagram represents the form the most vigorous individuals tend to assume when placed under the most favorable environmental conditions and such a type represents the maximum potentialities of the germ plasm of an individual or group under such conditions. The determination of such types makes it possible to distinguish the morphogenetic value of the specific organization of an individual or group as contrasted with the effects of environmental influence.

It may seem that in characterizing such a schematized configuration as the type of a whole series of endlessly fluctuating individuals there is a return to the vagaries of the ideal morphology of the beginning of the last century and it cannot be questioned that the evidence that the organization of the Pediastrum colonies is determined by fundamental principles whose perfect and complete expression is conceivable but is rarely if ever realized justifies in some degree the recognition of predeterminable and ideal types of structure. It is to be remembered, however, that the organization here involved is based on the physical properties of the substances concerned rather than any such abstractions as the principle of perfecting metamorphoses or even of predetermined harmonies.

Such types, of course, have little to do in many cases with the so-called nomenclatorial and historical types recognized in rules of nomenclaturc. It may, of course, be even a matter of accident whether the first specimens of a species that are discovered will happen to be biologically typical of the group to which they belong, and it is conceivable that with rigid adherence to a doctrine of 
historical types the nomenclatorial grouping might remain permanently at variance with a natural classification. It is to be remembered, however, that the careful student of to-day always endeavors to arrange all available material in groups, based on conceptions of phylogenetic types. So far as is possible he selects as typical those specimens which illustrate most perfectly the fundamental characters of the group for which they are to stand in the type relation. The aim of any student of a group of genera or species is to determine what are the natural types and his work is likely to be lasting or ephemeral in direct proportion to his success judged by this standard.

The possibility of discovering biological form types for the bewilderingly complex individuals and groups found among the higher plants may well seem too remote a possibility to have any practical significance, even if such types can be conceived as having any specific reality. The statement that every individual is equally normal in the sense that it as much as any other is the product of its environment plus its inherited constitutional characteristics is even taken to mean that every individual is equally typical of the "interbreeding group of blood relatives" to which it belongs.

The types set up by breeders of domesticated animals are artificially determined and may or may not coincide with what is natural for the race. Types determined by anthropometrical measurements give very exact pictures of the dimensional characteristics of a population but are not, directly at least, referable to biological principles of organization further than as they illustrate general tendencies to harmonies and adaptations in structure and functions.

What I have suggested as to the possibility of recognizing the form type of a semi-coenobe like Pediastrum is much more obviously true in the case of such simple filamentous coenobes as we find in the free floating species of Spirogyra and other representatives of the Conjugatae. Here the principle of organization of the colony is of the simplest. We have merely a sort of cellular metamerism, the exactly similar units being repeated in an indeterminate series. The oblong cylindrical cell form is transmitted directly in cell division and the axis of cell growth regularly persists through sexual cell fusion, zygospore formation, and germination. The arrangement of the cells is determined simply 
by the repeated divisions of the cells at right angles to the axis of the cylinder. The form type of such a coenobe is simply a cylinder made up of segments of dimensions characteristic for the species and inherited as qualities of the cells rather than of the colonies as wholes. The disharmony between the numbers produced by repeated cell bipartitions and those required to form stable surface tension figures in one plant does not exist in the case of such simple cylindrical types as are most of the Conjugatae.

I have described in the present paper only the organization of the eight- and sixteen-celled colonies of P. Boryanum with the object of suggesting the bearing of the data on the general question of types. The real nature of this organization, both cellular and intercellular, becomes clearer from a study of the method of development and especially the variations in type of both cells and colonies as found in the entire genus. Further observations on these points, as already noted, will be published elsewhere.

\section{INDEX OF REFERENCES}

I. Braun, A. Algarum unicellularium genera nova et minus cognita. Lipsiae. I 855 .

2. Harper, R. A. Morphogenesis in Pediastrum. Science II. $37: 385$. 7 Mrigiz.

3. Meyen, F. J. Beobachtungen ïber einige niedere Algenformen. Nova Acta Acad. Caes. Leop.-Carol. I4: 77I. I 828.

4. Nägeli, C. Gattungen einzelliger Algen. Zürich. I849.

5. - Die neuern Algensysteme. Zürich. 1847.

6. Nitardy, E. Zur Synonomie von Pediastrum. Beih. Bot. Centralbl. $32^{2}:$ III. I9I4.

7. Rhumbler, L. Der Aggregatzustand und die physikalischen Besonderheiten des lebenden Zellinhaltes. Zeits. Allg. Physiol. I: $279-388 . \quad 1902$. 


\title{
NOTES ON SOME MARINE ALGAE FROM THE VICINITY OF BEAUFORT, NORTH CAROLINA ${ }^{1}$
}

\author{
Marshall Avery Howe and Williail Dana Hoyt \\ The New York Botanical Garden \\ Washington and Lee University
}

(With plates I I-I5)

Most of the algae with which the present paper is concerned were obtained by Mr. Lewis Radcliffe of the U. S. Bureau of Fisheries through dredging operations on August II, I9I4, in "I $3 \frac{1}{2}$ to I 4 fathoms" of water on a reef about 23 miles off shore from Beaufort, North Carolina. Previous dredgings here under the direction of the Bureau of Fisheries had shown this submerged reef to be the northern limit, so far as known, of certain tropical and subtropical algae, such as Udotea cyathiformis. The present collection, though small, is of special interest inasmuch as it contains two species that had previously been known from Europe only and seven species that appear to us to be new. Some fragments of Dictyota dichotoma that were brought up by the dredge were particularly remarkable for the number of small epiphytes and endophytes that they bore.

Type specimens of the species described as new will be deposited in the U. S. National Herbarium; cotypes are in the herbaria of The New York Botanical Garden and of WV. D. Hoyt. Other species of algae from the submerged reef and from the Beaufort region in general will be described or enumerated in a more extended paper soon to be published by the junior author.

\section{Microchaete nana sp. nov.}

Stratum inconspicuous, submicroscopic; filaments loosely gregarious, mostly $\mathrm{IOO}-200 \mu$ long, $5 \cdot 5-9.0 \mu$ in diameter, curved near base or near middle, often arcuate-flexuous, mostly decumbent or ascending, occasionally prostrate or suberect, very slightly attenuate towards apex; vagina very thin, delicate, hyaline, scarcely visible; trichomata light olivaceous (?), $5.0-8.3 \mu$ in

${ }^{1}$ This paper is published with the permission of the U. S. Commissioner of Fish and Fisheries. 
diameter, slightly constricted at the septa towards apex, scarcely so below; cells I-3 (mostly I.5-2) times as broad as long, the apical broadly dome-shaped or subhemispheric; heterocysts subspheric or oroid, basilar, rarely double, 5.0-6.6 $\mu$ in diameter, or sometimes $8.3 \mu$ long; spores unknown. [PLATE I2, FIGURES I 2-I 7 .]

On Dictyota dichotoma, dredged "in I $3 \frac{1}{2}-\mathrm{I} 4$ fathoms," Lewis Radcliffe, August II, I9I4; accompanied by Streblonema solitarium, Elachistea stellulata, Phacostroma pusillum, Acrochaetium affine, etc.

It was at first suspected that this plant might prove to be identifiable with Microchaete purpurea J. Schmidt, ${ }^{1}$ described as an epiphyte on species of Fucus dredged near the Danish island of Laeso in the Kattegat, but a comparison with type material of this species kindly furnished by Dr. F. Borgesen of Copenhagen showed important differences. The trichomata of Microchacte nana are shorter than those of $M$. purpurea and are $5.0-8.3 \mu$ in diameter vs. $3-5 \mu$ in $M$. purpurea; the filaments are loosely gregarious and are mostly decumbent or ascending, while those of $M$. purpurea form densely congested, suberect, wick-like clusters, which in turn form on the surface of its host subdendroid or fucoid figures, slightly suggestive of certain forms of frost-crystals on a window-pane; the raginae of the filaments of $M$. nana are thinner, more delicate and less perceptible, though our material of M. nana is formalin-preserved, while that of $M$. purpurea is dried, which may account for a certain amount of the difference in this respect; the color of the trichomata of $M$. nana is, perhaps, not well preserved, but it would seem to be a light olivaceous rather than the red-purple of $M$. purpurea. Possibly Microchaete vitiensis Askenasy, described from islands in the Pacific Ocean, is a nearer relative. From description alone, M. vitiensis would appear to have erect and longer filaments ("filis millimetrum vix attingentibus") with thicker sheaths, which finally become ocreate.

\section{Derbesia turbinata sp. $110 \mathrm{v}$.}

Olive-green and nitent when dry, more or less repent, apparently forming straggling mats $8-9 \mathrm{~cm}$. broad (or high?), the basal parts sometimes here and there resolved into cysts; filaments $15-95 \mu$ (mostly $38-53 \mu$ ) in diameter, sparingly branched, the branching

\footnotetext{
'Bot. Tidsskr. 22:379, +12. I899.
} 
subdichotomous or more often lateral, the lateral branches usually without a basal septum, the others with or without one or two septa above the dichotomy; chloroplasts at first orbicular, elliptic, or ovate, $5-7 \mu$ in diameter, later irregularly confluent and fusiform; sporangia turbinate, broadly obconic-obovoid, broadly pyriform, or pestle-shaped, I I2-I $82 \mu$ long (excl. stalk), IO4-I56 $\mu$ broad, mostly about as broad as long, the apex subtruncate, the outline commonly somewhat obdeltoid; pedicel mostly I4-32 $\mu$ (rarely $70 \mu$ ) long, I5-2I $\mu$ broad, the pedicel cell usually about I 8-2 I $\mu$ high and broad, or sometimes broader than high (Iо $\mu$ X 2 I $\mu$ ); spores immature. [Plate II, Figures IO-I6.]

Dredged in $13 \frac{1}{2}-\mathrm{I} 4$ fathoms of water on reef about 23 miles off shore from Beaufort, North Carolina, Lewis Radcliffe, August I I, I9I4, in company with Cladophora sp.

In most of our material of Derbesia turbinata the chloroplasts are more or less decolorate and disorganized and they show numerous and conspicuous brownish violet pyrenoids. It is probable that in the younger stages the plant may be of a bright green rather than an olive-green color. Many of the sporangia show no pedicel cell, but such sporangia as a rule are smaller and evidently younger than those that are subtended by a stalk cell and we are inclined to the opinion that this cell is a regular and normal part of the stalk of the mature sporangium.

Derbesia turbinata seems to be distinguishable from the previously described species of the genus by its turbinate or very broadly pyriform sporangia, the maximum width of which is commonly about the same as their length, though sometimes a little less and sometimes even greater. The pedicel is usually very short, mostly $1 / 4-1 / 8$ as long as the sporangium, though, in occasionally occurring pestle-like structures, the length of the pedicel may approach that of the sporangium itself. Among the hitherto described species, Derbesia turbinata is perhaps best compared with $D$. repens Crouan, known to us only from descriptions and the Crouans' published figures. But D. repens is represented as having an obovoid or pyriform sporangium which is twice as long as broad and the enlarged detailed figure of a practically mature sporangium shows no pedicel cell. D. repens is apparently a smaller plant and an epiphyte.

Derbesia vaucheriaeformis (Harv.) J. Ag. was described from Key West, Florida, from sterile material, but the sporangia borne 
by southern New England plants that have been taken to be identical with it are very different in form and size from those of this Beaufort plant. Sterile specimens of $D$. e'uucheriaeformis collected by Harvey at Key West differ from $D$. turbinata in their yellowish green color, less nitent facies, manifestly erect and densely tufted habit, consistently dichotomous branching, and smaller more polygonal chloroplasts.

Streblonema solitarium (Sauv.) De-Toni, Syll. Alg. 3: 576. I 895 .

Ectocarpus solitarins Sauv. Jour. de Bot. 6: 97, 126. pl. 3.f. 24-27. I 892 .

On Dictyota dichotoma, dredged "in $\mathrm{I} 31 / 2^{-I}+$ fathoms," Lewis Radcliffe, August II, I9I4; accompanied by Elachistea stellulata, Phaeostroma pusillum, Acrochaetium affine, etc. This species was originally described as an endo-epiphyte of Dictyota dichotoma, Dictyopteris [Neurocarpus] polypodioides, and Taonia Atomuria from near Le Croisic on the western coast of France. In the Dictyota, in France, it is commonly associated with Elachistea stellulata, as is also the case in North Carolina. Both the Streblonema and the Elachistea have inconspicuous endophytic regetative filaments that make their way extensively in or near the cell walls of their host. The cortex of the host (in this formalinpreserved material from North Carolina) is so transparent that by focusing into and through it with the compound microscope one may follow the course of the interior filaments in a tolerably satisfactory manner. These filaments, in the case of the Streblonema, are found chiefly in the plane of juncture of cortex and medulla, but they often penetrate the medulla and sometimes reach the opposite cortex. They commonly follow the vertical and longitudinal walls so closely that they are not readily obrious on a casual examination. The filaments may seem to anastomose occasionally, but this is perhaps an optical illusion due to the close crossing of filaments in slightly different planes. The cxterior part of the plant in its simplest conditions consists simply of a single sessile plurilocular sporangium, or the sporangium may lee terminal on a simple few-celled exterior filament, or, in better-developed conditions, the exterior filament, remaining simple or sulsimple, may attain a length of $750 \mu$ and may bear 
one, two, or three short-stalked lateral sporangia. The exterior filaments are $10.5^{-I} 5.5 \mu$ in diameter and their cells are mostly 2-4 times as long as broad, though often much shorter at the base of a terminal hair. The interior filaments have about the same diameter as the exterior. The plurilocular sporangia are $40-78 \mu \times 14-36 \mu$. Since its discovery in France, Streblonema solitarium has been reported from southern England and Ireland, ${ }^{1}$ but, so far as we know, has not hitherto been recognized as American. It is, however, to be expected wherever its host occurs.

\section{Phaeostroma pusillum sp. nov.}

Thallus irregular in outline or suborbicular, $0.3-0.8 \mathrm{~mm}$. in diameter, the component closely repent filaments and their numerous curved or sinuous branches forming a moderately compact, more or less pseudoparenchymatous unistratose membrane, its margins commonly irregularly lobed or showing discrete filaments, such filaments with frequent subdivaricate, often recurved or incurved, occasionally pseudo-anastomosing branches; vegetative cells subcylindric or more often curved or of irregular diameter, mostly I0-I $6 \mu \times 5^{-10} \mu$, usually $1.5^{-2.0}$ times as long as broad; chromatophores suborbicular, irregularly discoid, or somewhat baculiform, commonly more or less fused, numerous and crowded, occasionally substellate-conglobate, or less numerous and somewhat reticulately disposed; hairs occasional, 8-Io $\mu$ in diameter, showing at the base $4-6$ short cells (5-10 $\mu$ long); plurilocular and unilocular sporangia on separate individuals; unilocular sporangia (I) scattered or aggregated, obovoid or subglobose, 8-I6 $\mu$ in diameter, sessile, or, (2) by subdivision and proliferation of the fundamental cell and by coalescence, forming elevated submoriform sori $16-48 \mu$ in diameter, the ultimate sporangia then smaller, mostly $5^{-8 \mu}$ in diameter, and often more angular; microspores about $\mathrm{I} .5 \mu$ in diameter; plurilocular sporangia scattered and solitary or loosely gregarious, ovoid, ellipsoid, subspheric, or subconic, sessile, suberect, $22-27 \mu \times$ I 5-I $8 \mu$, about 7-9 loculi measuring the length of the sporangium and 4 or 5 its maximum width. [PLATE I I, FIGURES I-9.]

On Dictyota dichotoma and stolons of Campanularian hydroids thereto attached, dredged in $13 \frac{1}{2}-\mathrm{I}+$ fathoms of water on reef about 23 miles off shore from Beaufort, North Carolina, August II, I9I 4 , by Lewis Radcliffe. One of us (II. D. Hoyt) has observed it also on Spyridia sp., collected at the same time and place.

${ }^{1}$ Batters, Cat. Brit. Mar. Alg. 30. 1902. 
The Phaeostroma grows associated with Elachistea stellulata, Streblonema solitarium, Acrochaetium affine, etc. It seems to prefer to border the closely repent stolons of the hydroid and it sometimes covers the stolons themselves. Most of the plants bear the unilocular sporangia; those with plurilocular sporangia are rare. Some of the plants with unilocular sporangia seem to show all gradations between the isolated scattered sessile sporangia (FIG. 6) and those that are aggregated on an elevated submoriform sorus (FIG. 9), and we believe that this variation in the mode of occurrence of the sporangia has no particular morphological or physiological significance. The elevated sori observed have been few in number and we have not ventured to sacrifice them in an attempt to make a vertical section through them, but we infer that the sterile pseudoparenchyma forming the base of the sorus is more than one cell thick. Elsewhere, the thallus is manifestly unistratose.

Of the four species that have been hitherto proposed for the genus Phaeostroma the present plant seems most closely allied to the type of the genus, $P$. pustulosum Kuckuck, which occurs on the leares of Zostera and on various algae in northern Europe and Greenland. From this, however, as figured and described by Kuckuck, ${ }^{1} P$. pusillum appears to differ amply in the smaller thallus, which remains unistratose in sterile parts, in the series of very short cells at the bases of the hairs, in the more regular, more ovoid, more ectocarpoid, less tuberiform, less aggregated plurilocular sporangia, and in the smaller $(5-16 \mu$ vs. $25-40 \mu)$ unilocular sporangia, which sometimes occur in elevated submoriform sori. So far as we are aware, the genus Phacostroma has not previously been reported from the American continent.

Elachistea stellulata (Harv.) Griff.; Aresch. Linnaca 17:26I. pl. o. f. 4. 1843. Harv. Phyc. Brit. 1: pl. 26I. 18+6-5I. Sauv. Jour. de Bot. 6: 6. pl. I. f. I, 2. 1892

Conferva stellulata Harv. Man. Brit. Alg. I32. I $8+1$ I.

Phycophila stellulata Kütz. Sp. Alg. 5+1. 1849.

Myractis stellulata Batters, Jour. Bot. 30: $173,17+. \quad 1892$.

On and in Dictyota dichotoma, "in 13 $1 / 2-14$ fathoms" of water, Lewis Radcliffe, August II, I9I4; associated with Streblonema

${ }^{1}$ Bot. Zeit. 53: 182-187. pl. 7. 1895. 
solitarium, Acrochaetium affine, Phaeostroma pusillum, Microchaete nana, etc.

The exterior parts of this interesting little endo-epiphyte form subhemispheric or oblong cushions $125-300 \mu$ in diameter. The cushions include numerous plurilocular sporangia but we have seen only two or three unilocular sporangia, while in the European plant, so far as we are acquainted with it, the unilocular sporangia seem to be much more frequent. ${ }^{1}$ The North Carolina plant seems to differ furthermore from the European in the smaller cushions, in the smaller diameter of its shorter filaments, and in having the sterile filaments, except their hairs, of about the same length as the plurilocular sporangia instead of conspicuously overtopping them. However, our plant has so many points in common with the European endo-epiphyte on the same host that we do not feel justified at present in considering it anything other than a small form of that species. A section of the cushion does not show the large colorless cells described and figured by Harvey as belonging to its basal part, but we do not find such in European specimens that we have examined; the exterior filaments spring from a small endophytic cushion made up of cells that are scarcely or not at all larger than those of the filaments, much as figured for this species by Saurageau.

In the North Carolina plant, the regetative filaments of the cushion are mostly 50-85 $\mu$ long and $7-9 \mu$ in diameter; many of the shorter terminate in a hair $10-12 \mu$ in diameter and often reaching a length of $400 \mu$. The plurilocular sporangia are fusiform or filiform, mostly $30-50 \mu$ long and $5.5^{-8.0} \mu$ in diameter; many of them consist of a single series of loculi, but more of them are two loculi broad except at base and apex, and rarely one may show three loculi across the middle. The endophytic filaments are of about the size of the epiphytic or a little stouter; they seem

${ }^{1}$ According to Batters, loc. cit., the "paranemata with short articulations," described and figured by Harvey, are the plurilocular sporangia, as are also, in part at least, the filaments figured by Areschoug. It seems to us probable that the plant figured by Kützing (Tab. Phyc. 8: I. pl. I. f. I. r 858) under the name Phycophila stellulata is not Elachistea stellulata (Harv.) Griff. The host, as figured by him, does not look like Dictyota dichotoma, the sterile filaments differ from those of E. stellulata in being conspicuously inflated near the middle, and the plurilocular sporangia are apparently more elongate and filiform. IVe find plurilocular sporangia abundant in specimens from Clare Island, Ireland, collected by A. D. Cotton, while in Crouan, Alg. Mar. Finistère $I$ and Desmazière, Pl. Crypt. Fr. $I \delta I \delta$, we have noted only unilocular sporangia. 
to prefer to follow the intercellular cavities between the cortex and medulla; they are sometimes closely associated with the enchphytic filaments of the Streblonema solitarium, but may be distinguished by their smaller diameter and shorter cells.

Eilachistea stellulata was first described from southern England but has since been reported also from France and from Ireland. Its presence in American waters has not hitherto been noted, so far as we know.

\section{Erythrocladia recondita sp. nov.}

Endophytic or pseudo-epiphytic, creeping in the superficial cell walls of other algae; thallus consisting at first of free irregularly radiating and irregularly branching filaments, soon becoming more or less pseudoparenchymatous (essentially monostromatic) in central parts, at length irregularly suborbicular and attaining a diameter of $0.2-1.5 \mathrm{~mm}$., or sometimes apparently broader through confluence; ramification lateral or subdichotonous, the lateral branches, especially in the younger plants, often divaricate; cells (protoplasts) varied and irregular in form, in surface view mostly oblong, quadrate, ovate, or panduriform, of ten curved, forked, or irregularly I- or 2 -lobed, $8-25 \mu$ long, 3-I $2 \mu$ broad; pyrenoids I-4 (usually I or 2 ), commonly $2.0-3.5 \mu$ broad and conspicuous; monoccious; spermatia oroid, $2-4 \mu$ in diameter, exserted or subexserted by slender stalks about I $\mu$ broad; carpogonia furnished with a beak or trichogyne exserted about $4-\delta \mu$; sporocarps forming a single carpospore (or rarely 2), these ovoid, oblong, or irregular, mostly $8-19 \mu$ in maximum diameter; non-sexual spores unknown. [Plate 12, Figures I-5; P'late I3, Figure I.]

In the superficial cell walls of Dictyota dichotoma, Beaufort, N. C., IT. D. Hoyt, September 7, 1906 (type)-associated with Acrochactium IIoytii; also on September I4, I906, in smaller quantity and less well developed; also in Dictyota dichotoma and other algae and in stolons of hydroids, "in $13 \frac{1}{2}-\mathrm{I}_{4}$ fathoms," on reef 23 miles from Beaufort, Lewis Radcliffe, August II, I9I 4.

In its earlier stages of development, Erythrocladia recondita bears some resemblance to E. irregularis Rosenvinge, ${ }^{1}$ (lescribed from Danish waters on Polysiphonia urceolata, but it differs from that species in being larger in all its parts (thallus finally $0.2-1.5$ mm. I's. $100 \mu$ hroad; cells $8-25 \mu \times 3-12 \mu$ vs. 7 -II $\mu \times 3.5^{-}$ $5.0 \mu$ ), in its more conspicuous pyrenoids, and in its scxual mode

${ }^{1}$ Kgl. Danske Vidensk. Selsk. Skrift. VII. 7: 72. f. I1, 12. 1909. 
of reproduction. We have hesitated long before deciding whether to refer this North Carolina plant to the genus Colaconema of Batters, the genus Erythrocladia of Rosenvinge, or to establish for it a new genus, differing from both of the named genera in its sexual method of reproduction. One of us (M. A. Howe) has recently ${ }^{1}$ expressed the opinion that Colaconema,$^{2}$ or its type species, C. Bonnemaisoniae, is "a close relative of Acrochaetium, near which it was finally placed by Batters." However, a reëxamination of a considerable number of specimens of Colaconema Bonnemaisoniae, with special attention to the position and development of the spores, convinces us that Colaconema is very closely allied to Erythrotrichia and Erythrocladia, as has been suspected by Rosenvinge. The "monosporangia" of $C$. Bonnemaisoniae are mostly terminal on short branches and when their "cup-like" base is not particularly well developed they may bear a superficial resemblance to monosporangia of an Acrochaetium, but typically the "sporangia" are subtended by a cup-like base, which may embrace the sporangium or spore to its middle. And the spores are not always terminal. They may be cut out from the side of the terminal cell or from the side (often obliquely near the distal end) of an ordinary or scarcely differentiated intercalary cell. In origin and form their resemblance to the spores of Erythrotrichia and Erythrocladia is most marked. Colaconema was described as "living in the cell-walls of various algae," while Erythrocladia was described as an epiphyte. But in specimens of E. irregularis, the type of the genus Erythrocladia, which we owe to the courtesy of Dr. Rosenvinge, its describer, the plant is clearly immersed in the outer walls of its host, Polysiphonia urceolata. In mode of reproduction and in habit of life there appears to be little difference between the type of Colaconema and the type of Erythrocladia. However, in the type of Colaconema, the thallus is loosely filamentous, with no observable tendency to radiate from any one point as a center and no tendency to form a pseudoparenchyma; the filaments are chiefly, but not wholly, confined to the outer walls of the superficial cells of its host; these filaments or their

${ }_{1}^{1}$ Mem. Torrey Club I 5: 83. I9I4.

2 Batters, Jour. Bot. 34: 8. Ja 1896. The homonymous genus Colaconema Schmitz, in Eng. \& Prant1, Nat. Pflanzenfam. $\mathbf{I}^{2}: 452$. 1907 , has been renamed Colacopsis by De-Toni, Syll. Alg. 4: I 170. 1903. 
branches may also penetrate to the inner cells of the cortex or subcortex, so that the plant is not so completely confined to one plane as is the case with the species that have been referred to Erythrocladia. In Colaconema (?) reticulatum Batters (loc. cit.) endophytic in Desmarestia Dudresnayi, the regetative conditions are more as in Erythrocladia, but $C$. (?) reticulatum is not the type species of Colaconema. These considerations have led us to prefer the generic name Erythrocladia for our plant. Although sexual reproduction has not hitherto been attributed to Erythrocladia, it would hardly seem that this character alone should be considered sufficient ground for proposing a new generic group; at least, so long as Erythrotrichia is allowed to hold a species (E. carnea) in which non-sexual reproduction only is known and another (E. obscura) in which both sexual and non-sexual modes of reproduction have been described.

As to color of living or freshly collected specimens of Erythrocladia recondita, we can say little, as our material has been either preserved in fluids or dried. To the best of our belief, however, its color is a dilute or bluish olivaceous. This endophyte attracts little or no attention when the surface of its host is being examined microscopically in ordinary ways, but as soon as iodine (potassiumiodide solution) is applied, it is differentiated with remarkable distinctness. 'The protoplasts of the Erythrocladia take up the iodine stain, becoming a purplish or bluish black, while the cells of its host are scarcely affected. The carpospores and carpogonia in particular have a special affinity for this stain and sometimes they alone will be colored. The have found iodine a most valuable reagent for differentiating small epiphytes and endophytes, especially when they belong to the Rhodophyceae and inhabit Phacophyceae or Chloropliyceae. When both host and parasite are Rhodophyccous, this reagent is not so effective, as both may react in about the same way, but even in such cases, there are often differences in color reaction that help to define the epiphyte or endophyte. Preparations thus stained may he mounted in glycerine or glycerine-jelly and preserved for considerable periods of time, but, in our experience, the iodine staining is not perma-

1 The genus Necvea l3atters (Jour. Bot. 38: 373. pl. 414. f. IS-22. 1900), cnclozoic in Flustra foliacea, has been compared with Erythrocladia by Sredelius (Eng. \& Pranil, Nat. Phanzenfam. $\mathbf{r}^{2}$ : Nachtrïge 196 . 19r 1), but from Batters' description and figures, Neevea would appear to us to be more nearly allied to Goniotrichum. 
nent. Specimens, however, that have been mounted in glycerine or glycerine-jelly may be washed off with water and restained with iodine at any time.

\section{Erythrocladia vagabunda sp. nov.}

Endophytic or pseudo-epiphytic, creeping in the superficial cell walls of other algae; thallus consisting chiefly of irregularly branching, uniaxially elongate or irregularly radiating filaments, finally spreading over areas $0.75^{-2.25} \mathrm{~mm}$. long or broad, of ten anastomosing or pseudo-anastomosing, and commonly forming here and there small irregular pseudoparenchymatous patches mostly 2-6 cells broad; ramification mostly lateral, rarely subdichotomous, often divaricate or rectangular; cells (protoplasts) for the most part irregularly oblong in surface view, of ten curved or I- or 2-lobed, 9-40 $\mu$ long, $6.5^{-1} 5 \mu$ broad; pyrenoids I-4 (usually I or 2$), 2-3 \mu$ broad; monoecious (?); sporocarps forming single carpospores (rarely 2 ?), these ovoid, oblong, or irregular, mostly I $2-25 \mu$ in maximum diameter; non-sexual spores unknown. [Plate i2, Figures 6-Ii ; Plate i3, Figure 2.]

In the superficial cell walls of Dictyota dichotoma, dredged "in I3 $1 / 2-$ I4 fathoms," Lewis Radcliffe, August II, I9I4; associated with Acrochaetium affine, Microchaete nana, Elachistea stellulata, Streblonema solitarium, Erythrocladia recondita, etc.

Erythrocladia vagabunda is evidently a close ally of E. recondita, but appears to differ in its straggling, obviously filamentous habit, in its more rectangular branching, in its forming pseudoparenchyma, if at all, in small irregular scattered patches instead of in a single central area, and in having cells of nearly twice the average diameter of those of $E$. recondita. It was our first impression that it might be considered a variety of $E$. recondita, connected perhaps with its deep water habitat, but we finally observed that it was associated, without intergrading, with a more minute, smaller-celled endophyte, the free filaments of which radiate from a pseudoparenchymatous center. This smaller plant we take to be the true $E$. recondita, very slightly modified by its deeper habitat. When iodine is applied, the protoplasts of this smaller plant take a darker blue-black or violet-black color than do those of the larger $E$. vagabunda. The two plants are shown side by side and more or less intertangled in our photograph.

With the more limited material at our disposal, we have not been able to demonstrate the sexuality of E. vagabunda so satis- 
factorily as in the case of E. recondita, but from the general similarity of the supposed carpogonia and sporocarps to those of $E$. recondita we feel no doubt as to its existence. In two instances, we have seen a supposed spermatium resting on the general surface above a supposed carpogonium. We have not observed any carpogonium beak or trichogyne and think it must be only slightly developed, if present at all.

The partly endophytic base of Acrochaetium affine, which sometimes develops short endophytic filaments or rhizoids, is occasionally found in such close contact with Erythrocladia vagabunda that it requires careful observation to satisfy one's self that the two things are not in organic continuity. The iodine stain, however, is an effective help in differentiating the two, the protoplasts of the Acrochaetium reacting with a reddish brown rather than a violet coloration.

\section{Acrochaetium infestans sp. nov.}

Endo- and epizoic, minute; interior filaments tortuous, intricate, serpentine, or labyrinthine, mostly $2.0-5.5 \mu$ in diameter, thin-walled, the branching very irregular, lateral, subdichotomous, or very rarely opposite, commonly divaricate from near the middle of a cell, the branches often subcircinately reflexed or inflexed, the interior cells mostly $12-60 \mu$ long, 3-1 8 times as long as broad, commonly curved or contorted and of irregular or fluctuating diameter, the terminal cells of branches of ten enlarged, subhamate, irregularly clavate, or subdivaricately forking, sometimes attaining a diameter of $7^{-8 \mu} \mu$, or, rarely, interior filaments forming a sort of pseudoparenchyma, with irregular cells sometimes IO-I $3 \mu$ broad; chromatophore small, substellate or irregularly discoicl, near the center of the cell or subparietal, showing a single pyrenoid; sporangiiferous filaments external, up to $90 \mu$ high (or $230 \mu$, including hairs), the simpler consisting of a single pedicel cell bearing $1-3$ sporangia (or, very rarely, the exserted sporangium sessile on an endozoic filament), the larger showing $\mathbf{I - 9}$ short, I-3-celled, rarely secund branches, the cells $4.5-6.5 \mu$ in diameter, 1-2 times as long as broad; hairs commonly present on the larger external filaments, flexuous and attaining a length of $125^{-170 \mu}$; sporangia terminal or lateral, solitary, binate, or ternate, ovoid or ellipsoid, $10-14 \mu \times 6.0-8.5 \mu$. [PLATE I4.]

In and on the stalks, stolons, and less commonly hydranths of small campanularian hydroids (perhaps representing more than one genus) attached to Dictyota dichotoma and other algae, dredged 
in $\mathrm{I} 3 \frac{1}{2}-\mathrm{I} 4$ fathoms of water on reef about 23 miles off shore from Beaufort, North Carolina, August I I, I9I4, by Lewis Radcliffe. The endozoic parts are embedded principally in the inner layers of the perisarc of the stalks, stolons, and occasionally the hydranths.

Acrochaetium infestans doubtless finds its nearest ally in Chantransia endozoica Darbish. (Ber. Deutsch. Bot. Ges. 17: I3-I7. pl. I. I 899), originally described as occurring in a bryozoan, Alcyonidium gelatinosum, on the southern coast of Ireland, and since reported also from Denmark by Rosenvinge (Kgl. Danske Vidensk. Selsk. Skrift. VII. 7: I28. 1909). From this species, as described and figured by Darbishire, Acrochaetium infestans appears to differ in having the diameter of both immersed and exserted filaments averaging about one half as great, in the much more tortuous, more irregularly branched interior filaments, the more curved and irregular cells of which are actually, on the average, two or three times as long, and relatively to their width, four to six times as long, as in the European species. The sporangia of Chantransia endozoica, as figured by Darbishire, are only slightly broader than the subtending sterile cells; in $A$. infestans, the mature sporangia are nearly twice as broad as the subtending cells. Darbishire noticed one possible hair in his $C$. endozoica, but was not sure that it really belonged to the organism in question. In Acrochaetium infestans, the larger exserted filaments commonly show hairs of remarkable length.

Acrochaetium infestans is associated with various mostly smaller algae that penetrate the hydrozoan little if at all. The more common and conspicuous of these are Acrochaetium affine and a closely adherent filamentous blue-green (Phormidium sp.?), the latter with trichomata $0.75-\mathrm{I} .5 \mu$ in diameter and cells mostly I-2 $(3 / 1-3)$ times as long as broad. The interior parts of the Acrochaetium infestans are, in our formalin-preserved material at least, so nearly colorless, and the plant in general is so small that it might easily escape observation if one did not happen to emphasize its existence through the use of differential stains. By applying iodine (potassium-iodide solution) the little plant is thrown into bold relief, its protoplasts becoming violet-red or brownish crimson, while its host becomes a light yellowish brown. 


\section{Acrochaetium affine sp. nov.}

Epiphytic, I.O-3.5 mm. high, from a large persistent basal cell (spore), this subglobose or ellipsoid, mostly $\mathrm{I}_{4}-26 \mu$ in diameter, finally becoming subpyriform and 20-33 $\mu$ high through the development of a subcylindric obtuse or truncate foot penetrating the host for about $\mathrm{I}^{-2}+\mu$, the basal cell remaining simple or occasionally developing one or more smaller accessory cells, or sometimes sending out short creeping, of ten more or less immersed, filaments $2-5$ cells long, these very rarely forming a small imperfect basal disc, the secondary basal cells often sending up erect filaments; erect primary filaments $\mathrm{I}-4$ (usually 2 or 3 ) from the primary basal cell, $6-\mathrm{I} 4 \mu$ in diameter, of ten subdichotomous or subtrichotomous at the distal end of the first cell, erect filaments from secondary basal cells I-t (when present), commonly more slender, $t^{-S \mu}$ in diameter, all filaments somewhat rigid below, becoming flexuous above, rather sparingly and irregularly branched, the ramification subdichotomous or distinctly lateral, ultimate branches $3.0-5.5 \mu$ in diameter, mostly elongate-virgate; terminal hairs often present, but rather inconspicuous; cells of filaments cylindric, firm-walled, mostly 3-9 times as long as broad; chromatophore parietal, usually thin and inconspicuous, single or fragmented, pyrenoid lateral; monoecious; antheridia usually close to the procarp, lateral or latero-terminal, solitary or in groups of 2 or 3 ; cystocarps (frequent) mostly 3-8-spored, carpospores I3-26 $\mu$ $\times S-I S \mu$; sporangia (uncommon) monosporous, occurring on sexual plants (sometimes at least), lateral on one-celled pedicels, lateral and sessile, or sometimes terminal on main branches, I S-27 $\mu$ X IO-IS $\mu$. [PLATE I 5.]

On Dictyota dichotoma, dreclged "in I3 1/2-I4 fathoms," Lewis Radcliffe, August II, I9It; accompanied by Microchaete nana, Streblonema solitarium, Elachistea stellulata, Phaeostroma pusillum, Erythrocladia vagabunda, E. recondita, etc.

Acrochactium affine is related to $A$. Hoytii Collins, ${ }^{1}$ described as an epiphyte on Dictyota dichotoma from the Beaufort region, to A. unipes Borg.," described as an epiphyte on Dictyota linearis from St. Croix, and to A. robustum $13 \phi r g .{ }^{3}$ described as an epiphyte on Sargassum vulgare from St. Thomas. It seems possible that a carefully conducted series of cultural experiments, with a reproduction, if practicable, of the natural growth conditions of these four alleged species, might be able to show that all four represent

1 Rhodora I0: 134. 1908.

2 Mar. Mlg. Danish West Indies 2: 35. 1915.

${ }^{3}$ Loc. cit. 40. 
conditions of a single polymorphous species. However, such experiments would be difficult to carry out and what they might prove is at the present time purely conjectural. The facts remain that our plant, taken as a whole, differs in several particulars from any one of the three plants named, and that, apart from the priority of Acrochaetium Hoytii and the apparent identity of the hosts of $A$. Hoytii and $A$. affine, there seems to be no compelling reason for the association of our plant with any one of the three names mentioned rather than with any other of the three. Under these circumstances it seems justifiable to give our plant a new specific name, which, like most new specific names, is a tentative one at best.

From Acrochaetium Hoytii, A. affine differs in its larger size (1.0-3.5 mm. vs. $0.3^{-1} .3 \mathrm{~mm}$. tall), in its sparing and irregular ramification with branches mostly long and flexuous (A. Hoytii commonly has numerous short, mostly I-5-celled branches and branchlets, sometimes springing from nearly every cell of the main axes, often once or twice compounded in a similar fashion and arranged in a corymbose-secund manner), in the usually greater diameter of the primary filaments (6-I $4 \mu$ vs. $5^{-7} \mu$ ), in the relatively longer more cylindric cells (mostly 3-9 vs. 2-4 diameters long), in the usually more imbedded primary basal cell, in the occasional formation of secondary basal cells, which now and then are so numerous as to constitute a small basal disc, in the larger (I8-27 $\mu \times$ IO-I $8 \mu$ vs. I I-I $5 \mu \times 5^{-6} \mu$ ) and infrequent sporangia, and in the relatively abundant cystocarps. The cystocarps of $A$. Hoytii were not observed by Mr. Collins. We have seen a very few cystocarps in $A$. Hoytii, but have not seen antheridia or procarps. The sporangia of $A$. Hoytii were described as on one-celled pedicels, but we find them often sessile also.

From Acrochaetium unipes, which we know only from Dr. B $\phi$ rgesen's description and figures, A. affine would appear to differ in having in mature conditions, except in rare cases, $2-4$ erect primary filaments. These are commonly subdichotomous or subtrichotomous close to the base, so that at first sight the effect of having $4^{-I} 2$ primary filaments is produced, while $A$. unipes has a single erect primary filament with apparently only lateral branching. No secondary basal cells are attributed to A. unipes. 
Sporangia are the only form of reproductive organs described for A. unipes and these would appear to be more uniformly uniseriate or secund than we have observed them to be in A. affine.

From Acrochaetium robustum, which also we know only from Dr. Borgesen's description and figures, A. affine would appear to differ in being a taller plant $(\mathrm{I}-3.5 \mathrm{~mm}$. vs. $1 \mathrm{~mm}$. or less), in having usually a single basal cell instead of a basal clisc and in the larger sporangia (I $8-27 \mu \times$ IO-I $8 \mu$ vs. I $2-I 6 \mu \times$ I I $\mu$ ). No cystocarps are known in $A$. robustum, but the sporangia are abundant.

Intermingled with the undoubted Acrochaetium affine we have seen a few plants with a filamentous or rhizomatous endophytic base, the original spore not differentiated and the basal filaments apparently creeping within the outer cell walls of its host and sending up erect external filaments here and there. We are inclined to believe that they represent a condition of the plant described above as $A$. affine, but not being wholly convinced as to their identity, we have endeavored not to include them in writing our diagnosis of this species. If they really represent a form of $A$. affine, they would indicate a greater range of variability in the basal parts of an Acrochaetium than recent writers on this genus have assumed to be possible. If our material includes two species, it is possible that our figures 5 and 14 , which seem to show scarcely enlarged original basal cells, are to be referred to the species that we are leaving undetermined. Our figure $x_{4}$, by the way, is rather suggestive of Børgesen's figure (loc. cit. 51.f. 53) of the basal part of his Acrochaetium Hypneae. In the matter of endophytic basal filaments, care must be taken, in the case of $A$. affine, not to confuse the base of this plant with the filaments of the endophytic Erythrocladia vagabunda and E. recondita, with both of which it is of ten very closely associated. Young few-celled filaments of $E$. recondita, in particular, often closely encircle the partly endophytic bases of the Acrochaetium and might easily be taken to be a part of it. On staining with iodine, however, the protoplasts of the Acrochaetium become a recklish brown, while those of the Erythrocladia become violetpurple or almost black. 


\section{Explanation of plates II-I5}

Plate i I

I-9. Phaeostroma pusillum

I. Margin of thallus, showing discrete repent filaments, plurilocular sporangia, hair, etc.

2. Enlarged detail, showing inmature plurilocular sporangium, chromatophores, etc.

3. A mature plurilocular sporangium in obliquely longitudinal view.

4. A mature plurilocular sporangium viewed from above (end view).

5. Margin of thallus (more compact than that shown in Fig. I), with unilocular sporangia. A sorus at $a$ and the beginning of a sorus at $b$.

6. Enlarged detail of thallus, showing chromatophores and unilocular sporangia as seen from above.

7. A young unilocular sporangium, viewed from above.

8. The beginning of a sorus, viewed from above.

9. A mature sorus of unilocular sporangia, viewed from above.

Figures I and 5 are enlarged 245 diameters; 3 and 4,670 diameters; 2,6 , and $7-9$, Ioło diameters.

\section{0-16. Derbesia turbinata}

IO. Apex of thallus, showing a young lateral branch.

I I. Lateral branching, or "unequal dichotomy."

12. A dichotomy of thallus.

13-16. Usual forms of sporangia. Fig. 13 shows a short pedicel cell; 15, a longer one; in 14 and 16 , no septa have appeared.

Figures 10-12 are enlarged 8I diameters; I3-I6, I62 diameters.

\section{Plate I 2}

\section{1-5. Erythrocladia recondita}

I. Portion of thallus near margin, viewed from above, showing outlines of protoplasts and of pyrenoids and also outlines of the cortical cells of its host.

2 and 3. Portions of cross sections of the endophyte and its host, showing the more or less exserted spermatia $(s p m)$ and the immersed vegetative cells.

4. Portion of a cross section, showing a carpogonium with exserted trichogyne.

5. Portion of pseudoparenchymatous thallus, viewed from above, showing protoplasts of vegetative cells, spermatia ( $s p m)$, carpogonium $(c p g)$, and sporocarps ( $s p c p)$.

Figures are all enlarged 670 diameters.

\section{6-I I. Erythrocladia vagabunda}

6. Portion of thallus, viewed from above, showing outlines of protoplasts and pyrenoids and also outlines of the cortical cells of its host. The cells, here enlarged 415 diameters, appear of about the same size as those of E. recondita when enlarged 670 diameters (Fig. I).

7. Portion of thallus, showing three vegetative cells, six sporocarps $(s p c p)$, and five cavities from which carpospores have been discharged.

8 and 9. Portions of thalli, showing vegetative cells and sporocarps ( $s p c p)$.

Io. A single carpospore lying on the surface of its host, in the outer walls of which it is already partially immersed.

I I. A young filament (four-celled stage), viewed from above.

Figures 6, 8, 9, and I I are enlarged 4I5 diameters; 7 and 10, 670 diameters. 


\section{2-17. Microchacte nana}

12. A young filament, prostrate but beginning to turn upward at apex. In this figure and the next the thickness and distinctness of the vagina are somewhat exaggerated.

13. An older and normally curved filament, showing two basal heterocysts, a rare or occasional character.

14. An unusually straight, apparently mature, filament.

15. Another filament with a curve of a frequent form near base.

16. Apex of filament shown in Fig. I5.

17. Base of filament shown in Fig. 15.

Figures 14 and 15 are enlarged 245 diameters; $12,13,16$, and 17,670 diameters.

\section{PLATE I 3}

1. Erythrocladia recondita. A photograph of the endophyte, made after staining with iodine. The larger darker cells are sporocarps. Enlarged I60 diameters.

2. Erythrocladia vagabunda. A photograph of the endophyte, made after staining with iodine. Some of the larger cells are sporocarps. A small colony of E. recondila, staining more deeply and having smaller cells, is shown near $B$ at the lower right-hand corner, 'where it is more or less intertangled with the E. vagabunda. Enlarged I60 diameters.

\section{Plate 14 \\ Acrochaelium infestans}

I. Endozoic filaments of the usual form, with two short exserted filaments. In the endozoic parts the outlines of protoplasts only (for the most part) are indicated, the cell walls being almost invisible.

2. An exserted sporangium sessile on an interior filament.

3. An exserted filament of three cells, one of which is a sporangium and another of which is probably an immature sporangium.

4. An exterior filament, with short branches, short hairs, and a single lateral sporangium.

5. A single typical cell of an interior filament, showing chromatophore, pyrenoid, etc.

6. Exterior filaments, showing sporangia in terminal clusters of three, and also one lateral sporangium.

7 and 1 I. Short exterior filaments.

8. A branched exterior filament, showing lateral and terminal sporangia. One of the emptied lateral sporangia is apparently being refilled or regenerated from the supporting vegetative cell.

9. A short exterior filament, showing regeneration of a terminal sporangium.

Io. Part of a plant, showing mode of branching and cortuous course of a part of an interior filament, etc.

12. An unusually long exterior filament, showing long hairs and short secund branchlets (solitary or geminate).

Figure 5 is enlarged 1,040 diameters; the others, 670 diameters.

\section{Plate I5}

Acrochactium affine

I. A spore attached to margin of the Diclyola thallus.

2. A spore that has developed a small accessory repent basal cell and is also beginning to send up an erect filament. 

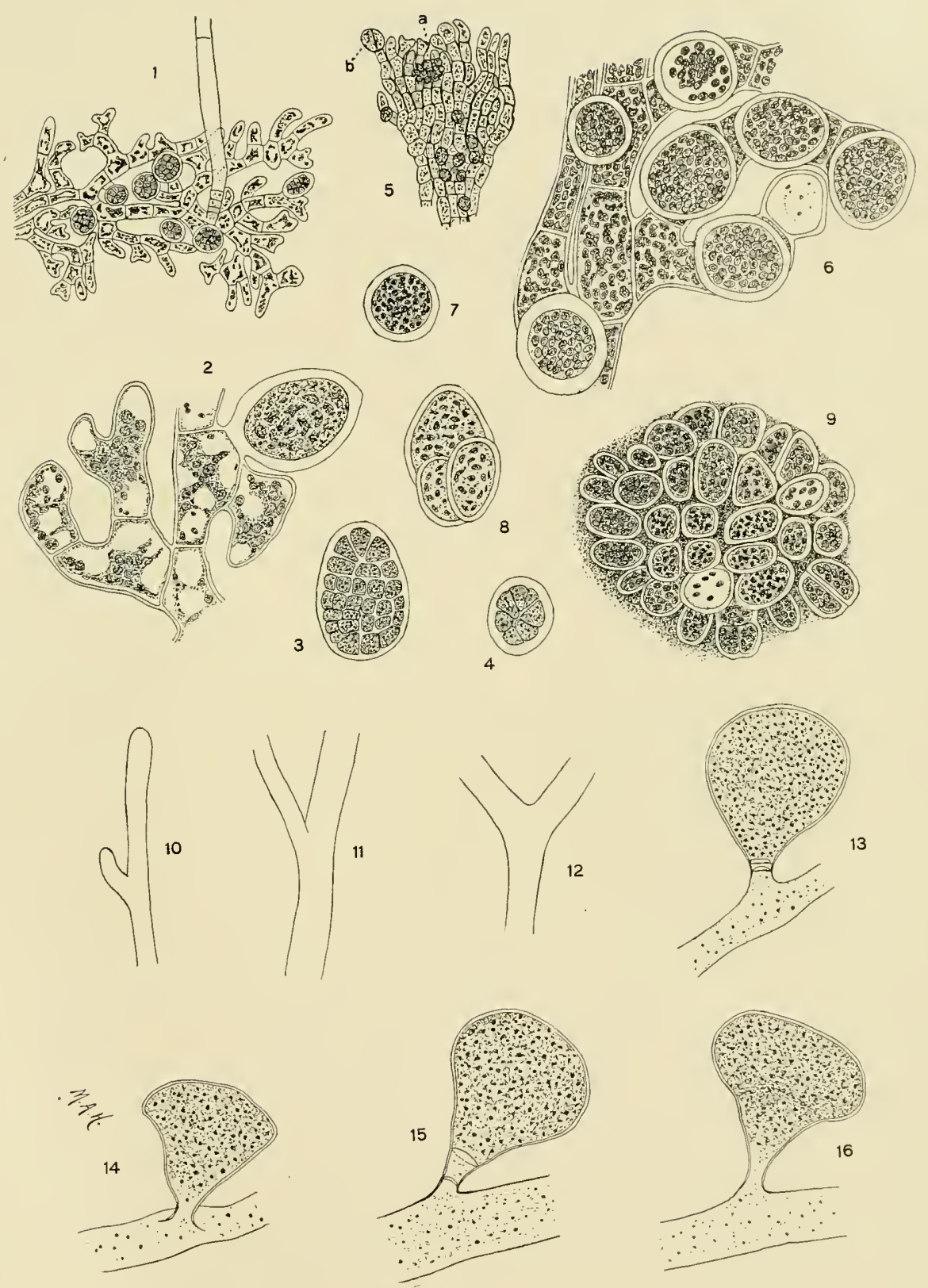

I-9. Phaeostroma pusillem Howe \& Hoyt IO-I6. DERBESIA TLRBINATA Howe \& Hoyt 



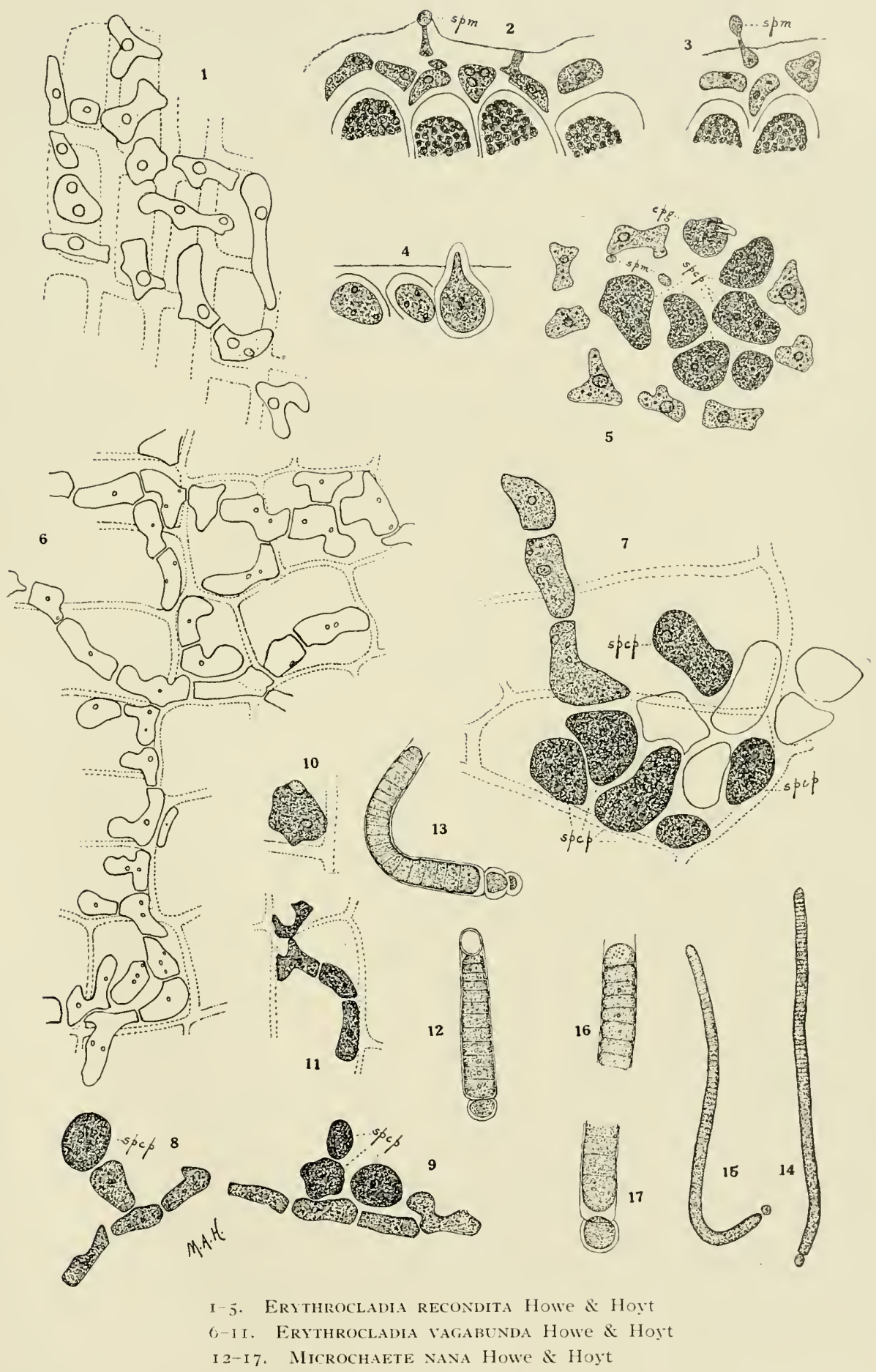




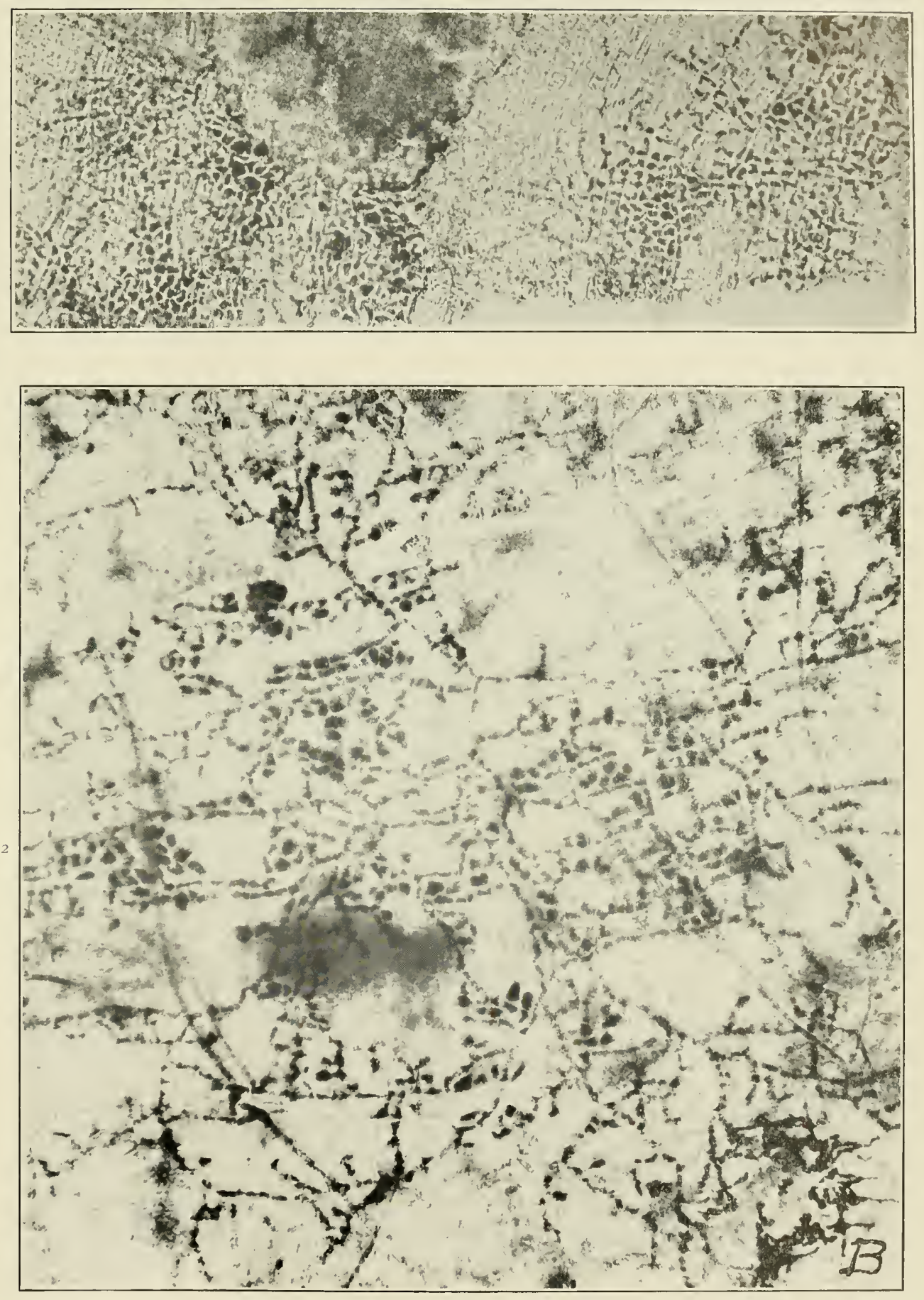

ERvtHROCladia RECONDITA Howe \& Hoyt

2. ErIthrociadi vagabunna Howe \& I Ioyt 



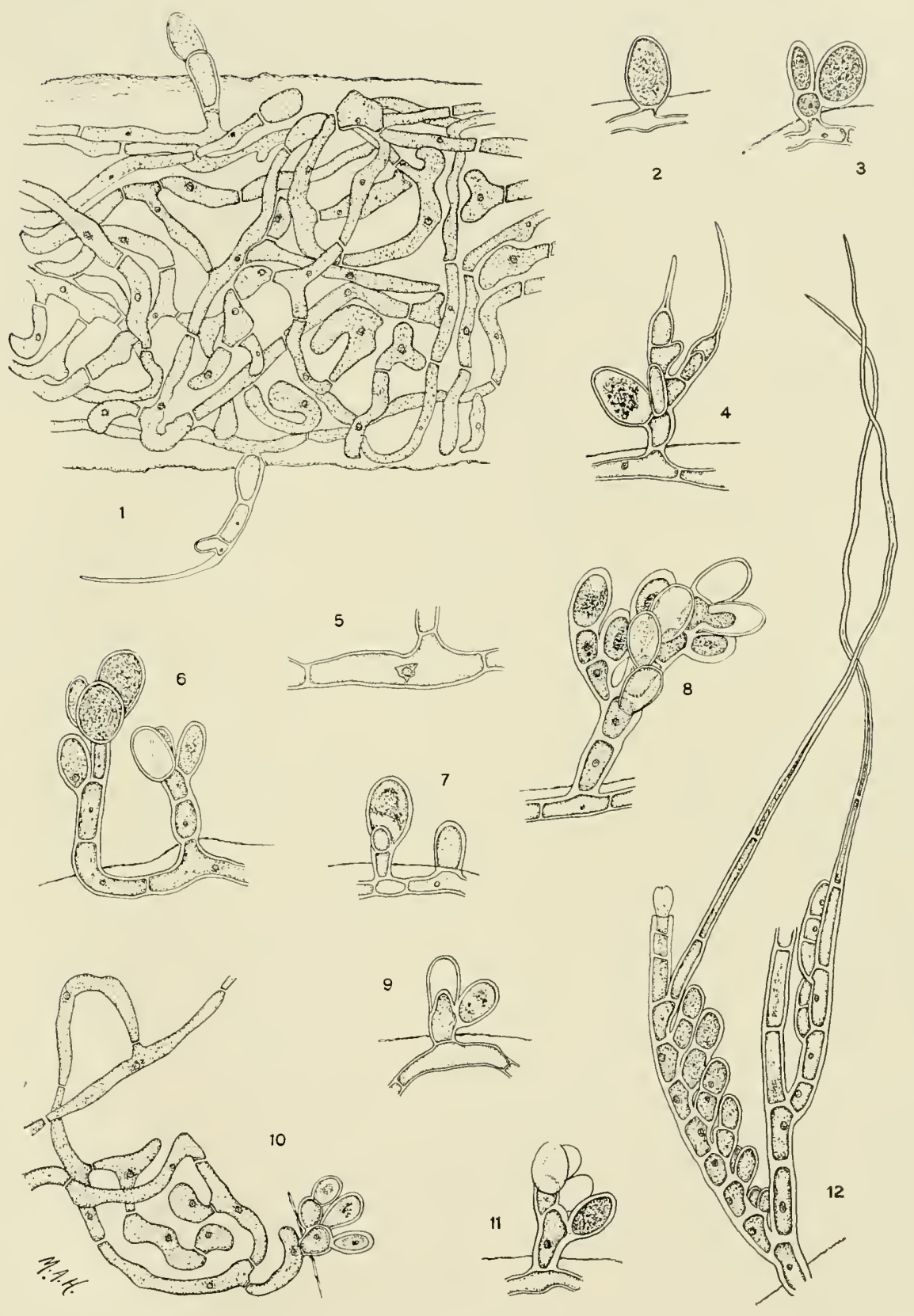

ACrcchaetium infestans Howe \& Hoyt 



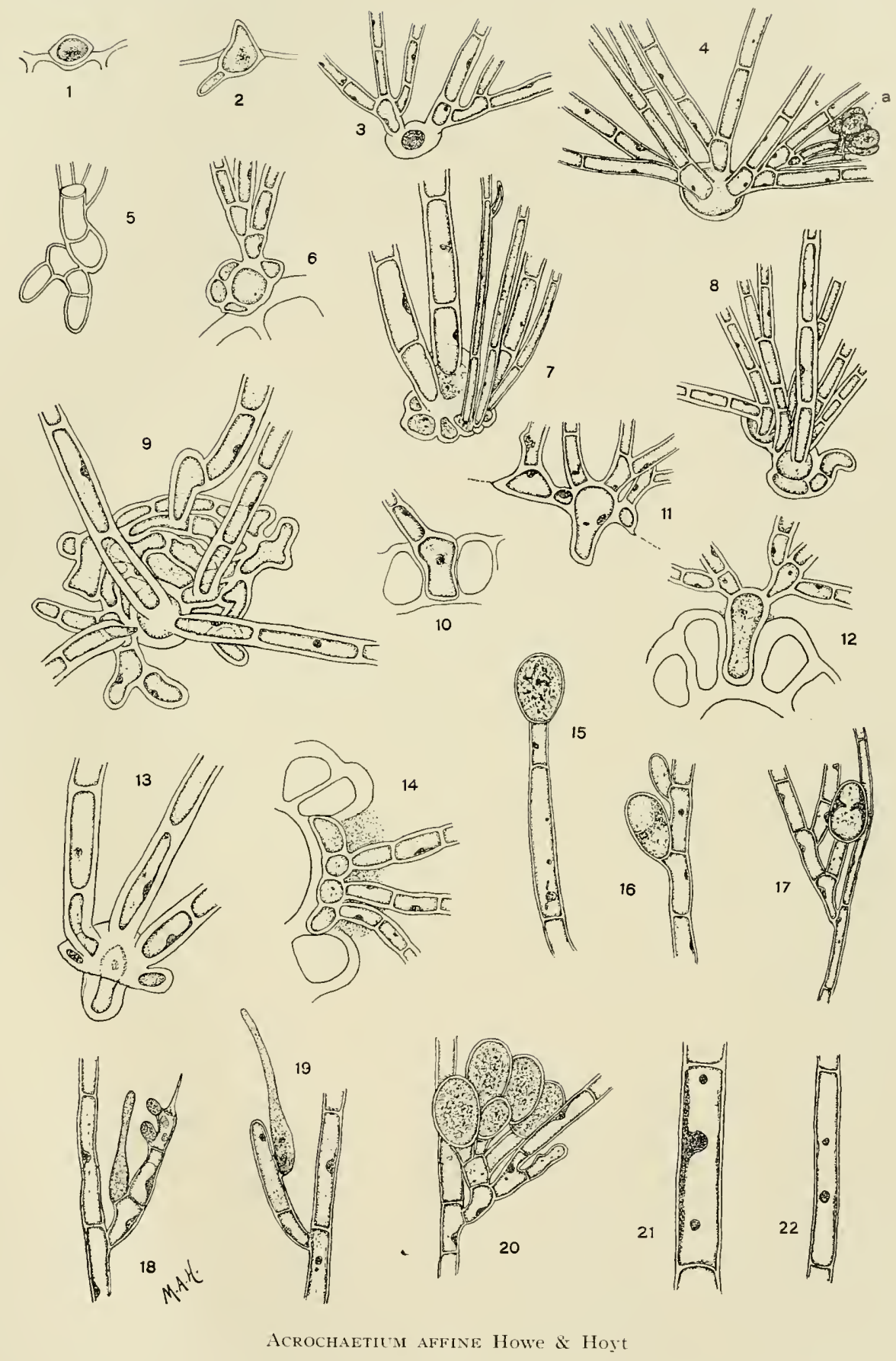



3. Base of a mature plant, showing simple basal cell and two erect filaments, each of which branches from its lowest cell.

4. Base of a similar, though larger plant, with four primary erect filaments, each branched at its base. A small cystocarp at $a$.

5. Base of a plant showing a scarcely enlarged basal cell, short repent basal filaments, and a single erect filament which has two branches from its lowest cell.

6. A vertical section through the base of a plant, showing a few small accessory cells that partly cover the primary basal cell.

7. Base of a plant showing accessory basal cells and three coarse and three slender erect filaments, none of which branches from its lowest cell.

8. Base of a plant with accessory basal cells, and erect filaments of various sizes.

9. Base of a plant that has developed a small imperfect basal disc, with the original spore manifest.

Io. Optical section of the margin of the Dictyota thallus, showing base of young plant with a single immersed basal cell and a single erect filament.

II. Optical section of the base of a plant, showing subpyriform semi-immersed primary basal cell and several superficial smaller secondary cells, some of which send up erect filaments.

12. Section through the margin of the Dictyota thallus, showing single subpyriform basal cell with penetrating foot.

I3. Base of a detached plant showing primary basal cell, its penetrating foot, three erect filaments, and two small accessory basal cells.

I4. Section of margin of the Dictyota thallus, showing four basal cells of approximately equal size that are more or less endophytic. The partly overlying cortical cells of the Dictyota are for the most part disintegrated, but this may have been accomplished by agencies other than the Acrochaetium.

15. A sporangium terminal on a main branch.

16. Sessile lateral sporangia.

17. A sporangium on a one-celled pedicel.

I8. Procarp and antheridia.

19. An older procarp with no obvious antheridia in its vicinity.

20. A cystocarp.

2I. A typical cell from one of the coarser filaments, showing chromatophores and parietal pyrenoid.

22. A typical cell from one of the more slender filaments.

Figures $\mathrm{I}-\mathrm{I} 7 \mathrm{7}$ are enlarged $4 \mathrm{I} 5$ diameters; $18-22,670$ diameters. 



\title{
SOMATIC AND REDUCTION DIVISIONS IN CERTAIN SPECIES OF DROSERA
}

\author{
Michael Levine \\ Columbia University \\ (with Plates I6-I9)
}

Rosenberg's work on the cytology of the so-called natural hybrid Drosera obovata has raised some of the most interesting points so far presented in the study of the chromosomes in hybridization. According to Rosenberg ('03, '04, '09) Drosera longifolia has forty chromosomes in the somatic cells, which fuse in the pollen mother-cell and embryo sac mother-cell and form twenty bivalent chromosomes. In Drosera rotundifolia he finds only twenty somatic chromosomes and ten bivalent chromosomes in the germ cells. He reports that these chromosomes are large and readily distinguishable from those in $D$. longifolia. In $D$. obovata, which has been considered a natural hybrid between $D$. longifolia and $D$. rotundifolia, he finds that there are invariably thirty heteromorphic chromosomes in each somatic cell, while in the pollen mother-cell or embryo sac mother-cell there are ten double chromosomes and ten single ones. Rosenberg claims that $D$. obovata received twenty chromosomes from $D$. longifolia and ten from $D$. rotundifolia. The pairing of the homologous parent chromosomes results in the formation of two kinds, namely single ones and double ones. In the heterotypic division of $D$. obovata the ten double chromosomes separate, ten dyads going to each pole. Rosenberg finds that the ten single ones are distributed unevenly to the poles so that some nuclei receive as many as eighteen chromosomes while others receive only twelve. Not infrequently one or more of the single chromosomes are left on the spindle. In the second division the nuclei may receive from thirteen to sixteen chromosomes each, while the belated chromosomes form dwarf nuclei which eventually disintegrate or form dwarf pollen grains. All the pollen in the hybrid is sterile. 
The appearance of lagging or belated chromosomes has been described for a great number of species and the phenomenon is associated with varying degrees of abnormality in the general behavior of the cells in which it occurs. Whether in the case of $D$. obovata such bodies are really chromosomes is certainly a question and my studies, to be described below, furnish some interesting suggestions in this connection.

Strasburger ('82) and later Juel ('97) have observed undoubted chromosomes on the spindles after the completion of the reduction divisions of the pollen mother-cells in Hemerocallis fulva. Strasburger and Juel both observed that these belated chromosomes become surrounded by nuclear membranes and form dwarf nuclei and later dwarf pollen grains. Juel emphasizes the fact that erery chromatic mass can become an individual cell and later divide. It must be remembered that already Wimmel ('50) for Fuchsia, Hofmeister ('48, '61) for Passiflora caerulea and Iris pumila, Tangl ('82) for Ifemerocallis fulva, Wille ('86) for twenty-three species of different flowering plants had found that a number of pollen grains less and greater than four may arise from a single pollen mother-cell by failure of the daughter pollen mother-cells to divide or by subsequent division of the cells of the tetrad. These views were later shared by Miss Lyon ('98) for Euphorbia corollata and Fullmer ('99) for Hemerocallis fulva. Beer ('01) confirmed Juel's conclusions. He re-investigated IVimmel's results on Fuchsia and found that some chromosomes lag behind on the spindle after the first division and finally give rise to dwarf nuclei. Less frequently these chromosomes fail to become nuclei and then they rapidly disintegrate.

Latour ('08) in his study of the development of pollen of Agave attenuata noticed groups of chromosome-like bodies in the cytoplasm and on the spindle in the first division of the pollen mother-cell. These bodies look in all respects like chromosomes. Each body soon becomes enveloped in a nuclear membrane and may then disintegrate, or several of them may unite to form a larger nucleus or they may join the body of the main nucleus.

Interesting abnormalities in division of the male germ cells have likewise been observed in a number of hybrids. The anomalies seem to be closely related to the appearance of chromosomelike bodies. Juel ('00) investigated the cytology of the hybrid 
Syringa rothomagensis and its parents $S$. vulgaris and S. persica. He found that the reduction divisions in the hybrid were abnormal. Invariably chromatin or chromosome-like bodies appear in the cytoplasm during division stages. These bodies take the chromatin stain and become invested with a nuclear membrane. The origin of these bodies is not clear. Juel believes that these bodies arise from the amitotic division of the nuclei of pollen mothercells which disintegrate. Juel holds that the sterility of pollen is due to the abnormality of the tetrad division. Tischler in his interesting papers ('05, '06, '08, '10) on the causes of the sterility of pollen in hybrid plants finds that in Ribes Gordonianum the chromosomes are irregularly distributed in the first division of the pollen mother-cells so that more than two daughter nuclei are formed. In sterile Bryonia hybrids and in three varieties of Musa sapientum he described similar conditions. In the former case he believes that the abnormality in the first and second divisions of the pollen mother-cells is similar to that in Hemerocallis fulva (Juel, '97). In Potentilla similar conditions appear, yet in both Bryonia and Potentilla normal pollen is also found. It is of interest to note that in the three varieties of banana, Dole, Radjah Siam, and Kladi, there are eight, sixteen and twenty-four chromosomes respectively.

Gates ('07) in a study of hybrids between Oenothera lata and $O$. Lamarckiana described and figured chromatic bodies in the cytoplasm of the pollen mother-cells during division. He observed the complete sterility of certain anthers of a flower and associated this condition with the appearance of these bodies. In a later paper ('14) Gates and Thomas reported their work on Oenothera lata and $O$. semilata. Here they found $\mathrm{I} 5$ chromosomes in the somatic divisions and that while in the pollen mother-cell the extra chromosome behaved differently-it most frequently was left behind on the spindle. Gates believes that the union and segregation of chromosomes tends to be in two numerically equal groups.

Geerts ('09, '11) in a cross between Oenothera lata and O. gigas found in the hybrid a condition similar to that observed by Rosenberg in $D$. obovata. The male gametes have fourteen chromosomes and the female gametes have seven chromosomes and the hybrid twenty-one, in two sets, seven and fourteen. In 
the equatorial plate stages of the heterotypic division Geerts claims to recognize seven double and seven single chromosomes. The double chromosomes divide and go to their respective poles, while four of the single chromosomes may go to one pole and three to the other. Not infrequently one or more of the single chromosomes fail to reach the poles and are left on the spindle. In the second division the three or four single chromosomes may divide but more commonly they disintegrate. Here again a chromosome may be left on the spindle and form a dwarf nucleus. Still, Geerts reports that pollen grains with ten or eleven chromosomes are not uncommon. Geerts regards his results as in perfect accord with that of Rosenberg on Drosera obovata and as opposed to those of Gates ('09) on the same hybrid. In both heterotypic and homoeotypic divisions of male cells of Oenothera gigas, Davis ('11) found chromosomes that fail to reach the poles and form supernumerary nuclei.

It is plain that the cases of chromosomes which fail to reach the poles are not confined to hybrids with parents having the unequal number of chromosomes.

In the cases so far considered there is a question as to whether the bodies appearing in the spindle in early telophase are really chromosomes. It is well known, however, that other deeply staining bodies may be found on the spindle in both the reduction and somatic divisions. Zimmerman ('93, '94) reported the appearance of bodies on the spindle and in the cytoplasm which in appearance and staining reaction agreed in all essentials with the nucleoli of the resting nuclei. Zimmerman believed that these bodies came from the nucleolus as a result of its disintegration during karyokinesis and called them extranuclear nucleoles. He held further that these bodies go into the daughter nuclei and fuse to form a new nucleole - a view subsequent investigation has not confirmed. Allen ('05) in Lilium canadense described and figured extranuclear nucleoles in the prophases of the pollen mother-cells. These bodies he claimed disappeared by the time spindles were formed. They reappeared and later were numerous in the equatorial plate stage. Gregory ('05) studied similar hodies in the fertile variety of the sweet pea, Emily Henderson. IIe found that the nucleolus fragments and spherical bodies, three to four in number, appear in the cytoplasm 
when the nuclear membrane disappears. The fate of these bodies he was unable to determine.

Beer ('12) reported that he found in the cytoplasm of Crepis taraxacifolia and $C$. virens a number of deeply stained granules which he refers to as chromatic droplets. In Matricaria Chamomilla similar bodies appear a short time after the heterotelophase. Beer believes these bodies are derived from portions of the nucleolus which have passed through the nuclear membrane. Similar phenomena have been described by Farmer and Digby ('10) for Polypodium vulgare. Many have claimed that chromatin may be extruded and appear as deeply staining bodies in the cytoplasm. Some claim for these bodies very important functions in the activities of the cell, others maintain that they are mere artifacts. Digby ('09, '10, '12, '14) in the study of spermatogenesis of Galtonia candicans, Crepis taraxacifolia, and Primula kewensis found that during synapsis part of the nuclear network or nucleolar substance passes through the nuclear membrane and forms a rounded or finger-like projection on the surface of the nucleus and may finally pass into the cytoplasm of the adjacent cell. These extruded masses become separated from the parent nucleus and become surrounded by a clear hyaline area and then take on the outward appearance of a nucleus; but later they disappear. Similar observations were made by Rosenberg ('09) for Drosera longifolia and Crepis virens. He claims that these extrusion substances are nothing more than the results of poor fixation. Koernicke ('01) claimed that these bodies indicate that the anther is in an abnormal condition at the time of fixation. Gates ('11) in his study of Oenothera gigas and O. biennis described the escape of chromatin from the nucleus of the pollen mother-cell into the adjacent cells. His figures correspond with those of Miss Digby. Carruthers ('11) claimed to find similar extrusion substances from the nuclei in the young asci of Helvella crispa. West and Lechmere ('15) described what they called budding of the nuclei in the pollen mother-cells of Lilium candidum. They claim that the nucleolus takes no part in the formation of these nuclear protuberances and that these bodies are normal and may represent the discharge of waste products of the cell.

In studying the chromosome number and reduction divisions with a view to determining whether wild hybrids exist also in 
America I was struck by the appearance, in a great number of sections, of chromosome-like bodies on the spindle and in the cytoplasm of the pollen mother-cells during the late telophases of both the first and second divisions. These bodies in their general characteristics resemble the belated chromosomes described and figured by Strasburger, Juel, Tischler, and others. These bodies were especially well shown in Drosera rotundifolia. Studies were also made of Drosera intermedia Hayne, D. filiformis, $D$. binata, and $D$. longifolia. Numerous plants of the first three species mentioned were collected in the bogs at Lakehurst, N. J. during the summers of I9I $3^{-'} 4^{-}$'I5. Flowers of all sizes were fixed in a number of fixing solutions such as Carnoy's, Bouin's, Merkel's, and Flemming's mixtures. The best results were obtained with Flemming's medium fixative. Flowers of $D$. binata were obtained from plants cultivated at the New York Botanical Garden. Similar fixing solutions were used on these flowers. My material of $D$. longifolia, ${ }^{1}$ of which I had relatively few plants, was kindly sent to me by Professor John Davidson from Vancouver Island. Its identification is unquestionable as shown by comparison with critically determined material in The New York Botanical Garden. The flowers were sent to me already fixed in Carnoy's, Merkel's, and Flemming's solutions. Living material available for identification purposes was also sent. A number of stains were used but Flemming's triple stain gave the best figures.

The nuclear phenomena are so much alike in the species studied that I shall treat of them collectively except where special mention is necessary. To make more certain the interpretation of my observations on the reduction divisions I have also studied the somatic divisions in the ovary and stamens.

Somatic divisions.-The regetative cells of the flower as well as the young archesporial cells are very favorable for study though the nuclei are not large. In the resting state the nuclear material is made up of a fine linin network with a number of minute but sharply defined chromatic bodies (FIG. I). These bodies are

${ }^{1}$ Through the kindness of Professor N. Wille, who sent me herbarium specimens of the Norwegian Drosera longifolia and D. intermedia Hayne, I was able to study and compare these two species with our American forms. I find these species quite distinct and readily separable, as maintained hy Dr. N. L. Britton ('o 7). 
undoubtedly like the prochromosomes of Rosenberg ('04) and Overton ('05). With careful study their number can be fixed at about twenty. In the case of $D$. longifolia, which is the species of special interest in view of Rosenberg's contention that its somatic chromosome number is forty, I have been unable so far by a study of the prochromosomes in the somatic cells to verify his conclusion. In my preparations, however, the prochromosomes were favorably shown in only a few cells. The prochromosomes stain sharply with gentian-violet but other smaller granules which stain faintly are also present. The nucleole stains a ruby red. Not infrequently one can find a cell with two or three nucleoles. The cytoplasm stains a faint orange. In the cells of the anther wall the cytoplasm is not at all dense and a number of large vacuoles appear, while in the immature pollen mother-cell the cytoplasm is densely granular with few or no visible vacuoles. The prochromosomes appear to spin out and form a spireme which fills the entire cavity of the nucleus. The band is narrow and seems to be continuous. The nucleole disappears, the spireme segments and twenty more or less angular chromosomes can be counted before a bipolar spindle can be recognized. In this stage also I had relatively little material of $D$. longifolia and considerable difficulty was encountered in making a definite count. The nuclear membrane disappears and the chromosomes are seen in equatorial plate stage (FIG. 2). The spindles are like those described by Rosenberg ('99) for Drosera rotundifolia - some may be pointed while others are broad-poled. In the early telophases of the somatic divisions a rudimentary cell plate (FIGS. 5, 6) is developed but the incipient stages of the process were not observed. The fibers at the center of the spindle shorten as shown by Strasburger (' 82 ), Timberlake ('00) and others. New fibers also appear which make the spindle seem to bulge out until the diameter of the spindle reaches across the width of the cell (Figs. 6-7). At the same time the nuclear masses seem to approach each other (FIG. 6). The cell plate continues to grow peripherally until it forms a diaphragm cutting the cell in two (FIG. 8). In the later telophases the chromosomes begin to anastomose and there seem to be lines of flowage of material from each chromosome. The stain is taken more deeply at the center of the mass while its intensity decreases as the distance from the center increases. The flowage progresses 
steadily until the chromosomes remain only as small granules in a fine reticulated structure. In the case of the last premeiotic division as described it may be clearly seen that the chromosomes form the prochromosomes of the pollen mother-cells as Rosenberg ('09), Digby ('10), and others have claimed.

Reduction divisions. - The pollen mother-cells were studied in $D$. rotundifolia, $D$. intermedia, and $D$. filiformis. In my material of $D$. longifolia the pollen grains were already mature so that the divisions forming the embryo sac alone were available for chromosome counts.

D. filiformis is most favorable for the study of the pollen mothercells on account of the somewhat larger cells. The germ cell nuclei are all provided with a single large nucleole and in it one invariably finds one or more large vacuoles as shown by Martins Mano ('05), Nichols ('01), and Digby ('08). These vacuoles afford no evidence that chromatin is budding off from the nucleole as suggested by Nichols, although in all species studied small globular bodies may occasionally be seen lying in contact with the nucleole as figured by Rosenberg ('09). The nucleole generally occupies a peripheral position in the nucleus and the prochromosomes (FIG. I5) are scattered in a fine linin network. These bodies are slightly elongated or rod-like granules which generally lie in pairs in the periphery of the nucleus. The prochromosomes are readily distinguishable from the other granular substances which appear in the nucleus at this time by their deep gentianviolet stain and their compact homogeneous consistency. By close study there may be found all stages in the transformation of the prochromosomes to form the leptoneme spireme. The process is similar to that shown by Overton ('05) for Calycanthus floridus. Two fine thread-like bands are formed, the leptoneme spireme (FIGS. 26, 27, 28) as figured by Berghs ('05) for D. rotundifolia and later by Rosenberg ('09). The mature leptoneme spireme can be clearly seen to be made up of two thin, parallel bands of a homogeneous structure. In some stages these threads seem to have fused and a single continuous spireme band appears (FIG. I6). Occasionally this fused band may have a beaded appearance, as shown by Rosenberg, Overton, and Allen. In this condition there is no evidence of its bivalent nature. It is quite apparent from the above that the pairing of the prochromosomes is to be side by side. 
By slow changes the spireme begins to contract and move toward the periphery of the nucleus and the synaptic stage is formed. All stages may be found in this contraction of the spireme. Anthers in the same flower are found in different stages other than synapsis. I cannot agree with Lawson ('11) that the synaptic knot is not an active contraction of the chromatin thread. The coils of the spireme can be readily traced in the early stages but as the knot becomes smaller and smaller the difficulty is increased but at no time is it impossible to trace the individual coils (FIGs. $17-18)$. The nucleole is generally enclosed in the meshes of the synaptic knot; that also helps to make the winding of the band more difficult to follow.

As the chromatin mass emerges from the synaptic knot there is a simultaneous shortening of the spireme and the pachyneme spireme is formed. Drosera filiformis is particularly favorable material for the study of this stage (see FIGS. 29a, 29b). When the pachyneme is fully developed it may be seen to consist of a number of loops which are evenly distributed through the nuclear cavity. The band is homogeneous and while it occasionally shows signs of a beaded structure it is as a rule very smooth. The chromatin material of the spireme next seems to accumulate in certain areas (FIG. 30) leaving clear spaces in the band between them. This stage is followed by further contraction and thickening and finally the breaking of the spireme into a number of segments as shown in FIG. 31. In Figs. 19, 32a, $b, c$, we have the representation of nuclei in diakinesis. The ten bivalent chromosomes are peripherally distributed. They are somewhat angular and approximately all the same size. Occasionally the chromosomes appear quadripartite (FIG. 9). In the embryo sac mothercell of Drosera longifolia I have been able to observe the breaking up of the pachyneme (FIGS. 40a,b) spireme. The cells are large and the nuclei in sections $5 \mu$ thick may be cut twice. I have been unable at this stage also to determine the number of chromosomes but I hope that in the coming summer with more material this question can be definitely settled.

The nucleole in this stage stains a vivid ruby red and a number of vacuolar areas are visible. The nucleole has in no way changed except that it has increased in size. I must agree with Martins Mano ('05) that there is no evidence here for the contention of 
Wager ('04), Gregory ('05), Nichols ('08), Darling ('09), and others that the nucleole by buclding forms chromosomes or chromosome material. Fine fibers appear in close proximity to the nucleus. I have not, however, found a definite felted zone. In some sections there is only the faintest indication of fibers present as shown in FIG. $32 a, b, c$. I have not traced the progressive development of the spindle. The spindles in the first division are larger but otherwise are like those of the somatic divisions. The chromosomes form a very evenly arranged equatorial plate stage. FIG. I I represents a polar view of a spindle and ten chromosomes can be counted. The chromosomes are quite angular and a definite longitudinal cleft divides the tetrads into dyads (FIGs. 10, 20, 33). At this time no abnormalities appear either in the cytoplasm or on the spindles. There is no indication of extranuclear nucleoles or portions of displaced chromosomes. FIG. I2 represents the dyads approaching their respective poles. Each chromosome appears longitudinally split, undoubtedly in preparation for the second division. After the chromosomes have reached the poles the central spindle persists in many cases and show all the peculiarities described by Went ('87) and Timberlake ('00). It is not uncommon, however, to find radial fibers coming from the chromosome groups (FIG. 23) and forming an irregular aster. Chromosome-like bodies now make their appearance in the cytoplasm and on the spindle fibers. I have observed them in Drosera rotundifolia, D. intermedia, and D. filiformis and only during the division phases. In color, size, and shape they remind one, howerer, of the belated chromosomes of Strasburger ('82), Juel ('00), or the unipaired chromosomes of the Drosera hybrid of Rosenberg ('04, '09) and the Oenothera hybrid of Cecrts ('09). They bear perhaps an even greater resemblance to the nucleole and look like the figures of extranuclear nucleoles of Zimmerman ('93) and more recently Allen ('05) for Litium. 'The size of these bodies varies; while some of them are about the diancter of the chromosomes others are smaller. They are spherical in shape but have a tendency to become angular. By their staining reaction it is difficult to determine whether they resemble more the chromosomes or the nucleole. By a careful study of a great number of these stages I am convinced that these bodies take a nucleolar stain. The 
position of these bodies on the spindle, very close to the newly formed nuclei, resembles that of the belated chromosomes shown by Strasburger, Juel, Tischler, Beer, Gates, Davis, and others. It is not at all probable that these bodies are chromosomes. Their number is large in some cells and they show no tendency to form central spindles or diminutive nuclei. One can count from nine to ten chromosomes in the daughter nuclei at this stage and as many as four equally large bodies lying in the spindle (FIG. 23) in the same cell. It seems quite improbable also that these bodies have a nucleolar origin. Their number and consequently their volume is far greater than that of the nucleoli (see FIGS. I3, 34). Yet in the homogeneity of their substance and their color with the triple stain they resemble nucleoles. That they are precipitation products formed in fixation is also quite out of the question. They appear in all three species mentioned above with all the different fixative and staining methods used. These bodies as a rule disintegrate shortly after the first division but they may be left in the cytoplasm until the completion of the second division, when the entire protoplast disintegrates. No evidence appears that these bodies are present at any stage in the second division earlier than the late telophase.

In the second or homoeotypic division the spindles (FIG. I4) are considerably smaller and are variously situated with respect to each other. The poles are usually single-pointed and the spindles in general are like those of the heterotypic division. The chromosomes are equally distributed on the spindle in the equatorial plate stage. In the early anaphase as shown in FIG. I4 they have split lengthwise and are beginning to move apart. The attachment of the mantle fibers is almost in the middle of the chromosome, so that U-, V-and L-shaped figures result. Although these chromosomes are small, in polar view twenty monads may be clearly seen.

While the majority of pollen mother-cells in anthers at a slightly older stage show three nuclei a considerable number appear with two and four. It is quite evident that in pollen cells with three or four nuclei simultaneous division or quadripartition of the pollen mother-cell must follow. In the case where three nuclei alone are visible the fourth nucleus lies either in the plane above or below, forming a tetrahedron, each nucleus situated at one of the 
apices. In the case where four nuclei are visible (FIG. 25) no tetrahedron is formed; the nuclei lying opposite each other form a pair and one pair usually lies at a slightly higher plane than the other. IThere two nuclei alone are visible in a pollen mothercell this may be due to the fact that the four-nucleated pollen mother-cell is so situated as to expose only two nuclei. It is likewise possible, although not so common, that the two nuclei are the results of cell division after the heterotypic division followed by nuclear division. From such figures it is accordingly clear that successive division or bipartition of the pollen mother-cell takes place as described below.

In the late telophase of the second, as in the first division, chromosome-like bodies appear on the spindle fibers and in the cytoplasm. In Fig. 24 three nuclei appear in a cell with their spindle fibers. One of the nuclei is intact while the other two are cut through in sectioning.

On the spindle fibers three bodies appear like those seen in the first division (see FIG. 23). In this figure in the complete nucleus there are unquestionably ten more or less spherical chromosomes, while in the preceding sections of the same cell ten chromosomes likewise appear in the other nuclei. In a slightly older stage, as shown in FIG. 25, of Drosera filiformis, two large bodics are seen on one of the central spindles with a number of smaller ones distributed through the cytoplasm. In another section of a late telophase stage of the homoeotypic division shown in FIG. 35 I found cytoplasmic bodies which stain faintly and were promiscuously scattered through the cytoplasm and on the spindle. In practically all cases where chromosome-like bodies appear, ten distinct chromosomes may also be clearly seen. What the subsequent history of these bodies is after the second division I have been unable to learn. It is quite clear that they do not form extra nuclei or dwarf nuclei as shown by Rosenberg, Tischler, Juel, Gates, and others. It is not wholly impossible, as held by Juel and Tischler, that these bodies may be the forerunners of abnormalities which eventually lead to the disintegration of the pollen mother-cell, but I have been unable to prove this. The formation of the normal pollen grains follows. The nuclei are reconstructed as they are after the heterotypic division. The central spindle fibers do not disappear but remain as prominent 
as they were in the early anaphase stages. Radiating fibers extending in all directions appear about each of the four nuclei.

Cell division.-It is well known now (Guignard, '15) that the division of the pollen mother-cell both in monocotyledons and dicotyledons may be either by successive division or bipartition or by simultaneous division or quadripartition. In Drosera rotundifolia, $D$. filiformis, and $D$. intermedia, both types of division were observed as intimated above. While it may be said that the predominant method is by quadripartition (FIGS. 36, 37), successive bipartition of the pollen mother-cell also appears. Cell divisions may follow at once in the heterotypic division. As mentioned above, the central spindle apparently remains unchanged but a cell wall is formed. The nuclei now divide again and this is followed by cell division so that four serially arranged pollen cells are formed (FIG. 38). For quadripartition no cell wall is formed after the first nuclear division. The nuclei divide again and after reconstruction in the presence of both central and radiating spindle fibers cell walls are formed simultaneously, cutting the cytoplasm into four approximately equal parts.

While successive stages of development of the cell wall through a cell plate have been observed in the somatic divisions as mentioned above, no indication is found of the presence of a cell plate in the divisions of the pollen germ cells. Farr ('16) finds that in Nicotiana and certain other dicotyledons quadripartition is the rule and that it is accomplished by furrow rather than a cell plate. The mother-cell wall in these cases is markedly thickened and fills the constriction furrow during the division. I have seen these preparations and the appearances are different from that in Drosera. Cannon ('03) and Samuelsson ('14) hold that cell division of the pollen mother-cell is brought about by the constriction of the cytoplasm as in the division in animal cells. If furrows are present in Drosera they must be extremely narrow like those shown in the slime moulds by Harper ('00, '14), which proceed from the periphery to the center of the cytoplasm (FIGS. 36, 37, 39).

As suggested above, certain pollen mother-cells disintegrate. The process of disintegration is comparable to that described by Tischler ('06) for Bryonia and Syringa hybrid pollen. After completion of the homoeotypic division the reconstructed nuclei lose their nuclear membranes and the nuclear content and cyto- 
plasm soon appear to be stretched. The chromatin and nuclear substances now dissolve and impart their staining properties to the entire cell contents. This is followed by a complete disorganization of the cell contents. The pollen grains may have formed mature walls before their cytoplasmic content disintegrates so that a considerable number of empty pollen grains have been found in Drosera longifolia, $D$. binata, $D$. rotundifolia, $D$. intermedia, and D. filiformis. There is considerable danger of confusing these disintegration stages with badly fixed or over-stained cells.

The pollen grain.-The pollen grains of the Droseraceac are unlike those of most species of plants in that the four pollen tetrads remain permanently united. While the fact is of common knowledge no adequate figures of these tetrad grains have been published. Drude ('91) figures the pollen grains of Drosera rotundifolia. He shows four pollen grains arranged in a tetrahedron and the outer surface of each grain thickly covered with spines. Drude also shows a number of tubules which arise from the angle formed by two adjacent pollen grains in the tetrad. He holds that these tubules are pollen tubes and are formed after the pollen reaches the stigma. Only one or two of them are functional and grow out to penetrate the style. Drude does not show the structure of the pollen grain in section nor does he describe the origin or the exact position of the tubules. Diels ('06) accepted these observations although he apparently never studied these tetrads himself. Rosenberg ('99) has also studied the pollen grains of Drosera rotundifolia. He also refers to these tubules as pollen tubes but correctly observes that they are formed before the pollen is discharged from the anther. He characterizes them later ('09) as pollen tube anlage which appear in great numbers as a crown surrounding the (base) external contact edges of the pollen grain. Rosenberg gives a number of text figures of sections of pollen grains; they are all inadequate and in some respects inaccurate. He gives no description of the origin of the tubule, though it appears from some of his figures that these tubules arise from the apex of the tetrahedral pollen grain.

The material of Drosera longifolia sent to me by. Professor John Davidson and of Drosera binata which I obtained at The New Jork Botanical Garden was very favorable for the study of the 
fully developed pollen tetrads. My studies were made on paraffin sections and on tetrads mounted in toto in glycerine to which a few drops of glacial acetic acid were added. The pollen grains in all the species I studied are arranged most commonly in tetrahedral form as were the nuclei in each of the pollen mother-cells just before cell division. Each tetrahedron of course shows three of the grains in one plane, while the fourth is hidden by them. All the contact walls of course intersect at an angle of $\mathrm{I}_{20}$. Between each two adjacent pollen grains a double row of projecting tubules may be seen, one row coming from each grain. These have been described by Drude as young pollen tubes. In my opinion they are to be regarded as highly specialized germ pores as will be further discussed below. In another less common type found in the Droseras the pollen grains are arranged in pairs; a line through the center of one pair lying at right angles to a similar line through the other pair, and in a different plane. This arrangement of the grains is shown in FIG. 42. A similar arrangement of the grains has been figured by Andrews ('05) for Epigaea repens L. The rows of tubules are also present with the grains in this arrangement. So far as I can find, this particular type of germ pore is peculiar to the Droseras and it is certainly worthy of more careful study than has yet been given to it.

Each surface of the four grains in a tetrahedron is triangular with one side more or less convex, which forms the base of the grain. The other three lateral faces are contact surfaces by which the pollen grain is joined to its neighbor in the tetrad. The exine of the external convex surface of each grain is thickly covered with short, almost tubercular spines as shown by Rosenberg ('09). The tips of the spines are occasionally ellipsoidal or lance-shaped. The exine of the contact walls of the grains is somewhat thinner than that of the external surface. On the inner surfaces of the contact walls are found the so-called "tubules" which constitute as already noted the most peculiar characteristics of the pollen grain of the Droseraceae. They arise at the time when the thickening of the wall is going on and constitute in effect a diverging series of channels or tubules lying on the inner surface of each of the three contact walls of a grain. As shown in TEXT-FIGURE I, they take their origin near the inner angle of each contact wall, that is, near the apex of the tetrahedral pollen grain, considering 
the outer curved surface as the base. These channels are separated from each other laterally (TEXT-FIGURE 2) by what are in effect thick ridges on the inner surface of the contact wall of the grain. Channels are thus formed which are roofed over against the mass of the grain. There are approximately from I 2 to 15 such channels to each pollen grain. These so formed tubules are some-

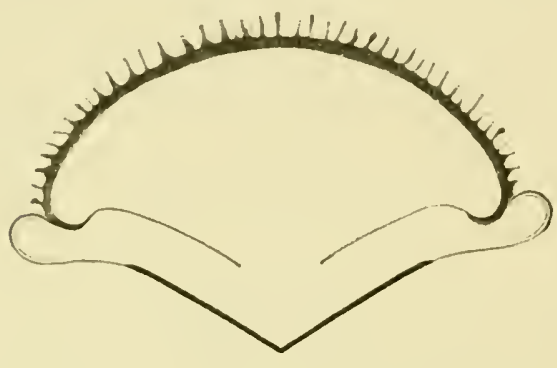

FIG. I. Longitudinal section through the apex of a pollen grain, showing the origin of the tubules.

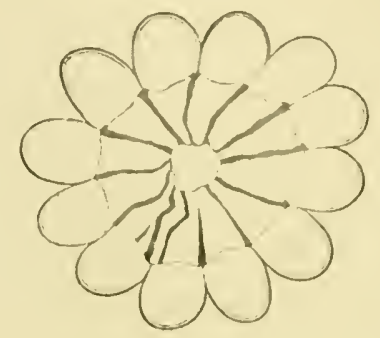

FIG. 2. Cross-section of a pollen grain with its spherical base removed, showing a diverging series of tubules.

what flattened against the pollen grain, as shown by comparing TEXT-FIGURES $I$ and 2. They are more or less club-shaped, tapering slightly toward the apex of the pollen grain and expanding and separating from each other at their exposed ends. The tubules have a much thinner coat than the walls of the pollen grain and in many instances exceedingly delicate spinules can be observed on their surface. The structure of a pollen grain of the Droseraceac may be compared to some extent to that of an Arcella. The pore in the flat surface of the Protozoan serves as an outlet for the pseudopods. In the case of the pollen grain the protoplasm streams out through what seems to be a pore (TEXTrIGURE 2) formed by the inner walls of the tubules and enters the mouths of the twelve to fifteen channels as shown in a median section of a pollen grain in FIG. 4I.

The question as to the function of these tubules has not as yet been fully determined by me. While Drude and Rosenberg believe they are pollen tubes no adequate evidence has yet been offered. It appears from observations of early stages that they are formed at the time the walls of the pollen grain are thickened and lead me to the belief that they are germ pores comparable to those found in such families as the Ericaceae, Oinotheraceae, and others. 
In the cross and median sections of the pollen grains studied I have been able to make further studies on the chromosome number in the nuclear divisions here. Nuclear divisions in the pollen grains of Drosera obovata have been described and figured by Rosenberg ('09) and my observations in general are in perfect accord with his. The pollen grain nucleus divides and two smaller cells are formed, as shown in FIG. 4I. I have studied these divisions very carefully in Drosera longifolia and find that the first division of the nucleus results in two equal nuclei. One of these divides again and two smaller nuclei are formed. Cell division follows and the daughter cells lie embedded in the cytoplasm of the pollen grain. While I have not been able to count the chromosomes on the spindle in these divisions, the nuclei of these small cells show prochromosomes. So far I have been unable to count twenty prochromosomes as maintained by Rosenberg for this species. In view of these observations it is quite apparent, as observed above, that further work must be done on this interesting species. It is hoped that cultivated material now growing in our greenhouses as well as fresh field material will be available during the coming summer, so that the reduction divisions in the pollen mother-cells of Drosera longifolia can be studied and the two species, D. longifolia and $D$. rotundifolia, can be crossed in an effort to obtain the so-called wild hybrid $D$. obovata.

I wish to mention here my indebtedness to Professor John Davidson for supplying me with material of Drosera longifolia and for his kind interest in the progress of my work. I also wish to thank Professor N. Wille for sending me his herbarium specimens of the Norwegian Drosera longifolia and $D$. intermedia. To Professor R. A. Harper I wish to extend my sincerest thanks for his kindly criticisms and helpful suggestions.

\section{Summary}

I. The somatic cell division is brought about by the formation of a cell plate similar to that described by Strasburger, Went, and Timberlake for Monocotyledons and Gymnosperms.

2. The chromosomes of the last premeiotic division form the prochromosomes of the pollen mother-cells, of which there are ten pairs distributed over the linin network on the periphery of 
the nucleus. Ten bivalent chromosomes may be counted in diakinesis and in the equatorial plate stage.

3. During the late telophase in the first division chromosomelike bodies appear in the cytoplasm and on the spindle of pollen mother-cells. The chromosome-like bodies resemble in general the belated chromosomes in size, shape, and structure but on closer examination they are found to be more like extranuclear nucleoles.

4. Similar bodies appear in the late telophase of the second division. That these bodies are the same as those seen in the first division is hardly possible, for no chromosome-like bodies have been observed at any other stage than in the telophases of the first and second divisions.

5. The fate of the chromosome-like bodies is undetermined. It is possible that they become dissolved in the cytoplasm after the completion of each division. Perhaps these bodies are the forerunners of abnormalities which bring about the disintegration of the cell. Sterile pollen grains appear.

5. Cell division of the pollen mother-cell is by bipartition or successive division and quadripartition or simultaneous division. In either case no cell plates have been observed. Cell division may possibly take place by constriction as in the case of the animal cells. The constriction furrows must be extremely narrow in the species of Drosera, like those described in the slime moulds.

\section{LiTERATURE CITED}

I905. Allen, C. E. Nuclear division in the pollen mother-cells of Lilium canadense. Ann. Bot. 19: 189-258. pl. 6-9.

1905. Andrews, J. M. Die Anatomie von Epigaea repens L. Beih. Bot. Centralbl. I9 $9^{1}: 3^{1}+-320$. pl. 6-8.

1901. Beer, R. The supernumerary pollen-grains of Fuchsia. Ann. Bot. 2 I : 305-307.

1912. Beer, R. Studies in spore development. II. On the structure and division of the nuclei in the Compositac. Ann. Bot. 26: 705-726. pl. 66, 67.

1905. Berghs, J. La formation des chromosomes hétérotypiques dans la sporogénèse végétale. La Cellule 22: 1+1-160. pl. I, 2.

1907. Britton, N. L. Manual of the flora of the Northern United States ind Canada.

1903. Cannon, W. A. Studies in plant hybricls. The spermatogenesis of hybricl cotton. 13ull. Torrey Club 30: 133-196. pl. $7^{-10}$. 
I9I I. Carruthers, D. Contributions to the cytology of IIeleclla crispa. Ann. Bot. 25: 243-252. pl. I \&, I9.

1909. Darling, C. A. Sex in dioecious plants. Bull. Torrey Club 36: I 77-I99. pl. I2-I4.

I9I. Davis, B. M. Cytological studies on Oenothera, III. A comparison of the reduction divisions of Oenothera Lamarckiana and O. gigas. Ann. Bot. 25: 94I-974. pl. $7 I-73$.

1906. Diels, L. Droseraceae. In Engler, A., Das Pflanzenreich $4^{112}$ : I-I32.

1909. Digby, L. Observations on "chromatin bodies" and their relation to the nucleolus in Galtonia candicans Decsne. Ann. Bot. $23: 49 \mathrm{r}-5302$. pl. 3,34 .

I910. Digby, L. The somatic, premeiotic and meiotic nuclear divisions of Galtonia candicans. Ann. Bot. 24: 727-757. pl. 59-63.

1912. Digby, L. The cytology of Primula kewensis and of related Primula hybrids. Ann. Bot. 26:357-388. pl. 4I-44.

1914. Digby, L. A critical study of the cytology of Crepis virens. Archiv. Zellforsch. 12: 97-I46. pl. 8-IO.

I891. Drude, O. Droseraceae. In Engler \& Prantl, Die Naturlichen Pflanzenfamilien. $3^{2}: 261-272$.

I9I0. Farmer, J. B., \& Digby, L. On the cytological features exhibited by certain varietal and hybrid ferns. Ann. Bot. 24: I9I-2 I2. pl. $16-18$.

I899. Fullmer, E. L. The development of the microsporangia and microspores of Hemerocallis fulva. Bot. Gaz. 28: 8I-88. pl. 7,8 .

1907. Gates, R. R. Pollen development in hybrids of Oenothera lata $\times O$. Lamarckiana and its relation to mutation. Bot. Gaz. 43: 8I-I I6. pl. 2-4.

I909. Gates, R. R. The behavior of the chromosomes in Oenothera lata $\times$ O.gigas. Bot. Gaz. 48: I79-I99. pl. I2-I 4 .

I9I I. Gates, R. R. Pollen formation in Oenothera gigas. Ann. Bot. 25 $5^{2}$ 909-940. pl. 67-70.

I9I4. Gates, R. R., \& Thomas, N. A cytological study of Oenothera mut. lata and $O$. mut. semilata in relation to mutation. Quart. Jour. Mic. Sci. 59: 523-57 I. pl. 35-37.

I909. Geerts, J. M. Beiträge zur Kenntnis der Cytologie und der partiellen Sterilität von Oneothera Lamarckiana. Rec. Trav. Bot. Néerland. 5: 93-206. pl. 5-22.

I9II. Geerts, J. M. Cytologische Untersuchungen einiger Bastarde von Oenothera gigas. Ber. Deutsch. Bot. Ges. 29: I60-I68. pl. 8 . 
1905. Gregory, R. P. The abortive development of the pollen in certain sweet peas, Lathyrus odoratus. Proc. Cambridge Phil. Soc. I3: I48-I 57. pl. I, 2.

I915. Guignard, M. Sur la formation du pollen. C. R. Acad. Sci. Paris $160: 428-433$.

I900. Harper, R. A. Cell and nuclear division in Fuligo varians. Bot. Gaz. 30:21 7-25I. pl. I4.

19I4. Harper, R. A. Cleavage in Didymium melanospermum (Pers.) Macbr. Am. Jour. Bot. I : I27-I44. pl. II, I2.

I848. Hofmeister, W. Ueber die Entwickelung des Pollens. Bot. Zeit. 6: 649-656. pl. 6 .

I86I. Hofmeister, W. Neue Beiträge zur Kenntnis der Embryobildung der Phanerogamen. Abh. Math.-Phys. Cl. K. Sachs. Ges. Wiss. 5 : $63 \mathrm{I}-760$. $p l$. $I-25$.

1897. JueI, H. O. Die Kernteilungen in den Pollenmutterzellen von Hemerocallis fulva und die bei denselben auftretenden Unregelmässigkeiten. Jahrb. Wiss. Bot. 30: 205-226. pl. 6-8.

I900. Juel, H. O. Beiträge zur Kenntnis der Tetradentheilung. Jahrb. Wiss. Bot. 35: 626-66o. pl. I 5, I6.

I90I. Koernicke, M. Ueber Ortsveränderung von Zellkernen. Sitz. Ber. Niederrhein. Ges. Nat. u. Heilkunde zu Bonn, I-I2.

1908. Lary de Latour, E. de. Sur des particularités cytologiques du développement des cellules-mères du pollen de l'A gave attenuata. C. R. Acad. Sci. Paris $146: 833-836$.

19II. Lawson, A. A. The phase of the nucleus known as synapsis. Trans. Roy. Soc. Edinburgh 47:59I-604. pl. I, 2.

I898. Lyon, F. M. A contribution to the life history of Euphorbia corollata. Bot. Gaz. 25: 418-426. pl. 22-24.

1905. Martins Mano, T. Nucléole et chromosomes dans le méristème radiculaire de Solanum tuberosum et Phaseolus vulgaris. La Cellule $22: 57-77 \cdot p l$. $I-4$.

1908. Nichols, M. L. The development of the pollen of Sarracenia. Bot. Gaz. 45: $3 \mathrm{I}-37$. pl. 5 .

1905. Overton, J. B. Ueber Reduktionsteilung in den Pollenmutterzellen einiger Dikotylen. Jahrb. Wiss. Bot. 42: I2I-I 53 . pl. 6,7 .

I899. Rosenberg, O. Physiologisch-cytologische Untersuchungen über Drosera rotundifolia L. I-I26. pl. I-2. Upsala.

1903. Rosenberg, O. Das Verhalten der Chromosomen in einer hybriden Pflanze. Ber. Deutsch. Bot. Ges. 2 I: I Io-I I9. pl. 7 .

1904. Rosenberg, O. Ueber die Tetradenteilung eines DroseraBastardes. Ber. Deutsch. Bot. Ges. 22: 47-53. pl. 4 . 
I909. Rosenberg, O. Cytologische und morphologische Studien an Drosera longifolia $\times$ rotundifolia. K. Sv. Vet.-Akad. Hand. 43:3-63. pl. $I-4$.

I9I4. Samuelsson, G. Ueber die Pollenentwicklung von Anona und Aristolochia und ihre systematische Bedeutung. Sv. Bot. Tidskr. 8: 18I-I 89.

I 882. Strasburger, E. Ueber den Teilungsvorgang der Zellkerne und des Verhältniss der Kerntheilung zur Zelltheilung. Arch. Micr. Anat. 2I : 476-590. pl. 25-27.

1882. Tangl, E. Die Kerne und Zelltheilungen bei der Bildung des Pollen von Hemerocallis fulva. Denksch. K. Akad. Wiss. Wien. Math.-Nat. K1. 45: 65-86. pl. $x-4$.

1900. Timberlake, H. G. The development and function of the cell plate in higher plants. Bot. Gaz. 30: 73-99, I54-I70. pl. 8, o.

1906. Tischler, G. Ueber die Entwicklung des Pollens und der Tapetenzellen bei Ribes Hybriden. Jahrb. Wiss. Bot. 42: 545579. pl. I5.

1906. Tischler, G. Ueber die Entwicklung der Sexualorgane bei einem sterilen Bryonia-Bastard. Ber. Deutsch. Bot. Ges. 24: 83-96. pl. 7 .

1908. Tischler, G. Zellstudien an sterilen Bastardpflanzen Arch. Zellforsch. I : 33-15I.

I9I0. Tischler, G. Untersuchungen über die Entwicklung des Bananen-Pollens. Arch. Zellforsch. 5: 622-670. pl. 3O, 3I.

1904. Wager, $H$. The nucleolus and nuclear division in the root apex of Phaseolus. Ann. Bot. I8: 30-55. pl. 5 .

I887. Went, F. Beobachtungen über Kern- und Zelltheilung. Ber. Deutsch. Bot. Ges. 5: 247-258. pl. II.

I915. West, C., \& Lechmere, A. E. On the chromatin extrusion in pollen mother-cells of Lilium candidum L. Ann. Bot. 29: 285-29I. pl. I5.

I886. Wille, N. Ueber die Entwicklungsgeschichte der Pollenkörner der Angiospermen und das Wachstum der Membran durch Intussusception. Krist. Vid. Selsk. Forh. 5: I-7I. pl. I-3.

I850. Wimmel, T. Zur Entwicklungsgeschichte des Pollens. Bot. Zeit. 8: 225-235, 24I-248, 265-270, 289-294, 313-32I.

1893. Zimmerman, A. Beiträge zur Morphologie und Physiologie der Pflanzenzelle. Tübingen.

I 894. Zimmerman, A. Ueber das Verhalten der Nucleolen während der Karyokinese. Bot. Centralbl. 57:303-305. 


\section{6 MEMOIRS OF THE NEW YORK BOTANICAL GARDEN}

\section{Explanation of plates}

All the figures were drawn with the aid of a camera lucida from preparations stained with Flemming's triple stain. Leitz $1 / 16$ objective and ocular + were used in making the outlines but ocular 3 with the draw tube extended $15.2 \mathrm{~cm}$. was used in drawing the cytoplasnic and nuclear details.

\section{Plate i6 \\ Drosera intermedia IIayne}

FIG. I. Resting stage of an immature pollen mother-cell, $\times 2.666$.

FIG. 2. Polar view of an equatorial plate stage of the premeiotic division of a pollen mother-cell, $\times 2,700$.

FIG. 3. Late anaphase of a somatic division, $\times 2,700$.

FIG. 4. Sinilar stage, showing the chromosomes very distinctly in young pollen mother-cell, $\times 2,700$.

FIG. 5. Beginning of a cell plate in the division of a vegetative cell, $\times 2,700$.

FIG. 6. A slightly older stage, $\times 2,700$.

FIG. 7. Cell plate in the premeiotic division of a pollen mother-cell, $\times 2,700$.

FIG. 8. Completion of the cell plate in the division of a vegetative cell, $\times 2,700$

FIG. 9. Diakinesis, showing bipartite and quadripartite chromosomes, $\times 2,666$.

FIG. IO. Equatorial plate stage of the heterotypic division of a pollen mothercell, $\times 2,666$.

FIG. I1. Polar view of an equatorial plate stage in the heterotypic division, $\times 2,666$.

FIG. 12. Anaphase stage of a pollen mother-cell in the heterotypic division, $\times 2,666$.

FIG. I3. Interkinesis, showing the chromosome-like bodies scattered in the cytoplasm and on the spindle fibers, $\times 2,666$.

FIG. I4. Early anaphase stage of the homocotypic division, $\times 2,666$.

\section{Plate 17}

Drosera rotundifolia (magnification, 2,666 diameters)

FIG. I5. Resting nucleus of a pollen mother-cell, showing paired prochromosomes.

FIG. 16. Leptoneme spireme, showing a single beaded structure.

FIG. 17. Early stage in synapsis.

FIG. I8. Same as Fig. I7, showing a somcwhat later stage.

FIG. 19. Early stage in diakinesis.

FIG. 20. Equatorial plate stage of the first division.

FIG. 21. Polar view of an early anaphase stage.

FIG. 22. Late anaphase stage of the first division.

FIG. 23. Interkinesis, showing chromosome-like bodies in the cytoplasm and on the spindle fibers.

FIG. 24. Reconstruction stage after the homocoty pic division, showing chromosomelike bodies on the spindle fibers.

\section{Drosera filiformis}

FIG. 25. Reconstruction stages after the homocotypic division, showing chromosome-like bodies.

\section{P'LATE I 8}

\section{Drosera filiformis}

FIG. 26. Leptoneme spireme, showing the double thread-like chromatin bauds, $\times 2,125$.

FIG. 27. Leptoneme spireme, showing the beaded structure of the chromatin bands, $\times 2,125$. 

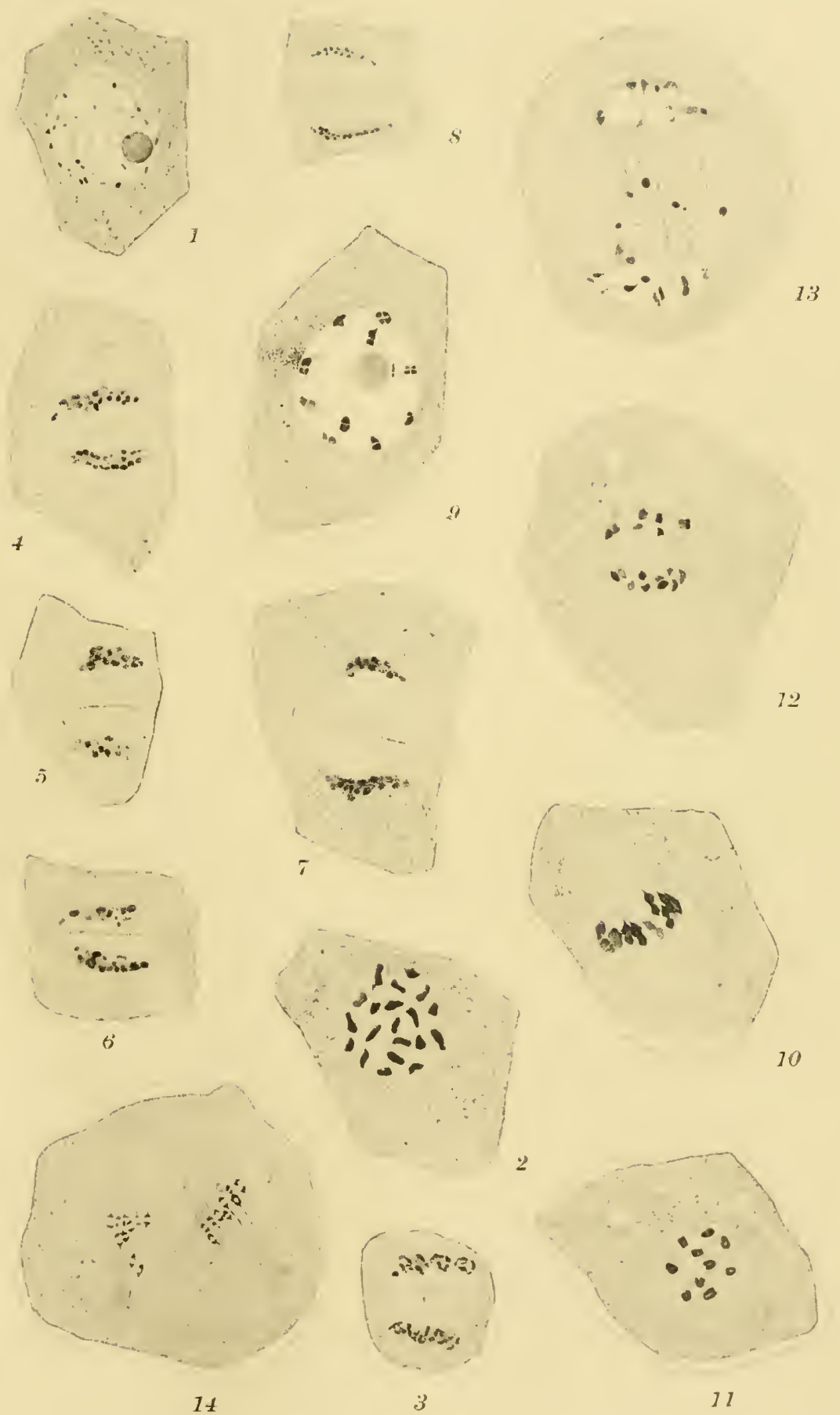

72

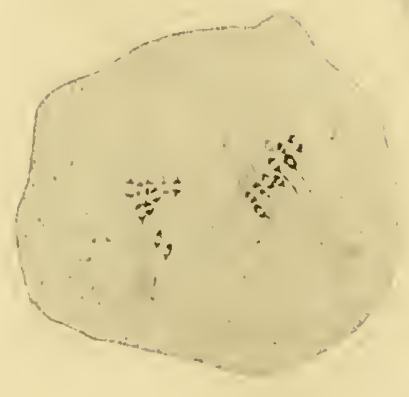

14

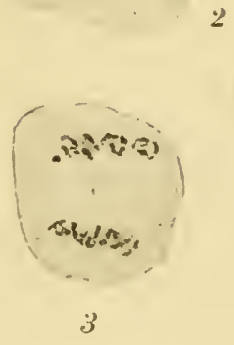

HELIOTYPE CO., BOSTON 


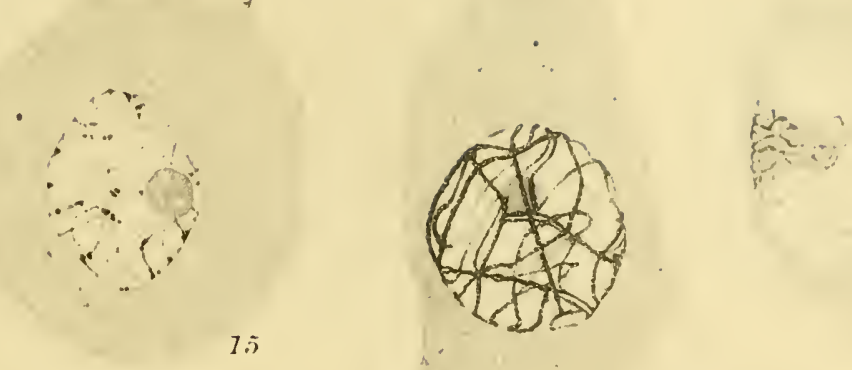

75

76
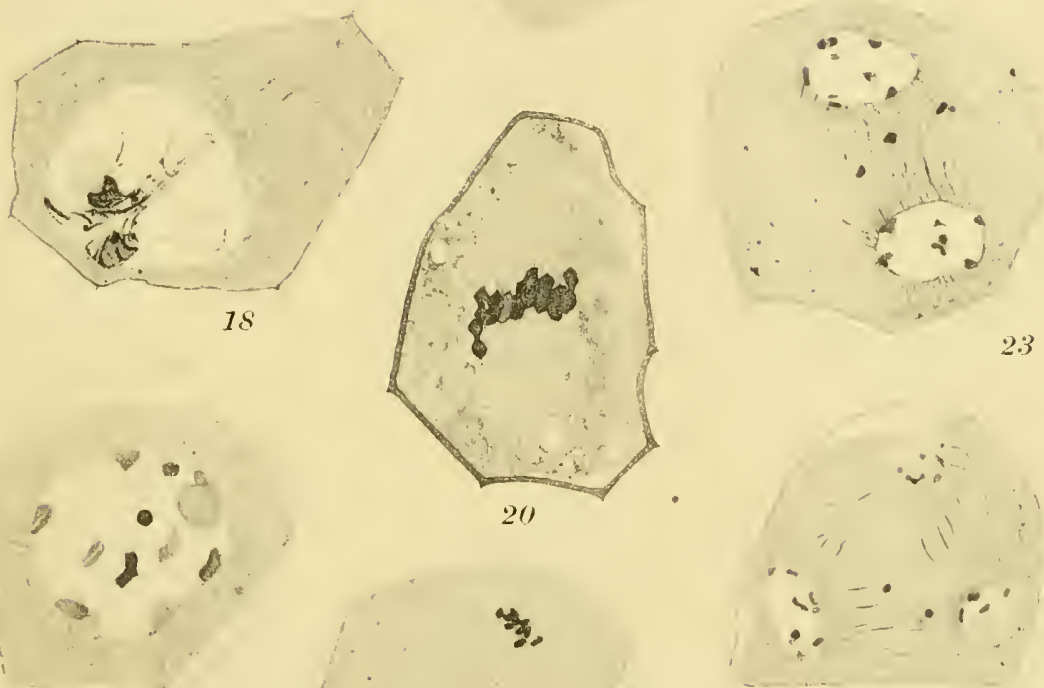

7.9

4

24

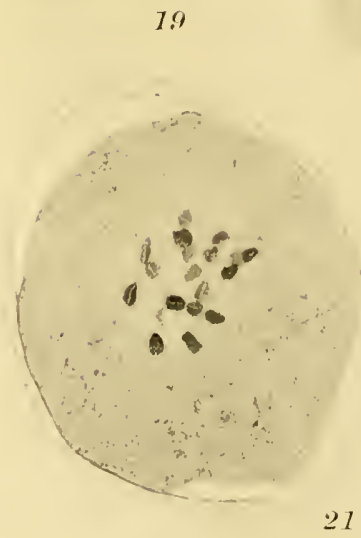

$x$

2.)

$\therefore 25$

- is

27

2.5

HELLTYPE CO, BOSTON 

$32 "$
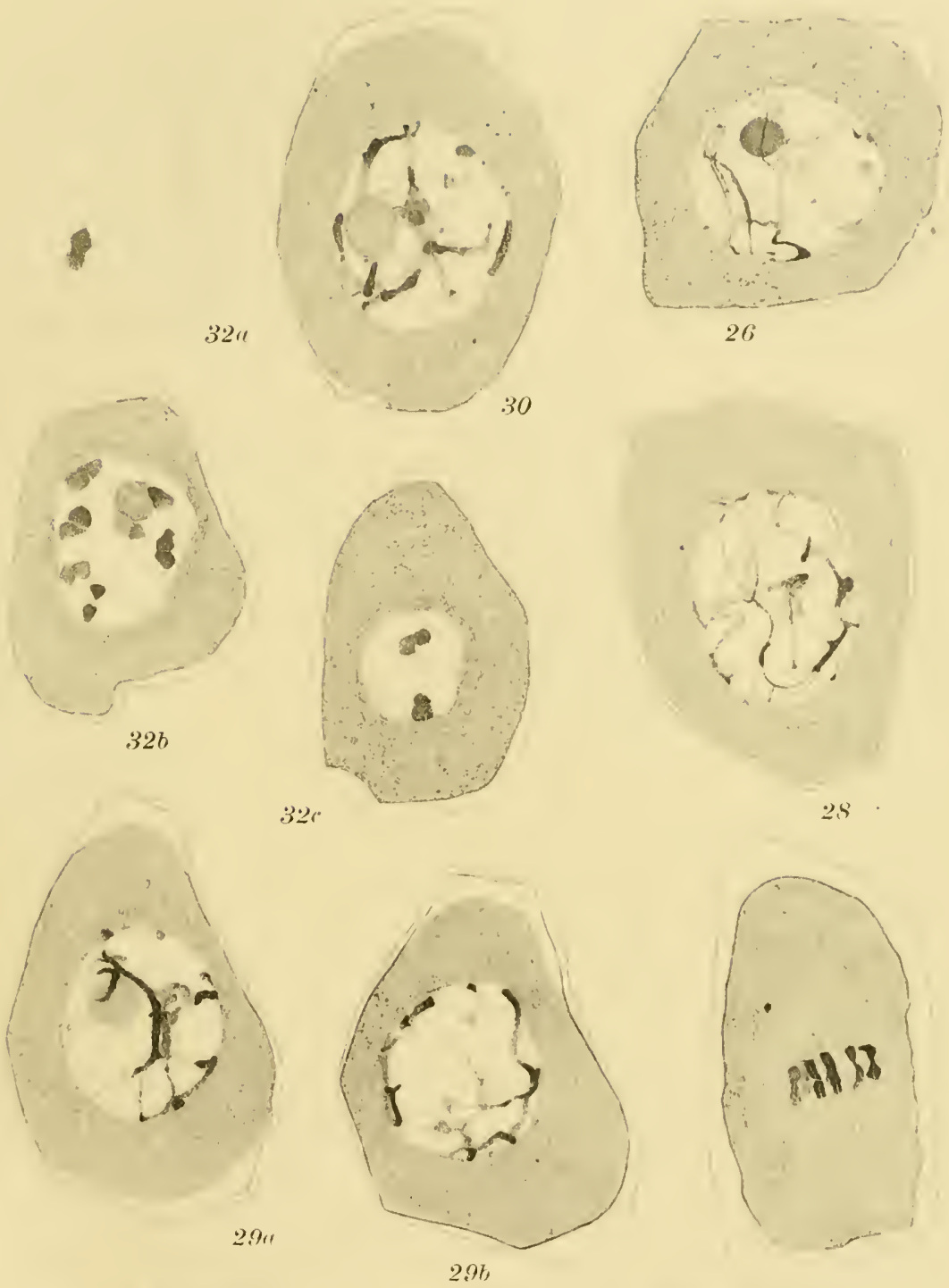

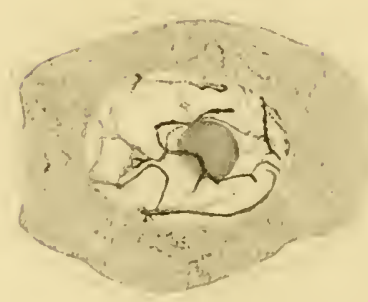

27

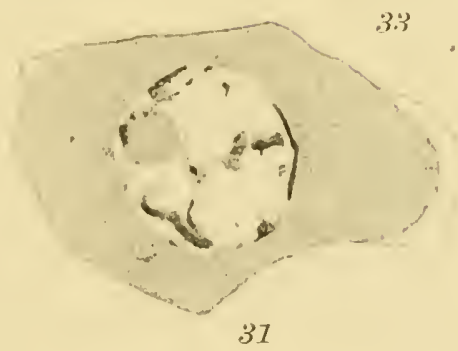




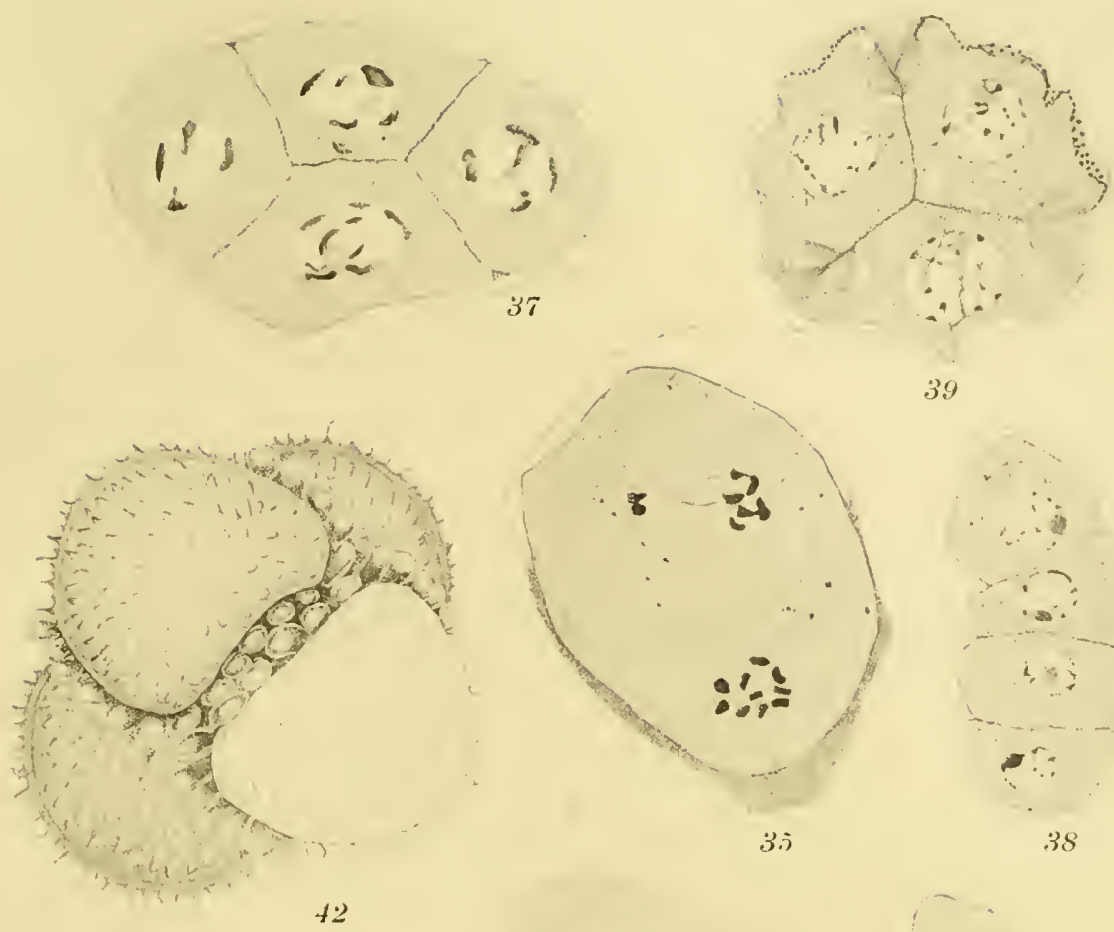

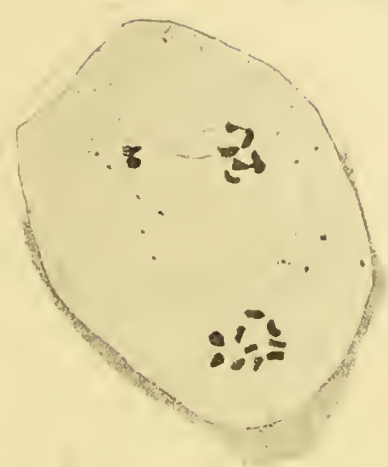

3.5

39

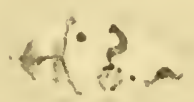

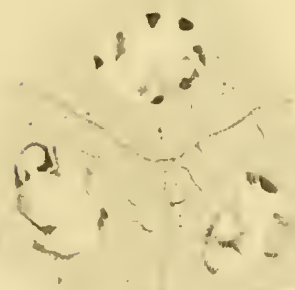

36

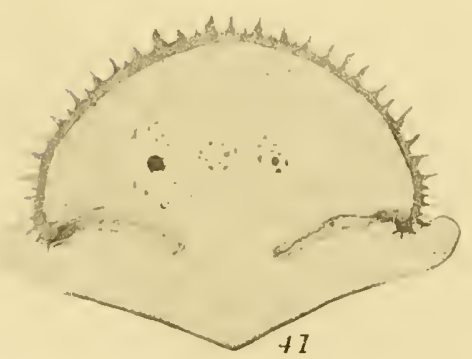

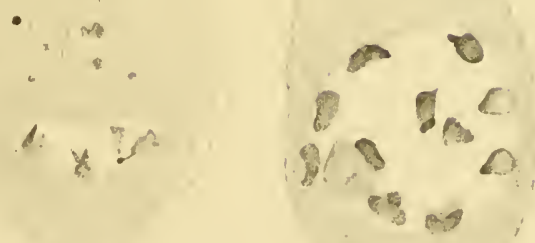

34 $\$ 011$

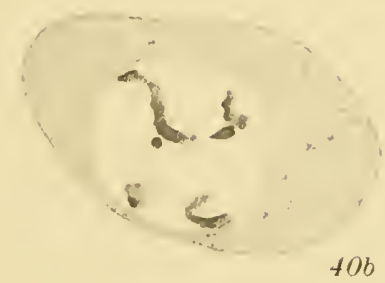

HELIOTYPE CO, BOSTON 

Fig. 28. Later stage, showing fusion of thread-like chromatin bands has begun $\times 2,125$.

FIG. 29. a. Sections of a cell, showing a pachyneme spireme. $b . \times 2,125$.

FIG. 30. Early stages in the segmentation of the pachyneme spireme, $X 2,125$.

FIG. 3I. Segmentation of the pachyneme spireme nearly completed, $\times 2,125$.

FIG. 32. $a, b, c$. Sections of a cell in diakinesis, $\times 2,666$.

Fig. 33. Equatorial plate stage, $\times 2,666$.

\section{Plate 19 \\ Drosera filiformis}

FIG. 34. Interkinesis, showing the chromosome-like bodies in the cytoplasm and on the spindle fibers, $\times 2,125$.

FIG. 35. Homoeotypic division in the early telophase, showing faintly stained chromatin-like bodies, $\times 2,125$.

FIG. 36. Pollen mother-cell divided, showing three cells and their nuclei in one plane.

FIG. 37. Pollen mother-cell divides, showing all four nuclei. A pair of opposite nuclei lying in a different plane from that of the other.

FIG. 38. Pollen mother-cell divides, showing four serially arranged pollen cells.

FIG. 39. Pollen tetrad in process of exine formation.

\section{Drosera longifolia}

FIG. 40. $a, b$. Sections of an embryo sac mother-cell, $\times 2,700$.

FiG. 41. Section of pollen grain, $\times 2,700$.

FIG. 42. Pollen tetrad in which pollen grains are arranged in pairs, a row of germ spores surrounding each pollen grain, $\times 2,700$. 



\title{
SELF, CLOSE, AND CROSS FERTILIZATION OF BEETS
}

\author{
HARRY B. SHAW \\ Federal Horticultural Board, U. S. Department of Agriculture
}

(WITH PLATE 20)

The writer distinguishes three types of fertilization, namely, (I) self fertilization, meaning that effected by pollen of the selfsame flower; (2) close fertilization, referring to that effected by the pollen of one flower upon any other flower of the same plant; (3) cross fertilization, that effected between the flowers of any two plants:

The protandrous character of the beet flower was demonstrated by Darwin and Rimpau. Although apparently the present methods of beet breeding have largely been based on the evidence of Darwin and Briem as to the susceptibility of the beet to close fertilization, the published data of these writers are not conclusive on this point. For the purpose of creating and continuing pure lines of sugar beets it has been the practice to isolate individual beets by inclosing each selected plant in a small tent of white fabric during the blooming period. (Plate I.) In more recent practice several plants are inclosed in each tent, cross pollination taking place among the inclosed plants.

Samples of the fabric used by several well-known German beetseed growers were obtained. The most closely woven of these is very similar to that used in the writer's experiments. (FIG. I, c.) Under such tents, single beets showed a fertilization of about 23 per cent, on the average. A somewhat greater percentage of fertilization has been obtained by European writers under their isolation tents.

Although the mechanism and sequence of beet bloom appear to be especially favorable for close fertilization, it became doubtful to the writer whether beets really are susceptible to close fertilization; it also became almost a matter of certainty that the 
above-described isolation tents do not prevent cross pollination. Separate flowering stems isolated with paper bags generally remained completely sterile, though occasionally a few flowers produced seed. Thrips can readily pass through the meshes of any of the above-mentioned fabrics, carrying beet pollen with them. The

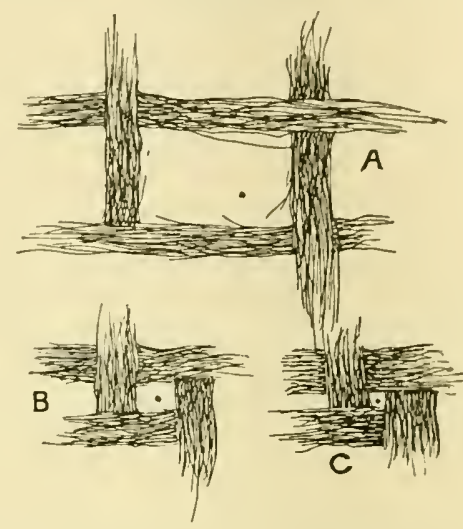

FIG. I. Sketch of a single mesh, greatly enlarged, of three samples of fabric used by German beet seed growers to isolate seed beets to prevent cross pollination. The dot in each mesh represents a beet pollen grain enlarged to the same extent. $(C)$ represenis also the fabric used by the writer.

writer has recently shown that wind-borne pollen sifts through the tops of tents made of LL sheeting, of 64 threads to the inch, this being the most closely woven fabric used. It is much more closely woven than most of the fabrics used by European beet breeders.

Apparently the only available method of isolating beets under normal conditions is to plant individual mother beets so remote from each other as to prevent cross pollination by wind or insects. A wind varying from 15 to 30 miles an hour will carry beet pollen over fields of alfalfa to a distance of 400 feet, but the writer was unable to discover any pollen at twice that distance. To be safe from cross pollination by insects a distance of probably two miles is necessary. In early experiments to isolate beets by distance it was not found possible to plant beets two miles away from each other and from garden leets grown by farmers. However this was possible at Jerome, Idaho, in 1913. In the early spring of that year a seed beet was planted at each of eight farms separated from each other by at least two miles, in a locality where it was 
known that no other beets were grown. The highest percentage of seed produced among these plants was 2.29; several of the plants remained entirely sterile, although otherwise their growth was normal.

After ascertaining that beet pollen can be preserved for a considerable time, experiments involving hand pollination and isolation with paper bags were carried out to determine conclusively whether the protandrous character of the beet flower might be overcome by separately preserving the pollen of individual flowers, collected when the anthers dehisced, and applying the pollen to the appropriate flowers when the respective stigmata had become receptive. This was done with several hundred flowers on numerous beets. All flowers thus self-pollinated remained sterile.

In addition, various types of close pollination were made, the work being distributed among many plants. For example: The pollen taken from flowers on one spike was applied to the receptive stigmata of other flowers on the same spike. Of these flowers 2.63 per cent were fertilized and produced seed; in addition, the carpels of 5.23 per cent of the flowers enlarged without forming seed.

The application of pollen from flowers on one spike to the stigmata of flowers on another spike on the same stem resulted in an average fertilization of 5.23 per cent, and a carpel stimulation of 5.8 per cent.

The transfer of pollen from flowers of one stem to the stigmata of flowers on another stem of the same plant resulted in the fertilization of 8.54 per cent of those flowers and the carpel stimulation of 3.47 per cent.

I. Self pollination: pollen to stigma of same flower... $0.00 \quad 0.00$

2. Close pollination: pollen of one flower to stigma of a nother flower on same spike......... $2.63 \quad 5.26$

3. Close pollination: similar to No. 2, but with modified technic................. $2.70 \quad \mathbf{1 . 4 3}$

4. Close pollination: pollen of flower on one spike to stigma of flower on another spike of same stem................... $5.23 \quad 5.80$

5. Close pollination: pollen of flower on one stem to stigma of flower on another stem of same plant...................... $8.54 \quad 3.47$

6. Close pollination: of plants isolated by distance... 0.00 to 2.29

7. Cross pollination................... roo.00 possible. 
When pollination is effected between two beets, although of the same progeny, the percentage of fertilization appears to be limited only by the refinement of the technic. These results are tabulated above.

No microscopic examination has yet been made to ascertain the behavior of the pollen tubes under the various conditions mentioned. No explanation or hypothesis is rentured at this time to account for the different responses observed on an individual beet. It is probable that minute biochemical differences exist, which increase in magnitude as the physical intimacy or relationship decreases. Other experiments have shown that the various buds on the crown of a seed beet behave as separate individuals, and that each bud on one beet may assume a different morphological development from the others in response to modifications in environmental factors.

\section{Explanation of plate 20 .}

A plat of seed beets in full bloom at the experiment station, Ogden, Utah, showing isolation tents of various sizes. It was found that wind-borne pollen can sift through these tents and cross-pollinate the protected seed beets. 


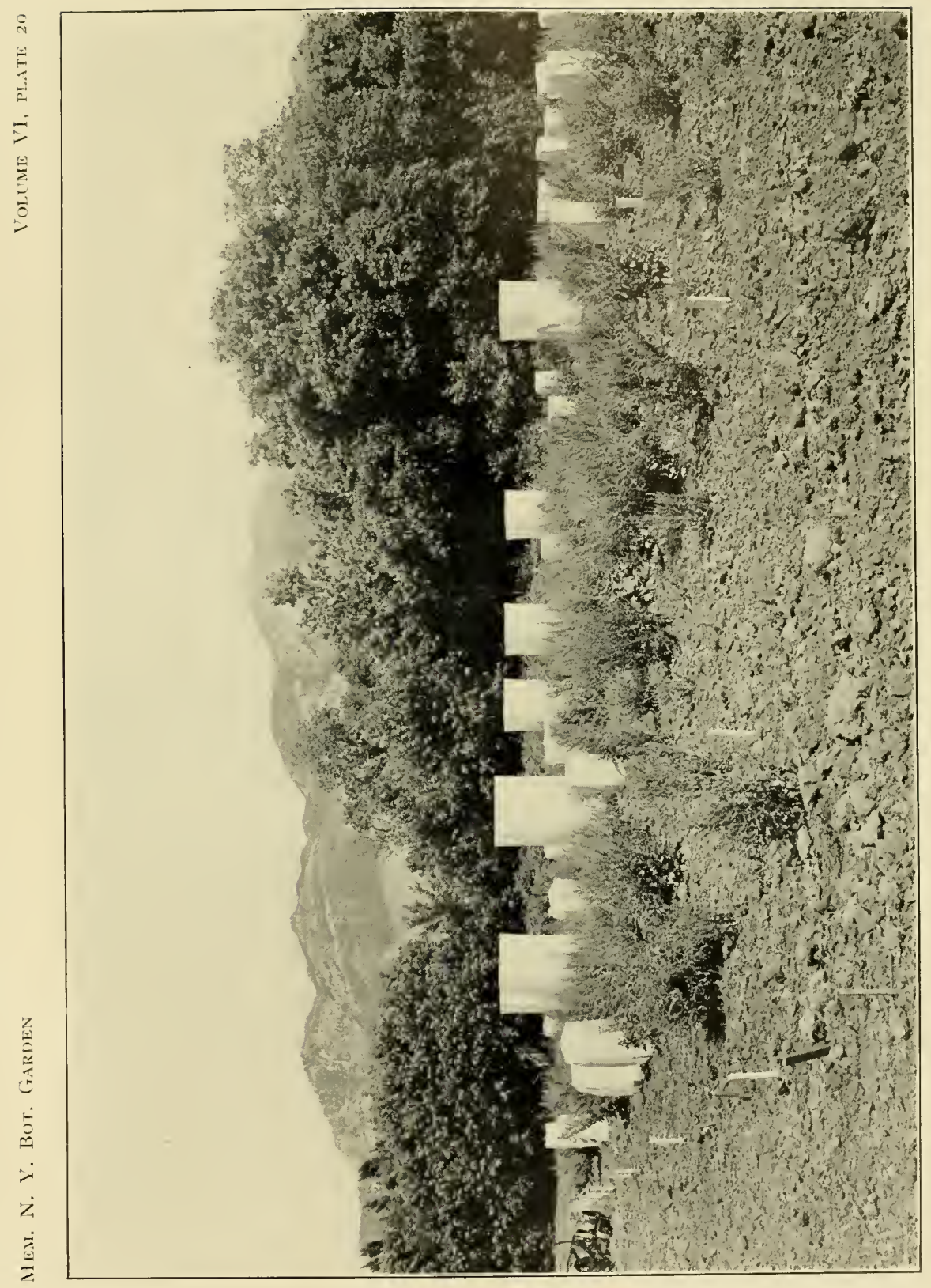

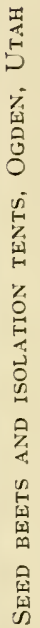





\title{
PRESENT STATUS OF THE PROBLEM OF THE EFFECT OF RADIUM RAYS ON PLANT LIFE*
}

\author{
C. Stuart Gager \\ Brooklyn Botanic Garden
}

The discovery of radioactivity during the last decade of the nineteenth century at once raised the interesting question, not "will it act as a stimulus to plant life," but "in what manner, and to what extent will it affect the various life functions?" Experimental inquiry established conclusions that any physiologist might have formulated a priori. As with any other form of energy to which plants are normally adjusted-viz., heat, light, gravitation, electricity, oxidation, and other chemical actions-radioactivity, within certain limits of intensity, favorably affects any physiological process, causing an acceleration of it up to a certain pointthe optimum; beyond that point the stimulus is too great, and the attempts at response result in retarded or unregulated functioning, disorganization, disease, and death.

In volume III of the Memoirs of The New York Botanical Garden, "Effects of the rays of radium on plants," published in December, Igo8, this was experimentally demonstrated for practically all the processes of plant life-germination, growth, respiration, irritability, cell-division, synthesis of carbohydrates, fermentation, and others.

Since that publication, several workers-chiefly in Europehave, from time to time, issued papers of various length, on the effects of radium-rays on plants; but a careful reading of nearly, if not all, of the literature has failed to disclose any real addition to our knowledge of the subject since i9o8. Other plant material has been used, and results have perhaps, in some cases, been stated in more accurate quantitative terms; but the net results of all investigations may still be accurately summed up by the brief statement that sufficed in 1908 , viz., The rays of radium

* Brooklyn Botanic Garden Contributions No. I5. 
act as a stimulus to plants; up to an optimum point the response is an acceleration of function, but beyond the optimum the response is a depression of function, culminating under certain conditions in complete arrest of physiological activity, or in the death of the tissue or organism.

Among those who have contributed to the literature of this subject since I908, may be mentioned Crochetelle (1913), Doumer (I9I2), Fabre (I9IO-II), Molisch (I9I2-I3), Petit (I9I3), Petit \& Ancelin (I9I3), Stoklasa (I9I2-I4), and Vacher (I9I3). It is significent to note that in characteristic European fashion, practically all of the papers published on the continent contain no reference to the Memoir of the New York Botanical Garden, though in a few rare instances a short "popular" paper by the author of that Memoir is cited.

Results of chemical study of very considerable significance in connection with the subject of photosynthesis, were presented by Stoklasa, Šebor, and Zdobnický, in I9I I and I9I3. These experiments ${ }^{1}$ deal with the synthesis of sugars from $\mathrm{CO}_{2}$ and nascent hydrogen, in the presence of $\mathrm{K}_{2} \mathrm{CO}_{3}$, under the influence of radium rays. Formaldehyde polymerized in the presence of potassium carbonate is stated to result in the formation of reducing sugars. A hexose and pentoses were positively noted, but no ketoses. This work has not been confirmed by other investigators. Since radioactivity is a constant and universal factor of plant environment the hypothesis that it may be concerned in the baffling process of photosynthesis is, to say the least, very attractive, and worthy of painstaking investigation. But the writer is inclined to believe that radioactivity is not involved as a normal factor in photosynthesis, even though it may, under certain conditions, favor the artificial synthesis of carbohydrates.

In connection with experiments, now in progress, on the use of radium-rays in medicine, and especially in the treatment of cancer and tumors, it is of the utmost importance to keep in mind that under certain conditions of exposure the malignant growth may be accelerated rather than retarded; but experiments with plants as well as with animals show that embryonic tissue is much more sensitive than mature tissue to radium-rays, and therefore

1Biochem. Zeitsch. 30: $433^{-} 456$. 1911. Compt. Rend. Acad. Sci. Paris 156 : $6+6-6+8 . \quad 1913$. 
more easily killed. If cancerous tissue is of embryonic nature, as seems not improbable, then it should be possible to treat it with success by exposure to the rays of any radioactive substance, if the proper strength of the radiation and the suitable conditions of exposure are accurately ascertained; otherwise more harm than good may result.

Among a rather large number of investigations on this subject may be mentioned that of Wood and Prime, ${ }^{1}$ as one of the more recent. These investigators found that $155 \mathrm{mgm}$. of radium bromide, screened with I $\mathrm{mm}$. of aluminum or with $0.8 \mathrm{~mm}$. of brass, and only about $1.5 \mathrm{~mm}$. distant from beating embryonal heart-tissue, does not kill it in 3 hrs., and does not stop the growth of connective tissue cells. The same exposure, however, does prevent the growth of Jensen rat-sarcoma, and inhibits, but does not wholly prevent, the growth of the Flexner rat-sarcoma. These observations are rightly held by the authors to emphasize the danger of generalizing from a limited number of experiments.

One of the members of the Pennsylvania Commission on the Chestnut Blight consulted the writer some time ago on the probable efficacy of a solution of some radium-salt injected into the circulation of the tree. Recalling that the fungus causing the chestnut blight is largely confined to the cambium-layer, and also recalling that the cambium is embryonic tissue, it is obvious that the injection into a tree of any radioactive substance in sufficient quantity to kill the fungal hyphae would also kill the cambium. The cure would be more fatal than the disease.

That a form of energy shown to be capable, under favorable conditions, of doubling the rate of growth of plants, might have great agricultural possibilities is a very alluring proposition, and was early subjected to experimental test. An exhaustive review of the literature is not essential here, but a few investigations may be noted.

Studies by Fabre ${ }^{2}$ indicate that the presence of radium bromide in the soil retarded the germination and development of Linum catharticum.

In I9I2 Ewart ${ }^{3}$ using a radioactive mineral, known experi-

${ }^{1}$ Proc. Soc. Exp. Biol. Med. II: I40-I42. 20 My I9I..

${ }^{2}$ Compt. Rend. Soc. Biol. Paris 70: 4I9-420. I9II.

3 Jour. Dept. Agr. Victoria r 0: 4 I 7 $7-42$ I. 
mentally to accelerate the germination of cereals, found that when it was applied "as a manure" to wheat there is first a stimulation, followed "on prolonged contact," by an injurious effect. Ewart's conclusion was that the radioactive mineral does not appear to have any direct agricultural value, at least so far as wheat is concerned.

Stoklasa ${ }^{1}$ exposed cultures of several nitrifying and denitrifying bacteria in nutrient solutions to the emanation from pitchblend, and from his results drew the inference that radioactivity exerts a considerable influence upon the general circulation of nitrogen, and is therefore important in connection with the fertility of the soil.

Malpeaux ${ }^{2}$ studied the effect of a material "said to be radioactive," on the growth of potatoes, sugar-beets, oats, turnips, and rye. While the exposed plants were thought to be darker green than the controls, and to have been slightly stimulated, the yields were not appreciably greater than where an ordinary fertilizer was used. An increase in the percentage of sugar in the beets was thought to be due to the influence of the rays.

In the same year Truffant ${ }^{3}$ studied the effect of growing various legumes in soils containing radium bromide, but also rich in nitrogenous and other mineral fertilizers. He reported that the larger the content of the radioactive substance, the smaller was the yield. Experiments with chrysanthemums grown in pots led to the conclusion that radioactive minerals in the soil, both soluble and insoluble, and especially the black oxide of uranium, may produce farorable results, but that radioactive residues from commercial factories may contain such deleterious substances as the salts of barium and sulphuric acid in injurious amounts. Experiments with spinach grown in the field gave no decisive results.

Studies by Rusby of the effect on crops of a substance claimed by the Standard Chemical Company, of Pittsburgh, Pa., to be radioactive led him to the conclusion that the substance, applied as a manure, caused a substantial increase in the crop yield of potatoes, radishes, celery, beans, cucumbers, tomatoes, egg plant, carrots, beets, spinach, peas, pumpkins, cabbage, squash, clover,

${ }^{1}$ Compt. Rend. Acarl. Sci. Paris $157: 879-882.1913$.

2 Vie Agr. et Rur. 3: 289-293 1914.

${ }^{3}$ Jardinage, Nay, 1914. Agr. News, Barbados 13: 215. 1914.

4Jour. N. Y. Bist. Card. I6: I-23. Ja 1915. 
peppers, corn, muskmelons, and other regetables. The radioactive fertilizer was applied to four plots of $\mathrm{roO} \mathrm{sq}$. $\mathrm{ft}$. each in amounts of 25,50 , IOO, and 200 lbs. respectively. The author concludes (p. I5) that, "The amount of radium required for the greatest results differed with different crops. In five cases 200 lbs. per Ioo sq. ft. gave the best results, in eight cases Ioo lbs., in five cases 50 lbs., and in eleven cases 25 lbs." "Families of plants," the author says, "showed the same varying susceptibility." Thus, plants producing underground crops, such as turnips and radishes, gave results analogous to those given by plants with aboveground crops, such as cauliflower, cabbage, and mustard. 'This statement is of considerable interest in view of the fact, disclosed by laboratory experiments, and recorded by several investigators, that tissues with chlorophyll react to radium-rays differently from tissues without chlorophyll.

Rusby states (p. 2I) that, "The relative effects on the upper and lower portions of a sloping plot have not been uniform. Of ten rows of celery so planted, plants on the lower rows are nearly twice as large as plants on the upper ones, and the transition is gradual and nearly equable. A possible explanation of this," says the author, "is by assuming that in case of a hard rain, with surface drainage, the emanations ${ }^{1}$ in the water in the soil would quickly diffuse through the surface water and be carried downward."

In this possible explanation two facts are overlooked: I. That freshly fallen rain water is radioactive, and produces physiological stimulation to plants, as was demonstrated by experiments recorded in the Botanical Garden Memoir above cited. The mere accumulation of this water in relatively larger quantities near the lower portions of a slope might cause differential conditions of radioactive energy, and therefore differential results.

2. The possibility that the differential results may be attributed solely to the excessive moisture at the lower portions of a drained slope. The plants involved were celery, and celery is well known to thrive in trenches, where there is, of course, more moisture than on a drained surface. The gradual transition in size is

\footnotetext{
${ }^{1}$ There is only one emanation (a radioactive gas) given off by radium. The author here doubtless means to refer to the ions (streams of which constitute the $\alpha$ and $\beta$ rays of radioactive substances), as well as to the radioactive gas or emanation.
} 
what one could expect under such conditions, regardless of the presence of a radioactive substance in the soil. In discussing his mutation experiments, deVries has called attention to the necessity of extreme care in securing an equable distribution of moisture, and to the fact that the common slight irregularities in the surface of the soil in seed-pans may cause marked differences in the rate of growth of seedlings.

If the application of minute traces of radioactive substances to the soil can produce an increase of yield, the fact would be of very great scientific as well as economic importance, more especially if, as Rusby states (p. 2I) "The beneficial effects continue over successive crops, perhaps for many years," while "The largest amount required by any crop would cost less than the increased market value of such crop the first year." The author well says (p. 2I) that radium is not a plant food, and that the necessity of fertilizer is but little decreased by its use. But that "The fertility of unused ground will spontaneously increase at a much greater rate when treated by radium," is not self evident from any facts that have been obtained by observation or experiment, though it ought not to be difficult to refute or to confirm it experimentally.

- But let us analyze the situation a little more thoroughly. The second chapter of the Garden Memoir reviewed a large literature, covering $\mathbf{I} 49$ titles, showing that radioactivity is normally a factor of plant environment; that freshly fallen rain and snow, soil, common rocks, soil-air, and, in fact, practically every kind and form of matter is more or less radioactive. The magazine advertisements of the radioactive compound employed by Rusby recommend that one pound will fertilize $50 \mathrm{sq}$. $\mathrm{ft}$. of soil. The compound is claimed to contain $0.05^{-0.08}$ microgram $\left(5\right.$ to $8 \times \mathrm{IO}^{-8}$ gram) per pound. Now fifty square feet of ordinary top soil has been found by experiment to contain approximately two millionths $\left(5 \times \mathrm{IO}^{-7}\right)$ grams of radium. In other words the use of the radioactive fertilizer according to the directions of its manufacturers would increase the radioactivity of the soil by only one tenth of the normal amount.

Ross" has also called attention to the fact that "the radium present, on an average, in an acre-foot of soil, is about roo times ${ }^{1}$ U.S. Dept. Agr. Bull. I49: 13 . II D 1914. 
greater than is contained in the quantity of radioactive manure commonly recommended for application to an acre."

Ramsay $^{1}$ has recently calculated that in order to double the amount of radioactive gas (emanation) in the soil "one must use about 75 milligrams of radium per acre at a cost of $\$ 7,500$." This amount is somewhat more than the possible increase in value of any crop per acre, however stimulated, yet a less amount of emanation would quite certainly be too weak to produce any appreciable physiological effect.

Hopkins and Sachs ${ }^{2}$ carried on extensive and careful experiments for two years with the radioactive fertilizer prepared by the Standard Chemical Company, of Pittsburgh (the same preparation that was used by Dean Rusby). Their final conclusion is as follows:

"Thus from the two years' work we have six trustworthy average results with corn, three 'for' and three 'against' radium, and we have eighteen averages with soy beans, nine 'for' and nine 'against' radium. In all of these trials the average variation from the checks is so slight and so evenly distributed 'for' and 'against,' as to lead only to the conclusion that radium applied at a cost of \$I, \$IO or \$IOO per acre has produced no effect upon the crop yields either the first or the second season."

The authors further point to the fact that to apply the radioactive preparation to the soil in the amounts recommended by Fabre would, at present market values, cost nearly $\$ 59,000$ per acre. To say the least, the results of various investigators seem rather conflicting.

About two years ago the writer was presented with ten pounds of a "radioactive" fertilizer, called B.D.R., by representatives of the Radium Bank (Banque du Radium), of Paris, and was requested to test its virtues for agriculture. Numerous experiments were carried out, some closely following the directions given by the representatives of the Radium Bank, and some according to suggestions obtained from three years of experience in testing the effects of radioactivity on plants. It is not necessary here to go into details, but only to state that the net results of the tests were absolutely negative.

${ }^{1}$ Science II. 42: $219 . \quad 1915$.

${ }^{2}$ Science II. 4 I : 732-735. 1915. 
Experiments by Lipman and Blair ${ }^{1}$ with the same compound gave entirely negative results; and Stevens? from experiments also with the same compound, found that growth was accelerated only when as much as $2 \frac{1}{2}$ per cent of the compound was applied to a soil. To employ it in agriculture in this proportion would take about 25 tons to the acre, which would cost the farmer, per acre, about $\$ 5,000$.

In reviewing the literature, it is remarkable to note that in a most no instances was the so-called radioactive fertilizer tested to see if it was really radioactive, and to what extent; nor was it analyzed chemically to ascertain what elements of plant "food" it might contain. Without making these tests it is folly to attempt to draw any inferences as to the value of radioactive substances in practical agriculture.

From a large number of experiments on crop plants, Berthault, Brétignière, and Berthault ${ }^{3}$ concluded that better results were obtained by combining radioactive substances with standard fertilizers. None of the results obtained by these authors were considered as due to the known presence of certain chemical compounds which stimulate plant growth; but all results were attributed to radioactivity, notwithstanding the authors' frank statement that, when the compound they used was tested, not a trace of radioactivity could be detected.

The evidence here briefly reviewed would seem to justify the broad inference that, although radioactivity may act as a stimulus to plant growth, our present knowledge of the cost of radium, and of its physiological effects, affords little, if any, ground for expectation that it possesses any value for practical agriculture.

1 New Jersey Agr. Exp. Sta. Bull. 269. My 29, I9I

${ }^{2}$ Stevens Indicator, April, 1914, p. 150.

${ }^{3}$ Vie Agr. et Rur. 2: 24I. I913. 


\title{
ENDEMISM AS A CRITERION OF ANTIQUITY AMONG PLANTS
}

\author{
Edmund W. Sinnott \\ Connecticut Agricultural College
}

Those species, genera, or families of plants which are restricted in their distribution to a particular region, and which from this circumstance are termed "endemic" in that region, have frequently been regarded as constituting the most ancient element in its flora. A discussion of the extent to which this characteristic of endemism may be used as a safe criterion of antiquity, particularly when we are dealing with plants belonging to different growth forms, is the purpose of the present paper.

An ecological analysis of the endemic elements in the floras of various regions throughout the world provides us with some suggestive facts which bear on this problem, for such an analysis shows that the important endemic types in the north temperate zone are radically different from those in the south temperate zone. The writer has compiled a list of the genera of dicotyledons which have 95 per cent or more of their species confined to Canada, the United States, and northern Mexico, and which may therefore fairly be said to be "endemic" in temperate North America. These genera comprise over 2,200 species, of which only 235 , or slightly over Io per cent, are trees or shrubs. In the non-endemic portion of the flora of this region, on the contrary, approximately 25 per cent of the species are woody plants, over twice as large a proportion as in the endemic. An analysis of the essentially endemic genera of Europe and adjacent temperate Asia and Africa reveals a similar preponderance of herbs here as compared with the non-endemic types.

In the southern hemisphere, however, precisely the reverse is true. In Australia, for example, 83 per cent $(3,347$ out of 4,024$)$ of the species of the endemic genera are trees or shrubs, but only 37 per cent $(623$ out of 1,687$)$ of the species of the non-endemic 
genera are plants of this sort. In New Zealand 65 per cent (206 species out of 315) of the endemic element is woody, but only 42 per cent of the species of the non-endemic element. In Patagonia and Fuegia, trees and shrubs comprise 52 per cent ( 347 out of 667) of the species of those genera which are practically confined to this region and which may fairly be called "endemic" in it, as opposed to 13 per cent (I20 out of 920) of the species of the non-endemic genera. The same fact is observable in South Africa, where 70 per cent $(3,296$ out of 4,686$)$ of the species of the "endemic" genera are woody, but only +2 per cent $(\mathrm{I}, 369$ out of 3,298 ) of the species of the non-endemic types.

In the north temperate land area, therefore, the endemic (presumably most ancient) element in the flora has a decidedly higher proportion of herbs than does the non-endemic element, whereas in the southern hemisphere, it has a decidedly higher proportion of woody plants. Does this indicate that herbs are in general a more ancient type of vegetation than trees and shrubs in the former area but a less ancient one in the latter? Such a conclusion is opposed to the evidence recently brought forward from various botanical fields ${ }^{1}$ in support of the view that the herbaceous type has invariably been derived from an earlier vegetation which was prevailingly woody, and the writer believes that the explanation of the preponderance of herbs in the endemic flora of the north temperate zone lies not in the antiquity of this growth type but rather in the high degree of rapidity with which plants belonging to it may undergo evolutionary change.

We must first of all distinguish clearly between two main types of endemic plants: on the one hand, the isolated and localized survivors of once much more widely spread types, which we may call "relict" endemics; and on the other hand, those plants which owe their endemism to the fact that they have never spread beyond the actual region of their evolutionary origin, and which may there be named "indigenous" cndemics. A list of the endemic genera of any large area, arranged according to natural relationships, is usually easy to divide in to these two categories, for genera which stand well apart from the rest, without near relatives, are doulutless isolated survivors of once much more

\footnotetext{
${ }^{1}$ Sinnott, E. IV., \& Bailey, I. W'. The origin and dispersal of herbaccons Angiosperms. Ann. Bot. 28: 547-600. O 1914.
} 
common forms; while those which occur in definite groups, all the members of which are closely related to one another, evidently represent locally developed types, each group of genera the nucleus for a new subfamily.

An analysis of the genera essentially endemic in temperate North America reveals the fact that practically all the woody types occurring in it are apparently "relict" endemics. Carya, Planera, Machura, A simina, Umbellularia, Sassafras, Dirca, Calycocarpum, Robinia, Ptelea, Nemopanthus, Ceanothus, Garrya, Symphoricarpos and many other shrub and tree genera exist without very near relatives in North America, and the conclusion that they are representatives of a flora at one time much more widely distributed is strikingly confirmed by fossil evidence, which shows that species of many of them flourished in Europe or Asia during Cretaceous or Tertiary time. That most of these forms are indeed relicts, and may therefore claim a relatively high degree of antiquity, seems certain.

We have observed, however, that the great bulk of North American endemic genera are herbaceous in habit. There are a number of herbaceous genera, for the most part poor in species, among the relict endemics; but it is well worthy of note that these are the decided exceptions, for the great majority of endemic herbaceous genera are not distributed thus scatteringly through the various families but occur in definite groups the members of which are closely related to one another. Examples of such grouping are: Stanleya, Thelypodium, and their allies; Lesquerella and its allies; and Leavenworthia and its allies among the Cruciferae: Eriogonum and its allies among the Polygonaceae: Sarracenia and Darlingtonia among the Sarraceniaceae: Heuchera and its allies among the Saxifragaceae: Zizia and its allies among the Umbelliferae: Pterospora and its allies among the Ericaceae: Cryptanthe and its allies among the Borraginaceae: Agastache and its allies among the Labiatae: Pentstemon and its allies; and Castilleja, Orthocarpus, and their allies among the Scrophulariaceae: Brickellia and its allies; Solidago, Bigelovia, and their allies; Townsendia, Sericocarpus, and their allies; Silphium and its allies; Rudbeckia and its allies; Madia, Hemizonia, and their allies; Baeria, Eriophyllum, Hymenopappus and their allies; Microseris, Krigia, and their allies and Lygodesmia, Troximon, and 
their allies among the Compositac; and a great number of others. There are over seventy of these groups among the Dicotyledons alone. The only woody genera which display such a segregation are Cercocarpus and its allies, which comprise the subfamily Cercocarpeae of the Rosaceae, and number only a very few species.

A similar constitution of the endemic flora may be observed in Europe where, centering in the Mediterranean region, there are scores of endemic herbaceous genera almost all of which fall into sharply marked groups of closely related forms. This is particularly noticeable among the Cruciferae, Leguminosae, Umbelliferae, and Compositae.

These two great arrays of what we have called "indigenous" endemic genera in North America and Europe seem to have their centers of dispersal in the western and southwestern United States and northern Mexico on the one hand, and in the Mediterranean region on the other. That they are confined almost entirely each to its own side of the ocean; that both are composed of groups of closely related genera, very many of which are rich in species; and that each constitutes a dominant and successful element in the flora of its own region, all sliggest that such endemic types have either actually had their origin, or have at least undergone the greater part of their development and dispersal since a free exchange of plants between Europe and North America was discontinued, presumably somewhere about the middle of the Tertiary. Had they been as common and widespread before that time as today, they would in all probability be represented now on both sides of the Atlantic, as are so many genera.

We may feel justified in concluding, therefore, that the "relict" and the "indigenous" endemics in the north temperate zone do indeed differ considerably in the degree of their anticuity; the former representing decidedly ancient types, which may be held to correspond to the ancient endemic genera of other regions, but the latter seeming to have arisen in much more recent times. The significant fact in the whole matter is that, with very few cxceptions, the indigenous endemics are composed entirely of herbacenus forms. In this wholesale development of new generic types, why should not trees and shrubs have taken the place which their abundance as species and individuals would seem to warrant? Why have not our local varieties and species of woody forms, 
which we believe to have arisen for the most part since the isolation of America from Europe, been extended much further and developed into new genera?

The explanation of the whole matter apparently lies in the fact that herbs, because of the brevity of their life cycle, are subject to much more rapid evolutionary change than are most woody plants. Given an equal degree of mutability, a species which has a hundred generations a century, as does an annual herb, will accumulate changes much more quickly, and will thus become altered in type much sooner, than will a species having only three or four, as do many trees, or even fifteen or twenty, as do the more rapidly maturing shrubs.

Other things being equal, therefore, the herbaceous element in any flora is the one which is quickest to change and which is always the first to show the effects of isolation by developing local types. North America and Europe, which have not long been separated from one another, will consequently show many "indigenous" endemic genera which are herbs, but few or none which are trees or shrubs.

The fact that herbs are so rare among the endemic types of the great land masses of the south temperate zone, as we noted above, is excellent evidence that the herbaceous element in the vegetation of these regions has but recently appeared. Had herbs been a prominent part of the flora there as long as they have in the north, it is hard to believe that they would not likewise have given rise to an endemic element very numerous in genera and species.

In any discussion of endemism and its usefulness in determining the comparative antiquity of the various portions of a flora, one should therefore make a clear distinction not only between "relict" endemics, which from their nature are among the older members of the flora, and "indigenous" endemics, which may or may not be so; but in addition, and more particularly, between endemic woody plants and endemic herbs. The former, from the extreme slowness with which they tend to become altered in type, may be generally counted upon as the most ancient floral element. Herbs are subject to such rapid evolutionary change that endemic types developed among them cannot well be compared as to antiquity with those appearing among trees or shrubs. 
This great difference in the rapidity with which plants undergo evolutionary development, depending on the growth type to which they conform, is therefore a fundamental consideration in any discussion of endemism.

\section{SUMMARY}

I. The endemic elements in the floras of the south temperate zone are preponderantly woody; those of the north temperate zone, preponderantly herbaceous.

2. A distinction should be drawn between "relict" endemics, which are survivors of a once more widely spread flora and therefore of relatively high antiquity, and "indigenous" endemics, which are of local development and therefore less ancient.

3. In the endemic floras of Europe and temperate North America almost all tree and shrub genera are relicts. The great majority of endemic herbaceous types, on the other hand, are apparently of indigenous origin and have presumably arisen or become widespread since a free exchange of plants between Europe and America was discontinued.

4. The predominance of herbs among indigenous endemic types is explained as due to the great rapidity with which plants belonging to this growth form may undergo evolutionary derelopment, owing to the extreme brevity of their life cycle. 


\title{
A BOTANICAL TRIP TO NORTH WALES IN JUNE
}

\author{
Arthur H. Graves \\ Connecticut College for Women
}

After a winter's work in the botanical laboratory of the Royal College of Science and Technology, London, I was glad to accept an invitation to join the faculty and students of the department in a trip to North Wales-a regular annual event in their curriculum.

Leaving London early, June 4, we arrived at Llanberis, Wales, at about sundown, in the heart of the mountain region and the end of our railroad journey. From Llanberis it was a stage drive of about five miles to our hotel, most appropriately named the Gorphwyspha-which is Welsh for House of Rest-situated at the head of the pass leading down into the Llanberis valley. On either side, steep, apparently barren mountains rose above us; and from our inn we could see the highest of them all, the giant Snowdon, rising to an altitude of 3,750 feet, overtopping a host of smaller peaks. Compared with our Rockies, or even our Southern Appalachians and White Mountains, this is no great elevation, and yet it must be remembered that the region is so close to the sea that this height is practically all sheer ascent.

These Welsh mountains, with their bare, sharp peaks, narrow ridges, and treeless slopes are most unlike our Southern Appalachians with their rounded contours and forested slopes. One could almost believe he were in the heart of the Alps if it were not for the lack of perennial snows and glaciers.

Although the geology of the region has not been fully worked out, its main features are evident. The whole region, originally submerged, was then overlaid with a stratum of Ordovician limestone, which was subsequently more or less altered by igneous intrusions. At present most of the limestone has been either eroded or mingled with lava, felstones, and dikes of greenstones. Consequently we find rocks containing various proportions of lime, while Cambrian shales and slates also occur at the lower altitudes. In general, the acid igneous rocks support little plant 
growth, while the areas containing limestone are well watered and rich in regetation.

Our excursions through this region covered a period of five days, and under the guidance of our leader, Professor J. B. Farmer, an Alpine climber of note, the plant collecting, interspersed with mountain climbing, proved a most delightful combination.

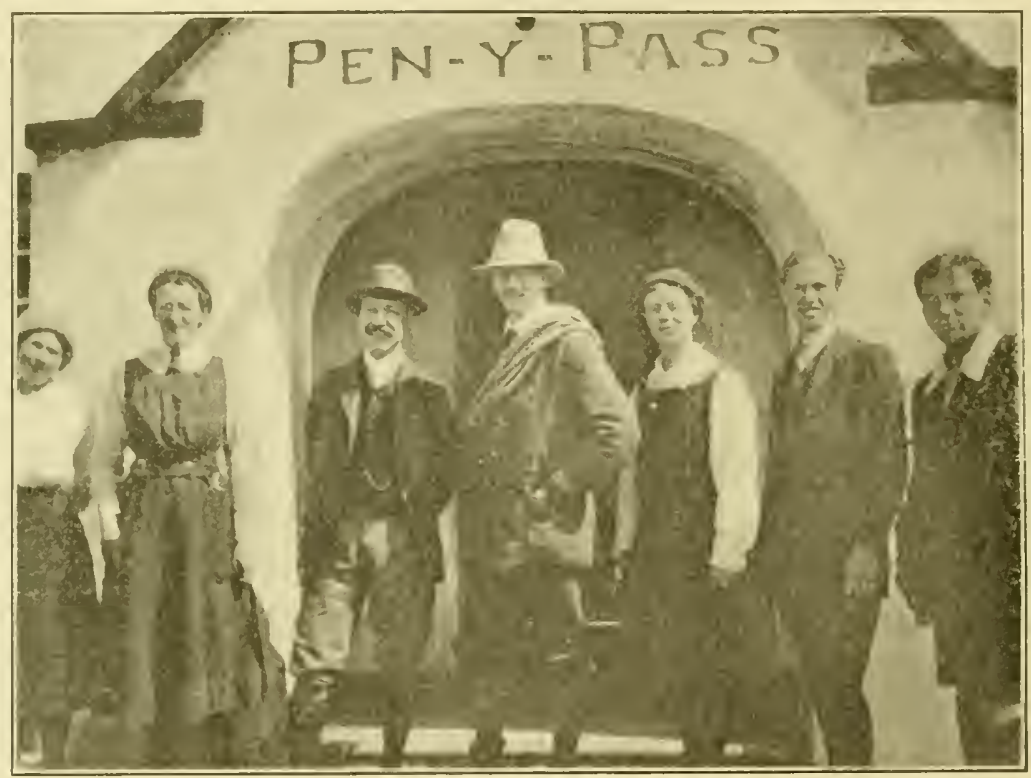

FIG. I. Some of the party in front of the inn, ready for a day's work; Professor J. B. Farmer at the center of the group.

Certainly the region is not one which an inexperienced botanist would pick out for collecting. As the eye traverses the mountain slopes, from their green valleys to their bleak, bare summits, the utter lack of a tree flora lends a peculiarly barren aspect to the vegetation (FIGS. 2 and 3 ). A closer inspection, however, gained during our ascent of these very slopes, reveals the fact that this apparent sterility does not extend to herbaceous plants. Especially is this true if one happens to follow a lead in which a fair proportion of limestone is mingled. Here one may come upon a bright pink carpet of Silene acaulis L. the moss campion, or the crimson Saxifraga oppositifolia L.; or the polygonaceous Oxyria digyna (L.) Ilill, the mountain sorrel, and the yellow-flowered Sedum 
roseum (L.) Scop., the roseroot, with its thick, odorous rootstocks, may nod alluringly from some rocky cleft. If he is fortunate, the climber may also find himself on a rocky shelf, where perhaps the brilliant yellow English cowslip, Primula veris L. and the red campion, Lychnis dioica L. await him with a blaze of glorious color. He may find intermingled with them also, plants of the handsome yellow globe-flower, Trollius europaeus L. These last three, how-

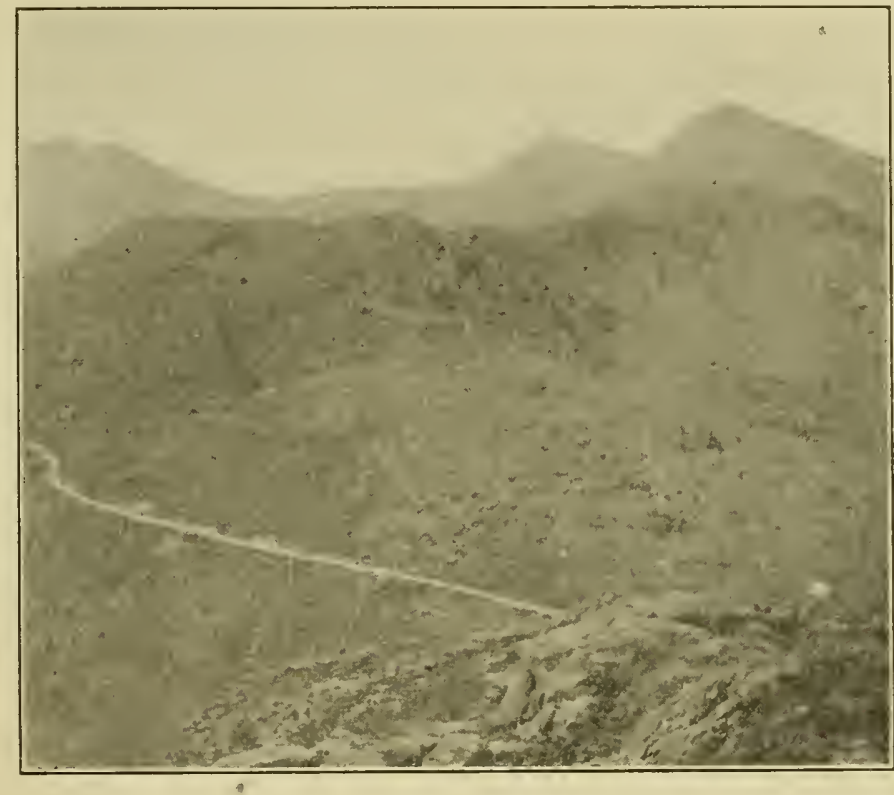

FIG. 2. View of Snowdon (the further sharp peak), and part of the Snowdon range, showing the rugged character of the country.

ever, are not exclusively mountain species like the former. Thalictrum alpinum L., the mountain meadow rue, and the little white Arenaria verna L., the vernal sandwort, are apt to occur nearby in the grass of the high mountain meadows.

One large boulder, impregnated with a fair proportion of calcareous rock, deserves especial notice for the richness of plant species it supported, and it was the more striking when compared with the poverty of the greenstones and felstones in the immediate neighborhood. On this rock, which we explored carefully, were found Solidago Virgaurea L., the only goldenrod of which Britain can boast (many of our species are cultivated in their gardens), 
Rubus saxatilis L., Antennaria dioica (L.) Gaertn., Pimpinella Saxifraga L., a small species of Hieracium, Galium boreale L., Campanula rotundifolia L., Asplenium viride Huds., and A. Trichomanes L., Silene acaulis L., and last, but perhaps the most attractive, the beautiful creamy white Dryas octopetala L., the mountain arens.

Other calcicolous species occurring here, many of them lowland and woodland forms, or even maritime, are Oxalis Acetosella L., Anemone nemorosa L. and Armeria vulgaris Villd. Of the ferns, Allosorus crispus Bernh., Phegopteris polypodioides Fée, P. Dryopteris (L.) Fée, Cystopteris fragilis (L.) Bernh., and Hymenophyllum Wilsoni Hooker, are most abundant. The green spleenwort, a very characteristic limestone plant, has already been mentioned.

Although we have designated the region as treeless, it would be hardly just to overlook an occasional specimen of Pyrus Aucuparia (L.) Ehrh., the mountain ash. When sheltered in some rocky nook, this grew to fair proportions, but in exposed locations was quite stunted. The low juniper, Juniperus communis L. var. montana Ait. too, on the lofty summits where it was abundant, hugged the earth so closely as to appear little more than a carpet. Salix herbacea L. also might be mentioned in this connection, although no one could possibly call it a tree. We found it high up on the summit of one of the peaks, perhaps 3,000 feet above sea level. Not a sign of other regetation was in sight, and careful search was necessary to locate even this plant. Its rootstocks held firmly down by flat stones, here and there, as if the hazard was great, it raised itself only very slightly from its surroundings. J collected one specimen about an inch high, bearing a staminate catkin. On the particular summit in question, the winds were so powerful that all the small flat stones with which the area was covered had sunk into hollows made underneath them by the gales. The whole summit, then, resembled a mosaic, so neatly had the stones been thus fitted together.

Three plants which never occurred in limestone soils, but formerl a most exclusive society of their own, were Calluna iutgaris (L.) IIull, Juniperus communis L. var. montana Ait., and Vuccinium Myrtillus L. As far as I could see, no intruder ever rentured into this community save Empetrum nigrum L. 'This 
combination held full sway near the tops of some of the peaks, or above about 2,00o feet altitude. Higher up they too disappeared, and the willow mentioned above was the sole member of the phanerogamous vegetation.

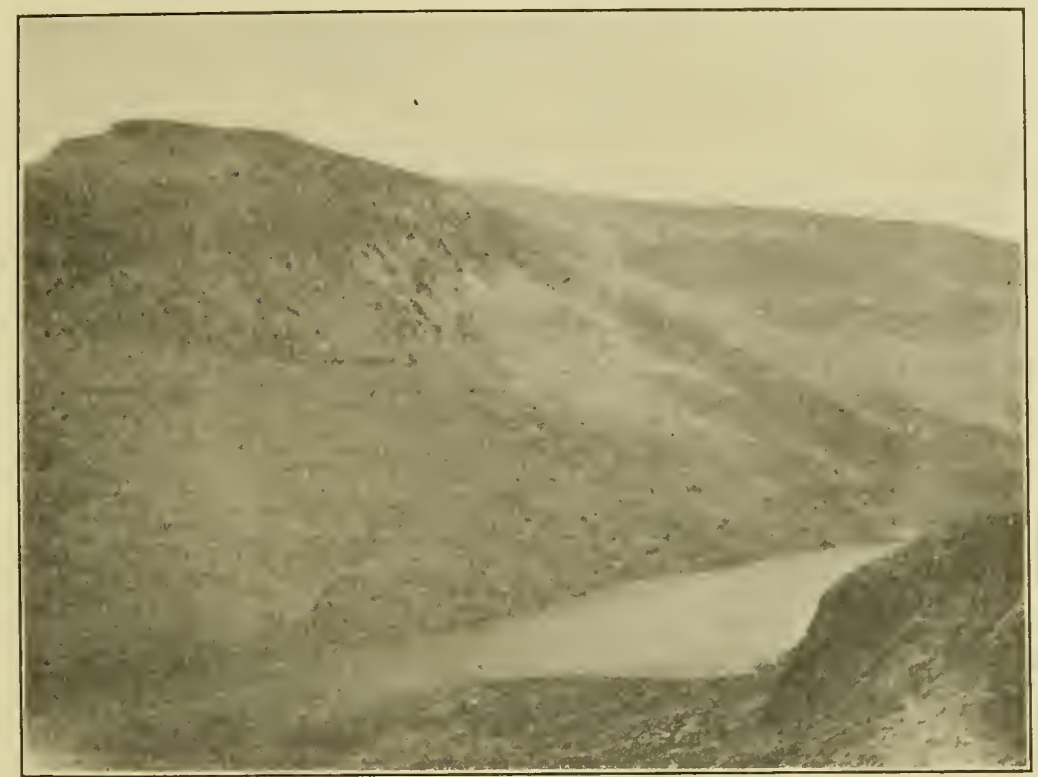

Fig. 3. A lake in the Nant Ffrancon Valley.

A gorgeous sight awaited us in one of the mountain tarns, where the cosmopolitan marsh marigold, Caltha palustris L., flourished with all the lavish richness of golden yellow color which American plant lovers know so well. In this same little lake, Isoetes lacustris L., Lobelia Dortmanna L., the latter of which I had collected the year before in a Connecticut pond, Littorella lacustris L., and Ranunculus Flammula L. grew in abundance. In other tarns, Menyanthes trifoliata L. was found to be plentiful.

One of the rarest plants in Britain, Lloydia serotina (L.) Sweet, was found high up in a narrow gorge. This is a small liliaceous plant with morphological characters closely resembling those of the tulip, but with a spreading perianth. It bears a single small white flower, with the perianth segments showing longitudinal reddish lines. Known in Britain only in some of the highest Welsh mountains, it also inhabits the high mountain ranges of 
Europe, the Caucasus region, and the alpine and arctic regions of North America.

A frequent plant, worthy of mention, was the insectivorous Pinguicula rulgaris L., also native with us from New Brunswick to Quebec, to Minnesota and far north.

Everywhere in the grassy meadows and slopes at the foot of the mountains Potentilla Tormentilla Sibth. was in evidence. It occupies much the same place in the flora as our cinquefoils, Potentilla canadensis L. and $P$. pumila Poir., and has a similar appearance, but it has only four petals. In the boggy spots in these meadows could be seen another insectivorous plant, also native with us, Drosera rotundifolia L. With it often grew Saxifraga stellaris L. and Chrysosplenium oppositifolium L., the latter under much the same conditions as our golden saxifrage, Chrysosplenium americanum Schw.

I must not fail to add our own Myrica Gale L., which, also indigenous there, was quite at home beside a meadow brook.

The mosses and liverworts are especially numerous, also the algae, but fungi were scarce. Over thirty species of liverworts were collected, and among the mosses was Oedipodium Griffithianum (Dicks.) Schwaegr. For a long time this was believed to be the only plant peculiar to the British Isles, until it was discorered in Norway, and it has since been found in Greenland and Alaska.

Perhaps one of the things which impressed me most throughout the whole trip was the comparatively large number of indigenous plants which are also native in North America, for not only those just mentioned, but many of the others named above are reckoned among our incligenous plants. The generally accepted belief in a closer relation or a connection between Europe and America in former geologic times was thus brought home to me more forcibly than ever before; for what could be more convincing evidence than to find such plants as the marsh marigold, the low juniper, and the sweet gale, thrifty and important members of the native flora! 


\title{
NORTH AMERICAN SPECIES OF ALLODUS ${ }^{1}$
}

\author{
C. R. ORTON \\ Pennsylvania State College
}

INTRODUCTION

The genus Allodus Arth. of the Uredinales is a group of parasitic fungi having pleomorphic spore-forms and so far as is known all species of the genus are autoecious.

The most conspicuous character of the genus is the frequent close association of aecia and telia on the same plant parts and the absence of distinct uredinia. These characters are identical with those of Uromycopsis (Schrot.) Arth., a genus exactly parallel with Allodus.

The failure to produce uredinia makes the aecial stage of particular interest from the taxonomic and cytologic standpoint. The cultural studies which have been made with species of this genus are substantiated by the taxonomic studies.

The descriptive matter herein given is as brief as possible without leaving out essentials. These descriptions together with the analytic key should enable the collector and mycologist to determine the species belonging to this genus, provided the specimens bear more than one stage of the rust. The presence of uredinia ( $i . e .$, uredinial sori, not necessarily urediniospores) at once throws a rust out of this genus while the grouping of the telia is quite distinct from that in the short cycle genus Dasyspora.

${ }^{1}$ Contributions from the Department of Botany, Pennsylvania State College, No. 6.

This paper is the result of investigations started in the Botanical Laboratory of the Purdue University Agricultural Experiment Station while the author was connected with that institution. Upon his removal to The Pennsylvania State College that part of the Arthur Herbarium dealing with the subject matter was very generously loaned for the continuation of this study. The writer is indebted to the officers and botanical staffs of these institutions, who have so generously aided him.

To Dr. J. C. Arthur, who has aided the writer in many ways, especial acknowledgment is made. To Dr. F. D. Kern the writer is greatly indebted for advice along special lines. Acknowledgment is made also to Dr. H. D. House for the determination of host plants of the genus Ipomoea. 


\section{COMPARISONS WITH OTHER RUST GENERA}

The relationship of Allodus to other genera of the tribe Dicaeomae is a most interesting subject. In many cases there are species properly referred to Dicaeoma and Dasyspora which are more closely related to species of Allodus than they are to any species in their respective genera. A good example of this sort of relationship is afforded by A. effusa on Viola lobata. There is an undescribed rust collected on Viola ocellata from the Rocky Mountains, the teliospores of which are like the former species, yet the rust has a full life cycle and is referred to the genus Dicaeoma. Another undescribed rust collected at Dunsmuir, California, on Viola lobata possesses only pycnia and telia and the teliospores are almost identical with $A$. effusa. Another example of the same kind of relationship, is found on Brodiaea, and other examples undoubtedly exist. Here we have what to all appearances seems to be three very closely related species or forms of one species, yet each is placed in a separate genus. To the phanerogamic taxonomist such a separation is most confusing and would be considered the height of inconsistency, for it fails to show what a well co-ordinated classification should, namely-a well-defined arrangement of species, families, etc., to show their true relationship to each other and to other groups. It must be conceded, however, that with the fungi, taxonomists are working on a different basis from those who work with flowering plants and animals. While in the fungi the term "species" may" represent in a psychological way just as definite a thing as it does to taxonomists of higher organisms, yet in reality the existing relationship is entirely different. Only among individuals where interbreeding of distinct lines of descent exists, do true species occur and therefore in the parasitic fungi the term species has an entirely different interpretation. From this standpoint it would seem to be unimportant whether a classification of such a group as the rusts shows all real relationships so long as the result is a clearer exposition of the nature and life histories of the organisms dealt with.

So far as comparisons have been made there is no apparent close relationship between species in the genera Allodus and Bullaria. A careful comparative study of these two genera is much needed. 
The genus Uromycopsis is exactly parallel with Allodus. They differ in no way except in the number of cells in the teliospore.

Exceedingly complex questions arise as to the relation and interrelation of the eight genera in the tribe Dicaeomae. If the classification of the rusts proposed by Arthur ${ }^{1}$ has accomplished nothing more, it has certainly opened up the whole subject from a new standpoint and presented the rusts in such a manner that many of these more difficult problems can be investigated more clearly than ever before.

\section{Genetic Relationship}

$K_{\text {Kern }}^{2}$ has pointed out that it appears more probable to suppose that the short cycle (Dasyspora) forms of rusts have been evolved at one step from the long cycle (Dicaeoma) forms by dropping out the intermediate spore forms. Olive ${ }^{3}$ on the other hand thinks that the long cycle forms have been evolved from the short cycle forms by a process of amplification.

The writer's work on Allodus and his study of this genus and the other genera of the tribe Dicaeomae indicates that some species of Allodus hold an intermediate position between Dicaeoma and Dasyspora and that in some cases the transition between the two extremes has been gradual rather than abrupt. It seems most logical to accept the view that Allodus has been evolved from autoecious species of Dicaeoma and that some species of Dasyspora have in turn originated from species of Allodus. The remarkable similarity of certain species of rusts in these three genera upon the same or closely related hosts, indicate such a condition as outlined above. Further prima facie evidence of such evolutionary tendencies is found in certain species of Allodus where occasional urediniospores occur in the telia. These urediniospores are in every detail like the urediniospores of its correlated species of Dicaeoma.

Bullaria appears to have developed from Dicaeoma in a manner parallel with Allodus. It seems possible that certain meteoro-

${ }_{1}$ Arthur, J. C. Eine auf die Struktur und Entwicklungsgeschichte begründete Klassifikation der Uredineen. Résult. Sci. Congr. Bot. Vienne 33I-3+8. I906.

${ }^{2}$ Kern, F. D. The genetic relationship of parasites. Am. Jour. Bot. 2: II6-I3I. I9I5.

${ }^{3}$ Olive, E. W. Origin of heteroecism in the rusts. Phytopathology I: $139-148$. I9II. 
logical conditions are closely bound up with the evolution of Allodus and Bullaria.

\section{HOST RELATIONSHIPS}

A tabular presentation of the host orders and families of Allodus is given below.

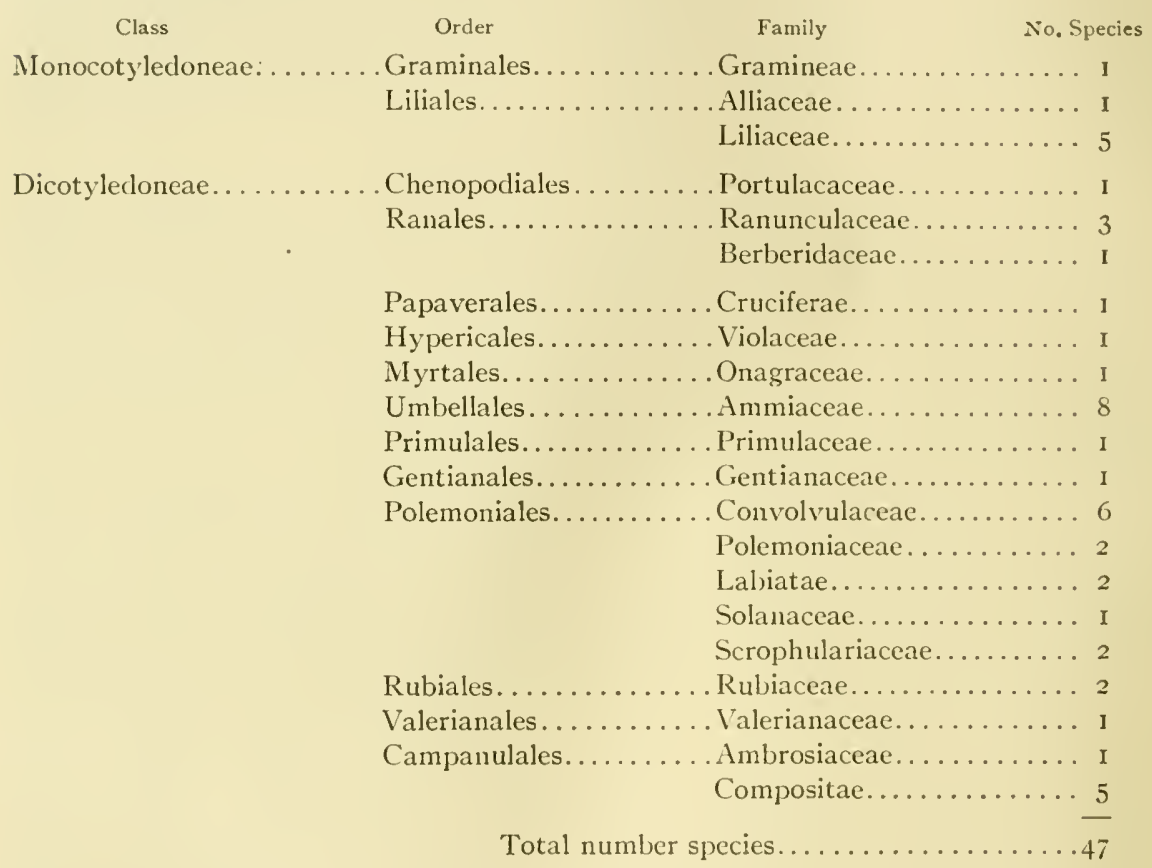

The most interesting point in connection with the host relationships is the absence of the order Rosales.

\section{LIFE HISTORY}

The genus Allodus was founded on Puccinia Podophylli Schw., a common rust in the United States cast of the Mississippi River. This species according to Olive ${ }^{1}$ possesses perennial mycelia of both gametophytic and sporophytic generations which intermingle more or less constantly throughout the young host. Later, independent sporophytic mycelia arising evidently from acciospore infection, give rise to telia of the scattered type.

${ }^{1}$ Olive, E. W. The intermingling of perennial sporophytic and gametophytic generations in Puccinia Podophylli, P. obtegens and Uromyces Glycyrrhizal. Ann. Myc II: $297-311 . \quad 1913$. 
This intermingling of mycelia of both generations is not known definitely to occur in any other species of Allodus and so can hardly be regarded as typical. Whether this species forms secondary aecia has not been proved. What little cultural data is at hand indicates that secondary aecia may or may not occur in the genus and the taxonomic studies bear out this statement.

The species in the genus appear to be quite variable in life history. A. claytoniata has been cultured by Dr. F. D. Fromme in the laboratory at Columbia University. His unpublished results show that aeciospores from primary aecia, when sown give rise to telia of the scattered type. The taxonomic studies on this species corroborate his results.

Bubák ${ }^{1}$ studied A. ambigzıa, a rust occurring in Galium A parine in Europe and North America. He found that primary aecia were followed by secondary aecia.

Treboux ${ }^{2}$ has more recently checked up Bubák's studies on A. ambigua and found them to be correct. These results are in accordance with those of Dietel ${ }^{2}$ who cultured Uromyces Behenis (DC.) Unger and Uromyces Scrophulariae (DC.) Fuckel, two species to be referred to the genus Uromycopsis, which has the same life cycle as Allodus. In both species in question he found that secondary aecia followed primary aecia.

Although the number of cultures are limited they indicate two distinct life histories. In one case primary aeciospores give rise to telia of the scattered type. In the other case primary aecia are followed by secondary aecia which in turn give rise to telia formed around the secondary aecia and from the same mycelium, or telia of the scattered type may be formed but whether these last arise from primary or secondary aeciospore infection is not known.

Other variations occur, such as evident perennial gametophytic mycelium which appears to exist in A. consimilis, A. Douglasii, A. Giliae, A. Chamaesarachae, A. intermixta, and A. Batesiana.

Cultural studies must be made to determine the nature of the

${ }^{1}$ Bubák, Fr. O rezích, které cizopasí na některých Rubiaceích. Sitz.-ber. Böhm. Ges. Wiss. I898 $8^{28}:$ I-23. I 898 . Reviewed in Zeitschr. Pfl.-Kr. 9: I I6. I899.

2 Treboux, O. Ann. Myc. I 0: 305. I9I2.

${ }^{3}$ Dietel, P. Über Rostpilze mit niederholter Aecidien-bildung. Flora 8r: 394-404. I 895 . 
sporophytic mycelium in these cases. It is probable that cases similar to $A$. Podophylli will eventually be found.

Aecia (secondary) unaccompanied by pycnia were found in twenty-four species and undoubtedly occur in other species, were their history known. 'This brings up the question of the status of the aecium as a distinct unalterable phase in the life history of certain rusts which lack uredinia.

It has generally been supposed that urediniospores were the only repeating spores in the rusts. The occurrence of repeating aeciospores in Allodus and Uromycopsis indicate that, while morphologically they are aecidioid, functionally they may be repeating spores.

All species of the genus are autoccious with one possible exception, A. graminella, a condition which may be said to be typical of rusts with a shortened life cycle. The only known exceptions are afforded by the genera Calyptospora and Gymmosporangium, both of which, with the single exception of Gymnosporangium nootkatense, lack uredinia also in their life cycle.

\section{Generic Description}

ALLODUS Arth. Résult. Sci. Congr. Bot. Vienne 345. 1906.

Cycle of development includes pycnia, aecia, and telia with distinct alternating phases; autoccious. Pycnia and other sori subepidermal.

Pycnia deep-seated, usually globoid or flask-shaped, with ostiolar filaments.

Accia erumpent, cupulate or cylindrical, of two sorts, primary and secondary; the primary aecia sometimes giving rise to secondary aecia unaccompanied by pycnia; the secondary aecia frequently followed by the telia. Peridium colorless, dehiscent by apical rupture, the margin lacerate or erose, erect, spreading or recurved. Acciospores catenulate, globoid or ellipsoid, often angular; the wall colorless or nearly so, verrucose.

Telia erumpent or long covered by the epidermis, arising either around or from within the secondary aecia and later independently; or arising at first inclependently from infection by aeciospores from the primary aecia. 'Teliospores free, pedicelled, two-celled; the wall colored, firm, smooth or verucosely sculptured.

Urediniospores rarely found in the telia.

Type species, Puccinia Podophylli Schw., on Podophyllum peltatum L. 


\section{ANALYTICAL KEY}

Teliospores spinulose.

Teliospores beset with long slender spines.

Teliospores coarsely tuberculate.

Teliospores less than $40 \mu$ long.

Apex not more than $5 \mu$ thick.

Apex up to $7 \mu$ thick.

Teliospores more than $40 \mu$ long.

Apex not more than $5 \mu$ thick.

Apex 6-12 $\mu$ thick.

Aeciospore wall $3 \mu$ or more thick.

Aeciospore wall less than $3 \mu$ thick.

Aeciospore wall coarsely verrucose.

Aeciospore wall finely verrucose.

Aeciospores $16-22$ by $19-26 \mu$.

Apex 12-19 $\mu$ thick.

Aeciospores $19-28$ by $24-34 \mu$.

I2. A. Podophylli.

2 I. A. asperior.

38. A. rufescens.

5. A. Carnegiana.

26. A. opulenta.

3o. A. superflua.

27. A. crassipes.

31. A. megalospora.

29. A. nocticolor.

Teliospores finely verrucose.

Apex less than $3 \mu$ thick.

Teliospores not over $30 \mu$ long.

36. A. Chamaesarachae.

Teliospores $30-40 \mu$ long.

Ruptured epidermis conspicuous.

Telia rupturing epidermis to form a conspicuous ostiole.

Telia not rupturing epidermis as above.

Ruptured epidermis not conspicuous.

Apex 3-5 $\mu$ thick.

Teliospore wall $\mathrm{x} \cdot 5^{-2} \mu$ thick.

Teliospores not constricted at septum.

Teliospores constricted at septum.

Teliospores conspicuously verrucose, especially at apex.

Teliospores very inconspicuously verrucose.

Teliospore wall $2.5-3.5 \mu$ thick.

42. A. intermixta.

18. A. Erigeniae.

23. A. lacerata.

2. A. pagana.

3. A. Calochorti.

37. A. Palmeri.

14. A. effusa.

Apex 5-8 $\mu$ thick.

Teliospore wall $\mathbf{I}^{-5^{-2}} \mu$ thick.

Teliospore wall 2-3 $\mu$ thick.

Pedicel normally placed, very short.

Pedicel placed at septum.

Pedicel normally placed, long.

Teliospore wall $3-4 \mu$ thick.

8. A. claytoniata.

33. A. Gitiae.

35. A. vertisepta.

22. A. Musenii.

39. A. Bowvardiae.

Teliospores striately verrucose.

Apex not thickened.

Teliospore wall $\mathbf{I}-\mathrm{I} .5 \mu$ thick.

Teliospore wall $2 \mu$ thick.

Teliospore wall $2-2.5 \mu$ thick.

Apex thickened up to $5 \mu$.

Teliospore wall $3-3.5 \mu$ thick.

Apex I2-23 $\mu$ thick.

6. A. subangulata.

4. A. Moreniana.

I7. A. Jonesii.

20. A. Lindrothii.

28. A. insignis.

Teliospores smooth. 
Teliospore wall, I-I.5 $\mu$ or less.

Teliospores small, less than $35 \mu$ long. Apex rarely thickened up to $3 \mu$. Apex 5-7 $\mu$ thick.

Teliospores of medium size, averaging $35^{-45} \mu$ long. Apex less than $7 \mu$ thick, telia permanently covered.

Apex 6-Io $\mu$ thick, telia tardily naked. Apex $7^{-1} 2 \mu$ thick, telia rather early naked.

Teliospores large, more than $45 \mu$ long.

Apex $3-5 \mu$ thick.

Apex $5^{-8} \mu$ thick.

Apex 7-I6 $\mu$ thick.

Teliospore wall $\mathbf{I} .5^{-2.5} \mu$ thick.

Teliospores small, not usually more than $40 \mu$ long. Apex 5-7 $\mu$ thick. Apex 7 -Io $\mu$ thick.

Teliospores of medium size, not over $60 \mu$ long. Apex not thickened.

Telia rather long covered by epidermis. Telia early naked. Apex 7-12 $\mu$ thick.

Teliospores slender, I 5-2I $\mu$ in width. Teliospores broader, up to $26 \mu$ in width.

47. A. subcircinata. 44. A. tenuis.

10. A. opposita.

40. A. ambigua.

45. A. gnaphaliata.

9. A. gigantispora.

46. A. Desmanthodii.

43. A. Batesiana.

19. A. microica.

13. A. consimilis.

24. A. melanconioides. 25. A. Swertiae.

I5. A. Ludaigiae. Teliospore pedicel colorless or nearly so. Teliospore pedicel chestnut-brown.

Teliospores large, $45^{-80} \mu$ long.

Teliospore wall $3-5 \mu$ thick.

Teliospore wall not over $3.5 \mu$ thick (on Gramineae).

Teliospore wall up to $5 \mu$ thick.

Teliospore pedicel persistent, stout (on Ammiaceae).

Teliospore pedicel fugaceous, fragile (on Labiateac).

Teliospore wall $5^{-7} \mu$ thick.
4I. A. commutata.

32. A. Douglasii.

II. A. areolata.

I. A. graminella.
I6. A. imperspicua.

34. A. mellifera.

7. A. Dichelostemmae.

I. Allodus graminella (Speg.) Arth. Résult. Sci. Congr. Bot. Vienne 345. 1906

Aecidium graminellum Speg. Anal. Soc. Ci. Argent. 12: 77. I 88 I .

Puccinia graminella D. \& H. Erythea 3: So. 1895.

Aecia epiphyllous, scattered, often along the veins; aeciospores $20-25$ by $20-30 \mu$; wall $3-4 \mu$ thick.

Telia epiphyllous, scattered or crowded about the aecia, of ten lineally confluent along the veins, early naked, ruptured epidermis conspicuous, pulverulent; teliospores broadly ellipsoid, 22-28 by $35-55 \mu$, rounded at both ends; wall dark chestnut-brown, $3^{-5 \mu}$ thick, the apex $7-9 \mu$ thick, smooth; pedicel colorless, rather stout, up to ioo $\mu$ long. 


\section{On Gramineae:}

Stipa eminens Cav.

Type locality: Buenos Aires, Argentina, on Stipa sp.

Distribution: California; also in South America.

Exsiccati: Ell. \& Ev. N. Am. Fungi 3350; Arth. \& Holw. Ured. 29a; Ell. \& Ev. Fungi Columb. 864.

2. Allodus pagana (Arth.) comb. nov.

Puccinia pagana Arth. Bull. Torrey Club 28:372. I9I I.

Aecia unknown.

Telia amphigenous, scattered, oval, tardily naked, somewhat pulverulent, ruptured epidermis disappearing at maturity; teliospores oval to fusiform, I $8-23$ by $27-35 \mu$, not constricted at septum; wall cinnamon-brown, $\mathbf{I} \cdot 5^{-2} \mu$ thick, thickened at apex, up to 3 or $4 \mu$, sometimes with pale papillae, very inconspicuously verrucose; pedicel colorless, fragile, half the length of spore or less.

On Alliaceae:

[?] Allium reticulatum Don.

Type Locality: Dead Lake, Pikes Peak, Colorado, on Allium reticulatum.

Distribution: Known only from type locality.

Exsiccati: Clements, Crypt. Form. Colo. I 4 I.

The host collection in the Arthur Herbarium is fragmentary. This species of rust is placed in Allodus chiefly because pycnia and uredinia are lacking in the collection.

3. Allodus Calochorti (Peck) Arth. Résult. Sci. Congr. Bot. Vienne 345. 1906

Puccinia Calochorti Peck, Bot. Gaz. 6:228. I 88I.

Puccinia anachoreta Ell. \& Hark. Bull. Calif. Acad. Sci. 1: I4. I 884 .

Puccinia Holwayi Diet. Hedwigia 32: 29. $\quad$ I 893.

Dicaeoma anachoreticum Kuntze, Rev. Gen. $3^{3}: 467 . \quad$ I 898.

Dicaeoma Holwayi Kuntze, Rev. Gen. $3^{3}: 469 . \quad$ I 898.

Aecia hypophyllous, in oval groups; aeciospores 16-23 by I9-26 $\mu$; wall I.5-2 $\mu$ thick.

Telia chiefly hypophyllous, gregarious or scattered, soon naked, pulverulent, dark chestnut-brown, ruptured epidermis conspicuous; teliospores broadly ellipsoid, I9-29 by $29-42 \mu$; wall chestnutbrown, I. $-2.5 \mu$ thick, thickened at apex $3-5 \mu$, rather prominently verrucose above; pedicel colorless, half the length of spore. 
Urediniospores occur rather frequently in the telia, being most abundant on $C$. Gunnisonii and $C$. longebarbatus, broadly ellipsoid, 2 I-26 by 26-3I $\mu$; wall light golden brown, $2-2.5 \mu$ thick, sparsely and finely echinulate, the pores indistinct, 5 or 6 , scattered.

On Alliaceae:

Allium sp. Calochortus albus Dougl., C. elegans Pursh, $C$. flavus Schult., C. Gunnisonii S. Wats., C. longebarbatus Dougl., C. mudus S. Wats. and C. Nuttallii T. \& G.

Trpe locality: Utah, on Calochortus Nuttallii.

Distribution: Nebraska to Washington and Mexico.

Exsiccati: Ell. \& Er. Fungi Columb. 1953; Barth. N. Am.

Ured. 127, 533, 622; Clements, Crypt. Form. Colo. 549; Garrett, Fungi Utah. 90.

4. Allodus Moreniana (D. \& T.) comb. nov.

Puccinia Moreniana Dudley \& Thompson, Jour. Myc. 10: 53. I904.

Aecia unknown.

Telia chiefly hypophyllous, scattered or sometimes grouped, oval to oblong, tardily naked, ruptured epidermis conspicuous, dark cinnamon-brown; teliospores oblong-elliptical, 20-2t by $33-50 \mu$, cells equal in size and shape; wall light cinnamon-brown, uniformly about $2 \mu$ thick, inconspicuously marked with longitudinal rows of fine papillae; pedicel colorless, about the length of spore.

On Liliaceae:

Dipterostemon capitatus (Benth.) Rydb. (Brodiaea capitata Benth.)

Type Locality: Old Cement Mill, Searsville Lake, San Mateo County, California, on Brodiaeu capitata.

Distribution: Known only from the type locality.

Note.-Puccinia nodosa E. \& H. occurs in the type collection of $A$. Moreniana. The portion of this type in the Arthur herbarium is fragmentary but it has the appearance of an Allodus.

5. Allodus Carnegiana (Arth.) comb. nov.

Puccinia Carnegiana Arth. Bull. Torrey Club 42: 587. I9I5.

Aecia amphigenous, gregarious, in roundish or oval groups; acciospores $23-27$ by $24-3+\mu$; wall $2-3 \mu$ thick.

Telia amphigenous, scattered or arising about or within the secondary aecia, oval or oblong, rupturing by a longitudinal 
slit, tardily naked, blackish; teliospores ellipsoid or oblong, $27-34$ by $42-58 \mu$; wall blackish when mature, $2.5-3.5 \mu$ thick, rarely thickened at apex up to $5 \mu$, coarsely and prominently tuberculate; pedicel colorless, up to the length of spore.

Urediniospores occurring rather commonly in the telia, broadly ellipsoid, $27-35$ by $32-42 \mu$; wall golden yellow to cinnamonbrown, about I-I.5 $\mu$ thick, finely verrucose, echinulate, the pores I 2-I 5 . scattered.

\section{On Liliaceae:}

Dipterostemon pauciflorus (Torr.) Rydb. (Brodiaea capitata pauciflora Torr.)

Type LOCALity: Tumamoc Hill, on grounds of the Desert Botanical

Laboratory of the Carnegie Institution of Washington, Tucson, Arizona, on Dipterostemon pauciflorus. (Altitude 2,700 ft., February 26, I914, no. 5801.)

Distribution: Known only from Tumamoc Hill, Tucson, Arizona.

Note.-Puccinia nodosa E. \& H. a long cycle rust on Dipterostemon capitatus (Benth.) Rydb. from Southern California and Puccinia tumamocensis Arthur, on Dipterostemon pauciflorus, collected from the same locality and at the same time as Allodus Carnegiana, possess teliospores remarkably like those of the lastnamed species.

6. Allodus subangulata (Holw.) comb. nov.

Puccinia subangulata Holw. N. Am. Ured. 1:25. 1905.

Aecia amphigenous, crowded in small orbicular groups; aeciospores $19-25$ by $24-30 \mu$; wall $2-2.5 \mu$ thick.

Telia amphigenous, scattered, oblong, tardily naked, chestnutbrown, ruptured epidermis conspicuous; teliospores broadly ellipsoid, angular, 20-30 by $35-40 \mu$, cells of ten unequal in size and shape; wall dark cinnamon-brown, uniformly I-I.5 $\mu$ thick, finely rugose, with a few prominent longitudinal ridges; pedicel colorless, rarely as long as the spore.

On Liliaceae:

Hookera pulchella Salisb. (Brodiaea congesta Smith, Dichelostemma congestum Kunth.)

Type Locality: State of Washington, on Brodiaea congesta. Distribution: Northwestern United States.

7. Allodus Dichelostemmae (D. \& H.) comb. nov.

Puccinia Dichelostemmae Diet. \& Holw. Erythea 3: 78. 1895. Aecia not known. 
Telia amphigenous, scattered or sometimes confluent, oval to linear, tardily naked, dark chestnut to chocolate-brown, ruptured epidermis conspicuous; teliospores very broadly ellipsoid, 38-45 by $43^{-58 \mu}$; wall dark chestnut-brown, uniformly $5^{-7} \mu$ thick, smooth; pedicel colorless, usually deciduous, of ten laterally attached, up to Ioo $\mu$ long.

\section{On Liliaceae:}

Hookera pulchella Salisb. (Brodiaea congesta Smith, Dichelostemma congestum Kunth.)

Type Locality: Bingen, West Klickitat Co., Washington, on Dichelostemma congestum.

Distribution: Washington and Oregon.

Exsiccati: Barth. N. Am. Ured. I39, 1541.

Note.-A. subangulata frequently occurs together with $A$. Dichelostemmae on the same host.

8. Allodus claytoniata (Schw.) Arth. Résult. Sci. Congr. Bot. Vienne 345. 1906

Caeoma (Aecidium) claytoniatum Schw. Trans. Am. Phil. Soc. II. 4: 294. 1832 .

Puccinia Mariae-Wilsoni G. IV. Clinton, Bull. Buffalo Soc. Nat. Sci. 1: I $66 . \quad$ I 873 .

Dicreoma claytoniatum Kuntze, Rev. Gen. $3^{3}: 466 . \quad$ I 898.

Puccinia claytoniata Peck, Bull. N. Y. State Mus. 6: 226. 1899.

Aecia amphigenous, regularly scattered, often over large areas and covering entire leaf and petiole; aeciospores I3-2 I by $18-23 \mu$; wall $\mathrm{I}-\mathrm{I} .5 \mu$ thick.

Telia chiefly hypophyllous, of ten thickly scattered, sometimes confluent, small, roundish, tardily naked, cinnamon-brown, pulvinate, ruptured epidermis noticeable, teliospores elliptical to terete, sometimes angular, I8-27 by $30-48 \mu$; wall light cinnamon-brown, I.5-2 $\mu$ thick, apex often thickened up to $7 \mu$ by a hyaline papilla, evenly and finely verrucose; pedicel colorless, short.

On Portulacaceae:

Claytonia asarifolia Bong. (Montia asarifolia Howell), Clay'tonia caroliniana Michx., Claytonia siberica L. (Montia siberica Howell), and Claytonia virginica $\mathrm{L}$.

Týe LOCAlity: New York, on Claytonia virginica.

Distribution: New England to IV. Virginia and the Pacific Coast. 
Exsiccati: Ell. \& Ev. Fungi Columb. 875; Shear, N. Y. Fungi 73, 13I; Seym. \& Earle, Econ. Fungi Suppl. B 27; Kellerm. Ohio Fungi 12, 72; Garrett, Fungi Utah. 67; Sydow, Ured. 323, 1315, 1316; Barth. N. Am. Ured. 29, I33, 424, 425, 538, 833; Ellis, N. Am. Fungi IOI7, 1027; Rab. Fungi Eur. 2909; Roum. Fungi Gall. 34I4.

Note.-An undescribed Dasyspora on Claytonia megarrhiza from Colorado has teliospores indistinguishable from those of $A$. claytoniata.

9. Allodus grgantispora (Bubák) Arth. Résult. Sci. Congr. Bot. Vienne 345. 1906

Puccinia gigantispora Bubák, Sitz.-ber. Böhm. Ges. Wiss. 1901: 9. I90I.

Aecia hypophyllous, occasionally caulicolous, on yellowish or reddish spots, roundish or elongated on veins; aeciospores I6-23 by $19-26 \mu$; wall about $\mathrm{I} .5 \mu$ thick.

Telia amphigenous, gregarious, arising about the secondary aecia or later scattered, small, long covered by the epidermis; teliospores cylindrical or linear, obtuse or truncate above, narrowed below, lower cell often twice the length of the upper, I3-I9 by $45^{-87} \mu$; wall $\mathrm{I}-\mathrm{I} .5 \mu$ thick, smooth, or with one to three longitudinal ridges, apex $3-12 \mu$ thick, usually darker; pedicel concolorous with lower part of spore, short.

On Ranunculaceae:

Anemone cylindrica A. Gray, A. globosa Nutt., and A. narcissiflora $\mathrm{L}$.

Type Locality: Livingston, Montana, on Anemone patens var. Nuttalliana, error for A.globosa. (Seymour, September 6, I 884.)

Distributron: Assiniboia to British Columbia and Colorado.

Exsiccati: Barth. Fungi Columb. 4058; Barth. N. Am. Ured. $632,633$.

Note.-This species is separated from Puccinia deBaryana Thuem. by its lack of stroma surrounding the telia. Dasyspora Anemones-virginianae (Schw.) Arth. is frequently found on the same host with these two species and also with heteroecious aecia belonging to Dicaeoma Clematidis (DC.) Arth.

\section{IO. Allodus opposita sp. nov.}

Aecia seen of secondary form only, hypophyllous, gregarious on discolored spots; small, cupulate; aeciospores subgloboid, I $4^{-1} 8$ by I $8-24 \mu$; wall I-I.5 $\mu$ thick, finely verrucose. 
Telia chiefly epiphyllous, opposite the aecia, flat, spreading, black, rery long corered by the epidermis; teliospores cylindrical, I3-I9 by 32-50 $\mu$, truncate or narrowed above; wall chestnutbrown, I-I.5 $\mu$ thick, smooth, apex thickened up to $7 \mu$; pedicel golden, short.

\section{On Ranunculaceae:}

Anemone globosa Nutt.

Type locality: Sulphur Springs, Colorado, on Anemone globosa (Clements, Crypt. Form. Colo. 563. July r9, I907).

Distribution: Known only from the type locality.

Exsiccati: Clements, Crypt. Form. Colo. 563.

The species differs from Puccinia japonica Diet. in having larger aeciospores and thicker-walled peridial cells.

I I Allodus areolata (D. \& H.) Arth. Result. Sci. Congr. Bot. Vienne 345. 1906

Puccinia areolata Diet. \& Holw. Bot. Gaz. 19: 30. I 894.

Dicaeoma areolutum Kuntze, Rev. Gen. $3^{3}: 467 . \quad$ I 898.

Aecia hypophyllous, in loose groups on yellowish spots, sometimes annular, circular or oval in outline; aeciospores I 8-24 by $2 \mathrm{I}-26 \mu$; wall about I $\mu$ thick, minutely verrucose.

Telia hypophyllous, gregarious on orbicular spots, small, circular, of ten in annular groups, early naked, chocolate-brown, ruptured epidermis noticeable; teliospores oblong to clavate, rarely elliptical, 20-32 by $45^{-80} \mu$; wall chestnut-brown, I.5-2 $\mu$ thick, smooth or minutely rugose, the pores covered with a pale umbo making the wall $7-9 \mu$ thick; pedicel colorless, fragile, rarely as long as spore.

Urediniospores occasionally found in the telia.

\section{On Ramunculaceae:}

Caltha biflora DC.

Type lochlity: Skamania Co., Washington, on Caltha biflora (Suksdorf 3 IS, August 12, I 886).

Distribution: Known only from Washington.

I2. Allodus Podophyli. (Schw.) Arth. Résult. Sci. Congr. Bot. Vienne 345. 1906

Aecidium Podophylli Schw. Schr. Nat. Ges. Leipzig 1: 66. 1822. Puccinia Podophylli Schw. Schr. Nat. Ges. Leipzig 1: 72. 1822. Puccinia aculeata Link, in Willd. Sp. Pl. 6: 79. 1825. 
Puccinia Podophylli Link, in Willd. Sp. Pl. 6: 79. I 825.

Puccinia aurea Spreng. Syst. Veg. 4: 568 . I827.

Caeoma (Aecidium) podophyllatum Schw. Trans. Am. Phil. Soc.

II. 4: 293. I832.

Puccinia aculeata Schw. Trans. Am. Phil. Soc. II. 4: 296. I832. Dicaeoma Podophylli Kuntze, Rev. Gen. $3^{3}: 470 . \quad$ I 898.

Aecia chiefly hypophyllous, closely gregarious on yellowish spots, sometimes over large areas; aeciospores I 8-24 by I9-29 $\mu$; wall about I $\mu$ thick, minutely verrucose.

Telia amphigenous and caulicolous, small, round, often gregarious in more or less orbicular areas on yellowish spots, tardily naked, chocolate-brown; teliospores clavate to elliptical, I9-26 by $40-55 \mu$; wall chestnut-brown, uniformly $1.5^{-2} \mu$ thick, sparingly beset with spines about $7 \mu$ long; pedicel golden yellow, rarely half length of spore.

\section{On Berberidaceae:}

\section{Podophyllum peltatum L.}

Type Locality: North Carolina, on Podophyllum [peltatum].

Distribution: New York to Minnesota and southward to the Gulf of Mexico.

Exsiccati: Rab.-Wint. Fungi Eur. 20II, 29I2; Ellis, N. Am. Fungi 257, 258; Seym. \& Earle, Econ. Fungi 253; Thuem. Myc. Univ. 547, 626; 'Vesterg. Micr. Rar. Sel. 783; Roum. Fungi Gall. 2429; Sydow, Ured. 76, $1318,1378,2127$; Kellerm. Ohio Fungi 13 , 55; Barth. Fungi Columb. 2267, 3365, 3462, $3566,3858,3960,4158,4760$; Barth. N. Am. Ured. 163,256 , 257, 463, 655, 959; Rav. Fungi Am. 482, 729.

13. Allodus consimilis (E. \& E.) comb. nov.

Puccinia consimilis Ell. \& Ev. Jour. Myc. 6: I20. II891.

Dicaeoma consimile Kuntze, Rev. Gen. 33: $468 . \quad$ I 898.

Aecia hypophyllous, apparently arising from a perennial mycelium, distributed rather evenly over the entire surface of leaves; aeciospores $\mathrm{I} 6-2 \mathrm{O}$ by $20-28 \mu$; wall about $\mathrm{I} .5 \mu$ thick, appearing smooth when wet.

Telia hypophyllous, arising from around or within the aecia, circular, pulvinate; teliospores broadly ellipsoid, I $6-22$ by $3 \mathrm{I}-37 \mu$; wall $1.5^{-2} \mu$ thick, dark cinnamon-brown, smooth, apex 7-Io $\mu$ thick, rounded; pedicel colorless, up to the length of spore, fugacious. 


\section{On Cruciferae:}

Sisymbrium linifolium (Nutt.) T. \& G.

Type locality: Helena, Montana, on Sisymbrium linifolium (Kelsey, May 19, I889, 54).

Distribution: Known only from Helena, Montana.

Note.-The life history of this species is uncertain, as the evident perennial aecia are accompanied by pycnia and telia, making a complicated condition. Culture work with this species must be carried out before its life history can be known with certainty. Most specimens referred to this species belong either to Puccinia Holboellii (Hornem.) Rostr. or Aecidium monoicum Peck.

I4. Allodus effusa (D. \& H.) Arth. Résult. Sci. Congr. Bot. Vienne 345. 1906

Puccinia effusa Diet. \& Holw. Erythea 3: 81. I895.

Aecia amphigenous, in rather loose groups often scattered over large portions of the leaf or along the petiole, more rarely annular, circular; aeciospores $16-23$ by $\mathrm{I} 9-30 \mu$; wall $\mathrm{I}-\mathrm{I} .5 \mu$ thick, rery inconspicuously verrucose.

Telia amphigenous, chiefly arising in or around the aecia, early naked, dark chocolate-brown; teliospores broadly ellipsoid to oblong, $20-30$ by $32-51 \mu$; usually rounded at both ends; wall chestnut to light chocolate-brown, $2.5-3 \mu$ thick, moderately verrucose above, nearly smooth below, the apex rarely thickened up to $5 \mu$; pedicel colorless, rarely the length of spore.

Urediniospores occurring sparingly in the telia, golden yellow, $2 \mathrm{I}-26$ by $27-35 \mu$, moderately echinulate; wall $3-3.5 \mu$ thick, the pores 2 , opposite, usually equatorial.

\section{On Violaceae:}

Viola lobata Benth. and V. praemorsa Dougl.

Type locality: Dunsmuir, California, on Viola lobata. (Holzay, May 30, 1894.)

Distributios: Washington to Northern California.

Exsiccati: Sydow, Ured. 2371; Barth. N. Am. Ured. 1438.

Note.-An undescribed Dicacoma on Viola ocellata, and a Dasyspora, also undescribed, on Viola lobata from Dunsmuir, California, are evidently correlated species. Dicaeoma Violae differs in having thinner-walled and usually lighter-colored teliospores. 
I5. Allodus Ludwigiae (E. \& E.) comb. nov.

Aecidium Ludwigiae Ell. \& Ev. Proc. Acad. Sci. Phil. 1893: I 35. I893.

Puccinia Nesaeae Ell. \& Ev. Bull. Torrey Club 22: 363. I 895.

(Not Aecidium Nesaeae Ger. Bull. Torrey Club 4: 47. I873.)

Dicaeoma Nesaeae Kuntze, Rev. Gen. $3^{3}: 469 . \quad$ I 898.

Allodus Nesaeae Arth. Résult. Sci. Congr. Bot. Vienne 345. 1906. Puccinia Ludwigiae Holway, N. Am. Ured. 1: 72. 1907. (Not

P. Ludwigiae Tepper, Bot. Centralb. 43: 6. I890.)

Aecia hypophyllous, in dense groups, of ten raised, rarely annular, on reddish spots, small, circular; aeciospores I3-I9 by I5$2 \mathrm{I} \mu$; wall $\mathrm{I}-\mathrm{I} .5 \mu$ thick, very minutely verrucose, appearing smooth in water.

Telia chiefly hypophyllous, inconspicuous, arising at first in and later around the aecia, uncovered, compact, dark cinnamonbrown; teliospores oblong to cylindrical or terete, I5-2I by 35-58 $\mu$; wall cinnamon-brown, $\mathbf{I} \cdot 5^{-2} \mu$ thick, smooth, apex 7-I $2 \mu$ thick, slightly paler; pedicel slightly tinted, sometimes as long as the spore.

On Onagraceae:

Ludwigia alternifolia L., L. glandulosa Walt., L. hirtella Raf., L. polycarpa S. \& P., L. sphaerocarpa Ell., L. virgata Michx., and L. palustris Ell.

Type Locality: Ellendale, Sussex County, Delaware, on Ludwigia sphaerocarpa (Commons, September I, I 892).

Distribution: Delaware to Iowa and to Florida and Louisiana. Note.-The telia are rarely collected; here described on $L$. polycarpa from Iowa and Missouri.

I6. Allodus imperspicua (Syd.) comb. nov.

Puccinia imperspicua Sydow, Monog. Ured. 1:36I. I902.

Aecia seen caulicolous only, gregarious, in oblong groups I-5 mm. long; aeciospores $\mathbf{I} 9-23$ by $2 \mathrm{I}-27 \mu$; wall about $\mathbf{I} \mu$ thick.

Telia amphigenous, caulicolous, scattered or occasionally confluent, roundish, early naked, pulvinate, chocolate-brown to blackish; teliospores broadly ellipsoid, $24-34$ by $34-5^{\mathrm{I}} \mu$; wall light chocolate-brown, 3-5 $\mu$ thick, the apex 7-Io $\mu$ thick, smooth; pedicel colorless, up to Ioo $\mu$ long.

On Ammiaceae:

Arracacia multifida.S. Wats. 
Type Locality: Rio Hondo, Mexico, on Arracacia multifida (Pringle, May 9, I89I).

Distribution: South Central Mexico.

Exsiccati: Ell. \& Er. Fungi Columb. 2060.

17. Allodus Jonesi (Peck) Arth. Résult. Sci. Congr. Bot. Vienne 345. I906

Puccinia Jonesii Peck, Bot. Gaz. 6:226. I88I.

Puccinia Cymopteri D. \& H. Bot. Gaz. 18:233. IS93.

Dicaeoma Cymopteri Kuntze, Rev. Gen. $3^{3}: 468 . \quad$ I 898.

Dicaeoma Jonesii Kuntze, Rev. Gen. $3^{3}: 469.1898$.

Aecidium Leptotaeniae Lindr. Medd. Stockh. Högsk. Bot. Inst.

$4^{9}: 8$. I901.

Puccinia Traversiana Syd. Monog. Ured. 1: 889. I904.

Accia chiefly hypophyllous, caulicolous, gregarious in roundish to oblong groups on yellowish spots; aeciospores $16-23$ by $18-26 \mu$; wall I-I.5 $\mu$ thick, finely verrucose.

Aecia amphigenous and caulicolous, scattered when foliicolous, often confluent on the stems, tardily naked, chocolate-brown to blackish; teliospores broadly ellipsoid to oblong, I $8-2+$ by $29-43 \mu$; wall dark cinnamon to chestnut-brown, $2-2.5 \mu$ thick, usually uniform, very minutely punctate to conspicuously verrucose, the tubercles usually arranged in longitudinal striations; pedicel colorless, deciduous, rarely the length of spore.

On Ammiaceas:

Aulospermum Betheli Osterh., A. purpureum (S. Wats.) C. \& R. (Cymopterus purpureus S. IVats.), Cogswellia foeniculacea (Nutt.) C. \& R. (Peucedanum foeniculaceum Nutt., Lomatium foeniculaceum C. \& R.), C. Grayi C. \& R. (Peucedanum Grayi C. \& R., Lomatium Grayi C. \& R.), C. macrocarpa (Nutt.) Jones (Pencedanum macrocarpum Nutt., Lomatium macrocarpum C. \& R.), C. nevadensis (S. W'ats.) Jones (Pencedamm nevadensis S. Viats.), C. orientalis (C. \& R.) Jones (Pencedanum nudicaule Nutt., Lomatium orientale C. \& R.), C. platycarpa (Torr.) Jones (Peucedanum simplex Nutt., Lomatium platycarpum C. \& R.), C. Suksdorfii (S. Wats.) Jones (Peucedanum Suksdorfii S. Wats., Lomatium Suksdorfii C. \& R.), C. triternata (Pursh) Jones (Peucedanum triternatum Nutt., Lomatium triternatum C. \& R.), Cymopterus acaulis (Pursh) Rydb., C. Fendleri 1. Gray, Cynomarathrum Eastioodii C. \& R., Leptotaenia 
Eatonii C. \& R., L. multifida Nutt. (Ferula multifida A. Gray). L. purpurea (S. Wats.) C. \& R. (Ferula purpurea S. Wats.), Musineon divaricatum (Pursh) C. \& R., M. Hookeri (T. \& G.) Nutt. (M. trachyspermum Nutt.), Phellopterus montanus Nutt. (Cymopterus montanus T. \& G.), Pteryxia calcarea (Jones) C. \& R., and P. terebinthina (Hook.) C. \& R. (Cymopterus terebinthinus T. \& G.).

Type Locality: Utah, on Ferula multifida and Peucedanum simplex (Jones, May and June).

Distribution: Alberta to California and east to Kansas and Nebraska.

Exsiccati: Carleton, Ured. Am. 3; Ell. \& Ev. N. Am. Fungi I448, I856, 3581; Ell. \& Ev. Fungi Columb. I298, I460, I966, I967, 2063; Barth. Fungi Columb. 3846; Sydow, Ured. 824, I929, I930; Clements, Crypt. Form. Colo. 567 ; Garrett, Fungi Utah. 5, 6, 7, 8; Barth. N. Am. Ured. $1055,1056,1146,1236,1556$. Note.-This species shows a wide variation in surface markings of teliospores on different hosts. On Musineon divaricatum great variation in this character is noticed on spores from one sorus.

I8. Allodus Erigeniae sp. nov.

Aecia amphigenous, caulicolous, gregarious, or scattered, cupulate or short-cylindrical, $0.2-0.4 \mathrm{~mm}$. in diameter; peridium colorless, margin incurved; peridial cells rhomboidal in longitudinal section, $2 \mathrm{I}-23$ by $29-45 \mu$, the outer wall finely striate, $5^{-7} \mu$ thick, the inner wall evenly and prominently lacerate-verrucose, $5^{-7 \mu}$ thick; aeciospores I6-2I by $\mathrm{I} 9-26 \mu$; wall $\mathrm{I}-\mathrm{I} .5 \mu$ thick, finely verrucose.

Telia chiefly hypophyllous, caulicolous, scattered, roundish to oval, $0.3^{-1} \mathrm{~mm}$. long, rather early naked, ruptured epidermis conspicuous, pulverulent, dark cinnamon-brown; teliospores broadly ellipsoid to oblong, 20-24 by $24-40 \mu$, slightly constricted at septum; wall cinnamon-brown, uniformly I. $5^{-2} \mu$ thick, finely and inconspicuously verrucose; pedicel colorless, short, fragile.

On Ammiaceae:

Erigenia bulbosa (Michx.) Nutt.

Type locality: London, Ontario, on Erigenia bulbosa (Deamess, May I 892).

Distribution: Ontario to Ohio.

Exsiccatı: Ellis, N. Am. Fungi Io4o b. 
19. Allodus microica (Ell.) comb. nov.

Puccinia microica Ellis, Jour. Myc. 7:274. I 893.

Dicaeoma microicum Kuntze, Rev. Gen. $3^{3}: 469 . \quad 1898$.

Aecia hypophyllous, gregarious, in roundish or oval groups; aeciospores, globoid, I4-I9 $\mu$ in diameter; wall $\mathrm{I}-\mathbf{I} .5 \mu$ thick, minutely verrucose.

Telia chiefly hypophyllous, caulicolous, crowded in and about the aecia or arising independently, rupturing by an apical pore, frequently in circular groups, cinnamon-brown; teliospores terete, I3-I9 by $27-42 \mu$; wall light cinnamon-brown, about $2 \mu$ thick, smooth, the apical pores covered with hyaline papillae, making the wall 5-7 $\mu$ thick; pedicel colorless, rarely as long as the spore.

On Ammiaceas:

Deringa canadensis (L.) Kuntze (Cryptotaenia canadensis (L.) DC.).

Type LocAlity: Garrett Park, Maryland, on Sanicula (?) error for Deringa canadensis (Southworth, May I890).

Distribution: Maryland to Iowa.

Note.-Puccinia Cryptotaeniae Peck is probably a correlated Dasyspora form. It has teliospores very similar to this species.

20. Allodus Lindrothii (Syd.) comb. nov.

Puccinia Lindrothii Sydow; Lindr. Acta. Soc. Faun. et Fl. Fenn.

22: 62. I902.

Puccinia sphalerocondra Lindr. Acta. Soc. Faun. et F1. Fenn.

22: 63. I 902.

Aecia chiefly hypophyllous, caulicolous, gregarious, in roundish or oblong groups; acciospores $\mathrm{I} 8-24$ by $23-32 \mu$; wall $\mathrm{I} .5^{-2} \mu$ thick, finely verrucose.

Telia chiefly hypophyllous, caulicolous, scattered, rarely confluent, rather early naked, ruptured epidermis conspicuous, chocolate-brown; teliospores broadly ellipsoid to oblong, I 8-26 by $29-42 \mu$; wall chestnut-brown, 3-3.5 $\mu$ thick, the apex rarely thickened up to $5 \mu$, evenly covered with longitudinal rows of small tubercles; pedicel colorless, rarely as long as the spore.

On Ammiaceac:

Drudeophytum Hartwegii (A. Gray) C. \& R. (Velaea Hartwegii C. \& R., Arracacia IIartwegii S. Wats.), and Velaea arguta (T. \& G.) C. \& R. (Deweya arguta T. \& G.).

Type Localnt: Berkeley, California on Arracacia Hartwegii (Blasdale, April 23 and May 3, 1894). 
Distribution: Known only from California.

Exsiccati: Sydow, Ured. 877, 878; Rab.-Wint.-Paz. Fungi Eur. 4022; Barth. N. Am. Ured. 349, 1256.

21. Allodus asperior (E. \& E.) comb. nov.

Puccinia asperior Ell. \& Ev. Bull. Washb. Lab. 1: 3. I884.

Dicaeoma asperius Kuntze, Rev. Gen. $3^{3}: 468.1898$.

Puccinia oregonensis Earle, Bull. N. Y. Bot. Gard. 2: 349. 1902. Allodus oregonensis Arth. Résult. Sci. Congr. Bot. Vienne 345.

I906.

Aecia hypophyllous, caulicolous, usually in large groups, of ten covering the entire surface of leaflets and considerable portions of the stems and petioles; aeciospores I 8-22 by 20-29 $\mu$; wall I.5$2 \mu$ thick, finely verrucose.

Telia hypophyllous, caulicolous, scattered or in small groups, of ten confluent, rather long covered by the epidermis, chocolatebrown; teliospores broadly ellipsoid to oblong, $2 \mathrm{I}-26$ by $29-40 \mu$; wall chestnut-brown, $2.5-3.5 \mu$ thick, the apex rarely thickened up to $5 \mu$, coarsely and sparsely tuberculate; pedicel colorless, rarely as long as the spore.

On Ammiaceae:

Leptotaenia dissecta Nutt. (Ferula dissoluta S. Wats.).

Type Locality: Klickitat Co., Washington, on Ferula dissoluta (June, I 883).

Distribution: Pacific Coast regions of the United States. Exsiccati: Barth. N. Am. Ured. I2I9.

Note.-Puccinia oregonensis was originally described as on Sanicula. The host is Leptotaenia.

\section{Allodus Musenii (E. \& E.) comb. nov.}

Puccinia Musenii Ell. \& Ev. Bull. Torrey Club 27: 6I. I900. Puccinia Seymourii Lindr. Med. Stockh. Högsk. Bot. Inst. $4^{9}: 4$. I90I.

Aecia unknown.

Telia amphigenous, caulicolous, scattered or confluent in large groups, long covered by the epidermis, black; teliospores broadly ellipsoid, $18-25$ by $29-42 \mu$; wall dark chestnut to chocolate-brown, 2-3 $\mu$ thick, the apex 4-7 $\mu$ thick, conspicuously but finely verrucose, especially at apex; pedicel colorless, usually deciduous, rarely 3 or 4 times the length of the spore. 
On Ammiaceae:

Musineon [Musenium] tenuifolium Nutt., Pseudocymopterus anisatus (A. Gray) C. \& R., P. bipinnatus (S. Wats.) C. \& R., and Oreoxis humilis Raf.

Trpe Locality: Freezeout Hills, Wyoming, on Musineon tenuifolium (Nelson, 449I, July I0, I 898).

Distribution: Montana to Colorado and Nebraska.

Exsiccati: Clements, Crypt. Form. Colo. I39; Barth. N. Am. Ured. 50 .

Note.-The teliospore wall gelatinizes and the spores swell to twice their normal size when heated in lactic acid.

\section{Allodus lacerata sp. nov.}

Aecia hypophyllous, caulicolous, gregarious on yellowish spots, frequently in two rows when on the veins; peridium white, margin deeply and conspicuously lacerate; peridial cells rhombic to rhomboidal in longitudinal section, $2 \mathrm{I}-26$ by $20-37 \mu$, the outer wall $4^{-5} \mu$ thick, smooth, the inner wall 5-7 $\mu$ thick, lacerateverrucose; aeciospores I 6-I 9 by I $8-23 \mu$; wall I-I.5 $\mu$ thick, finely verrucose.

Telia amphigenous, scattered, small, circular, early naked, chestnut-brown, ruptured epidermis not conspicuous; teliospores broadly ellipsoid, $23-26$ by $32-37 \mu$, constricted at septum; wall dark cinnamon-brown, uniformly $1.5^{-2} \mu$ thick, very minutely verrucose; pedicel colorless, half the length of spore or less.

\section{On Ammiaceae:}

Sanicula marilandica L.

Type locality: Palmer Lake, Colorado, on Sanicula marilandica (Bethel, August I, I903).

Distribution: Colorado to Canada.

Note-Puccinia Saniculae Grev. is a Dicacoma correlated with this species.

24. Allodus melanconioides (E. \& H.) Arth. Résult Sci. Congr. Bot. Vienne 345. 1906

Puccinia melanconioides Ell. \& Hark. Bull. Calif. Acad. Sci. 1:27. I $88+$.

Dicueoma melanconioides Kuntze, Rev. Gen. $3^{3}: 469$. Is98.

Aecia amphigenous, gregarious, annular; aeciospores $15^{-1} 8$ by $22-24 \mu$; wall about $1.5 \mu$ thick, finely verrucose.

Telia amphigenous, scattered, rather long covered by the epi- 
dermis; teliospores broadly ellipsoid $\mathrm{I} 9-29$ by $3 \mathrm{I}-49 \mu$; wall light chestnut-brown, uniformly $2-2.5 \mu$ thick, smooth; pedicel short, colorless.

On Primulaceae:

Dodecatheon cruciatum Greene, Dodecatheon latifolium (Hook.) Piper (D. Hendersonii A. Gray).

Type Locality: Antioch, California, on Dodecatheon "Meadia," error for D. latifolium.

Distribution: Pacific slope.

Exsiccati: Barth. N. Am. Ured. I55.

Note.-An undescribed correlated Dicaeoma occurs on the narrowleaved species of Dodecatheon.

\section{Allodus Swertiae (IVint.) comb. nov.}

Aecidium Swertiae Opiz, Seznam Rostlin II I. I852. [Hyponym.] Puccinia Swertiae Wint. Rab. Krypt. Fl. 1:205. I88I.

Dicaeoma Swertiae Kuntze, Rev, Gen. $3^{3}: 470 . \quad 1898$.

Aecia amphigenous, gregarious; aeciospores $16-22$ by $2 \mathrm{I}-29 \mu$; wall $I-I .5 \mu$ thick, light golden, finely verrucose, the pores rather distinct, scattered.

Telia amphigenous, scattered, chestnut-brown, rather early naked; teliospores broadly ellipsoid, $20-27$ by $33^{-43 \mu}$; wall light chestnut-brown, uniformly about $2 \mu$ thick, smooth; pedicel colorless, short.

Urediniospores occasionally found in the telia of European specimens.

On Gentianaceae:

Swertia perennis L., S. palustris A. Nels., and S. scopulina Greene.

Type LOCality: Bohemia on Swertia sp.

Distribution: Rocky Mountain Region; also in Europe.

Exsiccati: Clements, Crypt. Form. Colo. I44.

26. Allodus opulenta (Speg.) comb. nov.

Puccinia opulenta Speg. Anal. Soc. Ci. Argent. 9: 170. 1880. Aecidium Ipomoeae Speg. Anal. Soc. Ci. Argent. 9: I73. 1880. Dicaeoma opulentum Kuntze, Rev. Gen. $3^{3}: 469 . \quad$ I 898.

Aecia of primary form hypophyllous, sparsely gregarious, aecia of secondary form amphigenous, gregarious, frequently along the veins; aeciospores I $8-24$ by 2 I-3I $\mu$; wall $3-3.5 \mu$ thick, verrucose.

Telia amphigenous, usually surrounding the secondary aecia, 
frequently confluent, forming large sori, light chocolate-brown, rather early naked; teliospores cllipsoid, $24-35$ by $45-70 \mu$, dark chestnut-brown; wall $3 \cdot 5^{-}+\mu$ thick, rather coarsely and sparsely verrucose, the apex IO-I $3 \mu$ thick, with a semi-hyaline umbo; pedicel tinted next to the spore, up to I $35 \mu$ long.

On Convolvulaceae:

Exogonium arenarium Choisy (Ipomoea arenaria Steud., I. Steudeli Millsp.).

Type locality: Boca del Riachuelo, Argentina, on Ipomoea acuminata (Spegazzini, I880).

Distribution: West Indies; also in South America.

Exsiccati: Barth. N. Am. Ured. 429.

Note.-This species is readily separated from the other species of Allodus occurring on Ipomoea by the uniformly thick-walled aeciospores.

27. Allodus crassipes (B. \& C.) Arth. Résult. Sci. Congr. Bot. Vienne 345. 1906

Puccinia crassipes Berk. \& Curt. Grev. 3: 5+. I874.

Puccinia Ipomoeae Cooke; Lagerh. Tromsö Mus. Aarsheft. 17: 6I. I 895 .

Dicaeoma crassipes Kuntze, Rev. Gen. $3^{3}: 468 . \quad$ I 898.

Dicaeoma Ipomoeae Kuntze, Rev. Gen. $3^{3}: 469 . \quad$ I 898.

Aecia chiefly hypophyllous, often gregarious orer the entire leaf, aeciospores $16-22$ by $19-26 \mu$; wall $\mathrm{I}-\mathrm{I} .5 \mu$ thick, finely verrucose.

Telia amphigenous, surrounding the aecia, gregarious and of ten confluent to form large sori, early naked, dark chocolate-brown; teliospores broadly ellipsoid, $24-32$ by $39-6$ I $\mu$; wall $3-4$ thick, dark chestnut to chocolate-brown, moderately to sparsely and rather coarsely verrucose, the apex 6-9 $\mu$ thick with a broad semi-hyaline umbo; pedicel stout, tinted next to the spore, up to I $00 \mu$ long.

On Convolvulaceae:

Ipomoea cathartica Poir. (I. acuminata (Vahl) R. \& S., Phabartis cathartica Choisy), I. purga (IVender.) Hayne (I. Jalapa Nutt. \& Coxe), I. purpurea (L.) Roth, I. tiliacea (IVilld.) Choisy (I. fastigiata Sweet), I. trichocarpa Ell. (I. carolina Pursh, I. commutata R. \& S., I. caroliniana Pursh), I. triloba L. Tyé locality": Santee Canal, South Carolina, on Ipomoea trichocarpa. 
Distribution: Florida to Mexico and the West Indies; also probably in South America.

Exsiccati: Barth. Fungi Columb. 2456; Rav. Fungi Am. 792.

Note.-Aecidium Ipomoeae-panduranae Schw., and Aecidium convolvulatum Link, are species of Albugo according to notes in the Arthur Herbarium.

28. Allodus insignis (Holw.) comb. nov.

Puccinia insignis Holw. Ann. Мyc. 2: 392.1904.

Aecia of secondary form epiphyllous, occurring singly or in groups of two or three on rather large yellow spots; aeciospores not seen owing to lateness of collection.

Telia chiefly epiphyllous, in annular groups surrounding the aecia, dark chocolate-brown, small, pulvinate, rupturing at apex to form a characteristic ostiole; teliospores ellipsoid, 25-3I by 52-69 $\mu$, usually narrowed above; wall dark chestnut to chocolatebrown, $3-3.5 \mu$ thick, moderately and very inconspicuously verrucose-striate, the apex I2-23 $\mu$ thick, narrowed to form a semihyaline apiculus, slightly rugose at base; pedicel colorless, up to $85 \mu$ long.

On Convolvulaceae:

Ipomoea Wolcottiana Rose.

Type Locality: Cuernavaca, Mexico, on Ipomoea sp., now determined as I. Wolcottiana (Holway, September 25, I895).

Distribution: Known only from the type locality.

29. Allodus nocticolor (Holw.) comb. nov.

Puccinia nocticolor Holw. Ann. Myc. 2: 39I. I 904.

Aecia chiefly hypophyllous, in groups over nearly the entire leaf; aeciospores I9-24 by $24-29 \mu$; wall $2-3 \mu$ thick, thickened above $5^{-8} \mu$, very finely verrucose.

Telia chiefly epiphyllous, in confluent groups opposite or about the aecia, early naked, blackish; teliospores terete to fusiform, 26-32 by 5 I-7I $\mu$; wall dark chocolate-brown, 3-4 $\mu$ thick, coarsely and sparsely verrucose, the apex $12-19 \mu$ thick, nearly concolorous; pedicel up to $\mathrm{I} 60 \mu \mathrm{long}$, tinted close to the spore, frequently swollen below to twice the average diameter.

On Convolvulaceae:

Ipomoea fistulosa Mart. and Ipomoea intrapilosa Rose.

Type Locality: Cuernavaca, Mexico, on Ipomoca intrapilosa.

Distribution: Mexico.

Exiccati: Barth. N. Am. Ured. I $46 I$. 
30. Allodus superflua (Holw.) comb. nov.

Puccinia superfua Holw. Ann. Myc. 2: 392. 1904.

Aecia hypophyllous, the secondary form occurring singly or in groups; aeciospores $\mathrm{I} 6-\mathrm{I} 9$ by $2 \mathrm{I}-26 \mu$; wall $2-2.5 \mu$ thick, coarsely verrucose.

Telia chiefly epiphyllous, scattered, singly or in small groups over entire leaf, pulvinate, dark chocolate-brown, ruptured epidermis conspicuous; teliospores $25-32$ by $46-64 \mu$, broadly ellipsoid; wall $3 \cdot 5^{-}+\mu$ thick, lark chestnut to chocolate-brown, rather coarsely and sparsely tuberculate, the apex $8-12 \mu$ thick, nearly conculorous; pedicel light brown next to spore, up to $90 \mu$ long, uniform.

\section{On Conrolvulaceae:}

Ipomoea arborescens (H. \& B.) G. Don.

Trpe Locality: Iguala, State of Guerrero, Mexico on Ipomoea murucoides, error for $I$. arborescens.

Distribution: Known only from the type locality.

\section{I. Allodus megalospora sp. nov.}

Aecia chiefly hypophyllous, gregarious or occurring singly, distributed over the entire leaf, opposite the telia; acciospores 19-28 by $24^{-3}+\mu$; wall $\mathrm{I}-2 \mu$ thick, finely verrucose.

Telia chiefly epiphyllous, occurring singly or in groups, often confluent to form large pulverulent sori, of ten on the veins opposite the aecia, early naked, dark chocolate-brown, ruptured epidermis soon becoming inconspicuous; teliospores ellipsoid, $24^{-3} 3$ by 48-7 I $\mu$; wall $t^{-5} \mu$ thick, chocolate-brown, coarsely tuberculate, the apex $7^{-12} \mu$ thick, nearly concolorous; pedicel tinted next to spore, stout, up to i i $5 \mu$ long.

On Convolvulaceae:

Ipomoea arborescens (H. \& B.) Don, I. carolina L. (not I. carolina Pursh), I. intrapilosa Rose, and I. murucoides R. \& S. Type locality: Oaxaca, Mexico, on Ipomoea murucoides.

Distribution: Mexico and the ITest Indies.

Exsicciti: Sydow, Ured. 2036; Barth. N. Am. Lred. 429.

32. Allodus Douglasii (Ellis \& Ev.) comb). nov.

Puccinia Douglasii Ell. \& Er. Proc. Acad. Phil. 1893: I52. I 893. Dicaeoma Douglasii Kuntze, Rev. Gen. $3^{3}: 468 . \quad 1898$.

Puccinia Richardsoni Sydow, Monog. Treel. 1: 3 I7. 1902.

Aecia hypophyllous, covering the leaves, apparently from a perennial mycelium; aeciospores $\mathrm{I} 3-\mathrm{I}$ ) by $\mathrm{I} 7-2 \mathrm{I} \mu$; wall $\mathrm{I}-\mathbf{I} .5 \mu$ thick, fincly verrucose. 
Telia hypophyllous, usually in linear series along each side of the midrib, circular, pulvinate, dark chestnut-brown; teliospores ellipsoid to subpyriform, I 6-24 by $35-60 \mu$; wall $2-2.5 \mu$ thick, light chestnut-brown, smooth, the apex 8-I2 $\mu$ thick, concolorous; pedicel concolorous, rather stout, up to $55 \mu$ long.

On Polemoniaceae:

Phlox alyssifolia Greene, $P$. depressa (A. Nels.) Rydb., P. diapensioides Rydb., P. diffusa Hook., P. Douglasii Hook., and $P$. subulata L.

Type Locality: Detroit, Utah, on Phlox Douglasii.

Distribution: New Jersey to Washington, and New Mexico.

Exsiccati: Ell. \& Ev. N. Am. Fungi 299I; Ell. \& Ev. Fungi. Columb. I466; Barth. N. Am. Ured. 54.

33. Allodus Giliae (Peck) comb. nov.

Aecidium Giliae Peck, Bot. Gaz. 4: 230. 1879.

Puccinia plumbaria Peck, Bot. Gaz. 6: 238. I88I.

Puccinia Wilcoxiana Thuem. Myc. Univ. 2032, I88I.

Puccinia plumbaria phlogina Ellis, N. Am. Fungi I044. I883.

[Hyponym]

Aecidium Wilcoxianum Thuem. Myc. Univ. 2226. I 884. [Hy-

ponym]

Aecidium Cerastii Wint. Hedwigia 24: I79. 1885.

Aecidium Phlogis Peck; Arth. Bull. Iowa Agr. Coll. 1884: I67.

I 885. [Hyponym]

Puccinia fragilis Tracy \& Gall. Jour. Myc. 4: 20. I888.

Puccinia arabicola Ell. \& Ev. Jour. Myc. 6: I I9. I89I.

Aecidium Phlogis Ell. \& Ev. Bull. Torrey Club 24: 284. 1897.

Puccinia Purpusii P. Henn. Hedwigia 37:270. 1898.

Dicaeoma arabicola Kuntze, Rev. Gen. $3^{2}: 467 . \quad$ I 898.

Dicaeoma fragile Kuntze, Rev. Gen. $3^{3}: 468 . \quad$ I 898.

Dicaeoma plumbarium Kuntze, Rev. Gen. $3^{3}: 470 . \quad$ I 898.

Allodus plumbaria Arthur, Résult. Sci. Congr. Bot. Vienne 345.

Puccinia giliicola P. Henn. Hedwigia 37:270. 1898.

Accia hypophyllous, usually covering the entire leaf, apparently perennial; aeciospores I3-I9 by I4-22 $\mu$; wall about I $\mu$ thick.

Telia chiefly hypophyllous, caulicolous, scattered, rather long covered by the epidermis; teliospores broadly ellipsoid, I9-25 by $3 \mathrm{I}-45 \mu$; wall $2-2.5 \mu$ thick, light chestnut-brown, finely and closely verrucose, the apex $4-7 \mu$ thick; pedicel colorless, short. 
On Polemoniaceae:

Leptodactylon californicum H. \& A. (Gilia califormica Benth.), L. Nuttallii (A. Gray) Rydb. (Gilia Nuttallii A. Gray), Linanthus ciliatus (Benth.) Greene (Gilia ciliata Benth.), Microsteris gracilis (1)ougl.) Greene (Collomia gracilis Dougl., Gilia gracilis Hook.), M. humilis Greene, M. micrantha (Kell.) Greene, Phlox divaricata L., P. longifolia Nutt., P. multiflora A. Nels., P. speciosa Pursh, and $P$. Stansburyii (Torr.) Heller.

Type Locality: Alta, Wasatch Mts., Utah, on Gilia Nuttallii (Jones, August, alt. 8,00o ft.).

Distribution: Ontario to Mashington and south to California and Iowa.

Exsiccati: Ell. N. Am. Fungi 1044, I432; Ell. \& Ev. N. Am. Fungi 1831,3582 ; Ell. \& Ev. Fungi Columb. 763, I861, 1970; Rab.-Wint. Fungi Eur. 3519; Roum. Fungi Gall. 3926, 5213; Thuem. Myc. Univ. 2032, 2226; Sydow, Ured. I212, I527, 1936, I937, I938, I939; Garrett, Fungi Utah. I, 2, 3, 37, 38; Barth. Fungi Columb. 3857, 4761; Barth. N. Am. Ured. I62, 254, 255, 360, 1362; Rab.-Paz. Fungi Eur. 4221.

Note.-Several of the species listed in the synonymy were described on erroneously determined hosts.

34. Allodus melliferd (D. \& H.) Arth. Résult. Sci. Congr. Bot. Vienne 345. 1906

Puccinia mellifera Diet. \& Holw. Erythea 1:25. I 893.

Accia chiefly hypophyllous, singly or in small groups over a large portion of leaves; aeciospores I9-22 by 22-3I $\mu$; wall light cinnamon-brown, 3-4 $\mu$ thick, of ten appearing thicker, very finely verrucose, the pores visible, scattered.

'Telia amphigenous, caulicolous, scattered, early naked; teliospores broadly ellipsoid to obovoid, 25-3 I by $40-47 \mu$; wall $3-5 \mu$ thick, chestnut-brown, smooth, the apex $7-9 \mu$ thick, concolorous; pedicel colorless, fragile, up to i io $\mu$ long.

On Labiatae:

Audibertia grandiflora Benth. (Salvia spathacea Creene), A. incana Benth., and A. stachyoides Benth. (Salvia mellifera. (rreene).

Type localnty: P’asadena, California, on Salvia mellifera.

Distributiox: California to Nevada and Mexico.

Exsiccati: Barth. N. Am. Ureel. 757. 
35. Allodus vertisepta (Tracy \& Gall.) Arth. Résult. Sci. Congr. Bot. Vienne 345. 1906

Puccinia vertisepta Tracy \& Gall. Jour. Myc. 4:21. I888.

Diorchidium Tracyi De-Toni, in Sacc. Syll. Fung. 7: 736. I888.

Aecia chiefly hypophyllous, gregarious on circular, discolored spots; aeciospores broadly ellipsoid to pyriform; I 7-20 by $28-40 \mu$; wall $2-2.5 \mu$ thick, rather prominently and moderately verrucose, thickened at apex and base about equally, $5^{-9} \mu$, golden.

Telia chiefly epiphyllous, scattered, early naked, ruptured epidermis not conspicuous; teliospores subgloboid when seen with both cells in view, broadly ellipsoid with only one cell in view; wall dark chestnut to chocolate-brown, $2.5-3 \mu$ thick, finely verrucose, the apex 6-7 $\mu$ thick, hyaline at the tip; pedicel colorless, attached at septum, up to $50 \mu$ long.

On Labiatae:

Salvia ballotaeflora Benth. and S. Sessei Benth.

Type locality: New Mexico on Salvia ballotaeflora.

Distribution: New Mexico to Mexico.

Exsiccati: Barth. N. Am. Ured. 275, 875.

Note.--The so-called uredo are really aecia, according to a note in the Arthur Herbarium by Holway, who has examined the original specimen at the Mo. Bot. Garden.

36. Allodus Chavaesarachae (Syd.) Arth. Résult. Sci. Congr. Bot. Vienne 345. 1906

Puccinia Chamaesarachae Sydow, Monog. Ured. 1:263. 1902.

Aecia hypophyllous, gregarious, covering nearly the entire surface of leaves and dwarfing the plants; aeciospores $16-19$ by 20-25 $\mu$; wall $1.5^{-2} \mu$ thick, finely verrucose.

Telia chiefly hypophyllous, within or among the secondary aecia, sometimes confluent; teliospores broadly ellipsoid, I 7-20 by $25^{-3}$ I $\mu$; wall about $2 \mu$ thick, light chestnut-brown, very finely verrucose, the apex very slightly thickened, about $3 \mu$; pedicel colorless, short.

\section{On Solanaceae:}

Chamaesaracha nana A. Gray.

Type Locality: California, on Chamaesaracha nana.

Distribution: California and Nevada.

Exsiccati: Ellis, N. Am. Fungi I476; Barth. Fungi Columb. 3840 ; Barth. N. Am. Ured. 229.

Note.-All collections from Truckee are from California; not from Nevada as the data on packets appear to show. 
37. Allodus Palmeri (D. \& H.) Arth. Résult. Sci. Congr. Bot. Vienne 3+5. 1906

Puccinia Palmeri Diet. \& Holw. Erythea 7: 98.1899.

Aecia chiefly hypophyllous, scattered or in annular groups; aeciospores $\mathrm{I} 7^{-20}$ by I9-29 $\mu$; wall I.5-2 $\mu$ thick, golden.

Telia amphigenous, scattered among the secondary aecia, pulvinate, ruptured epidernis conspicuous; teliospores broadly ellipsoid, I $7^{-25}$ by $3^{I-43 \mu}$; wall $I .5^{-2} \mu$ thick, dark cinnamon-brown, minutely verrucose, appearing smooth when wet, the apex $3^{-5} \mu$ thick; pedicel light golden, short.

On Scrophulariaceae:

Pentstemon chionophilus Greene, $P$. confertus Dougl., $P$. Harbourii A. Gray, P. Menziesii Hook., P. Newberryi A. Gray, $P$. ovatus Dougl., P. pinetorum Piper, and P. humilis Nutt. Type locality: Lake Tahoe, California, on Pentstemon confertus. Distribution: Washington to Colorado and Nevada. Exsiccati: Barth. N. Am. Ured. 1463.

38. Allodus Rufescens (D. \& H.) Arth. Résult. Sci. Congr. Bot. Vienne 345. 1906

Puccinia rufescens Diet. \& Holw. Bot. Gaz. 18:253. I893.

Dicaeoma rufescens Kuntze, Rev. Gen. $3^{3}: 470 . \quad 1898$.

Aecia amphigenous, singly or in groups, scattered over entire leaf; aeciospores $17-23$ by $20-29 \mu$; wall $\mathrm{I}-\mathrm{I} .5 \mu$ thick, yellow.

Telia amphigenous, occurring around and among the secondary aecia, rather large, ruptured epidermis not conspicuous; teliospores broadly ellipsoid, $19-26$ by $29-42 \mu$; wall $2-3 \mu$ thick, light cinnamon-brown, coarsely verrucose, the apex thickened up to $7 \mu$; pedicel colorless, short.

On Scrophulariaceae:

Pedicularis canadensis L., P. centranthera A. Gray, and $P$. semibarbatus A. Gray.

Type locality: King's River Cañon, California, on Pedicularis semibarbatus (Holway, July I5, I 892).

Distribution: Colorado to California.

Exsiccati: Sydow, Ured. $78_{1}$; Barth. N. Am. Ured. I267; Clements, Crypt. Form. Colo. 576 .

39: Allodus Bouvardiae (Griff.) comb. nov.

Puccinia Bonvardiae Griff. Bull. Torrey Club 29:297. 1902.

Accia hypophyllous, gregarious; aeciospores i9-23 by $23-26 \mu$; wall $\mathrm{I}-\mathrm{I} .5 \mu$ thick, finely verrucose. 
Telia chiefly epiphyllous, scattered, pulvinate, ruptured epidermis not conspicuous; teliospores broadly ellipsoid, 26-29 by 35-45 $\mu$; wall $3-4 \mu$ thick, chestnut-brown, finely verrucose, the apex up to $7 \mu$ thick, with a hyaline umbo; pedicel colorless, up to I oo $\mu$ long, slightly roughened below.

\section{On Rubiaceae:}

Bouvardia triphylla Salisb.

Type Localıty: Santa Catalina Mts., Arizona, on Bouvardia triphylla.

Distribution: Known only from Arizona.

Exsiccati: Griff. W. Am. Fungi 394.

40. Allodus ambigua (A. \& S.) Arth. Résult. Sci. Congr. Bot. Vienne 345. I 906

Aecidium Galii ambigumm A. \& S. Consp. Fung. I I6. I 805.

Puccinia difformis Kunze, Myk. Hefte 1: 7I. I8I7.

Puccinia ambigua Lagerh.; Bubák, Sitz.-ber. Böhm. Ges. Wiss.

$1898^{28}:$ I 4. I 898.

Aecia hypophyllous, grouped on reddish-brown spots; aeciospores I 4-I9 by I 7-22 $\mu$; wall about I $\mu$ thick, finely and distinctly verrucose.

Telia hypophyllous and caulicolous, arising from around the secondary aecia or scattered, rather long covered by the epidermis, cinereous; teliospores ellipsoid $\mathrm{I} 4-22$ by $3 \mathrm{I}-43 \mu$; wall light chestnut-brown, about I $\mu$ thick, smooth, the apex 6-Io $\mu$ thick; pedicel slightly tinted, up to the length of spore.

\section{On Rubiaceae:}

Galium Aparine L.

Type locality: Germany, on Galium Aparine.

Distribution: Ohio to British Columbia and California; also in Europe.

Exsiccati: Sydow, Ured. 2259; Brenckle, Fungi Dakot. 59; Barth. N. Am. Ured. 1426.

4I. Allodus commutata (Syd.) Arth. Résult. Sci. Congr. Bot. Vienne 345. I906

Puccinia commutata Sydow, Monog. Ured. 1:201. 1902.

Aecia hypophyllous, gregarious or scattered over leaf, often on large yellow spots; aeciospores I2-I9 by I6-2 I $\mu$; wall I-I.5 $\mu$ thick, finely verrucose.

Telia amphigenous, caulicolous, around the secondary aecia, 
circular, rupturing at the apex to form a characteristic ostiole; teliospores ellipsoid, 20-26 by 39-59 $\mu$; wall $\mathbf{I} .5^{-2} \mu$ thick, dark cinnamon-brown, the apex $7-9 \mu$ thick, with a semi-hyaline umbo; pedicel slightly tinted next to the spore, short.

On Valerianaceae:

Valeriana acutiloba Rydb., V. edulis Nutt., V. occidentalis Heller, and $V$. sitchensis Bong.

TyPE LOCALity: Europe, on Valeriana officinalis.

Distribution: British Columbia to New Mexico; also in Europe. Exsiccati: Ell. \& Ev. N. Am. Fungi $22 I I$; Barth. N. Am. Ured. $23 I$.

42. Allodus intermixta (Peck) Arth. Résult. Sci. Congr. Bot. Vienne $345 . \quad 1906$

Puccinia intermixta Peck, Bot. Gaz. 4:218. 1879.

Aecidium intermixtum Peck, Bot. Gaz. 4:23I. I879.

Dicaeoma intermixtum Kuntze, Rev. Gen. $3^{3}: 469 . \quad$ I 898.

Aecia amphigenous, over entire leaf, apparently from a perennial mycelium; aeciospores, $17-22$ by $22-28 \mu$; wall about $1.5 \mu$ thick, finely verrucose.

Telia amphigenous, scattered among the accia, epidermis rupturing at apex to form a conspicuous ostiole; teliospores broadly ellipsoid, $20-25$ by $3 \mathrm{I}-37 \mu$; wall $\mathrm{I} .5^{-2} \mu$ thick, cinnamonbrown, very finely verrucose, the apex very slightly thickened to $3 \mu$; pedicel colorless, short.

On Ambrosiaceae:

Iva axillaris Pursh.

Type Lochlity: Green River, IVyoming, on Iva axillaris.

Distribltion: South Dakota to Washington and New Mexico.

Exsiccati: Ell. \& Ev. N. Am. Fungi 2230, 2252a, 2405; Barth.

Fungi Columb. 376r, 3845; Griff. IV. Am. Fungi 200; Garrett,

Fungi Utah. I63; Barth. N. Am. Ured. 747, 748, 1457; Ell. \& Er. Fungi Columb. 63.

43. Allodus Batesiana Arth. Résult. Sci. Congr. Bot. Vienne 3+5. 1906

Puccinia Batesiana Arth. Bull. Torrey Club 28: 661. I90I.

Aecia hypophyllous, gregarious or scattered, often on discolored spots; aeciospores, I $6-20$ by $22-26 \mu$; wall about I $\mu$ thick.

Telia chiefly hypophyllous, gregarious, or scattered, often arising about the accia, long covered by the epidermis, blackish, 
surrounded in the sori by a well-developed dark brown stroma; teliospores terete, sometimes truncate above, I $5^{-I 9}$ by $45^{-5} 8 \mu$; wall about I $\mu$ thick, cinnamon-brown, smooth, the apex 7-I $6 \mu$ thick; pedicel tinted, short.

On Compositae:

Helicopsis helianthoides (L.) Sweet and H. scabra Dunal.

Type locality: Long Pine, Nebraska, on Helicopsis scabra.

Distribution: Nebraska, Iowa, Minnesota and Delaware.

Exsicchti: Ell. \& Ev. Fungi Columb. 1463; Griff. IV. Am. Fungi 322; Barth. Fungi Columb. 4I4I; Barth. N. Am. Ured. 125, 929.

44. Allodus tenuis (Schw.) Arth. Résult. Sci. Congr. Bot. Vienne 345. I 906

Caeoma (Aecidium) tenue Schw. Trans. Am. Phil. Soc. II. 4: 293. I 832 .

Puccinia tenuis Burr. Bot. Gaz. 9: I88. I884.

Dicaeoma temue Kuntze, Rev. Gen. $3^{3}: 470 . \quad 1898$.

Aecia hypophyllous, in annular groups on discolored areas or scattered in small groups over the leaf; aeciospores II-I4 by I2-I $7 \mu$; wall about I $\mu$ thick, finely verrucose.

Telia chiefly hypophyllous, intermixed with the secondary scattered aecia, long covered by the epidermis, surrounded in the sori by a well-developed brown stroma; teliospores fusoid to cylindrical, II-I 4 by $26-3+\mu$; wall cinnamon-brown, about I $\mu$ thick, smooth, the apex 5-7 $\mu$ thick; pedicel concolorous, short.

On Compositae:

Eupatorium urticaefolium Reich. (E. ageratoides L. f.)

Type Locality: Bethlehem, Pennsylvania, on Eupatorium ageratoides.

Distribution: Vermont to West Virginia, Minnesota, and Iowa. Exsiccati: Ell. N. Am. Fungi I420, I838; Ell. \& Ev. N. Am. Fungi I810; Rab.-Paz. Fungi Eur. 4141; Barth. N. Am. Ured. 65.

45. Allodus gnaphaliata (Schw.) Arth. Résult. Sci. Congr. Bot. Vienne 345. 1906

Aecidium gnaphaliatum Schw. Trans. Am. Phil. Soc. II. 4: 292. I 832.

Puccinia investita Schw. Trans. Am. Phil. Soc. II. 4: 296.1832. Dicaeoma investitum Kuntze, Rev. Gen. $3^{3}: 469 . \quad$ I 898.

Aecia hypophyllous, opposite conspicuous yellow areas on the leaf, gregarious; aeciospores $\mathrm{I}^{-2}-23$ by $20-29 \mu$; wall $\mathrm{I} .5^{-2} \mu$ thick, rather conspicuously verrucose. 
Telia hypophyllous, scattered, rather tardily naked; teliospores clavate to pyriform, I $7-25$ by $36-53 \mu$; wall dark chestnut-brown, I-I.5 $\mu$ thick, smooth, the apex $7-$ I $2 \mu$ thick; pedicel light golden, rarely as long as the spore.

On Compositae:

Gnaphalium californicum DC., G. decurrens Ives, G. leptophyllum DC., G. leucocephalum A. Gray, G. margaritaceum L., G. obtusifolium L. (G. polycephalum Michx.), G. oxyphyllum DC., and G. semiamplexicaule DC.

Type Locality: Bethlehem, Pennsylvania, on Gnaphalium polycephalum.

Distribution: United States and Mexico.

Exsiccati: Ell. \& Ev. Fungi Columb. I285, I764; Sydow, Ured. I773; Barth. N. Am. Ured. 549; Ell. \& Ev. N. Am, Fungi 3560.

46. Allodus Desmanthodi (D. \& H.) Arth. Résult. Sci. Congr. Bot. Vienne 345. 1906

Puccinia Desmanthodii Diet. \& Holw. Bot. Gaz. 31: 33t. I90I.

Aecia amphigenous, gregarious; acciospores $14-19$ by $17-20 \mu$; wall $\mathrm{I}-\mathrm{I} .5 \mu$ thick, with fine deciduous, verrucose markings.

Telia chiefly hypophyllous, gregarious over large areas, usually surrounding the aecia, long covered by the epidermis, surrounded in the sori by a dark brown stroma; teliospores terete to cylindrical, I2-I 6 by 45-6I $\mu$; wall cinnamon-brown, I-I.5 $\mu$ thick, smooth, the apex $5^{-8 \mu}$ thick; pedicel concolorous, up to the length of spore.

On Compositae:

Desmanthodium fruticosum Greenm. and D. oratum Benth.

Type Locality: Oaxaca, Mexico, on Desmanthodium ovatum. (IIolway, 3665, Oct. I8, I 899.)

Distribution: Mexico.

Exsiccati: Barth. N. Am. Ured. 234, 1540.

47. Allodus subcircinata (E. \& E.) Arth. Résult. Sci. Congr. Bot. Vienne 345. I906

Puccinia subcircinata Ell. \& Ev. Jour. Myc. 3: 56. I 887.

Dicaeoma subcircinatum Kuntze, Rev. Cien. $3^{3}: 470 . \quad$ I 898.

Accia hypophyllous, annular, or in small groups on conspicuous yellow areas of the leaf; aeciospores $16-19$ by $17-20 \mu$; wall I-I.5 $\mu$ thick, finely verrucose. 
Telia chiefly hypophyllous, surrounding the secondary aecia or scattered, sometimes confluent to form large sori, rupturing at the apex to form a conspicuous ostiole; teliospores broadly ellipsoid, I 5-2 I by 25-32 $\mu$; wall chestnut-brown about I.5 $\mu$ thick, smooth, the apex sometimes thickened to $3 \mu$; pedicel colorless, rarely as long as the spore.

On Compositae:

Senecio atriapiculatus Rydb., S. crassulus A. Gray, S. dispar A. Nels., S. hydrophilus Nutt., S. hydrophilus pacificus Greene, S. integerrimus Nutt., S. lugens Rich., S. taraxacoides (A. Gray) Greene, and S. triangularis Hook.

Type Locality: Mt. Paddo, Washington, on Senecio triangularis. (Suksdorf, Aug. I 885.)

Distribution: Nebraska to California and British Columbia.

Exsiccati: Ell. \& Ev. N. Am. Fungi 1840; Ell. \& Ev. Fungi Columb. 1459; Sydow, Ured. 782, 1943; Garrett, Fungi Utah. 29, 106; Barth. Fungi Columb. 4468; Barth. N. Am. Fungi 1371,1372 .

Note.-This species is distinguished from Allodus Senecionis (Lib.) Arth. by the slightly smaller aeciospores and the scarcely thickened apex of the teliospores, without the hyaline umbo. A. Senecionis is not known to occur in North America.

Aecidium

Cerasti, 199

claytoniatum, i $8+$ convolvulatum, I 97

Galii ambiguum, 203

Giliae, I 99

gnaphaliatum, 205

graminellum, I 80

intermixtum, 204

I pomoeae, 195

Ipomoeae-panduranae, 197

Leptotaeniae, I90

Ludwigiae, 189

monoicum, I 88

Nesaeae, 189

Phlogis, 199

Podophylli, I 86

podophyllatum, I 87

Swertiae, 195

tenue, 205

Vilcoxianum, 199

Allodus

a mbigua, 177,203

areolata, I 86 asperior, 193

\section{INDEX TO SPECIES}

Batesiana, 177,204

Bouvardiae, 202

Calochorti, I8I

Carnegiana, I 82,183

Chamaesarachae, 177,201

claytoniata, $177,184,185$

commutata, 203

consimilis, 177,187

crassipes, I96

Desmanthodii, 206

Dichelostemmae, $\mathrm{I}_{3}$

Douglasii, 177, I 98

eff usa, I 88

Erigeniae, 19I

gigantispora, I 85

Giliae, 177, 199

gnaphaliata, 205

graminella, I 78 , I 80

imperspicua, I 89

insignis, 197

intermixta, I 77, 204

Jonesii, I90

lacerata, I94

Lindrothii, I92

Ludwigiae, I 89

megalospora, 198

melanconioides, 194 mellifera, 200

microica, 192

Moreniana, I 82

Musenii, I93

Nesacae, I 89

nocticolor, 197

opposita, I 85

opulenta, I95

oregonensis, 193

pagana, I 8 I

Palmeri, 202

plumbaria, 199

Podor ny li, I 78 , I 86

rufescens, 202

subangulata, I 83

subcircinata, 206

superflua, I98

Senecionis, 207

Swertiae, 195

tenuis, 205

vertisepta, 200

Caeoma

claytoniatum, I 84

podophyllatum, I 87

tenue, 205 
Dasyspora

Anemones-virginianae, I 85

Dicaeoma

anachoreticum, I S I

arabicola, 199

areolatum, I 86

asperius, 193

claytoniatum, I 84

Clematidis, 185

consimile, 187

crassipes, 196

Cymopteri, I90

Douglasii, 198

fragile, 199

Holway i, 18 I

intermixtum, 204

investitum, 205

Ipomoeae, 196

Jonesii, 190

melanconioides, 194

microicum, I92

Nesaeae, 189

opulentum, I95

plumbarium, 199

Podophylli, I 87

rufescens, 202

subcircinatum, 206

Swertiae, I95

tenue, 205

Violae, 188

Diorchidium

Tracyi 201

Allium, I81, I 82

Anemone, 185, I 86

Arracacia, 189, '190, 192

Audibertia, 200

Aulospermum, 190

Bouvardia, 203

Brodiaea, I 82, I $83,18+$

Calochortus, 182

Caltha, 186

Chamaesaracha, 201

Claytonia, $18+185$

Cogswellia, 190

Collomia, 199

Cryptotaenia, 192

Cymopterus, 190, I9I

Cynomarathrum, 190

Jeringa, 102

Desmanthorlium, 206

Deweya, 192

Dichelostemma, $183,18+$

Dipterostemon, 182,183
Puccinia

aculeata, I 86, I 87

ambigua, 203

anachoreta, I 8 I

arabicola, 199

areolata, 186

asperior, 193

aurea, I 87

Batesiana, 204

Bouvarrliae, 202

Calochorti, I 8 I

Carnegiana, I 82

Chamaesarachae, 201

claytoniata, I 8 t

commutata, 203

consimilis, 187

crassipes, 196

Cryptotaeniae, I92

Cymopteri, I90

deBaryana, 185

Desmanthodii, 206

Dichelostemmae, I 83

difformis, 203

effusa, 188

fragilis, 199

gigantispora, 185

giliicola, I99

graminella, 180

Holboelli, 188

Holwayi, 18 I

imperspicua, I 89

insignis, 197

intermixta, 204

investita, 205

I pomoeae, 196

japonica, I 86
Jonesii, 190

Lindrothii, I92

Ludwigiae, I 89

Mariae-Wilsoni, 184

melanconioides, 194

mellifera, 200

microica, 192

Moreniana, 182

Musenii, 193

Nesaeae, I 89

nocticolor, 197

nodosa, 182, I 83

opulenta, 195

oregonensis, 193

pagana, I 8 I

Palmeri, 202

plumbaria, 199

plumbaria phlogina, 199

Podophylli, 176, 178, 186, I 87

Purpusii, 199

Richardsonii, 198

rufescens, 202

Saniculae, I94

Seymourii, 193

sphalerocondra, 192

subangulata, I 83,184

subcircinata, 206

superflua, 198

Swertiae, I95

tenuis, 205

Traversiana, 190

tumamocensis, I $\delta_{3}$

vertisepta, 200

Wilcoxiana, I99

\section{INDEX TO HOST GENERA}

Dodecatheon, 195

Drudeophytum, 192

Erigenia, 191

Eupatorium, 205

Exogonium, 196

Ferula, I9 I, I93

Galium, 203

Gilia, 199, 200

Gnaphalium, 206

Helicopsis, 205

Hookera, 183, I 8 t

Iponioea, 196, 197, 198

Iva, $20 t$

Leptodactylon, 199

Leptotaenia, I90, I9 I, I93

Linanthus, 200

Lomatium, 190

Ludwigia, 189

Microsteris, 199, 200

Montia, $18+$
Musineon, 191, 194

Oreoxis, I9t

Pedicularis, 202

Pentstemon, 202

Peucedanum, I90, I9 I

Phabartis, 196

Phellopterus, i9I

Phlox, 199, 200

Podopliyllum, i 87

Pseudocymopterus, I94

Pteryxia, I9I

Salvia, 200, 201

Sanicula, 192, 193, 194

Senccio, 207

Sisymbrium, I 88

Stipa, I 8 I

Swertia, 195

Valeriana, 204

Yelaea, I92

Viola, I7t, I 88 


\title{
THE DEVELOPMENT OF LEPIOTA CRISTATA AND L. SEMINUDA
}

\author{
Geo. F. Atkinson \\ Cornell University
}

(WITH PLATES 21-26)

\section{INTRODUCTION}

The development of the fruit body in the Agaricaceae, with special reference to the differentiation and organization of the principal parts, has been studied in comparatively few forms. Approximately sixty species representing some twenty genera have been examined. More than three fourths of these species were studied during a comparatively early period, from 1842 to I889, when the methods of technique employed were less satisfactory than at the present time. Consequently many of the species studied during that period were more or less imperfectly examined. During the last decade less than a dozen species have been studied. Owing to progress in technique, this study has been correspondingly intensified and more satisfactory results have been obtained.

The unfolding of the parts of the fruit body, after their organization in the young basidiocarp, has been studied in a large number of species. But this phase of the work relates almost wholly to macroscopic observations on the gross morphology. These studies of the grosser features in development cover a period of about one hundred years, beginning early in the nineteenth century, when the science of mycology began to emerge from its mystic age. These morphological features have been the chief elements on which all our taxonomic systems of the fungi have been based. We continue to shuffle them into new patterns, or dies, for the rearrangement of present, or the manufacture of new genera, without a clear understanding, in many instances, of their real taxonomic significance.

A study of the origin, differentiation, and organization of the 
parts of the basidiocarp in the Agaricaceae is essential to a clear understanding of their taxonomic value. There is needed a study of development of many more species representing all the principal genera and their subdivisions, as well as some of the lesser ones, before we shall be in a position safely to make any generalizations in regard to the prevalence of any mode of origin or development of the principal parts of the fruit body, or of their relative taxonomic importance. These studies on the development of Lepiota cristata and L. seminuda are offered as a further contribution to this subject. They deal chiefly with the origin, differentiation, and organization of the pileus, stem, lamellae, and veil, in the young primordial basidiocarps. The origin of the primordial basidiocarp, and the nuclear phenomena in the ontogenetic cycle, while exceedingly interesting and important problems, do not appear, so far as we know at present, to be closely correlated with the differentiation of the parts in the primordial fruit body.

\section{LEPIOTA CRISTATA}

Material.-Lepiota cristata is a small plant, usually about $4^{-6}$ $\mathrm{cm}$. high, with a pileus $\mathrm{I}-2.5 \mathrm{~cm}$. broad, and the stem $2-4 \mathrm{~mm}$. thick. The general color is whitish, the pileus being adorned with numerous dark, fibrous, more or less erect scales formed by the laceration of its upper surface, more crowded over the center, thus giving the plant a cristate appearance. It occurs singly, or more frequently in troops; rarely are the plants so closely clustered that two or three may be joined at the base. It grows on the ground in woods and open places from spring until autumn. The material for this study was collected, fixed in chromacetic and imbedded in paraffin by Miss Gertrude Douglass during the summer of 1914 . The plants were gathered chicfly along Cascaclilla Creek by a path in a grove of mixed hemlock spruce and hard timber, mainly oak; some also from a similar grove by a path along Fall Creek, the two streams bordering the Cornell University Campus on the south and north sides. Where the plants occur in troops there is usually an abundance of the "spawn" in the soil and individuals in all stages of development are to be found. In such cases, the spawn often continues to produce fresh individuals for a period of one to several wecks. This succession of individuals distributed on the spawn, when weather conclitions are favorable, assures the 
normal organization and development of the young basidiocarps. The material was sectioned, and stained with fuchsin, by the writer.

Differentiation of pileus and stem fundaments.--The youngest basidiocarps examined were rather long-ovate in form, I $\mathrm{mm}$. long by $0.5 \mathrm{~mm}$. in diameter (FIG. I). At this stage there is no differentiation into pileus and stem primordia. But the young fruit body is slightly differentiated into a basal area of a more compact texture, oval in form, the rounded apex extending into the upper area of looser texture which fits over it somewhat like a mitrate calyptra, the elements of the two areas merging along the border zone. The basal area takes the stain more deeply, the hyphae are rather intricately interwoven, while those of the upper region extend more or less in a longitudinal direction. In the mitriform area the general direction of the hyphae is also longitudinal, but they are more or less interwoven. Those over the apex, or crown, are thus more or less perpendicular to the surface, while those on the lateral face below the crown are parallel with the surface.

The basal portion of the young fruit body is the "foot," the basal part of the stem, corresponding to the bulb. From the apex of this the stem fundament arises endogenously by new growth of hyphal branches upward and by interstitial elongation. This new growth area progresses toward and partly into the mitriform area above, where it begins to expand laterally, forming the pileus primordium. Stem and pileus primordia at this stage form an internal area somewhat sheaf-shaped in outline as shown in FIGURE 2. The mitriform area at this stage belongs chiefly to the blematogen, but the boundary between blematogen and pileus primordium is very indefinite. The blematogen also extends down on the stem fundament. The hyphae of the blematogen layer above and on the flanks of the pileus fundament are radial and somewhat interwoven, but are more nearly parallel in their arrangement than in younger stages represented by FIGURE I.

Origin and development of the hymenophore primordium.-The pileus primordium continues to enlarge by radial growth and by the origin of new hyphal branches. On the lower marginal periphery numerous new hyphal branches arise, extending laterally 
and somewhat downward, at an oblique angle from the stem axis. These branches at first are more or less isolated, are slender, and make their way through the loose mesh of the ground tissue. As they increase in number they become more or less crowded, and parallel. This internal annular zone of new growth is the primordium of the hymenophore and pileus margin (FIGS. 3-6). The hyphae are rich in protoplasm and stain deeply in contrast to the hyphae of the ground tissue and of the pileus and stem fundaments. In median longitudinal section of the young basidiocarps, the hymenophore fundament appears as two symmetrically disposed deeply stained areas near the margin of the pileus above the weakly developed annular cavity as shown in FIGURE 3. Its character is more clearly seen in longitudinal "tangential" sections.

FIGLRE 4 is from a "tangential" section of the same basidiocarp, parallel with the stem axis and through the hymenophore primordium. The light area is the weak annular cavity with shreds of the ground tissue extending across the cavity. The slender hyphac above the cavity are those of the hymenophore primordium. They are parallel, but not very crowded, their ends do not form an even lower surface, but their different lengths and loose arrangement indicate a fimbriate condition of the hymenophore primordium. FIGURE 6 is from a similar section of another basidiocarp. 'The annular cavity is not so well formed, but the character of the hymenophore primordium is well shown. FigurE 5 is from a section of the same hasidiocarp (as represented in FIGURE 6), also "tangential, " but it runs through the stem surface in the angle at the.junction of pileus and stem. The hymenophore is therefore not continuous in this section, but is shown as two broad deeply stained areas one on either side of the central pileus tissue.

Origin of the general anmular gill cavity.-The rapid increase in the elements of the hymenophore, and their increase in diameter as the primordial stage of the hymenophore changes to the palisade stage, together with the centrifugal and epinastic growth of the pileus margin, ${ }^{1}$ produces a tension on the ground tissue below

1 for a full discussion of the organization and development of the hymenophore and its relation to the aunular cavity see Atkinson, Geo. F. Norphology and development of Agaricus Rodmani. Proc. An. Phil. Soc. 54:309-343. pl. o-13. 1915. 
which ruptures it and forms an internal, annular cavity below the hymenophore primordium. Since the lamellae are later formed in this cavity, as downward projecting salients, it is known as the general annular prelamellar (or gill) cavity. In Lepiota cristata this cavity is not proportionately so large as in Lepiota seminuda described later in this paper. It is weak in the FIGUREs 3 to 6 , but as the palisade area is organized and the gill salients begin to form the annular cavity is more pronounced. It is as broad as the area between the stem and margin of the pileus, but not very deep, as shown in FIGUREs $7-17$. The epinastic growth of the margin of the pileus lifts the veil up to some extent, thus narrowing the cavity, but in the cases observed the veil is not crowded against the margin of the lamellae, as sometimes occurs in the species of the genus Agaricus (Atkinson, '15). It may very likely occur in certain individuals of Lepiota cristata.

Origin of the lamellae.-The growth of the pileus margin is centrifugal. The extension of the hymenophore primordium, developed on its under surface is therefore also centrifugal, the older stages being next the stem and the younger ones next the margin of the pileus. As the primordium of the hymenophore ages, the hyphae increase in number by new branches crowding in between the older ones. The hyphae also increase in diameter, becoming parallel and closely packed side by side. Their free ends also come to reach the same level, thus forming an even palisade layer. This begins next the stem and proceeds in a centrifugal manner toward the margin of the pileus, the primordial condition of the hymenophore gradually becoming changed into the palisade condition.

The lamellae arise as downward growing radial salients of the level palisade. These salients begin next the stem and progress centrifugally toward the margin of the pileus (for details of this process see Atkinson, '15). Figures 7 -I2 show the origin of the lamellae in one fruit body. The sections from which the photographs were made were selected from a series of sections passing from the middle of the pileus toward its margin. FIGURE 7 is a median longitudinal section, and is therefore nearly or quite parallel with the lamellae. At the left side of the figure the section passes parallel with and through the lamellae, while on the right it passes in a slightly oblique direction. FIGURE 8 is 
from a section on one side of the central axis of the stem. At the left a gill salient is shown cut obliquely, while at the right the section is from between two adjacent lamellac. In FIGURE 9 the section is "tangential" and not far from the angle of the junction of stem and pileus; since the lamellae are free from the stem, no salients are present over the middle area of this section, but on either side a few salients are shown which are cut nearly, but not quite in a transverse direction, since they radiate outward from near the stem. In FIGURE I0, still farther away from the stem, a few very low salients are present over the middle area which are cut transversely, while the lamellae on either side, farther from the stem, are cut obliquely, those nearer the pileus margin more so than those toward the stem. In FIGURE II, from a section a little farther from the stem, the gill salients over the middle area are stronger and still more so in FIGURE I2. The salients (FIGS. II and I2) show but a slight downward extension of the level palisade area. Here are the extreme "posterior" ends of the lamellae, which remain as very low and more or less rudimentary salients. From the extreme "posterior" ends of the lamellae they increase rapidly in breadth for the mature lamellae are broader at some distance from the end and then round off behind (next the stem). The middle salients in FIGURES II and I 2 , at this distance from the stem, are arrested in growth immediately, or very soon after their clownward extension from the level palisade.

FIGURES I3-I 6 are from a similar series of sections of another basidiocarp. FIGURE $\mathbf{I} 5$ is from a "tangential" section the middle area of which passes through the sterile area between the stem and posterior ends of the lamellac. For sake of clearness it may be mentioned that in typical species of Lepiota the lamellae are free from the stem, so that there is a circular sterile area of the pileus between the stem and lamellae, which is of greater or lesser extent in different species. FIGURE 16 is from a section nearer the margin of the pileus.

Organization of the blematogen and its union with the pileus fundament.-In very young basidiocarps, as represented in FIGURES $\mathrm{I}$ and 2 , the character of the blematogen has been described above. Over the crown of the young basidiocarp and external to the pileus fundament it consists of slender hyphae 3-6 $\mu$ in diameter. They extend in a longitudinal direction in 
the apex of the primordial basidiocarp, $i . e_{.}$, parallel with the axis of the stem. They are radial or perpendicular to the upper and lateral surface of the young pileus primordium after its appearance. While the general direction is radial, the hyphae are more or less flexuous ${ }^{1}$ and somewhat interwoven. This tissue is loose, since there are rather conspicuous interhyphal spaces. Lateral to the stem fundament the hyphae of the blematogen are nearly or quite parallel to the stem axis, $i$. e., they are not radial, or perpendicular to the surface of the basidiocarp, while they are radial or perpendicular over the pileus fundament.

As the fruit bodies become older the blematogen becomes more definitely organized into a compact palisade layer of hyphae over the pileus and extending a short distance below the margin. Lower down on the surface of the stem the hyphae remain nearly or quite parallel with the stem surface. In FIGUREs 3 and 5 the more compact nature of the blematogen layer is manifest. It is still better shown in FIGURES $7-14$ and in FIGURE I7. Here it forms a distinct layer which can be seen to extend some distance below the margin of the pileus, but is not so distinct far down over the stem as it is in Lepiota clypeolaria (see Atkinson, '14). The radial character of the outer portion of the blematogen is well shown in FIGURE 17 . These radial hyphae are $5^{-10} \mu$ in diameter and $30-40 \mu$ long, but in mature specimens the dimensions are greater. These radial hyphae spring from a thin zone of pseudoparenchyma, similar to that in Lepiota clypeolaria (loc. cit.), but not so well marked.

As the pileus primordium increases in growth it becomes firmly united with the inner zone of the blematogen, so that the latter becomes concrete with the surface of the pileus, and the outer surface of the blematogen becomes the surface or "cuticle," of the mature pileus as usually understood.

The marginal or partial veil.-The marginal, or partial, veil, as in species of Agaricus, Lepiota clypeolaria and Armillaria mellea described by the writer ('14, '15) consists partly of a section of the blematogen, and partly of ground tissue extending between the margin of the pileus primordium and the stem, the ground

1 For a discussion of the blematogen and its relation to the volva in Amanita and Amanitopsis, and to the universal veil in Lepiota clypeolaria, and certain species of Agaricus, see Atkinson, 'I 4 and 'I 5. 
tissue undergoing considerable increase during development. Some growth from the pileus margin is incorporated with it.

\section{LEPIOTA SEMINUDA}

Material.-Lepiota seminuda is a very pretty, pure white, rather small plant, $\mathrm{I}-4$ or $5 \mathrm{~cm}$. high as it usually occurs in the vicinity of Ithaca, $\mathrm{N}$. Y. It grows in troops on decaying leaves and small twigs or branches. It is covered with a loose powdery, or mealy, substance of globose or broadly elliptical cells from the blematogen. 'The partial veil is very frail, and usually clings to the margin of the expanded pileus, so that the mature plants are usually exannulate. The slender stem is usually devoid of an annulus, or has a delicate and fugacious one. Lacking a collar, it is literally decolleté, and may be said to be seminude. The material for this study was collected during the summer of I9I4, in Cascadilla Wroods on the campus of Cornell University, where it has been found during a number of past years. The plants were very numerous, thickly scattered over the leaves and decaying twigs in a moist thicket, so that all stages from minute plants in the earliest stages of the differentiation of pileus and stem fundaments to maturity were available. They were fixed in chromacetic fluid, and the smaller specimens, as in the case of those of Lepiota cristata, were lightly stained in toto with eosin, so that their orientation in the paraffin could be readily seen. The sections were stained with fuchsin.

The pileus and stem primordia.-The youngest basidiocarp studied was approximately $0.5 \mathrm{~mm}$. long by $0.25 \mathrm{~mm}$. in diameter. A median longitudinal section is shown in FIGURE $\mathrm{I} S$. The young pileus and stem primordia are already organized within the ground tissue and are enveloped by the blematogen of loose texture. From the appearance of the sections of this young basidiocarp, I am inclined to think that the young stem fundament is organized first and that the pileus is organized later by progressive new growth in the ground tissue from the stem apex, so that a sheaflike structure is formed surrounded by the blematogen: at least the primordial areas of both stem and pileus are outlined prior to the organization of the hymenophore fundament.

Organization of the hymenophore primordium.- The hymenophore primordium, as in Lepiota cristala, arises as an internal 
annular zone of new growth on the lower side of the margin of the pileus fundament and is well shown in FIGURE I9. This figure is from a longitudinal, and nearly median, section of a young basidiocarp. The hyphae of the hymenophore primordium extend outward and downward at an angle of about $45^{\circ}$ from the axis of the stem. By the introduction of numerous new branches this internal annular zone of new growth is already quite compact and takes a deep stain on account of the abundant protoplasm in the young hyphae. But the lower surface of the hymenophore primordium is still uneven and more or less frazzled or fimbriate, since the slender tapering hyphae in their growth through the ground tissue beneath have not reached the same level and are less crowded because of their tapering form. This is well shown in FIGURES $2 \mathrm{I}$ and 22, which are from more highly magnified photomicrographs of the hymenophore and adjacent tissue at the left side of FIGURE I9.

Even at this young stage the margin of the pileus fundament and of the hymenophore shows epinastic growth. The transsection of the hymenophore presents a slightly arched form, convex above, concave below. At the extreme left of the hymenophore fundament in FIGURES $2 \mathrm{I}$ and 22 , the hyphae are more loosely associated, since this portion of the hymenophore is the younger. This rapid increase in the elements of the hymenophore primordium over that of the ground tissue below produces a pressure which exerts a tension on the loose ground tissue and it is gradually torn apart, forming the general annular, prelamellar cavity. A very early stage in the formation of this cavity is shown in FIGURES 19-22. Figure 20 is from a section through one side of the annular hymenophore primordium parallel with a tangent to its surface and also parallel with the axis of the stem. The uneven, ragged lower surface of the hymenophore at this stage is shown, as well as the early stage of the gill cavity with isolated hyphae or slender loose strands extending across the weak cavity.

Organization of the level palisade.-Since growth of the pileus margin and of the hymenophore primordium is centrifugal, the older stage of the hymenophore is next the stem. It is in this region that the primordial stage of the hymenophore first passes over in to the level palisade stage by increase in the number of the 
hyphal branches, by their increase in diameter, and by the free ends of the hyphae reaching the same level. This stage is well shown in FIGURES 23 and 24 from a slightly older basidiocarp. The general plane of the under surface of the hymenophore rises at a strong oblique angle from the stem, but epinasty of the pileus is curving the margin downwards. In FIGURE 24 the axis of the stem is at the right. The palisade condition of the older portion of the hymenophore, $i . e$, the portion at the right, near the stem, is well shown. The free ends of the hyphae now register and form an even, or "level," surface. The younger portion, at the extreme left, is still in the primordial stage as shown by the more slender hyphae and the unregistered position of their free ends.

FIgURE 25 is from a "tangential" section of the same basidiocarp. This palisade stage of the hymenophore is shown over the middle area which is not far from the stem, while on either side, farther away from the stem, the hymenophore is still in the primordial stage. In older ${ }^{1}$ basidiocarps, represented by "tangential" sections in FIGURES $27-3 \mathrm{I}$, the level palisade is shown to be well established prior to the origin of the gill salients. FiGURE 26 is from the same fruit body, but is from a median longitudinal section, and thus being parallel with the direction of the young lamellae, one cannot determine with certainty whether or not the fundaments of the lamellae have begun their appearance. None are evident on one side of the basidiocarp shown in FIGURES 27 and 28 , nor on the left side of FIGUREs 29 and 30 from the opposite side.

The anmular prelamellar cavity.-The general annular, prelamellar cavity is large and well formed in Lepiota seminuda before the lamellae begin their development. The formation of the cavity begins early by tension on the ground tissue underneath the expanding hymenophore primordium. It rapidly enlarges with increased growth of the hymenophore and pileus, so that on transsection it is circular or elongate, as shown in FIGUREs 23, 26, and 32 , or broadly elliptical in "tangential" section, as in FIGURES $25,27,28,30$, and 31 .

Origin of the lamellae.-Since the prelamellar cavity attains such a large size in comparison with the small size of the fruit body,

${ }^{1}$ For a full description and method of interpretation of sections of the basidiocarp, with the aid of diagrams, see Atkinson, Morphology and levelopment of Agaricus Rodmani. Proc. Am. Phil. Soc. 54:309-3+3. pl. g-13. 1915. 
the origin of the lamellae is very clear. Another feature which adds to the clear and easy interpretation of the origin of the lamellae is found in the broad and distant primary salients, as well as in the proportionally broad sterile zone between the gills and stem. The lamellae arise as downward growing salients of the level palisade area of the hymenophore. In the basidiocarp represented in FIGUREs 27-3I, very slight but broad salients had begun to form on one side, while on the other side the hymenophore was still in the level palisade stage. In FIGUREs 27 and 28 there is no evidence of the downward folding or growth of the palisade layer to form the young lamellae. On the other side of the hymenophore, shown in FIGURES 30 and $3 \mathrm{I}$, there are slight, but distant downward folds of the palisade area. In FIGURE 29 there is scarcely any evidence of such downward growth, unless it be at the right hand in the middle of the arched hymenophore. This longitudinal section just passes through the surface of the stem at the angle of junction of the pileus and stem. FIGURE 30 is from a section farther from the stem, with slightly greater magnification. At the right there is a single broad salient, much more marked than the very slight fold at its posterior end shown in FIGURE 26. FIGURE 3I is from a section still farther from the stem. Here are shown four broad salients, the strong one at the right being a section of the same gill fundament as the one in FIGURE 30. The other three are much lower salients and represent the earliest downward growth of the level palisade to form the gill salients.

FIGURES $32-36$ represent sections of a slightly older basidiocarp, selected from a series passing from the middle of the stem and pileus to the margin of the pileus, all parallel with the axis of the stem. Figure 33 at some distance from the stem shows four strong salients, and one low one of a secondary gill at the left. At the extreme right and left the hymenophore is still in the primordial stage. FIGURE 34 is still nearer the margin of the pileus, where the two low salients are younger stages of the two middle ones shown in FIGURE 33. FIGURE 35 is still nearer the margin of the pileus and these two salients are still younger and lower, while in FIGURE 36 , yet nearer the pileus margin, there is only a very slight suggestion of two low and broad folds of the level palisade. On either side the hymenophore is still in the primordial stage. 
Organization of the stem.-The stem fundament represented in FIGURE I 8 is quite homogeneous, consisting of slender longitudinal hyphae, nearly parallel, but more or less interworen. The tissue at the base, perhaps not strictly belonging to the stem proper, but forming the foot, is somewhat more dense. As the plants age the stems become slightly differentiated. The core of the stem does not keep pace in growth with the rather thick external cylindrical portion. As a result the stem becomes hollow. This probably is partly due to a lesser growth of the center, but perhaps is to be attributed chiefly to the rapid growth of the exterior, thus producing a tension which tears the core apart, first leaving it in a more or less shredded condition, until finally it becomes hollow. Except for a thin external layer the hyphae of the stem increase greatly in size, come to lie strictly parallel, and the protoplasm in the stout cylindrical cells becomes attenuate. A thin external layer is made up of more slender cells rich in protoplasm. This layer stains more deeply and is well shown in FIGURES 26, 27, 29, and 32. The parallel hyphae of the stem continue up to the junction of the stem and pileus. Near the apex of the stem the cells become shorter, but are still parallel. The transition to the pileus trama is rather abrupt, shown by the looser texture of the pileus trama and the strongly interwoven hyphae. The hyphae in the periphery of the stem apex curve rather abruptly into the lower surface of the pileus trama adjacent to the hymenophore, a thin zone of which has a denser texture than the main part of the pileus trama.

The blematogen.--The blematogen consists of a rather thick zone of radiating hyphae, quite distinct from an early stage. When the pileus fundament is first organized the limits between pileus and the blematogen layer are very indefmite. But as the hymenophore and pileus margin are organized the limits are more clearly discerned. Later as the surface of the pileus becomes better outlined the limits between blematogen and pileus are quite clear. The cells of the blematogen layer become very large and globose or subglobose. The hyphae become strongly constricted at the septa, and very likely the middle lamellae become weakened so that the cells readily separate. These loose cells form the "powder" or "meal," which makes so conspicuous a covering on the pileus and stem. The blematogen therefore 
crumbles and with light friction is easily removed down to the surface of the pileus. But since no definite pileus surface layer is organized as in certain species of Coprimus as in C. micaceus, C. radians, etc., the pileus does not become smooth by desquamation as it does in those species. The distinction between blematogen and pileus and stem is well shown in FIGUREs 23, 26-28, 32, and 33 . In FIGURES $26-28$ it has cracked away from the pileus leaving the surface of the latter rough from fragments of the blematogen or "universal veil," which are still concrete with the pileus surface.

The partial veil.-The partial veil, as in Lepiota cristata, consists of a short section of the blematogen, and of the ground tissue between the margin of the pileus and the surface of the stem. This ground tissue forms a thin zone in comparison with the thick zone of the blematogen. In FIGURE 37 it is about onethird the thickness of the blematogen, but a large portion of the latter has crumbled away. The proportion is better shown in FIGURE 23, where the ground tissue is about one-fourth to one-fifth of the blematogen, but the limit between the two elements is not definitely drawn. At and just below the apex of the stem the thickness of the ground tissue of the partial veil is much greater.

\section{PRIMARY DIFFERENTIATION OF BASIDIOCARP}

In the species of Agaricaceae with endogenous origin of the hymenophore, there appear thus far to have been described three types of differentiation of pileus, stem, and hymenophore fundaments in the primordium of the young basidiocarp.

I. The pileus area or primordium, is outlined first, as represented by Hypholoma sublateritium and $H$. fasciculare (Miss Allen, '06; Beer, '11), Amanita rubescens (deBary, '66, '84, '87), Amanitopsis vaginata (Atkinson, '14). This type was observed by Fayod (' 89, p. 279). The pileus primordium he called the "couche pileogène." He arrived at the conclusion that this type prevailed in the Agaricaceae.

2. The hymenophore primordium is outlined first. This type is represented by Agaricus campestris (Atkinson, '06), Agaricus arvensis (Atkinson, '14), Agaricus Rodmani (Atkinson, '15), Armillaria mellea (Atkinson, '14), and Stropharia ambigua (Zeller, '14).

3. The stem fundament is outlined first, followed by the pro- 
gressive differentiation of the pileus area from its apex, followed by the differentiation of the hymenophore fundament, represented by Lepiota cristata and $L$. seminuda.

A similar type is presented in the development of Rozites gongylophora according to the account by A. Möller ('93, p. 70), who describes also the presence of an outer envelope (homologous with the blematogen) and an inner envelope (which forms the partial veil proper). His description of the origin of the hymenophore primordium, the palisade stage, the origin of the general annular prelamellar cavity, as well as the origin of the gills by downward growing radial processes of the palisade stage, is in entire harmony with the account given here of the procedure in Lepiota cristata and L. seminuda. The morphology of Rozites gongylophora is that of a typical Lepiota and the spores examined in water are white, although the spore mass is bright ochre color.

In some of these species the precedence in the differentiation of one or another part of the fruit body seems to vary to some extent. In Agaricus arvensis it appears that the pilcus arca may be differentiated simultaneously with the hymenophore primordium, and in Lepiota clypeolaria it would appear that the stem and pileus fundaments may be differentiated simultaneously or possibly in some cases the stem primordium may precede that of the pileus.

Another type is described by Fischer ('09) in Armillaria mucida. He states that the pileus is differentiated first by the appearance of a palisade layer of radial hyphae at the apex of the basidiocarp primordium, and underneath the very thin "universal veil" (?protoblem). The organization of the palisade progresses down the sides and then inward over the under surface of the pileus, there forming the palisade stage of the hymenophore. This type is so unusual that its confirmation wouli seem desirable. It may be pointed out, however, that some species of the agarics, notably some species in the genus Marasmius, have similar cystidia in the hymenium and surface of the pileus, which suggests a possible close relation in the origin of these surfaces. From the account given by Fischer it would seem that the "universal veil" which he describes is a protoblem and that the blematogen is absent, since the pileus surface and hymenophore primordium are continuous. Thus, leaving the protoblem out of account, the 
origin of the hymenophore would be similar to the method in certain gymnocarp forms.

\section{SumMary}

I. In Lepiota cristata the stem fundament is first organized in the base of the young basidiocarp. The pileus fundament is later organized by progressive growth and differentiation from the stem apex, the stem and pileus fundaments together forming a sheaf-like internal area enveloped by ground tissue and the blematogen. The organization of the stem and pileus fundaments in Lepiota seminuda is probably similar, for the fundament of the two forms a similar internal sheaf-like area.

2. The hymenophore primordium in both species arises by numerous branches rich in protoplasm, extending outward and downward from the lower outer margin of the pileus primordium. The pileus margin is also organized in connection with the hymenophore fundament. Together they form an internal, annular zone of new growth. Continued marginal growth by the origin of new elements extends the hymenophore and pileus margin in a centrifugal direction.

3. The primordial stage of the hymenophore is characterized by parallel slender hyphae whose general direction of growth is downward, but it becomes arched by epinastic grow th of the pileus. In the primordial stage of the hymenophore the lower surface is loose and velvety, or fimbriate, and the free ends of the hyphae lack register, $i$. e., they show an unequal reach. The primordial stage passes to the level palisade stage of the hymenophore by increase in number and thickness of the hyphal branches, and by the register of their free ends, so that a compact even under surface is formed. This begins next the stem and progresses in a centrifugal direction toward the margin of the pileus.

4. The lamellae arise as downward growing radial salients of the level palisade. The gill salients begin on the older portions of the hymenophore palisade and proceed in a centrifugal direction toward the margin of the pileus. Thus, at an intermediate stage of devélopment of the young basidiocarp, three stages of hymenophore development are present, the primordial zone next the pileus margin, preceded by the level palisade zone, and this by the zone of young gill salients next the stem. These progress in a centrifugal direction until the primordial stage is transformed into the level palisade and the latter into the gill salients. 
5. A general, annular, prelamellar cavity is present in both species. The ground tissue beneath the young annular hymenophore zone lags behind the latter in growth and the tension thus arising tears the ground tissue apart, forming a general annular cavity into which the gill salients extend. It is distinct in both species, but very large in $L$. seminuda in comparison with the size of the basidiocarp.

6. The blematogen ("universal veil" p. p. of Fries and other writers) is prominent in both species, but more striking in Lepiota seminuda than in L. cristata. In the latter species, in the young stage, it consists of radiating, slender, more or less flexuous hyphae over the pileus area, and of longitudinal hyphae parallel with the stem axis, below the pileus area. As the pileus is organized and becomes concrete with the blematogen, the latter over the pileus and for a short distance below the pileus margin, becomes organized into a definite duplex layer, the outer zone consisting of a compact palisade of cylindrical hyphae, the inner forming a thin zone of small-celled pseudoparenchyma. With the expansion of the pileus the blematogen layer over the pileus becomes torn into more or less erect fibrous scales, giving the pileus a cristate appearance. In Lepiota seminuda the radial hyphae forming the blematogen become transformed into chains of globose or subglobose cells which easily fall apart, giving a mealy or powdery appearance to the basidiocarps. The blematogen thus crumbles easily and with slight friction may nearly all be rubbed off the pileus, leaving only fragments of it attached to the pileus surface. But it does not become separated from the pileus by a cleavage layer as the volva of the Amanitue is, nor does complete desquamation take place by the formation of a well-defined outer pileus layer as in certain species of Coprinus.

\section{BibliogRAPIIY}

1906. Allen, C. L. The derelopment of some species of Hypholoma. Ann. Myc. 4:387-394. pl. 5-7. 1906.

1906. Atkinson, G. F. The development of Agaricus campestris. Bot. Gaz. 42: 24I-264. pl. 7-12. 1006.

1914. The development of $A$ garicus arrensis and A. comtulus. Am. Jour. Bot. I: 3-22. pl. I, 2. 1914.

1914 . The development of Armillaria mellea. Myc. Centralb. 4: 113-121. pl. 1, 2. 1914 . 
1914. - Homology of the universal veil in Agaricus. Myc. Centralb. 5: I3-I9. pl. I-3. I9I4.

1914. The development of Lepiota clypeolaria. Ann. Myc. I 2 : 346-356. pl. I3-I6. I9I4.

I9I4. The development of Amanitopsis vaginata. Ann. Myc. 12: 369-392. pl. I7-19. I9I4.

1915. Morphology and development of Agaricus Rodmani. Proc. Am. Phil. Soc. 54:309-343. pl. 7-I3. S diagrams. I9I5.

I859. Bary, A. de. Zur Kenntniss einiger Agaricinen. Bot. Zeit. I7: 385-388; 393-398; 40 I-404. pl. I3. I 859.

I866. Morphologie und Physiologie der Pilze, Flechten und Myxomyceten. Leipzig, I 866.

I884. - Vergleichende Morphologie und Biologie der Pilze, Mycetozoen und Bacterien. I 884.

I887. Comparative morphology and biology of the fungi, mycetozoa and bacteria. Oxford, I887.

I9II. Beer, R. Notes on the development of the carpophore of some Agaricaceae. Ann. Bot. 252:683-689. pl. 52. I9II.

I877. Brefeld, O. Botanische Untersuchungen über Schimmelpilze 3: I-226. pl. I-II. I 877 .

I889. Fayod, V. Prodrome d'une histoire naturelle des Agaricinées. Ann. Sci. Nat. Bot. VII. 9: I8I-4I I. pl. 6, 7. I 889.

1909. Fischer, C. C. E. On the development of the fructification of Armillaria mucida Schrad. Ann. Bot. 23: 503-507. pl. 35. I909.

I856. Hoffmann, H. Die Pollinarien und Spermatien von Agaricus. Bot. Zeit. I4: I37-I48; I53-I63. pl. 5. I856.

I860. - Beiträge zur Entwickelungsgeschichte und Anatomie der Agaricinen. Bot. Zeit. I8: 389-395; 397-404. pl. I3, I4. I 860 .

I86I. - Icones analyticae fungorum. Abbildungen und Beschreibungen von Pilzen mit besonderer Rücksicht auf Anatomie und Entwickelungsgeschichte, I-I05. pl. I-24. I86I.

I914. Levine, M. The origin and development of the lamellae in Coprinus micaceus. Am. Jour. Bot. I: 343-356. pl. 39, 40. I9I4.

I893. Möller, A. Dic Pilzgärten einiger südamerikanischer Ameisen. Bot. Mittheil. Tropen 6: I-I27. pl. I-7. I 893.

I9I4. Zeller, S. M. The development of Stropharia ambigua. Mycologia 6: I39-I 45. pl. I24, I25. I9I4. 


\title{
Explanation of plates $21-26$
}

(Photograplis by the author)

\author{
Plate 2 I
}

Lepiota cristata, various forms from the vicinity of Ithaca, N. Y.

\section{Plate 22}

Lepiota seminuda. Upper group from Cascadilla IVoods, Campus, Cornell University (No. 535I Cornell Univ. Herb.). Middle group, part of same magnified nearly two times, showing the mealy stem and pileus. Lower group from a spruce forest in the Jura Mountains, France, near Pontarlier.

\section{Plates 23-26}

The magnifications of the photomicrographs are as follows: Fig. $38 ; 25$ diameters. Figs. I3, I4, I5, 16; 30 diameters. Figs. 7, 8, 9, I0, I I, I2; 35 diameters. Fig. 32; 42 diameters. Fig. 23; 50 diameters. Figs. I, 2, 3, 5, 17;60 diameters. Figs. 26, 27, $28,29,3$ I, 33, 34, 35, 36; 65 diameters. Figs. 18, 19; 80 diameters. Fig. 33; 100 diameters. Figs. 20, 25; I30 diameters. Fig. I I; I50 diameters. Figs. 4, 6; I60 diameters. Fig. 21; 200 diameters. Fig. 24;320 diameters. Fig. 22; 500 diameters.

\section{Plates 23 And 24. Lepiota cristata}

FIG. I. (No. I8.) A median longitudinal section of a young basidiocarp with fundament of stem, as darker interior area.

FIG. 2. (No. I6.) Median longitudinal section. Fundament of stem and pileus enveloped by ground tissue, and blematogen as an external zone.

FIG. 3. (No. 5/2-I.) Median longitudinal section. Primordium of hymenophore as two darker staining internal areas symmetrically disposed on either side above early stage of the annular cavity appearing as two light areas. The pileus is further organized and concrete with the blematogen, which shows as a lighter external zone.

FIG. 4. (No. 5/2.) Longitudinal "tangential" section of same basidiocarp, passing through the hymenophore primordium and anuular prelamellar cavity. Note the slender, loosely arranged hyphae of the hymenophore primordium projecting down into the gill cavity.

FIG. 5. (No. 9/r.) Longitudinal "tangential" section of another basidiocarp, just passing out from the stem. Note the densely staining sections of the hymenophore on cither sicle and the early stage of the gill cavity below:

FIG. 6. (No, 1-2.) Longitudinal "tangential" section of another basidiocarp passing through one side of the hymenophore primordium, which is the dark transverse area, the slender hyphae growing down into the loose ground tissue below. The latter is beginning to tear apart, forming a very early stage of the gill cavity.

FIG. 7. (No. 6/2-I.) Median longiturlinal section of older basidiocarp. The young lamellae are cut nearly in a parallel direction. The blematogen shows distinctly on the right hand side over the pileus and extending down past the pileus margin and on the outsicle of the partial veil proper, the latter formed of ground tissue and sone growth from pileus margin.

Fis. 8. (No. 6/I-I.) Same basidiocarp, lut section slightly "tangential" and through one side of the stem. Blematogen and partial veil proper, as in Fig. 7 . On the left a gill cut obliquely; on the right the section passes between two gills.

FIGs. 9-I2. Four longitudinal "tangential" sections of the same basidiocarp selected from a series showing origin of lamellae as downward growing salients into the general annular gill cavity. 
Figs. I3 and I4. (No. 28.) Sections of another basidiocarp, I3 median, I4 slightly "tangential."

FIGS. I5 and I6. "Tangential" sections of the same basidiocarp.

FIG. I7. (No. 29.) Portion of median longitudinal section of a nearly mature basidiocarp (stem at right), showing marign of pileus, which is very strongly epinastic. Blematogen concrete with the surface of the pileus proper, showing distinctly over margin of pileus and extending down over the ground tissue which forms the partial veil proper between margin of the pileus and stem.

\section{Plates 25 AND 26. Lepiota seminuda}

FIG. 18. (No. 7.) Median longitudinal section, showing primordium of stem and pileus surrounded by ground tissue, and blematogen on the outside.

FIG. 19. (No. Io.) Median longitudinal section of a slightly older basidiocarp, showing transsections of the hymenophore primordium on either side with beginning general annular prelamellar cavity below. Note arched section of pileus primordium between the transsections of hymenophore primordium, the loose ground tissue above, and the blematogen of globular cells as an external envelope of pileus and extending far down over the stem. The ground tissue below pileus margin and hymenophore primordium is the fundament of the partial veil proper which is covered externally by a section of the blematogen.

FIG. 20. (No. 19.) Longitudinal "tangential" section of another basidiocarp, passing through one side of the annular hymenophore primordium and the beginning annular gill cavity.

Figs. 2I and 22. More highly magnified photomicrographs of the left side of figure 19 , showing hymenophore primordium in transsection, the ground tissue below, and the blematogen outside at the left.

FIG. 23. (No. I I-I.) Median longitudinal section of a slightly older basidiocarp. Pileus further organized; primordial stage of the hymenophore next the stem has changed to the palisade stage, prelamellar cavity is well formed, blematogen appears as a very distinct external layer.

FIG. 24. More highly magnified photomicrograph of the left side of figure 23 (stem axis, not shown, is at the right), palisade stage of hymenophore at right, primordial stage, and margin of pileus at left, blematogen to the extreme left, the external portion not shown, partial veil proper between blematogen and gill cavity below pileus margin and primordial stage of hymenophore.

FIG. 25. "Tangential" section of same basidiocarp, passing through one side of annular hymenophore and gill cavity. Hymenophore above cavity, palisade stage in the middle and primordial stage on either side.

FIGs. 26-3I. Longitudinal median and "tangential" sections of a basidiocarp in which the palisade stage of the hymenophore is just passing into the stage of the gill salients. Fig. 26 shows the large prelamellar gill cavity in transsection; the stem is well organized with an external layer of more slender hyphae richer in protoplasm which stains dark; the blematogen has separated from the pileus here and also in figures 27 and 28 . Fig. 27 "tangential" and a little beyond the stem. The hymenophore shows no evidence of gill salients. Fig. 28 nearer margin of the pileus, no gill salients on this side of the hymenophore. Figs. 29-3I are from tangential sections of the other side of the pileus; fig. 29 is just in the surface of the stem at the angle of junction of stem and pileus, no gill salients shown near the stem since there is a sterile zone between the posterior ends of the gills and stem; toward the margin of the pileus in the upper part of the arched hymenophore there is the slightest evidence of a young gill salient; fig. 30 , 
the slight gill salient is stronger as this is farther from the stem; fig. $3 \mathrm{I}$, farther from the stem and four very slight gill salients are seen, the one at the right is the same one as shown in fig. 30 , but is lower since it is nearer the margin of the pileus and younger.

FIGS. 32-36. (No. 9.) Similar series of sections from a slightly older basidiocarp in which the gill salients are better organized near the stem where they are older, successively lower and younger toward the margin of the pileus where in figure 36 there is but the slightest evidence of the palisade stage thrown into two salients, with the primordial stage of the hymenophore shown on either side at the extreme margin of the pileus.

FIG. 38. (No. 20.) "Tangential" section through pileus and hymenophore about midway between stem and margin of pileus in a nearly mature basidiocarp.

Fig. 37. (No. 17/2.) From one side of a nearly median longitudinal section of another basidiocarp showing margin of the pileus and the blematogen to the right. Below the margin of the pileus is the ground tissue forming the partial veil proper with a section of the blematogen outside and concrete with it. 


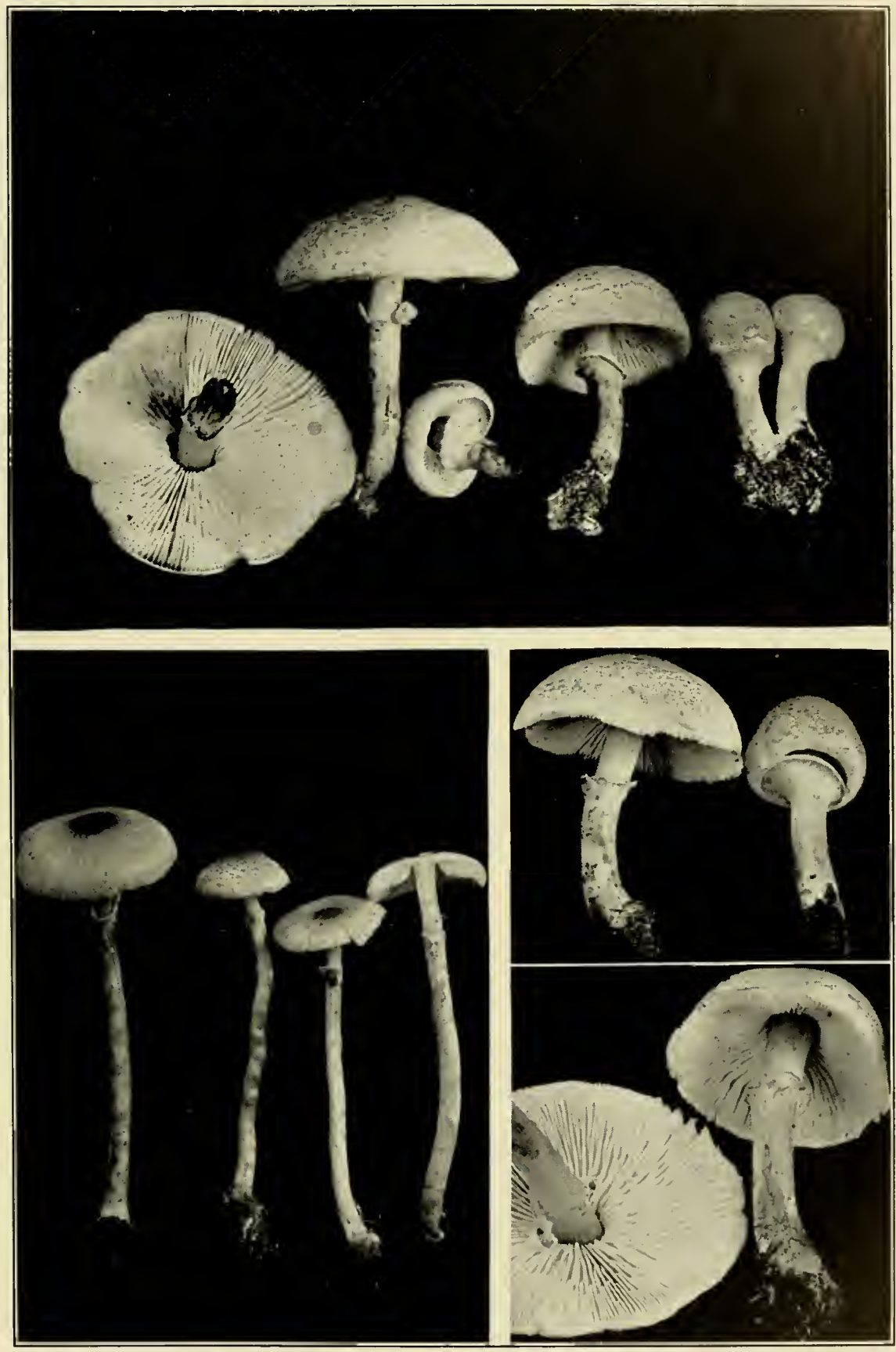

LEPIOTA CRISTATA 



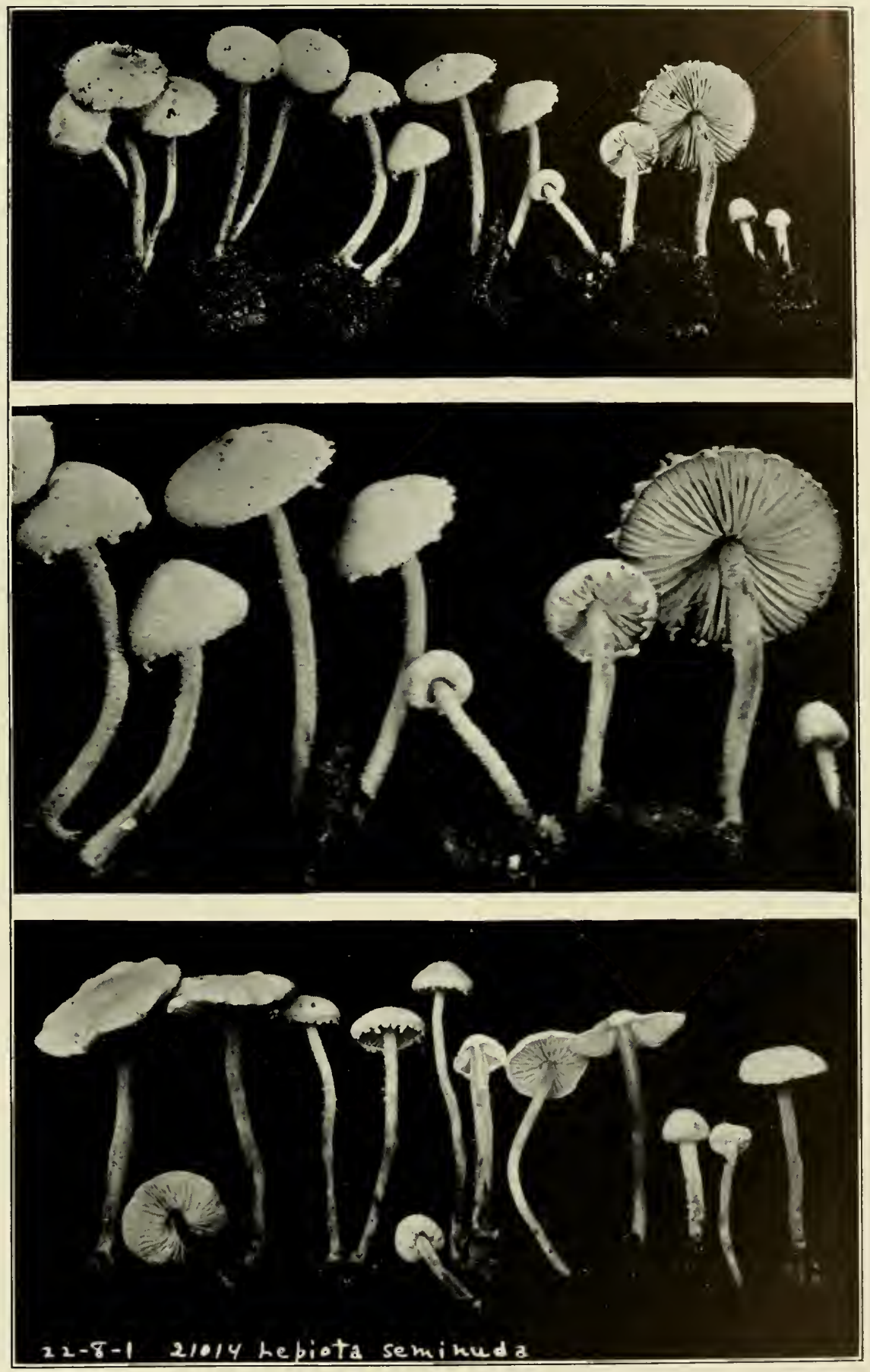

LEPIOTA SEMINUDA 



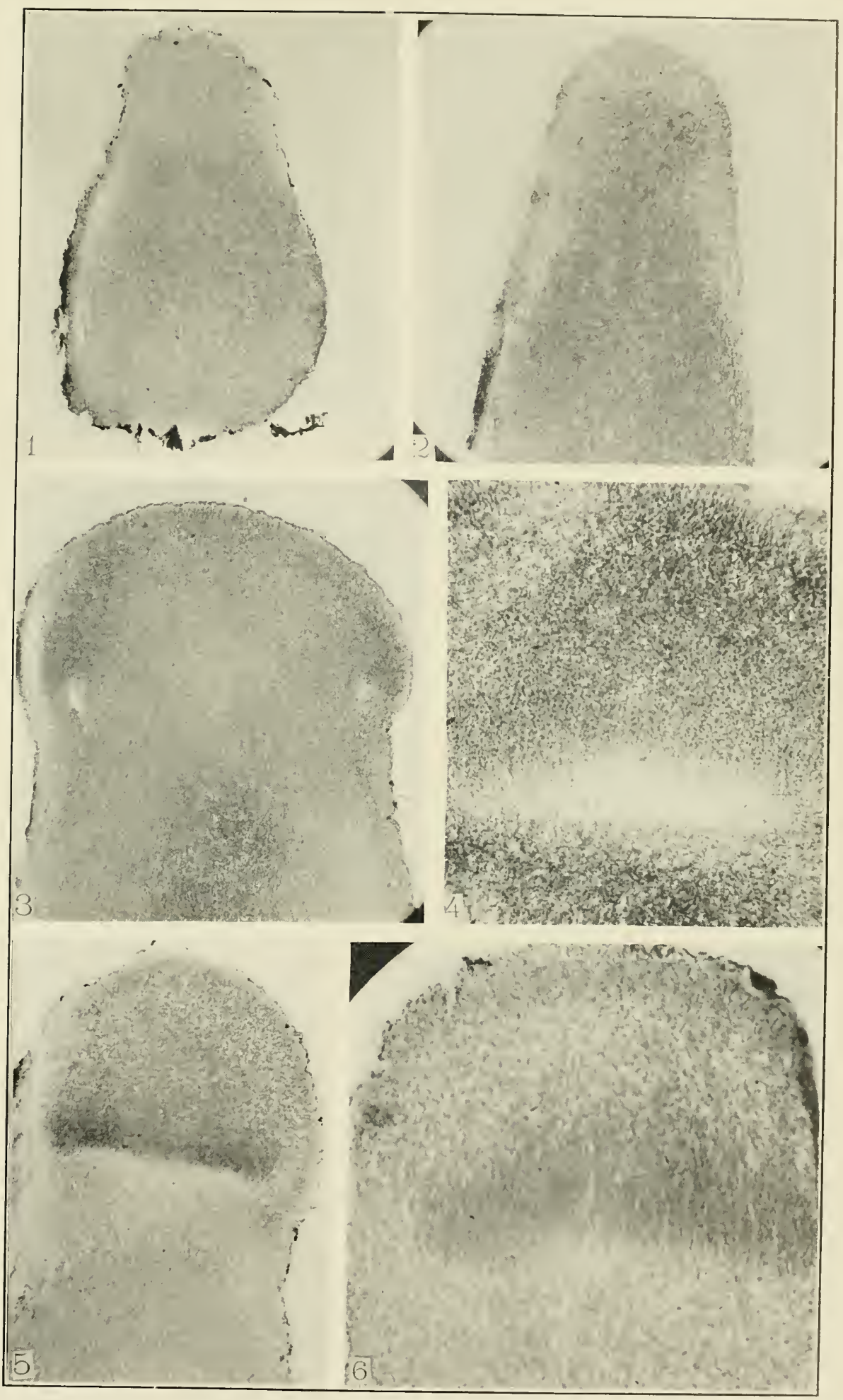





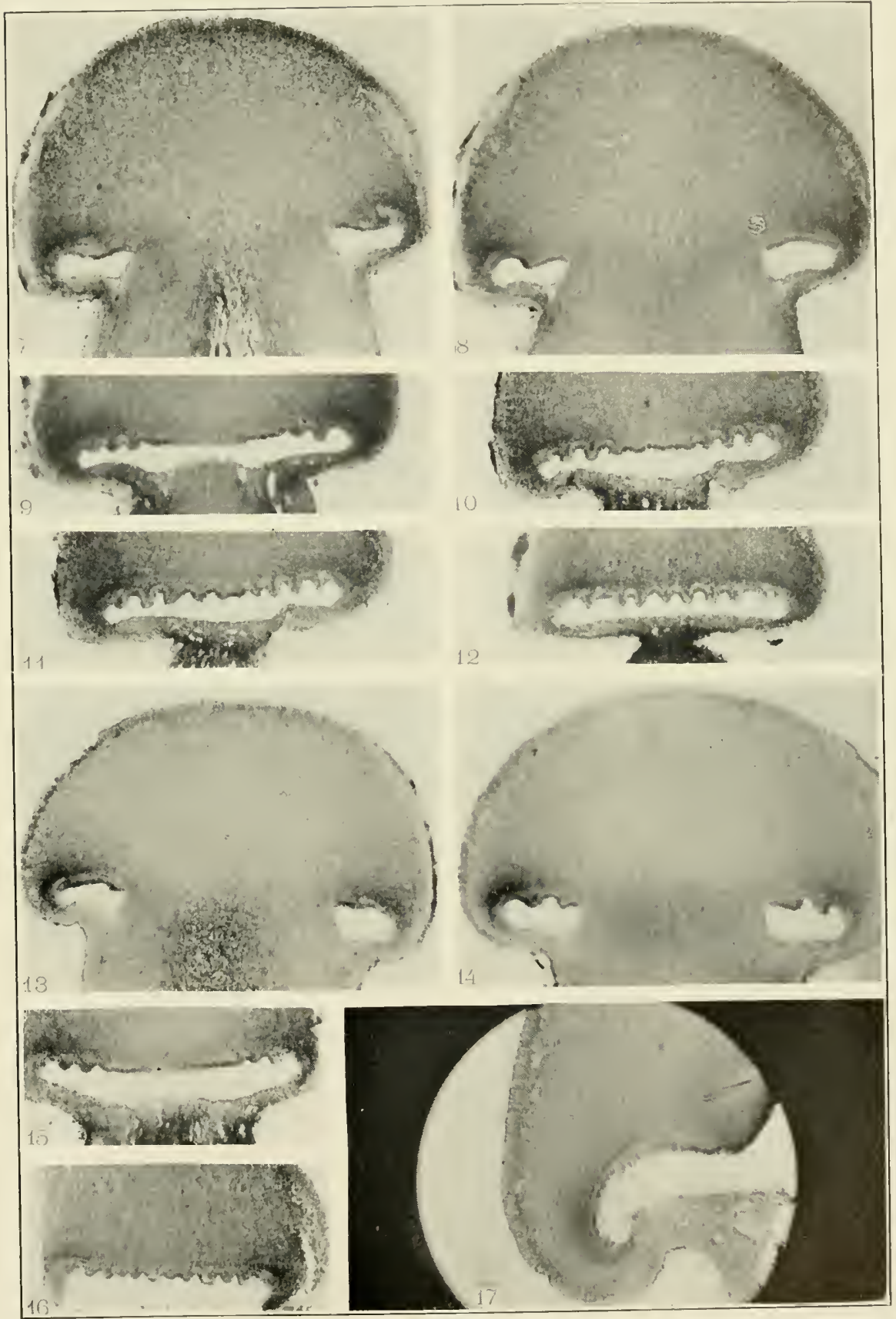

LEPIOTA CRISTATA 



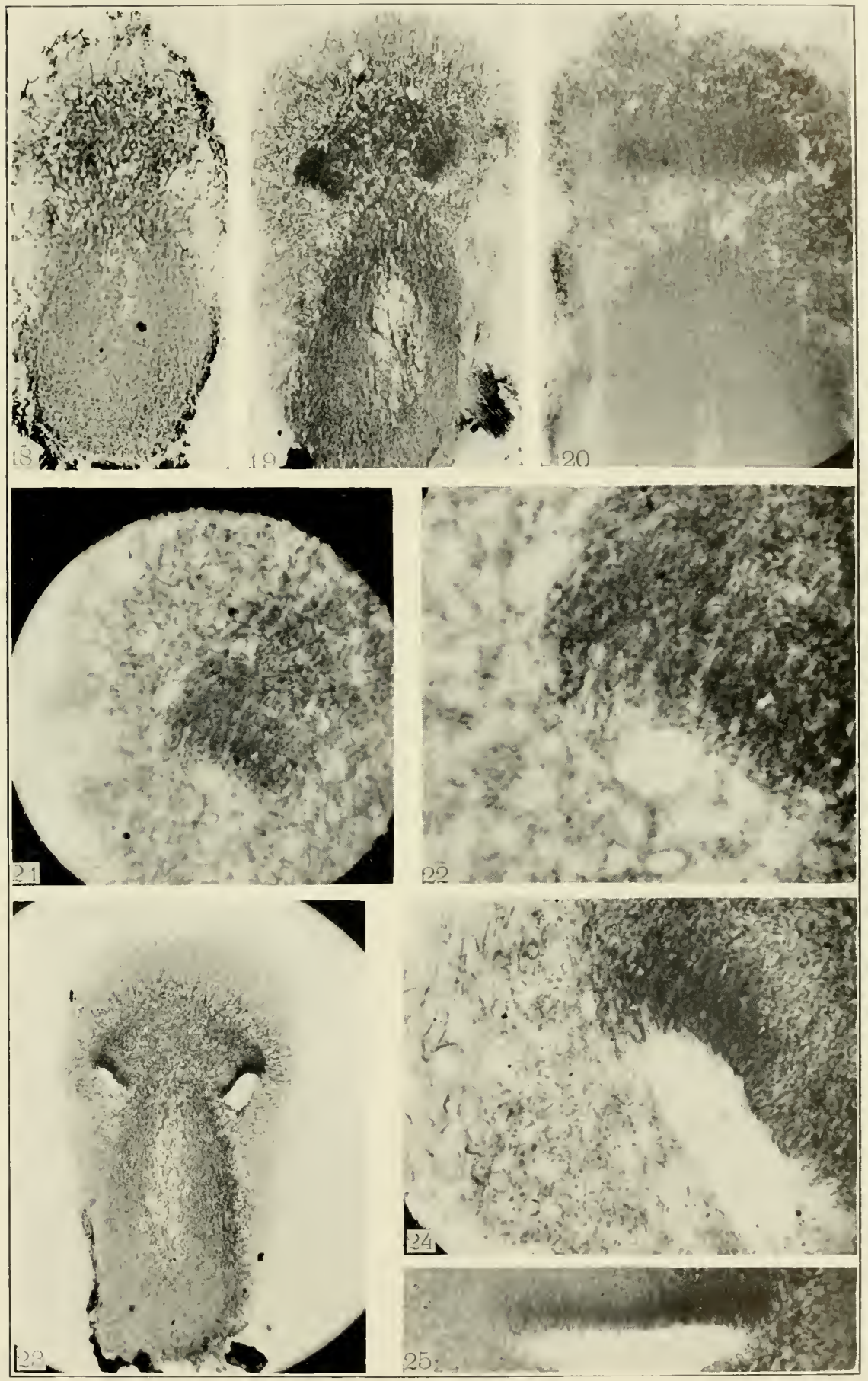

LEPIOTA SEMINUDA 



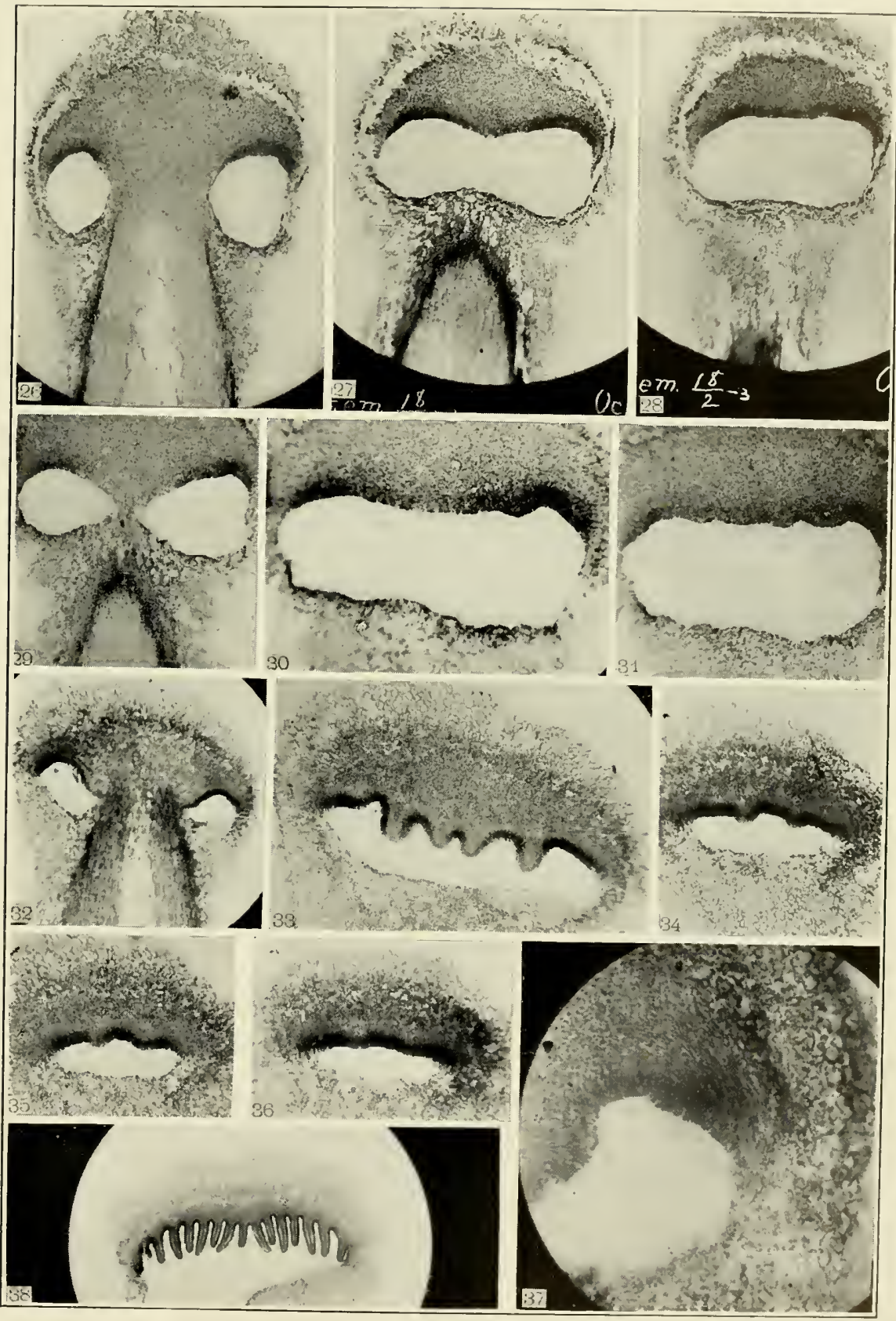

LEPIOTA SEMINUDA 



\title{
A TETRACOTYLEDONOUS RACE OF PHASEOLUS VULGARIS
}

\author{
J. Arthur Harris \\ Station for Experimental Evolution
}

\section{INTRODUCTORY REMARKS}

The practical utility of cotyledon number in schemes of classification has been the cause of great emphasis being tacitly laid upon the constancy and fundamental significance of this character.

The tenability of such a position has been considered by various writers. In part this has been quite incidental to a discussion of the homology of the cotyledon, as, for example, in the paper by Lyon $^{1}$ and in some of the older morphological literature to which reference may be obtained from papers cited below. In larger measure the discussion has centered directly on the problem of the origin of the monocotyledons. Sargant in $1902^{2}$ and again in $1903^{3}$ contributed extensive data from seedling stages to the problem. At about the same time my interest in the questions was aroused by anomalous seedlings of Pachira of the Malvaceae ${ }^{4}$ and in an early discussion ${ }^{5}$ I outlined some of the chief problems requiring investigation. More recently Coulter and Land $^{6}$ and Coulter $^{7}$ have discussed the subject upon the basis of embryological evidence.

These papers deal primarily with the problem of monocotyledony

${ }^{1}$ Lyon, M. E. The phylogeny of the cotyledon. Postelsia I: 57-86. 1902.

${ }^{2}$ Sargant, E. The origin of the seed-leaf in monocotyledons. New Phytologist I: I07-II3. I902.

${ }^{3}$ Sargant, E. A theory of the origin of the monocotyledons founded on the structure of their seedlings. Ann. Bot. I 7: I-92. pl. I-8. I903.

${ }^{4}$ Harris, J. Arthur. The germination of Pachira, with a note on the names of two species. Trans. Acad. Sci. St. Louis 13: 203-209. pl. 9-II. 1903.

${ }^{5}$ Harris, J. Arthur. The importance of investigations of seedling stages. Science II. 22 : I $84-186$. 1905 .

${ }^{6}$ Coulter, J. M., \& Land, IV. J. G. The origin of monocotyledony. Bot. Gaz. 57: 509-519. pl. 28-29. 1914 .

${ }^{7}$ Coulter, J. M. The origin of monocotyledony. Ann. Mo. Bot. Gard. 2: 175-183. I915. [Illust.] 
and dicotyledony, although the question of the origin of cotyledons in excess of two is not left altogether out of account.

In the literature of experimental breeding both an increase in the number of cotyledons in dicotyledonous plants and a decrease (in the form of syncotyledony) has been discussed, chicfly in the universally known work of de Vries. The purpose of the present contribution to our knowledge of the subject is to give the history and a brief characterization of an apparently fixed polycotyledonous race of the common garden bean.

\section{ORIGIN OF RACE}

In the autumn of 1907 I secured in Athens County, southeastern Ohio, a series of 160 individually harvested plants of this so-called navy or white soup beans. These have been grown for various purposes since that time in pedigreed but unguarded experimental cultures. The history of the first four generations I907, I908, I 909, and I9 Io has been given elsewhere, ${ }^{1}$ and many physiological and morphological characteristics and interrelationships of this group of plants have been expressed quantitatively in a series of papers ${ }^{2}$ dealing with this among other varieties of beans.

In I9I I a large quantity of seed from the Igog culture grown in southeastern Ohio was planted at Cold Spring Harbor for the purpose of investigating certain points that have no relevancy in this place. In the spring of 1912 the seed grown in I9I I was germinated by lines to determine the number and type of seedling abnormalities. Altogether records of the characteristics of 238,015 seedlings were made. Of these 4,286 were recorded as in some degree abnormal, and were placed (with the exception of 30 plants which were discarded), in the field with 5,098 normals from the same parent plants for future propagation. Nine of these abnormal plants-designated by their field numbers in the I9I 2 column of Table 1 -were distinguished by producing exclusively abnormal offspring, 85 in all, in 1913 . These form the recognized beginning of the race here described.

Three of the I0I2 plants produced but a single viable offspring

${ }^{1}$ Harris, J. Arthur. A first study of the influence of the starvation of the ascendants upon the characteristics of the descendants. Am. Nat. 46: 313-3+3,656-67t. $f$. I-II. 1912.

${ }^{2}$ See a bibliography in $\mathrm{Am}$. Jour. Bot. $1: 4^{10-411 .} 1915$. 
seedling in 1913. Two of these died before maturity. Thus the experiment was reduced to the progeny of seven plants none of which have since been lost, although the death rate in germination is high, and a considerable proportion of the I9I 3 plants died before maturity or were killed by frost.

TABLE I

\begin{tabular}{|c|c|c|c|c|c|c|c|}
\hline \multirow{2}{*}{$\begin{array}{l}\text { Parent num- } \\
\text { ber, } 19122\end{array}$} & \multicolumn{3}{|c|}{ Offspring plants } & \multirow{2}{*}{$\begin{array}{l}\text { Parent num- } \\
\text { ber, } 1912\end{array}$} & \multicolumn{3}{|c|}{ Offspring plants } \\
\hline & r913 & 1914 & 1915 & & $19{ }^{13}$ & $I_{914}$ & 1915 \\
\hline \multirow{5}{*}{$\begin{array}{l}3,221 \\
5,570 \\
5,831 \\
5,802 \\
5,764\end{array}$} & \multirow{5}{*}{$\begin{array}{r}38 \\
9 \\
5 \\
7 \\
7\end{array}$} & \multirow{5}{*}{$\begin{array}{r}\text { I I } \\
62 \\
\text { I4 } \\
3 \text { I } \\
45\end{array}$} & \multirow{5}{*}{$\begin{array}{r}2,426 \\
2079 \\
106 \\
594 \\
977\end{array}$} & 5,782 & $3^{1}$ & - & - \\
\hline & & & & 7,026 & 12 & 90 & 1,365 \\
\hline & & & & 4,434 & $\mathbf{I}^{1}$ & 一 & 一 \\
\hline & & & & 5,349 & 3 & 5 & 55 \\
\hline & & & & Total. . . . & 85 & $36 I$ & 7,602 \\
\hline
\end{tabular}

The seven pedigrees gave a total of $36 \mathrm{I}$ abnormal offspring ${ }^{2}$ in I9I4 and of 7,602 in $1915 .^{3}$

In I912 there was no reason to distinguish the 9 seedlings which gave rise to the race here under consideration from any other of the 4,286 abnormal ones secured in the germination of the 238 , or 5 plants. They were quite naturally described by means of the same schedule as the other plants. Because of the great variation in the structural characteristics of bean seedlings, the classes of these descriptive schedules were necessarily of a very general and comprehensive nature. Had it been possible to foresee that these plants would be particularly interesting because of their progeny, each one would of course have been described and figured in detail.

According to the records of the schedule employed, only one of the plants has a normal axis (Class I). Six were described as slightly broadened (Class II) and two as very greatly broadened or fasciated (Class III).

In only a single case are the cotyledons described as normal in number and insertion. In one seedling they were unrecorded. In four seedlings they were three and in two cases four in number.

\footnotetext{
${ }^{1}$ Died in 1913.

${ }^{2}$ In addition to these three were three of questionable character and seven apparently morphologically normal plants, which will be discussed below.

${ }^{3}$ The actual number of plants in I9I5 was somewhat higher, but because of the pressure of other experimental work in the spring the sand in the seed pans could not be worked over for plants which had died at an early stage in germination.
} 
In three instances there were one or more axillary shoots from the cotyledons.

In all plantlets the primordial leaves were highly abnormal in insertion, form, or number.

In I9I 3 and I9I t numerous plants were available for comparative study, and extensive descriptive notes were drawn up. Since, taken as a whole, these showed the same general characteristics as the I9I5 series, which is described quantitatively below, it seems unnecessary to present details concerning them.

As noted above, there were in the I9I4 culture seven plants described as morphologically essentially normal. Three of these had purple hypocotyls, indicating accidental hybridization with some variety with pigmented seed-coats. Four of these plants died, three produced offspring. Two of these three were purple-stemmed seedlings which produced dark-coated seeds. These were clearly hybrids due to vicinism. The third plant, with a green hypocotyl, produced white seeds which gave only normal plants in 1915. Possibly this was due to the accidental introduction of a normal seed. The line is being continued.

In I9I5 there were 2 plants among the 1,202 studied in detail which had the normal number of both cotyledons and primordial leaves. A few other plants of the same kind occurred among the 6,400 plants which were not described so minutely. These numerically normal plants generally have other features of leaf form or texture which indicate that they belong to the race. Some of these individuals will be bred further. In the meantime, I consider them as merely the extremes of a highly variable series. Their presence seems to me at present to qualify in no degree the conclusion that the race is fully constant.

The first question concerning this tetracotyledonous race that the reader would like to have decided is the nature of its origin.

While it was secured at the rery beginning of a selection experiment, it can not possibly be regarded as produced or built up by selection. It was merely isolated. It was isolated simultaneously in seven, and probal,ly in nine, ${ }^{1}$ individuals. 'The records show that all of these nine plants belong to a single line, the produce of plant 139 of 1907.

${ }^{1}$ The four offspring seerllings of plants 5,782 and 4,434 died without producing sect. Their progeny could not, therefore, be adecpuately tested. 
Concerning the structure of the seedling of the 1907 plant, or of that of its six $F_{1}$ (I908) and six $F_{2}$ (I909) descendants, nothing is actually known. The seeds were planted directly into the field. Seedling characters were not studied until I9I2.

It seems highly probable that these seven or nine seeds were produced by a single plant of the I9I I culture. It does not seem profitable to consider the various points at which the fundamental variation may have occurred. That the race originated some time between 1907 and I9II inclusive is clear from the fact that a relatively normal strain of plants from the same line of plants is at present under cultivation at the Station for Experimental Evolution.

In the I9I 2 germinations, line I 39 gave a total of 4,375 seedlings of which 4,239 were normal and $\mathrm{I} 36$ (including the 9 plants the offspring of which are here considered) were abnormal. Of the 4,375 seedlings studied in I9I 2 a series of $7 \mathrm{I}$ abnormal (excluding the 9 here especially under consideration) and 79 normal individuals were grown to maturity and produced a total of I,62 I offspring seedlings in I913. All these progenies were relatively normal, containing a total of only 45 abnormal plants or 2.78 per cent, as compared with sensibly roo per cent in the so-called tetracotyledonous race.

Thus the origin of this race of plants has all the characteristics of a de Vriesian mutation.

\section{Quantitative characterization of the RaCe}

The precision of a quantitative description of the race is limited by technical difficulties in counting in the case of the discrete variates and by the possibility of personal equation in the case of the characters which must be described in arbitrary categories.

Because of the pressure of other experiments and the difficulties of classifying plants with such a high degree of abnormality the description of the 1915 germinations of these lines was necessarily incomplete. To have expressed adequately the characteristics of several thousands of plants of such complexity of structure would have required many weeks' work, and in the present state of our knowledge of the morphology of the bean seedling would have been of doubtful value.

I have therefore limited myself to a detailed study of a portion of the material only. 
As a test of our ability to determine the characteristics consistently, we classified two lots of seedlings which should within the limits of the probable error of random sampling be the same except for differences due to age. One of these is designated as more mature series and the other as the less mature series. The closeness of agreement between the constants for these two series should furnish some measure of the accuracy with which the plants can be classified. The results of these determinations are given in the tables below.

\section{Axis}

The axis may be either round and slender throughout or considerably broadened or even divided.

Four classes, designated by Roman numerals, have been recognized :

I. Normal; terete, simple and slender throughout.

II. Epicotyl or sometimes both epicotyl and hypocotyl slightly broadened or fasciated.

III. Epicotyl or both epicotyl and hypocotyl much broadened or fasciated.

VI. Division of the epicotyl into two or more branches. This refers exclusively to divisions occurring below primordial leares, not to the formation of two terminal buds beyond them, since it was not always possible to make out this point.

In the classification of the stem much trouble was given by axillary shoots from the cotyledons. Because of the scatter of the cotyledons and the occasional occurrence of leaves interspersed among the cotyledons, it was not always possible to decide whether an apparently branched axis represented a true dichotomy or the development of axillary buds.

With respect to this character the individuals in the series are distributed as follows:

\begin{tabular}{|c|c|c|c|c|c|c|}
\hline \multirow{2}{*}{ Character of axis 1} & \multicolumn{2}{|c|}{ l.ess mature series } & \multicolumn{2}{|c|}{ More mature series } & \multicolumn{2}{|c|}{ Both series } \\
\hline & Frequency & Percent & Percent & Frequency & Frequency & Percent \\
\hline $\begin{array}{l}\text { I. Normal. ......... } \\
\text { II. Slightly fasciated.... } \\
\text { III. Greatly fasciated.... } \\
\text { II. Mlore or less divirled }\end{array}$ & $\begin{array}{r}90 \\
206 \\
20 \\
114\end{array}$ & $\begin{array}{r}20.93 \\
47.91 \\
4.65 \\
26.51\end{array}$ & $\begin{array}{r}42.88 \\
18.78 \\
4.66 \\
33.68\end{array}$ & $\begin{array}{r}331 \\
1+5 \\
36 \\
260\end{array}$ & $\begin{array}{r}+21 \\
351 \\
56 \\
374\end{array}$ & $\begin{array}{r}35.03 \\
29.20 \\
4.66 \\
31.12 \\
\end{array}$ \\
\hline
\end{tabular}

\footnotetext{
t The terms used are explaincel in greater detail in the text.
} 
The results of the two determinations are in fair agreement except for Classes I and II. It is exceedingly difficult to avoid personal equation in distinguishing between these two classes. I attribute the wide differences in percentage frequencies to this cause.

The fact that less than 5 per cent of the seedlings have axes which are described as much broadened or fasciated, taken in connection with the uncertainty of the division between the normal and the slightly broadened axis, indicates that the increase in the number of cotyledons and primordial leaves is not fundamentally due to fasciation. It appears rather to be attributable (when any modification of the stem is involved) to division of the axis or to the production of axillary shoots from the cotyledons. To this point I shall return below.

\section{Cotyledons}

While the race has been called tetracotyledonous, the number of cotyledons is really highly variable, as is shown by the totals of TABLES II and III, and graphically in DIAGRAM $I$.

TABLE II

Cotyledons and LEAVES IN LESS Mature SERIES

Leaves

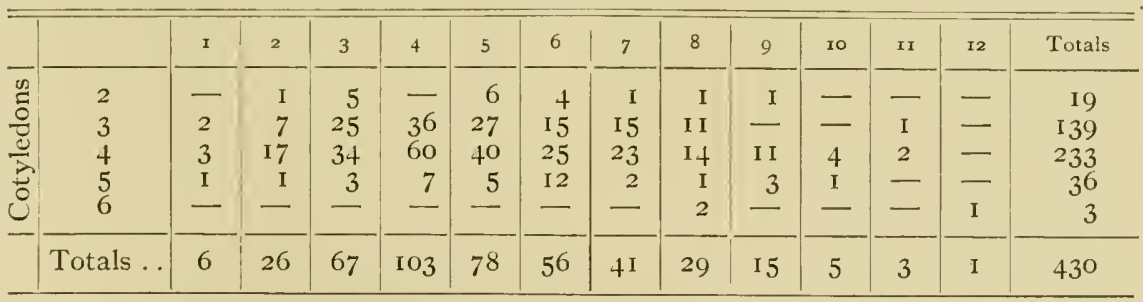

TABLE III

Cotyledons and leaves in more mature series

Leaves

\begin{tabular}{|c|c|c|c|c|c|c|c|c|c|c|c|c|c|c|c|}
\hline & & I & 2 & 3 & 4 & 5 & 6 & 7 & 8 & 9 & ro & II & 12 & $x_{4}$ & Totals \\
\hline \multirow{7}{*}{$\frac{\frac{n}{0}}{\frac{0}{0}}$} & 2 & - & I & 6 & 3 & 2 & I & $I$ & - & - & 一 & - & - & - & $I_{4}$ \\
\hline & 3 & I & I3 & 44 & 59 & 47 & $2 I$ & 13 & 7 & 4 & 3 & I & - & - & 213 \\
\hline & 4 & 4 & 34 & 80 & 127 & 100 & 72 & 32 & 24 & I3 & 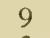 & 5 & - & I & $50 \mathrm{I}$ \\
\hline & 5 & 二 & 二 & 4 & 5 & 9 & 8 & 2 & 4 & 一 & & I & I & - & 37 \\
\hline & 0 & - & 二 & E & - & $-^{2}$ & $\bar{I}$ & I & I & 二 & - & E & 二 & 二 & $\begin{array}{l}6 \\
I\end{array}$ \\
\hline & & 5 & 48 & 132 & 5 & I6 & 7 & & 36 & 5 & $\pi$ & & & & \\
\hline & & & 40 & 134 & 195 & 100 & 102 & $5 \mathrm{I}$ & 30 & 17 & 15 & & & 1 & 772 \\
\hline
\end{tabular}


The most of the cotyledons are large and typical in form but occasionally those which are small and scale-like are observed. They may be inserted in a regular whorl or widely scattered along the axis. Nevertheless the counting of the number of cotyledons can, I think, be carried out with reasonable accuracy. ${ }^{1}$

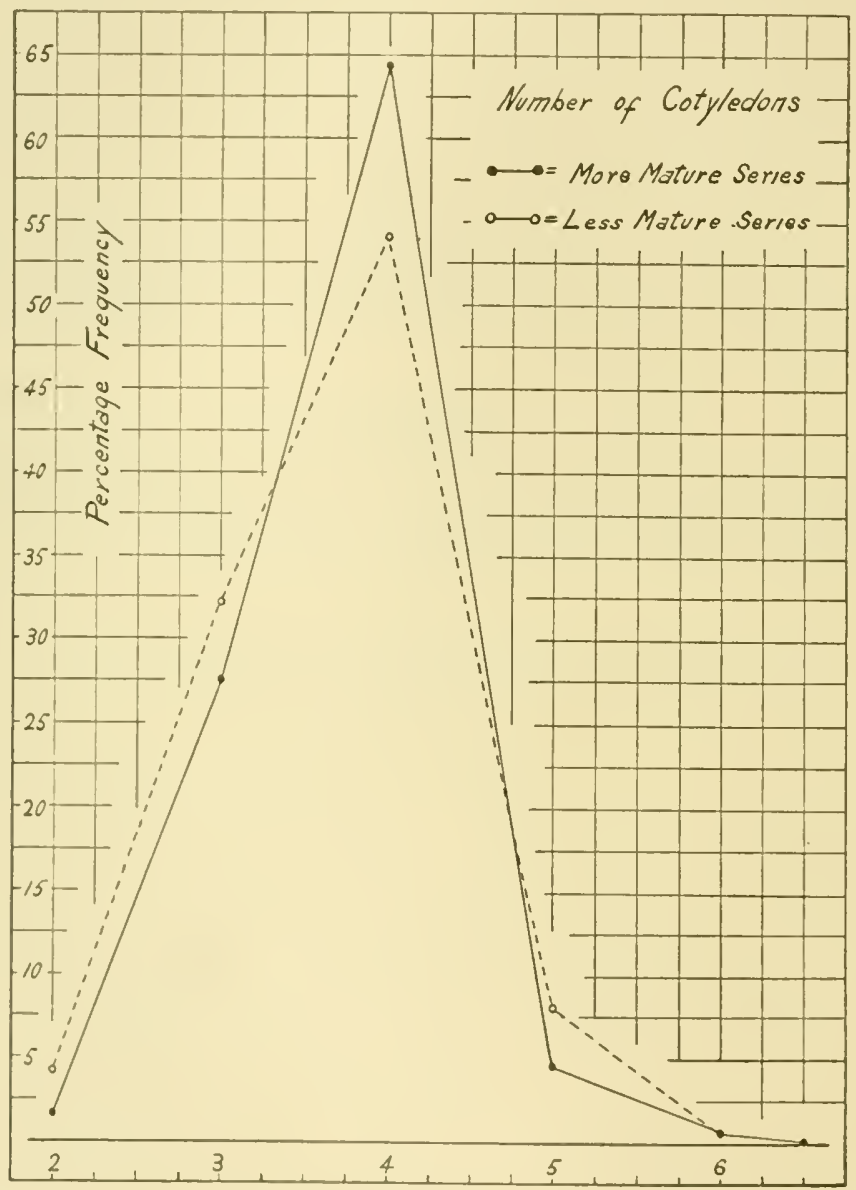

1)LAGRAM I. Frequency distribution of number of cotyledons per plant.

The tables and graphs show that in samples of the present size the range is from two to seven cotyledons. There is a distinct mode in both samples upon four cotyledons. The distributions are de-

I In a few cases we determined the number of cotyledons from the number of scars, but in only a few. 
cidedly asymmetrical, the mode lying above the mean. There seems no obvious advantage in fitting theoretical curves to these observed frequency distributions, at least until wider series of data grown under experimentally controlled conditions are available.

The variation constants for number of cotyledons are as follows.

\begin{tabular}{|c|c|c|c|}
\hline & Mean & Standard deviation & $\begin{array}{l}\text { Coefficient of } \\
\text { variation }\end{array}$ \\
\hline Less mature series..... . . & $3.686 \pm .023$ & $0.716 \pm .017$ & $19 \cdot+3 \pm .+6$ \\
\hline More mature series... & $3.755 \pm .015$ & $0.616 \pm .011$ & $16.70 \pm .29$ \\
\hline Difference................... & $.069 \pm .028$ & $0.100 \pm .020$ & $3.03 \pm .55$ \\
\hline More and less mature combined.... & $3.730 \pm .013$ & $.65 t \pm .090$ & $17.5 t \pm .25$ \\
\hline
\end{tabular}

Thus there is an average of about three and seven tenths cotyledons per plant, with an absolute variation as measured by the standard deviation of about seven tenths of a cotyledon, or seventeen to eighteen per cent.

The question of the relationship between the character of the axis and the number of cotyledons can not be discussed in detail here. The accompanying table shows the average number of cotyledons for each type of axis.

\begin{tabular}{|c|c|c|c|}
\hline \multirow{2}{*}{ Class of axis } & \multicolumn{3}{|c|}{ Mean number of cotyledons } \\
\hline & Less mature series & More mature series & Both series \\
\hline 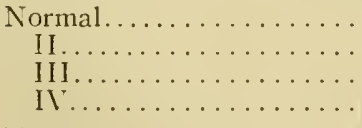 & $\begin{array}{l}3.63 \\
3.70 \\
3.80 \\
3.68\end{array}$ & $\begin{array}{l}3.70 \\
3.74 \\
3.83 \\
3.82\end{array}$ & $\begin{array}{l}3.69 \\
3.72 \\
3.82 \\
3.78\end{array}$ \\
\hline 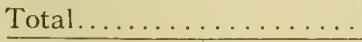 & 3.69 & 3.77 & 3.73 \\
\hline
\end{tabular}

It is clear that there is no intimate dependence of cotyledon number upon the structure of the stem. If the comparison be reduced to that between plants with axes normal or only slightly broadened ${ }^{1}$ and those with axes much broadened or divided, the results are:

\begin{tabular}{|c|c|c|c|}
\hline \multirow{2}{*}{ Class of axis } & \multicolumn{3}{|c|}{ Average number of cotyledons } \\
\hline & Less mature series & More mature series & Both series \\
\hline 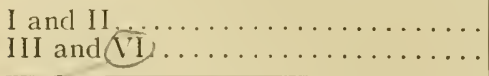 & $\begin{array}{l}3.68 \\
3.70\end{array}$ & $\begin{array}{l}3.7 \mathrm{I} \\
3.82\end{array}$ & $\begin{array}{l}3.70 \\
3.79\end{array}$ \\
\hline Totals . . . . . . . . . . . & 3.69 & 3.76 & 3.73 \\
\hline
\end{tabular}

1 The combination of these two classes seems to be necessary because of the difficulty of distinguishing sharply between them. 
These differences are very slight indeed. Such results indicate very clearly that the increase in the number of cotyledons over the normal which characterizes this race is not fundamentally due to a broadening of the axis.

The accompanying table shows that about fifty per cent of the plants are recorded as having produced shoots from the axils of the cotyledons.

\begin{tabular}{|c|c|c|c|c|c|c|}
\hline & \multicolumn{2}{|c|}{ 1.ess mature series } & \multicolumn{2}{|c|}{ More mature series } & \multicolumn{2}{|c|}{ Botb series } \\
\hline & Frequency & Per cent & Per cent & Frequency & Frequency & Per cent \\
\hline $\begin{array}{l}\text { With axillary shoots... } \\
\text { Without axillary shoots }\end{array}$ & $\begin{array}{l}227 \\
203\end{array}$ & $\begin{array}{l}52.79 \\
47.21\end{array}$ & $\begin{array}{l}46.89 \\
53.11\end{array}$ & $\begin{array}{l}362 \\
+10\end{array}$ & $\begin{array}{l}589 \\
613\end{array}$ & $\begin{array}{l}49.00 \\
51.00\end{array}$ \\
\hline
\end{tabular}

It is interesting to note that a higher proportion of the plants are recorded as producing axillary shoots in the less mature series than in the more mature series. The difference is probably due merely to the errors of random sampling, but the fact that the axillary shoots are not more abundant in the more mature series indicates that they are not structures of late development.

\section{Primordial leares}

The following conditions present real obstacles to the determination of the number of primordial leaves with a high degree of precision.

(a) When the scedlings are very young all the primordial leaves are not fully expanded, and there is consequently some technical difficulty in determining the true number. (b) When the plants have grown to a considerable size shoots are apt to have developed from the axils of the cotyledons which by this time may have fallen. It is exceedingly difficult, as pointed out above, to distinguish between these axillary shonts and the longitudinal or latcral division of the stem. This is especially true if the cotyledons have fallen. Since the earlicr leaves on the axillary shoots are apt to be simple, they would, if inclucled, increase the number of primordial leares. (c) It seems quite probable that some of the axillary shoots have started development during the maturation of the secel. Since it is impossible to distinguish between these axillary shoots and hranches of the stem originating otherwise, primorelial leaves found on them should be counted in. 
Thus there is really very great difficulty in determining which simple leaves should be counted as belonging to the primordial ones. What one would like to do would be to include only these which were laid down in the seed. This we tried to do.

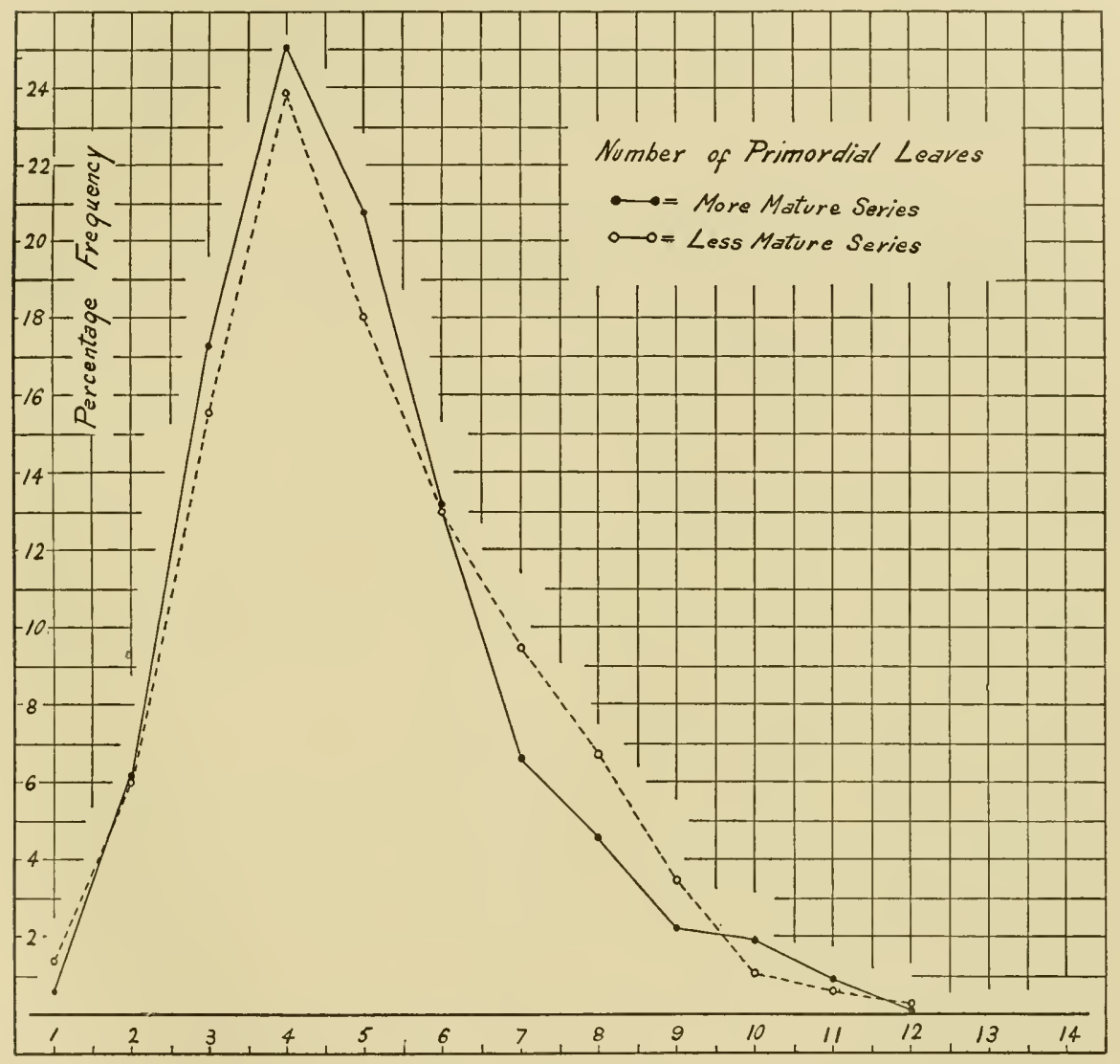

DiAgRAm 2. Frequency distribution of number of primordial leaves per plant.

The distribution of the number of leaves per plant is given in the totals of TABLES II and III and represented graphically in DIAGRAM 2.

Inspection of the totals of the tables shows that number of leaves has a far wider range of variation than number of cotyledons. In both cases the greatest frequency falls upon four. In both cases the distributions are decidedly asymmetrical. In the case of the leaves, however, the mean falls above the mode-in 
fact is greater than the mode by almost one unit-whereas in the cotyledons the average was less than the modal class.

The variation constants are as follows:

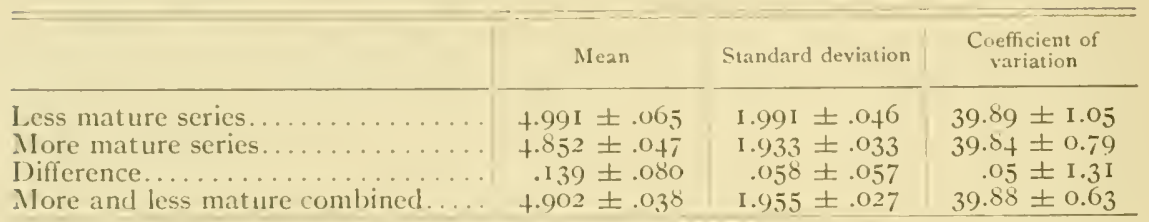

The samples do not differ significantly in any constant.

Comparing the constants for number of cotyledons and leaves on the basis of the total materials I find the following constants:

\begin{tabular}{|c|c|c|c|}
\hline & Constants for cotyledons & Constants for leaves & Difference in constants \\
\hline 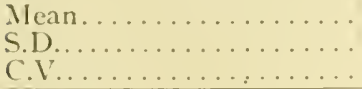 & $\begin{array}{c}3.730 \pm .013 \\
.654 \pm .090 \\
17.54 \pm 0.25\end{array}$ & $\begin{array}{l}4.902 \pm .038 \\
1.955 \pm .027 \\
39.88 \pm 0.63\end{array}$ & $\begin{array}{l}1.172 \pm .040 \\
1.301 \pm .094 \\
22.34 \pm 0.68\end{array}$ \\
\hline
\end{tabular}

Thus the mean number of leaves is about $3 \mathrm{I} .4$ per cent higher than the mean number of cotyledons, the absolute variation in leaf number is about 200 per cent greater and the relative variation as measured by the coefficient of variation is over twice as great as in the case of cotyleclon number.

The number of leaves per plant is in some degree related to the character of the axis. Examined in the crudest manner possible, ${ }^{1}$ by determining the average number of leaves produced by plants with different types of axis, I find the following results:

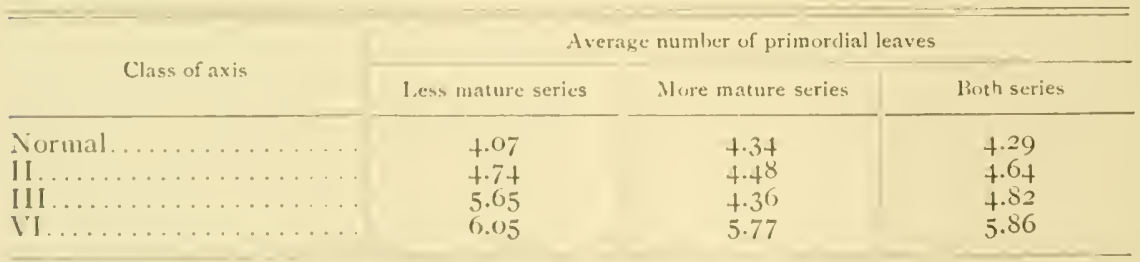

Thus an increase in the number of primordial leaves is associated with a broadening or division of the axis. This increase is distinctly greater than in the case of the cotyleclons.

I With a more careful classification of the structure of the axis it will be profitable to apply correlation formulae to the problem. 
If the plants be thrown into two groups only, as was done above in the examination of cotyledon number, the results are:

\begin{tabular}{|c|c|c|c|}
\hline \multirow{2}{*}{ Class of axis } & \multicolumn{3}{|c|}{ Average number of primordial leaves } \\
\hline & Less mature series & More mature series & Both series \\
\hline $\begin{array}{l}I \text { and } I I \\
\text { III } \text { and } V I \ldots \ldots \ldots \ldots\end{array}$ & $\begin{array}{l}4.54 \\
5.99\end{array}$ & $\begin{array}{l}4.39 \\
5.60\end{array}$ & $\begin{array}{l}4 \cdot 44 \\
5.72\end{array}$ \\
\hline Totals............... & 4.99 & 4.85 & 4.90 \\
\hline
\end{tabular}

The differences are far larger than in the case of the cotyledons, but the mean number of leaves on plants with normal or but slightly broadened axes is so high that the results fully substantiate the conclusions drawn above, that the approximate doubling in the number of cotyledonary and foliar organs is not fundamentally due to a broadening of the axis.

If the seedlings be classified without regard to the structure of the axis into those with and those without axillary shoots, the results show that in both less and more mature series the plants with the axillary shoots have a higher number of primordial leaves. Thus:

\begin{tabular}{|c|c|c|c|}
\hline & $\begin{array}{l}\text { Mean leaves in plants } \\
\text { without axillary shoots }\end{array}$ & $\begin{array}{l}\text { Mean leaves in plants } \\
\text { with axillary shoots }\end{array}$ & Difference \\
\hline $\begin{array}{l}\text { Less mature series. . . . . . . } \\
\text { More mature series...... }\end{array}$ & $\begin{array}{l}4.507 \pm .083 \\
4.746 \pm .064\end{array}$ & $\begin{array}{l}5.423 \pm .094 \\
4.972 \pm .069\end{array}$ & $\begin{array}{l}.916 \pm .125 \\
.226 \pm .094\end{array}$ \\
\hline Difference. & $.239 \pm .105$ & $.45 \mathrm{I} \pm .117$ & \\
\hline
\end{tabular}

This is quite what one would expect from the fact that the simple leaves of axillary shoots which seemed to have developed in the seed were counted in the number of primordial leaves. The constants show, however, that the difference is not large, amounting on the average to less than a leaf in the two series considered.

The fact that the excess in number of primordial leaves in plants with axillary shoots is greater in the less mature than in the more mature series, shows that there can be no considerable error introduced by the counting of simple leaves of late development.

With respect of size, form, and structure the leaves vary enormously. They range from those which are minute to those which are far larger than the primordial leaves of normal plants. Length, 
breadth, and form of base and apex are extremely variable. Generally the leaves were moderately plane, but in some instances they were highly irregular, with revolute margins.

In some, but not numerous, instances filiform filaments occupy the positions of primordial leaves, and have been counted as such.

Monophyllous obliquely infundibuliform ascidia are abundant. In the less mature series 2.42 per cent of the leaves and in the more mature series 2.38 per cent of the leaves are thus modified. This is extremely abundant as compared with any other strain of Phaseolus anlgaris with which I have had experience.

The various combinations of cotyledons and primordial leaves per seedling are shown by the double entry TABLEs II and III. the totals of which have already served in the discussions of cotyledon and leaf number. Here the entries in the body of the table show the frequency of occurrence of plants with the number of cotyledons indicated at the left and the number of primordial leaves designated in the upper margin.

From these tables the degree of correlation between the number of cotyledons and the number of primordial leaves can be at once determined. The results are:

$\begin{array}{ll}\text { For less mature series, } & r=.117 \pm .032 \\ \text { For more mature series, } & r=.157 \pm .024 \\ \text { For both series combined, } r=.139 \pm .019\end{array}$

Since perfect correlation is numerically represented by a coefficient of unity, it is clear that the degree of interdependence between cotyledon number and primordial leaf number is very slight. This result may come as something of a surprise to geneticists who have stated that the correlation between the two is perfect.

The actual relationship between the two variates can be clearly brought out by calculating equations to smooth the mean number of cotyledons associated with different numbers of primordial leaves and the mean number of primordial leaves associated with different numbers of cotyledons. They are:

For less mature series-

$$
\begin{aligned}
& l=3.792+.325 c \\
& c=3.75+.042 l
\end{aligned}
$$


For more mature series-

$$
\begin{aligned}
& l=3.004+.492 c \\
& c=3.513+.050 l
\end{aligned}
$$

For both series combined--

$$
\begin{aligned}
& l=3.356+.4 \mathrm{I} 4 c \\
& c=3.502+.046 l
\end{aligned}
$$

The second term of the equation shows that for each deviation of one cotyledon from the mean number of cotyledons there is a deviation of about four tenths of a leaf from the mean number of leaves. For each deviation of one leaf from the mean number there is associated a mean deviation of only about five hundredths of a cotyledon.

These lines are shown graphically with the empirical means in DIAGRAM 3. The agreement between the observed and the smoothed frequencies is not very close. ${ }^{1}$

At present it seems undesirable to attempt a closer statistical analysis of the data. Such would better be reserved until wider and more precisely recorded series of observations on plants grown under more closely controlled conditions are available.

\section{Recapitulation}

The teratological race of Phaseolus vulgaris described in the preceding pages has proved constant with exceptions which may probably be disregarded for three offspring generations. These comprise $85,37 \mathrm{I}$ and 7,602 individuals respectively. A limited test of the fourth offspring generation has indicated perfect constancy.

The race appeared in a "pure line" of beans derived from a single parent plant grown in 1907. It was isolated in seven and probably in nine individuals grown in 1912 from mass culture seed harvested in I9II. All the circumstances of its origin are characteristic of de Vriesian mutation.

While Tetracotyledonous has been selected as the most convenient single descriptive term, the race is differentiated from the normal

${ }^{1}$ A part of the discrepancy is, however, apparent rather than real. Thus the aberrant means for cotyledon number for plants with $\mathrm{I} 2$ and $\mathrm{I}+$ leaves are based upon a single seedling each. Plants with 6 and 7 cotyledons are but ro of the I,202 individuals. The very aberrant average for leaf number associated with 6 cotyledons in the less mature series is based upon 3 individuals only. 
bean seedling in numerous characters. The axis may be broadened or divided. The cotyledons are highly variable in number and insertion. Axillary shoots from the cotyledons are abundant. The primordial leaves are most variable in number and form. Foliar asciclia are frequent.

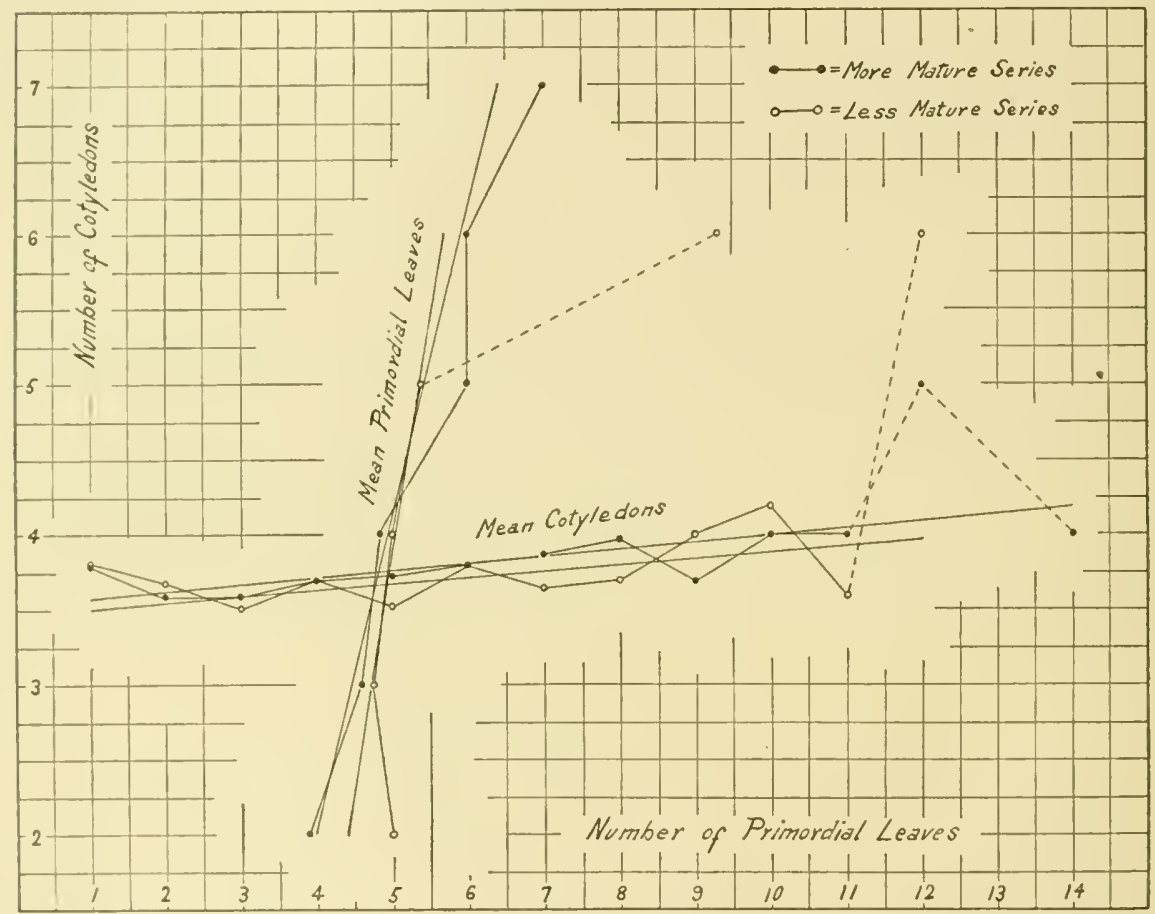

DIASRAM 3. Interrelationship of number of cotyledons and number of primordial leaves per plant.

Both cotyleclons and primordial leaves have a modal frequency of four, lout are highly variable in number. The cotyleclons range from 2 to 7 and the primordial leaves from $\mathrm{I}$ to $\mathrm{I} f$ in the samples studied in detail. The cotyledons have a mean number of about 3.70 , with a variability of about 17.5 per cent. The primordial leaves have a mean of about 4.90, with a variability of nearly 40.0 per cent. Thus the primordial leaves are more variable in number than the cotyleclons.

The correlation between number of cotyledons and number of leares is low. 


\title{
JAPANESE SPECIES OF. GYMNOSPORANGIUM*
}

\author{
FRANK D. KERN \\ Pennsylvania State College
}

Several years ago, while preparing an account of all the known species of Gymnosporangium,$^{1}$ the writer's attention was especially attracted to the species reported from Japan. It did not seem at all likely that the specimens and meager culture data then available from that country adequately represented the genus as it probably existed there. Since that time the publication of several new species, based upon Japanese material, together with some additional culture data has materially added to our information. Mycologists and plant pathologists in America also have an interest in these forms because of the fact that they are likely to be introduced into this country on nursery stock, such instances having already occurred. ${ }^{2}$

The best-known Japanese species is G. japonicum described by Sydow in I 899 [Hedwigia 38: I4 I (Beibl.)]. This appears on gradual fusiform enlargements of the stems of Juniperus chinensis. In I900 M. Shirai reported successful cultures between this form and Roestelia koreaensis on Pyrus sinensis (Zeitschr. Pflanzenkr. 10: 1). The correctness of this cultural result has not been questioned by the various writers who have had occasion to refer to it, until the recent work of Ito (Tokyo Bot. Mag. 27: 22I. I9I3). This investigator in May, I9I3, made cultures from a steminhabiting form on Juniperus chinensis, which was without doubt G. japonicum, on Pyrus sinensis, P. Malus, Amelanchier asiatica, and Pourthiaea villosa. If this were related to Roestelia koreaensis, which was described on Pyrus sp., positive results should have been expected upon one or both of the species of Pyrus, but such

* Contributions from the Department of Botany, Pennsylvania State College, No. 7.

${ }^{1}$ Part II. A biologic and taxonomic study of the genus Gymnosporangium. Bull. N. Y. Bot. Garden 7:424-476. I9II.

${ }^{2}$ Clinton, G. P. Ann. Rep. Conn. Agr. Exp. Sta. I 9r2: 350. I9r3. Kern, F. D. Loc. cit., p. 46r. Jackson, H. S. Jour. Agr. Research 5: I003-I009. 1916. 
was not the case. After seventeen days yellow spots were observed upon the Pourthiaea and in five weeks aecia had developed, while the other three species remained uninfected. While at first this seems to be at variance with the previous results of Shirai, it is comparatively easy to trace out the error in the work of the latter. He had present on his culture material both a stem and a leaf form. It can be said now without doubt that the leaf-inhabiting form was responsible for his culture on Pyrus sinensis. Not appreciating the possibility that he was dealing with two species, a misinterpretation of his results was a very natural outcome. The Roestelia produced on Pourthiaca by Ito is undoubtedly the one which was described by Henning in I 894 as R. Photiniae (Hedwigia 33: 23I) and later referred to Gymnosporangium by the writer (Kern, loc. cit. 4+3). Accordingly, $G$. japonicum, the stem form, is to be considered genetically related to $R$. Photiniae and not to $R$. koreaensis. In I9I2, Sydow described an aecial stage on Cydonia vulgaris from Japan as $G$. spiniferum (Ann. Myc. 10:78). It seems likely in the absence of cultures that this should be regarded as a synonym of $G$. Photiniae. The small pale aeciospores agree perfectly. The peridial cells agree well as to size and thickness of walls; the spines may be somewhat coarser and longer in G. spiniferum but they do not differ essentially. The peridium is longer and more robust in G. Photiniae on Pourthiaea but none of the species which occur on the leaves of $C y d o n i u$ seen to be as robust on it as on the other hosts. This is very noticeable in G. Nidus-avis, a North American species, which occurs on Amelanchier and Cydonia. The revised synonomy and host list for this species would now be as follows:

Gymosporangium Photiniae (P. Henn.) Kem, Bull. N. Y. Bot. Garden 7: +43. I9I I

Roestelia Photiniae P. Henn. Hedwigia 33:231. I894.

Gymnosporangium japonicum Sydow, Hedwigia 38: IfI (Beibl.). 1899.

Gymnosporangium spiniferum Sydow, An11. Myc. 10: 7S. I912.

I. Aecia, with spiniferous peridial cells, on Cydonia vulgaris (L.) Pers. and Pourthiaea villosa (Thunb.) Dec. (Photinia villosa Dec., Photinia laevis DC.).

III. Telia, with spores $48-66 \mu$ long, on the woody twigs and branches of Juniperus chinensis L. 
The suggestion in the foregoing paragraph that a leaf-inhabiting form on J. chinensis was responsible for Shirai's culture on Pyrus sinensis makes it necessary to dispose of that form in some way. When the writer prepared his monograph there were no Japanese species described on the leaves or green branches of Juniperus with the possible exception of G. asiaticum Miyabe (Bot. Mag. Tokyo $17^{2}: 34$. I903). This was described in the Japanese language and so far as the writer could make out was not sufficiently characterized to establish the name. It carries with it the information that the Gymnosporangium is on the leaves of Juniperus chinensis, Pyrus sinensis, and Cydonia vulgaris. So far as the general nature of the telia and the aecial connections are concerned, the observations of Miyabe and the work of Shirai agree. This situation is further strengthened by culture work of Hara in I9I3 (Bot. Mag. Tokyo 27:348). There seems little doubs that the aecia with which we are dealing here are all referable to $R$. koreaensis P. Henn. As to the identity of the telial phase and a proper name for it, the solution is not so easy. If we regard $G$. asiaticum as a hyponym we find the next name which has been proposed for a leaf-inhabiting Japanese form is $G$. Haraeanum (Sydow (Ann. Myc. 10:405. I9I2). In the original publication, Sydow made no mention of an aecial connection but in a very clear and comprehensive review of the whole matter Ito (Bot. Mag. Tokyo 28:220-223) has shown that the leaf forms described by Shirai, Hara, and Sydow are identical and without doubt belong with $R$. koreaensis on Pyrus sinensis. In I9I4 Long ${ }^{1}$ founded $\mathrm{a}^{\cdot}$ new species, Gymnosporangium chinense, on specimens of Juniperus chinensis which were imported from Japan by the Elm City Nursery, IVestville, Connecticut, and which were brought to the attention of mycologists and pathologists by Clinton. This same importation of junipers had on them a stem form which has been identified without doubt as G. Photiniae (G. japonicum). Long recognized that this new species on the leaves and green twigs of Juniperus chinensis was very closely related to G. Haraeanum on the same host and originally from the same general locality. He concluded, however, that the two were distinct, stating that "they differ in certain fundamental microscopic characters." The chief difference which he points out is the position of the germ pores in the colorless thin-walled telio-

${ }^{1}$ Long, W. H. Jour. Agr. Research I: 354. I9I4. 
spores. Clinton ${ }^{1}$ in a later discussion fails to find the difference in the location of the pores and on the whole "sees no real reason for considering Long's species as distinct." After an examination of the specimens and a consideration of the whole matter the writer agrees with Clinton that the grounds are insufficient for the separation of a new species according to Long. The writer would further disagree with Long's intimation that a character such as the location of germ pores in the colorless thin-walled teliospores is a fundamental character. If one were attempting to draw a fine distinction between the specimens from Japan and those collected in Connecticut the presence of large numbers of thickwalled $(2.5-3 \mu)$ teliospores in the former as compared with one moderately thick-walled $(I-I .5 \mu)$ in the latter is more noticeable than any other point. This is probably due to the fact that the Connecticut specimens are somewhat less mature. It has been known for a long time that the same telial sorus in the genus Gymmosporangium may contain two sorts of spores, thick-walled ones and lighter colored thinner-walled ones. Long has attempted to establish a third type intermediate between the two extremes. This simply supports the idea that the thick- and thin-walled spores do not represent two types but simply two extremes with gradations existing between them. Referring again to the germpores, it may be said that their location in the teliospores of this genus is variable. There is a marked tendency for the pores in both cells of two-celled spores to be near the septum but in the uppermost cell there may be one at the apex with or without any at or near the septum. It is entirely probable that the thinnerwalled spores may have a tendency toward terminal pores in the apical cell when the thick-walled spores may show the usual arrangement at the septum. It seems improbable that such a tendency could be sufficiently marked to use it even as a minor specific character. Accordingly, the full synonymy for the form on the leaves and green stems of Juniperus chinensis would be as follows:

Grinosporangium koreanise (P. Henn.) Jackson, Jour. Agr. Research 5: 1006. I916.

Roestelia koreaensis P. Henn. Warb. Monsunia 1: 5. 1900.

'Clinton, G. P. Ann. Rep. Conn. Agr. Exp. Sta, for 1914 (Report of the Botanist. for 1913$): 15,16.1914$. 
Tremella koreaensis Arth. Proc. Indiana Acad. Sci. 1900: I36. I 901 .

Gymnosporangium asiaticum Miyabe, Bot. Mag. Tokyo $17^{2}: 34$. I903. [Hyponym]

Gymnosporangium Haraeanum Sydow; H. \& P. Sydow, Ann. Myc. 10:405. 1912 .

Gymnosporangium chinense ["is"] Long, Jour. Agr. Research 1: 354. I9I4.

I. Aecia with rugose peridial cells, on Cydonia vulgaris (L.) Pers., Cydonia japonica (Thunb.) Pers., and Pyrus sinensis Lindl.

III. Telia with spores $35^{-50} \mu$ long, on the leaves and green twigs of Juniperus chinensis L.

Ito in the paper already cited remarks that if we accept names according to priority G. japonicum would become G. Photiniae and $G$. Haraeanum would be changed to G. koreaense. He states, however, that he is retaining the old names. An interesting problem in nomenclature is presented by such provisional transfers. There are other similar cases on record.

In the account of the genus Gymnosporangium in the North American Flora, vol. 7 , the species $G$. japonicum was included as no. 2I, p. 20I, and the error of associating $R$. koreaensis was continued there. The species was included because it was known to have been imported into America. ${ }^{\mathrm{I}} \quad$ Every effort was made to stamp it out and it probably did not become established. There is the same basis for including $G$. koreaense in such a descriptive account. ${ }^{2}$ It should be inserted among the forms appearing on leaves or leafy twigs. It might well follow G. fraternum, from which it could be separated by the teliospores being not or only occasionally thickened at the apex, whereas they are uniformly thicker above in G. fraternum.

Having determined that there is a caulicolous form, G. Photiniae, on Juniperus chinensis with aecia on Pourthiaea and Cydonia, and a foliicolous form, G. koreaense, on the same host

\footnotetext{
${ }^{1}$ Since this paper was prepared two other importations of this species have come to the attention of the writer, one collected by F. N. Rhodes, Seattle, Washington, imported from Yokohama, Japan, the other collected by J. WV. Hotson on the campus of the University of Washington, Seattle, Wash., both in May, I915.

${ }^{2}$ Recently (Feb. 28, 1916) Professor H. S. Jackson has reported in the Journal of Agricultural Research (5: 1003-1009) the complete establishment of this species in Oregon, and has referred to incomplete evidence of its establishment in California.
} 
with aecia on Pyrus and Cydonia, we apparently have not yet exhausted the possibilities with regard to Jumiperus chinensis. There appears to be another caulicolous form on this host which is connected with aecia on various species of Malus, viz. Gymnosporangium Yamadae Miyabe. Miyabe uses this name in a Japanese report of the Sapparo Botanical Society (Bot. Mag. Tokyo $17^{2}: 34$ ). With some assistance the writer makes out that this occurs on the "stout part" of the stem of Juniperus chinensis with aecia on the leaves of Malus (Pyrus) Malus, Malus (Pyrus) spectabilis, and Malus (Pyrus) Toringo. Through the kindness of Dr. H. Sydow the writer has secured a specimen of the aecia on Malus spectabilis. The peridial cells are verruculose with small oval papillae, being quite unlike the spiniferous ones of $G$. Photiniae or the rugose ones of $G$. koreaense. The chestnut-brown aeciospores are also very unlike the yellow ones of $R$. Photiniae, which without doubt belongs to a caulicolous form on $J$. chinensis. Believing that the Roestelia represented a good species the writer used the name $G$. Yamadae, in his monographic account (Bull. N. Y. Bot. Garden 7: 446. I9II), giving credit to Miyabe. A full description of the aecial stage was given but the telia were said to be unknown. To that we can now add what should have been included then, that the telia are said to be on the stems of Juniperus chinensis but that is all the information which we have.

Pourthiaea villosa also has another aecial stage upon it which is extremely interesting. This one is not Roestelia-like but has short cupulate peridia. In structure and habit this form which Sydow named Aecidium Pourthiaeae is so much like the North American species, G. Blasdaleanum, that the writer has tentatively referred it to that species. Our $G$. Blasdaleanum, which is coming to be of considerable importance, ${ }^{1}$ has been culturally comnected to a telial form on the incense cedar, Heyderia decurrens (generally referred to as Libocedrus decurrens). While there has been $n$ report from Japan of a similar telial form, and even though Heyderia decurrens does not occur there, the fact that

\footnotetext{
'See Jackson, H. S. A new pomaccous rust of economic importance, Gymnosporangium Blasdaleanum. Phytopathology 4:26I-270. I9I4. And O'Gara, P. J. The Pacific Coast cedar rust of the apple, pear, quince and related pome fruits caused by Gymnosporangium Blusdaleanum. Tech. Bull. No. 2, Office of Pathologist and Local U. S. Weather Bureau Station for Rogue River Valley, 1913.
} 
another species of Heyderia is known in the Orient makes the suggestion worthy of consideration. Altogether there have been three aecidioid aecia described on pomaceous hosts. These are interesting because the host relation calls for a Gymnosporangium connection, whereas the structure would not appear to do since most Gymnosporangium species produce roestelioid aecia. There can, however, be no question about the connection of G. Blasdaleanum, which possibly includes the Japanese form, with aecidioid forms on various Pomaceae. The third form is Aecidium Sorbi Arth., from the northern Pacific Coast region of North America. Several years ago the writer ${ }^{1}$ predicted the relationship of this with Uredo nootkatensis Trelease on Chamaecyparis nootkatensis. At that time such a prediction was quite novel since it was not certain that the Uredo nootkatensis represented a Gymnosporangium. Since that time Arthur ${ }^{2}$ has reported the discovery of telia in this form.

There is also additional field evidence that it is related to Aecidium Sorbi as predicted. This is an especially interesting species since it is the only one in which uredinia are known to occur. It is suggested that the additional spore-stage, together with cupulate aecia and foliicolous telia, may indicate a primitive condition of this type of rust. Species occurring on the branches producing fusiform swellings or gall-like outgrowths and related to aecia with peridia grown out in a roestelioid fashion would be later and more specialized developments. In connection with such developments repeating (uredinial) stages have dropped out of the life-cycle according to such a view.

Reference has been found to only one other species of Gymnosporangium from Japan. Its standing or nomenclature apparently has not become involved and a brief mention will be sufficient. The first reference is to the occurrence of aecia on Pyrus Miyabei by Miyabe in 1903 (Bot. Mag. Tokyo $17^{2}: 35$ ). He used the name Roestelia solitaria but so far as I am able to interpret there was not sufficient description to establish this name. Dietel in the same year proposed the name $R$. solenoides. Several

\footnotetext{
${ }^{1}$ Prediction of relationships among some parasitic fungi. Science II. 3I: 833 . I910.

${ }^{2}$ A Gymnosporangium with repeating spores. Phytopathology 4: 408. I9I4 (abstract). Am. Jour. Bot. 3: 40-46. I916.
} 
years later Yamada and Niyabe ${ }^{1}$ reported successful cultures showing the relationship between this Roestelia and a caulicolous telial form on Chamaecyparis pisifera, to which they applied the name Gymnosporangium Miyabei. If we accept the oldest valid name even though it was first applied to the aecial stage, the name of the species is Gymnosporangizm solenoides (Diet.) Kern, (Bull. N. Y. Bot. Gard. 7: 450. I9I I). The aecial hosts belong to the genus Sorbus. Aside from Pyrus Miyabei Sarg., which is the same as Sorbus alnifolia K. Koch, Sorbus Aria Crantz also is reported as a host.

1 Eine neue Gymnosporangiumart. Bot. Mag. Tokjo 32:21-28. 1908. 


\title{
CYTOKINESIS OF THE POLLEN-MOTHER-CELLS OF CERTAIN DICOTYLEDONS
}

\author{
Clifford HARrison FARr \\ Columbia University
}

(With PLates 27-29)

I. TABle of Contents

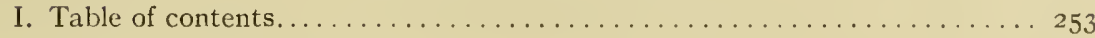

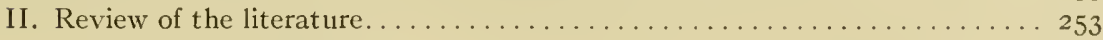

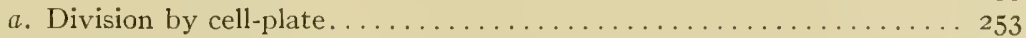

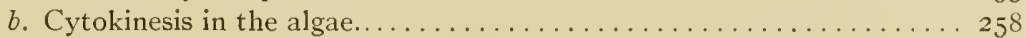

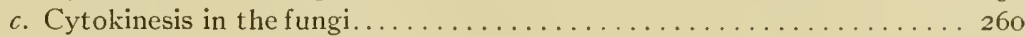

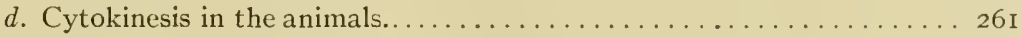

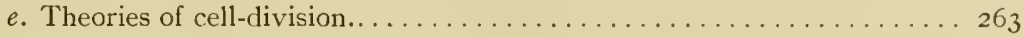

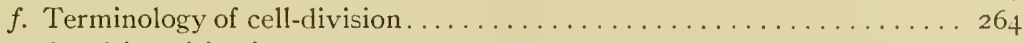

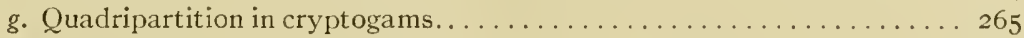

$h$. Quadripartition in gymnosperms..................... 268

i. Pollen-formation in monocotyledons.................. 269

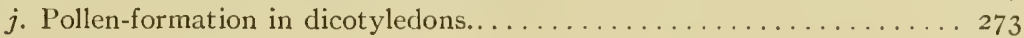

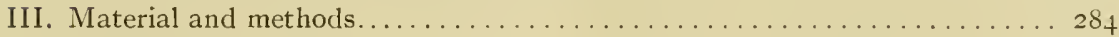

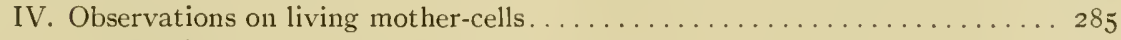

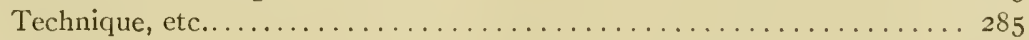

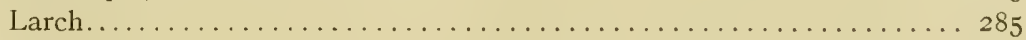

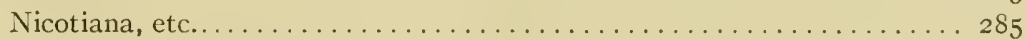

V. Thickening of the mother-walls in Nicotiana................. 290

VI. The central spindles in Nicotiana . . . . . . . . . . . . . . . . . . 293

VII. Constriction furrows and nuclear migration in Nicotiana . . . . . . . . . . 295

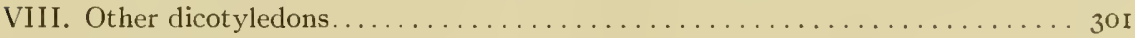

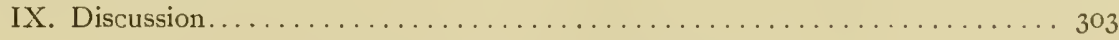

Similarity of animals and plants in cell-division.

Quadripartition in dicotyledons, monocotyledons, etc.

Conclusions based upon literature.

Possibility of electrically charged cell-membranes.

The mother-wall and cell-division.

An hypothesis as to the physical chemistry of cell-plates.

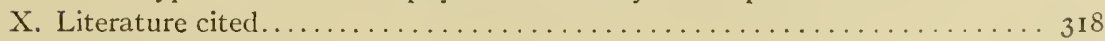

XI. Explanation of plates...................... 3 I6

\section{REview OF the Literature}

\section{a. Division by cell-plate}

Since the notable observations of Strasburger (67a) in 1875 on the existence of the so-called cell-plate as a stage in the cyto- 
kinesis of higher plants, the assumption has become general that such a structure is universally present in angiosperms, gymnosperms, ferns, and bryophytes. Strasburger already in I 875 discussed the formation of the plate by fusion of thickenings on the central spindle-fibers, its splitting to form the boundaries of the daughter-cells, and the secretion of the cellulose wall or walls between the new daughter-cell boundaries. Strasburger's views have been critically confirmed and enlarged by Treub for the orchids, Mottier for the mother-cells of the lily, Hof for the roottips of Ephedra, Pteris, and Vicia, Nèmec for Allium, and Timberlake for the root-tips of Allium and for the pollen mother-cells of the larch. In addition to this critical work there has appeared in the literature a vast number of more or less casual statements corroborating this interpretation with regard to the cells of various representatives of nearly all groups of the higher plants. Apparently in only one instance has a serious attempt been made to question the universal occurrence of cell-plate formation in the cytokinesis of higher plants, namely, the work of Baranetsky (4) in I880. which has not been recognized as presenting such an exception to this rule, doubtless chiefly because it does not furnish the positive proof of how division may be accomplished without a cell-plate.

On the other hand, it has been just as carefully established that the animal cell clivides without the formation of a cell-plate in the equator of the central spindle. Flemming's attempt to homologize the "zwischenkorper" of certain animal cells with the cell-plate of plants has not been generally accepted. The "zwischenkörper" has not been shown to play any part in the formation of the new plasna membranes, whereas this is recognized as a large part of the function and activity of the cell-plate.

Treul) $(75 a)$ in 1878 presented the first careful observations of cell-division in living material. His fundings, in general, agree with those of Strasburger; but in Epipactis, he reports, the daughter nuclei travel from one side of the ce'l to the other, while the cell-plate is being laid down progressively between them. He believed, however, that the cell-plate was of cytoplasmic origin.

In 1887 Went (79) for the first time presented the idea that the fibers in the center of the spindle disappear during the growth of the cell-plate. Nottier (44a) in I 897 confirmed Strasburger's ob- 
servations, using as material the mother-cells of Lilium fixed in Flemming's solutions and stained with the safranin, gentian-violet, and orange $\mathrm{G}$ combination. It must be remembered that Strasburger's initial work was done on alcoholic material. Mottier studied the process following the heterotypic nuclear division and found that there is "eine auffallende Verdickung der Fäden" in the equatorial region. The mother-cell-wall is shown in his figures to thicken meanwhile to about one twentieth of the diameter of the cell. Strasburger $(67 \mathrm{~g})$, from his study of Lilium and Alstroemeria, found that it is the fibers in the center of the spindle in which the equatorial swellings first occur. The elements composing the plate are pulled out and become extremely thin in the middle; and as soon as they break a middle layer appears between them. These equatorial swellings he had $(67 f)$ previously designated by the name, "Dermatosomen"; but this term has not been extensively used since then. Hof (30) in 1898 stated that the cell-plate formation is accompanied by the shortening of the fibers of the central spindle, but showed no drawings to support this view. Wager (78) more recently has figured cell-plates in the root-tips of Phaseolus. Davis (11) concluded that the fibers involved in the formation of the cell-plates of the spore-mothercells of Anthoceros are not those of the central spindle which remained from karyokinesis; but that they are newly organized in the cytoplasm after the disappearance of the latter. Mottier $(44 b)$ in I900 modified his former opinion as to the origin of the cell-plate in Lilium, and after a study of Dictyota makes the following statement: "That the cell-plate in the higher plants is formed by a lateral union or fusion of the thickened connecting fibers may be seriously questioned, for in some cases these fibers do not thicken very appreciably in the equatorial region, nor do they lie sufficiently close to one another to enable the slightly thickened middle parts to meet and fuse . . . the conclusion seems justifiable, that the cell-plate is formed by a homogeneous plasma which is conveyed to the cellplate region and deposited there by the connecting fibers." $\mathrm{He}$ presents no new drawings of Lilium in support of this interpretation.

The most extensive and satisfactory study of cell-plate formation in the higher plants in recent years is that of Timberlake (73) on the pollen-mother-cells of the larch and the root-tips of the onion. The author found that the two types of cells are very 
sim:lar in their procedure in cell-plate formation; he notes, however, a number of differences which evidently seemed to him of minor importance, but in the light of the following discussion appear to be by no means insignificant. His drawings and photographs present the only adequate attempt since Strasburger's "\%ellbildung und Zelltheilung" to arrange a sequence of stages in the formation of the cell-plate. The figures of cell-plates by others are mostly isolated and introduced merely incidentally.

In the onion root-tip Timberlake describes the process in less detail than in Larix. He believes that new connecting fibers are formed at the periphery of the spindle, both in the early stages of spindle enlargement and during cell-plate formation. Except for the violet-stained fibers the cytoplasm is homogeneous and without granules. The first indication of equatorial differentiation is in the appearance of an orange-staining zone in that region. With the triple stain this zone stains like the young cell-wall, but it does not take ruthenium red or iron-haematoxylin, so that it is probably of different constitution, though Timberlake believes it is of carbohydrate nature. He likens it to the orange zone in Saprolegnia, and the neutral zone in Fucus. The spindle fibers become apparently thinner in this orange zone, prior to the appearance of the cell-plate elements, which the writer describes as "thickenings of the spindle-fibers" or "swelling on the fiber." He is unalble to find evidence of any movement of cytoplasmic granules toward the equator to form the cell-plate, as suggested by Treulb. The cell-plate elements are found sometimes to appear before re-organization of the daughter nuclei.

In the larch the central spindle-fibers are found not to multiply by longitudinal division in the early stages of spindle cnlargement, as Strasburger holds. But their apparent increase in number is due to their separation, after being aggregated in bundles by pressure of the chromosomes as they move to the poles. The equatorial thickenings on the fibers are much more pronounced than in the onion root-tip. In addition to them there are granules which are blue with Flemming's triple stain, and are variously distributed within the cell during the anaphases and telophases, sometimes "in rows and sometimes sticking to the connecting fibers." The central spindle-fibers at first thicken near the nuclei, giving the same appearance as the fibers of the 
onion, which are attenuated at the equator. The fibers of the larch then become of uniform diameter, and lastly thicken at the equator, giving rise to swellings. The process continues until the fibers begin to disappear near the nuclei, that is, shorten. "All of the fibers that form cell-plate elements are completely used up in the growth of the cell-plate." The swellings enlarge, come in contact, and fuse. They do not split before fusing. The central spindle grows peripherally, that is, centrifugally by the addition of fibers. The cell-plate splits in the center and the new wall is secreted (fig. $2 \mathrm{r}$ ). There are thus three processes going on: cell-plate formation, plasma membrane formation, and wall formation. In the larch they are all shown to take place centrifugally, and Strasburger (67a) figured the same condition in Anthericum after the heterotypic division. Timberlake believes that the wall formation may occur by the secretion of an unstainable solution, perhaps a carbohydrate, between the two plasma membranes. The phenomenon of the separation of the two plasma membranes is discussed in some detail. Of the process he says: "It is hard to conceive of a layer of protoplasm becoming differentiated into two separate layers similar in all apparent respects to each other."

Studies in physical chemistry since the date of Timberlake's paper, especially in the behavior of colloids, should throw considerable light upon these processes of cell-division. The wellknown fact of the crystalloid nature of cell-walls and starch grains made it seem likely that the cell-plate is not of this nature, but is more probably colloidal; and its being visible, both in living and fixed material, would indicate that it is probably a suspensoid. Though probably colloidal, it is not very different either physically or chemically from the rest of the cytoplasm, or a surface boundary would form between them, such as delimits the nucleus; in other words, the cell-plate differs from the plasma membranes to which it gives rise, in that it is apparently permeable to substances in the cytoplasm indiscriminately.

A number of interesting variations from the typical procedure are noted by Timberlake in larch. "Whether the mother-cell divides into four cells which form the pollen grains by successive or simultaneous division depends upon the number of spindlefibers existing in connection with the first nuclear division. If 
there are enough fibers to form a cell-plate completely across the cell, successive division results; while if the cell-plate does not reach across the cell it is absorbed in to the rest of the protoplasm and the final division takes place simultancously after the second nuclear division." As noted later, Juel (35a) and Tangl (70) have found similar incipient cell-plates in the pollen mother-cells of IIemerocallis. Though, in the latter, they may not extend from one side of the mother-cell to the other, they seem to reach a condition of maturity as far as they do develop, and remain suspended in the cytoplasm, not being absorbed, as Timberlake reports for the larch.

\section{b. Cytokinesis in the algae}

The algae display a considerable range of variation in their method of cell-division. Strasburger was disposed to regard a number of them as having cell-division by means of a cell-plate; but the evidence, so far presented, is by no means conclusive that the division is as it has been found in the higher plants. However, McAllister (45) in his study of so simple a form as Tetraspora found a great similarity to the typical seed-plant habit of division.

The cytokinesis of Oedogonium has been much studied but without clear results. Strasburger $(67 a)$ claims that after the nucleus divides in the center of the cell, something like a cellplate, consisting among other things of a series of black dots is formed. Tuttle (77) and Wisselingh (83) have since confirmed Strasburger's observations as to the presence of an equatorial differentiation between the daughter nuclei. In the cell-division of Spirogyra there exists a somewhat greater departure from the cell-plate type. Strasburger $(67 a)$ early described the centripetal development of a cross-wall in the form of a girdle at the equator of the cylindrical cell. The girdle grows by the deposition of material on its inner edge where starch granules accumulate. The existence of true central spindle fibers running between the two daughter nuclei is still cloubtful. In Cladophora we have an instance of division of a multinucleate cell without even the semblance of a cell-plate. This was first observerl by ron Mohl (43a) in his famous pionecr work upon the origin of the cell. In I 854 Pringsheim (53) reported the finding of a thin division wall hefore the centripetal ingrowth is completed; but about twenty years 
later Strasburger (67a) worked out the details more carefully, There is a ring-like girdle of cell-wall material which grows centripetally across the middle of the cell. As in Spirogyra the ring is margined by a circle of dense protoplasm. In Ulothrix the same author $(67 a)$ presents an example of a uninucleate cell which after karyokinesis forms its cross wall entirely centripetally. There is no doubt an excellent field for research on the cell-division of these filamentous green algae.

In the brown algae several instances have been reported of a division of the protoplast simultaneously across the equator of the cell. This perhaps should not be taken to mean that the celldivision takes place suddenly, but rather that at any one moment the process is at the same stage of development in all parts of the equatorial plane. Strasburger $(67 k)$ and more recently Swingle (68) have investigated the process in Sphacelaria. Swingle finds that cell-division is first indicated by the transverse arrangement of the alveoli in the equatorial plane between the daughter nuclei. A number of granules may appear in this region, and presently a fine line is noticed forming a bridge across the entire cell, or sometimes only across a part. A cellulose wall then appears. The author is unable to rela te this to the spindle fibers which are considered insufficient in number, and do not multiply during the processes just described. It is concluded that the process is not dependent upon the activity of the kinoplasm, but, nevertheless, may be under the control of the nuclei.

Mottier (44b) found a similar manner of cell-division in Dictyota. Neither Swingle nor Mottier present in figures any stages in the development of the partition. They each give one figure, and supplement this by description. While the latter is valuable, it cannot replace an accurate reproduction of the evidence at hand. Until some one presents an adequate series of stages of the process we must continue to regard their evidence as not entirely convincing. In fact it may even be questioned as to whether we should apply the term cell-plate to these various sorts of formations in the lower plants; it seems desirable rather to restrict the term to that perfectly definite sort of structure that Timberlake and others have described, and which seems to be so prevalent in the higher plants.

Farmer and Williams $(18 a+b)$ have studied the division of 
the protoplasm in the ongonia of Fucus, where there are eight nuclei, each of which becomes separated at the same time from the others by plasma membranes; that is, there are no divisions of the cytoplasm during the three preceding nuclear divisions. They describe the process as beginning by the elongation of the eight nuclei and the development of polar radiations. The division planes themselves are marked by the accumulation of granules which are repelled equally from all nuclei. These granules fuse into plates which divide the protoplast into its eight respective parts. The authors refer to the process as due to a repulsion of material from the nuclei, but it may as well be considered an ordinary diffusion of material away from the nuclei. It is then essentially like the cell-plate formation in higher plants, except that a central spinclle is absent. It will be noted that this is also an instance of simultaneous partition as in Sphacelaria and Dictyota.

Fucus is not the only alga in which the division of a protoplast in to more than two parts has been studied. Strasburger $(67 a)$ noticed the quadripartition of the zygospore of Craterospermum [Mougeotia], by ring-shaped primorclia of the cross-walls, that is, by infolding and constriction in a centripetal manner. A more lucid description was given by Berthold (6) in 1886 of tetraspore formation in the red alga, Chylocladia. Here we have the partition into four spores which are tetrahedrally arranged by "sechs dementsprechend orientirte Membranleisten welche, wie bei Spirogyra, allmählich von der Zellperipherie nach innen vordringen." No cell-plate is involved in the process. I'nfortunately no figures of the cells in division are given.

\section{c. Cytokinesis in the fungi.}

Division by cleavage furrows without the formation of a cellplate is the common method among the fungi, as Harper has shown in many forms. There is the simple bipartition of a two-nucleate cell, as in the conidiophores of the Erysipheae (28a) the more complex "progressive cleavage" of the multinucleate sporanges, and also of the Nlucorineac, etc. (28c). Careful study and search has revealed no evidence of the formation of a partition planc or cell-plate in advance of the cleavage furrow, the only differentiation which takes place, being in certain cases the appearance of a clearer hyaline zone, instead of a dense protoplasm, just in 
front of the furrow. In the case of Synchytrium, Harper (28c) suggests that there are two processes involved in cleavage. "If in Synchytrium the nuclei are centers for the formation of kinoplasm, and it proceeds outward from them by diffusion in all directions till it reaches the plasma membrane; this will be correspondingly increased in thickness, and if the mass be decreasing in volume by loss of water and tending to split up like a mass of drying starch, the membrane might perhaps press into the furrows thus formed, so as to become the surface layer of the forming segments."

In the Myxomycetes (28f), Harper finds further evidence of the correlation of loss of water with cell-division. In Didymium celldivision is accompanied by an extrusion of cell-sap, "which is initiated and controlled by changes in the spore-plasm." The writer suggests that "If we add to this conception of the nucleus as a center of water retention the further conception, suggested by its relation to cell-plate formation in the higher plants and the ascus, that it is a center for the production of plasma membrane materials, we have two factors which would work in harmony to bring about the process of progressive cleavage described, since the diffusion outward from the nucleus of substances to be used in forming the plasma membrane would again tend to cause the cleavage planes to pass midway between any given pair of nuclei." In his work on Fuligo (28d) the same author found that while the cleavage furrows cut midway between two nuclei, the process has no relation to the orientation of the preceding nuclear division figures.

\section{d. Cytokinesis in animals}

In the animal kingdom there is considerable variation in the process of cytokinesis, though it hardly displays as wide a range of types as the plant kingdom. In the typical case the cell becomes ellipsoidal and there is a tendency for the two halves, each containing one nucleus and one centrosome, to round up, which is accomplished by a constriction furrow. This is particularly true of some of the small eggs, as those of worms. On the other hand, some eggs with large yolk, as those of the frog, retain their general spherical form, and the furrow is more in the nature of a line of dehiscence. Terni (71) has recently published figures which show that amphibian cells may divide either by a broad curved 
furrow (fig. 26), or a sharp furrow (fig. 25), or a lroad furrow with a sharp angle (fig. 40).

How widespread in the animal kingdom this very simple type of cell-division may be is not entircly clear. Such cells as eggs which occur free in the medium, lend themselves much more readily to cell-division studies than do cells of tissues, such as cartilage, muscle, etc. They are also of greater interest from a reproductive standpoint, and hence it is no wonder that most of our knowledge of animal cell-division is based upon the observation of such cells. In the minds of many zoölogists there has not been an adequate distinction between the processes of nuclear and cell-division. Rabl in I885 published his paper entitled "Leber Zelltheilung" (54), which devotes only two paragraphs to cell-division proper, and over Ioo pages to karyokinesis. This simply serves to indicate the place of secondary interest to which cytokinesis had been relegated.

None the less, a rast amount of effort has been expended in attempting to find some equivalent in animal cells of Strasburger's beautiful and clean-cut figures of cell-division in the higher plants. Hofmann (31) in I 898 published an excellent review of the literature bearing on the existence of a cell-plate in animals, and adds some interesting observations on hydroids and Lima.x. He deliberately chose animal cells which were imbedded in a matrix having a high coefficient of riscosity and a low coefficient of elasticity, so that the external conditions would closely simulate those of most plants. There can be no doubt that he found equatorial differentiations, as had Flemming and others before him; but whether these should be considered homologous to the cell-plate of the higher plants is not entirely certain. U'nfortunately, his preference for the iron-haematoxylin stain makes comparison with the leading botanical investigations difficult. No orange zone is reported such as Timberlake found in the onion. Only one figure of Limax and one of Trutta show an inflated spindle; whereas many figures of all species studied present an hourglassshaped spindle. There are only a few cases noted of granules fusing to form a plate, in most instances the granules remaining quite distinguishable. Several cases show a large globular zwischenkorper; and none show a centrifugal splitting of the plate. The present tendency among reputable zoölogists is to 
avoid the attempt to harmonize the cell-plate in plants with any equatorial differentiation in animal cells; and it seems advisable, at least, to use the term "zwischenkorper" or "diasteme" for such structures in animals, reserving the word "cell-plate" for the higher plants only.

\section{e. Theories of cell-division}

Very numerous theories of cell-division and related phenomena have been offered. Perhaps most students have believed that it is an expression of the working of the architectural mechanism of the cell. One school believes that there is a radiating system of organic rays about the centrosome. To this belong: Van Beneden, Boveri, Flemming, Hertwig, Solger, Zimmermann, Heidenhain, and Kostanecki. Von Fick (27) takes exception to this in that it does not take account of the surface relations; and Rhumbler assumes that cell-division is brought about by a combination of surface forces and those of the internal mechanism.

A number of investigators have attempted to place the study on a physico-chemical basis by proposing what have been referred to as the dynamic theories of cell-division. Gallardo (22) reviews the literature up to I902. Fol in I873 suggested that the achromatic figure resembles the arrangement of iron filings over a magnet. Soon afterwards Strasburger referred to the resemblance of the spindle to a magnetic field as a peculiar coincidence. A number of workers modeled fields of force to represent mitotic figures in various kinds of media; Giard in I 876 in liquids; Faraday with sulphate of quinine crystals in spirits of turpentine; Gueblard with copper and lead acetates; and Bütschli with gelatin. Errera in 1880 discredited the belief that there are electrical phenomena at work in the cell by experiments with cells of Tradescantia dividing in the field of a powerful magnet. He interpreted celldivision as a hydrodynamic process. Fick in 1897 made the suggestion that macroscopic models cannot reproduce microscopic phenomena, since capillarity and other molecular forces are at work in the one but not in the other. Prenant contends that there are two forces: a traction or centripetal force; and a compression or a centrifugal force. Meves discredits the idea of the fibers as representing lines of force on the ground that they often cross; but Wilson affirmed that "the crossing of rays is not neces- 
sarily fatal to the assumption of dynamic centers." Gallardo attempts to show how the tilting of the spindle may cause an apparent crossing of fibers which really do not cross. The trained cytologist will, however, hardly accept this as proof that there is no crossing of fibers in the cell. Wilson objects to the dynamic interpretation on the ground that it cannot explain the tripolar figures. Hartog (29) has made, perhaps, the most careful attempt to correlate the kinoplasmic fibers with lines of force. He concludes that they are the result of a force which is "analogous to magnetism, and still more to statical electricity." Their behavior is due to their relative conductivity: the fibers, membranes, and chromosomes being of high conductivity.

Still more recently, interesting studies on the chemical changes in the cell incident to cell-division have appeared. Robertson (55) suggests that cholin is formed as a by-product about the daughter nuclei, and cliffuses in all directions, hence reaching its maximum concentration in the equatorial plane. This causes a diminution in surface tension along the equator and hence the two hemispheres round up against each other. 'That the cleavage furrow is due to decreased surface tension is also held by Loeb and Lillie; but McClendon and Bütschli contend that it is due to increased surface tension at the equator, which brings about a constriction in that region. McClenclon (46) has performed many unique experiments in support of his view; these have been otherwise interpreted by Rohertson, and the latter has devised experiments to demonstrate the opposite contention; with the result that there is still a question as to which condition does exist.

\section{f. Terminology of cell-division}

In spore-mother-cells each nuclear division may be at once followed by cell-division, or cell-division may take place after the four nuclei have been formed. There has been some confusion in the terminolngy here. Strashurger referred to the latter process at first by the term "simultan" $(67 a)$, and later $(67 f)$ by the word "Viertheilung." The same writer refers to the process of partition in Fucus and Sphacelaria as simultaneous, as opposed to progressive. It secms that this term simultaneous should be restricted to the type of cell-division in these brown algae, meaning that the process of division is at the same stage of derelopment 
in all parts of the division plane. In referring to the two types of division characteristic of spore-mother-cells, Guignard (26c) calls them "bipartition successive" and "quadripartition simultanée." I shall refer to them as simply bipartition and quadripartition respectively.

There is also some confusion as to the use of the word "tetrad." Farmer and many zoölogists have applied it to certain chromosomes in diakinesis, while it has also been used by others to refer to the four spores resulting from a single mother cell. The latter use, no doubt, grew out of the fact that these four spores are frequently tetrahedrally arranged; and consequently there comes the question as to whether four spores arranged in a monoplanal rectangle or a rhomb should also be called a tetrad. In view of this confusion and inasmuch as "the four spores" is generally understood as referring to the product of a single mother-cell, it seems more reasonable to restrict the term tetrad solely to the chromosomes.

One more instance of confused terminology might be noted in this connection. The terms, "phragmoplast" and "cell-plate," are used to refer to the same thing. The former is of more common occurrence in the older literature, and its use has been resumed recently by Ernst and Schmidt (15) and others. Inasmuch as the structure in question is transitional, and during its existence the cell is constantly undergoing transformation, it would seem to possess little similarity to such permanent cell-organs as the plastids. Since the term, "phragmoplast," suggests such a relationship, it should probably be abandoned, and the term "cellplate" alone be retained.

\section{g. Quadripartition in cryptogams}

As noted above, the phenomenon of quadripartition occurs in the algae in the germination of the zygospore of Craterospermum [Mougeotia] and in the formation of the tetraspores of Chylocladia and other red algae. Quadripartition has been reported in a number of instances for the bryophytes. Strasburger was the first to do this $(67 a)$, when in Pellia he reported a tetrahedral lobing of the mother-cell, and division by cell-plates following. In the same form Farmer has reported both bipartition $(16 c)$ and quadripartition $(16 d)$ by cell-plates with the nuclei tetrahedrally ar- 
ranged. In Aneura [Riccardia] (17), Farmer and Moore describe a transformation of the mother wall into a quadrilobed structure during reduction. After the heterotypic karyokinesis a wall is formed across the interzonal fibers; after the homoeotypic division the respective lobes are delimited from each other at the center of the original cell, by walls which take up the same position as do soap bubble films when placed in boxes of corresponding form. Lltimately fresh walls are formed around the content of each cell, and the spores separate by the solution of the original walls. Earlier (16a) Farmer had described quadripartition into four tetrahedrally arranged spores in Pallavicinia and Aneura as taking place only partially by cell-plates, "the cell-walls at their inner angles grow into the cell-cavity," and the spores finally become separated by the appearance of membranes. In Fossombronia and Plagiochasma, he is uncertain as to the relation of cellplates to cell-division. He has also reported $(16 d)$ quadripartition by cell-plates in Fegatella [Conocephalum], in which they are in the form of a rhomb, with five connecting spindles instead of six. In all his work Farmer has omitted reference to the mother-cell-wall and fails to show it in most of his drawings.

The conditions which obtain in Anthoceros have been more extensively studied and by more investigators. Von Mohl (43b) first described the division by "auf der innern Seite der Zellwandung hervorsprossende Leisten . . später gegen die Mitte der Zelle zusammenwachsen und sich daselbst vereinigen" (pp. 282, 283). Schlacht (62) later (fig. 46) indicated centripetal development of a cell-wall after the cleavage of the content (fig. $4 \mathrm{I}$ ). Hofmeister $(32 b)$ found the same procedure and studied it by plasmolyzing the cell-content and observing the projection of the new walls centripetally. He adds the interesting olservation that the mother-wall swells during the process of division. Strasburger $(67 a)$ in the publication in which he established the predominance of cell-plates in the cell-division of higher plants by multiplying the cases of its occurrence, reports that Anthoceros has in its spore formation a tetrahedral quadripartition by cell-plates, followed by a rounding up process. The most recent work upon this genus is that of Davis (11). He agrees that the quadripartition is tetrahedral, but notes that the fibers crossing the division-planes are not parallel, but assume 
varying courses and may anastomose. These he believes are not the spindle fibers but rather that they have arisen after the spindle, resulting from the homoeotypic karyokinesis, has disappeared. In this case the cell-walls are formed in the cytoplasm without reference to the fibers. His figure 26 indicates the development of a cell-plate from the center of the tetranucleate mother-cell outward in three (in all, six) directions toward the mother-wall. This should be described then as neither a centripetal nor a centrifugal development, for the latter terms should be used with respect to the individual spindles, and not to the cell as a whole; it might better be referred to as progressive from one side of the spindle to the other, such as Treub noted in his study of the orchids. In view of the following study it is evident that further investigation of cell-division in the mother-cells of Anthoceros should be undertaken.

The mosses have scarcely been studied at all in this respect. Sachs on page 13 of his textbook (59) reports tetrahedral quadripartition in the spore-formation of Funaria. Hofmeister (32b) shows that the mother-wall of Phascum swells to eight times its original thickness, and the cell doubles its diameter during the reduction divisions.

In the ferns several cases of quadripartition have been reported. Calkins (9) describes such in Pteris, where division occurs tetrahedrally and by cell-plates, but no figures are given of the process. In Osmunda a similar instance is given by Smith (65). Here the tetrahedral arrangement of the nuclei is said to be brought about by a rotation of the spindles and chromosome aggregates during the homoeotypic karyokinesis, the heterotypic spindle having meanwhile broken down into a granular mass. In Botrychium Stevens (66) describes a similar dense equatorial plate of cytoplasm following the heterotypic spindle. In this species the nuclei at the time of quadripartition may be arranged either in a tetrad or a rhomb. The division is by cell-plates and the mother cell-wall is not shown to thicken during the process. In Polypodium, Russow (58) described successive bipartition, the mothercell-wall swelling in water.

Among the fern allies there is a considerable range of variation in the cytokinesis incident to spore formation. For Equisetumi Russow (58) reported tetrahedral quadripartition, the division of 
the protoplasm beginning at the center of the mother-cell and proceeding outward. Hofmeister $(32 b)$, however, noted that there was successive bipartition and that a plate of granules, or sometimes a ring of granules at the equator preceded the centripetal development of the partition wall. Strasburger $(67 a)$, describing the same species, says that there are irregular masses of material heaped up in the equatorial plane. He describes the division as quadripartition by cell-plates, the position of the nuclei heing either tetrahedral or monoplanal. The mother-cell-wall is reported to swell when placed in a glycerine solution. His figures $(67 b)$ are not entirely convincing that there is a plate and not a row of granules across the equator, and they do not demonstrate a centrifugal partition. In Psilotum he (67a) also shows an equatorial accumulation of material at the time of the two successive divisions. In the same form Hofmeister (32b) reports monoplanal quadripartition and mentions a girdle of granules about the equator "ohne dass das Auftreten einer solchen Scheidewand vorausginge." In Isoetes Strasburger (67a) reports tetrahedral quadripartition by cell-plates, the fibers crossing and swelling at the equator. In Marsilea Russow (58) reported tetrahedral quadripartition; and more recently Strasburger $(67 j)$ has published quite an extensive paper on Marsilea in which he reports quadripartition in both the macrospore and microspore formation. His figures show both a monoplanal and a tetrahedral arrangement of the nuclei in the metaphases of the homoeotypic division. The microsporemother-wall is shown in the figures to be thickened, but no thickenings of the fibers are shown. Strasburger $(67 d)$ has also reported quadripartition in Lycopodium.

\section{h. Quadripartition in gymnosperms}

In the cycads also the mother-wall thickens during the reduction divisions. In this group, however, division into spores is accomplished by two successive bipartitions. The nuclei may lic either in one plane or in a tetrad, as described by Jurányi (36) for Ceratozamia. His figures of the first division show constriction furrows accompanied by thickening of the mother-wall. Stages in the second division are not figured. Treul, found rather obscure cell-plates in the first division of Zamia (75b).

In the larch, as noted above, Timberlake has reported both 
quadripartition and bipartition (73), with a predominance of the latter. Harper (28d) asserts that in the former cases the materials of the spindles of the heterotypic division may be used in the homoeotypic nuclear divisions. Hofmeister $(32 b)$ reported centripetal division of the cytoplasm in the spore formation of certain Abietineae, but this has never been confirmed. He also notes the absence of a cell-plate and the swelling of the mother-cell-wall in the divisions in Pinus.

\section{i. Pollen-formation in monocotyledons}

In the monocotyledons a considerable number of instances of quadripartition have been reported. Mottier (44c) shows it in his figure of the embryo-sac of Helleborus, where the nuclei are arranged in a rhomb, with five spindles and upon each a cellplate. The same investigator gives an interesting figure from the embryo-sac of Lilium. The four nuclei at the micropylar end of the sac may be arranged either in one plane or tetrahedrally, the latter condition being shown in the drawing. Cell-plates are formed between each pair of nuclei, and also one on the fibers which extend from the egg into the cytoplasm of the embryo-sac. This is one of the few instances of cell-plate formation on fibers which do not run between nuclei. Others are the embryo-sac of Ephedra studied by Strasburger, and the embryo development of Picea as shown by Hutchinson (33) in his figure 4I.

The strong tendency to believe that all cell-division in the higher plants proceeds according to the classic type of Strasburger's central spindle and cell-plate formation has been noted. Nonethe-less the literature contains some indications that in many cases of quadripartition the process may be a furrowing from the surface inward, quite as in the animal and many lower plant cells. Berthold (6) in I 886 wrote (p.21 7): "Beidersimultanen Viertheilung der Pollenmutterzellen scheinen bemerkenswerthe Besonderheiten nicht aufzutreten. Die neue Zellplatten bilden sich hier entweder wie gewöhnlich bei den höheren Pflanzen und auch in den Sporemutterzellen von Anthoceros und Isoetes zuerst frei im Zellraum, um erst nachträglich an die alte Membran sich anzusetzen, oder aber sie dringen von dieser aus, Cladophora und Spirogyra entsprechend, gegen das Zellinnere vor, wie oben schon erwähnt, in Form dicker, plumper Leisten." 
Of cell-division in the pollen-mother-cells of the higher plants von Mohl (43c) as early as I 85 I made the following remark: "Eine eigenthümliche Bildungsweise, welche die Theilung der Zellen und die freie Zellbildung verbindet, zeigen die Pollenkörner und die Sporen der höheren Kryptogamen. Die Mutterzelle derselben theilt sich nach vorausgegangener Entwickelung von vier, aus der Theilung eines einzigen Kernes hervorgehenden Zellenkernen und gleichzeitiger Resorption desjenigen Kernes, welcher zu ihrer Entstchung Veranlassung gegeben hat, durch Einfaltung ihres Primordialschlauches und allmählige Ausbildung von Scheidewänden (deren es je nach der relativen Lage der Zellenkernevieroder sechs sind) in vier Abtheilungen (Naegeli's Specialmutterzellen) oder sie theilt sich zuerst in zwei Abtheilungen, welche sich wieder in je zwei Kammern (Naegeli's Specialmutterzellen zweiten Grades) abtheilen. Hofmeister (32a) in I86I attempted to distinguish between the monocotyledons and dicotyledons on the ground that the cell-plate in the former is progressively formed from one side of the cell to the other, whereas in the latter, according to von Mohl's observations on the Malvaceae, it develops centripetally. At the same time he reported that quadripartition occurred in Naias major and in two species of Iris. Later (32b) he placed pollen-mother-cells of Iris in water and found that in one-half hour the mother-wall becomes thickened and the protoplast divides by constriction furrows. Dippel in I869 distinguished between the monocotyledons and dicotyledons on the basis of bipartition and quadripartition in the pollen-mother-cells respectively; and Samuelson (60) and others have more recently reiterated this view, noting such exceptions as Nymphaea and Asclepias.

Guignard has been most active in accumulating evidence that quadripartition occurs in monocotyledons. He first found it in orchids (26a) where cell-plates are formed from a series of granules, and stain a pale violet with haematoxylin. He shows only one figure of the process, and in this the four nuclei lie in one plane and granules but no plates are present in the equators. On the other hand, Hofmeister's (32a) figures of bipartition in Neottia ovata and Orchis Morio indicate incipient constriction, but are unaccompanied by description. Guignard (26c) very recently has published a note giving a list of monocotyledons in which he 
has observed quadripartition. This includes three species of Aloe, four of Iris, two of Sisyrinchium, three of Ixia, two of Antholyza, and one each of Freesia, Haworthia, Monbretia, Gasteria, and Apicra. He also refers to the literature on the occurrence of quadripartition in monocotyledons and bipartition in the pollenmother-cells of dicotyledons. He cites as cases of the former the work of Strasburger on two species of Asphodelus, and of Tangl, Strasburger, and Juel on Hemerocallis, besides referring to his own study of orchids, in all of which, except Cypripedium, he found quadripartition. As presenting cases of bipartition in pollenformation of dicotyledons he mentions the following papers: Strasburger on Ceratophyllum; Ernst and Schmidt on Rafflesia; Strasburger, Frye, and Gager on Asclepias; and Frye and Blodgett on A pocynum. As showing intermediate types of partition he refers to the work of Samuelsson on Anona and Aristolochia, to his own observations on Magnolia, and to those of Andrews on Magnolia and Liriodendron. Guignard has not yet published his study of the cytology of the process, but notes the tetrahedral arrangement in Sisyrinchium, and the thickening on the inner surface of the mother-wall at the point of insertion of the partition. The paper very clearly establishes the situation as to quadripartition in the flowering plants.

Hofmeister $(32 b)$ in I 867 showed that division in the pollenmother-cells of Tradescantia occurs by cell-plate formation. And Baranetsky (4) has since confirmed this. Miyake (42) shows a figure ( 152 ) of what should probably be interpreted as a cellplate in this form; and the nuclei lie far apart at the time of its formation. In Allium also he figures a cell-plate after the heterotypic karyokinesis with the nuclei far apart. He also reports a cell-plate following the same division in Galtonia. Strasburger $(67 a)$ had previously shown that two successive bipartitions by cell-plates occur in Fritillaria, Lilium, Allium, and Anthericum. His figure of the last-named form shows very well the centrifugal splitting of the cell-plate and the centrifugal formation of the new wall between the new plasma membranes. In Allium he claims, as Wimmel (82) had previously figured, that the mother-wall enlarges and that the cell-plate after the heterotypic karyokinesis may be accompanied by a constriction, "ein ringformiges Beginnen dieser Zellwand an der WTand der 
Mutterzelle." Tschistiakoff (76) says of Epilobium that the division is by constriction of the plasma membrane, the cell-wall being formed from the periphery inward and from the center outward; that is, a combination of centripetal and centrifugal wallformation (p. 82):

No careful and complete study of the sequence of stages has been given for any one of these plants. In most instances the evidence consists of an isolated drawing without a description, or a statement with neither description nor drawing to substantiate it. Lilium has perhaps been studied more than any other form. In addition to Strasburger's early work, Farmer (16b) in I 895 affirmed that a cell-plate was present after the heterotypic karyokinesis, as did Mottier (44a) a year later. Allen (1a) in 1905 published a figure of a cell-plate in the heterotypic division and says that the same occurs in the homoeotypic mitosis. The nuclei are shown to be far apart during cell-plate formation. Schaffner $(61 a)$ a year later also published a singled rawing of a cell-plate in the heterotypic division. In his textbook Sachs (59) shows successive bipartition in Funkia, "a lamella of the cell-wall completely divides the mothercell. . . The place where the wall of the mother-cell and the partition-wall meet soon becomes thicker, and the two claughter-cells here become rounded off." Wiegand (80) shows a figure of a cellplate after the heterotypic karyolinesis of Potamogeton, the peripheral portion of which is without spindle fibers. Of Convallaria he says, "A strong nuclear plate follows the division resulting in a cross wall separating the cell into two hemispherical parts." There may be some question as to whether this is the correct use of the term, nuclear plate. Duggar (14b) gives one figure of a cellplate in the heterotypic division of Symplocarpus, and a similar one of Peltandra. For Trillium Atkinson (3) gives two figures of cell-plates in the heterotypic division. In like manner Schaffner (61b) treats Agave. For Galtonia Miss Diglyy (13a) show's a thickened mother-wall and a cell-plate in her figure 72. In figure 8I she shows the homocotypic clivision occurring apparently after cytokinesis had taken place in the first division; but in figure 79 there is no indication that cell division had occurred previous to the second division. No discussion of this appears in her paper. Tangl (70) in 1882 reported quadripartition with four cell-plates accompanied by an invagination of the mother- 
wall in Hemerocallis, but the same year Strasburger (67c) published the statement that the cell-wall is constructed after the first division in this form. Juel $(35 a)$ in I 897 presented a long paper in which he showed that the cell-plates after the heterotypic karyokinesis in Hemerocallis are incompletely developed and remain suspended in the cytoplasm. The same writer later $(35 b)$ reported ephemeral cell-plates in Carex after both the heterotypic and homoeotypic karyokineses. In Zea Mays Kuwada (37) has reported that after the heterotypic karyokinesis the mother-cell occasionally constricts without the formation of a cell-plate (text-fig. 2); this he associates with a subsequent amitosis and the frequent abortion of the pollen. He found the peculiar constriction in only two preparations. In $M u s a$ Tischler (74d) describes (p. 637) the daughter cells after the heterotypic nuclear division as "durch Plasmamembranen voneinander abgegrenzt." The daughter-cells re-divide several times in various planes, forming either a row, a sphere, a square, a rhomb, etc.

\section{j. Pollen-formation in dicotyledons}

The evidence regarding the formation of cell-plates in the pollenmother-cells of dicotyledons is even more variable and fragmentary, though the authors' statements are frequently very positive. Naegeli (47) in 1842 was the first to publish on this point. For Oenothera he shows a figure of tetrahedral quadripartition, in which the mother-cell-wall is thickened. He figures a similar condition for Cucurbita Pepo and Bryonia, in the latter case showing an evident constriction. He describes the process only briefly, "auf der innern Oberflache der Membran sechs vorspringende Leisten; dann plötzlich die Bildung von Scheidewänden, die sich in Centrum berühren." He believes, however, that the dividing layers are of the nature of cell-plates and not ingrowths of the cell-wall, as he attempted to show by plasmolysis.

In $185^{\circ}$ Wimmel (82) confirmed the observation of Naegeli on Oenothera and added studies on two or three other genera. In Convolvulus he found that the division is accomplished by a furrowing and shows a figure of the process. The mother-wall is considerably thickened. In Momordica Elaterium he found a successive division, and figures the mother-wall here also as somewhat thickened. In Althaea rosea he figures a division by cell- 
plate with the mother-wall somewhat thickened. Three years later von Mohl (43c) published figures of spore formation in the same plant which indicate a division by constriction sometimes accompanied by a cell-plate and sometimes not.

In 1854 Pringsheim (53) prompted by the work of von Mohl, to whom he refers in his preface, presented a study of bipartition and quadripartition in pollen-formation. On page 54 he describes the thickening of the mother-cell-wall by regular layers as in collenchyma formation. In Althaea there is a quadripartition, either monoplanal or tetrahedral, which appears first as "Trennungslinien." Division, he says, is, however, accomplished by the ingrowth of the mother-wall, as in the Conferveae. In figure 4, plate $\mathrm{IV}$, there is represented a monoplanal square, with a ridge on the inner surface of each of the four sides of the mother-wall, and a square area in the center. He does not adequately describe this central square. From the following study it will be seen that it is not unlikely that the central square represents a mass of mother-wall material which has followed the constriction furrows toward the center of the tetranucleate cell. In I 865 Rosanoff (56) published a couple of figures, 24 and 25, of Acacia paradoxa in which are shown successive bipartition, the second division of which is accomplished by constriction, and invagination of the mother-wall at right angles to the first division and beginning first along the periphery on the mother-wall and only after a time becoming apparent on the division wall of the heterotypic mitosis. The author does not discuss the process.

Hofmeister (32b) in 1867 included in his book on the "Pflanzenzelle" certain studies of pollen-formation which have not been followed up by later investigators and seem to have been quite forgotten in the recent tendency to ascribe all division of plant cells to the activity of a cell-plate. However, in the light of the following study and of much evidence which has up to the present remained quite isolated, it seems just to attribute to Hofmeister priority in grasping the real situation as to the pollen formation of dicotyledons. Not only did Hofmeister study Althaea rosea, which had received so much attention previously, but he also worked on the Cucurbitaceac and the Passifloreae, in addition to certain monocotyledons and $A$ nthoceros. In the dicotyledons he reported a centripetal quadripartition and figured it in Passi- 
flora. In addition to observing the living material, means were used for studying the wall and protoplast separately. He dissolved the wall by means of sulphuric acid or copper-oxyammonia, whereupon he could see the constriction furrows in the plasma membrane independent of the cell-wall. On the other hand he plasmolyzed the cell-content and in this way assured himself that the ridges upon the inner surface of the cell-wall grow centripetally to cut the protoplast into the daughter-cells. As noted above, in Iris he induced division by causing the motherwall to swell in water, but he does not report the repetition of this for any dicotyledons, though he did induce the cell-walls to swell. On page $7 \mathrm{r}$ he states that the gelatinization of the cellwall permits the enlargement of the protoplast. If, however, the inner layers only swell, the cell-content is compressed. In addition to quadripartition he also reports bipartition by cell-plate in Passiflora.

Seven years later Sachs (59) presented a whole series of figures of quadripartition in the pollen-formation of Tropaeolum minus. These are evidently drawn from living material and show various conditions of shrinkage and collapse of the protoplast, which, as will be shown later, do occur in material crushed out under the cover-glass. The drawings show very well the thickened wall, and the centripetal formation of the cross-walls. In his discussion Sachs does not agree exactly with the interpretation of Hofmeister and conceives of quadripartition being brought about by absorption of the heterotypic cell-plate and the reconstruction of it in addition to the formation of other cell-plates after the homoeotypic karyokinesis. He says that quadripartition in Tropaeolum occurs by the ingrowth of the mother-cell-wall at its junction with the cell-plates. He, however, does not support this contention by drawings.

Strasburger followed the next year with his famous work on the formation of cell-plates $(67 a+b)$ in a great many plants, in which he included drawings of what he interpreted as cell-plates in the pollen-formation of Tropaeolum majus. This is the most complete series of stages in division of the pollen-mother-cells of any dicotyledon that Strasburger has ever published, his other studies presenting merely single drawings. A careful survey of these drawings of Tropaeolum reveal apparently swellings of the 
spindle fibers at the equator, but the evidence that these form a plate is by no means convincing. When it is remembered that this material was fixed in alcohol, and that Strasburger repeatedly expressed his opinion that the pollen-mother-cells of dicotyledons were very unfavorable material for study, there arises a grave doubt as to whether we are justified in accepting these drawings as final proof of the existence of true cell-plate formation in this species. In his discussion he recognizes an "Einschnürung" of the mother-cell, and a thickening of the wall at the equator in the form of a ridge.

On division in the pollen-formation of other dicotyledons, Strasburger gives a few fragmentary remarks. He noted quadripartition in Cucumis, Delphinium, Aconitum, Glaucium, Althaea, and Bryonia, but gives no figures or descriptions of the process. In his paper on Asclepias (67h) in r90I, Strasburger showed a peculiar condition, where successive bipartition of the pollenmother-cells results in a row of four cells. The mother-wall is not thickened, in fact it is scarcely discernible in the drawing. His only descriptions of the division processes are that they are by cell-plates. The following year he published (67i) his Ceratophyllum paper, in which he includes no description of cell-division but only one figure, number 46 . The mother-cells appear to be closely packed, and to have very thin walls. A partition apparently results from the heterotypic mitosis. The second division may be either monoplanal or tetrahedral.

A few papers have given rather good evidence of the existence of cell-plates in the mother-cells of dicotyledons. Ernst and Schmidt (15) recently found successive bipartition by means of cell-plates in Raffesia. It is stated that the nuclei may be arranged either monoplanally or tetrahedrally. Frye and Blodgett (21) in 1905 also reported successive bipartition in the pollen-mothercells of A pocynum. They do not discuss the details of the process, but show that it may result in the four spores being arranged tetrahedrally or monoplanally in a square, rhomb, pyramid, or row. In the drawing of the monoplanal square they suggest the existence of a cell-plate, following the homocotypic karyokinesis. The mother-wall is not shown to be thickened.

In 1907 Lubimenko and Maige (40) described a peculiar division in Nymphaea in which a cell-plate is formed after the heterotypic 
karyokinesis, but disappears before cell-division is accomplished. Their figures indicate a tetrahedral quadripartition; but in only one figure, 54, is a cell-plate indicated, and this after the second nuclear division. The mother-wall in the drawing is about one twentysecond of the diameter of the cell. During exine formation the mother-cell-wall is shown to be much thicker. They explain ( $\mathrm{p}$. 450) their omission to figure a series of stages in the cell-plate formation after the homoeotypic division as due to a condensation of the cytoplasm about the nucleus, and the formation of a cellplate so quickly that the different stages could not be found.

The pollen-formation of Magnolia has been investigated by several; and apparently it is of another intermediate type. Guignard (26b) found that the heterotypic spindle enlarges by the formation of new fibers. Before it reaches the plasma membrane the fibers become very conspicuous and stain heavily in the equatorial region. A granular plate is not shown to appear in the center, but the fibers are grouped together, leaving clear spaces between them. Soon a ridge appears on the inner surface of the mother-cell-wall, which in optical section resembles a wedge projecting toward the center of the cell. This furrow he likens to those in the celldivision of Cladophora and Spirogyra. The invaginating ring is heavier than in the latter, and the fibers do not thicken enough to account for its ingrowth. As the ring advances the spindle fibers on either side disappear. It does not regularly at this time continue its growth until cytoplasmic division is complete, but stops when the depth of the furrow is about equal to the breadth of the isthmus or protoplasmic bridge remaining between the two halves of the mother-cell. In a few cases the division is said to be complete. The fibers are reformed across the isthmus after the homoeotypic division, and the cytokinesis previously begun is completed usually slightly before the daughter-cells divide. The second division is said to begin like the first, but is more rapid and continues without interruption. He shows no figures of these later stages, which, in fact, constitute the crucial point in establishing the nature of this division. This work was succeeded in rgor by that of Andrews (2). In the title of his paper he includes both Magnolia and Liriodendron, and he does not indicate in his drawings from which plants they were taken. He agrees in most particulars with Guignard, except that he 
states that the first division is completed by the formation of a cell-plate across the isthmus. "The formation of the cell-plate of the second mitosis is about in the same way" (p. 139). His figures show constrictions of the protoplast, but in no case do they indicate the semblance of a cell-plate. The most recent work on Magnolia is that of Maneval (41). He makes no reference to the work of Guignard, but says that the division is simultaneous, while his figures are not entirely in harmony with this interpretation.

In I9I4 also there appeared the paper of Samuelsson on Anona and Aristolochia (60) in which he attempts to establish a relationship between monocotyledons and dicotyledons on the basis of the occurrence of both bipartition and quadripartition of the pollen-mother-cells in these forms. In Aristolochia he reports successive bipartition, resulting in a monoplanal square or a pyramidal arrangement of the spores. In Anona he figures a monoplanal square in which the mother-cell-wall is in thickness about one fourteenth of the diameter of the cell. As Guignard found in Magnolia, he reports for Anona that in the telophases of the heterotypic mitosis the division of the cytoplasm begins as an equatorial constriction on the periphery of the cell, which is completed after the homocotypic karyokinesis. The cytokinesis after the homoeotypic karyokinesis is said to agree completely with the first. He does not refer to a cell-plate in any connection throughout the whole paper. He gives no description of his drawings, which appear to be very poorly reproduced. Shibata and Miyake (63) present a similar case in Houttuynia, which they consider as associated with the abortion of pollen in that form.

It thus appears that there are a number of dicotyledons which display a type of cell division of the pollen-mother-cells which has been regarded as intermediate between true bipartition and true quadripartition. It is generally recognized, however, that the majority of dicotyledons form their microspores by a quadripartition of the mother-cells; but the details of this process of quadripartition have not been accurately determined, and the data in the literature regarding it is not entirely consistent. Some papers as noted below give evidence of the existence of cell-plates in this cytokinesis, while others indicate that it may be accomplished by furrowing.

In I 898 Lawson (38) published in the Proceedings of the Cali- 
fornia Academy of Sciences a figure, 24, of Cobaea which shows a pollen-mother-cell after the homoeotypic karyokinesis with the four nuclei tetrahedrally disposed and not appressed to the plasma membrane, though cytoplasmic division has not yet occurred. The spindles are inflated and the mother-wall is about one thirtieth of the diameter of the cell. There is a concavity of the plasma membrane on one side of the mother-cell, a convexity on another, and the third side is flattened. "Cell-plates are now formed in the usual way" (p. I78). Two years later there (8) appeared in the same journal a paper by Miss Byxbee on Lavatera. Her figure 24, also of a mother-cell, has four nuclei arranged in a monoplanal rhomb also with the suggestion of five spindles between them. The mothercell-wall is here about one twenty-second of the diameter of the cell, and there is no indication of the division of the cytoplasm either by cell-plates or by furrows. Here also the statement is made that "cell-plates are formed later on" (p. 69). This is the only reference to cytokinesis in the paper. It is evident that the statements as to cell-plates in both Cobaea and Lavatera must be regarded as quite unreliable.

Tischler has reported a number of instances of quadripartition in pollen-formation, but has never described the details of the process. In 1906 in connection with his study of sterile Bryonia hybrids $(74 a)$, he gives a figure, number 7 , of a mother-cell in which quadripartition would no doubt occur. But he does not refer to it in the text, nor does the drawing show the mother-cellwall. In the same year in his study of Ribes hybrids (74b), he presents two figures indicating quadripartition, one tetrahedral, the other rhomboidal. In 1908 in further work along this line, he gives a number of similar figures $(74 c)$. Number 14 shows the mother-wall thickened to about one fourteenth of the diameter of the cell in Mirabilis. Number 19 indicates that bipartition has occurred after the heterotypic division, the mother-wall being about one twentieth of the diameter of the cell. In figure $7 \mathrm{I}$ he shows a tetranucleate cell of Potentilla, with the mother-wall thickened to one tenth the diameter of the cell. Figures 99 and Ioo show a like condition in Syringa. Of Mirabilis he writes (p. 44), "In nicht wenigen Fällen gelingt aber die Ausbildung der Zellplatte nicht mehr: wir erhalten vierkernige Zellen." This constitutes the only evidence which he gives of having seen cell-plates 
in any of these forms. Of Syringa, Juel (35b) states that there is quadripartition by cell-plates, but gives no figures to show it. In the same way Duggar (14a) refers to Bignonia, but his figures do not show cell-plates.

In his paper on reduction in the pollen-mother-cells of dicotyledons, Overton (51) presents a figure of Podophyllum, number 7o, which indicates cell-plate formation after the heterotypic division. The mother-wall is not shown, and the division is not discussed in the paper. Mottier $(44 a)$ in his paper on the same subject, based also on Podophyllum, show's that cell-division does not always occur after the heterotypic division. He gives two figures after the homoeotypic karyokinesis with the four nuclei arranged in a rhomb, with five spindles connecting them. No cell-plates are shown. By four figures of late stages of the heterotypic division he shows that the spindle fibers of that division disappear in the center and are replaced by a granular plate. In his text he says only, "Die Zellplatte wird in der für Lilium zuvor beschriebenen Weise angelegt." We must conclude that in Podophyllum an ephemeral cell-plate is formed after the heterotypic division, but the division after the homoeotypic karyokinesis should be further studied.

Wille (81) in I 886 presented a paper on the formation of the wall of the pollen grains of 22 different plants, in which are incidentally introduced a number of observations of interest in the present study. He derotes especial attention to the thickening of the mother-wall, which he contends is by intussusception, but gives no evidence that anything more than a swelling or gelatinization actually occurs. The thickened wall is said to be made up of "wasserarme und wasserreiche Schichten," as Naegeli and Strasburger held for starch grains. 'Though both monocotyledons and dicotyledons were studied, he considers division of the pollen-mother-cell as taking place in all cases by successive bipartition by cell-plates. At the end of this paper Wille reports a number of instances of the formation of pollen grains in other than groups of four, the irregularities ranging from one to fourteen in different species. He also described lobed microspores as occurring along with the normal globular forms.

It appears that in no instance is the evidence conclusive that quadripartition of the pollen-mother-cells of any dicotyledon is 
effected by means of cell-plates. That some dicotyledons form their microspores by two successive divisions with cell-plate formation, can scarcely be doubted, as is shown in Asclepias, Ceratophyllum, Apocynum, and Rafflesia. But it is generally recognized that the majority of pollen-mother-cells of dicotyledons do not divide in this way. The best evidence of quadripartition by cellplate is that of Strasburger in his work on the alcoholic material of Tropaeolum, which has been shown above to be not beyond question. On the other hand there is some evidence that cleavage furrows may be involved in the process. The work of Naegeli, Wimmel, von Mohl, Sachs, and Hofmeister suggest it, though such early work should not be taken as by any means final. Guignard and Samuelsson directly affirm it in Magnolia and Anona respectively.

There is also a considerable list of additional papers which in one way or another indicate that furrowing may be involved in the division of the pollen-mother-cells. As early as I880 Baranetsky (4) in addition to confirming Strasburger's observations on successive bipartition by cell-plates in the pollen-mother-cells of Tradescantia, studied this stage in four different dicotyledons. He shows two figures of Hesperis matronalis with incipient furrows along the equator. He does not describe them, but says, "Strasburger gibt an, dass 'in allen Fällen' der Theilung der secundären Kerne die Bildung einer Zellplatte $z$ wischen ihnen vorausgeht. Bei den von mir überhaupt beobachteten Dicotylen: Pisum sativum, Lathyrus odoratus, Hesperis matronalis, Ipomaea tricolor, konnte ich diese Angabe nicht bestätigt finden."

Ishikawa (34) in his figure, number I I, of Dahlia shows a pollenmother-cell in which four nuclei are tetrahedrally arranged. They do not lie near the plasma membrane, but spindles are shown extending between them without the slightest indication of a cellplate. At the equator on one side there is a concavity, and the other two sides are flattened. No mother-wall is shown, and the paper contains no discussion of the process.

Osawa $(50 b)$ shows several figures of division of the cytoplasm in the pollen-mother-cells of Taraxacum. Figure 22 is of a pollenmother-cell with four nuclei tetrahedrally arranged; no motherwall is shown. The spindle fibers are thickened at the middle throughout about one half their length. One side of the cell is 
concave, and two flattened; no cell-plate is shown. In the text he only says "the cell-walls are formed between these four nuclei, producing the normal tetrad." Figure 55 shows an instance of bipartition of the pollen-mother-cell. In Daphne he $(50 a)$ shows a marked furrow on two sides of the mother-cell, which is about to undergo tetrahedral quadripartition. There are also indications of cellplates here. The mother-wall is about one ninth of the diameter of the cell.

Rosenberg (57a) show's a schematic drawing, text figure III., of successive bipartition in Hierucium venosum. In text figure $\mathrm{V}$. he has a tetranucleate mother-cell which is rectangular, and without a thickened wall. He says (p. I 49), "The following division stages correspond with, for instance, those of Tanacetum or Taraxacum, and the development of the pollen cells does not offer anything extraordinary." In no instance does he show a cell-plate. Of Drosera he shows several figures of quadripartition. Figure 22 $(57 b)$ shows the four nuclei in one plane in the form of a rhomb, with four spindles of equal size, and a fifth small spindle between the two opposite nuclei which are in closest proximity. No indication of a cell-plate is shown. Figure $2 \mathrm{I}$ shows a similar stage with tetrahedral arrangement of the nuclei. In figure 2 the mother-wall is shown much thickened and a cleavage furrow is beginning in the equator at the metaphase of the homeotypic division. No cell-plates are likewise shown here. During the course of my investigation on Nicotiana and other forms described below, Levine (39) in his studies on the germ cells of Drosera observed loth bipartition and quadripartition in which the mother-cell-wall is much thinner and more angular, as in Asclepias, Ceratophyllum, etc. His figures show no broad constriction furrow, and at the stage when partition has apparently just been completed, the appearance is as if the mother-cell had divided by cell-plate formation. Drosera is one of the plants in which the four pollen grains thus formed never separate. Whether this has anything to do with the mode of cytokinesis in microspore formation is a problem for further investigation.

In her study of Parnassia Miss Pace (52) presents a figure, 54, which shows tetrahedral quadripartition with the invagination of the thickened mother-wall along the equators. Fibers are shown crossing the equator, but there is no indication of a cell-plate. 
The paper contains no discussion of this peculiar situation. Shoemaker (64) in Hamamelis shows tetrahedral quadripartition with an incipient furrow in figure $3 \mathbf{I}$. The mother-wall is much thickened, and no cell-plate is indicated. Miss Fraser (20) in her figure $3 \mathrm{I}$ of Vicia indicates tetrahedral quadripartition; spindles are shown, but no cell-plates; the plasma membranes are rather indistinct, but there are indications of equatorial cleavage furrows. Miss Digby (13b) in her figure, 42 , of Primula indicates tetrahedral quadripartition with broad furrows on both sides, which are, however, not exactly equatorial. No cell-plates are shown. In figure 67 the mother-wall is shown to be greatly thickened after the division is complete. She writes, "The cytoplasm between the nuclei constricts," but she makes no reference to the presence or absence of a cell-plate. Miss Nichols (49) reports tetrahedral quadripartition, in which the cytoplasm "constricts." Her figure 39 shows such a condition, but there are only two, nuclei shown. Gregory (25) figures for Lathyrus a constriction of the protoplast after the heterotypic division. This he states is accompanied by amitosis and is related to sterility of pollen. He evidently regards it as abnormal, as he says that in the fertile pollen the division is "of the usual type." Cannon (10) in his paper on hybrid cotton shows quadripartition in figure I4. In figure 16 he shows division taking place between two nuclei by a broad cleavage furrow; no fibers or cell-plate are shown in the cytoplasm. Of the process he says, "Indentations appear in the periphery of the cytoplasm and midway between the nuclei, which deepen into constrictions, and finally accomplish the separation of the nuclei and the formation of the tetrads." He, however, does not discuss the existence of a cell-plate.

The figure which best indicates quadripartition by cleavage furrows is that of Beer $(5 b)$ on Crepis; unfortunately this is unaccompanied by description. He reports quadripartition in Matricaria Chamomilla and Crepis taraxacifolia. Three figures of the latter and one of the former indicate this. In Crepis the mother-cell-wall is slightly thickened, and the nuclei are appressed to the plasma membrane before the cleavage furrow is well developed. No cell-plate is shown; but figures 57 and 58 show a constriction at different stages of development. The relation of the mother-wall to the furrow is not shown. Tahara (69) in his 
figure 9 shows that the mother-wall in Crepis is about one fourteenth of the diameter of the cell, just before quadripartition occurs. In Ipomoea Beer ( $5 a$ ) shows the mother-wall very much thickened after the homocotypic clivision. He says that this wall gives a reaction to tests for callose and pectose, but does not discuss the cytokinesis. In Oenothera he says the mother-wall dissolves in I per cent $\mathrm{NaOH}$ only after about 24 hours. It is not soluble in strong phosphoric acid. It stains with Bismarck brown, methylene blue, and fuchsin. He therefore concludes it is a modified form of callose or pectose. He says of division that "Septa are developed which form an extension of the mucilaginous mother-cell-wall." Gates (23), however, diagrams a cell-plate in his figure 47 , though he does not discuss the process in his paper on Oenothera.

\section{Material AND methods}

The greater part of the work here reported has been clone upon the pollen-mother-cells of Nicotiana Tabacum. In addition observations were made for comparison upon the pollen-mother-cells of Primula sinensis, Tropaeolum majus, Ambrosia artemisiaefolia, Chrysanthemum frutescens, and Helianthus anmus. The roottips of the last-named were also studied and compared with the root-tips of the onion and the pollen-mother-cells of Larix and Lilium.

Both living and fixed preparations of the pollen-mother-cells were studied. With the exception of the Ambrosia material, the flowers were collected from individuals growing in the Columbia University greenhouse. In most cases the stamens were fixed individually to insure good penetration of the reagents; however, in the Compositae it was found more practicable to treat the entire flower.

The material was fixed in Flemming's chromic-acetic-osmic solutions in the weak, medium, and strong proportions. The following reagents were also employed: Merkel's; picro-formol; Wilson's sublimate acetic; and Benda's solution. The strong Flemming's formula was found to be the most satisfactory, and had incidentally the additional advantage of being the same reagent which Timberlake and Mottier used, thus affording means of more direct comparison. The same might be said of Flemming's triple stain. While iron-haematoxylin was also used, it contributed little of value to the study. 
Sections were made for the most part five microns thick. In some instances, however, it was found advisable to cut them only three or four microns thick so as to remove all of the superficial material from median sections of the dividing mother-cell.

To Professor R. A. Harper, under whose supervision this study was pursued, are due many thanks for his valuable suggestions and criticism, which are deeply appreciated.

\section{OBSERVATIONS ON LIVING MOTHER-CELlS}

The study of living material is without doubt a very valuable method in cytological research. So far as the more obvious facts of cell division are concerned, such studies give unimpeachable data, as is evidenced by the accuracy and suggestiveness of the studies of such early cytologists as Naegeli, Pringsheim, and Hofmeister. Lundegardh and others are certainly pursuing a wise course in devoting a large amount of attention to the living cells.

The chief difficulty in the study of living cells lies in the fact that they can be retained in their normal condition for so short a time. In this respect the students of animal cells are more fortunate, since body-fluids may be used to keep the cells alive almost indefinitely. The pollen-mother-cells of the larch are found to break down within ten or twelve minutes after crushing out the content of the anther into tap water. Even before this time has expired, and often almost immediately, the nucleus appears to enlarge, doubtless due to a decrease in the osmotic pressure of the medium. The introduction of a trace of weak alkali was found to prolong the period of normal appearance to between fifteen and eighteen minutes. The pollen-mother-cells of Tropaeolum, Chrysanthemum, Helianthus, and Nicotiana were studied in the living condition. This was attempted with Primula; but here the mother-cells were apparently bound together so firmly that the entire content of the pollen-sac remains intact during the process of crushing out, and to separate the cells would involve so much abuse of the protoplast as to make the results of no value. In the other dicotyledons noted, the mother-cells readily wash out separately from the anther as soon as it is cut. In these forms the protoplast retains its natural appearance longer than in the larch. This may perhaps be attributed to the enormously thickened 
mother-wall. The relative thickness is all the more striking when it is remembered that the mother-cells of the larch have a diameter two or three times that of these dicotyledons. The thickness of the mother-wall in the larch is usually less than one tenth of the diameter of the protoplast; whereas in the other forms it is usually more than one third of the diameter of the protoplast.

In the larch the mother-cells seem to pass through the reduction divisions in about forty-eight hours. The wall thickens slightly during the first division; but those of adjacent cells do not cohere, and they separate readily. The various stages in the divisions can be quite easily identified. The nuclei, chromosomes, and very often the spindle fibers are plainly distinguishable. One of the very evident features is the centrifugally forming cellplate. The cell-plate can be progressively followed from its incipiency as a little streak in the equator, until it reaches the plasma membrane upon either side. It is frequently attached to the plasma membrane upon one side, while it is as yet incompletely developed upon the other. There is no evidence that the plasma membrane proceeds inward either in the form of a concavity or a sharp furrow to meet the cell-plate, the division of the cy.toplasm being apparently entirely a function of the latter. However, after the cell-plate is complete, a sharp furrow does appear at its juncture with the plasma membrane of the mothercell. The formation of this furrow has been referred to by Strasburger as a rounding-up process. Just what is its relation to celldivision is not entirely clear. In the entire process of cell-division in the broadest sense of the word, there are involved at least four distinct processes: the division of the nucleus, the formation of the cell-plate, the formation of the new plasma membranes, and the formation of the new cross-wall.

In Nicotiana the presynaptic mother-cells (FIG. I) are angular in form, the lateral walls being rectilinear in section, and scarcely, if at all, thickened more than are those of the ordinary vegetative cells. The corners, however, are thickened so as to appear in section somewhat like those in collenchyma tissues, though no signs of laminations, such as Pringsheim reported, can be found either in the living or fixed material. The mother-cells when teased out in a drop of water may be seen at this stage to be rarely isodiametric, but are usually longer in one dimension than in the others. 
During synapsis the more or less sharp angles become rounded off, so that the cell approaches more nearly to an ellipsoid or ovoid form. At the same time the mother-wall may be seen in crushedout material to have developed a considerable thickening at either end of the cell. It is frequently noticeable that the mother-wall is flattened on one side parallel to the longitudinal dimension. This flattening may even be so marked that the central optical section appears triangular, or the apex of the triangle may be truncated. When two cells lie contiguous to each other, their flattened faces, which represent the bases of such triangles, are often seen in living material to lie appressed to each other (FIG. 4); and it is at least suggested that this line of contiguity may mark the plane of the last preceding mitosis. Pairs of mother-cells, in which the protoplasts have completely divided into the microspores, may even be found in this relation (FIG. I4), the mother-wall retaining its original form.

The nucleus is seen to undergo progressive enlargement during the stages of presynapsis and of synapsis proper. Lubimenko and Maige (40) believe that this is carried to the point of bursting of the nuclear membrane. No evidence of the latter phenomenon was observed in the present study. Sometimes the nucleus would swell and burst, thereupon completely collapsing, but this was thought to be due to the abnormal medium in which the cells had been placed.

The wall continues to thicken during synapsis, and upon the advent of diakinesis (FIG. 2) it is thicker on all sides, but is still more markedly so at either end. The nature of the process of thickening of the cell-wall will be discussed under the observations on fixed material. The heterotypic spindle may lie either in the longitudinal axis of the mother-cell (FIG. 2I), or transverse to it (FIG. 3). As the homoeotypic division takes place (FIG. 4) the wall becomes quite uniformily thickened on all sides. The homoeotypic spindles are frequently at right angles to each other, though they may be at a much smaller angle. After the reorganization of the daughter nuclei there appear occasionally in the living material a few central spindle fibers; though these are difficult to make out. One instance (FIG. 4) was found in which quite a definite row of granules might be seen in the plane midway between the nuclei. The whole cytoplasm, of course, appears 
very granular in the living material, and it could not be determined whether the granules in question had any specific relation to division. The failure to find further evidence of these granules after studying a great number of living cells, makes one doubt their relation to cell-division. That such rows of granules might appear in any part of the cell is indicated by the evidence from fixed material presented below.

After the homoeotypic mitosis the protoplast assumes a spherical form within the cell-wall, which conforms to the protoplast on its inner surface, but which may have an outer surface of various forms. It would appear that the mother-cell-wall is of such viscosity as to yield to the pressure due to the cell-turgor, but that is has too high a coefficient of viscosity readily to assume a spherical form itself when freely suspended in water. As Hofmeister suggests, there may be a difference in the viscosity of the inner and outer layers of the wall, so that the one takes the form of the enclosed protoplast, while the other retains some of the effects of the cxternal pressure under which it existed within the pollen-chamber. In other words, the outer portion of the cellwall has an elasticity which operates against its external form being permanently changed by the application of transitory pressure.

When the daughter nuclei become completely re-organized they withdraw as far as possible from each other in the cell, usually assuming a tetrahedral arrangement. Soon the cell-cavity becomes lobed (FIG. 5). It seems that this is not the consequence of the protrusion of the plasma membrane in the region of each nucleus, as Farmer and Moore (17) described for similar cells of Aneura; but it appears rather that it is due to furrowing of the plasma membrane along the plane midway between each pair of nuclei. The first indication of the furrowing is to be found in the flattening of the protoplast on four sides, each of which is parallel to the plane of three nuclei, so that the en tire protoplast assumes the form of a tetrahedron, the nuclei lying near the corners. A depression appears in the center of each flattened surface, and the depression of each face is connected with that of each of the others by a furrow which bisects the edge of the tetrahedron across which it passes. These furrows may either take the form of a broad concavity with smooth curves, equaling in width about one half of 
the length of one edge of the tetrahedron, as is shown on the upper side of FIGURE 6; or they may be more abrupt, as indicated on the lower side of the same drawing. In no case was the inner edge of the furrow found to be sharp. In cells in which the protoplast has collapsed and shrunken into a smaller ball, the wall retains the form which it had at the time that the collapse occurred (FIG. 7). In such cases the appearance is as of ridges on the inner surface of the mother-cell-wall. The presence of these ridges in the fresh living material and their persistence, after plasmolysis has drawn the turgid protoplasm away, demonstrates that they are in no sense artifacts, or related to plasmolysis in any way, but that they actually occur in the division of the cell.

The furrowing of the plasma membrane and the simultaneous invagination of the mother-wall take place more rapidly at certain places than at others. It is evident that if there are four nuclei arranged tetrahedrally and equidistant from each other within a sphere, there will be four points upon the surface of that sphere which are equidistant from each of three of the nuclei. These points are the centers of the faces of the tetrahedron above described. By the transformation of the sphere into the tetrahedron the plasma membrane has been brought closer to the nuclear membrane. At these four points above mentioned on the plasma membrane the constriction of the mother-cell continues to proceed more rapidly than elsewhere. Thus there are formed four projections of the inner surface of the cell-wall which are equidistant from each other, one being in the center of each face of the tetrahedron, and which are connected with each other by a ridge of less magnitude. These projections, or invaginations, continue to elongate toward the center of the cell, and consequently in the direction of the fourth nucleus, keeping at all times equidistant from the three nuclei. As a result the four projections meet in the center of the tetranucleate cell, and fusion of their tips occurs (FIG. 8). Thus there are organized four protoplasmic masses each with a single nucleus and connected with each of the other four by an isthmus of cytoplasm, at first quite broad. It is evident that there would be six such isthmuses, not more than three of which would show in any one optical section.

Apparently each isthmus constricts independently of the others. 
Many stages may be found showing different degrees of this constriction (FIGS. 9, IO, I2). The daughter-cells are not at first spherical. This may be related to the resistance of the thick mother-wall to transformation of form, or to the unequal rates at which the isthmuses narrow (FIG. II). Upon the completion of the division each of the four cells is separated from each of the other three by a lateral wall which is thicker in its periphery and thinner at its center. Its form persists even after the protoplasts undergo plasmolysis (FIG. I3). Since in living cells the protoplast completely fills the space enclosed by the cell-wall, it will be seen that the daughter-cell is not perfectly spherical, but rather has in section the form of an ellipsoid. Such a condition is shown to the right in FIGURE I4. To the left, however, are cells which have proceeded a step farther and have approached the spherical form. Later (FIG. I5) the cells become exact spheres. This last change is accompanied by their enlargement and a decrease in thickness of the mother-cell-wall. The latter may involve a dissolution of the inner portion of the cell-wall. The entire cell does not retain its initial outline at this time, but assumes more nearly that of a tetrahedron; the division of the single spherical protoplast into four spherical protoplasts and the growth of the later has involved a considerable increase in the total volume, which has doubtless led to a stretching of the outer portion of the mother-wall. As the exine of the spores appears this mother-wall becomes thinner and thinner and finally disappears entirely.

From a study of the living material it has been shown that normally the mother-cell of Nicotiana thickens its walls during synapsis and the heterotypic karyokinesis, that no division of the cytoplasm occurs after the latter, lut that the homoeotypic karyokinesis takes place almost immediately and is followed by a division of the tetranucleate cell into four uninucleate spores. This division involves a furrowing of the protoplast in the planes midway between the nuclei. It is not possible in the living material to determine the relation of cell to cell within the tissue, nor to study critically the details of the process of division.

\section{I'. TIICKENING OF TIIE MOTHER-WALLS}

In the fixed material it is found, as noted above, that the mother-wall begins to thicken during synapsis, commencing first 
at the corners, especially at the ends of the cell (FIG. 20). It is here thickened to a maximum degree of I.4 microns, though the greater part of the thickened portion is about 1.05 microns in thickness. The mother-cells are arranged in the pollen chamber in general in two plates, lying side by side. The individual cells are usually elongated transversely to these plates, so that the one end of each mother-cell abuts upon the tapetal layer and the other upon the intercellular spaces between the two plates. It is as if the mother-cells mutually compressed each other, causing this modification of form, and permitting the thickening of the wall at first only at the points of least pressure.

In diakinesis the mother-wall is much more thickened. It may even reach a maximum of 7 microns, which is nearly as thick as it ever becomes. Usually, however, the thickened portion of the cell-wall in diakinesis has a maximum of about 4.2 microns, and its average thickness is about 2.8 to 3.5 microns. It is usually thickened throughout about one half of its area. In the early anaphases of the homoeotypic division the ends of the mothercell are thickened to from 4 to 6 microns, and the lateral faces about 2 microns. The thickest portion of the wall at this time comprises about three fourths of its area. In the late telophases, however, the entire wall becomes almost uniformly thickened, so that it becomes difficult to determine the original longitudinal axis of the cell (FIGS. 24, 25). After re-organization of the daughter nuclei the wall appears thickened all around (FIG. 26), but there are variations in the degree of thickening which are not uniformly distributed. From the way the cells fit together in the pollen chamber it seems reasonable to conclude that the variations in thickness are related to the association of the mother-cells and their mutual pressure, etc., rather than to the composition of the mother-wall.

The absence of lamination or other visible differentiation in the mother-cell-wall indicates that the thickening process is not a growth by intussusception or apposition, but merely a swelling or gelatinization of the secondary strata of the mother-cell-wall. The wall appears perfectly homogeneous and stains a deep orange. A survey of the substances which stain orange in the cytoplasm leads one to the conclusion that they are often transitional forms of carbohydrates. Denniston (12) found an orange zone about 
the starch grains and attributed such a constitution to it. The orange zone which Timberlake found preceding the advent of the cell-plate is very likely composed of carbohydrate which was perhaps in the process of polymerization from a soluble sugar of low molecular weight through the less soluble dextrins, etc. and ultimately into cellulose. The orange-staining bodies in the cytoplasm of so many plant cells may possibly also be carbohydrate material of varying degrees of polymerization.

The history of the mother-cell-wall also indicates that during reduction it may be passing through transitional stages leading ultimately to its dissolution and disintegration. In most plant cells the mother-cell-wall persists after mitosis and becomes a part of the cell-wall of each daughter cell. The wall of the pollenmother-cell, however, like that of other spore-bearing structures disappears as an entity, while the walls of the daughter cells are constructed entirely anew within the mother-cell. As has been shown above, the mother-wall beginning at the time of synapsis continues to thicken to a marked degree during the reduction divisions, and finally dissolves. It seems hardly possible that this thickening of the mother-cell-wall can be in the nature of growth, such as doubtless does occur in the formation of so permanent a structure as the exine, for example. Chemically considered this thickening of the mother-wall is probably in the nature of a colloidal swelling or hydration. Fischer (19) has recently attempted to demonstrate that hydration is not a stage in the process of solution as it has usually been considered. Though it may be that solution is not an absolutely necessary consequence of hydration, it is still true that very often, if not usually, solution does follow hydration. There is at least this much of a sequence in these cases; and solution involves a greater increase in colloidal dispersity than does hydration. It, therefore, does not seem illogical to conclude that the thickening of this mother-cell-wall is in the nature of an increase in colloidal dispersity of the substance of the wall, which process continues, and ultimately leads to such extreme dispersity that an entire dissolution of the mother-wall ensues. In addition to the cases of thickening of the mother-wall noted in the table below, Wille figures (81) this condition in It dicotyledons. 


\section{The CENTRAL SPINDLES}

After the heterotypic karyokinesis the central spindle persists connecting the two daughter nuclei (FIG. 21). Fibers may be found running apparently the entire distance from one nucleus to the other; they are attenuated near their ends, giving the appearance of their being thickened throughout about one half or two thirds of their length in the central region. Careful examination, however, leads one to conclude that the fibers do not pull away from the nuclei. Scattered about in the cytoplasm are a few red-stained bodies, three of which are shown in the drawing. The hyaline area about each is probably an optical illusion due to diffraction. Comparison of this stage with a similar one in the dividing cells of the onion root-tip reveals the fact that in the latter the spindle fibers are somewhat more thickened throughout one half of their length in the central portion, and a very distinct orange zone and cell-plate have already begun to form in the equatorial region of the spindle. In the mothercells of Nicotiana, however, no orange zone appears across the equator, and no blue-stained plate is developed. The fibers (FIG. 22) continue to become more arched, as the mother-cell approaches more and more the spherical form, and the rather rudimentary spindle takes on a more inflated aspect. The peripheral cytoplasm perhaps appears to be now more fibrillar; fibers run out from the nucleus in all directions to the plasma membrane and frequently cross along the surface of the spindle. There is no evidence that these crossing fibers become transformed into peripheral spindle fibers. In the later stages the fibers of the central spindle proper seem not infrequently to cross each other, whereas earlier (FIG. 2I) such a condition was quite exceptional. It is difficult to state how this is brought about. There are apparently, however, many more fibers present in the cytoplasm in the later stages than immediately after the heterotypic karyokinesis.

The longitudinal axes of the homoeotypic spindles, as was observed from the study of living material, are frequently at right angles to each other (FIG. 23). By the time the metaphases of the second division have been reached, the heterotypic spindle has entirely disappeared. The cytoplasm presents a densely granular structure with evidence neither of alveoli nor of fibers; 
the only kinoplasm present is the rery distinct fibers of the spindles. The granules appear to be aggregated into more or less spherical groups (FIG. 24), which give almost a flocculent appearance to the cytoplasm. In addition there are scattered about many redstained granules, which are about one eighth of the dianeter of the chromosomes and hare no special arrangement.

In the mother-cells of Nicotiana, when the daughter nuclei have become fully organized (FIG. 26), there is found a spindle between each pair of nuclei, that is, there are six spindles. These spindles are indistinguishable from each other, in other words it is not possible to tell either from the nuclei or from the spindles which of the four nuclei are sister nuclei. There must be then a disappearance of the homocotypic spindles and the organization of six new spindles from the cytoplasm, or the former persist and there are organized four new spindles which are indistinguishable from them. As far as could be determined, the latter is the procedure in this form (FIGS. 24, 25).

Before the nuclear membranes are formed, the six spindles have become organized and are indistinguishable. The individual fibers are straight and parallel, the spindles not taking on the inflated appearance until about the time of the formation of the nuclear membranes. At first the fibers appear rather attenuate at their ends, as in the homocotypic division; but very soon (FIG. 26) they are quite uniform throughout, at least there is no zonal differentiation. The fibers run from each nucleus to the others and to the plasma membrane as well. Were it not for the arching of the peripheral fibers of the spindle, it would almost seem as if the fibers radiate in all directions from the nuclei, and that the spindle is more or less an incidental and unavoidable consequence. It seems quite likely, however, that the spindle should be recognized as a special structure, though the other fibers, as far as the evidence goes, are of similar composition and character. In FIGURES 26,27 , and 28 the attempt was made to show all the fibers in the section, which was five microns in thickness, by changing the focus progressively during the course of making the drawing. A similar method was employed by Allen (16) in his paper on Polytrichum. It will be seen that the filers are attached to the nuclei more or less in bunclies or tufts; from a single tuft there may proceed fibers both to the plasma membrane and to one or more 
nuclei. They rarely, if ever, run parallel or to the same region on another membrane. Quite regularly these tufts of fibers seem to be attached to the nuclear membrane just above the chromatic mass resulting from the transformation of a chromosome. These chromatic masses are practically all peripherally placed in the nucleus. It has been several times suggested that the material of the fibers is of nuclear origin, and this would indicate that the chromatin may have something to do with their formation or secretion from the nucleus.

\section{THE CONSTRICTION FURROWS AND NUCLEAR MIGRATION}

In the tetranucleate pollen-mother-cell we have a condition which offers peculiar advantages for studies in nuclear migration, especially inasmuch as when first formed the nuclei are closely appressed to the plasma membrane (FIG. 26), whereas after sporeformation they lie in almost the exact center of the daughter cells. (FIG. 37). I have studied quite carefully the origin of the tetrahedral arrangement of the nuclei. It is by all means the prevailing arrangement in Nicotiana. In the examination of practically all of the hundreds of mother-cells in a single stamen, only four could be found which departed from this perceptibly, and none of these had a perfectly monoplanal disposition. The origin of the tetrahedral arrangement can not be attributed to the homoeotypic spindles, being from the first at right angles to each other. Probably in somewhat less than 50 per cent. of the mother-cells are they exactly at an angle of $90^{\circ}$ during the anaphases. More often they have an inclination of from $45^{\circ}$ to $60^{\circ}$. However, when the chromosomes have reached the poles, the four aggregates which they compose are found to be almost invariably equidistant, tetrahedrally arranged, and appressed to the plasma membrane (FIG. 25). It is thus just before nuclear re-organization that the tetrahedral arrangement is finally determined. Giesenhagen (24) has written extensively on the orientation of spindles and division planes, attributing them largely to the polarity of the mother-nucleus.

As noted, the cell was at first perfectly spherical, but soon the sides parallel with the spindles appear flattened (FIG. 27), the whole cell thus becoming a tetrahedron with each of its four faces lying over a group of three nuclei and parallel to the spindles between them. 
At the middle of some of the spindle fibers at this stage there appear to be thickenings, but these little masses may also be found apparently unassociated with fibers. Occasionally one or two fibers nearer the center of the mother-cell may be found with a dense granular mass near its middle point. Such sporadic appearances are doubtless responsible for the statements by many authors that the division is of the ordinary cell-plate type; but there is no evidence that the fibers shorten at this time or at any time in the process of division. They are never seen to pull away from the nuclei and no plate or similar structure across the equator of the spindle is formed. The fixed material shows no plasmolysis in these stages, and the red, blue, and orange stains were well balanced. No difficulties in technique, such as Strasburger reports having encountered in the dicotyledons he studied, were here experienced. In a number of instances rows of granules were found; but these are as frequently, if not more of ten, located in other parts of the cell than the equatorial planes. Such a one may be seen in the upper left-hand corner of FIGURE 27 , in the lower right-hand corner of FIGURE 28 , in FIGURE 30 , and in the lower left-hand corner of FIGURE 32. They are probably in most cases the result of chance distribution of granules, and only in three instances, FIGURES 27,39 , and $3 \mathrm{I}$, can they be considered as having any relation to cell-division. The last-named figure presents the nearest approach to a cell-plate which could be found. It might be argued that these rows of granules in various positions between the nuclei are composed of material which is diffusing from the nuclei to the plane of division, but no accumulation of such material in that plane in the form of a plate could be found.

A slight depression or concavity appears almost immediately (FIG. 27) in the plasma membrane at the equatorial plane of the spindle. At first it is rather abrupt, though the exact center of the concavity is always a smooth curve and never a sharp edge. Soon, however, this broadens into a wide smooth curve (FIG. 28), giving the mother-cell a lobed appearance. Spindle fibers may run to the plasma menbrane in the region of the furrow, but there seems to be no tendency for them to be oriented thereupon any more than upon other points along the membrane. The spindles seem at this time to take on a little more definite organization. Not so many fibers are found crossing each other, and the 
individual spindles seem to be pressed together along the line where they are in contact, each one being thus quite definitely delimited. This results in many instances in the appearance of a triradiate figure composed of bundles of fibers (FIG. 28).

As the furrow deepens to the level of the outer margins of the nearest two nuclei it again becomes somewhat sharper. Meanwhile the nuclei slowly draw away from the plasma membrane (FIG. 29). The two edges of the furrow approximate an angle of $90^{\circ}$ with each other, but the edge of the furrow is always rounded (FIG. 30). By this time the spindle has almost lost its inflated appearance. The peripheral fibers are no longer arched, as in the earlier stages.

The question as to the relation of the furrowing to the growth of the plasma membrane is a difficult one. It seems certain that growth of this membrane must take place at some time during the process of cell-division. It is not easy to determine whether the fibers are pushed before the invading membrane in the equatorial plane, as in animal cells, or whether the middle portions of the fibers as they successively come in contact with the invading membrane become absorbed in it, the remainder of the fiber between either nucleus and the new membrane persisting as radiating fibers. Such a transformation of fibers into plasma membrane would resemble that described by Harper (28b) for free cell formation in the ascus. The existence of such radiating fibers from the nucleus to the plasma membrane of the furrows may be found in all later stages of the division process (FIGS. 30-36). It seems not improbable that in Nicotiana also the spindle fibers are in part transformed into the plasma membrane. It is not, however, by any means proven that this is the only source of new plasma membrane material; but it is not surprising to find that here as well as in the cases where the cell-plate is the precursor of the plasma membrane, we may have the origin of that membrane from the fibers (kinoplasm) of the cell. As evidence accumulates it seems more and more likely that this kinoplasmic material arises from the region of the nucleus; this is then only further evidence that the material of the plasma membrane has its primary origin in the nucleus of the cell. The presence of radiating fibers from all sides of the nucleus to the plasma membrane, not only during division but as well in the young microspores both those of dico- 
tyledons and of the larch, where in the latter case the division is by a cell-plate, makes the above interpretation possible whether it be assumed that the membrane grows by intussusception or apposition. There is no reason for presuming that the radiating fibers may not contribute to the growth of the plasma membrane as well as do the spindle fibers.

Considering the tetranucleate cell with the constriction furrows (FIG. 30) as a whole, it will be noted that inasmuch as there are six spindles, no two of which are parallel, there will be six furrows. Three of these furrows come together above each point of contiguity of three spindles. In other words, there are four points on the surface of the mother-cell at each of which three furrows meet. These points are the centers of the four faces of the tetrahedron. Each of these points of intersection is equidistant from the three nuclei, the mutual spindles of which are bisected by these furrows. Since the median line of each furrow is the arc of a circle which is smaller than a great circle of the tetranucleate cell, the points of deepest depression of these furrows are at their points of intersection, consequently there are four projections of the plasma membrane in to the protoplast. Since the mother-cell-wall conforms to the plasma membrane exactly, the condition might be described as four equidistant invaginations of the mother-wall, each of which is connected with the others by a ridge upon the inner surface of the wall. These projections proceed gradually toward the center of the cell, keeping equidistant from the three nearest nuclei, and growing toward the fourth. It is thus apparent that these four projections finally meet in the center of the tetranucleate cell, before the furrows have conpleted the division in the equator of each spindle (FIG. 32).

The first indication of the growth of these projections toward the center of the mother-cell is in the straightening of the spindle fibers noted above (FIG. 30). This straightening results in the fibers pulling away. from the center of the mother-cell, leaving a space which is triangular in section, lut is really pyramidal, in the center of the cell. The eccentric position of the projection of the mother-wall shown in FIGURE $3 \mathrm{I}$ is not typical, and is doubtless due to the failure to cut all three spindles in the median plane, the one on the lower right side heing cut near the periphery of the spindle. Figure 32 gives the typical condition. The 
projection of the mother-wall is triangular in section, the angles which are, however, never sharp, representing the edges of the furrows as they cut into the equator of the spindles. Figure 33 shows a section cut through the center of one of the nuclei of the mother-cell and tangential to two others, showing the projection of the mother-wall extending in to the center of the cell where it has fused with those from the three other directions.

By the fusion of the four projections of the mother-wall at the center of the mother-cell the latter is divided into four uninucleate protoplasmic masses, each connected with the other three by a broad isthmus of cytoplasm through which spindle fibers continue to pass. The furrows continue to deepen, as before, and the projection of the mother-wall enlarges transversely so that there is a constriction of the isthmus between each pair of daughter cells.

While these processes are going on, there is simultaneously a migration of the nuclei away from the plasma membrane (FIGS. 28-37); until at the end of the division the nucleus occupies the central position in the daughter cell. The conditioning factors in such migration have, of course, not yet been determined with certainty; it is, however, interesting to note that should the nuclei be thought of as bearing electric charges of like sign, they would behave as described: namely, assume a tetrahedral disposition before cell-division. And if further we think of the plasma membrane as bearing an electrical charge of sign unlike to that of the nuclei, the nuclei would ultimately move to a central position in the daughter cells, in other words to the position of equilibrium, considering that they bear charges unlike that of the plasma membrane.

The tetrahedral arrangement of the nuclei, and consequently of the microspores, seems to be the prevalent disposition among dicotyledons and, in fact, among all of the higher plants, especially those in which quadripartition has been found. Below is given a table, showing certain data on this point given in the literature. Of the forms studied in this investigation the predominant disposition in all is tetrahedral, though Chrysanthemum shows a greater diversity in this respect than any of the other species It will be seen that out of 50 forms of bryophytes, pteridophytes, and spermatophytes which have been studied in this respect, 40 are reported to have the tetrahedral arrangement; in 
only ig have the nuclei been noted in the form of a rhomb or square; four forms occasionally show pyramids, and in three is found the arrangement in a single row: Of 42 forms which have quadripartition, 37 have the tetrahedral and I the rhomboidal or rectangular arrangement; none of these are reported to have the nuclei or spores arranged in a pyramid or row. It will thus be seen that the tetrahedral arrangement is by far the predominant, and the arrangement of the cells in pyramids or rows the most rare. The rhomboidal and rectangular disposition occupy intermediate relations, but the data have not been accurately enough recorded to determine which of these later is the more frequent. Hofmeister, Berthold, and Errera early contributed olservations on the adjustment of the plasma membrane to Plateau's law of minimal surface; and Thompson (72) has recently called attention to this work, expressing the relation that (p.424)" in a complex system of films . . . three partition-walls and no more meet at a crest, at equal angles." Harper (28e) in his study of Gonium colonies has laid particular stress upon the tendency of cells to group themselves in threes. He finds a tendency in the four-celled stage to shift from a rectangular monoplanal arrangement to that of a rhomb, wherein two of the cells opposite each other are closer together than the other pair, but in the older colonies the central four cells usually take the arrangement of a perfect square partly on account of the tension from the peripheral cells of the colony. This tension may be the consequence of the tendency for the peripheral cells to form groups of three with the central cells. The law of least surfaces certainly applies also to these mother-cells in quadripartition. It is evident that in the pyramidal arrangement of four spores in one plane there is one group of three, in the rhomboiclal there are two groups of three, and in the tetrahedral there are four groups of three. It is apparent that if a surface be described about four spheres of equal size in such a way that it is tangential to the surface of the included spheres which are in contact with it, the extent of this described surface will vary with the arrangement of those splieres in the following descending order: linear, pyramidal, rectangular, rhomboidal, and tetrahedral. If then the mother-cell-wall is exerting a force of compression upon the four spores and the latter allhere closely together, we would expect to find the tetrahedral arrangement of the spores to be the 
most common. This is, of course, what we have observed above. But it should be remembered that the tetrahedral arrangement has been shown in Nicotiana to be determined, not during the division of the mother-cell, but previously near the close of the nuclear divisions. It is quite probable then that the restraining tension of the wall has very little to do with initiating the tetrahedral arrangement, though it may play a large part in the maintenance of such orientation. It is quite possible, as noted, that the appearance of the tetrahedral arrangement is to be attributed to a mutual repulsion between the daughter nuclei, and an attraction between them and the plasma membranes. It may be also that the movements of the plasma membrane in forming the furrow during cell-division, as described above, are in part at least an expression of this same force of attraction between it and the nuclei.

Each isthmus of the single mother-cell does not necessarily constrict at the same rate as the others (FIGS. 34, 35, 36). The division may, in fact, be entirely completed between two nuclei, before the isthmus between others has fairly begun to narrow. As the division proceeds the two sides of the same furrow come to lie more nearly parallel (FIG. 35), resulting in each of the daughter cells approaching more nearly to the spherical form. It is quite likely that this narrowing of the furrow is, in fact, to be attributed to the surface tension of the daughter cells. The portion of the surface of mother-cell over each nucleus, however, retains the form of an arc with a longer radius, indicating that the mother-wall is quite resistant to the rounding up process.

As division is completed, there is quite a definite system of radiating fibers in the cytoplasm (FIG. 36), running from the nuclear membrane to the plasma membrane and quite evenly distributed over the latter. Finally, however, the cytoplasm returns to the reticular appearance which it bore at the beginning of synapsis (FIG. 37), and the spores lie imbedded in the mothercell-wall as a sort of matrix while the spore-coats are being developed.

\section{OTHER DICOTYLEDONS}

In the five other dicotyledons studied, the process of cytokinesis in the pollen-mother-cells was found to agree in all general particulars, as far as studied, with that in Nicotiana. In view of 
this fact, together with the large amount of collateral eridence presented in the review of the literature given, it seems quite probable that in a majority if not in all of the dicotyledons in which quadripartition of the pollen-mother-cells occurs, there is a division of the cytoplasm by constriction furrows, as above described for Nicotiana, without the development of a true cellplate.

In Helianthus there is a greater number of blue-stained granules irregularly distributed throughout the cell at about the time of the beginning of the invagination of the mother-wall. They also frequently appear to be in chains, but these may lie either in or out of the equatorial plane. No evidence was found of these granules being arranged in the form of a plate. The same thickening of the wall occurs as in Nicotiana.

In Chrysanthemum frutescens a large number of irregularities occur as to number of pollen-grains formed from a single mothercell. There sometimes appears to be only one, no division of the mother-nucleus taking place. In other cases, two, three, four, or five nuclei may be present and as many spores may be formed, respectively. When five are present they may all lie in one plane with one nucleus in the center and the other four at equal distances about it. In such cases there are eight spindles. The tetrahedral arrangement is, on the whole, less frequent in Chrysanthemum than in Nicotiana. The size of the respective nuclei in the mothercell also varies. Sometimes it appears as if a nucleus was organized from a single chromosome, and several instances of very small pollen-grains have suggested that these might be later stages of such an aberrant development as Juel found was the case in Hemerocallis. A study of nuclear division in Chrysanthemum would doubtless lead to interesting results. The cell-division of the pollen-mother-cells appears to be as described above for Nicotinna. This last statement may also be made for the other member of the Compositae that was studied, namely Ambrosia artemisiifolia.

The author is able to confirm the statement of Miss Digby that constriction occurs in Primula. No evidence of a cell-plate was found. The isthmus between the nuclei in the later stages takes the form of a narrow neck, the daughter cells being farther apart than in Nicotiana. With regard to Tropacolum, mother- 
cells were found which confirmed the figures of Strasburger with respect to the row of granules in the equatorial plane; but rarely, if ever, were they as prominent as his drawings show them, and they are arranged in chains and not in a plate. Furthermore, other mother-cells were found which contained no such chain of granules, or, if one was present, it lay in another part of the cell. The hourglass-like figures which appear in Primula were also noted in Tropaeolum. No evidence of a true cell-plate was found.

There is in these pollen-mother-cells no indication of a centrifugally formed continuous cell-plate such as is so conspicuous in the pollen-mother-cells of the lily and the larch and in vegetative cells of the higher plants. The central spindle is poorly developed and there is no shortening of its fibers. But the fact that we have here, as in cell-plate formation, the close association of the fibers with the formation of the plasma membrane, points to the importance of the study of these structures in their relation to the phenomena of cell-division.

Further studies are contemplated, involving a wide range of species and extending to the nuclear phenomena incident to quadripartition.

\section{Discussion}

The existence of a form of division by furrowing in certain cells of the higher plants suggests the possibility of ultimately harmonizing the usual division by cell-plates in these forms with the division by so-called constriction in the higher animals. As noted above, there are in the lower plants and animals also types of cell-division more or less intermediate between these two extremes; and it seems highly probable that the processes involved in these essential phenomena of cellular reproduction are determined by the fundamental physico-chemical properties of the complex colloidal protoplasmic mass. The fact that in many cases of quadripartition, as described above, there is a gelatinization of the cell-wall just prior to the division of the cell by furrows indicates that the cell-wall may be an important factor in controlling such form changes as occur in division by furrows. This only emphasizes the contention that botanists have no right to consider the protoplast alone as the cell. The growing and dividing cell of the higher plants should be thought of as a unit comprised both of protoplast and cell-wall. It is certainly a striking fact 
that these pollen-mother-cells whose walls become a gelatinous matrix, like that present in so many animal cells, especially eggs, and whose protoplasts assume a spherical form like the egg cells of many animals, divide in a fashion quite analogous to that of the latter: namely, by a centripetal furrowing of the cytoplasm without the formation of a cell-plate.

The occurrence of the various types of division of the sporemother-cells of the higher plants, as shown by the data thus far accumulated in the literature, is indicated in the following table. It must constantly be remembered that much of it is introduced incidentally to other investigations and is based on fragmentary evidence. With this in mind the evidence as to quadripartition, arrangement of spores, and thickening of the wall, presented by the early cytologists, who had these things definitely in mind, are quite as dependable as the isolated statements of more recent workers.

\begin{tabular}{|c|c|c|c|c|c|}
\hline Plant & ARRANGEMENT & PARTITION & DIVISION $\mathrm{BY}$ & AUthor & MOTHER-IVALL \\
\hline Aneura & tetrahedral & $\begin{array}{l}\text { bi- } \\
\text { quadri- }\end{array}$ & cell-plates & $\begin{array}{l}\text { Farmer \& } 1 \\
\text { Farmer }\end{array}$ & Moore \\
\hline Pellia & $"$ & bi- & " " & " & thick \\
\hline$"$ & " & quadri- & " " & Strasburger & \\
\hline Fegatella & rhomb & 4 & $"$ & Farmer & \\
\hline Pallavicinia & tetrahedral & “ & " " & " & \\
\hline Anthoceros & ." & “ & furrowing & Hof meister & \\
\hline "1 & " & 16 & cell-plates & Strasburger & \\
\hline “ & “ & 16 & $(?)$ & Davis & \\
\hline Funaria & " & “ & & Sachs & \\
\hline Pleris & “ & “ & cell-plates & Calkins & \\
\hline Osmunda & $" “$ & " & " & Smith & \\
\hline Botrychium & u & “" & “ & Stevens & thin \\
\hline " & inonoplanal & $" 4$ & “ & “. & $" 1$ \\
\hline Polypodium & & & & Russow & \\
\hline $\begin{array}{c}\text { Equisetum } \\
\text { ". }\end{array}$ & tetrahedral & $\begin{array}{l}\text { quadri- } \\
\text { bi- }\end{array}$ & furrowing & $\begin{array}{l}\text { Russow } \\
\text { Hofmeister }\end{array}$ & \\
\hline “ & tetrahedral & quadri- & cell-plates & Strasburger & thick \\
\hline “ & monoplanal & "1 & " 1 & " & " \\
\hline Psilotum & & bi- & " $\quad$ " & ، & \\
\hline " & monoplanal & & furrowing & Hofmeister & \\
\hline Isoetes & tetrahedral & quadri- & cell-plates & Strasburger & thick \\
\hline Marsilea & “ & "1 & (?) & "1 & ". \\
\hline " & monoplanal & “ & (?) & " & “ \\
\hline Ceratozamia & "، & bi- & $\begin{array}{l}\text { furrow. } \\
\text { cell-plates }\end{array}$ & Jurány•i & " \\
\hline.. & tetrahedral & “ & furrow. & " & $"$ " \\
\hline
\end{tabular}




Plant
Zamia
Pinus
Larixt
".


Allium
Tradescantia
Fritillaria, Lilium,
Anthericum
Funkia
Potamogeton,
Convallaria
Symplocarpus,
Peltandra
Trillium
Agave
Zea
Musa
“
"“

\section{Neottia \\ Orchis \\ Cypripedium \\ Epilobium}

\begin{tabular}{|c|c|c|}
\hline ARRANGEMENT & Partition & Division BY \\
\hline “ & “" & $\begin{array}{l}\text { cell-plates } \\
\text { cell-plates }\end{array}$ \\
\hline monoplanal & “" & " " " \\
\hline $\begin{array}{c}\text { tetrahedral } \\
\text { “ }\end{array}$ & bi- & cell-plates \\
\hline monoplanal & bi- & ، \\
\hline
\end{tabular}

Author Mother-IVAll

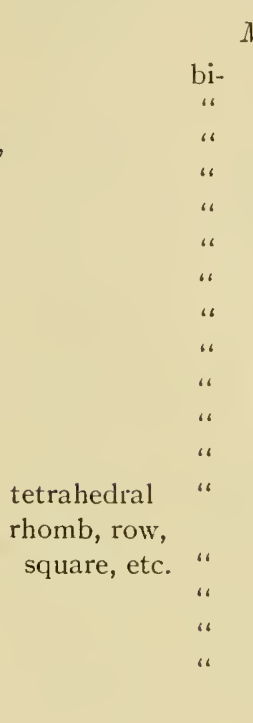

\section{Monocotyledons}

Carex

Hemerocallis

Naias

Iris

Orchids monoplanal

Sisyrinchium tetrahedral

Aloe, Ixia, Freesia,

Apicra

Monbretia, Gasteria,

Haworthia

Asphodelus

Epipactis

Potamogeton

pyramid

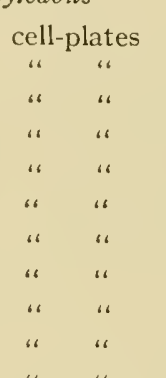

Pringsheim

Hof meister

Strasburger

"4

Sachs

Wiegand

Duggar

"، "

Atkinson

(?) Tischler

(?)

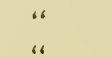

no cell-plates Hof meister

“

thick

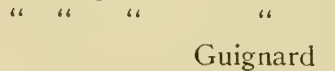

cell-plates and

furrowing Tschistiakoff

cell-plates Juel

incomplete

quadri-

furrowing

cell-plates

Hofmeister

Guignard

".

“

"

"،

"،

Strasburger

Wille

medium

cell-plates

(4)

thick

thick

Strasburger thin

Ernst \& Schmidt

$\begin{array}{cl}\text { Asclepias } & \text { row } \\ \text { Ceratophyllum } & \text { tetrahedral "“ } \\ \text { Rafflesia } & \text { monoplanal “ } \\ \text { " } & \text { tetrahedral " } \\ \text { monoplanal " }\end{array}$

Dicotyledons

thin

“ 
Plaxt

Apocynum

"

Passiflora

Taraxacum

Hieracium

Momordica

Mirabilis

Aristolochia

Acacia

Lathyrus

Nymphaea

Podophyllum

Syringa

Bignonia

Lavatera

Cobaea

Cucumis

Cucurbuta, Bryonia

Oenothera

"،

Althaea

".
Tropaeolum
".
"
Ribes
Mesperis, Pisum
Lathyrus, Ipomoea
Dahlia
Drosera

Hesperis, Pisum

Lathyrus, I pomoea

Drosera

Arraxgement Partition Division BY Author Mother-IVall, row, pyra-

mid, square "

rhomb,

tetrahedral

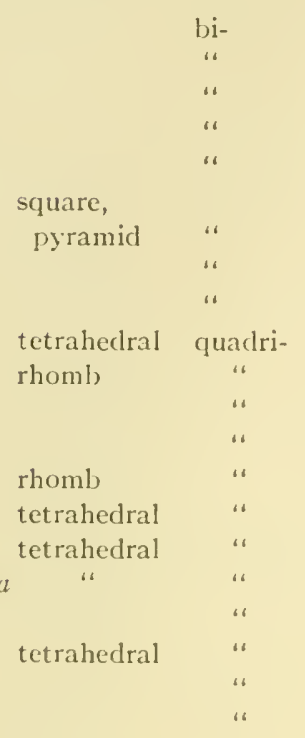

tetrahedral quadri-

square

tetrahedral

tetrahedral

tetrahedral, rhomb

tetrahedra! quadri-

rhomb,

Hieracium
Daphne
Tarnxucum
Convolvulus
IIouttuynia
Passiflora
licin
Primulu

tetrahedral monoplanal tet rahedral

tetrahedral

$$
\text { cell-plates }
$$

“

\section{Frye \& Blodgett}

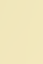

\section{Hofmeister \\ Osawa \\ Rosenberg \\ IVimmel \\ Tischler \\ thick \\ thick}

Samuelsson

no cell-plates Rosanoff

furrowing Gregory

(?) cell-plates Lulimenko \& Maige

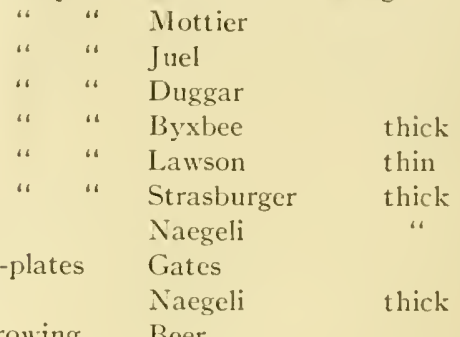

furrowing Beer

cell-plates at

times von Mohl

cell-plates IIimmel

(?) Pringsheim

(?)

cell-plates Strasburger

cell-plates and

furrowing Sachs

furrowing (see above) thick

Tischler

no cell-plates Baranetzky

" " " " "

" " " Ishakawa

$\begin{array}{ccc}\text { (?) } & \text { Rosenberg } & \text { thick } \\ \text { (?) } & \text { "1 } & \text { thin } \\ \text { (?) } & \text { Osawa } & \end{array}$

(?)

furrowing Wimmel thick

Shibata \& Miyake

Hofmeister thick

Fraser

Diglyy thick

(see above) 


\begin{tabular}{|c|c|c|c|c|c|}
\hline Plane & ARRANGEMENT & PARtition & Division BY & AUTHOR & MOTHER-IVALI \\
\hline Sarracenia & " & " & " & Nichols & \\
\hline Gossypium & & “" & “ & Cannon & \\
\hline Crepis & tetrahedral & “" & ““ & Beer & thick \\
\hline Hamamelis & ، & “ & ، & Shoemaker & “ \\
\hline Parnassia & ، & “ & “ & Pace & “" \\
\hline Nicotiana & $\begin{array}{l}\text { rhomb, } \\
\text { tetrahedral }\end{array}$ & “ & “" & (see above) & ") \\
\hline Chrysanthemum & tetrahedral & “ & " & " $" ،$ & $"$ \\
\hline Ambrosia & " & “ & “ & " & "“ \\
\hline Helianthus & “" & $"$ " & " & " & " \\
\hline
\end{tabular}

It will thus be seen that quadripartition has been reported in, at least, 32 dicotyledons, I I monocotyledons, I gymnosperm, 6 ferns, I moss, and 5 liverworts. Bipartition in the spore-mothercells has also been reported in each of these groups, except the mosses; but only 12 cases are noted in dicotyledons, and I 8 in monocotyledons. Quadripartition by cell-plate formation has been reported most abundantly in the liverworts, due largely to the work of Farmer, and in the ferns. Nine cases have been reported among the dicotyledons; they are: in Oenothera by Gates, in Podophyllum by Mottier, in Syringa by Juel, in Lavatera by Byxbee, in Cobaea by Lawson, in Bignonia by Duggar, in Althaea by von Mohl and by Wimmel, and in Cucumis and Tropaeolum by Strasburger. The statements by the writers of some of these papers as to the presence of a cell-plate have been seriously brought into question by more recent work on the same plants. The other papers give no figures which in any way demonstrate the presence of a cell-plate in these divisions. Their evidence consists entirely of statements without confirmatory description or figures, and in view of my results on Nicotiana can not be accepted as final evidence. On the other hand, there is more or less evidence that quadripartition occurs by furrowing and without a cellplate in $2 \mathrm{I}$ dicotyledons. In $\mathrm{I} 8$ dicotyledons quadripartition is reported as accompanied by a thickening of the mother-wall. In none of these has a cell-plate been demonstrated beyond doubt. In fact, no case has been proven in any plant, so far as the present survey of the literature goes, in which quadripartition by cellplates has been found in a cell with a greatly thickened motherwall. The nearest approach to this is given in Strasburger's

1 The data in the last column are based upon the authors' drawings respectively, measuring from the outer boundary of the cell wall to the protoplast. 
study of Equisetum and Isoetes, done at the same time as that on Tropaeolum, and presenting the same evidence, which in the light of the observations recorded above, must be regarded as doubtful.

IVe are forced to conclude with Guignard then, as against Dippel, Samuclsson, and others, that quadripartition and bipartition may occur in either monocotyledons or dicotyledons. Furthermore, there is no doubt that cell-plates occur in the bipartition of the pollen-mother-cells as well as the vegetative cells in both monocotyledons and dicotyledons. We have seen that the wall of the pollen-mother-cell may be thickened in members of either one of these groups. So that there seems to be no evidence that these two groups of flowering plants differ in general in any way in their mode of microspore formation.

Since so little is known of the dynamics of cell-activities of any kind it is very difficult even to attack the question as to what physico-chemical processes are involved in cell-division. However, it is to be hoped that the discovery of a closer relation between the two diverse types of cell-division: that by furrowing, characteristic chiefly of animal cells, and that by cell-plate, common to higher plants, will help to bring to view a new standpoint from which the physiological processes of cell-division may be more effectively studied.

The almost infinite complexity of protoplasm has been so often emphasized that it need not be further mentioned here. In addition to the great varicty of chemical compounds in the cell, these exist in all sorts of physical states. 'There are' particles in suspension, and substances in true solution; and between these two extremes there are substances in all possible degrees of dispersity, including suspensoids and emulsoids, making up the colloidal mass of protoplasm. Not only is there an almost infinite complexity, but the material is in a constant state of flux.

In describing above my observations on the migration of muclei, it was suggested that the nuclei move about in the mother-cell as if they all bore electrical charges of like sign while the plasma membrane bore charges of opposite sign. The location of electrical charges on the membranes of the cell seems quite probable from the standpoint of recent developments in physical chemistry. According to the Giblos-Thomson principle, there is a tendency for substances to accumulate upon surfaces. It is practically 
certain that the ions of many inorganic salts are to be found within the cell, and these are known to have a relatively high speed of diffusion, and hence might be thought of as accumulating upon the membranes of the cell. If, as there is some evidence to indicate, the plasma membrane is colloidal and if it may be inferred that the same is true of the nuclear membrane, this colloidal condition would serve to increase very much the amount of ionic material which might be adsorbed upon the membranes. It is not difficult then to see how great numbers of ions might accumulate there, and if they are of like sign they would give to that membrane an electric charge.

If, for example, the nuclear sap were markedly acid and the cytoplasm be markedly alkaline, there will accumulate upon the plasma membrane charges of one sign, while upon the nuclear membrane there will accumulate predominately charges of the opposite sign. It seems thus possible from a physico-chemical standpoint that such membranes may have acquired opposite charges. But for the purpose of this discussion, it makes no difference how these membranes may have received their charges; it is simply proposed to show that they, at least at certain stages, behave as if so charged.

As noted above, the nuclei of like charge would repel each other and hence take up a tetrahedral arrangement within the cell. The charges upon the plasma membrane and nuclear membranes would not necessarily be neutralized by contact of the membranes since the ions are adsorbed.

The mutual repulsion of the nuclei and their attraction for the plasma membrane opposed by the repulsion between different areas of the plasma membrane will tend to transform the perfect sphere into a tetrahedron with four equal triangular faces, each parallel to the plane of three of the nuclei. Now the center of each of these triangular faces will be attracted equally by each of these three nuclei and also to some degree by the fourth. The resultant of these four forces will tend to draw this point toward this fourth nucleus; and the latter will exert relatively more force of attraction upon this point than any one of the other three nuclei; for, though it is farther away, it is working in the direction along which the point will move. This portion of the plasma membrane will tend to move toward the fourth nucleus, that is, toward the 
center of the cell, and there will thus be formed an invagination or projection of the plasma membrane from the center of each of its triangular faces toward the center of the cell. Now let the accompanying diagram represent the cell at the stage just described:

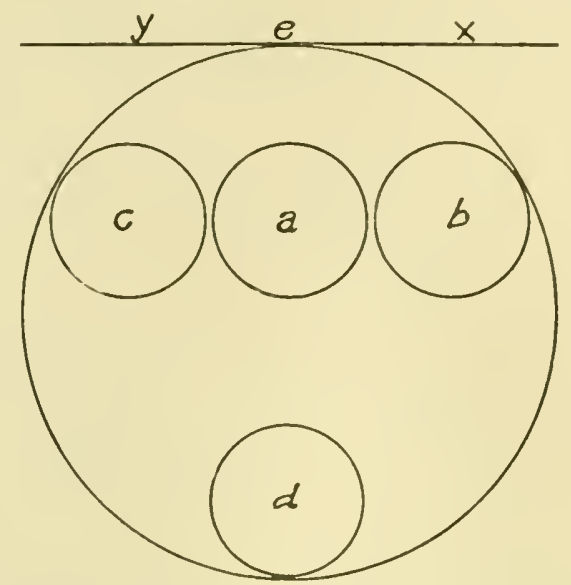

TEXT-Figure I. Diagram of mother-cell before division.

Let $a, b, c$, and $d$ be the four nuclei, and let $c$ be a point on the plasma membrane equidistant from $a, b$, and $c$. The cell is shown in its three dimensions, and these must be kept in mind during the discussion. Two of the four nuclei, $a$ and $c$, are on either side of the plane of the diagram. Let $x y$ be a plane tangential to the plasma membrane at the point $e$, and let $x$ be the point of intersection of the perpendicular dropped from $b$ to the plane $x y$. By actual measurement of the cells, $e d$ is about I6 microns, $c b$ is It microns, and $x b$ is 7 microns. Now if there is an attraction between each of the nuclei and the point $e$, this point would tend to move along the line $e d$. Let $E B$ represent the force exerted by $b$ to draw $e$ along the line ed. Then the force exerted by $a$ and $c$ respectively would also be equal to $E B$; therefore the total force exerted by the three nuclei, $a, b$, and $c$ will be $3 E B$. Let $E B$ represent the force exerted by $b$. The force exerted by $a$ and $c$ respectively will also be $E B$. Now the angle xeb may be shown geometrically to be one-half of a right angle. Therefore the resultant of the forces exerted by the three nuclei, $a, b$, and $c$, will be about $2 E B$. Now $e d$ is less than $2 c b$, and therefore, since the force is inversely proportional to the square of the distance, 
the actual force exerted by $d$ would be less than $E B$. As $e$ approaches $d$ this force would be much greater, whereas the force resulting from the attraction of $a, b$, and $c$ would diminish. The resultant of forces in the early part of the process would be about $3 E B$. But in a binucleate cell the resultant of forces which would operate to draw the plasma membrane along the equatorial plane would be the sum of the attracting forces of only two nuclei, each in such a relation as $b$ to $e$. It thus appears that the resultant of forces in a binucleate cell would be less than those in a tetranucleate cell.

When the furrow is formed, the nucleus is more nearly enveloped by the plasma membrane and hence the position of equilibrium, on the basis of the electrical charges postulated above, would be nearer the center of the lobes. And when constriction is complete we should find the nucleus in the exact center of the daughter cell. It is to be borne in mind, of course, that the furrows as they come nearer and nearer together, being of like sign will repel each other. Also the opposite surfaces of the same furrow as it grows deeper and deeper will more and more repel each other. The problem almost immediately becomes too complex for analysis in the present condition of our knowledge as to the actual distribution of the ions in the cell solutions and on its membranes. I have merely endeavored to point out certain possibilities as to the distribution of the forces concerned in initiating cell-division by the process of constriction. While it is not contended that these electrical charges are the only factors in the division of the cells, yet it is interesting to note that both the nuclear and plasma membranes behave in the initial stages of division as if so charged.

It is quite likely that the thickened mother-wall exerts no unevenly distributed force of compression upon the protoplast while in the spherical form. The tetrahedral arrangement of the spores has been shown to have originated in the migration of the nuclei when the mother-cell was spherical in form, hence it is not necessary to postulate the cell-wall as the determining factor in the accomodation to least surfaces, which is effected by the tetrahedral arrangement. Furthermore, the surface tension of the protoplast may be well thought to operate to bring about this result. The mother-wall seems to behave as if it were a plastic, more or less gelatinous, substance with some elasticity, so that it 
would offer little or no resistance to changes in form of the cell within. The mother-cell then as soon as the mutual pressure of other cells is removed, assumes the form of least surface, doubtless due to cell-turgor and surface tension.

It seems entirely probable that the cellulose wall of the typical plant cell exerts much more opposition to changes in the form of the protoplast, and has a restraining effect against an increase in volume. But whether the typical cell-wall of plants has a high or low degree of elasticity, we must conclude that these mothercells with their spherical form and loose arrangement in the pollenchamber are free to undergo such changes in volume and form as their internal constitution will favor. The pollen-mother-cell thus approaches the condition which is found in the egg cells of many animals, and it is quite suggestive that we should here find a mode of cell-division quite like that in the latter. Whether we shall be able to explain this division in plants on the basis of surface tension, as Robertson and McClendon have attempted in animal cells, is perhaps a question. But it is clear that such factors as surface tension, osmosis, and electrostatic equilibrium are involved and their relation to the process must be considered.

It may be that this close approach in the quadripartition of pollen-mother-cells to the animal type of cell-division may throw some light on the nature of the cell-plate. It is possible that in all cell-divisions, animal and plant alike, there are fundamental conditions tending to cell-plate formation, and that in the majority of the cells of higher plants alone do we have the full complement of factors necessary for the expression of these conditions in the form of a visible structure. The ability of these pollen-mothercells to enlarge to a point of equilibrium between osmotic pressure and surface tension may present conditions favorable for the process of anatonose, as Errera termed it, in which soluble substances are formed in the equatorial plane. In the ordinary tissue cells of the higher plants, the retentive cell-wall and adjacent cells may make such enlargement impossible so that katatonose occurs and a coagulation or precipitation of a compound organic salt, takes place in the region of the equator. The relation of the spindle fibers to cell-plate formation, and the relation of the former to the nuclei, favors the idea that the cell-plate is primarily of nuclear origin. It is not unthinkable that in all cases complex or simple 
unsatisfied soluble ions may diffuse outward in all directions from the nuclei, possibly streaming along the paths in the colloidal protoplasm marked by the fibers. The ions from different nuclei would meet in an equatorial plane and might, if conditions admit, form an undissolved compound. If, however, the cell was able to admit water and increase in volume in response to the increased osmotic pressure, these salts might remain at a concentration below the saturation point and hence not precipitate. May it not be that such a condition exists in these mother-cells, which are able to increase their volume considerably? On this interpretation there would be in these mother-cells an invisible cell-plate of soluble material, and the relation of division by furrows to that of the ordinary type of higher plants becomes more comprehensible.

\section{Literature cited}

I. Allen, C. E. (a) Ann. Bot. I9: 189-256. I905. (b) Arch. Zellforsch. 8: I 2 I-I 88. I 912 .

2. Andrews, F. M. Beih. Bot. Centralbl. I I : 134-I42. 1902.

3. Atkinson, G. F. Bot. Gaz. 28: I-26. I 899 .

4. Baranetzky, J. Bot. Zeit. 38: 24I, 265, 28I. I 880.

5. Beer, R. (a) Ann. Bot. 25: I99-2I4. I9II. (b) Ann. Bot. 26: 705-726. I9I2.

6. Berthold, J. Protoplasmamechanik. Leipzig. I 886.

7. Boveri, Th. Zool. Jahrb. I4:630-653. I901.

8. Byxbee, E. S. Proc. California Acad. Sci. Bot. III. 2:63-82. 1900.

9. Calkins, G. N. Bull. Torrey Club 24: IOI-I I5. I 897.

Io. Cannon, W. A. Bull. Torrey Club 30: I33-I72. 1903.

I I. Davis, B. M. Bot. Gaz. 28: 89-I09. I 899 .

12. Denniston, R. H. Trans. Wisconsin Acad. Sci. 15: 664-708. D 1907 .

13. Digby, L. (a) Ann. Bot. 24: 727-757. I9Io. (b) Ann. Bot. 26: 357-388. I9I2.

14. Duggar, B. M. (a) Bull. Torrey Club 26:89-105. I899. (b) Bot. Gaz. 29: 8I-97. I900.

I5. Ernst, A., \& Schmidt, E. Ann. Jard. Bot. Buitenzorg II. I2: I-64. 1913 .

I6. Farmer, J. B. (a) Ann. Bot. 8: 35-52. I894. (b) Flora 80: 5667. I895. (c) Ann. Bot. 9: 363, 364. I 895. (d) Ann. Bot. 9: 469-523. I 895 .

17. Farmer, J. B., \& Moore, J. E. S. Quart. Jour. Mic. Soc. 48: 489-557. 1905. 
I 8. Farmer, J. B., \& Williams, J. L. (a) Phil. Trans. Roy. Soc. London B. I90: 623-645. I 896. (b) Ann. Bot. I0: 479-487. I 896 .

19. Fischer, M. H. Science II. 42:223-226. 1915.

20. Fraser, H. C. I. Ann. Bot. 28:633-642. I9I 4.

2 I. Frye, T. C., \& Blodgett, E. B. Bot. Gaz. 40: 49-53. 1905.

22. Gallardo, A. Interpretación dinámica de la división celular. Buenos Aires, 1902.

23. Gates, R. R. Bot. Gaz. 43: 8I-I I5. I 907.

24. Giesenhagen, K. Zelltheilung im Pflanzenreiche. I-9I. 1905.

25. Gregory, R. P. Proc. Camb. Phil. Soc. I3: I+8.

26. Guignard, M. (a) Ann. Sci. Nat. VI. I4:26-45. I882. (b) Ann. Sci. Nat. VIII. 6: I77-220. I897. (c) Compt. Rend. I6o: 428-433. I9I5.

27. Gurwitsch, A. Morphologie und Biologie der Zelle. 437 pp. Jena. I904.

28. Harper, R. A. (a) Jahrb. Wiss. Bot. 29: 655-685. I 896 . (b) Jahrb. Wiss. Bot. 30: 249-284. I 896 . (c) Ann. Bot. I3: 467525. I 899. (d) Bot. Gaz. 30:2 I7-25I. I 900. (e) Trans. Am. Micro. Soc. 3I: 65-82. I9I2. (f) Am. Jour. Bot. I : I27-It+. 1914 .

29. Hartog, M. Proc. Roy. Soc. London. B. $76: 548-567 . \quad$ I 905.

30. Hof, A. C. Bot. Centralbl. 76: 65-, I I3-, 22 I-227. 1898.

3I. Hofmann, R. W. Zeit. Wiss. Zool. 63:379-432. I 898.

32. Hofmeister, W. (a) Abh. math.-phys. Cl. K. Sächs. Ges. Wiss. 2: 636. I86I. (b) Lehre von der Pflanzenzelle. Leipzig. I 867.

33. Hutchinson, A. H. Bot. Gaz. 59:287-300. I9I5.

34. Ishikawa, M. Bot. Mag. Tokyo. 25: I-8. I9II.

35. Juel, H. O. (a) Jahrb. Wiss. Bot. 30:205-226. 1 897 . (b) Jahrb. IViss. Bot. 35: 626-659. I 900.

36. Jurányi, L. (Ref.) Bot. Centralbl. I2: 2 I3-2 I6. I 882.

37. Kuwada, Y. Bot. Mag. Tokyo. 25: 163-I8I. I9I I.

38. Lawson, A. A. Proc. California Acad. Sci. Bot. III. I: I68-I88. I 898 .

39. Levine, M. Mem. N. Y. Bot. Garden 6: I25-147. I9 I6.

40. Lubimenko, W., \& Maige, A. Rev. Gén. Bot. I9: 40I, 433, +74. 505. 1907.

4I. Maneval, W. E. Bot. Gaz. 57: I-3I. 1914.

42. Miyake, K. Jahrb. Wiss. Bot. 42:83-120. I905.

43. Mohl, H. von. (a) Diss. 1835, umgearbeitet in den Vermischten Schriften. I845. (b) Linnaca I3:274-290. I839. (c) Grundzïge der Anatomie und Physiologie der vegetabilischen Zelle. I 85 I. 
44. Mottier, D. M. (a) Jahrb. Wiss. Bot. 30: I69-204. I 897 . (b) Ann. Bot. 14: 163-192. I900. (c) Jahrl. Wiss. Bot. 31: 125I 58 . I 897 .

45. McAllister, F. Ann. Bot. 27:68 I-695. I9I3.

46. McClendon, J. F. Jour. Phys. 27:240-275. I910.

47. Naegeli, K. Zur Entwickelungsgeschichte des Pollens. Zürich, I $8+2$.

48. Nemec, B. Jahrb. Wiss. Bot. 33: 3I 3-336. I 899.

49. Nichols, M. L. Bot. Gaz. 45: 3I-37. 1908.

50. Osawa, J. (a) Jour. Coll. Agr. Imp. Univ. Tokyo 4: 237-264. I9I3. (b) Arch. Zellforsch. I0:450-469. I9I3.

5I. Overton, J. B. Jahrb. Wiss. Bot. 42: I2 I-I 53. 1906.

52. Pace, L. Bot. Gaz. 54: 306-329. I9I2.

53. Pringsheim, N. Pflanzenzelle. Berlin, I 854 .

54. Rabl, C. Jahrb. Morph. I0: 2 I4-330. I 885 .

55. Robertson, T. H. Arch. Entw. Mech. Org. 32:308-3I3. I9II.

56. Rosanoff, S. Jahrb. Wiss. Bot. 4: 44I-450. I 865 .

57. Rosenbeg, O. (a) Bot. Tidssk. 28: I 43-I70. I907. (b) Ber. Deutsch. Bot. Ges. 2 I : I IO-I I9. I903.

58. Russow, E. Mem. Pecersb. Acad. VII. I9: I-205. I 872.

59. Sachs, J. Lehrbuch der Botanik. I 874 .

6o. Samuelsson, G. Sv. Bot. Tidsk. 8: I8I-I89. I9I4.

6I. Schaffner, J. H. (a) Bot. Gaz. 4I: I83-I90. I906. (b) Bot. Gaz. 47: I98-2I I. I 909.

62. Schlacht, H. Bot. Zeit. 8: 457-, 473-, 489-. $\quad$ I 850.

63. Shibata, K., \& Miyake, K. Bot. Mag. Tokyo 22: (28r)-(3I6). 1908.

64. Shoemaker, D. N. Bot. Gaz. 39:248-266. I905.

65. Smith, R. W. Bot. Gaz. 30:36I-377. I900.

66. Stevens, W. C. Ann. Bot. I9: 465-474. I905.

67. Strasburger, E. (a) Ueber Zellbildung und Zelltheilung. Jena, I875. (b) La formation et la division des cellules. Jena, I876. (c) Ueber den Theilungsvorgang der Zellkerne und das Verhaltniss der Kerntheilung zur Zelltheilung. Bonn, I 882 . (d) Ueber den Bau und das Wachstum der Zellhaute. Jena, I 882. (e) Arch. Mik. Anat. 23: 3-62. I88+. ( $f$ ) Hist. Beit. I : I 258. I 888. (g) Jahrb. Wiss. Bot. 3I : 5 II -598 . I 898 . (h) Ber. Deutsch. Bot. Gesell. I9: 450-46I. I90I. (i) Jahrb. IViss. Bot. 37: 477-526. I902. (j) Flora 97: 123-I9I. I907. (k) Hist. Beitr. 4:49-I 58. I892.

68. Swingle, W. T. Jahrb. Wiss. Bot. 30: 297-350. I 897.

69. Tahara, M. Bot. Mag. Tokyo 24:23-27. I9Io.

70. Tangl, M. Denksch. K. Akad. Wiss. Wien 45: 73-. 1882. 
7I. Terni, T. Arch. Zellforsch. I 2: I-96. I9I 4.

72. Thompson, D'A. W. Science II. 34: 4I7-428. I9II.

73. Timberlake, H. G. Bot. Gaz. 30:73-99; 154-170. 1900.

74. Tischler, G. (a) Ber. 1)etıtsch. Bot. Ges. 24:83-96. I906. (b) Jahrb. Wiss. Bot. 42: 545-5i8. I906. (c) Arch. Zellforsch. I: 33I51. I908. (d) Arch. Zellforsch. 5:622-670. I910.

75. Treub, M. (a) Verh. K. Akad. Wetensch. Amsterdam I9: I-34. I 878. (b) Ann. Jard. Bot. Buitenzorg 2:32-53. 1885.

76. Tschistiakoff, J. Bot. Zcit. 33: I-, I7-, 33-,81-, 97-, 329-, 345 . I 875 .

77. Tuttle, A. H. Jour. Exp. Zool. 9: 143-157. I910.

78. Wager, H. Ann. Bot. 18: 29-55. 1904.

79. Went, F. C. Ber. Deutsch. Bot. Ges. 5: 247-258. I 887.

8o. Wiegand, K. M. Bot. Gaz. 28: 328-359. I 899 .

8I. Wille, N. Forh. Vidensk.-Selsk. Christiania, no. 5. I 886.

82. Wimmel, T. Bot. Zcit. 8: 225-, 241-, 265-, 289-, 313. I $85^{0}$.

83. Wisselingh, C. van. Beih. Bot. Centralbl. 23: I 37-I56. I 908.

\section{Explanation of plates 27-29}

The accompanying drawings were made with a Leitz one-sixteenth objective, Apert. 1.32, and ocular, number 3 , with a tube length of 15 . The cells are magnified about 1000 times in figures I to 19 inclusive, which are of living cells of Nicotiana. The fixed cells of Nicoliana, figures 20 to 37 inclusive, were drawn about 1875 times their actual size.

1. Mother-cell in presynapsis.

2. Diakinesis, wall thickened.

3. Equatorial plate stage of heterotypic karyokinesis.

4. Anaphase and telophase of homoeotypic mitosis.

5. Furrows which divide mother-cell just appearing.

6. Similar stage, showing large intercellular spaces.

7. Similar stage, with content plasmolysized to show ridges on wall.

8. Furrows well developed, and having invarled the center of the cell.

9. Isthmus becoming (quite narrow.

10. Another cell in similar stage.

I1. Isthmus having become very narrow.

12. Similar stage.

13. Division completc, cell plasmolyzel to show form ol cross-wall.

If. Division complete, spores changing from an elliptical to a spherical form.

I5. Spores become perfect spheres, mother-wall becomes thinner.

16. Four spores of unequal size, within the mother-wall.

17. Three spores of equal size within the mother-wall.

I8. Two large and one small spore within the mother-wall.

19. Two spores within the mother-wall.

20. Synapsis, showing wall thickened at ends of cell, and midelle lamella.

21. After heterotypic karyokinesis, ends of fibers attenuated.

22. A little later, spindle inflaterl, wall thickening. 
Men. N. Y. BOt. GALDEN

Volume Vi, plate 27

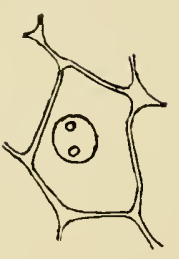

I.

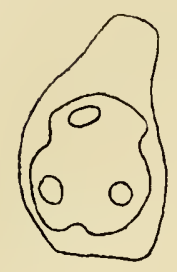

5.

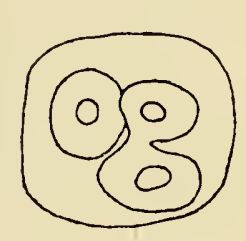

9.

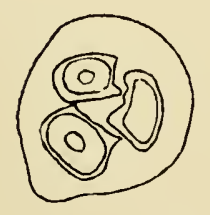

13.

2.

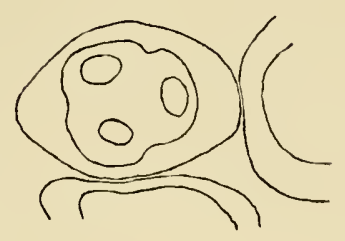

6.

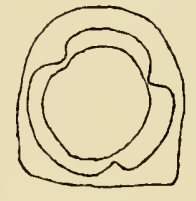

7.

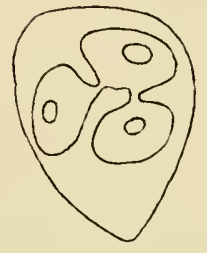

IO. II.

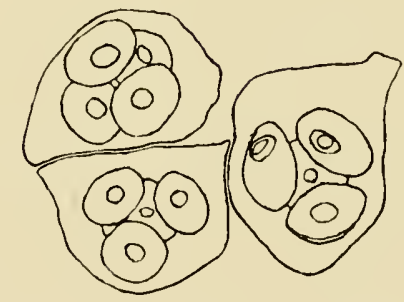

I4.

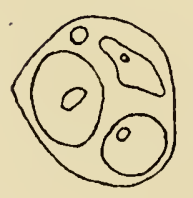

I6.

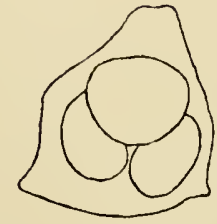

17.

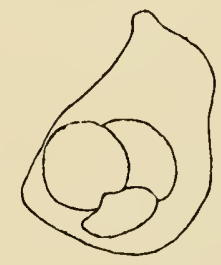

I8.

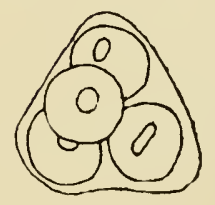

I5.

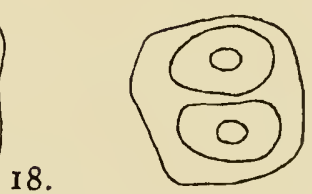

I9.

I2.

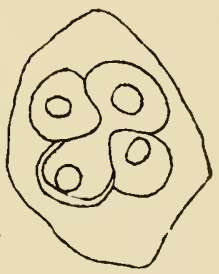





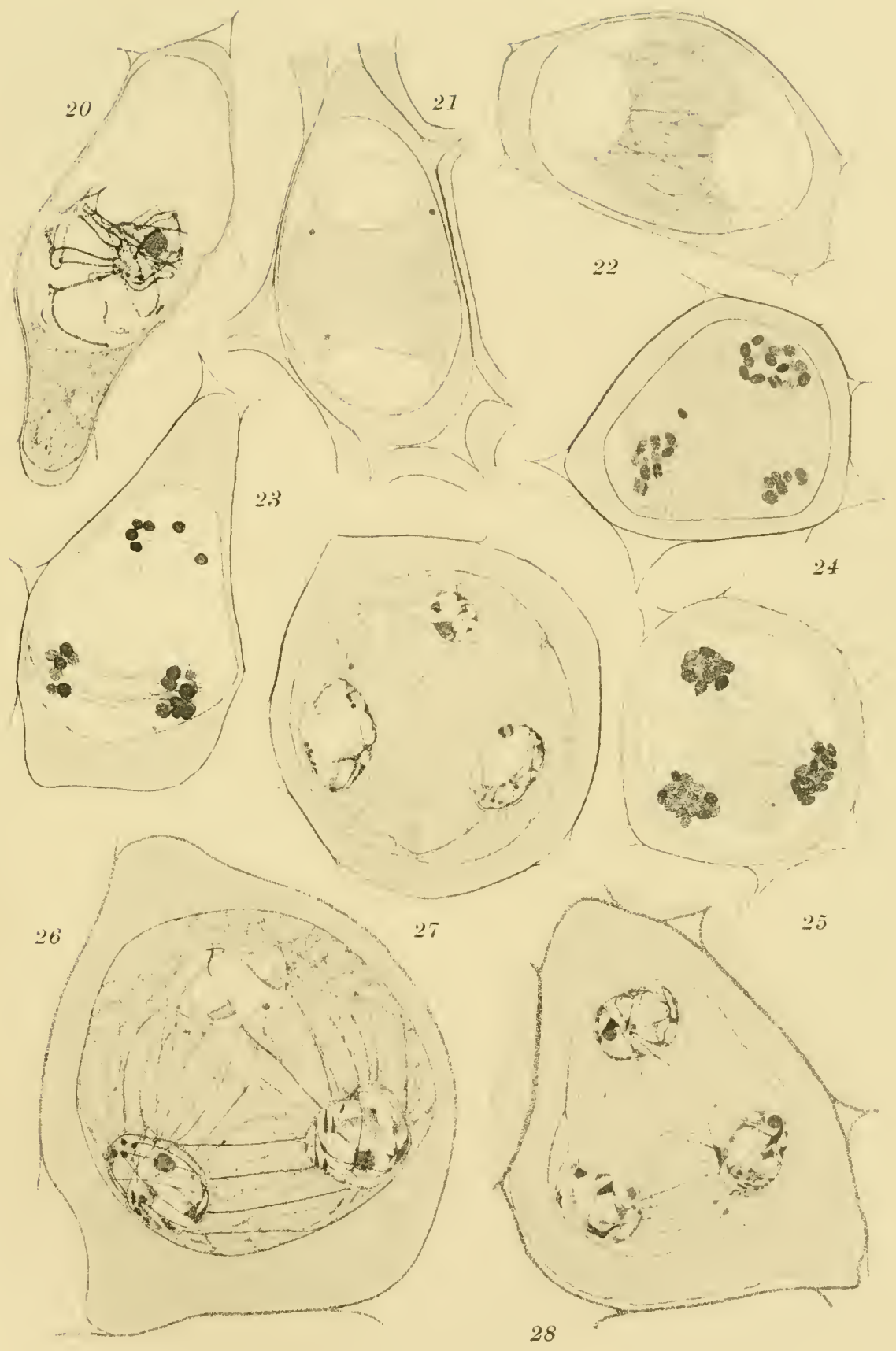

HELIOTYPE CO, BOSTON 



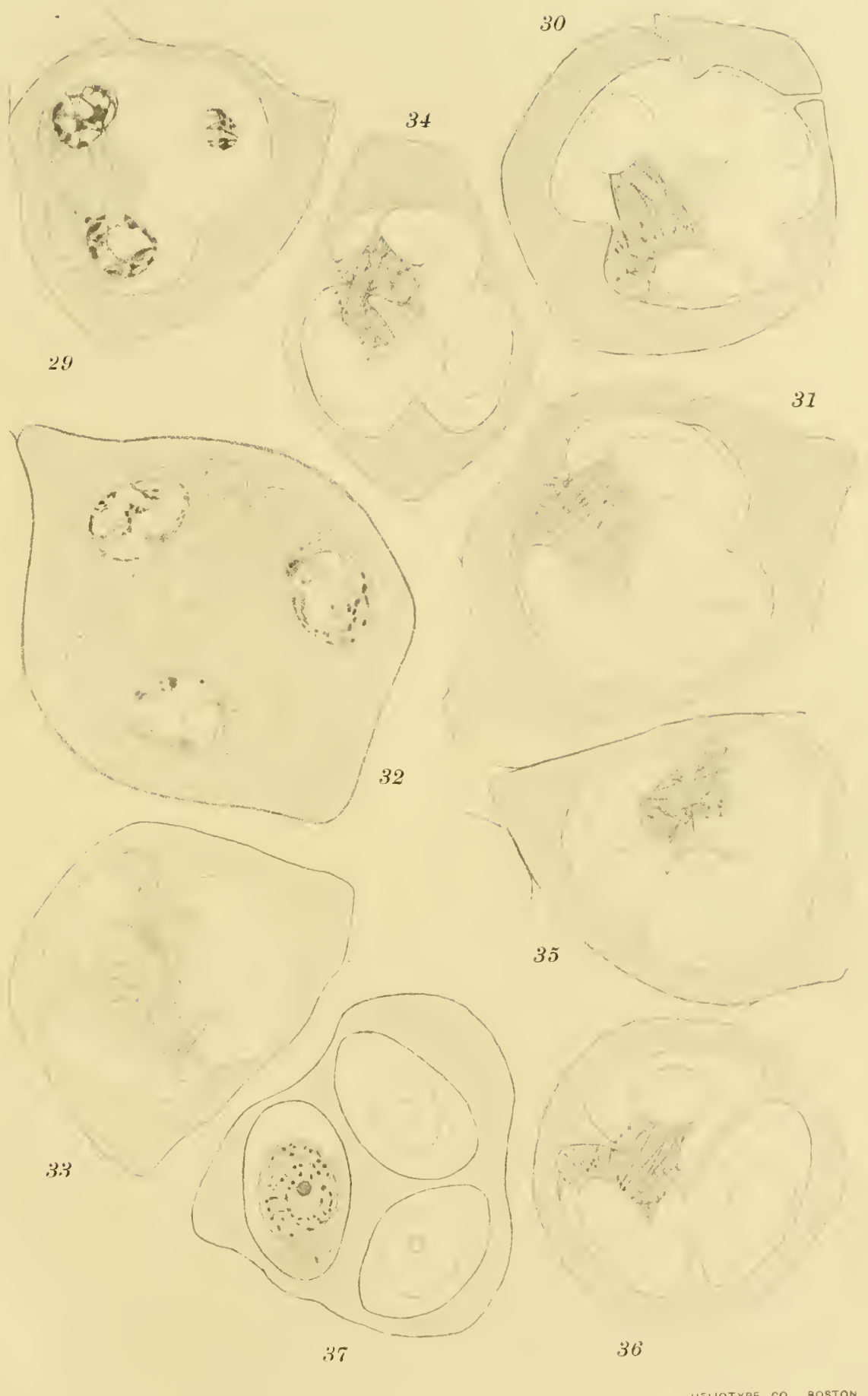

MELIOTYPE CO., BOSTON 

23. Anaphase of homoeotypic, spindles nearly at right angles, cytoplasm not shown.

24. Early telophase, cytoplasm granular, wall uniformly thickened.

25. A little later, cell spherical, spindles appearing, peripheral cytoplasm not shown. 26. Nuclei organized, cytoplasm fibrous, wall much thickened, surface only of upper nucleus shown.

27. First indication of cell-division, upper nucleus not shown in central section.

28. Sides of mother-wall becoming concave, spindles distinct.

29. Furrows deepen, nuclei draw away from the membrane.

30. Spindle fibers straighten, and draw away from the center of the cell.

3I. Furrows become more abrupt.

32. Projections of the mother-wall reach the center of the cell, all three nuclei shown in central section.

33. Tangential to two nuclei, showing the invagination of the cell-wall.

34. Unequal narrowing of isthmuses.

35. Furrows sharpen, and daughter cells begin to round up.

36. Division complete at one isthmus, before the others.

37. Spores distinct and imbedded in the thickened mother-wall, cytoplasm alveolar. 



\title{
PLANT ECOLOGY AND THE NEW SOIL FERTILITY
}

\author{
Chas. B. Lipman \\ University of California
}

The writer of this brief statement begs the indulgence of his auditors and requests consideration by them of his suggestion for employing the methods of modern soils science in the study of problems of plant ecology. It has been demonstrated beyond cavil that no royal road is available which leads to the solution of the problems of plant nutrition under field conditions and to that of a control of all the factors necessary to proper plant growth which are controllable. Moreover, empiricism has proved itself woefully inadequate to cope with the problem in the face of one of the most complex situations which confront the investigator in any branch of scientific activity. It appears to be high time therefore that methods be adopted in plant ecological investigations which are based on sound principles obtained from investigations in the pure sciences. The methods of attack employed by the modern soils scientist it seems to me are admirably adapted to such study since they have resulted from an attempt to escape, in soils science, from the empirical and haphazard, and are now forging ahead systematically with one factor in view at a time, in the development of a new and more justifiable view-point in soil and plant studies.

Until now the criteria employed in the study of the so-called plant associations have been few and their raison d'être ofttimes a questionable one. From the standpoint of the soil, moreover, scarcely any criteria have been developed which might serve us in judging of the conditions instrumental in causing the establishment of flora through secular selection. To be sure, some attention has been paid to the reaction of the soil as affecting the nature of the flora and studies have been made which bear on the part played by the plants with nitrogen fixing powers in establishing through encouragement or competition certain recognized plant associations. Unfortunately, hoiverer, the question of a soil's 
reaction has been accorded so much weight in these considerations that natural floras have been classified in accordance with their dependence on or antipathy for lime. In the case of the study of the influence of the nitrogen-fixing powers of plants, on the other hand, and their effects in the premises, a mere beginning has been made. Such attempts therefore as have been made to correlate natural floras with the soil conditions upon which they are produced, have on the whole been obstacles rather than aids to progress.

It is well known to all of you that plant physiology has been making great strides in its campaign against the unknown in plant nutrition. Some of you may also be aware that the more modern soils scientists employing the results of plant physiology and those of physical and colloid chemistry have been able to shed much light on certain hitherto mysterious manifestations in plant growth and plant diseases. Their methods have consisted in studying the effect not only of the qualitative nature, but also of the balance between components and the total concentration of the nutrient solution. Moreover, they have gained some insight into the processes whereby colloids are enabled to affect the foregoing factors very markedly as well as to affect the available water supply. In addition, they have learned to study the specific requirements of plants for forms of plant food materials and these investigations have already yielded and will continue to yield data of great moment in our approach to a more definite knowledge of plant requirements and hence of the rôle played by soil conditions in the establishment of floras. In illustration of these remarks, I may call your attention to the studies of Hutchinson and Miller and of Schreiner and his associates on the influence of the form of nitrogen best suited to the nutrition of certain plants, to Skene's work on the reaction of peat soils in relation to characteristic floras there, and to the experiments of Stiles, Tottingham, Shive, McCall, Gile and others on the concentration of the nutrient solution and its effect on plant growth.

A consideration of such studies, and I have only adverted to a few of them here, must impress the student of plants and soils with their momentous significance for the future of our knowledge of plant biology both pure and applied. Particularly for the subject immediately under consideration it would appear to the 
writer to be of the greatest importance in studies of any given natural flora like the chapparal formation on the Pacific coast, for example, that we know something regarding the following factors in their relationships with the plants in question.

I. The proper qualitative nature of the soil solution.

2. The proper balance between the components thereof.

3. The proper concentration of the soil solution.

4. The proper form of nitrogen for the plants.

5. The influence of quantity and quality of organic matter.

6. The proper basicity or acidity for the plant.

7. The mutual influence of plants growing together on their welfare.

Studies on these subjects now being made by the modern specialist in soil fertility on cultivated plants and by some plant physiologists in general can therefore render great aid to the phytogeographer and plant ecologist in the solution of problems which cannot fail to interest all biologists.

It is therefore hoped that many coöperative experiments may be established between the plant ecologist and the soils scientist in all parts of this country and elsewhere. Such coöperation will surely redound to the benefit of all the branches of study concerned and to the investigators individually who may be involved in them. 



\title{
CHEMOTROPIC REACTIONS IN RHIZOPUS NIGRICANS
}

\author{
Arthur H. Grates \\ Connecticut College for II'omen
}

The question of the behavior of fungal hyphae in relation to chemotropic stimuli has for some time been a rather weak element in the groundwork of our knowledge of the physiology of the fungi. Miyoshi, ${ }^{1}$ who was the first one to carry on any considerable investigation of the subject, tested a large number of chemical substances for their power of inducing chemotropic reactions in fungal hyphae. As a result of this work he declared that many of the substances exerted a positive stimulus, causing the hyphae to grow toward the diffusion centers, others a negative stimulus, so that the hyphae turned away, while still others seemed to produce no effect. Without going into Miyoshi's work more in detail here, the main thing for us to observe is his conclusion that chemical substances do cause reactions, expressed in more or less marked growth curvatures.

The work was taken up again by $\mathrm{Clark}^{2}$ in 1902 , and later in I 906 by Fulton. ${ }^{3}$ The most significant thing about their investigations was the fact that although using his same methods, they were utterly unable to confirm Miyoshi's conclusions. Growth curvatures of the hyphae were indeed observed, but apparently not as a result of the stimulus of the substances tested. Among his control experiments, Miyoshi had injected leaves with pure water, sowing spores on the leaf surface. No turning of the hyphae through the stomata resulted in this case, although the turning had been marked when the leaf was injected with, e. g., cane sugar solutions. Clark injected leaves with various concentrations of copper, cobalt salts, etc., and found that in this

${ }^{1}$ Miyoshi, M. Ueber Chemotropismus der Pilze. Bot. Zeit. 52: I-28. 1894.

${ }^{2}$ Clark, J. F. On the toxic properties of some copper compounds with special reference to Bordeaux mixture. Bot. Gaz. 33: 26-48. 1902.

3 Fulton, H. R. Chemotropism of fungi. Bot. Gaz. 4I: 8I-I08. 1906. 
case the germ tubes near the stomata curved towards and grew directly into them. But he obtained a similar result with leaves injected with pure water only. In experiments in which he used perforated mica plates, he found that the germ tubes near the perforation always "grew toward the opening if it communicated with a layer of medium in which no spores had been placed." Although he had no occasion to follow out this line of work experimentally, he advanced the hypothesis that Rhizopus is "markedly negatively chemotactic to some secretion of its own mycelium, and this negative chemotropism is much greater than any positive chemotropism it may have for food substances or oxygen."

Also, in Miyoshi's control experiments, in which he used perforated membranes, he claimed that when the layers of medium were of the same nature on both sides of the membrane, the spores being sown in one of the layers, no turning towards the other layer resulted. On the other hand, Fulton, after using essentially similar methods, announced as follows: "All of the fungi tested show a tendency to turn from a region in which hyphae of the same kind are growing, toward one destitute of hyphae, or in which the hyphae are less abundant. . . . This may be regarded as a negative reaction to stimuli from chemical substances which owe their origin in some way to the growing fungus."

Miyoshi's conclusions have in general been accepted by recent writers of textbooks on plant physiology. The late Professor Barnes $^{1}$ described Miyoshi's results, but also wrote significantly as follows: "Very striking reactions to chemical compounds of many sorts have been ascribed to the hyphae of fungi and to pollen tubes. Chemotropism of the latter may be maintained still as it has not been seriously impeached; but that of fungus hyphae has been brought under suspicion by the latest researches, and may be either established or disproved by further study."

The present paper is a short review of work which was carried on at the Laboratory of Plant P'hysiology and Pathology, Imperial College of Science and Technology, London, under the direction of Professor $V$. H. Blackman, in the hope of deciding between the views of Clark and Fulton on the one hand and those of Niyoshi on the other.

${ }^{2}$ Coulter, J. M., Barnes, C. R., \& Cowles, H. C. A texthook of botany for colleges and universities $\mathrm{I}: 473-474.1910$. 
Although Rhizopus nigricans Ehrenb. was the species mainly worked with, Botrytis cinerea Pers. and Penicillium No. 24 Thom $^{1}$ were also used, and there is evidence at hand that the results given for Rhizopus are applicable to them also.

In work of this sort the methods are all-important, especially the method of estimating the intensity of the chemotropic reaction as expressed in the directions assumed by the hyphae. The method finally adopted for this, as well as an account of all of the technique, will be published later: it will suffice to say here that the method is based on the doctrine of chances; i. e., considering a large number of hyphae, if all external conditions are equal, as many hyphae should turn in one direction as another. Any deviation will indicate a reaction to a disturbing force.

For making the preparations, the perforated mica plates were adopted which were used by Miyoshi and also by Fulton and Clark, with the holes, however, spaced farther apart; as preliminary experimental work had shown that with the holes nearer together the diffusion was fairly rapid. The perforated plates separated two layers of medium, and various combinations of spores and chemical substances in these two layers were tried, as will be shown later. As to the external conditions under which the experiments were carried on, all inequalities of moisture content in the medium and in the surrounding atmosphere were as far as possible eliminated, and the preparations were incubated in a dark chamber at a constant temperature.

Experiments with the "staling substance."-Very early in the work, while testing various percentages of sugar and glucose, I obtained a complete confirmation of the results of Clark and of Fulton in that the hyphae always turned towards the sporeless layer, whether it contained sugar or not. The more hyphae present, the stronger was the turning. If the spores were sown in both layers, no turning resulted in either layer, or it was not nearly as pronounced. According to the hypothesis of Fulton and Clark, above stated, this phenomenon was probably due to a negative chemotropic reaction to some substance excreted by the mycelium of the fungus itself.

In order to prove this hypothesis, the problem was now to

1 Thom, C. Cultural studies of species of Penicillium. U. S. Dept. Agr. Bur. An. Ind. Bull. II8. I9I0. 
obtain, if possible, this substance, which we may for convenience call the "staling substance," free from mycelium; and determine whether, if incorporated in a sporeless layer, it would repel the hyphae from growing into that layer.

It was found impossible to grow the fungus luxuriantly enough in sugar solutions (probably on account of the lack of nitrogen) to produce an adequate amount of the staling substance. But turnip juice, pressed from autoclaved white turnips, was finally tried with excellent results. Previously sterilized flasks containing this, and inoculated with Rhizopus spores, produced a luxuriant growth in a few days. After about a month, the juice was poured off and freed of any spores and mycelium by centrifuging. The staled juice had a sour, malt-like odor, and showed an acid reaction to litmus. By addling this juice to the agar for the sporeless layer, and using the fresh juice for the layer with spores, no turning of the hyphae resulted. In previous experiments where fresh instead of stale juice had been used, but with the other conditions the same, the turning had invariably been practically Ioo per cent (cf. C of table r.). Furthermore, by evaporating the staled juice under reduced pressure at laboratory temperature to one half volume, or double strength, the hyphae were caused actually to turn away from the vicinity of the holes.

The theory that the hyphae excrete some substance or substances which produce a negatively chemotropic effect, is therefore fully proved, and the chief evidence may be summarized as follows:

I. According to the strength of concentration of the staling substance, the hyphae show no turning toward, or may turn away from, a layer containing this.

2. When an approximately equal amount of mycelium occurs in two layers, each composed of the same medium, no turning from one layer to the other results.

3. The hyphae always show a marked turning from the medium in which they are growing to a medium without hyphae, provided the latter does not contain their staling substance or other negatively chemotropic substances.

Experiments with fresh turnip juice.-After the existence and nature of the negative chemotropism was settled, it was easier to search for a possible positive chemotropism. For, without 
going into detail, it was clear from the fact that the hyphae are continually producing a staling substance, that the number of spores and the length of the hyphae must be taken into account in experimental work on positive chemotropism. In the experiments with agar with fresh turnip juice added, the first definite indication of a positive chemotropism-working, it is true, side by side with the negative chemotropism-was obtained. The hyphae grew much more vigorously in the turnip juice medium than in sugar media. They did not in all cases grow faster: the chief difference consisted in the thickness of the germ tubes, which were twice or three times as thick as when grown in glucose or cane sugar agar. Probably on account of this healthier development they reacted much better to chemotropic influences than when grown in the sugars.

Combinations of spores and medium were tried with results such as shown in the following table. The arrangement of films and spores in each combination - the latter denoted by a large letteris shown in the first column. Here the mica plate is represented by the short line separating the two films, with their composition and the location of spores in them as stated.

TABLE I

\begin{tabular}{|c|c|c|}
\hline & Nature of preparation & Amount of reaction \\
\hline A & $\begin{array}{l}\text { Plain agar } \\
\begin{array}{c}\text { Turnip-juice agar } \\
\quad+\text { spores }\end{array}\end{array}$ & $60-90 \%$ \\
\hline B & $\begin{array}{l}\text { Turnip-juice agar } \\
\begin{array}{c}\text { Plain agar } \\
+ \text { spores }\end{array}\end{array}$ & $\begin{array}{l}100 \% \\
\text { (noticeable ten diameters } \\
\text { from hole) }\end{array}$ \\
\hline $\mathrm{C}$ & $\begin{array}{l}\text { Turnip-juice agar } \\
\text { Turnip-juice agar } \\
\quad+\text { spores }\end{array}$ & $\begin{array}{l}100 \% \\
\text { (noticeable three diameters } \\
\text { from hole) }\end{array}$ \\
\hline
\end{tabular}

The turning toward the holes in $\mathrm{B}$ and $\mathrm{C}$ was most remarkable, but in $A$ was not nearly so pronounced. The only difference between $\mathrm{B}$ and $\mathrm{C}$ lay in the distance from the hole at which the turning became noticeable, in the same period of time. In $\mathrm{C}$, the reaction was apparent at a distance of from three to four diameters of the hole, counting from its margin. But in B, the turning could be observed as far as ten diameters from the hole. In B 
and $\mathrm{C}$ the turning in all cases was roo per cent., while in $\mathrm{A}$ it varied from 60 to 90 per cent.

In $\mathrm{C}$, since the turnip juice was everywhere of practically the same concentration, the only force exerted must be due to the staling substances produced by the hyphac, i. c., a negative chemotropic force. In B, however, where we have the most marked turning of all, we can fairly assert that the turnip-juice agar in the sporeless layer is the cause of the additional stimulus, and exerts, therefore, a positive chemotropic stimulus; in other words, in this case the positive and negative forces are working together. This is borne out by the condition in $\mathrm{A}$, where in the lower layer the positive chemotropic force is working against the negative chemotropic force, with the resulting decrease in the percentage of hyphae reacting.

Since the existence of a positive chemotropic stimulus was thus established, the next point was to determine the relative strengths of the two stimuli. In the above experiments, the hyphae had been allowed to grow to a considerable length, none being under $300 \mu$, and it was reasoned that with long hyphae the negative chemotropic stimulus would be much greater than with short ones. On the other hand, the positive chemotropic force should be exerted just as strongly on short hyphae as on long ones. In view of this, younger stages were examined, with results such as set forth in the following table. The arrangement of data is as in TABLE I.

Table II

\begin{tabular}{|c|c|c|c|c|c|}
\hline & Nature of preparation & $\begin{array}{l}\text { Per cemt of reaction } \\
\text { at } 63 / 4 \text { hrs. from } \\
\text { sowing }\end{array}$ & $\begin{array}{l}\text { Per cent of re- } \\
\text { action at } 71 / 4 \\
\text { hrs. from sow- } \\
\text { ing }\end{array}$ & $\begin{array}{l}\text { Per cent of re- } \\
\text { action at } 8 \text {; } \\
\text { hrs. from } \\
\text { sowing }\end{array}$ & $\begin{array}{l}\text { Total no. of } \\
\text { hyphae ex- } \\
\text { amined }\end{array}$ \\
\hline$A$ & $\begin{array}{l}\text { Plain agar } \\
\text { Turnip-juice agar } \\
+ \text { spores }\end{array}$ & $+2^{1}$ & +18 & +43 & 468 \\
\hline 13 & $\begin{array}{l}\text { Turnip-juice agar } \\
\text { Plain agar + spores }\end{array}$ & +94 & +99 & +94 & 593 \\
\hline D) & $\begin{array}{c}\text { Turnip-juice agar } \\
+ \text { spores } \\
\text { Plain agar + spores }\end{array}$ & $\begin{array}{l}-13 \\
+17\end{array}$ & $\begin{array}{l}-8 \\
+\quad 38\end{array}$ & $\begin{array}{l}-30 \\
+46\end{array}$ & 1025 \\
\hline$E^{2}$ & $\begin{array}{l}\text { Turnip-juice agar } \\
\text { + spores } \\
\text { Turnip-juice agar } \\
\text { + spores }\end{array}$ & $\begin{array}{l}-6.7 \\
+\quad 0.75\end{array}$ & & & 1228 \\
\hline
\end{tabular}

$1+$ and - signs indicate positive and negative chemotropic reaction respectively.

${ }^{2}$ Examined at 7 and $7{ }_{4}^{3}$ hours after sowing. 
The combinations in $\mathrm{A}$ and $\mathrm{B}$ correspond to those in TABLE I, but $\mathrm{D}$ and $\mathrm{E}$ are new.

$\mathrm{E}$ represents the control, for here conditions were made as much alike as possible in both upper and lower layers. The turnip juice being everywhere practically the same in concentration, no positive chemotropic force is acting. If the number and length of the hyphae were also equal in both films, the turning on both sides should be no more pronounced in one direction than another. But it is practically impossible to prepare films of exactly the same spore number per unit of volume, and it is reasonable to assume that the more mycelium in a given preparation, the more staling substance will be given off by the hyphae. This is doubtless one of the factors which will influence the final percentages in this case. Another factor is the personal error in estimation. In spite of this, however, the method is accurate to within Io per cent, as shown by tests to be published later.

The results in $\mathrm{A}$ and $\mathrm{B}$ correspond with the same combinations in the older preparations described above, and the same observations apply here. In $\mathrm{A}$, as would be expected in the young stage where the hyphae are very short-averaging $40 \mu$ here in $63 / 4$ hours - the effect of the negative chemotropic stimulus is slight. Later, in $7 \frac{1}{4}$ and 8 hours, when the hyphae are longer and more staling substance has been given off, the percentage of turning toward the spore-free layer is gradually increased; and as we have seen in the older preparations described above, may become ultimately about oo per cent. In B, we have of course the positive and negative chemotropic forces working together, which accounts for the pronounced reaction.

A consideration of $\mathrm{D}$ now bears out our interpretation of $\mathrm{A}$ and B. For since both films here contain spores, the amount of staling substance is more or less equalized throughout the preparation, and the force of the negative chemotropic stimulus is therefore practically eliminated. Any reaction which occurs should be due to a positive chemotropism, and as the tables show, there is considerable turning from the plain agar to the turnip juice agar. This last experiment is the one which gives the final clinching evidence for positive chemotropism.

On the basis of these results we can get some approximate idea of the relative intensity of the positive and negative chemotropic 
stimuli. Our knowledge of the relation between individual variation in sensitiveness of the germ tubes and the intensity of the acting stimulus is of course very vague. However, it seems safe to assume that in general a larger percentage of turning means a stronger stimulus.

If, then, we denote by $n$ the strength of the stimulus causing negative chemotropism and by $p$ that causing positive chemotropism, we have in $A$ of the above table, using the per cent of reaction in the oldest preparations, $n-p=43$; whereas in $B$ we have $n+p=94$, taking the oldest preparations here also. Since the hyphae in these two corresponding cases were approximately equal in length, and the number of spores in the films was about the same, a comparison is legitimate. By eliminating the $p$ 's we have then, $2 n=137$, or $n=68.5: p$ will then be 25.5 . In other words, under the special conditions of this experiment, the positive chemotropic stimulus exerted by the turnip juice is a little more than one third as strong as the negative chemotropic stimulus exerted by the staling substances of the hyphae themselves.

Similar experiments were carried on with cane sugar and glucose. Briefly, the results of these showed a slight positive reaction to the sugar or glucose, but so small as to be hardly above the percentage of error. The invariable uniformity with which it appeared, however, is good evidence for the validity of the result. A full account of these experiments, as well as other points, will be left for later publication.

\section{SUMMARY}

I. Conclusive evidence has been obtained to substantiate the hypothesis put forward by Fulton and by Clark that many fungi exhibit a negative chemotropism toward their own metabolic products (staling substances).

2. Positive chemotropism towards such substances as turnip juice, cane sugar and glucose, also exists, but under ordinary conditions of growth, the effect is very much less than that of the negative chemotropism mentioned above.

3. The substances present in turnip juice exert a much stronger positive chemotropic effect than, e. g., io per cent cane sugar, which suggests that plant juices in general may evoke a fairly high positive chemotropic response. 
4. It is probable that the distribution of a parasitic fungus in its host is due not so much to positive chemotropic stimuli as to the dominant negative chemotropism towards its own staling products.

In conclusion, I would like to express my great indebtedness to Professor V. H. Blackman, of the Imperial College of Science and Technology, London, who made this work possible by his invaluable assistance and unstinted advice. 



\title{
SELF- AND CROSS-POLLINATIONS IN CICHORIUM INTYBUS WITH REFERENCE TO STERILITY
}

\author{
A. B. Stout \\ Nere York Botanical Garden
}

(With PLATE 30)

TABLE OF CONTENTS

INTRODUCTION. . . . . . . . . . . . . . . . 334

DISCUSSION OF LITERATURE BEARING ON PHYSIOLOGICAL INCOMPATIBILITY . . . 339

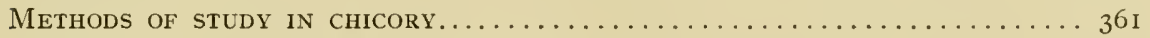

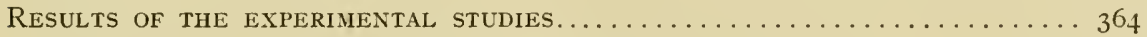

Phenomena of self-compatibility and self-incompatibility . . . . . . . 364

Self-sterility and self-fertility among plants of the $F_{1}$ generation...... 368

Self-sterility and self-fertility in $\mathrm{F}_{2}$ progenies derived from seed of self-

fertile $\mathrm{F}_{1}$ plants...................... 37 I

Self-fertility and self-sterility among plants of the $F_{3}$ generation, etc. ... 374

Summary of the $F_{1}, F_{2}$, and $F_{3}$ generations................ 378

Self-sterility and self-fertility in the variety "improved red-leaved

Treviso".............................. 382

Self-sterility in hybrids between a wild white-flowered plant and a plant

of the "improved striped-leaf" variety.................. 383

Phenomena of physiological inter-incompatibility and compatibility ...... 384

Results of crosses involving $A$ and various of its progeny......... 384

Results of crosses between $(A \times C)$ plants and the parents. . . . . . . . . 387

Results of crossing $\left(A \times E_{3}\right)$ plants and the parents. . . . . . . . . . 389

Results of cross-pollination involving $\left(A \times E_{22}\right)$ hybrids. . . . . . . . 39 I

Results of cross-pollination involving the variety "improved red-leaved

Treviso" .................................. 393

General summary of all cross-pollinations................... 395

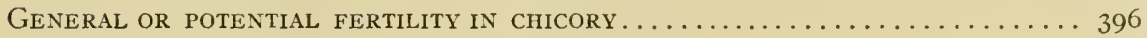

OBSERVATIONS ON EFFICIENCY OF OPEN POLLINATIONS. . . . . . . . . . . . 397

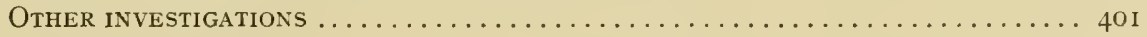

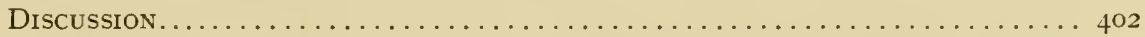

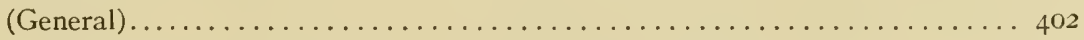

Special phases of the phenomena of sterility and fertility ........... 408

The relation of cross-incompatibility to self-incompatibility . . . . . . 408

The sporadic and fluctuating nature of sterility resulting from physi-

ological incompatibility........................ 409

The relation of incompatibilities giving sterility to cell organization.... 412

Relation of vegetative vigor and fertility to inbreeding and cross-breeding 416

Relation of sterility from physiological incompatibility to vegetative

vigor and production of sex organs..................... 422 
The contrast between sterility from physiological incompatibility and sterility from impotence.......................... +23

Significance of serum incompatibilities, etc............... 428

The phenomena of pollen-tube growth................... 436

Types of sterility in dimorphic and trimorphic plants........... $4+0$

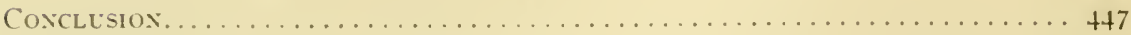

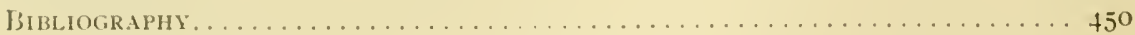

\section{INTRODLCTION}

The whole subject of sterility in plants and animals has been sometimes more or less obscured by a loose and fluctuating use of terms. A mass of data has, however, accumulated which makes possible now a more careful grouping of the facts and a more exact use of terms. The subject may be further obscured in reference to plants by the uncertainty and confusion which has to some extent existed as to the terminology of sexual reproduction. Here there is no dispute as to the facts either of anatomy, morphology, or physiology; the dispute has been wholly as to the applicability of the terms male and female, as used by zoölogists, to certain plant structures that in their morphology are sporophytic. On this point it will suffice to say that I shall consider pistils and stamens as male and female reproductive organs during any stage of their development. whether containing in the strict sense spores, gametophytes, or gametes. When necessary to distinguish between them and their product they will be spoken of as male and female sporophylls; the embryo sac and pollen tubes (male and female gametophytes with no morphological counterpart in animals) will be so designated, and egg cells and sperm cells will be spoken of as male and female germ cells or gametes. The male and female gametophytes are, of course, morphologically and physiologically differentiater and constitute a new and a haploid generation. Their action in fertility and sterility in higher plants is, however, closely conditioned by the anatomy and the cell organization of the sporophyte which prorluces them.

From our present knowledge of the facts and causes of sexual sterility in plants, we may distinguish three main classes:

I. Sterility from impotence, in which, as I shall use the term, normal sporophylls (with spores), gametophytes, or germ cells are not formed. This it seems to me is a proper limitation of the term which is, of course, frequently used more generally to refer 
to various sorts of sterility, especially as it appears in animals. Here belong such cases as:

(a) Complete impotence involving either the absence of all floral and sex organs as in Pelargonium Madame Salleron or the lack of sporophylls only as in certain double-flowered plants like Matthiola:

(b) Partial or complete impotence with reference to one or the other type of sporophyll as seen in such cases as impotence of pistils only in double-flowered varieties of Petunia; in the impotence of stamens as in Oenothera lata; in the marked impotence of both sporophylls (failure to develop normal spores), as in the wellknown cases of contabescence of anthers and impotence of pistils with abnormal development of spores, as exhibited by many hybrids and by such plants as Oenothera Lamarckiana whose hybrid origin is at least more remote; in the marked impotence of parthenocarpic varieties, as in Citrus species; in the impotence of the male sex organs as in the grape; or that of the female sex organs, as in red clover (arrested sexual differentiation) at certain stages.

While the causes are no doubt physiological, impotence expresses itself as a failure in the development of the reproductive organs or of the germ cells themselves, rather than as a failure in the proper functioning in fertilization of such organs or germ cells. They are all essentially cases of degeneration in the sporophyte, including the production of its spores, excepting the cases of degeneration of a maturing gametophyte itself, such as Dorsey ('14) has described in Vitis.

Impotency of certain types may be either temporary or permanent, both in animals and in plants, and may exhibit variations and fluctuations especially in response to such factors as disease and cultural conditions.

II. Sterility from incompatibility.-This class includes plants which produce apparently normal reproductive organs and germ cells, but which are nevertheless sterile through either a structural or a functional incompatibility. The old question whether there can be a functional failure without a structural cause I shall not discuss here.

The term incompatibility has been, of course, used to characterize a wide range of causes of failure in reproduction, but it can 
well be limited in its application to those causes existing in the plants themselves which prevent fertilization in and between plants with normal reproductive organs and gametes.

In such cases we may distinguish two quite distinct types of incompatibility:

I. Anatomical incompatibility due to more or less marked structural differences as:

(a) Obvious specific differences in structure, such as the comparative length of styles in two such species as Mirabilis Jalapa and M. longiflora.

(b) Structural differences within a species, such as dimorphism or trimorphism as seen in Linum and Lythrum (which may be correlated with true physiological incompatibility).

(c) Many structural adaptations that prevent self-fertilization and secure cross-pollination (hercogamy).

The investigations reported in this paper do not concern this class of incompatibilities, and a further discussion or classification of the almost innumerable floral modifications involved will not be attempted here.

2. Physiological incompatibility. -When complete potency exists and morphological compatibility is perfect or morphological incompatibilities and hercogamy are eliminated by proper pollination, sterility may still be present as a result of physiological conditions which make impossible the union of male and female gametes.

In the flowering plants this incompatibility may make itself manifest in the growth of the pollen-tube through the tissues of the stigma and style, or in the more intricate processes of fusion of the gametes. So far as known, such physiological incompatibility, at least in the flowering plants, may be due to conditions in either the sporophyte or gametophyte. In lower forms of plant life and especially in those forms with well-marked alternation of generations with an autonomous existence of a monoecious gametophyte or of male and female gametophytes, such incompatibilities would be more strictly gametophytic. Even in the flowering plants, however, this sort of incompatibility is, it would seem, most intimately concerned with the fundamental processes involved in fertilization, and presents problems whose solution will unquestionably throw much light on the nature of sexual fusions in general. 
The term physiological incompatibility may well be used to refer specifically to such cases of sterility in plants as Jost and Correns have assumed are due to individual stuffs or to line stuffs in which the stigma secretions are said to inhibit rather than to stimulate the growth of certain pollen tubes, or to cases where egg cells and sperms do not usually unite in self-fertilization, as reported in the hermaphrodite animal Ciona intestinalis (Castle '96, Morgan '04, '10, '13).

While sterility due to physiological incompatibility is most clearly in evidence when there is no anatomical incompatibility of sex organs, it no doubt also exists in connection with anatomical differences in numerous cases of interspecific sterility.

III. Embryo abortion.--Sterility due to degeneration and death of embryos during various stages of their development and quite subsequent to an apparently normal fusion of germ cells is common, as illustrated in varieties of the apple (Kraus '15), in certain hybrids of tobacco (Goodspeed '15), and in various Oenotheras (Davis '15 $a$, '15b). Goodspeed ('15) has used the term "phenospermy" in describing empty seeds produced "either with or without pollination." While the term is etymologically correct in its reference to the seed as a sperm, the term may be misleading to zoölogists. Also there may well be many cases of abortion that do not even lead to the production of seed-like structures. It seems best to the writer to use the expression "embryo abortion" for all cases of degeneration during the growth of the embryo. Except in cases of the development of embryos by apomixis all such cases would imply fertilization.

No doubt all such cases of embryo abortion are fundamentally due to physiological causes and that many such involve quite local intercellular physiological conditions, especially in the cases of seed sterility that accompany the development of large fleshy fruits in which, as Kraus ('15) has pointed out, there are "varying degrees of interdependence of seed and flesh formation," and that from the standpoint of fruit-growing a distinction should be made between self-fertility (seed production) and self-fruitfulness (fruit production). Aside from the relations of seed and flesh formation there is abundance of evidence that sterility and unfruitfulness may both result in many fruit crops (Waite '95, for pears; Lewis and Vincent '09, for apples; Backhouse '11, for plums; Gardner 
'13, for cherries; and others) from pure physiological incompatibility. Some cases of seed abortion may involve general constitutional weakness on the part of the mother plant or animal. Still other cases of seed abortion may involve an incompatibility, intracellular in action, between chemical or structural elements of the two sex cells which fuse to give the double mechanism of the cells of the new sporophyte as especially noted by de V'ries ('10, p. 258). The whole phenomenon of embryo abortion in its relation to the other types of sterility as noted above needs thorough investigation, especially in respect to the extent and clegree of cytoplasmic incompatibilities that may exist between the egg and sperm immediately after fertilization.

It should be recognized that the total sterility observed in a species may involve several or even all the types of sterility as outlined above. This is the case, for example, in red clover (Trifolium pratense). In this species (Martin, '13; Mestgate and Coe, '15), there is often impotence especially in the first crop in that the female reproductive organs of ten remain regetative; there is anatomical self-incompatibility seen in the adaptations for cross pollination, and there is physiological self-incompatibility in the very marked self-sterility that is known to exist; there is embryo abortion not only of the usual fluctuating accidental type, but in the regular abortion of one of the two ovules of each ovary both of which are said to be fertilized. In the Oenotheras, Davis ('15 $a$ and $b$ ) has pointed out that "pollen sterility" or "pollen abortion" is rery marked and that "the total amount of sterility both gametic and zygotic is simply amazing" ('15b, p. 13). He also suggests that "some degree of pollen and ovule sterility must be expected to result" if there is also selective fertilization. Here the phenomena of impotence of various grades and of embryo abortion and degeneration are clearly present and it is suggested that physiological incompatibility giving selective fertilization is also in operation.

It is, however, sufficiently clear that typical cases of the various classes here noted may exist more or less independently and that they are quite distinct at least in the direct expression of the contributing causes.

The investigations here reported are concerned with a sterility which involves physiological incompatibility, and I shall discuss aspecially the literature relating to this class. 


\section{DISCLSSION OF THE LITERATURE BEARING ON} PHYSIOLOGICAL INCOMPATIBILITY

All the more recent conceptions of the nature of sterility involving physiological incompatibility in non-dimorphic species are but modifications of the general view of Darwin that its causes are to be sought in conditions of differentiation in the constitution of the sexual elements. Some of Darwin's most extensive experimental work was done on the problem of the relative fertility resulting from selfing and crossing as bearing on the origin of variations and their perpetuation and accumulation in evolution. His publications reveal a wide knowledge of the facts of fertility and sterility, which with his discussions have a direct bearing on such important points as, (a) occurrence of self-sterility, (b) nature and causes of self-sterility due to self-incompatibility, $(c)$ relation of fertility to vigor of plants and to genetic relationship (whether inbred or cross-bred), $(d)$ the nature of differentiation involved in sexual reproduction as seen in sterility and fertility.

(a) Darwin's conceptions of self-sterility (due to physiological incompatibility) were based on a comprehensive knowledge of the occurrence of such phenomena. As early as 1868 he reports in over thirty species the occurrence of "self-impotent" plants which according to the literature and from his own observations could not be fertilized with pollen from the same plant. He says regarding them: "They are sometimes so utterly self-impotent that, though they can readily be fertilized by the pollen of a distinct species or even distinct genus, yet, wonderful as the fact is, they never produce a single seed by their own pollen" ('68, 2: I64).

Darwin ('77) later discusses under the term "self-sterile" plants the cases of physiological self-incompatibility which he has previously ('68) designated as "self-impotent," adds several species to the list of such plants, and from his own data on Eschscholtzia californica, Abutilon Darwinii, Senecio cruentus, Reseda odorata, and Reseda lutea shows that self-sterility is present not as a fixed and uniform behavior, but that it is fluctuating in its expression among different species and also fluctuating among individuals of the same species. Darwin obtained seed from a strain of Eschscholtzia califormica which Müller (Hildebrand '68; Müller' 69; Darwin '68) had found to be completely self-sterile in Brazil for six genera- 
tions. Two plants grown from such seed were feebly or semi-selffertile; the next year plants (number not given) raised from this selffertilized seed were likewise feebly self-fertile. The experiments are not extensive nor are pedigrees indicated, yet it is clear that some plants were fully self-sterile and others self-fertile to some degree, giving different results in Brazil, England, and Germany, which Darwin concludes is evidence of an influence of climate acting on the sexual constitution ('77, p. 333).

With Abutilon Darwinii there was a feeble self-fertility in at least some of the plants grown in England from the cross-fertilized seed of plants which Müller found to be self-sterile in Brazil.

Three plants belonging to two varieties of Senecio cruentus were completely self-sterile, but fully cross-fertile.

Darwin describes his experiments with Reseda odorata in considerable detail. Seven plants grown in I 868 were fully selfsterile in all controlled pollinations which were made, although three of them produced seed by spontaneous pollination which, as Darwin points out, may have been accidental cross-pollination. Sixteen combinations of cross-pollination involving five of these plants were, it appears, fertile. The next year, however, three plants raised from a new supply of seed were strongly self-fertile and one other plant was feebly self-fertile. In I87o six more plants were grown; two were almost completely self-sterile and four were strongly self-fertile. In $\mathrm{I} 87 \mathrm{I}$, of five plants grown from seed of the self-fertile plants of 1870 , three appeared to be fecbly self-fertile. No eviclence of cross-sterility was found in any of these plants.

In Reseda lutea, Darwin olserved self-sterile plants and isolated two for study, one of which was "quite self-fertile," while the other was "partially sclf-sterile."

(b) Regarding the nature and causes of self-sterility clue to physiological incompatibility, Darwin points out that this sort of self-sterility is widely distributed, that it differs much in degree in different plants, and that among individuals of the same parentage some may be self-sterile while others are self-fertile, quite as revealed by the pedigreed cultures of Cichorium which I shall report later and which, no doubt, would likewise appear in Cardamine and in Nicotiana hybrids were attention especially given to this point. The phenomenon appeared, as he observed it, in plants of cross- 
bred origin. Darwin concluded that the sporadic character of the phenomenon is an evidence of an incidental and abnormal condition which he says "we may attribute to some change in the conditions of life acting on the plants themselves or in their parents."

Darwin developed no formal hypothesis of sterility (physiological incompatibility) like that of Jost or of Correns, but contented himself with such vague statements as: "in most cases it is determined by the conditions to which the plants have been subjected" ('77, p. 343). He emphasizes the variations in the selffertility of Eschscholtzia in different climates, but just how climatic influences operate he does not attempt to say. Of the causes in Reseda odorata, in which plants of the same parentage grown in the same culture were self-sterile or self-fertile, he states "we are forced in our ignorance to speak of the cause as due to spontaneous variability; but we should remember that the progenitors of these plants, either on the male or the female side, may have been exposed to somewhat different conditions" ('77, p. 344). His main interest in the whole subject was undoubtedly from the standpoint of the search for the causes of variations which may become the material for natural selection in producing evolutionary changes, but it is to be specifically noted that he considers that the view that self-sterility (physiological self-incompatibility) "is a quality which has been gradually acquired for the special purposes of preventing fertilization must, I believe, be rejected" ('77, p. 345), and that "we must look at it as an incidental result dependent on the conditions to which the plants have been subjected" ('77, p. 346).

(c) From the above it is clear that Darwin distinguished the phenomena of self-sterility from the decreased sterility which he conceived to result from close genetic relationship. Darwin ('77) presents data from extensive experiments with cross- and selffertilization of plants which he considers proof that the degree of self-fertility in species regularly self-fertile is less than that of cross-fertility, and that close inbreeding decreases the fertility. This effect he considers is especially evident in the "innate fertility" (general or potential power to produce seed judged by the fertility of a plant when exposed to open pollination by insects), which he finds is, as a rule, decidedly greater in plants raised from 
cross-fertilization or, in the case of dimorphic and trimorphic plants, from legitimate pollination (pollination usually involving pistils and stamens of the same length). The causes operating in such cases are considered to be different from those causing self-sterility as seen in plants like Eschscholtzia, for Darwin states that self-sterility (sterility due to physiological self-incompatibility) "must be different, at least to a certain extent, from that which determined the difference in height, vigor, and fertility of the seedlings raised from self-fertilized and crossed seeds; for we have already seen that the two classes of cases do not by any means run parallel" but that "this want of parallelism would be intelligible if it could be shown that self-sterility depended solely on the incapacity of the pollen tubes to penetrate the stigma of the same flower deeply enough to reach the orules" ('77, p. 3+2).

Darwin fully realized that the effects of inbreeding, as judged by regetative vigor and fertility, exhibit wide fluctuation, and that his results show that decreased fertility does not always result from continued self-fertilization or inbreeding in the cases of his highly self-fertile strains of Ipomoea and Mimulus ('77) and in the appearance of equal-styled and highly self-fertile varieties of Primula weris and $P$. sinensis, so that, as he admits, it is "difficult to aroid the suspicion that self-fertilization is in some respects advantageous" ('77, p. 352). Burck ('08) very exhaustively reviews Darwin's results and raises the question whether inbreeding ever decreases fertility and concludes that the data show $(a)$ that the greater fertility which appeared in crosses involved impure varicties whose fertility has been already decreased by hybridization; (b) that continued self-fertilization does not lead to decreased fertility and (c) that pure (homozygous) plants show no advantage when crossed either in regetative vigor or fertility.

(d) Darwin's conception of the nature of the differentiation involver in sexual reproduction, in relation especially to sterility and fertility, emphasized and clearly delimited the current theory of sex, that it is differences between the sexes and sex elements that make sexual reproduction possible and fruitful. Thus he was of the opinion that "some degree of differentiation in the sexual system is necessary for the full fertility of the parent plants and for the full vigor of their ollspring" (' 77, p. 34t, 345). "Fer- 
tilization of one of the higher plants depends, in the first place, on the mutual action of the pollen-grains and the stigmatic secretion or tissues, and afterwards on the mutual action of the contents of the pollen-grains and ovules. Both actions, judging from the increased fertility of the parent plants and from the increased powers of growth in the offspring, are favored by some degree of differentiation in the elements that unite so as to form a new being" ('77, p. 456). As to the conditions operating in selfsterility, Darwin states that "their sexual elements and organs are so acted on as to be rendered too uniform for such interaction, like those of a self-fertilized plant long cultivated under the same conditions" ('77, p. 345). Darwin here considers that it is lack of differentiation that leads to self-sterility.

Darwin, however, expressed no opinion of the exact nature of this assumed differentiation, such, for example, as Sachs' conception of formative stuffs, Weismann's theory of idioplasmic differentiation due to assumed qualitative cell divisions, or de Vries' theory of intracellular pangenesis. While the determination of the nature of differentiation is essential to the knowledge of sex phenomena, we are not at the present time able to give a precise and exact account of the basal facts involved.

It is clear, however, that Darwin does not mean merely visible differences such as shape, size, and color of sexual and other organs, and that in speaking specifically of constitutional differentiation he is mainly concerned with egg and sperm cells. He notes, however, that an attempt to compare sex relations with chemical affinity or attraction is in harmony only with certain phases of fertilization. The difficulty of relating pure chemical affinities to the phenomena of so-called sex affinity is well illustrated by Darwin's discussion. This has become more apparent as the cytological facts are revealed, so that it is now very evident that the chemist knows of no purely chemical relations comparable to the cellular reactions of fertilization.

Darwin quite fully subscribed to the doctrine of functional independence of the elements or units of the body as a general doctrine of differentiation of organs, and of the modification of such organs by environmental conditions. This was in fact the basis of his doctrine of pangenesis. That this sort of differentiation is different in degree at least from that of the sexual elements was apparently a view held by Darwin. 
The general term "differentiation" is used rather indiscriminately by Darwin, as it is quite generally, to apply to $(a)$ different parts of the same individual, $(b)$ to individuals as a unit, $(c)$ to groups of individuals constituting a strain, a species, or a larger group. The nature, interrelations and fluctuations of these different kinds of differentiation involve, we may note, some of the most interesting of the unsolved biological problems of today.

It is clear, as will be noted more fully later, that the differentiation is of different kinds and of different degrees, and that it fluctuates in its expression through fertility both in self- and crossfertilization. It would appear that in the lesser fertility of inbred stock compared with that of cross-bred stock, which did appear in some instances, Darwin saw a lack of constitutional differentiation due to the more intimate relationship of parts concerned. It is clearly evident, however, that he did not place the development of self-sterility (physiological incompatibility) on any such basis. He attempts thus to distinguish complete sterility (from physiological incompatibility) from that which he thought is associated with decreased vegetative vigor due to inbreeding, and to ascribe only the latter to lack of differentiation from close relationship.

Darwin was not fully aware that, aside from "illegitimate pollination," cross-sterility between plants of the same species and of seed origin can exist quite as decidedly as does self-sterility. He had quite clearly shown that intercrossing (inbreeding within a variety), especially if the plants had been grown for some time under similar conditions, may not give increased fertility and vigor, and thus be quite similar to the assumed results of self-fertilization. While in general Darwin assigned the causes of sterility to lack of constitutional differentiation in sex, he did not relate the peculiar condition of self-incompatibility to the decreased fertility assumed to arise from close relationship, but to a sporadic response to influences of environment. Furthermore, he failed to see any relation between the self-sterility in non-dimorphic species as Eschscholtzia californica and that in dimorphic forms, a point that will be discussed later.

Attempts were made carly in the study of self-sterility (selfincompatibility) to (letermine the causes and to analyze the constitutional conditions through a comparative study of the growth 
of pollen tubes in self- and cross-fertilization. This is an attempt to discriminate degrees or grades of differentiation through the immediate requirements and interactions between the sex organs of a single plant and of different plants. Such considerations, of course, involve the extensive studies that have been made upon the physiology of pollen tubes in the attempt to determine their irritability and nutritive requirements and to what extent their development is determined by direct stimulation of the egg.

Jost ('07) was the first to summarize such evidence in formulating a theory of self-sterility. He points out from the results that he and others have obtained in experimental studies of pollen germination and pollen-tube growth, that the different species exhibit a wide variation with more or less marked specific physiological differentiation, which we may note is quite in harmony with the more recent studies. The stimulating influence of sugars, or proteids to pollen-tube growth, and the fact that a regulation giving a very limited supply of water is all that is necessary for the germination and early growth of pollen tubes is an evidence that the growth of pollen tubes in the pistil, as in artificial cultures, is quite independent to a certain degree of the direct influence of the eggs.

Within the species, however, self-sterility may arise from quite individual conditions irrespective of any specific physiological differentiation. In such cases Jost points out: $(a)$ the pollen may not germinate, $(b)$ the growth of tubes for a plant may be poor in its own conducting tissues, $(c)$ the tubes may not respond to chemotropic stimuli in tissues of its own pistil, $(d)$ the two sex cells may not be able to unite, $(e)$ the product of their union may make very poor development, or that several of these conditions may combine to give sterility. All of these classes except the last I have included under the class "physiological self-incompatibility;" any failure in development after fertilization I have classed as "embryo abortion" for reasons already stated.

These limitations of fertilization operating so decidedly in the individual are made the basis of the application by Jost of the old doctrine of "individual stuffs" which is, perhaps, the first formal hypothesis which has been advanced to account for the phenomena of physiological self-incompatibility. The theory is in brief that:

(a) Different plants even of the same species and strain are characterized by qualitatively different chemical substances; 
(b) That the pistils and pollen tubes of any one plant possess the same "individual stuff" ; and

(c) That the best growth of pollen tubes is made when they penetrate into stigmas having another kind of individual stuff.

In respect to the "individual stuff" there is, it is assumed, a differentiation between individuals quite analogous to that which the chemical theory of species assigns to different groups of organisms. In the single individual, however, parts so anatomically differentiated as sex organs are assumed to possess the same individual stuff. Thus the distribution of the "stuff" is entirely independent of any distribution of formative stuffs in organogenesis as Sachs conceived it, or of segregations of germ plasm units in development (in Weismann's sense), in the reduction process of sporogenesis, or of the degree of organ specificity that may exist. In spite of all known anatomical and physiological differentiation of the organs concerned, there is, it is assumed, a lack of differentiation in respect to the distribution of the particular individual stuff.

Jost's general theory minimizes the significance of fluctuating variation in self-sterility, although he was fully aware that such variations appear. In 1905 , ninety-three autogamous pollinations with Corydalis cava gave six capsules, an evidence that all plants of this species are not absolutely self-sterile. That the operation of any assuned individual stuffs is fluctuating is also apparent from Jost's careful studies of rye (Secale cereale). Ulrich, especially, had already shown three varieties to be feebly selffertile, and that varietal and individual differences exist, so that Jost remarks "Wir sahen schon bei Corydalis, dass diese Pflanze wahrscheinlich nicht alsolut selbststeril ist. Es ist wohl möglich, class es absolut selbststerile Pflanzen überhaupt nicht gibt' ('07, p. 89). Jost's own studies on Secale were with a race known as Secale montanum, in which from many isolated heads he obtained only three seeds, one of which contained an embryo. The results of careful studies showed that in this variety pollen tubes from xenogamous (pollen from another plant) pollination penetrated to the micropyle in seren 10 nine hours, while tubes from autogamous pollination after twenty-four hours had only reached the base of the pistil. From certain of the experiments it appears that tubes from geitonogamous (pollen from another flower of the 
same plant) pollinations grew much more rapidly and there is some evidence especially by Ulrich ('02) that in rye such pollinations may be slightly more fertile than autogamous pollinations. Such results suggest that the assumed individual stuffs are different in different parts of the plant, and Jost even considers that when self-fertilization occurs in varying degrees the cause is to be sought in variations in the qualitative nature of the pollen. Further evidences of such variation are seen in the experiments with two plants of Hemerocallis flava which Jost found to be self-fertile to some degree. This result he does not consider as proof that Focke ('93) was wrong in reporting this species as self-sterile, but that different races and even different individuals may exhibit marked differences in the degree of self-fertility.

Jost's facts are in accord with those of Darwin both in respect to the fluctuating behavior of self-sterility and to the poor development of pollen tubes, which is the rule in such cases. Darwin considers that highest fertility in general is due to differentiation in the sexual elements and that both the growth of the pollen tubes and the mutual action of germ cells are improved by increasing these differences, at least up to a certain degree. Jost's view is based on the same underlying conception of sex. He makes Darwin's assumptions of "differentiation" concrete by assuming that the differentiation is one of chemical substances, his individual stuffs. Each plant has its own individual stuffs and hence when both reproductive organs and elements are derived from a single plant they have the same individual chemical substance, and hence lack the differentiation necessary for proper functioning.

For the explanation of cases of feeble self-fertility, and Jost expresses doubt that any hermaphrodite plant is fully self-sterile, Jost assumes that individual variations may exist among the pollen grains, giving qualitative differences quite equal to that of the individual stuffs in different plants. Jost presents some evidence that geitonogamy is more effective than autogamy, but does not develop the idea that the variation in self-fertility may have any relation to the actual physical relationship of the organs concerned with respect to relative location on a plant.

With reference to the production of differentiating chemical substances both of specific and individual sorts, Jost states: "Nan 
hat aber wohl allgemein geglaubt, diese Differenzen seien im Protoplasma, spezieller im Idioplasma, noch spezieller im Idioplasma des Kernes zu suchen. Demgegenüber haben nun die vorliegenden Intersuchungen mit Notwendigkeit zu der Annahme geführt, dass lösliche und diffusible Stoffe Träger der individuellen Differenzen scin können" ('07, p. II2). Jost further suggests the relation of these soluble substances to such specific substances as exist in the blood, lymph, and secretions of animals, and to the so-called antibodies which develop in the fluids of organisms cluring the development of immunity.

Jost thus relates the cause of self-sterility to a lack of differentiation, which develops quite independently of the hereditary functions of germ plasm and which is quite individual, and in development is purely epigenetic. The assumed similarity in the fluids of the sex organs and sex cells exists solely because they have developed on the same plant.

Morgan's ('04, '10) noteworthy work on the causes of selfsterility in the usually self-sterile animal Ciona intestinalis gives data which Morgan considers as evidence that the failure to selffertilize is due to cytoplasmic relations established in the individual. Morgan's theory of sexual fusion is a chemical one; the actual entrance of the sperm into the egg is held to be a result of a chemical reaction which occurs at the point of contact, and that this reaction is dependent on a constitutional dissimilarity of the gametes involved. His results are in close harmony with his general views that self-incompatibility is, in Ciona, due to physiological processes quite individual in development and cytoplasmic in action, and that germ cells may be decidedly influenced by such individual conditions irrespective of their own particular idioplasmic composition.

For the experimental studies the eggs and sperms were removed from the animals and the results of self- and cross-fertilization were studied in sea water quite free from influence of body fluids and with a relatively small amount of body tissues involved in the form of testa cells adhering to the eggs. Here, it would appear, the processes of fertilization may be in some respects simpler than in the higher plants where the relation of pollen tubes and tissues of pistils precedes the fusion of sex cells. Morgan was unable to remove the self-immunity of eggs to the sperm of 
the same individual by the use of ether, by changing temperature, or by using various chemicals specially influential in altering surface tension of the eggs. Experiments to determine if such incompatibility could be acquired through transplantation were likewise negative. It was found that body fluids inhibit all fertilization evidently from causes quite different from those operating in self-incompatibility.

In the artificial removal of eggs and sperm for these experiments, the difficulty of securing good sperm was a source of much experimental error, but Morgan's results show that self-sterility was the rule and that only to a limited degree does self-fertilization occur in his strains, while general cross-fertility is nearly always possible provided both eggs and sperm are in good condition.

Morgan considers that this self-incompatibility is due to an absence of the necessary reaction between egg and sperm as the point of contact and that such inaction is because of similarity. Conversely, the entrance of sperm into the egg in cross-fertilization is due to the necessary reaction occurring as a result of differences between the egg and sperm. Morgan very adequately points out that self-sterility of this sort is not due to a similarity of "hereditary factors" carried by the sex cells, for they are haploid, and are derived from parents that cannot be considered homozygous. They can only be considered similar because both have developed in the same individual. They are alike, he points out, only because their protoplasmic substances have been under the same influence.

It should be noted that Morgan points out that such a condition might also arise from inbreeding in which what is called "homozygosity" might develop, giving similarity to the hereditary complex. In 1904 Morgan suggested that although in all selffertilized hermaphrodite. animals and plants the common origin of the sex organs involves conditions identical with those assumed to cause self-sterility in Ciona, the action may be less marked and not sufficiently strong to give self-sterility.

This analysis of the generalized term "constitutional similarity" assumes that in self-sterile strains of plants and animals, in which crossing is necessary for reproduction, the similarity must be conceived to rest in individual cytoplasmic relations. This is the conclusion that Morgan makes as late as $19 \mathrm{I} 3$ in a general review 
of the subject, although it may be noted that he is here inclined to consider farorably the interpretations, especially of Pearl and Correns, that these are definite Mendelian units accountable for sterility and fertility. His analysis of their data is, however, not critical and the riew that cytoplasmic relations established in a heterozygous individual are quite of the same nature as similarity in heredity factors brought about by inbreeding is equally suggestive that in the latter case the cytoplasmic relations may also be the most important.

In rather marked contrast to Morgan's results are those of Fuchs ('14), which show clearly that Ciona intestinalis at Naples is self-fertile to a "very varying degree in different individuals." Fuchs, however, fails to see any relation of such phenomena to that of self-sterility in plants like Reseda and Cardamine, chiefly because he does not seem aware that here the same degree of variation may be in evidence. Fuchs, further, considers that cross-fertility is nearly absolute in his strains; the cases of poor results are in general attributed to pathological conditions. His actual results show, quite as clo Morgan's, that there is a wide range of variation in the fertility of different crosses. 'Fuchs' experiments are scarcely convincing on this point as no adequate number of indivichals were tested with two or more individuals. Numerous very critical experiments were planned to test various phases of the physiology of fertilization in Ciona, but the number of tests made were most frequently too limited for conclusive results. Furthermore, these experiments as well as those of crossfertilization were made with individuals whose self-fertility or self-sterility was not determined. The results, however, suggest that the egg and the ovary extracts, and the blood of individuals when added to sea water containing eggs and sperms of two different inclividuals increase the percentage of eggs fertilized. It is suggested that the eggs of self-sterile individuals give off some substance that inhibits the sperm of that indivichal; but one experiment was marle to determine if (ggg extracts of an individual B inhilit the action of the sperm of $B$ on eggs of $A$ (Fuchs, table VIII), but the result shows no such action. In this experiment, however, it was not determined whether $A$ or $B$ were self-sterile. The influence of egg extracts on self-fertilization and cross-fertilization between animals of similar or of clifferent grades of self-fertility 
is not reported. And it does not appear that tests similar to those that Lillie has reported were made for the operation of any auto-agglutinins or iso-agglutinins that would give some clue to the intricate relation of self- and cross-sterility and fertility, and for which such a hermaphrodite as Ciona seems especially farorable.

Neither Darwin, Jost, nor Morgan (including his work of I9Io) was fully aware of or took into consideration the fact that physiological relations may operate to prevent cross-fertilization between certain members of the same variety or strain (not involving the so-called illegitimate pollinations in dimorphic or trimorphic plants). That such may be the case is, from our present knowledge, suggested by the results obtained by various early investigators. Darwin ('68, pp. I69-170) states that it has long been known that several species of Passiflora do not produce fruit unless "fertilized by pollen taken from a distinct species." From the evidence pertaining to Passiflora alata it seems highly probable that certain cases of cross-incompatibility arose. In respect to Gladiolus hybrids (pp. I72, I73), it is stated that "certain varieties would not set seed although pollen was used from distinct plants of the same variety, which had, of course, been propagated by bulbs, but that they all seeded freely with pollen from any other variety." Focke ('90 and '93) found that in Lilium bulbiferum all plants of the same clone were cross-sterile, but that sister plants of seed origin were fully cross-fertile.

In the production of fruit, especially in pears (VVaite '95), plums (Backhouse, '11), apples (Lewis and Vincent '09), and cherries (Gardner '13), it has quite generally been known to fruit-growers that certain varieties were "self-sterile," others "partially self-sterile," and others "self-fertile." In the selfsterile varieties the self- and cross-fertility among plants of the variety may be so feeble that the planting of other varieties as pollinizers is often practiced. In these studies the horticulturists have determined the more general facts that pertain to practical results in fruit-growing. Aside from the fact that the propagation of these varieties is vegetative the physiological requirements for fruit development further complicate the processes of seed development, but it is very evident that quite independent of these factors a very marked physiological incompatibility is in evidence in these varieties. 
Waite ('95) has shown that 22 varieties of pears are self-sterile (unfruitful) and 14 are self-fertile. In many of the "self-fertile" varieties the fruits formed were entirely seedless, while fruits on the same tree resulting from intervarietal pollination were well supplied with sound seeds. In these experiments no essential differences were noted in intervarietal fertility and fruitfulness.

Lewis and Vincent ('09) report 59 varieties of apple that are self-sterile, $\mathrm{I} 5$ varieties that are self-fertile and $\mathrm{I} 3$ varieties that are partially self-fertile. The Spitzenberg variety, for example, was found to be feebly self-fertile, giving only about 3 per cent of fruit with self-pollination. While no marked cases of intervarietal sterility were found, there were rather decided differences in the degree of fruitfulness. In many of the "self-fertile" varieties the fruits were seedless. In these varieties, especially, the number of seeds was increased and the quality and size of the fruit were decidedly improved by intervarietal pollination.

All varieties of the sweet cherry, 16 in number, which were tested by Gardner ('13) were found to be self-sterile under enforced natural self-pollination; 3 per cent was the highest "set" of fruit obtained from any variety. Under field conditions there is evidently greater fruitfulness, although for purposes of fruitgrowing the varieties are "practically self-sterile." It was found that at least three varieties are strongly inter-sterile, necessitating the use of other varieties as pollinizers. It is also to be noted that in a few cases reciprocal intervarietal crosses gave different results; crossed one way they were sterile, but crossed the other way they were fertile. The relation of intervarietal sterility to descent is considered by Gardner. It was determined that seedling trees in and about orchards of self-sterile varieties are of ten good pollinizers to these varieties. Also from the known pedigrees of several varieties it appears that a seedling variety may be interfertile with its seed-parent varicty, and that two seedling varieties derived from the same variety may be inter-fertile to some degree. The inter-relationships in respect to sterility are shown to be widely fluctuating and, Gardner concludes, do not show correlation with closeness of relationship. While environmental factors are influential in the production of fruit, the marked self-sterility of inclividual plants, the intra-varietal sterility, and the cases of inter-varietal sterility are not due to "any inherent weakness of either ovaries or pollen grains" (Gardner '13, p. 17). 
All these cases are especially interesting in showing that selfsterility may be so strongly persistent in large numbers of offspring propagated vegetatively that in practical fruit production proper pollinizers are necessary. In the cases of intervarietal sterility reported by Gardner, we see a phenomenon quite identical with that which Correns reports, almost simultaneously, in Cardamine, in which the possibility of cross-sterility between sister plants of a seed progeny was proven and the interrelations of sterility studied in a pedigreed seed progeny.

The studies made by Correns ('12, '13) places the emphasis on the phenomena of cross-sterility which he made the basis of a theoretical explanation of sterility (due to physiological incompatibility), which is decidedly different from that announced by Jost.

Correns ('12, '13) successfully crossed two self-sterile plants of Cardamine pratensis which he had obtained from different localities. The sixty plants reared from this cross were, Correns states, completely self-sterile, although in his tables it appears that at least one of them did set seed to self-pollination. These plants exhibited all degrees of incompatibility when crossed among themselves and with their parents. Correns attempts to explain the phenomena of both self- and cross-sterility observed in Cardamine by the assumption of chemical substances, which he calls "line stuffs" and which he assumes are represented in germ cells by units which segregate in germ-cell formation. This is a real attempt to solve the problem of the nature and the inheritance of physiological self- and cross-incompatibility and hence deserves most careful consideration, especially as it represents perhaps the best Mendelian interpretation that is possible.

The sixty sister plants derived from the cross between plants designated as $B$ and $G$ when pollinated with pollen of these parents fell into four classes: some were sterile to pollen of $B$ and $G$, and Correns hence concludes these have the constitution $B G$; some were fertile with pollen of $B$, but sterile to pollen of $G$, and these have the constitution $b G$; plants fertile to pollen of $G$ and sterile to $B$, have the constitution $B g$, and those fertile with pollen of both $B$ and $G$ have the constitution $b g$. The parent plants are hence assumed to form four kinds of gametes with respect to the line stuffs involved; thus $B$ produces gametes $B$ and $b$, while $G$ 
produces gametes $G$ and $g$. Two gametes, Correns assumes, can combine only if different, hence the four classes of progeny $B G$, $b G, B g$, and $b g$, judged by their fertility or sterility with the pollen of the parents.

It is obrious that this interpretation is based on several assumptions quite secondary to the general doctrines of Mendelian hehavior, and quite limited and individual in application.

The diploid constitution of the parents is represented by $B b$ and $G g$. This is the usual notation for the presence and absence of an assumed factor. Here, however, " $B$ " is the line stuff derived from one immediate parent and " $b$ " is quite another line stuff from the other parent, but assumed to be inactive in the plant $B$. The same is true of " $G$ " and "g." In the matter of notation, it would be more correct for his interpretation if Correns represented these different substances by a different letter representing the composition assumed as $B x$ and $G y$.

Correns treats the offspring belonging to the classes $B g$ and $b G$ as if they also build only one active line stuff. The class $B G$, however, builds two line stuffs, as both $B$ and $G$ are assumed to be active. The assumption is that some plants may build two active line stuffs, others only one. Furthermore, the line stuffs $b$ and $g$ (or $x$ and $z$ ) assumed to be inactive in plants $B$ and $G$ are transmitted to offspring, at least of the groups $B g$ and $b G$ in the inactive condition. It is not explained what line stuff the plants of the $b g$ class build, but as these plants are said to be self-sterile, either one or both of the same line stuffs which were inactive in the parents and which were inactive in the sister plants $B g$ and $b G$ now becomes active or other active stuffs are operating (Correns even considers the latter to be possible).

Chance combinations between all gametes are, it is assumed, not possible. No plants of the combination $B B, G G, b b$ or $g g$ are assumed to appear as offspring of $B b$ or $G g$. The plant $B b$ produces two kinds of pollen, $B$ and $b$, but is self-sterile to both; therefore, the active line stuff $B$ of the pistils inhibits pollen tubes with $B$ and also $b$ (which is another line stuff in inactive condition), or the inactive stuff $b$ is inhiliting the $b$ pollen t uhes. It should be noted, however, that later $(1)+21)$ Correns classifies the progeny of the cross $b G \times B b$ in four classes, $B b, B G, b G$, and $b b$, so that here " $b$ " eggs in the plant $b G$ can be fertilized from $b$ pollen or $B$ 
pollen of plant $B b$. This sort of combination is assumed not to be possible in the previous crosses. Why the plants $b G$ and $B b$ cannot likewise be fertilized by their own $b$ pollen is not clear.

These discrepancies and assumptions of special conditions arise in part from the interpretation that sterility is concerned only with the interaction between the pistil, composed of diploid cells, and the pollen tubes with cells of haploid constitution. Yet in regard to the interaction, all of the pollen grains are treated as if they were alike, although a single grain is assumed to carry only one line stuff and to transmit this in purity.

Correns' results are excellently tabulated, but the number of seed per capsule is not recorded, nor is there given a standard of optimum fertility. The development of the capsules is judged and graded as nichts, einsamig, sehr schlecht, schlecht, ziemlich schlecht, ziemlich gut, sehr gut, and gut; or beschädigt. It is not clear that capsules classified as "schlecht" always contained seed, or that there is any development of completely empty pods. A study of the data given, however, shows that all degrees of crossfertility and cross-sterility appeared. This may be illustrated by some of the results of pollinations from plant $B$ as recorded in table I, p. 403.

$\begin{array}{cc}\text { Female parent } & \text { No. of flowers } \\ 2 \mathrm{qu} & 5 \\ \text { I l } & 5 \\ \text { I a } & \text { IO } \\ \text { I k } & 9 \\ \text { I u } & \text { IO } \\ \text { I y } & 13 \\ 2 \mathrm{p} & 10 \\ 2 \mathrm{ab} & 12\end{array}$

Results

alle sehr gut

alle gut

6 nichts, 3 ziem!ich gut

7 nichts, I gut, I schlecht

9 nichts, I schlecht

I 2 nichts, I sehr schlecht

alle nichts bis auf I einsamige Schote alle nichts

Correns realized that such results are difficult to classify. "Die Ergebnisse entsprachen nicht ganz meinen Erwartungen; sie waren nicht so eindeutig scharf, wie ich gehofft hatte, und zwar in doppelter Hinsicht" (p. 40o), and also that there is "Grossere Schwierigkeiten für die Beurteilung der Ergebnisse bot das 'schlechte' Ansetzen; wenn $z$. B. in einer Schote nur einige wenige Samen oder nur einer ausgebildet wurde" (p. 40I). Yet Correns does not fully recognize that a feeble fertility or a partial sterility may actually exist quite apart from any or all artificially unfavorable conditions and errors in manipulation. The data 
show that of the $60 \mathrm{~F}_{1}$ plants pollinated from the parent $B, 46$ set some seed, although in Correns' grouping only 32 are credited as being fertile: pollen from the parent $G$ gave some seed in 52 cases, but Correns credits 30 as being fertile. To summarize in tabular form the actual results and the grouping as given by Correns:

From data

Plants fertile in some degree to both $B \& G \quad 39$

" " " " " " $" B$ only

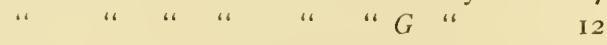

" " $\quad$ to neither $B$ nor $G$
Classification of Liorrens I 6

I 6

14

It

Correns' whole interpretation rests largely on the classification of the plants into nearly equal groups, to obtain which it is necessary to consider 35 cases of feeble fertility as fully sterile and I I cases of no fertility as fully fertile.

In table 3 Correns gives the results of all possible reciprocal pollinations involving eight of the progeny and both parents. One pair of reciprocals involving parent $B b$ and offspring of the $B G$ class were sterile; but in another pair ( $B$ with $I \mathrm{~m}$.) both were fertile. The pair involving $B b$ and $B g$ were both sterile; hence the " $g$ " pollen of $B g$ was inhibited by $B$ or $b$ of the stigmas of $B b$; and in the reciprocal cross, " $b$ " pollen was inhibited by the altogether different substances " $B$ " or " $g$ ". Of the two pairs of reciprocals involving parent $G g$ and offspring $B G$, one pair were sterile and one pair fertile to some degree. Three pairs gave different results: $G g \times b G$ (plant $I$ ae) was sterile, the reciprocal feebly fertile; $G g \times B g$ (plant $2 b$ ) was sterile, the reciprocal was strongly fertile; $G g \times b G$ (plant $2 e$ ) was sterile, the reciprocal was feebly fertile. Of the other thirteen pairs of reciprocals each pair gave the same result; the interaction between pistils and pollen was the same irrespective of the fact that no two of the plants concerned possessed the same combination of line stuffs.

Correns made over 700 of the 3,5 to possible cross-pollinations between the 60 offspring and these were well distributed to give adecuate tests of the interrelations of the four classes. The plants classed as $b g$ which should, according to assumption, be crossfertile to all other plants met the expectation more fully than any other class, as out of $3+\mathrm{I}$ cross combinations involving $b g$ plants as one or both parents only +8 were fully sterile. Combinations involving $B G$ plants with $B g, b G$, or $B G$ plants should be sterile; 
of 207 such combinations 48 were fertile in some degree. There were wide variations, however, in the individual behavior of the various group combinations, as can be illustrated by the following summary compiled from tables 8 and 9 :

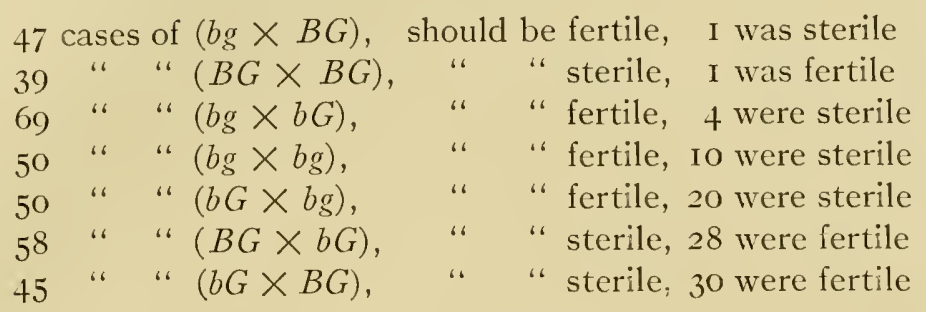

In general, as in the crosses with parents, the cases of crossfertility exceeded expectations; out of 299 cases that should have been cross-sterile, II 3 combinations were fertile. In the tables Correns includes data on self-pollinations of 13 plants and of these it appears that three $(2 d, 2 e$, and $2 h)$ were partly self-fertile; in five of the plants reported self-sterile only two flowers were tested, in two only three, in one plant four, and in one plant six. No doubt a larger number of self-pollinations would reveal more plants self-fertile. It also appears from the data of table $8 \mathrm{~A}$ that at least one plant included in the tables ( $I C$ ) was not even tested for selffertility. There is no data given regarding the self-sterility of the other 46 plants of the $F_{1}$ generation.

Correns' results are important in establishing the fact that crossincompatibility may exist between closely related plants which also exhibit self-incompatibility. His contention that both selfand cross-sterility are due to the same kind of interactions is suggestive. That this incompatibility depends upon and exists between line stuffs whose presence depends on an "anlage" which is inherited and which follows the Mendelian law of segregation is, however, not supported by his evidence. It is plain from Correns' data that such a simple explanation is not adequate, even if we believe that incompatibility is largely dependent upon chemical compounds and definite processes.

These results show very clearly that there are wide variations in the degree to which cross-sterility exists among different plants, that conditions giving sterility are not identical in all plants and that when complete cross-sterility exists it may be quite independent of germ-cell differences resulting from reduction divisions. 
It should be noted that Baur ('11, p. 2I 2) had already suggested a simple Mendelian explanation for the behavior of self-sterility. Antirrhinum molle, which is "streng selbststeril" when crossed with the self-fertile species $A$. majus, gave, he reports, only self-fertile $F_{1}$ progeny while the $F_{2}$ consisted of both self-fertile and self-sterile, the former being in the greater number. Baur has not published any data regarding the number of plants, the variations which they exhibited, nor is there any evidence on the very important questions of self- and cross-sterility in the species Antirrhinum molle. Lotsy ('11) has, however, grown $\mathrm{F}_{2}$ generations of these hylorids and reported that such wide diversity exists in their selffertility and self-sterility that at least in certain lines of descent no two individuals can be considered the same. Compton ('12, '13), likewise, supports the view that self-fertility (in Reseda) is a simple Mendelian dominant over self-sterility. He considers that it is even simpler than Correns conceives it to be in that the self-sterile plants are really recessives possessing absence of substances either stimulative or nutritive to the growth of the pollen tubes, and that self-fertile plants, which do exist, may or may not breed true. Compton's conception of the simple presence and absence of a substance stimulating growth attempts to account for self-fertile and self-sterile plants, but is hardly considerative of any phenomena of cross-fertility or cross-sterility, especially among plants self-sterile. Compton has not published the data of his investigations.

At this stage in the study of the phenomena of self-sterility East presented data showing that self-sterility may be almost complete among a culture of hybrid plants which exhibit feebly if at all the phenomena of cross-sterility. East, although formerly considering that Nicotiana alata grandiflora and N. Forgetiana, together with other Nicotiana species, are fully self-fertile, finds ('15) that cases of self-incompatibility may have appeared in at least one of these species and that from one cross four generations totaling over 500 plants were tested and found completely selfsterile. When crossed among themselyes they were almost completely fertile. However, from the data given by East, it appears that no systematic crossings were made in the $F_{1}$, and that only twenty plants of the $\mathrm{F}_{2}$, twelve of the $\mathrm{F}_{3}$, and ten of the $\mathrm{F}_{4}$ were used in such crosses; with these, however, 289 combinations are 
reported of which thirteen were sterile, and four gave less than fifty per cent of the full fertility. Of the total of more than 500 hybrids of the several generations only forty-two were used in intercrossing. While East admits that the evidence indicates the possibility of "true cross-sterility" he is inclined to view the partial or feeble fertility seen in four crosses as accidental. East finds that in the self-pollinations, pollen germinates abundantly, but the tubes show no acceleration of growth when they penetrate nearer to the ovaries as do the pollen tubes in cross-fertilization. This we may note is in accord with numerous observations made by Scott, Müller, Darwin, Hildebrand, Jost, and Correns. Quite in common with Jost, East considers that the pistils produce stimulating substances, but further assumes that the secretion of such substances is "called forth only by a gamete that differs from the somatic cells between which the pollen tube passes."

According to this view self-sterility is largely an individual matter depending on too great a similarity or a lack of necessary constitutional differentiation which is in this particular quite the view of Darwin, Jost, and Correns. The conception differs especially from Darwin's in limiting the operating dissimilarity to the pollen grains: the pollen must possess in its constitution at least one hereditary element which is not present in the more complex pistillate cells. No matter how simple or how complex a pistil may be, pollen tubes will grow well, provided they possess some different element. The view differs radically from that of Baur, Correns, and Compton in assuming that there are no specific factors, anlages, or determiners which are directly concerned with fertility or sterility, and which are inherited as such. The inference is that the ability to form the specific enzymes and stimulating substances is present in all plants of the race or series of hybrids. The production of the necessary enzymes in the pollen tube and their subsequent action in calling forth secretion in the pistil is conditioned by the one-sided dissimilarity as noted above, and is a secondary property of the general hereditary complex.

The fundamental conception is, of course, that the germ cell constitution is made up in part at least of definite units which are anlages, either directly or in combination with other units, for the expression of characters. This raises the highly important question whether such units exist with anything more than rela- 
tive constancy and purity. It is also clear that the assignment of different and independent degrees of influence in the development of sterility to the various assumed units would theoretically account for any sort of fluctuation or variation in the individual development of self-fertility. Such explanations, however, do not add to the understanding of the actual chemical and physiological processes and only very indirectly to the practical problems of the effects of inbreeding and the development of highly self-fertile races. It would appear also that this view limits the constitutional differences to hereditary elements quite independent of any cytoplasmic relations that may exist, which in this respect is in accord with the conception of Baur and Correns and Compton, but not agrecing with the views of Darwin and Jost and Morgan. If this be true, it is not clear why somatic cells of the pistil cannot react farorably with pollen tubes if the former possess some element different from the pollen; but as such a relation always exists and most especially so with hybrids such as East reports, there would be, from this basis, universal self-fertility.

East assumes that the tobacco hybricls are self-sterile because none of the pollen grains produced by a plant possess any hereditary element not present in the somatic cells of that plant. But no pollen of a plant ever does, unless there are vegetative mutations, segregations, or other variations among the branches and among the pistils and stamens of a plant, so the conception fails to account for self-fertility, especially of lines breeding true, which is a widespread phenomena in plants and which East has repeatedly insisted is the rule in Nicotiana species.

From the reviews just given, it is evident that intensive studies regarding the facts of cross- and self-incompatibility in plants have been attempted only in the two cases reported by Correns and East, and that even in these cases much desirable data were not obtained. It is very obvious that before we can arrive at any comprehensive conception of the principles involved, much more evidence is needed. It is with especial reference to such data that the writer here presents the results of studies with chicory ( $\mathrm{Ci}$ chorium Intybus) which pertain to the expression and the heredity of physiological self- and cross-incompatibility. 


\section{METHODS OF STUDY IN CHICORY}

This species is especially favorable for such a study. The species is one of the Composites. All the flowers of each head are ligulate; they are perfect and alike (see PLATE 30). The flowers open almost simultaneously not only in a single head but in the various heads (from I to perhaps IOO) that open in any one day on any one plant. In regard to anatomical development and compatibility the conditions give absolute potential self- and cross-fertility, the only exception in my cultures being a few plants which have appeared that are impotent in some degree.

Furthermore, an individual flower head is normally open but a few hours and all of its flowers shed their pollen at the same time. As the various heads opening in any one day on a plant or on different plants are quite uniform in this respect, differences in the maturity of sex organs in these flowers are, it would seem, as nearly absent as is possible in any plant.

The hour of opening and the period during which flower heads remain open varies with the weather conditions and with the season. During a warm sunny period in midsummer the procedure in the experimental plots at the New York Botanical Garden is in general like that recorded for the 3Ist of July, I9I2. On this date, at 6:30 A. M. the flower heads were mostly open but the individual corollas were not fully extended or flattened out and none of the pistils were protruding through the stamen ring. At 6:40 a few pistils were protruding (see PLATE 30, FIGS. I and 4): at 7:05 the styles of these flowers were fully protruding, but the stigmas were appressed to each other, a stage in which the rough spiny exterior of the style and stigmas drags out considerable pollen; bumble bees and various other insects began to appear: at 7:30 the stigmatic lobes began to spread (FIG. 7): at 8:00 the stigmas of all flowers were fully extended and the lobes separated and strongly recurving (FIGS. 2, 5, and 9), thus exposing the inner stigmatic surfaces; insects were very busy gathering pollen: at Io:Oo the petals began to wither, fade, and close in over the pistils: at I0:30 nearly all heads were closed never to open again (FIG. 3 and II). This sequence in development is shown in the heads and individual flowers portrayed in PLATE 30.

On such a day, only the interval between $7: 45$ and 9:30 A. M. 
can be properly used in manipulating cross- and self-pollinations. In making controlled self-pollinations heads that have opened under a bag are used. One head is removed with a pair of scissors and the petals are cut away as shown in FIGURE 5. The group of broken anther-sacs with the protruding stigmas is used to brush thoroughly the inner surfaces of the expanded stigmas of attached flower heads that have opened under a bag on the same plant. Heads thus treated are tagged and the bags are replaced until a later day. This method insures the distribution of a plant's own pollen on the stigmatic surfaces at a time when these are fully exposed. The chief source of error is the chance that winged insects, which are sometimes very active, may gain access to a head while the bag is removed. To decrease such error two persons have coöperated in the manipulations, one keeping a constant watch while a bag is removed. When insects are observed to alight on a head, which occasionally occurs, the head is removed. Pollen may also be distributed by wind. That such errors cannot be entirely prevented is obvious, and in some cases the results seem to show that such an error has occurred. The scissors used in cutting away the petals are dipped in alcohol after a plant is worked and the hands of the operators are washed in water.

In making crosses involving a seed parent known to be selfincompatible, the method used is quite like that of selfing except that flower heads from one plant are used as a source of pollen applied to the flowers of another plant. Crossing onto a seed parent that is self-fertile necessitates the depollination method described by Oliver ('10). In testing the effects of selfing and crossing, it was always the aim to use several heads on one date, and if conditions allowed, to make the same combination on a different date in the same season or even in different years until at least ten heads had been treated.

Some cases of failure to set seed, especially when an entire head soon shrivelled, were no doubt due to injury such as bruising in handling or by contact with the paper hags or with twigs. Such a source of error was operating in all cases of fertility. The data for heads of branches that obviously became broken or otherwise injured were discarded.

In regard to the immediate development after pollination, there 
appears to be no difference between heads that produce seed and those that do not. The heads close and the petals wither as described, and the mass of withered corollas break from the ovaries and fall to the ground in about twenty-four hours in quite the same manner. For a few days the young achenes show no differences, but in the course of ten days or two weeks, those of self-sterile and of cross-sterile pollinations become shrivelled and lightcolored, and are not closely packed in the head; and such development also occurred when the stigmas, stamens, and petals of unopened flowers were shaved off with a razor, a procedure to which a number of the parent plants of I9I 2 were submitted in testing whether parthenogenesis occurs in Cichorium as it does in Taraxacum.

In the later stages of seed development, it was in most cases not difficult to distinguish the heads having viable seed nor difficult to distinguish seeds with embryos from empty seeds. It may be noted that as a single flower of Cichorium produces only one seed, which is a somewhat conspicuous achene, the judgment of fertility is simpler than is the case in plants which produce capsules with numerous small seeds, some of which are nearly always empty from various local physiological conditions not involving any incompatibility between pollen and stigma. In determining the result of pollinations, the tagged heads were inspected frequently during the period of the ripening of seed. When a head matured it was removed and the seeds carefully examined one by one, and all that appeared to contain embryos were placed in a seed envelope together with the tag belonging to the head, while the complete data were recorded on the envelope. The tags were collected from all heads that produced no seed and in which there was no apparent injury of branches. English sparrows and goldfinches were frequent in the Garden and through feeding on the seed interfered to some extent with the seed collection. In nearly all cases their visits were confined to heads that produced good seed; their interference with manipulated heads, indicated in the tables, involves in some cases the question of the degree of fertility shown by plants. As all manipulations were recorded in a daybook, the final data for any plant were readily compiled from this record, from the envelopes and from the tags of seed collections into the final form of a card catalogue. 
It is not possible to judge with absolute certainty concerning every seed as to whether it is viable or not. Davis ('15) has shown that such difficulty exists in Oenothera, in which large numbers of seed-like structures may not germinate and that there is great irregularity in the time of germination of viable seeds, which makes it desirable to employ special methods in growing pedigreed cultures. In sowing seed of Cichorium, it is my method to sow the secds from each head in separate seed pans containing sterilized soil. The seeds are relatively few, thus far never more than twenty-two for a pan. As soon as plants are well started they are placed in pots and properly labeled, but the seed pan is kept for a period of three or four months. Some irregular germinations have been noted extending at the most over a period of about five weeks.

There were no seed sowings from seed collections judged as viable that did not give some germination. As far as tested no plant was judged as self-fertile that did not produce some viable seed. Not all seeds containing embryos proved to be viable. In the plantings of 1915 , for example, selfed seeds of twenty-one plants judged as self-fertile were sown to the number of 268 ; from these 218 plants were grown into the rosette stage and there were about 20 plants that died or were killed by slugs soon after germination. On this basis the viability of seeds which were judged as possessing embryos was about 85 per cent.

\section{RESULTS OF THE EXPERIMENTAL STUDIES}

Phenomena OF SELF-COMPATIBILITY AND SELF-INCOMPATIBILITY

The experimental study of self-sterility in Cichorium Intybus was begun by the writer in I9I2, when it was found that numerous plants of hoth wild and cultivated strains failed to set seed when sclf-pollinated under control. The investigations were originally planned to test the inheritance of flower color and other characters in wild white-lowered plants by inbreeding, and by crossing with bluc-flowered plants of both wild and cultivated stock. In I II , secds were collected from three wild white-flowered plants that were growing on the campus of the University of Wisconsin. Later these plants, designated as $A, B$, and $C$, were dug up and replanted in the breeding plots at the New York Botanical Garden. The seed collected from these plants was sown in October, I9I I; 
the seedlings were grown in pots in a greenhouse until spring, when they were planted in the field giving sixty-six plants, twentyseven of which were from seed of the plant $A$.

In order to secure blue-flowered plants of a decidedly distinct strain from that of wild plants growing in the vicinity of plants $A$, $B$, and $C$, there were also grown in I9I 2 twenty-nine plants of a cultivated variety, the seed of which was obtained from J. M. Thorburn and Company (No. 4300, Catalogue of I9II) and which had been grown by the firm of Ernst Benary of Erfurt, Germany. The variety was the unimproved "common" chicory grown in various parts of Europe for salad. These plants are designated as the $E$ series. Besides being blue-flowered, the plants of this series were decidedly more robust than the plants of the wild strains. The latter were from $2 \frac{1}{4}$ to 3 feet tall and were, as a rule, scraggly. The plants of the cultivated strain were from 5 to $6 \frac{1}{2}$ feet tall and possessed many more leaves and branches. Both the wild and the cultivated strains exhibited wide variations especially in the shape of the leaves and in the amount of red coloration.

In the summer of 1912, various crosses were made between plants $A, B, C, E_{3}$, and E22 using the depollination method described by Oliver ('10). These plants together with about thirty others were self-pollinated. The crosses, which involved few individuals, were successful (see TABLE 2), but the self-pollinations of that year failed in every instance.

TABLE I

DATA FOR PLANTS FULLY SELF-STERILE

\begin{tabular}{|c|c|c|c|c|}
\hline Plant & No. of pollinations & Total heads & Heads with no seed & Heads with seed \\
\hline$A \ldots \ldots \ldots \ldots$ & IO & 29 & 29 & o \\
\hline$B \ldots \ldots \ldots \ldots$ & 4 & 20 & 20 & o \\
\hline C.. & 6 & 40 & 39 & $I^{1}$ \\
\hline$E_{3}$ & 4 & 23 & 23 & 0 \\
\hline$E 8 \ldots \ldots$ & 3 & 22 & 22 & 0 \\
\hline$E 22 \ldots \ldots \ldots \ldots$ & 6 & $2 \mathrm{I}$ & $2 \mathrm{I}$ & o \\
\hline$A 7 \ldots \ldots \ldots$ & 2 & I 5 & I5 & o \\
\hline$A 8 \ldots \ldots$ & 3 & 20 & 20 & o \\
\hline$A g \ldots \ldots \ldots \ldots$ & 2 & IO & 10 & o \\
\hline$A I 7 \ldots \ldots \ldots$ & 4 & I 3 & I 3 & 0 \\
\hline$A$ I & 3 & I0 & IO & o \\
\hline$A 23 \ldots \ldots \ldots$ & 3 & 25 & 25 & o \\
\hline$A 27 \ldots \ldots \ldots$ & 3 & IO & IO & 0 \\
\hline
\end{tabular}

${ }^{1}$ Six seeds: evidently by experimental error. 
In I9I3, the plants grown in the previous year were retained and several sets of seedlings grown from the crossed seed. These plants were tested as fully as conditions permitted for self-sterility and for fertility among themselves, and careful records kept of all manipulations. The evidence that self-sterility was the rule in these plants may be presented in table $\mathrm{I}$. Here the plant is named and data given regarding the number of heads pollinated, the number of dates upon which pollinations were made, and the number of heads with no seed or with seed.

The results were very conclusive for these plants. The number of individual heads tested is high, ranging from io to to for a plant. The plants $A, B, C, E_{3}$, and E22 were also tested in I9I4 (as well as in I9I2, of which no record was kept), and, with the exception of one head of plant $C$, not a single seed was produced.

Similar data could be given for other plants. None of the 29 plants of the cultivated common chicory ( $E$ series) nor of the 27 plants of the $A$ series (progeny of open-fed seed of plant $A$ ) proved to be self-fertile in any degree. Twenty-five other plants, progeny of plants $B$ and $C$, tested for self-fertility gave the same results. It will be noted that further instances of self-sterility appeared in the $F_{1}, F_{2}$, and $F_{3}$ generations. Furthermore, self-sterility appeared as the rule in all the varieties of chicory grown at the breeding plots. In I9I3, about twenty-five plants were grown of each of the following varieties: (I) Magdeburg, large-rooted; (2) Magdeburg, strap-leaved; (3) Witloof; (4) improved spotted; (5) improved red-leaved Treviso; (6) improved striped-leaved; (7) long cylindrical-formed giant; (8) improved large-leaved; (9) improved white; (Io) large-rooted Silesian, and (Io) common or wild chicory (Barbe de Capucin). The seeds of these varieties were furnished by the J. M. Thorburn Company, and was obtained by them from France and Germany through their foreign agents. Self-pollinations were tried on several plants (usually five) of each of these varieties, but in no case was a plant found to be selffertile in any degree. Crosses between many of these plants failed quite as is shown in TABLE I.

Careful examination was made of the mature pollen of many plants, including all the plants mentioned in TaBLE I. Very few shrivelled grains were found and it was very evident that impotence in respect to pollen production is not the cause of 
the self-sterility in chicory. Neither are there in Cichorium any apparent anatomical differences in the flower parts that would constitute a factor in the question of fertility. The type of flower is quite identical in all cases and the pistils and the stamens are the same in position, and of the same relative length both on a single plant and on various plants. All the flowers with the exception of an occasional stray tubular flower are ligulate and are quite identical in respect to general structure.

That the sex organs of self-sterile plants are effective for reproduction under certain conditions is conclusively shown when crosses are made between plants that are self-sterile. As shown in TABLE 2 the pollen of the plants $A, B$, and $C$, which was ineffective in selfing, was productive of seed when used in cross-pollination. In this and in succeeding tables there is given the number of different dates on which the pollinations were made (under Dates), the total number of heads involved, the number of heads in which no seed were produced, the number of heads in which seeds were produced, and the enumeration of the seeds obtained for each head. Later tables include additional data which will be readily understood. In all cases involving crosses the seed parent is placed first in the combination as represented and in the designation of each plant the known ancestry is indicated by the numbers used.

TABLE 2

Results OF SUCCESSFUL CROSSES INVOLVING SIX OF THE PARENT PLANTS

\begin{tabular}{|c|c|c|c|c|c|}
\hline \multirow{2}{*}{ Plants } & \multicolumn{5}{|c|}{ Record for heads pollinated } \\
\hline & Dates & Total & With no seed & With seed & Seeds per head \\
\hline$A \times B$. & 2 & 12 & 2 & IO & $2,3,4,6,7,7$, IO, IO, I I, I 5 \\
\hline$B \times A$. & 3 & 7 & o & 7 & $2,3,6,8,10,14,17$ \\
\hline$A \times C$. & 4 & 14 & 3 & I 1 & $2,6,7,7,8,8,1+15,17,18$ \\
\hline$C \times A$ & 2 & I I & o & I 1 & 3 , I I, I I, I $2,14,14,16,16,19,19,20$ \\
\hline$A \times E_{3}$. & $\ldots$ & $\ldots$. & $\ldots \ldots$ & 3 & $9, I_{4}$, I 5 \\
\hline$E_{3} \times A$ & $\cdots$ & & $\ldots$ & 2 & 6,9 \\
\hline$A \times E 22$ & $\cdots$ & ... & $\ldots \ldots$ & 12 & $5,6,7,8, \mathrm{IO}_{1}, \mathrm{I}_{3}, \mathrm{I}_{3}, \mathrm{I} 4, \mathrm{I} 4, \mathrm{I} 5, \mathrm{I} 5, \mathrm{I} 7$ \\
\hline$E_{22} \times A$ & ... & $\ldots \ldots$ & $\ldots \ldots \ldots$ & 12 & $6,6,6,7,10,12,14,14,15,15,17,17$ \\
\hline$E_{3} \times C$. & .... & $\cdots \cdots$ & $\ldots \ldots \ldots$ & 6 & $6,8,12,15,16,18$ \\
\hline$C \times E_{3} \ldots$ & & & $\ldots$ & 2 & $8, \mathbf{1}+$ \\
\hline$C \times E 22$ & & $\cdots \cdots$ & $\cdots \cdots$ & 3 & I I , I 5, I9 \\
\hline$E 22 \times C$ & $\cdots$ & … & ..... & 6 & $3,3,5,5,15, \mathrm{I} 8$ \\
\hline
\end{tabular}

The crosses given in TABLE 2 which involve plants of the $E$ series were made in I9I 2 and no exact record was kept of the number of heads that were pollinated, as at that time it was not 
known that the questions of fertility were involved. The data pertain only to the heads from which seed was collected. The successful results of reciprocal crosses show that the self-sterility observed in these plants was not due to impotence of either pollen or egg cells.

It should be noted that differences in the number of seeds produced per head, such as are shown in TABL.E 2 and in all later tables, are not due to the number of flowers in the heads. In $19 \mathrm{I}+$ counts were made of the flowers in 5.3 heads borne on plant 4 ; the number varied from 15 to 22 with the mean at 18 . Data on 283 heads of plant $B$ gave a frequency distribution ranging from 13 to 20 with the mean at $\mathbf{5} 5.8$. A total of 395 heads of plant $C$ gave a range from 13 to 22 flowers per head with the mean at 18.9 . As shown in TABLE 2, the seeds collected per head varied on plant $A$ from o to 18 ; on plant $B$ from o to 17 , and on plant $C$ from o to 20. In these crosses the depollination method (Oliver '10) was used and some of the failures may very well be due to injuries or to failure to make the proper pollination of all pistils. It is evident, however, that there is a rather marked degree of fertility in these crosses. The number of complete failures per head is low and there are about half the heads that give a large number of seeds and some heads produced close to the maximum number possible.

Self-sterility and self-fertility among plants of the F $F_{1}$ generation.In the summer of 1913 , a crop of plants was grown from seed obtained by crossing the plants A,C, E3, and E22. As these plants came into bloom they were tested for self-sterility and the investigations were continued during the summer of $191+$ in the attempt to test quite adequately every plant that lived through a flowering period. The results are given in TABLE 3 .

Of the 172 plants reported in TABLE 3 there were 157 (over 90 per cent) that were completely self-sterile. Fifteen plants set some seed to controlled self-pollination: some of these as $\left(E_{3} \times A\right) n o .+$ and $\left(E_{22} \times A\right)$ no. Io were decidedly self-fertile, setting seed in the greater mumber of heads: eight plants were self-fertile in less degree, in that seeds were obtained in relatively few heads (for example, see data for $(A \times E 22)$ no. 2 and no. f) and in sonce cases as in $(4 \times E 22) n o$. \& the number of seeds per head was also low; there were five plants each of which produced but one head with seed. 
TABLE 3

DATA FOR THE SElF-POLlinations of THE $F_{1}$ PROGExy

\begin{tabular}{|c|c|c|c|c|c|c|}
\hline \multirow[b]{2}{*}{ Plant } & \multicolumn{6}{|c|}{ Recrord for heads pollinated } \\
\hline & Dates & Total & $\begin{array}{c}\text { With no } \\
\text { seed }\end{array}$ & $\begin{array}{l}\text { With } \\
\text { seed }\end{array}$ & Seeds per hcad & $\underset{(\zeta)}{\text { Ferility }}$ \\
\hline 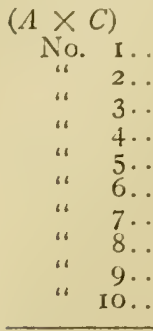 & $\begin{array}{l}\text { I } \\
\text { I } \\
2 \\
1 \\
2 \\
1 \\
3 \\
2 \\
1 \\
1\end{array}$ & $\begin{array}{r}3 \\
5 \\
5 \\
5 \\
7 \\
5 \\
10 \\
10 \\
11 \\
4 \\
\end{array}$ & $\begin{array}{r}3 \\
5 \\
5 \\
5 \\
6 \\
5 \\
10 \\
10 \\
11 \\
4 \\
\end{array}$ & $\begin{array}{c}0 \\
0 \\
0 \\
0 \\
1 \\
0 \\
0 \\
0 \\
0 \\
0\end{array}$ & $6 \ldots \ldots \ldots \ldots$ & 0.05 \\
\hline 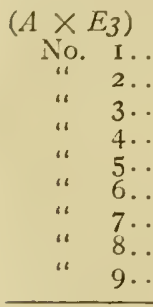 & $\begin{array}{l}4 \\
3 \\
2 \\
3 \\
2 \\
1 \\
1 \\
2 \\
2\end{array}$ & $\begin{array}{r}16 \\
\text { I2 } \\
8 \\
\text { I4 } \\
\text { IO } \\
6 \\
5 \\
5 \\
6\end{array}$ & $\begin{array}{r}16 \\
12 \\
8 \\
14 \\
10 \\
6 \\
5 \\
7 \\
6\end{array}$ & $\begin{array}{l}0 \\
0 \\
0 \\
0 \\
0 \\
0 \\
0 \\
1 \\
0\end{array}$ & $17 \ldots \ldots$ & 0.13 \\
\hline 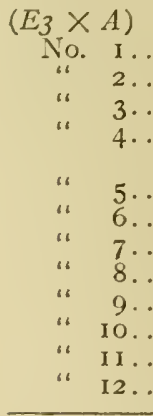 & $\begin{array}{l}2 \\
3 \\
1 \\
8 \\
\\
3 \\
8 \\
1 \\
1 \\
1 \\
1 \\
2 \\
4 \\
\end{array}$ & $\begin{array}{r}8 \\
12 \\
4 \\
29 \\
11 \\
11 \\
31 \\
4 \\
5 \\
4 \\
5 \\
10 \\
18\end{array}$ & $\begin{array}{r}\text { I I } \\
26 \\
4 \\
5 \\
4 \\
5 \\
7 \\
18\end{array}$ & $\begin{array}{r}0 \\
0 \\
0 \\
20 \\
\\
0 \\
4 \\
0 \\
0 \\
0 \\
0 \\
3 \\
0\end{array}$ & $\begin{array}{r}2,3,6,7,7,8,10,13,13,13,14,15 \\
16,17,17,18,18,18,19,19 \ldots \\
2,3,3,4 \ldots \ldots \ldots \ldots \ldots \ldots \ldots\end{array}$ & $\begin{array}{l}0.48 \\
0.02\end{array}$ \\
\hline 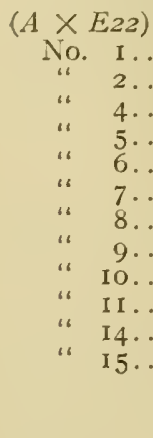 & $\begin{array}{l}\text { I } \\
9 \\
8 \\
8 \\
1 \\
3 \\
5 \\
2 \\
2 \\
3 \\
3 \\
6\end{array}$ & $\begin{array}{r}7 \\
34 \\
26 \\
32 \\
5 \\
11 \\
21 \\
6 \\
7 \\
16 \\
12 \\
17\end{array}$ & $\begin{array}{r}7 \\
28 \\
20 \\
31 \\
5 \\
\text { II } \\
21 \\
4 \\
7 \\
16 \\
12 \\
\text { II }\end{array}$ & $\begin{array}{l}0 \\
6 \\
6 \\
1 \\
0 \\
0 \\
0 \\
2 \\
0 \\
0 \\
0 \\
6\end{array}$ & $\begin{array}{l}2,3,4,5,6,10 \ldots \ldots \ldots \ldots \ldots \ldots \ldots \\
1,3,3,4,4,4 \ldots \ldots \ldots \ldots \ldots \ldots \ldots \ldots \ldots\end{array}$ & $\begin{array}{l}0.06 \\
0.04 \\
0.01\end{array}$ \\
\hline
\end{tabular}




\begin{tabular}{|c|c|c|c|c|c|c|}
\hline \multirow[b]{2}{*}{ Plant no. } & \multicolumn{6}{|c|}{ Record for heads polinated } \\
\hline & lates & Total & $\begin{array}{l}\text { With no } \\
\text { seed }\end{array}$ & $\begin{array}{l}\text { With } \\
\text { seed }\end{array}$ & Seeds per head & $\underset{(\zeta)}{\text { Fertility }}$ \\
\hline 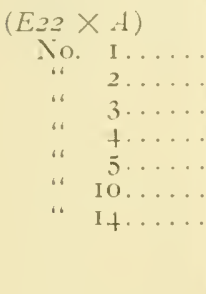 & $\begin{array}{l}5 \\
4 \\
1 \\
3 \\
1 \\
1 \\
3\end{array}$ & $\begin{array}{r}5 \\
11 \\
5 \\
15 \\
5 \\
5 \\
10\end{array}$ & $\begin{array}{r}5 \\
10 \\
5 \\
15 \\
5 \\
0 \\
9\end{array}$ & $\begin{array}{l}0 \\
\text { I } \\
0 \\
0 \\
0 \\
5 \\
1\end{array}$ & $\begin{array}{l}6,6,9,10,13 \ldots \ldots \ldots \ldots \ldots \\
\text { s. } \ldots \ldots \ldots \ldots \ldots \\
\text { Io other plants of this series were } \\
\text { self-sterile }\end{array}$ & $\begin{array}{l}0.51 \\
0.04\end{array}$ \\
\hline 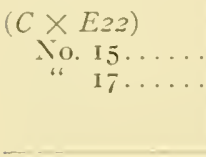 & $\begin{array}{l}+ \\
\text { II }\end{array}$ & $\begin{array}{l}15 \\
24\end{array}$ & $\begin{array}{l}\text { I3 } \\
2 \mathrm{I}\end{array}$ & $\begin{array}{l}2 \\
3\end{array}$ & $\begin{array}{l}\text { I, I } 2 \ldots \ldots \ldots \ldots \ldots \ldots \ldots \ldots \\
9,1+1+\ldots \ldots \ldots \ldots \ldots \\
\text { I } 7 \text { other plants of this series were } \\
\text { self-sterile }\end{array}$ & $\begin{array}{l}0.05 \\
0.07\end{array}$ \\
\hline$\left(C \times E_{3}\right)$ i I $\mathrm{p}$ & lants al & self-st & terile & & & \\
\hline$\left(E_{3} \times C\right) \quad 6$ & .. & ." & " & & & \\
\hline Series If. 30 & " " & "، & $"$ & & See TABLE 8 & \\
\hline
\end{tabular}

The intensity of the character of self-fertility may be estimated for the self-fertile plants of this generation and also of the following generations and expressed in terms of the percentage of flowers which produced seed. Statistical studies have been in progress on the variation and the heredity of flower number and from these data the average number of flowers per head is quite accurately known for all but three of the self-fertile plants that have thus far appeared. Multiplying this average by the number of heads concerned in the controlled self-pollinations gives a very accurate estimate of the number of flowers upon which the percentage of seed can be computed. The average number of flowers per head for the self-fertile plants of the $F_{I}$ generation ranged from I7.I to 20.8, and the average fertility computed, as just stated, for these plants varied from I per cent to 5 I per cent.

Some of the data, especially that when only one head produced seed, may involve an experimental error. In the case of $(A \times$ E22) 110.5 , thirty-one heads produced no seeds, while one head gave five seeds, a result that might have been due to experimental error as well as to a low degree of self-fertility. In plant $\left(\alpha \times E_{\jmath}\right) n o . \delta$, one head out of eight set seerl, in $\left(E_{2} 2 \times A\right)$ no. 2 one head out 
of ten, but the data compare very favorably with that for such plants as $\left(E_{3} \times A\right)$ no. 6 in which four heads out of thirty-one (proportionally about I out of 8 ) set some seed.

The thirty hybrids (series $\mathrm{I}_{4}$ ) between a plant of the "stripedleaved improved" variety and a plant of the $(A \times C)$ hybrids were all completely self-sterile, as is shown in detail in TABLE 8 .

It is very clear, however, that some of these $F_{1}$ hybrids were quite decidedly self-fertile, and the evidence is likewise strongly indicative that varying degrees of fertility exist, giving plants that are to be considered as feebly self-fertile.

Self-sterility and self-fertility in $F_{2}$ progenies derived from seed of self-fertile $F_{1}$ plants.--Pedigreed cultures have been grown from the seed of various of the self-fertile plants just mentioned, and the plants constituting this $\mathrm{F}_{2}$ generation have been selfed during I9I4 and 1915 as fully as conditions allowed. The results are tabulated in TABLE 4 . In this table the designation of the plant gives its pedigree; the portion in parenthesis, as $\left(E_{3} \times A\right)$, indicates the grandparents, the following number is the number of the immediate parent. Under the caption "seeds per head," there are indicated several instances of the removal of seeds from the heads by birds. When there was reason to believe that such heads had contained some good seeds, the record is simply given as $B$; when the birds had left some seeds these were collected and the result recorded, as for example, $\mathrm{I}+\mathrm{B}$, or $6+\mathrm{B}$, etc. In this table there is also recorded the color of the flowers as to whether blue (B) or white (IV).

It is especially noticeable that as far as tested the progeny of a self-fertile plant are not all self-fertile. The plant $\left(E_{3} \times A\right)$ no. 4 was decidedly self-fertile (see TABLE 3 ), but of the 18 plants thus far tested among its progeny 8 were completely self-sterile. The series $\left(E_{3} \times A\right)-6$ - composed of four plants were all self-sterile. Nineteen offspring of $(A \times E 22)-2-$ were tested and of these Io were self-sterile; one plant of this series (no. 2) was an abnormal plant with a dwarf habit of growth and nearly all of its flowers were almost completely cleistogamous, with the anthers mostly contabescent. Besides being strongly impotent it was self-sterile. The series $\left(A \times E_{22}\right)-4^{-}$was composed of 3 self-sterile and 7 self-fertile plants, $(A \times E 22)-O$ - of 4 self-sterile and 2 self-fertile plants, and $\left(E_{22} \times A\right)-I O-$ of $\mathrm{I} 2$ self-sterile and I I self-fertile. 
TABLE 4

DATA FOR THE SELF-POLLINATIONS OF THE $\mathrm{F}_{2}$ GENERATION

\begin{tabular}{|c|c|c|c|c|c|c|c|}
\hline \multirow[b]{2}{*}{ Plant } & \multirow{2}{*}{ 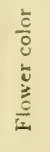 } & \multicolumn{6}{|c|}{ Record for heads pollinated } \\
\hline & & 巳̈ & 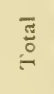 & 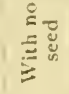 & 㣢 & Seeds per head & $\begin{array}{c}\text { Fertility } \\
(\zeta)\end{array}$ \\
\hline 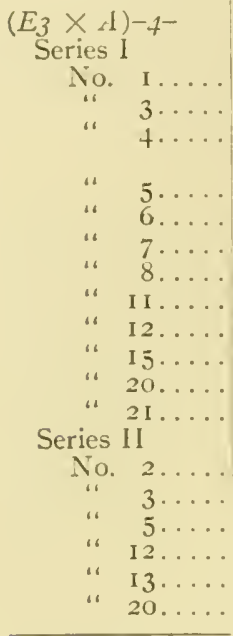 & $\begin{array}{l}\text { B } \\
1 \mathrm{~V} \\
\mathrm{~B} \\
\mathrm{~B} \\
\mathrm{~B} \\
\mathrm{IV} \\
\mathrm{II} \\
\mathrm{B} \\
\mathrm{II}\end{array}$ & $\begin{array}{l}5 \\
2 \\
2 \\
2 \\
2 \\
2 \\
2 \\
2 \\
4\end{array}$ & $\begin{array}{r}17 \\
5 \\
4 \\
10 \\
6 \\
6 \\
7 \\
8 \\
10\end{array}$ & $\begin{array}{r}\text { I I } \\
0 \\
4 \\
\text { I } 7 \\
\text { I } \\
4 \\
10 \\
2 \\
6 \\
7 \\
8 \\
5 \\
2 \\
3 \\
2 \\
11 \\
2 \\
0\end{array}$ & $\begin{array}{r}0 \\
9 \\
17 \\
0 \\
4 \\
0 \\
0 \\
4 \\
0 \\
0 \\
0 \\
5 \\
5 \\
3 \\
3 \\
0 \\
4 \\
7\end{array}$ & 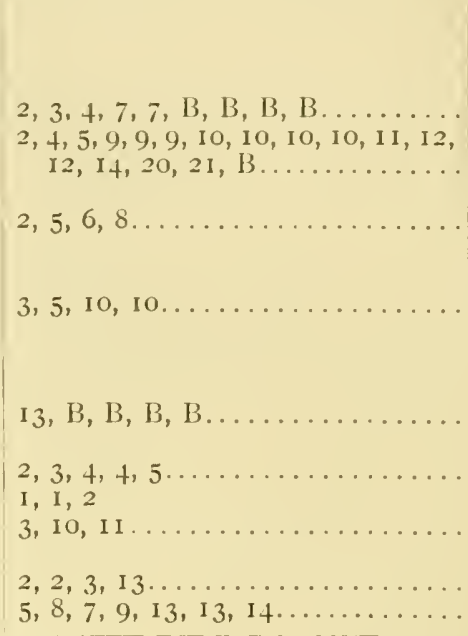 & $\begin{array}{c}\dagger \\
0.13 \\
0.03 \\
0.28 \\
0.21 \\
0.50\end{array}$ \\
\hline $\begin{array}{cc}\left(E_{3} \times A\right) & -6- \\
\text { No. } & 2 \ldots \ldots \\
" & 3 \ldots \ldots \\
" & 4 \ldots \ldots \\
& 6 \ldots \ldots\end{array}$ & $\begin{array}{l}\mathrm{B} \\
\mathrm{B} \\
\mathrm{B} \\
\mathrm{B}\end{array}$ & $\begin{array}{l}4 \\
4 \\
2 \\
1\end{array}$ & $\begin{array}{r}11 \\
20 \\
4 \\
5\end{array}$ & $\begin{array}{r}\text { I I } \\
20 \\
4 \\
5\end{array}$ & $\begin{array}{l}0 \\
0 \\
0 \\
0\end{array}$ & & \\
\hline 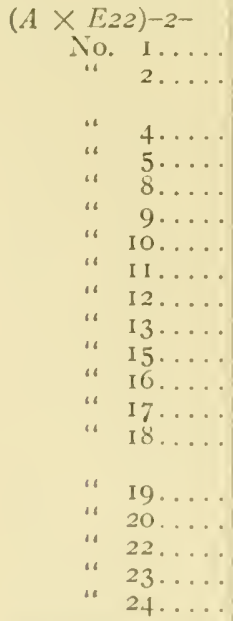 & $\begin{array}{l}\text { IV } \\
\text { B } \\
\text { B } \\
\text { B } \\
\text { IV } \\
\text { B } \\
\text { WV } \\
\text { B } \\
\text { I3 } \\
\text { IV } \\
\text { B } \\
\text { IV } \\
\text { IV } \\
\text { IV }\end{array}$ & $\begin{array}{l}2 \\
2 \\
2 \\
2 \\
3 \\
2 \\
3 \\
3 \\
2 \\
2 \\
1 \\
2\end{array}$ & $\begin{array}{r}10 \\
8 \\
11 \\
5 \\
7 \\
10 \\
9 \\
11 \\
6 \\
15 \\
10 \\
12\end{array}$ & $\begin{array}{r}2 \\
3 \\
10 \\
0 \\
3 \\
0 \\
9 \\
5 \\
6 \\
15 \\
10 \\
1 \\
8 \\
12 \\
3 \\
11 \\
8\end{array}$ & $\begin{array}{r}8 \\
5 \\
1 \\
5 \\
4 \\
10 \\
0 \\
6 \\
0 \\
0 \\
0 \\
\text { I I } \\
\\
0 \\
0 \\
8 \\
0 \\
0\end{array}$ & 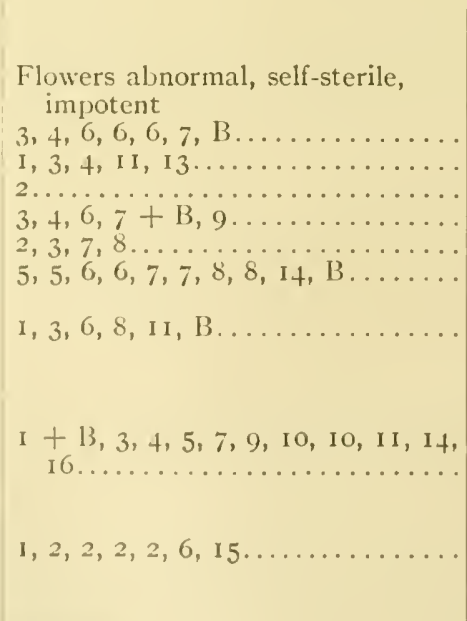 & $\begin{array}{l}0.19 \\
0.22 \\
0.01 \\
0.32 \\
0.16 \\
0.42 \\
0.15\end{array}$ \\
\hline
\end{tabular}

$\dagger \%$ not computed 
TABLE +-Continued

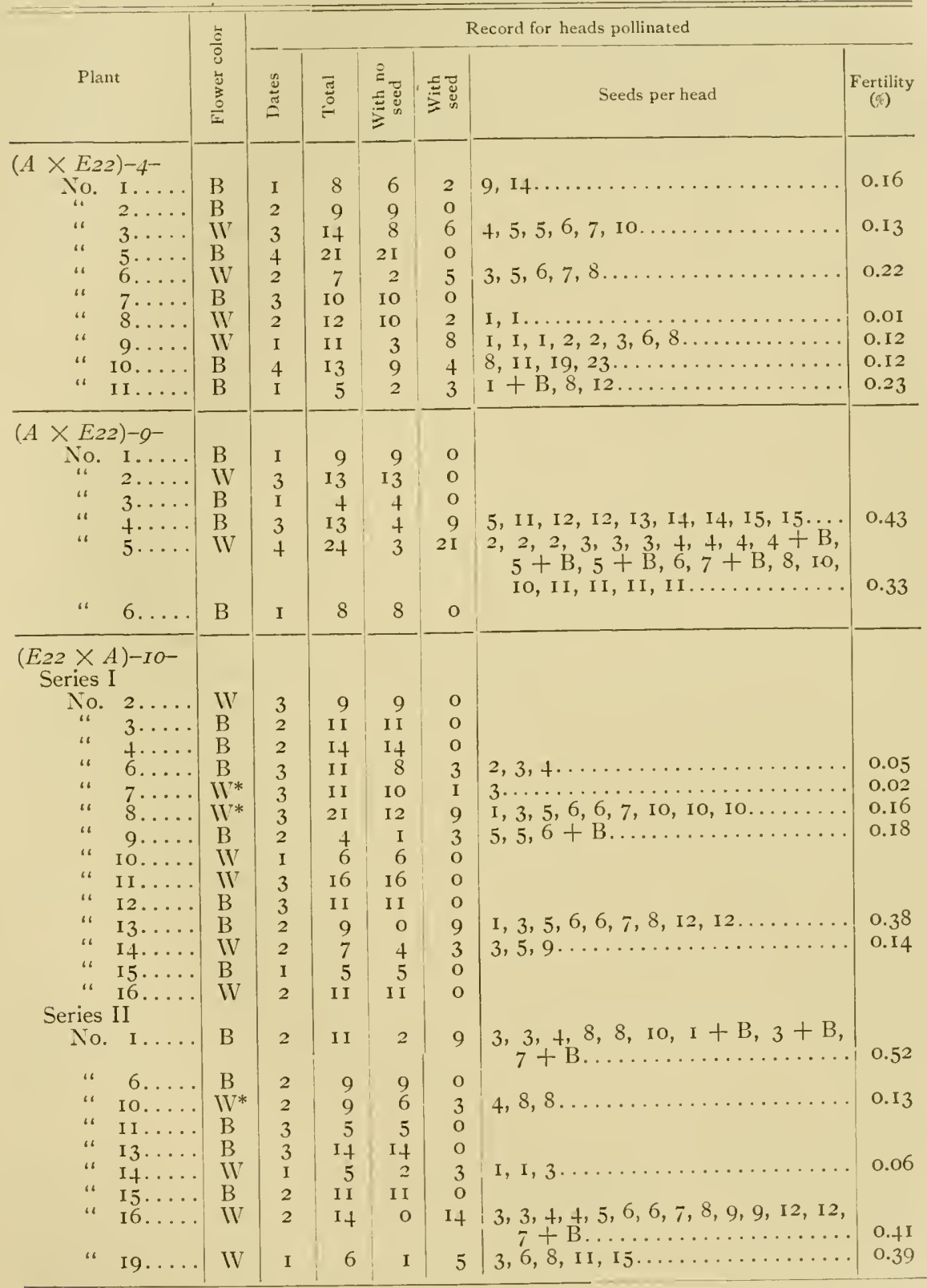

* Color of stamens variable 
The numbers of self-fertile and self-sterile plants are nearly equal for most of the series, giving a total of $4 \mathrm{I}$ self-sterile and 39 selffertile plants. The latter exhibit, as in the case of self-fertile plants of the preceding generation, degrees of self-fertility varying from high to very low, the average per plant, determined as already described, ranging from I per cent to 52 per cent.

The facts regarding the flower color of these $F_{2}$ hybrids are of interest as evidence of the actual occurrence of self-fertility. All the plants included in TABLE 4 are of the $F_{2}$ generation of crosses between the white-flowered wild plant $A$ and the blue-flowered plants nos. 3 and 22 of the cultivated chicory (E series). The $F_{1}$ parents were all bluc-flowered, the color locing a light-blue chicory with flowers frequently of a lavender-violet shade. The $F_{2}$ generation recorded in TABLE 4 split up in to 46 blue-flowered and 25 white-flowered plants. The shade of blue varied greatly among the blue-flowered plants and of the plants classed as whiteflowered 3 showed a noticeable variation from the usual type of white flower. The plants $A, B$, and $C$, and all the plants thus far grown from crosses between them, possess flowers that are pure white except for a decided and continuous blue stripe extending up the middle of each anther, making well-marked and conspicuous stripes in the ring of anthers. This is also the case in most blue-flowered plants in my cultures, although the stripes are here usually somewhat more intense. Plants $($ E22 $\times A)-1 O-$, nos. 7 and 8 of series I and no. $I O$ of series 2 , however, had flowers with the blue stripes much reduced, and in no. 7 there were only faint traces of them. In a general grouping of white-flowered and blueflowered, the splitting of this $F_{2}$ generation in respect to flower color does not very closely conform to the so-called Mendelian formula for a monohybrid ratio. The splitting in this generation, howerer, is indicative that the seed set by the $\mathrm{F}_{1}$ generation were the result of self-fertilization and not due to parthenogenesis which may hare developed.

Self-fertility and self-stcrility among plants of the $F_{3}$ generation grown from seed of self-fertile $F_{2}$ plants.-In I9 5 several pedigreed cultures were grown from self-fertilized seed obtained from various of the $F_{2}$ plants. The results of self-pollinations on these plants are tabulated in TABLE 5 . 
TABLE 5

Data For the SElF-pollinations of THE $\mathrm{F}_{3}$ GeNeration

\begin{tabular}{|c|c|c|c|c|c|c|c|}
\hline \multirow[b]{2}{*}{ Plant } & \multirow{2}{*}{ 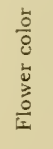 } & \multicolumn{6}{|c|}{ Record for heads pollinated } \\
\hline & & 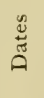 & : & 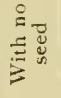 & 点莣 & Seeds per head & $\begin{array}{c}\text { Fertility } \\
\left.(\zeta)^{\prime}\right)\end{array}$ \\
\hline 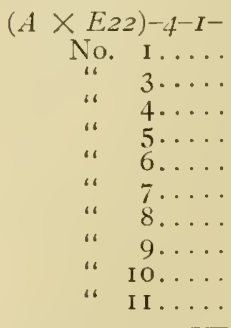 & $\begin{array}{l}\text { B } \\
\text { WV } \\
\text { B } \\
\text { B } \\
\text { B } \\
\text { B } \\
\text { WV } \\
\text { B } \\
\text { B } \\
\text { B } \\
\text { WV }\end{array}$ & $\begin{array}{l}2 \\
1 \\
2 \\
3 \\
2 \\
2 \\
2 \\
2 \\
2 \\
3\end{array}$ & $\begin{array}{r}2 \\
5 \\
8 \\
18 \\
9 \\
12 \\
17 \\
10 \\
16 \\
16\end{array}$ & $\begin{array}{r}2 \\
5 \\
8 \\
18 \\
9 \\
12 \\
17 \\
10 \\
16 \\
16\end{array}$ & $\begin{array}{l}0 \\
0 \\
0 \\
0 \\
0 \\
0 \\
0 \\
0 \\
0 \\
0\end{array}$ & & \\
\hline 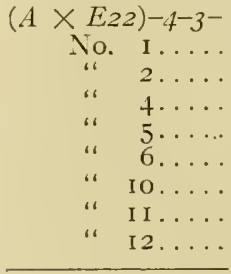 & $\begin{array}{l}\text { IV } \\
\text { WV } \\
\text { WV } \\
\text { IV } \\
\text { II } \\
\text { IV } \\
\text { IV } \\
\text { WV } \\
\text { WT }\end{array}$ & $\begin{array}{l}3 \\
2 \\
2 \\
6 \\
6 \\
2 \\
4 \\
5 \\
4 \\
4\end{array}$ & $\begin{array}{r}6 \\
5 \\
4 \\
9 \\
7 \\
10 \\
\text { I0 } \\
\text { I }\end{array}$ & $\begin{array}{r}2 \\
\mathrm{I} \\
\mathrm{I} \\
9 \\
5 \\
5 \\
3 \\
5 \\
\mathrm{I} \\
\end{array}$ & $\begin{array}{l}4 \\
4 \\
3 \\
0 \\
2 \\
7 \\
5 \\
0\end{array}$ & 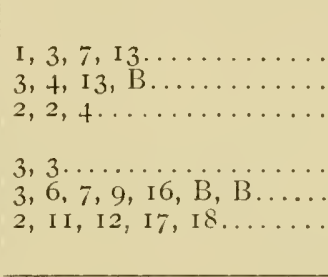 & $\begin{array}{l}0.21 \\
0.26 \\
0.11 \\
\\
0.05 \\
0.29 \\
0.32\end{array}$ \\
\hline 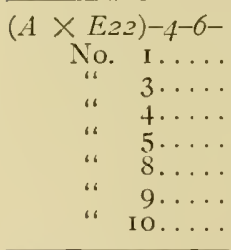 & $\begin{array}{l}\text { WV } \\
\text { WV } \\
\text { W } \\
\text { W } \\
\text { W } \\
\text { W } \\
\text { W } \\
\text { W }\end{array}$ & $\begin{array}{l}2 \\
2 \\
5 \\
2 \\
4 \\
3 \\
3\end{array}$ & $\begin{array}{r}8 \\
6 \\
\text { I I } \\
6 \\
7 \\
5 \\
4\end{array}$ & $\begin{array}{l}8 \\
1 \\
9 \\
6 \\
5 \\
5 \\
3\end{array}$ & $\begin{array}{l}0 \\
5 \\
2 \\
0 \\
2 \\
0 \\
\text { I }\end{array}$ & 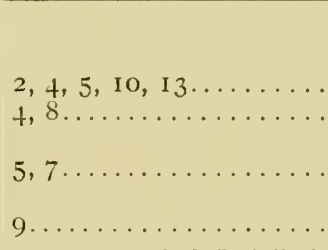 & $\begin{array}{l}0.31 \\
0.06 \\
0.10 \\
0.13\end{array}$ \\
\hline 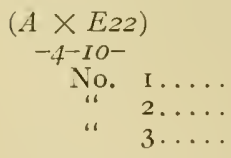 & $\begin{array}{l}\text { B } \\
\text { B } \\
\text { IV } \\
\text { II }\end{array}$ & $\begin{array}{l}2 \\
3 \\
2\end{array}$ & $\begin{array}{r}10 \\
9 \\
2\end{array}$ & $\begin{array}{r}10 \\
9 \\
2\end{array}$ & $\begin{array}{l}0 \\
0 \\
0\end{array}$ & 、 & \\
\hline 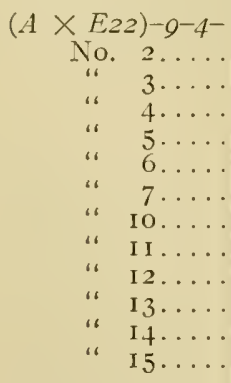 & $\begin{array}{l}B \\
B \\
B \\
B \\
B \\
B \\
B \\
\text { WV } \\
B \\
B \\
B \\
B \\
B\end{array}$ & $\begin{array}{l}2 \\
1 \\
\text { I } \\
5 \\
2 \\
2 \\
4 \\
5 \\
6 \\
1 \\
6 \\
6\end{array}$ & $\begin{array}{r}9 \\
9 \\
7 \\
7 \\
6 \\
4 \\
13 \\
11 \\
16 \\
6 \\
16 \\
10\end{array}$ & $\begin{array}{r}9 \\
9 \\
2 \\
6 \\
6 \\
3 \\
4 \\
4 \\
46 \\
16 \\
6 \\
16 \\
7\end{array}$ & $\begin{array}{l}0 \\
0 \\
5 \\
\text { I } \\
0 \\
\text { I } \\
9 \\
7 \\
0 \\
0 \\
0 \\
3\end{array}$ & $\begin{array}{l}\mathrm{I}, 2+B, 4,6,8 \ldots \ldots \\
\mathrm{I} \ldots \ldots \ldots \ldots \\
8 \ldots \ldots \ldots \\
1,2,2,2,4,4,5,6,10 \\
1,2,2,5,9,13, \mathrm{~B} \ldots \ldots\end{array}$ & $\begin{array}{l}0.20 \\
0.01 \\
\\
0.13 \\
0.17 \\
0.20\end{array}$ \\
\hline
\end{tabular}


TABLE 5-Continued

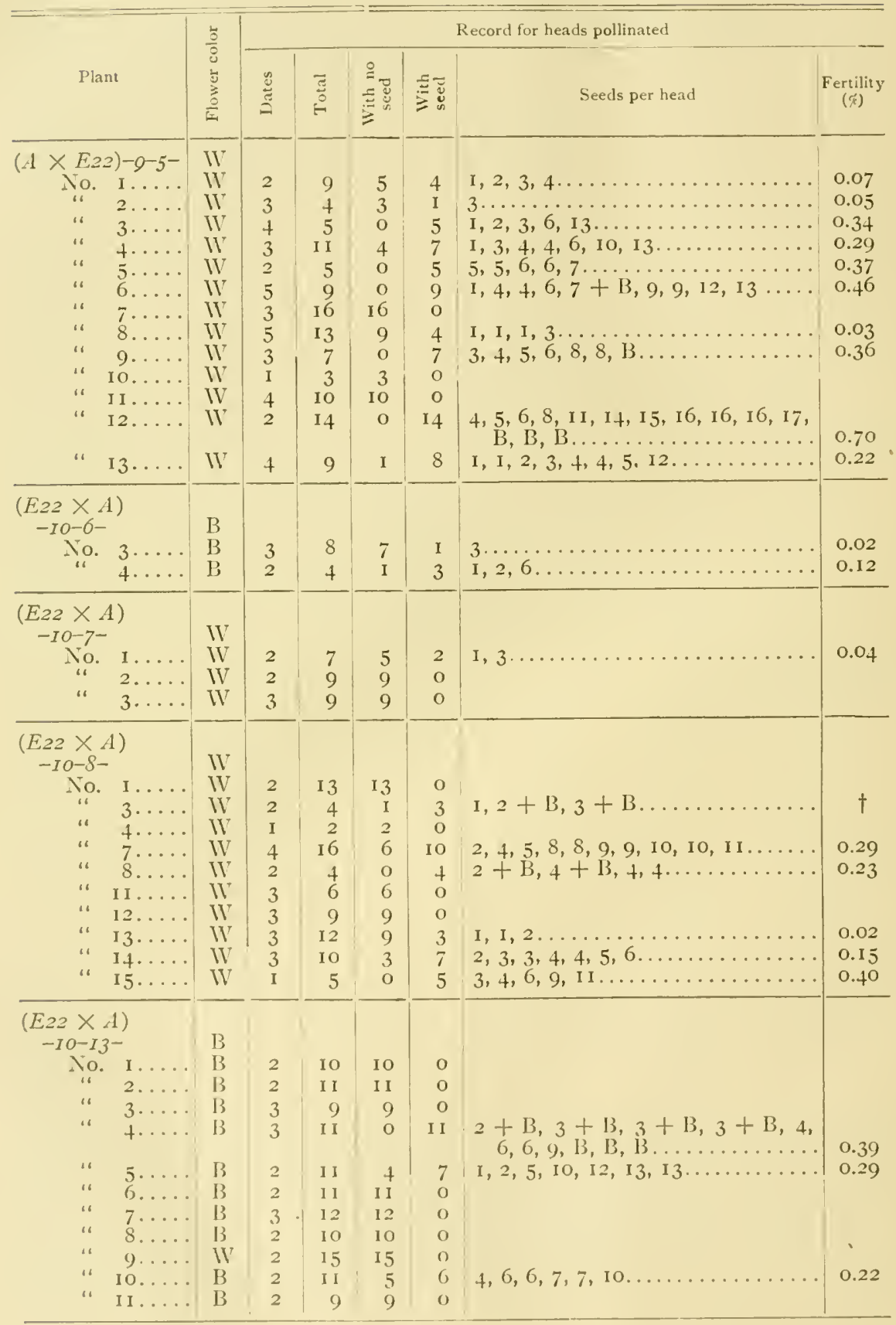


TABLE 5-Continued

\begin{tabular}{|c|c|c|c|c|c|c|c|}
\hline \multirow[b]{2}{*}{ Plant } & \multirow{2}{*}{ 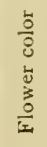 } & \multicolumn{6}{|c|}{ Record for heads pollinated } \\
\hline & & 岁 & 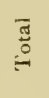 & 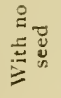 & 炡 & Seeds per head & $\underset{(\xi)}{\text { Fertility }}$ \\
\hline $\begin{aligned}(E 22 \times A) \\
-I 0-I 3- \\
\text { No. } \\
\text { “ } 12 . \\
\text { “ } 13 \\
\text { “ } 15 . \\
\text { " } 16 . \\
\end{aligned}$ & $\begin{array}{l}B \\
\text { WV } \\
B \\
B \\
B \\
B\end{array}$ & $\begin{array}{l}2 \\
3 \\
3 \\
2 \\
2\end{array}$ & $\begin{array}{r}7 \\
\text { I I } \\
\text { I } 2 \\
\text { I } 2 \\
\text { 1 } 2\end{array}$ & $\begin{array}{r}3 \\
0 \\
\text { 1 } 1 \\
12 \\
12\end{array}$ & $\begin{array}{r}4 \\
\text { II } \\
\text { I } \\
0 \\
0\end{array}$ & 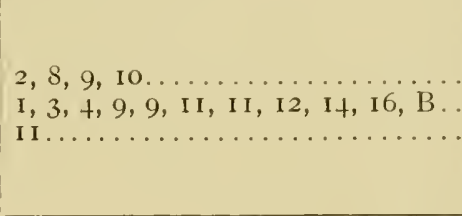 & $\begin{array}{l}0.25 \\
0.56 \\
0.01\end{array}$ \\
\hline 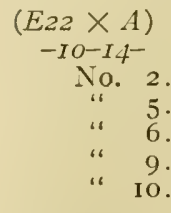 & $\begin{array}{l}\text { W } \\
\text { W } \\
\text { W } \\
\text { WV } \\
\text { W } \\
\text { WV }\end{array}$ & $\begin{array}{l}2 \\
2 \\
3 \\
2 \\
2\end{array}$ & $\begin{array}{r}9 \\
5 \\
7 \\
5 \\
13\end{array}$ & $\begin{array}{r}9 \\
5 \\
2 \\
2 \\
\mathrm{I} 3\end{array}$ & $\begin{array}{l}0 \\
0 \\
5 \\
3 \\
0\end{array}$ & $\begin{array}{l}1,3,3,4,5 \ldots \ldots \ldots \ldots \ldots \ldots \ldots \ldots \ldots \ldots \ldots \ldots \ldots \ldots \ldots \ldots \ldots \ldots \ldots \\
2,4,8, \ldots \ldots \ldots \ldots\end{array}$ & $\begin{array}{l}\text { O.I3 } \\
\text { O.II }\end{array}$ \\
\hline
\end{tabular}

A glance at this table shows that the families in the third generations exhibit much the same sort of behavior in respect to fertility and sterility as did the preceding generation. No series in which more than two plants were grown was composed of plants all of which were self-fertile. One series, $(A \times E 22)-4^{-I-}$, was composed of 10 plants all of which were self-sterile; $(A \times E 22)-4-3-$ was composed of 2 self-sterile and 6 self-fertile plants, and (E22 $\times A)-I O-I 3-$ had IO self-sterile and 6 self-fertile plants. Taken as a whole, there were 46 self-sterile and 43 self-fertile plants; 48 per cent of the plants were self-fertile in some degree. Of the preceding generation 39 out of 80 plants were self-fertile, à percentage of 48 . In both generations, considered as a whole, the number of self-sterile plants was slightly greater than those selffertile, but the ratio of the two was the same.

In respect to the degree of self-fertility exhibited by individual self-fertile plants of this $F_{3}$ generation, as judged by the seed set in the controlled self-pollinations, there were all degrees ranging from high self-fertility ( 70 per cent in the plant $(A \times E 22)-9-5-n o . I 2)$ to very feeble self-fertility, both in reference to percentage of heads giving seed and to the number of seeds in the heads. On the individual record the different plants exhibit varying degrees of self-fertility quite the same as was seen in the $F_{1}$ and the $F_{2}$ generations, but with a few plants with a higher percentage. 
Here as in the $\mathrm{F}_{2}$ the inheritance of flower color is evidence that seed-setting is the result of self-fertility and is not due to parthenogenesis or to stray pollinations resulting from experimental error. Six of the series were from $\mathrm{F}_{2}$ white-flowered plants and all of these were composed of white-flowered plants, although it should be stated that there was considerable variation in respect to the development of blue stripes on the anthers. The fact that $F_{2}$ white-flowered plants gave only white-flowered progeny is evidence that the seed from which they grew was not the result of accidental cross-pollination. The five other series of the $F_{3}$ were from $\mathrm{F}_{2}$ blue-flowered plants, and, with one exception (which is series (E22 $\times A)-I O-6$ - of only two plants), the progeny split up, giving a total of 33 blue-flowered and 8 white-flowered plants. This we may also consider as evidence of self-fertilization.

Summary of the $F_{1}, F_{2}$, and $F_{3}$ generations.-For purposes of summary and comparison the data for the three generations and for certain families are presented in TABLE 6 . Here the frequency distribution is given with the plants grouped in classes on the basis of their self-fertility; the average fertility for the selffertile plants and for the entire generation or series is computed from the actual percentages already given in TABLES 3,4 , and 5 . One of the $F_{2}$, and one of the $F_{3}$ self-fertile plants are not included in this distribution because data on the seed number are not complete due to the gathering of seed by birds. It is fully recognized that a larger number of pollinations might change the results in numerous cases, that plants which appear self-sterile may in reality be but very fecbly fertile, and that some of the seed-setting in cases of very low fertility may be due to stray pollinations. The number of plants in the $\mathrm{F}_{2}$ and the $\mathrm{F}_{3}$ generation is nearly the same, and the methods of manipulation used were quite identical, so it would appear that such a comparison can quite properly be made.

In the first generation, 15 plants out of 172 were self-fertile in some degree; the average percentage for the 14 plants upon which flower data are arailable was I1.6, and the percentage for the entire generation was 0.94 . The $F_{2}$ which was grown from selffertile parents and in which selection for self-fertility lirst appeared gave 39 self-fertile plants and 4 I self-sterile plants; the average fertility (of 38 plants as figured) is $2 \mathrm{I} .9$ per cent and that of the 
entire generation is 9.9 per cent. The third generation gave 46 self-sterile and 43 self-fertile plants; the average fertility of the generation is 9.9 per cent and that of the self-fertile plants is 2 I.I per cent.

TABLE 6

SUMmary of $F_{1}, F_{2}$ ANd $F_{3}$ Generations

\begin{tabular}{|c|c|c|c|c|}
\hline & $\begin{array}{c}\text { Total } \\
\text { number } \\
\text { of } \\
\text { plants }\end{array}$ & 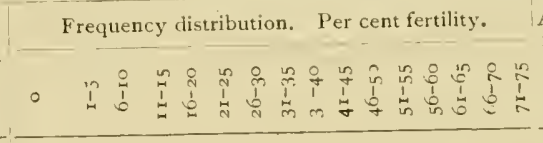 & $\begin{array}{l}\text { Average } \\
\text { fertility } \\
\text { of self- } \\
\text { fertile } \\
\text { plants }\end{array}$ & $\begin{array}{l}\text { Average } \\
\text { fertility } \\
\text { of all } \\
\text { plants }\end{array}$ \\
\hline $\begin{array}{l}\cdots \\
\cdots \\
\cdots \\
\cdots\end{array}$ & $\begin{array}{l}172^{*} \\
80^{*} \\
89^{*}\end{array}$ & 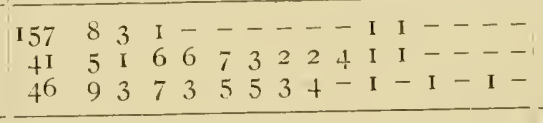 & $\begin{array}{l}0.1 \text { I } 6 \\
0.219 \\
0.2 \text { II }\end{array}$ & $\begin{array}{l}0.0094 \\
0.099 \\
0.099\end{array}$ \\
\hline $\mathrm{F}_{1}, \mathrm{~F}_{2}, \mathrm{~F}_{3} \ldots \ldots \ldots \ldots \ldots$ & $3+^{I}$ & $2+4227 \mathrm{I}+9 \mathrm{I} 2856+32 \mathrm{I}-\mathrm{I}-$ & 0.199 & 0.074 \\
\hline $\begin{array}{l}\mathrm{F}_{1} \text { plant }\left(E_{3} \times A\right) \text { No. }+ \\
\mathrm{F}_{2} \quad\left(E_{3} \times A\right)-4^{-} \\
\end{array}$ & $\overline{1} 8^{*}$ & 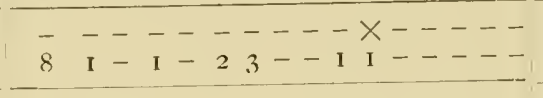 & $\begin{array}{l}0.4^{8} \\
0.26\end{array}$ & $0.13^{8}$ \\
\hline $\begin{array}{l}\mathrm{F}_{1} \text { plant }\left(A \times E_{22}\right) \text { No. } 2 \\
\mathrm{~F}_{2} \quad\left(A \times E_{22}\right)-2-\end{array}$ & 19 & $\begin{array}{l}X--1--1 .-1-1 \\
\mathrm{I}-\mathrm{I} 3 \mathrm{I}-\mathrm{I}-\mathrm{I}-\mathrm{I}----\end{array}$ & $\begin{array}{r}0.06 \\
0.2+ \\
\end{array}$ & o. I I 2 \\
\hline 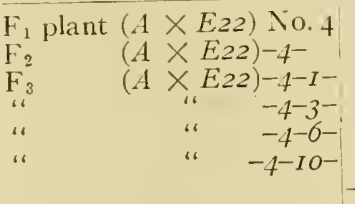 & $\begin{array}{r}- \\
10 \\
10 \\
8 \\
7 \\
3 \\
\end{array}$ & 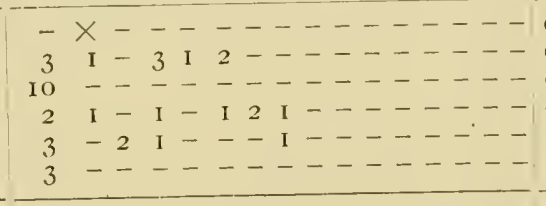 & $\begin{array}{l}0.04 \\
0.1+1 \\
0.000 \\
0.206 \\
0.150 \\
0.000\end{array}$ & $\begin{array}{l}0.099 \\
0.000 \\
0.155 \\
0.085 \\
0.000\end{array}$ \\
\hline Summary............ & 38 & 2 I 22255 I $3222 \quad \ldots$ & 0.201 & $0.07 t$ \\
\hline 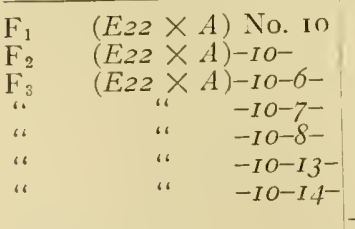 & $\begin{array}{c}- \\
23 \\
2 \\
3 \\
10^{*} \\
16 \\
5 \\
\end{array}$ & $\begin{array}{rrrrr}- & \overline{1} & - & - & -\end{array}$ & $\begin{array}{l}0.5 \mathrm{I} \\
0.197 \\
0.070 \\
0.040 \\
0.2 \mathrm{I} 8 \\
0.236 \\
0.120\end{array}$ & $\begin{array}{l}0.094 \\
0.070 \\
0.013 \\
0.121 \\
0.107 \\
0.048\end{array}$ \\
\hline Summary........ & 59 & 316 I $62+2-4$ I - I $-\cdots$ & 0.200 & 0.093 \\
\hline
\end{tabular}

* One self-fertile plant not included in frequency distribution or in averages.

It is quite evident that there is close agreement in the $F_{2}$ and $F_{3}$ generations both in the proportion of self-fertile plants and in the average percentage fertility of the same. In both respects these generations are decidedly higher than the $F_{1}$. A glance at the distribution shows that in all three generations the distribution is decidedly skew and rather irregular, with the largest number of plants in the self-sterile class and in the classes showing low self-fertility. In the $F_{1}$ there were only two plants haring higher percentage of fertility than 13 per cent, and these show 
48 per cent and $5 \mathrm{I}$ per cent. In the $\mathrm{F}_{2}$ and $\mathrm{F}_{3}$ there was a more general and graded distribution between the extremes, but in the $\mathrm{F}_{3}$ two plants exhibited a percentage of 56 and 70 , the latter being a decided advance over any plant of previous generations. Considering the three generations together, the frequency curve becomes more regularly skew with large numbers of individuals in the self-sterile class and fewer numbers in the successive classes leading to higher self-fertility. While the average percentage of the $F_{3}$ is not higher than that of the $F_{2}$, there are certain plants with decidedly increased self-fertility.

A further point of considerable significance in respect to the heredity of self-fertility pertains to the relative behavior of families derived from parents which had decidedly different degrees of self-fertility. Progenies of the two plants of the $F_{1}$ showing high self-fertility were grown. Of I 8 descendants of $\left(E_{3} \times A\right)$ no. 4 , only 1o were self-fertile with an average percentage of 26 ; for the 9 for which data were secured I plant showed a fertility of 50 per cent and another of 43 per cent. From $(E 22 \times A) n o$. IO, in an $\mathrm{F}_{2}$ generation of 23 plants only I I were self-fertile with an average percentage of i 9.7 and with no plant as strongly self-fertile as the parent. The $\mathrm{F}_{3}$ progenies continued from 5 of the $\mathrm{F}_{2}$ plants of this family, as summarized in TABLE 6 , gave rather irregular results, but with the average of each series decidedly lower than that of the grandparent. The total averages are 20.I per cent for the self-fertile plants, and 9.3 per cent for all plants, which is only slightly above that for the entire $F_{1}, F_{2}$, and $F_{3}$ populations.

In comparison with these, the progenies of plants exhibiting low self-fertility showed no appreciable differences in fertility. For example, the progeny of $(A \times E 22)$ no. 2, a plant only 6 per cent self-fertile, gave 9 self-fertile plants out of 19 with an arerage percentage of 24 and a range extending to 52 per cent. Likewise the $\mathrm{F}_{2}$ from $\left(A \times E_{22}\right)$ no. 4 showed an average fertility of $\mathrm{I}_{4} . \mathrm{I}$ per cent and the $F_{3}$ an average of 18.5 per cent with the total average quite like that of families derived from parents highly fertile.

Offspring from $\mathrm{F}_{2}$ plants, either highly or feebly self-fertile, behave quite similarily and regress in marked manner toward the average of the $F_{2}$ generation. The higher averages for inclividuals or for lines of progeny occur without direct relation to the percentage fertility of the immediate parentage. 
TABLE 7

RECORD FOR SELF-POLLINATIONS OF THE CULTURES OF "IMPROVED RED-LEAVED TREVISO"

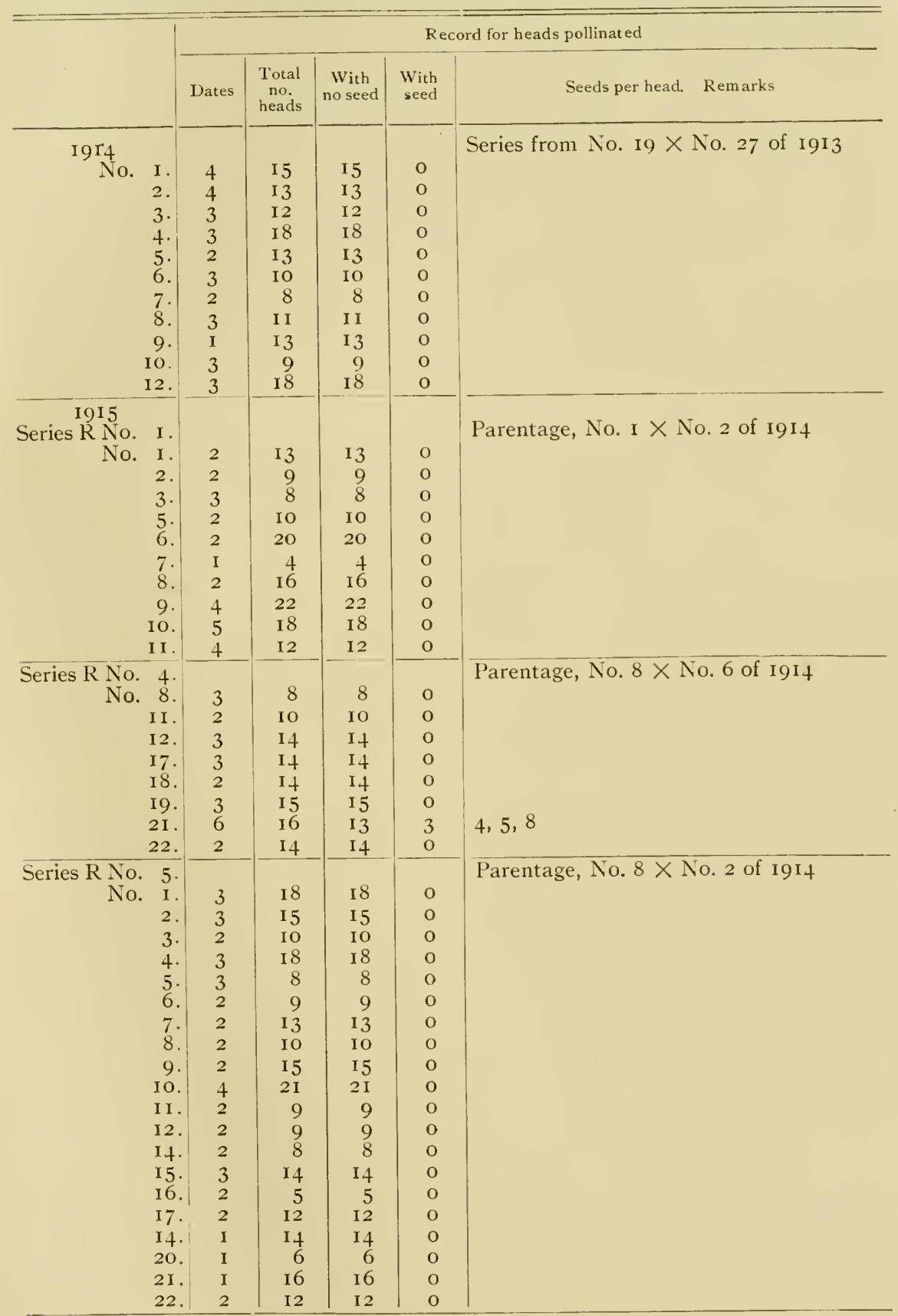


In the study of the self-fertility of the $\mathrm{F}_{1}, \mathrm{~F}_{2}$, and $\mathrm{F}_{3}$ generations, comprising a total of $34^{\mathrm{I}}$ plants, controlled self-pollinations were made on 3, Ifo flower heads, which involved a total of at least 55,000 individual flowers.

Self-sterility and self-fertility in the variety "improved red-leaved Trei'iso."-It has already been stated in this paper that as far as tested the plants of eleven cultivated varieties grown in I9I3 were fully self-sterile. Several plants of the variety red-leared Treviso grown in that year were fasciated. Cross-fertilized seed was obtained between two of these from which pedigreed progenies have been grown for two generations with the special aim of determining the hereditary behavior of the fasciation. The 49 plants thus grown were quite fully tested for self-fertility as shown in the data compiled in TABLE 7 .

The eleven sister plants grown in I9It were completely selfsterile. The smallest number of heads self-pollinated on any one plant was 8 and the largest I 8 , but in no case was a single seed set. Cross-pollinations between certain of these plants were successful, giving seed for a crop in I9I5, of which 38 plants were tested for self-fertility. Only one of these plants showed any trace of selffertility and this plant (no. 2 I of series 4, I9I5) was but feebly self-fertile, setting 4,5 , and 8 seeds, judged to contain embryos, in 3 out of 16 heads manipulated. These data indicate that in this variety self-sterility prevails, but that an occasional instance of self-fertility may arise.

In respect to fasciation, leaf-shape, degree of red pigmentation, and various other characters the plants of each generation showed wide variation. In the $\mathrm{F}_{2}$ generation a few plants were not fasciated. They were all quite similar in general vigor, habit of growth, and flower color, but otherwise there were such wide variations that the race must be considered as decidedly impure.

These plants were derived by inbreeding within a single variety and constitute the only intravarietal breeding that I have conducted with chicory unless the one generation of progeny from $A \times C$ is to be thus considered. In both cases, however, the self-sterility is almost absolute and cross-sterility is high. Such evidence raises the question whether cross-breeding between selfsterile plants of strains and varieties that are not of close blood relationship favors the development of compatibility according to 
Darwin's contention regarding fertility in general, or whether inbreeding and self-fertilization of pure races or strains gives the greater fertility as Burck argues. Neither Darwin nor Burck considered in this connection the sort of sterility (from physiological incompatibility) seen in chicory.

Self-sterility in hybrids between a wild white-flowered plant and a plant of the "improved striped-leaf" variety.-Further data on the point just mentioned were gained from $\mathrm{F}_{1}$ plants obtained by crossing a white-flowered plant $(A \times C)$ no. $I$ with a plant of the variety known as the "improved striped-leaf." The five plants of this variety which were tested were fully self-sterile. The parent used in this cross was one of the plants tested. The cross was originally

TABLE 8

DATA FOR SElF-POLLINATIONS OF F 1 PLANTS GROWN FROM A CROSS BETWEeN $(A \times C)$ No. I AND A PLANT OF THE VARIETY "IMIPROVED STRIPED-LEAF"

\begin{tabular}{|c|c|c|c|c|c|c|}
\hline & \multirow[b]{2}{*}{ Plant } & \multicolumn{5}{|c|}{ Record for heads pollinated } \\
\hline & & Dates & $\begin{array}{c}\text { Total } \\
\text { no. } \\
\text { heads }\end{array}$ & $\begin{array}{c}\text { Heads } \\
\text { with no } \\
\text { seed }\end{array}$ & $\begin{array}{l}\text { Heads } \\
\text { with } \\
\text { seed }\end{array}$ & Remarks \\
\hline $\begin{array}{c}\text { No. } \\
\text { "6 } \\
\text { " } \\
\text { " } \\
\text { "6 } \\
\text { " } \\
\text { "6 } \\
\text { " } \\
\text { "6 } \\
\text { " } \\
6\end{array}$ & 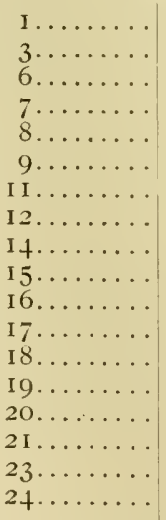 & $\begin{array}{l}3 \\
4 \\
2 \\
2 \\
3 \\
3 \\
2 \\
2 \\
2 \\
2 \\
2 \\
3 \\
1 \\
3 \\
1 \\
3 \\
1 \\
2\end{array}$ & $\begin{array}{r}\text { I } 1 \\
\text { I } 8 \\
\text { I } 2 \\
8 \\
23 \\
\text { I I } \\
\text { I } 2 \\
\text { I } 2 \\
\text { I } 7 \\
\text { I } 2 \\
\text { I I } \\
\text { IO } \\
\text { I I } \\
\text { I I } \\
9 \\
\text { I } 2 \\
\text { I } 2 \\
\text { I } 4\end{array}$ & $\begin{array}{r}\text { I I } \\
\text { I } 8 \\
\text { I } 2 \\
8 \\
23 \\
\text { I I } \\
\text { I } 2 \\
\text { I } 2 \\
\text { I } 7 \\
\text { I } 2 \\
\text { I I } \\
\text { I O } \\
\text { I I } \\
\text { I I } \\
9 \\
\text { I } 2 \\
\text { I } 2 \\
\text { I } 4\end{array}$ & $\begin{array}{l}0 \\
0 \\
0 \\
0 \\
0 \\
0 \\
0 \\
0 \\
0 \\
0 \\
0 \\
0 \\
0 \\
0 \\
0 \\
0 \\
0 \\
0\end{array}$ & Series with $(A \times C)$ no. I as seed-parent. \\
\hline $\begin{array}{l}\text { "6 } \\
\text { "6 } \\
\text { " } \\
\text { " } \\
\text { " } \\
\text { " } \\
" 1 \\
" 1 \\
\text { " }\end{array}$ & 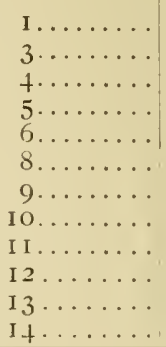 & $\begin{array}{l}\text { I } \\
2 \\
3 \\
2 \\
3 \\
3 \\
2 \\
3 \\
2 \\
1 \\
2 \\
\text { I }\end{array}$ & $\begin{array}{r}3 \\
8 \\
\text { I } 6 \\
\text { I } 7 \\
\text { I I } \\
\text { I I } \\
\text { I } 4 \\
\text { I } 5 \\
\text { I I } \\
5 \\
8 \\
6\end{array}$ & $\begin{array}{r}3 \\
8 \\
\text { I } 6 \\
\text { I } 7 \\
\text { I I } \\
\text { I I } \\
\text { I } 4 \\
\text { I } 5 \\
\text { I I } \\
5 \\
8 \\
6\end{array}$ & $\begin{array}{l}0 \\
0 \\
0 \\
0 \\
0 \\
0 \\
0 \\
0 \\
0 \\
0 \\
0 \\
0\end{array}$ & Series with $(A \times C)$ no. I as pollen-parent \\
\hline
\end{tabular}


made to test the inheritance of red coloration. The plant $(A \times C)$ no. $I$, as were its parents $A$ and $C$, was without any apparent trace of red coloration in leaves and stems, while in the leaves and stems of the "improved striped-leaf" plants there was a very strong red coloration. Of the $F_{1}$ generation a total of 30 plants tested proved to be completely self-sterile as is shown in TABLE 8 .

These plants were all blue-flowered, but they showed almost every conceivable variation in respect to the amount and distribution of red coloration. As there were no self-fertile plants, further generations were not grown. The complete self-sterility of the plants of the generation grown is, however, an indication that crossing between widely separated strains does not necessarily give the development of self-fertility.

In the various self-pollinations that have been made, a total of 63I plants have been tested for self-sterility; the number of flower heads manipulated is about 4,100, and the number of flowers concerned is hence about 74,000 . The studies were at first quite general for wild plants and for plants of eleven different cultivated varieties whose pedigrees were not known. The later studies, which embrace the greater number of plants, were made on plants of pedigreed stock, as will appear from the foregoing data.

\section{Phenomena of physiological inter-incompatibility AND COMPATIBILITY}

During the experimental work of 1912 it became evident that cross-fertility such as has been reported in TABLE 2 does not alway's occur in Cichorium, and that not only is there self-sterility, but also cross-sterility, quite as Correns ('12) afterward reported for Cardamine.

Results of crosses involving $A$ and various of its progeny.--Several crosses attempted in 1912 between wild white-flowered plants grown from seed of the plant $A$ completely failed. On this account opportunity was taken during the summer of I9I 3 to test the behavior of certain sister plants when crossed among themselves and with a parent plant. For this purpose 8 plants, all white-flowered and derived from open-fertilized sced of the plant $A$, were tested as fully as the conditions allowed. These plants were in their second year of growth and had all proven to 
be self-sterile in the experiments of the previous year, data for which are given in TABLE $\mathrm{I}$. The data for the crosses attempted with these plants are given in TABLE 9.

TABLE 9

DATA FOR CROSSES INVOLVING PLANT $A$ AND VARIOUS OF ITS PROGENY DERIVED BY OPENPOLLINATION

\begin{tabular}{|c|c|c|c|c|c|}
\hline & \multicolumn{5}{|c|}{ Record for heads pollinated } \\
\hline & Dates & $\begin{array}{l}\text { Total } \\
\text { no. } \\
\text { heads }\end{array}$ & $\begin{array}{l}\text { Hearls } \\
\text { with no } \\
\text { seed }\end{array}$ & $\begin{array}{c}\text { Heads } \\
\text { with } \\
\text { seed }\end{array}$ & Number of seeds per head \\
\hline$A \times A 7 \ldots \ldots$ & 2 & 7 & 2 & 5 & $3,5,7,8,9$ \\
\hline$" A 8 \ldots \ldots$ & 2 & 5 & I & 4 & 7,8, I 7, I 7 \\
\hline "Ag..... & I & IO & o & IO & 7,9, I0, I0, I I, I3, I 3, I 3, I 5, I 7 \\
\hline "AI7.... & 2 & I6 & I 6 & o & \\
\hline "Arg..... & 2 & I 2 & I 2 & 0 & \\
\hline$" A 23 \ldots \ldots$ & 2 & IO & IO & 0 & \\
\hline "A27.... & 2 & I5 & I & It & $3,3,3,6$, I I, I I , I 2, I 3, I $3, I_{4}$, I 4, I 5, I 5, I 5 \\
\hline$A 7 \times A \ldots \ldots$ & 6 & 30 & 30 & o & \\
\hline "A8.... & 2 & I I & I I & 0 & \\
\hline "Ag..... & 2 & I I & 0 & I I & $2,4,6,6,6,8,8,8,9$, Іо, І I \\
\hline "Arg.... & 2 & I 7 & 17 & o & \\
\hline$" A 23 \ldots$ & I & 7 & 7 & 0 & \\
\hline "A27... & I & 4 & 2 & 2 & 5 , I I \\
\hline$A 8 \times A \ldots \ldots$ & 4 & I3 & I 2 & I & IO \\
\hline "A7.... & 2 & 7 & 7 & o & \\
\hline "A9..... & I & 4 & 2 & 2 & $5, \mathrm{I} 4$ \\
\hline "AI7.... & 2 & IO & Io & o & \\
\hline "AIg.... & I & 9 & 9 & o & \\
\hline "A23.... & I & IO & Io & 0 & \\
\hline "A27, . . & I & 5 & 3 & 2 & 6,7 \\
\hline$A_{9} \times A_{16} \ldots \ldots$ & 3 & I 4 & 3 & I I & 5,5, I I, I 2, I $3, \mathrm{I}_{3}, \mathrm{I} 3, \mathrm{I} 4, \mathrm{I} 5$, I 8, I 8 \\
\hline "AIg.... & I & 4 & 3 & I & 5 \\
\hline "A27... & I & 4 & 4 & o & \\
\hline$A I 7_{6} \times A \ldots \ldots$ & 3 & I I & I I & o & \\
\hline & 2 & IO & 6 & 4 & $I, 3,5,6$ \\
\hline “A8.... & 2 & 9 & 5 & 4 & $3,6,7,8$ \\
\hline & 2 & 9 & 8 & I & I \\
\hline " $A 23 \ldots$ & $\begin{array}{l}1 \\
2\end{array}$ & $\begin{array}{r}8 \\
12\end{array}$ & $\begin{array}{l}8 \\
6\end{array}$ & $\begin{array}{l}0 \\
6\end{array}$ & \\
\hline$A I Q \times A \ldots \ldots$ & 2 & 8 & 8 & 0 & $3,4,5,5,7,9$ \\
\hline "A7... & I & 9 & 8 & I & IO \\
\hline “ $A \delta \ldots$ & I & 8 & 6 & 2 & 6,6 \\
\hline "A27... & I & 10 & 2 & 8 & $5,6,7,7,7,8$, I I, I I \\
\hline$A 23 \times A \ldots \ldots$ & 2 & IO & IO & 0 & \\
\hline " $A 7 \ldots$. & 3 & I4 & I I & 3 & $2,3, \mathrm{I} 3$ \\
\hline A8..... & I & 8 & 6 & 2 & 4,7 \\
\hline Ag..... & 2 & IO & 2 & 8 & $7,7,8,8$, I I, I 2, I 4, I 5 \\
\hline "AI9... & I & 5 & 5 & 0 & \\
\hline$A 27 \times A \ldots \ldots$ & I & 7 & 5 & 2 & IO, I 2 \\
\hline " $\quad A 8 \ldots \ldots$ & I & 2 & 0 & 2 & I, 2 \\
\hline Ag..... & I & 6 & I & 5 & $2, \mathrm{II}, \mathrm{I} 3, \mathrm{I} 4, \mathrm{I} 6$ \\
\hline "AI9... & I & 5 & 0 & 5 & $6,7, \mathrm{I} I, \mathrm{I} 2, \mathrm{I} 2$ \\
\hline " $A 23 \ldots$ & I & 5 & 3 & 2 & 6,9 \\
\hline
\end{tabular}

No one plant involved in these experiments proved to be either fertile or sterile to all plants with which it was crossed. The 26 
plant $A$ as a seed parent was fertile to + and sterile to 3 ; as a pollen parent it was fertile with 3 and sterile with + . The plant $A 7$ as a seed-parent was fertile with 2 and sterile with 3 of the sister plants, and also sterile with the parent $A$; as a pollen-parent it was sterile with $\mathbf{I}$, and fertile with 3 of the sister plants and also fertile with $A$. The plant $A I_{7}$ as a seed-parent was fertile to 4 sister plants and sterile to one and with the parent $A$; as a pollenparent it was sterile to one sister and to the parent $A$, which were the only two cases attempted.

In most cases the data are fully conclusive for positive or negative results, but there were numerous instances of feeble cross-fertility, giving results quite similar to the cases of feeble self-fertility already reported. In some cases, as in the $A 8 \times A$ combination, where only one head out of thirteen set seed, there may have been an experimental error. The evidence is clear, however, that cross-incompatibility exists among these plants and that among those which are compatible varying degrees of such a condition may exist.

TABLE 9 includes data on I 6 reciprocal crosses; 7 pairs between parent $A$ with I of its offspring and 9 pairs between sister plants. Nine of these gave similar results; 5 pairs were fertile and 4 pairs were sterile. In 7 pairs, however, the reciprocals were different. These cases are of special interest and are collected in TABLE 10.

The parent plant $A$ was fertile to the pollen of $A 7$, but the reciprocal was sterile. When it appeared from the seed produced that this was the condition, the pollinations of $A 7$ were continued until 30 heads of $A 7$ were pollinated with pollen from plant $A$, but not a single seed was produced. Pollen of plant $A$ was effective on plants $C, E_{3}$, and $E_{22}$ (see TABLE 2) and on plants $A 9$ and $A 27$ (TABLE 8 ); also the plant $A 7$ produced seed abundantly to pollen of $A$ g besides setting abundant seed to open pollination, so it is clear that impotency was not involved and that the compatibility is different for the reciprocals. The results in the case of $A g \times$ $A 27$ and $A S \times A I 7$ are quite decisive, although a smaller number of heads were tested. In the other four cases the fertility of the one reciprocal was low in that a small proportion of heads set seed; here the fertility was of the grade cuite comparable to the frequent cases of feeble self-fertility already reported. It is, however, to be recognized that as already stated such results may 
TABLE IO

RECIPROCAL CROSSES GIVING DIFFERENT RESULTS

\begin{tabular}{|c|c|c|c|c|c|c|}
\hline & \multirow[b]{2}{*}{$\begin{array}{c}\text { Heads } \\
\text { with no } \\
\text { seed }\end{array}$} & \multirow[b]{2}{*}{$\begin{array}{l}\text { Heads } \\
\text { with } \\
\text { seed }\end{array}$} & \multirow[b]{2}{*}{ Seeds per head } & \multicolumn{3}{|c|}{ Data for the reciprocal } \\
\hline & & & & $\begin{array}{c}\text { Heads } \\
\text { with no } \\
\text { seed }\end{array}$ & $\begin{array}{l}\text { Heads } \\
\text { with } \\
\text { seed }\end{array}$ & Seeds per head \\
\hline 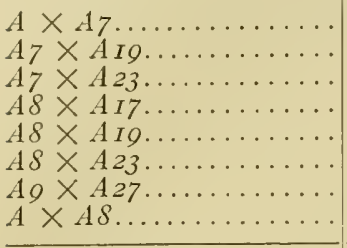 & $\begin{array}{r}2 \\
17 \\
7 \\
\text { I0 } \\
9 \\
\text { I0 } \\
4 \\
\text { I }\end{array}$ & $\begin{array}{l}5 \\
0 \\
0 \\
0 \\
0 \\
0 \\
0 \\
4\end{array}$ & $3,5,7,8,9$ & $\begin{array}{r}30 \\
8 \\
\text { I I } \\
5 \\
6 \\
6 \\
\text { I } \\
\text { I } 2\end{array}$ & $\begin{array}{l}0 \\
\text { I } \\
3 \\
4 \\
2 \\
2 \\
5 \\
1\end{array}$ & $\begin{array}{l}\text { I0 } \\
2,3,13 \\
3,6,7,8 \\
6,6 \\
4,7 \\
2,11,13,14,16 \\
\text { IO }\end{array}$ \\
\hline 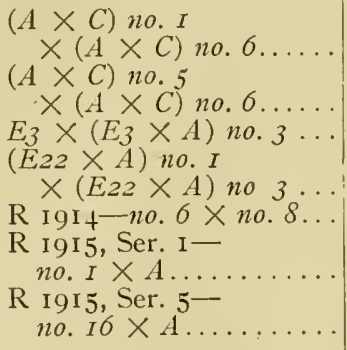 & $\begin{array}{l}4 \\
6 \\
5\end{array}$ & $\begin{array}{l}2 \\
\text { I } \\
3 \\
\text { I } \\
0 \\
0\end{array}$ & $\begin{array}{l}2,5 \\
2 \\
I, 4,5 \\
3\end{array}$ & $\begin{array}{l}10 \\
4 \\
4 \\
5 \\
3 \\
3\end{array}$ & $\begin{array}{l}0 \\
0 \\
0 \\
0 \\
6 \\
2\end{array}$ & $\begin{array}{l}\text { 6, 8, IO, IO, I I, I } 2 \\
\text { IO, I } 3\end{array}$ \\
\hline
\end{tabular}

involve in some instances an experimental error. There were also cases such as the cross $A \times A 8$ in which one reciprocal was strongly fertile and the other very feebly fertile. Seven other reciprocals, reported in detail in later tables, have given different results and these cases are included here. In these, as a rule, the fertile combination is only feebly fertile, and while the results in some cases may be subject to some doubt there can be no doubt from the data of TABLE io that reciprocals may actually give different degrees of fertility even to the extent of one being highly fertile and the other fully sterile.

Results of crosses between $(A \times C)$ plants and their parents.The artificial pollinations bearing on cross-incompatibility which were conducted in I9I4 and I9I5 were directed to plants whose immediate parents were both known. On account of the difficulty of performing all possible combinations, no series has been fully completed, but the data thus far obtained are given in the following tables.

The data in TABLE I I pertain to the crosses that were made with the $(A \times C)$ plants. Six plants were used as seed-parents and 
TABLE I I

DATA FOR CROSS-POLLINATIONS INVOLWNG PLANTS $A, C$, AND THEIR PROGEXY

\begin{tabular}{|c|c|c|c|c|c|c|}
\hline \multirow[b]{2}{*}{ Seed parent } & \multirow[b]{2}{*}{ Pollen parent } & \multicolumn{5}{|c|}{ Record for heads pollinated } \\
\hline & & Dates & $\begin{array}{l}\text { lotal } \\
\text { no. } \\
\text { seeds }\end{array}$ & $\begin{array}{c}\text { Heads } \\
\text { with no } \\
\text { seed }\end{array}$ & $\begin{array}{l}\text { Heads } \\
\text { with } \\
\text { seed }\end{array}$ & Seeds per head \\
\hline 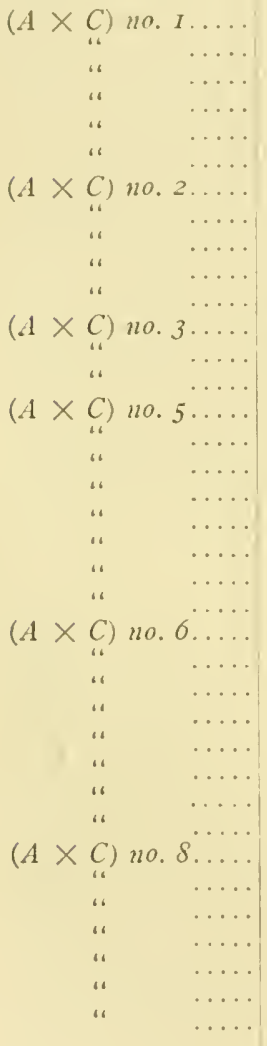 & 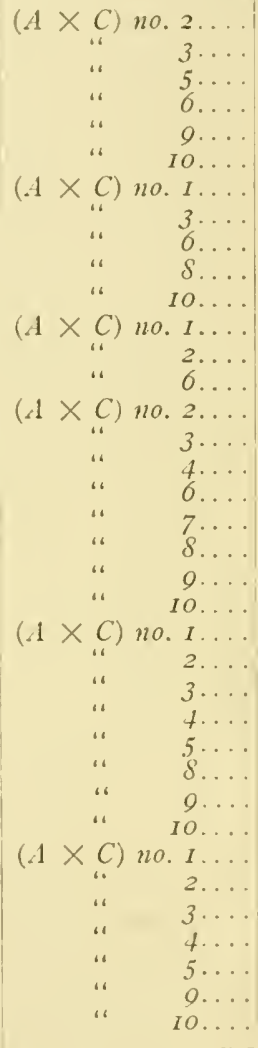 & 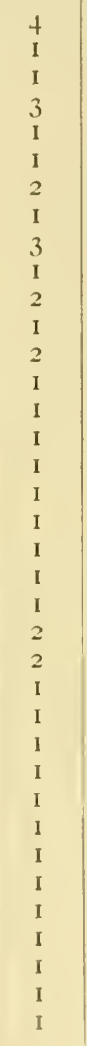 & $\begin{array}{r}14 \\
4 \\
10 \\
12 \\
3 \\
5 \\
9 \\
4 \\
8 \\
3 \\
7 \\
5 \\
6 \\
3 \\
5 \\
5 \\
3 \\
5 \\
2 \\
2 \\
6 \\
2 \\
10 \\
10 \\
5 \\
5 \\
4 \\
5 \\
8 \\
5 \\
3 \\
5 \\
4 \\
5 \\
5 \\
7 \\
4\end{array}$ & $\begin{array}{r}12 \\
4 \\
10 \\
10 \\
3 \\
5 \\
8 \\
4 \\
8 \\
3 \\
7 \\
5 \\
6 \\
3 \\
5 \\
3 \\
3 \\
4 \\
1 \\
1 \\
6 \\
2 \\
10 \\
10 \\
5 \\
5 \\
4 \\
5 \\
8 \\
5 \\
3 \\
5 \\
4 \\
5 \\
4 \\
6 \\
4\end{array}$ & $\begin{array}{l}2 \\
0 \\
0 \\
2 \\
0 \\
0 \\
1 \\
0 \\
0 \\
0 \\
0 \\
0 \\
0 \\
0 \\
0 \\
0 \\
0 \\
2 \\
0 \\
I \\
I \\
I \\
0 \\
0\end{array}$ & $\begin{array}{l}6,7 \\
2 \\
6 \\
5\end{array}$ \\
\hline 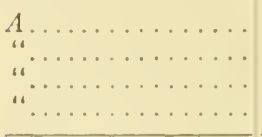 & 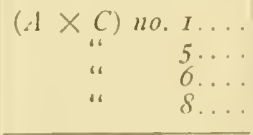 & $\begin{array}{l}1 \\
\text { I } \\
2 \\
\text { I }\end{array}$ & $\begin{array}{l}6 \\
4 \\
6 \\
3\end{array}$ & $\begin{array}{l}0 \\
3 \\
5 \\
1\end{array}$ & $\begin{array}{l}6 \\
1 \\
1 \\
2\end{array}$ & 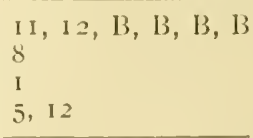 \\
\hline 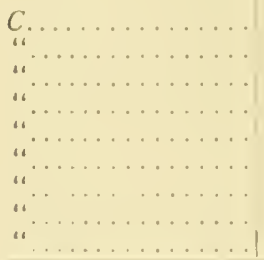 & 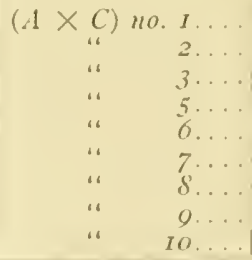 & $\begin{array}{l}2 \\
2 \\
1 \\
2 \\
1 \\
1 \\
2 \\
2 \\
2\end{array}$ & $\begin{array}{r}4 \\
5 \\
+ \\
10 \\
4 \\
2 \\
8 \\
6 \\
10\end{array}$ & $\begin{array}{r}4 \\
5 \\
4 \\
10 \\
4 \\
11 \\
8 \\
4 \\
10\end{array}$ & $\begin{array}{l}0 \\
0 \\
0 \\
0 \\
0 \\
2 \\
0 \\
2 \\
0\end{array}$ & 2,2 \\
\hline
\end{tabular}


all Io were used as pollen-parents in a total of 50 combinations, of which only I 5 were fertile and these were all cases of feeble fertility. There were 9 pairs of reciprocals; 5 were both sterile; 2 were fertile and 2 gave different results as already noted in TABLE IO.

Four of the $(A \times C)$ plants were used as pollen-parents on $A$; all were fertile to some degree. Nine were crossed with the parent $C$; all but two were sterile. The four plants fertile to $A$ were sterile to $C$.

The cross-compatibility within this series measured by the fertility of the crosses made was decidedly feeble, both in respect to the series as a whole and in respect to the individual combinations with perhaps the exception of the cross $A \times(A \times C)$ no. $I$. No one plant, either as a seed-or a pollen-parent, was consistently fertile or sterile to any considerable number of its sister plants. There were no indications of impotency in any of these plants and they all set considerable seed from open pollinations.

Results of crossing $\left(A \times E_{3}\right)$ plants and their parents.-The $\mathrm{F}_{1}$ plants derived from crossing $A$ and $E_{3}$ were crossed among themselves and with their parents to the extent reported in TABLE I2. Of the $\left(A \times E_{3}\right)$ plants four were used as seed-parents with pollen of 9 sister plants in $\mathrm{I} 7$ combinations. Two were strongly fertile, I was feebly fertile, and 13 were sterile. All 9 plants of this series were sterile to the parent $A$. It may be noted that in the two strongly fertile combinations the pollen-parent was no. 8 , a plant which in self-pollination (TABLE 3) was feebly selffertile. This plant, however, was sterile as pollen-parent with the parent $A$.

Two of the $\left(E_{3} \times A\right)$ plants were seed-parents in $\mathrm{I}_{4}$ combinations involving sister plants. One cross was strongly fertile, I was feebly fertile and $\mathbf{2} 2$ were sterile. Ten of the plants were tested as pollen-parents with $A$; of these combinations 3 were sterile and 7 were fertile in some degree. Seven were tested as pollen-parents with $E_{3} ; 5$ were fertile and 2 were sterile. Six were used as seedparents with the pollen of $E_{3}$, and of these 2 combinations showed feeble fertility.

Both series $\left(A \times E_{3}\right)$ and $\left(E_{3} \times A\right)$ showed among themselves on the whole a low degree of fertility, although 3 of the 5 individual cases of fertile crosses were highly fertile. In respect to 
T.IBLE 12

DATA FOR CROSS-POLLINATIONS INTOLVING PLANTS $A, E_{3}$, AND THEIR PROGENY

\begin{tabular}{|c|c|c|c|c|c|c|}
\hline \multirow[b]{2}{*}{ Seed parent } & \multirow[b]{2}{*}{ I'ollen parent } & \multicolumn{5}{|c|}{ Record fur head's pollinated } \\
\hline & & Dates & $\begin{array}{l}\text { Total } \\
\text { no. } \\
\text { heads }\end{array}$ & $\begin{array}{c}\text { Heads } \\
\text { with no } \\
\text { seed }\end{array}$ & $\begin{array}{l}\text { Heads } \\
\text { with } \\
\text { seed }\end{array}$ & Seeds per head \\
\hline 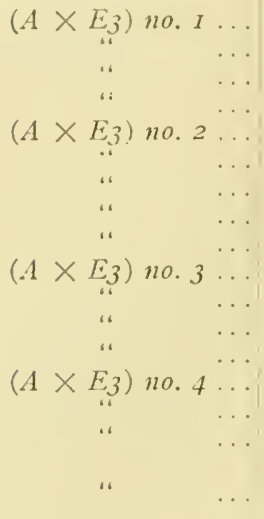 & 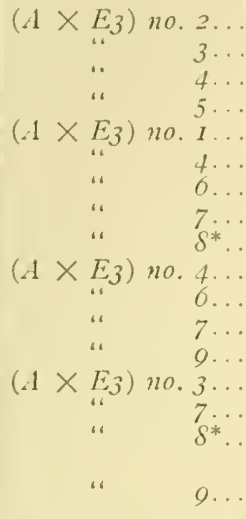 & $\begin{array}{l}\text { I } \\
1 \\
I \\
\text { I } \\
3 \\
2 \\
\text { I } \\
2 \\
I \\
\text { I } \\
2 \\
\text { I } \\
\text { I } \\
\text { I } \\
\text { I } \\
4 \\
\text { I } \\
\text { I }\end{array}$ & $\begin{array}{r}4 \\
2 \\
1 \\
3 \\
11 \\
10 \\
2 \\
6 \\
5 \\
5 \\
3 \\
6 \\
5 \\
5 \\
5 \\
12 \\
\\
5\end{array}$ & $\begin{array}{r}4 \\
2 \\
1 \\
3 \\
11 \\
10 \\
2 \\
6 \\
0 \\
5 \\
3 \\
6 \\
3 \\
5 \\
5 \\
0\end{array}$ & $\begin{array}{r}0 \\
0 \\
0 \\
0 \\
0 \\
0 \\
0 \\
0 \\
5 \\
0 \\
0 \\
0 \\
2 \\
0 \\
0 \\
12 \\
\\
0\end{array}$ & $\begin{array}{l}3,3,8, \mathrm{~B}, \mathrm{~B} \\
\mathrm{I}, 2 \\
4,5,5,6,9,10,12, \\
15,16,16,17,18\end{array}$ \\
\hline 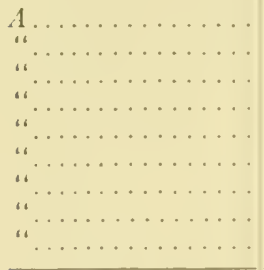 & 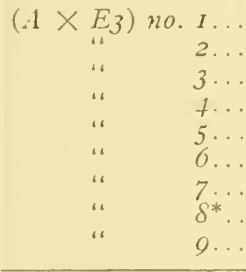 & $\begin{array}{l}2 \\
1 \\
2 \\
2 \\
2 \\
1 \\
2 \\
1 \\
2\end{array}$ & $\begin{array}{l}8 \\
5 \\
8 \\
3 \\
6 \\
2 \\
4 \\
5 \\
4\end{array}$ & $\begin{array}{l}8 \\
5 \\
8 \\
3 \\
6 \\
2 \\
4 \\
5 \\
4\end{array}$ & $\begin{array}{l}0 \\
0 \\
0 \\
0 \\
0 \\
0 \\
0 \\
0 \\
0\end{array}$ & \\
\hline 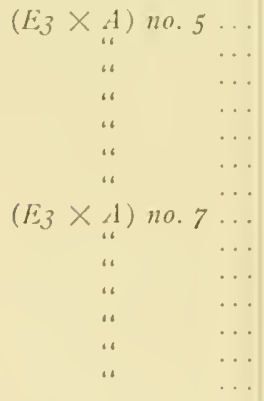 & 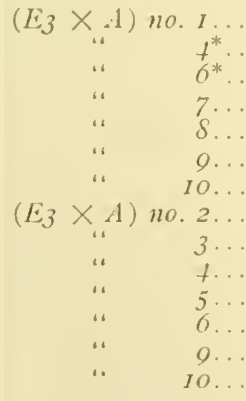 & $\begin{array}{l}\text { I } \\
2 \\
\text { I } \\
\text { I } \\
\text { I } \\
\text { I } \\
\text { I } \\
\text { I } \\
\text { I } \\
1 \\
\text { I } \\
\text { I } \\
\text { I } \\
\text { I }\end{array}$ & $\begin{array}{l}4 \\
6 \\
6 \\
5 \\
2 \\
4 \\
2 \\
4 \\
3 \\
5 \\
3 \\
2 \\
5 \\
5\end{array}$ & $\begin{array}{l}4 \\
6 \\
4 \\
5 \\
2 \\
4 \\
2 \\
4 \\
3 \\
5 \\
3 \\
2 \\
5 \\
0\end{array}$ & $\begin{array}{l}0 \\
0 \\
2 \\
0 \\
0 \\
0 \\
0 \\
0 \\
0 \\
0 \\
0 \\
0 \\
0 \\
5\end{array}$ & $8,15,15,15,17$ \\
\hline 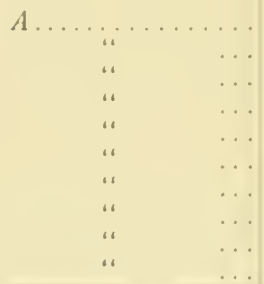 & 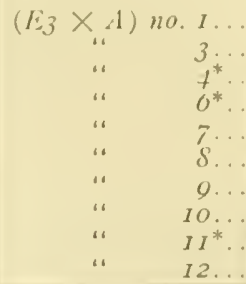 & $\begin{array}{l}1 \\
1 \\
3 \\
2 \\
1 \\
1 \\
1 \\
1 \\
1 \\
1\end{array}$ & $\begin{array}{l}4 \\
4 \\
5 \\
8 \\
2 \\
+ \\
2 \\
3 \\
4 \\
2\end{array}$ & $\begin{array}{l}2 \\
4 \\
1 \\
3 \\
0 \\
4 \\
0 \\
0 \\
4 \\
1\end{array}$ & $\begin{array}{l}2 \\
0 \\
4 \\
5 \\
2 \\
0 \\
2 \\
3 \\
0 \\
1\end{array}$ & $\begin{array}{l}1,4 \\
6,12,15,4+13 \\
8,16,17,13,13 \\
2,7 \\
10,15 \\
5,12,13 \\
3\end{array}$ \\
\hline
\end{tabular}


TABLE 12-Continued

\begin{tabular}{|c|c|c|c|c|c|c|}
\hline \multirow[b]{2}{*}{ Seed parent } & \multirow[b]{2}{*}{ Pollen parent } & \multicolumn{5}{|c|}{ Record for heads pollinated } \\
\hline & & Dates & $\begin{array}{l}\text { Total } \\
\text { no. } \\
\text { heads }\end{array}$ & $\mid \begin{array}{c}\text { Heads } \\
\text { wlth no } \\
\text { seed }\end{array}$ & $\begin{array}{c}\text { Heads } \\
\text { with } \\
\text { seed }\end{array}$ & Seeds per head \\
\hline 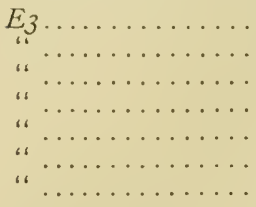 & $\begin{array}{cr}\left(E_{3} \times . A\right) & \text { no. } I . . \\
& \\
. & 2 . \\
. & 4^{*} \\
. & 6^{*} \\
. & I I^{*} \\
. & I 2 .\end{array}$ & $\begin{array}{l}\mathrm{I} \\
\mathrm{I} \\
2 \\
3 \\
\mathrm{I} \\
\mathrm{I} \\
\mathrm{I}\end{array}$ & $\begin{array}{l}2 \\
5 \\
8 \\
5 \\
4 \\
5 \\
5\end{array}$ & $\begin{array}{l}2 \\
3 \\
5 \\
2 \\
2 \\
\text { I } \\
5\end{array}$ & $\begin{array}{l}0 \\
2 \\
3 \\
3 \\
2 \\
4 \\
0\end{array}$ & $\begin{array}{l}2,6 \\
1,4,5 \\
B, B, B \\
8, B \\
8,8,3+B, 7+B\end{array}$ \\
\hline 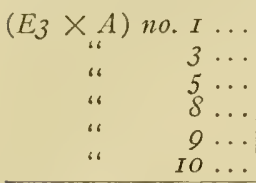 & 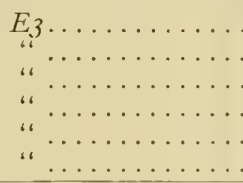 & $\begin{array}{l}\text { I } \\
\text { I } \\
\text { I } \\
\text { I } \\
\text { I } \\
\text { I }\end{array}$ & $\begin{array}{l}3 \\
4 \\
4 \\
3 \\
4 \\
4\end{array}$ & $\begin{array}{l}3 \\
4 \\
3 \\
3 \\
3 \\
4\end{array}$ & $\begin{array}{l}0 \\
0 \\
\mathrm{I} \\
0 \\
\mathrm{I} \\
\mathrm{O}\end{array}$ & 2 \\
\hline
\end{tabular}

* A self-fertile plant.

fertility as pollen-parent with their own parents, there was a marked contrast; the $\left(A \times E_{3}\right)$ plants were completely sterile to $A$, while the $\left(E_{3} \times A\right)$ plants were highly fertile to $A$ and also to $E_{3}$. On the other hand, of the 6 plants of $\left(E_{3} \times A\right)$ used as seed-parents with pollen of $E_{3}$, only 2 showed any degree of fertility.

The table includes data on five pairs of reciprocals; of the $\left(A \times E_{3}\right)$ plants, no. I with no. 2 , and no. 3 with no. 4 gave no seed, of the $\left(E_{3} \times A\right)$ series, no. 5 with no. 7 were sterile, and the pair $\left(E_{3} \times A\right)$ no. $I$ with $E_{3}$ were sterile; but $\left(E_{3} \times A\right) n o .3 \times E_{3}$ was sterile while its reciprocal was fertile.

There were I I cases in TABLE I 2 (indicated by *) in which pollen from a self-fertile plant was used on the pistils of a self-sterile plant; such pollen proved fertile in 8 combinations and sterile in 3 . The number of crosses is not great, but is evidence that the pollen of self-fertile plants gives much the same sort of results in crossing as pollen of self-sterile plants.

Results of cross-pollinations involving the $(A \times$ Ez2) hybrids.Of the $(A \times E 22)$ series there has been opportunity to test I plant (no. IO) as seed-parent with $2 \mathrm{I}$ of its sister plants. The data given in table 13 shows that there was fertility in but 4 of these crosses. Eleven were used as pollen-parents on $A$; of these 5 were sterile and of the 6 fertile crosses, I (no. 4) was highly fertile. 
TABLE 13

D.ITA FOR CROSS-POLLINATIONS INOLWING PLANTS A, E22, AND THEIR PROGENY

\begin{tabular}{|c|c|c|c|c|c|c|c|}
\hline \multirow[b]{2}{*}{ Seed parent } & \multirow{2}{*}{\multicolumn{2}{|c|}{ Pollen parent }} & \multicolumn{5}{|c|}{ Record for heads pollinated } \\
\hline & & & Dates & $\begin{array}{l}\text { Total } \\
\text { no. } \\
\text { heads }\end{array}$ & $\begin{array}{c}\text { Heads } \\
\text { with no } \\
\text { seed }\end{array}$ & $\begin{array}{l}\text { Heads } \\
\text { with } \\
\text { seed }\end{array}$ & Seeds per head \\
\hline 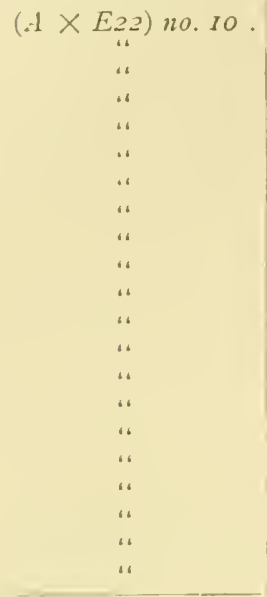 & 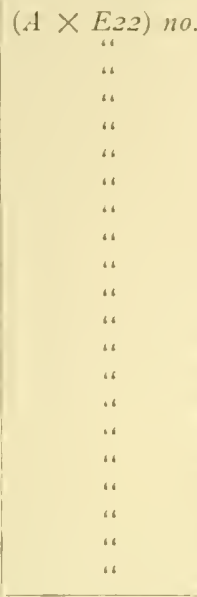 & $\begin{array}{l}4^{*} \\
5 \\
11 \\
15^{*} \\
17 \\
18 \\
19 \\
25 \\
33 \\
36 \\
41 \\
12 \\
43 \\
17 \\
46 \\
18 \\
49 \\
50 \\
52 \\
59 \\
61\end{array}$ & $\begin{array}{l}\text { I } \\
\text { I } \\
\text { I } \\
2 \\
\text { I } \\
\text { I } \\
\text { I } \\
2 \\
\text { I } \\
\text { I } \\
\text { I } \\
\text { I } \\
\text { I } \\
\text { I } \\
\text { I } \\
\text { I } \\
\text { I } \\
\text { I } \\
\text { I } \\
\text { I } \\
\text { I }\end{array}$ & $\begin{array}{l}6 \\
5 \\
3 \\
7 \\
4 \\
3 \\
6 \\
7 \\
3 \\
5 \\
5 \\
5 \\
6 \\
4 \\
3 \\
3 \\
5 \\
2 \\
4 \\
3 \\
5\end{array}$ & $\begin{array}{l}6 \\
5 \\
1 \\
5 \\
4 \\
0 \\
6 \\
7 \\
2 \\
5 \\
5 \\
5 \\
6 \\
4 \\
3 \\
3 \\
5 \\
2 \\
4 \\
3 \\
5\end{array}$ & $\begin{array}{l}0 \\
0 \\
2 \\
2 \\
0 \\
3 \\
0 \\
0 \\
1 \\
0 \\
0 \\
0 \\
0 \\
0 \\
0 \\
0 \\
0 \\
0 \\
0 \\
0 \\
0\end{array}$ & $\begin{array}{l}\text { I I, B } \\
\mathrm{B}, \mathrm{B} \\
2,9,13\end{array}$ \\
\hline 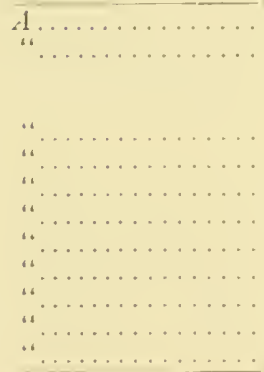 & $\begin{array}{c}(.1 \times E 22) n o \\
\text { ". } \\
\text { ". } \\
\text { ". } \\
\text { ". } \\
\text { ". } \\
\text { ". }\end{array}$ & $\begin{array}{l}2^{*} \\
4^{*} \\
15^{*} \\
22 \\
24 \\
30 \\
35 \\
36 \\
40 \\
41 \\
55\end{array}$ & $\begin{array}{l}3 \\
\text { I } \\
\text { I } \\
\text { I } \\
\text { I } \\
\text { I } \\
\text { I } \\
\text { I } \\
\text { I }\end{array}$ & $\begin{array}{l} \\
4 \\
5 \\
4 \\
9 \\
8 \\
5 \\
3 \\
3 \\
4\end{array}$ & $\begin{array}{l}4 \\
2 \\
3 \\
9 \\
8 \\
4 \\
3 \\
3 \\
1\end{array}$ & $\begin{array}{l}0 \\
3 \\
1 \\
0 \\
0 \\
1 \\
0 \\
0 \\
3\end{array}$ & $\begin{array}{l}1,6,6,12,14 \\
2,2,4,6,6,6,7 \text {, } \\
\text { 10, I I, I1, 12, } 12 \text {, } \\
\text { I 2, I3, I } 15,15 \\
5,7,8 \\
3 \\
3\end{array}$ \\
\hline 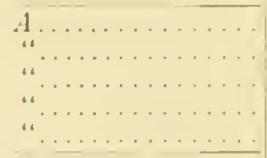 & $\begin{array}{c}\left(E_{22} \times 11\right) n o \\
\text { ". } \\
\text { " }\end{array}$ & $\begin{array}{c}1 \\
2^{*} \\
5 \\
8 \\
18 \\
\end{array}$ & $\begin{array}{l}\text { I } \\
\text { I } \\
\text { I } \\
\text { I } \\
\text { I }\end{array}$ & $\begin{array}{l}4 \\
6 \\
3 \\
3 \\
5\end{array}$ & $\begin{array}{l}2 \\
1 \\
1 \\
3 \\
0\end{array}$ & $\begin{array}{l}2 \\
5 \\
2 \\
0 \\
5\end{array}$ & $\begin{array}{l}1,7 \\
3,6, \text { I I, I I, I } 3 \\
2,16 \\
10,13,14,17,18\end{array}$ \\
\hline 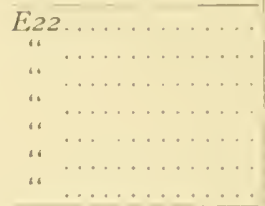 & $\begin{array}{c}(1 \times 1 \% 22) n o \\
\text { ". } \\
\text { ". } \\
\text { ". } \\
\text { ". }\end{array}$ & $\begin{array}{l}2^{*} \\
4^{*} \\
10 \\
11 \\
15^{*} \\
30 \\
62\end{array}$ & $\begin{array}{l}\text { I } \\
2 \\
\text { I } \\
2 \\
\text { I } \\
\text { I } \\
\text { I }\end{array}$ & $\begin{array}{r}5 \\
10 \\
2 \\
10 \\
5 \\
3 \\
8\end{array}$ & $\begin{array}{r}4 \\
10 \\
2 \\
8 \\
4 \\
3 \\
8\end{array}$ & $\begin{array}{l}1 \\
0 \\
0 \\
2 \\
1 \\
0 \\
0\end{array}$ & 7.9 \\
\hline $\begin{array}{c}(E 22 \times A \\
\| \\
\text { " }\end{array}$ & 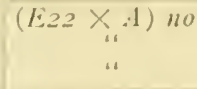 & $\begin{array}{l}3 \\
5 \\
6\end{array}$ & $\begin{array}{l}\text { I } \\
\text { I } \\
\text { I }\end{array}$ & $\begin{array}{l}5 \\
4 \\
5\end{array}$ & $\begin{array}{l}+ \\
+ \\
5\end{array}$ & $\begin{array}{l}1 \\
0 \\
0\end{array}$ & 3 \\
\hline 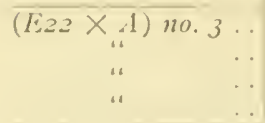 & $\begin{array}{c}\left(K_{22} \times .1\right) n o \\
. \\
. "\end{array}$ & $\begin{array}{l}1 \\
2^{*} \\
0 \\
10^{*}\end{array}$ & $\begin{array}{l}1 \\
1 \\
1 \\
1\end{array}$ & $\begin{array}{l}5 \\
5 \\
1 \\
5\end{array}$ & $\begin{array}{l}5 \\
7 \\
+ \\
5\end{array}$ & $\begin{array}{l}0 \\
0 \\
0 \\
0\end{array}$ & \\
\hline
\end{tabular}

* Self-fertile plant. 
Of the 7 tested as pollen-parents with E22, 3 showed crossfertility.

The plant $(E 22 \times A)$ no. $I$ was sterile with pollen of two sister plants and feebly fertile to one; the plant $(E 22 \times A)$ no. 3 was sterile to pollen of 4 sister plants. The parent plant $A$ was tested with pollen of 5 of the $(E 22 \times A)$ plants, with 4 of which it was fertile.

As far as tested the hybrids of this series showed strong crosssterility, as out of 28 combinations only 5 were fertile. On the other hand there was rather marked fertility when pollen of these plants was used on the parent $A$.

Eleven of the crosses given in TABLE I 3 involve pollen from a self-fertile plant with a seed-parent that is self-sterile: 6 of these crosses were fertile. The pollen of the self-fertile plant $(A \times$ E22) no. 4 was sterile to the parent E22 and to a sister plant $(A \times E 22)$ no. Io, but was highly fertile to the parent $A$. These results agree with those of TABLE 12 in showing that the self-fertile plants are not cross-fertile as pollen-parents with all of their sister plants, and that when fertile there may be considerable variation in the degree of fertility. These facts are suggestive that cross-sterility from physiological incompatibility may exist between plants of the same species that are self-fertile. The difficulty of making emasculations or depollinations in chicory necessary to controlled cross-pollination between self-fertile plants had thus far deterred me from making this test.

A summary of the cases of back crosses given in TABLES 9, II, I 2 , and I 3 shows that plant $A$ was crossed as a seed-parent with 46 of its progeny and that in 25 cases there was fertility. The total of all back crosses of offspring on a known parent is 69 , of which 35 were fertile and $3+$ sterile. The number agrees more closely than do the results of Correns with his theoretical ratio for such a cross in Cardamine. The range of variation in the actual fertility, however, is so great in both cases that the grouping of all offspring into two classes with reference to cross-fertility with a parent is of little significance, and in addition the results obtained in the pedigreed self-fertile strains of chicory show that the conception of line stuffs is untenable.

Results of cross-pollinations involving the variety "improved redleaved Treviso."-Data have already been presented (TABLE $\tau$ ) for 
394 MEMOIRS OF THE NEW YORK BOTANICAL GARDEN

TABLE It

DAtA FOR CROSS-POLLINATIONS INVOLING THE VARIETY "RED-LEAVED TREVISO

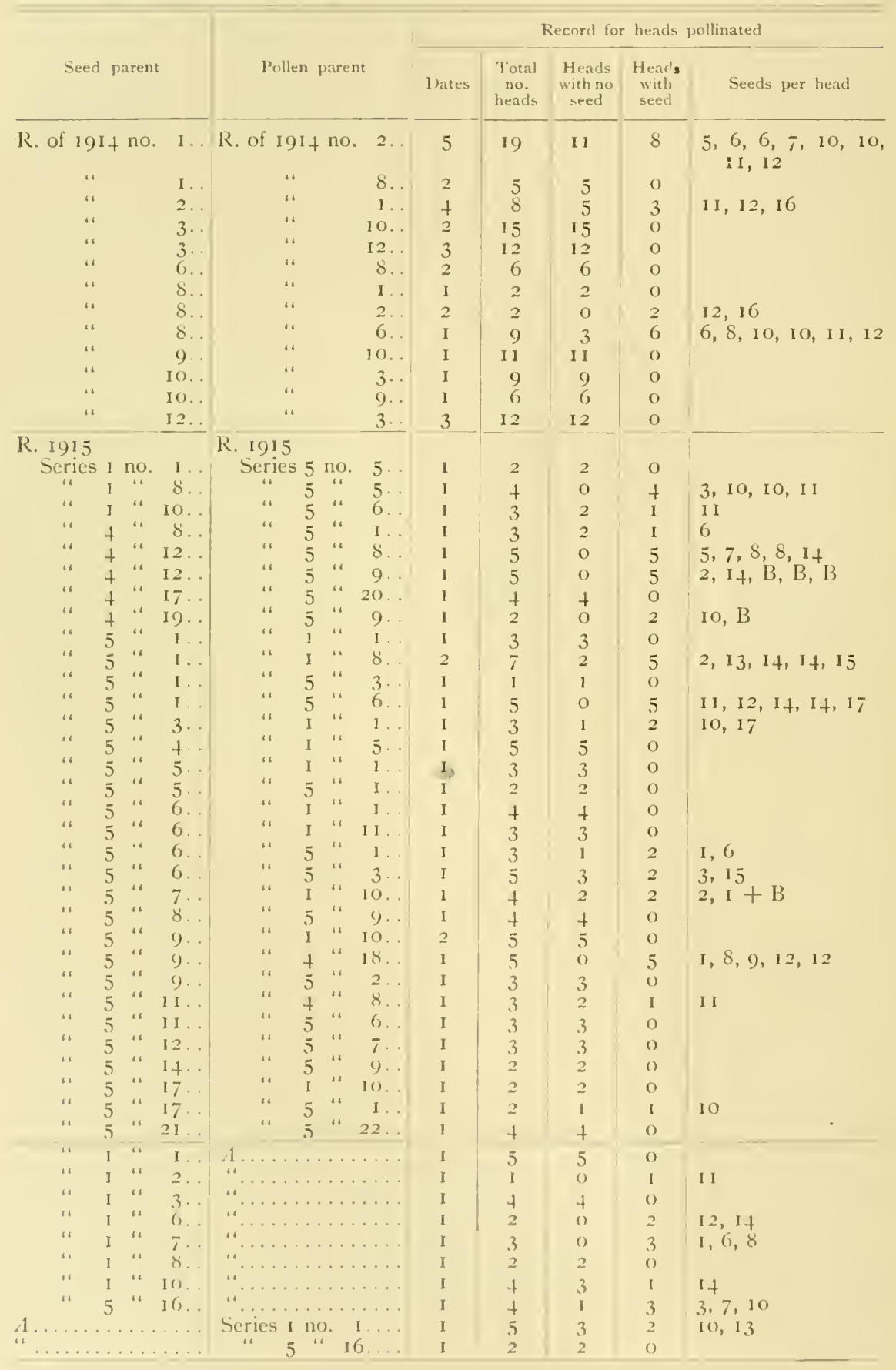


the self-pollinations of plants of this variety. In order to keep the variety in pedigreed culture for a study of the heredity of fasciation it was necessary to make numerous crosses to find fertile combinations. In I9I5 crosses were also made with the wild white-flowered plant $A$ which has figured prominently in the studies already reported. These data are compiled in TABLE I4.

In I9I4, I 3 cross-pollinations were made, of which only 4 were compatible. The work of this year involved 6 pairs of reciprocal pollinations, four pairs ( 1 with 8), (3 with IO), (3 with I2), and ( 9 with IO) were sterile, one pair ( $I$ with 2) were both fertile, and one pair ( 6 with 8 ) gave different results as there was fertility only when no. 8 was the seed-parent.

In I9I5, thirty-two crosses were attempted between various of the plants grown from the seed of the previous year. Fifteen of these were fertile in some degree and in at least 6 crosses there was rather high cross-fertility. No one plant was tested to a considerable number of other plants either as a seed- or as a pollenparent.

The results with this variety have a special bearing on the general question of the influence of close relationship to fertility. Twenty-four of the crosses were with plants of series 5 , I9r 5 , as a seed-parent. These plants were derived from the cross $(8 \times 2)$ of the previous year. Of the 12 combinations with sister plants as pollen-parents, 7 were sterile. Of Io crosses with plants of series I as pollen-parents, 7 were sterile. The 2 series had the same grandparents but different immediate parentage. The results of the crosses made show no marked differences between crosses within a series or between different series.

It is also to be noted that plants of this variety were not all fertile with pollen of the wild plant $A$ as 3 of the 8 plants thus crossed were unproductive of seed. Of two crosses with $A$ as seedparent I was fertile. The two reciprocals that were made gave different results, as especially noted in TABLE IO.

General summary of all cross-pollinations.-In tables 2, 9, I I, $\mathrm{I}_{2}, \mathrm{I}_{3}$, and $\mathrm{I}_{4}$, data are presented for crosses involving I 25 different plants. A total of 274 different combinations was attempted, of which I 59 were sterile and I 5 were fertile in some degree. General cross-fertility on the whole seems less pronounced than is cross-sterility. TABLE 2 is not fully representative of the results 
obtained in 19I2, as there were several crosses attempted which were sterile but of which no complete record was kept. In TABLE 9 the fertile combination exceed the sterile, being 26 to 17 ; in the other tables, each of which relates to pedigreed stocks, the sterile crosses exceed the fertile and agree in the general results for all crosses.

The total number of reciprocals made is 47 , of which 15 were both fertile, is were both sterile, and It gave a different result. The latter have already been summarized in TABLE IO.

The total number of flower heads concerned in the cross-pollination reported is 2,168, which involve about 40,000 individual flowers.

The total number of heads upon which the results of controlled self- and cross-pollinations were fully recorded is 6,26I. All of these pollinations were made by the writer with the exception of the pollinations made by Mr. A. C. Fraser, who continued the experiments during six weeks of the summer of I9It while the writer was absent from the New York Botanical Garden. In all of the pollinations, excepting those made in 1912, the writer was assisted by a second person. Mr. A. C. Fraser assisted in this work during the season of 1913, and Mr. Charles Holste has assisted during the seasons of I9I 4 and I9I5. The writer wishes to record here his appreciation of the assistance thus given.

\section{GENERAL OR POTENTIAL FERTILITY IN CHICORY}

As the chicory plants grow in my experimental plots and wild about New York and especially at Madison, Wisconsin, where the writer has seen them in considerable numbers, there is no obvious suggestion of sterility of any sort. Neither is there such an indication from the conditions in the fields grown for seed production which the writer saw in I9It in the grounds of the Dippe Brothers at Quedlinburg and of Ernst Benary at Erfurt, Germany. The gardeners in charge of chicory-growing for these firms had no idea that sterility of any but the most accidental sort is present in this species. All plants seem to set an abundance of seed. In any package of commercial seed, however, from the writer's experience, there are many light-colored and shrunken seeds that fail to germinate. 
There appear to be no definite statements in the literature of any sterility in Cichorium Intybus. Fruwirth ('09) describes very adequately the development of the flower parts in the processes of opening and notes the adaptation for self- and cross-pollination. He also records that he failed to obtain seed from branches that he had enclosed for spontaneous self-pollination; in ten trials of selfing he obtained no seed, but as the weather was rainy he does not consider his tests conclusive. He suggests, in discussing possible methods that may be used in hybridization, that if selfpollinated flowers set no seed the act of castration might be omitted in crossing and only precaution taken to prevent insects from bringing pollen. It is this method that the writer has most generally used in crossing onto a seed-parent known to be completely self-sterile. The $F_{1}$ generations grown from crosses inrolving plants $A, C, E_{3}$, and $E_{22}$ and which are especially concerned with this paper were from seed obtained by employing the depollination method as described by Oliver ('10).

\section{OBSERVATIONS ON EFFICIENCY OF OPEN- POLLINATION}

To test the efficiency of open-pollinations and to obtain evidence on the efficacy of pollinations in successive days throughout the season, observations were made in I9I4 on the flowers of a large main branch on each of two plants. Each morning with the exception of Sundays and days of heavy rain the flowers in each head on the branches selected were counted and a tag was placed about the base of the head recording the date of blooming and the number of flowers. Later the seeds were counted and the number also recorded.

Data were thus taken on plant $C$ from July 2 to August 24, I9I4, and these data are given in TABLE $\mathbf{5} 5$.

A total of II 4 heads of plant $C$ was observed (not including seven heads which set seed but were completely shelled by birds). comprising 2,304 flowers of which 1,402 set seed judged to contain embryos. The percentage of flowers setting seed was 6I. The number of seed per head ranged from 0 to 21 . In two instances every flower in a head produced a seed. There were but five heads that set no seed and these bloomed near the middle of the season; three of these opened on the same day, July I4. 


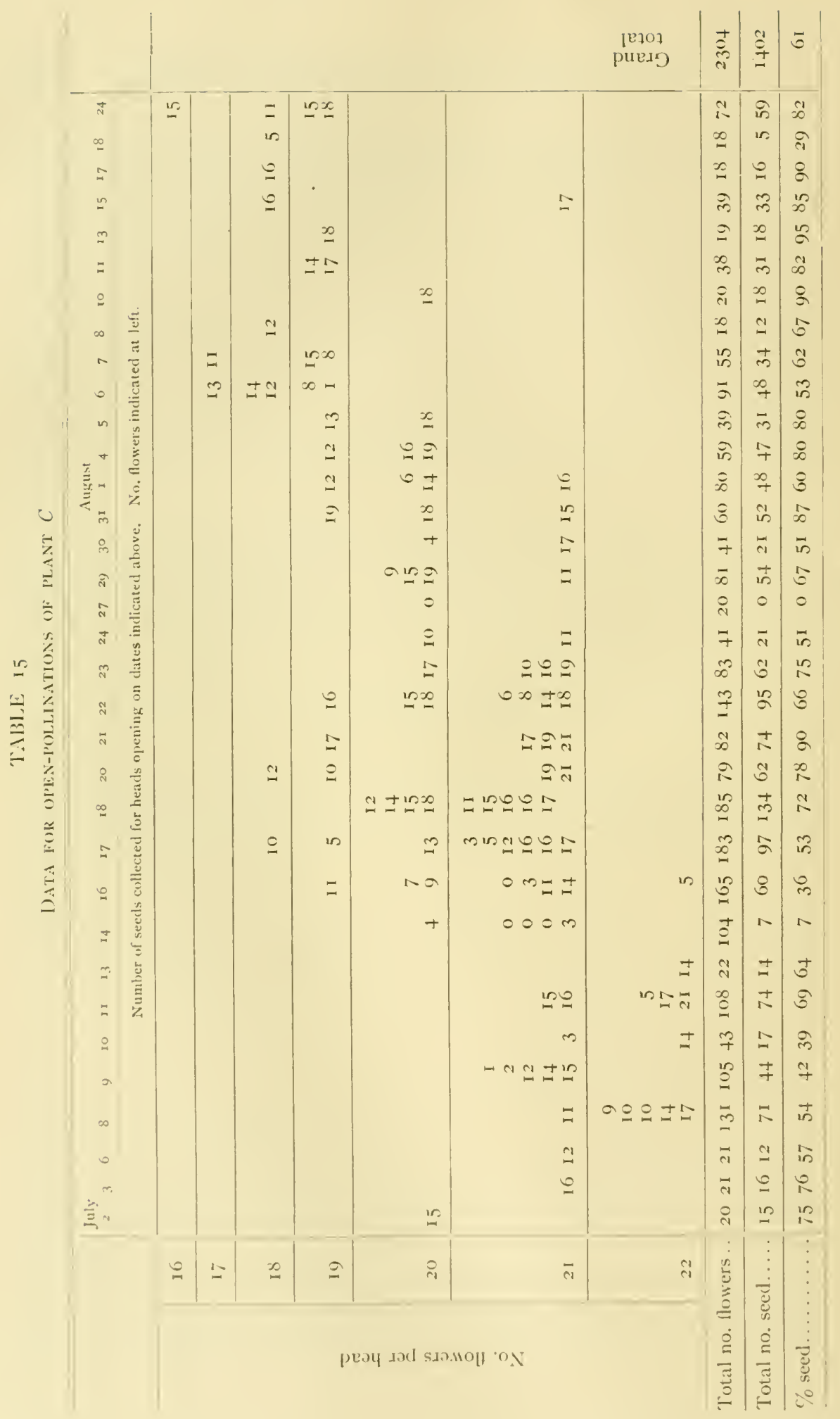


are not included in the table. The highest number of seeds for a single head was I2. There were I2 cases of no seeds per head; Io of these were on July It, the same date when 3 heads of plant $C$ (see TABLE I 5) failed to set seed. The weather records taken at the Garden show that on that date it was cloudy with some rain. Evidently on this particular day the weather conditions were unfavorable to insect pollination or to fertilization.

In comparison with plant $C$, the plant $\left(C \times E_{3}\right)$ no. 6 exhibited a low degree of fertility; the daily percentage of seeds set was lower and the number of seeds per head was consistently less. Such results may be due to a marked cross-incompatibility on the part of plant $\left(A \times E_{3}\right)$ no. 6 to a greater number of plants in its vicinity. The fact that there were quite constantly few seeds per head is, however, quite in line with the conditions encountered in selfing and crossing. It is quite clear that the difference in the total seed production of these two plants is not due to a difference in flower number. Here the determination of flower number enables one to compute accurately the percentage of seed produced on the basis of the total that is possible.

The data in TABLES It and 15 are quite conclusive that heads on any part of the plant at any time in the season are productive of seed; a point that seemed equally evident from the writer's experience with the controlled pollinations.

From the data of TABLEs I 5 and i6, Dr. J. A. Harris has computed the correlation of flower with seed number per head according to the method he has reported ('10). There is in both cases a very slight negative correlation. This is so slight, howerer, that it scarcely if at all affects the general results and conclusions, as it is clear that random pollinations at any time very fairly represent the fertility of the combination, and that the marked differences in fertility of self-and cross-pollinations are entirely independent of differences in flower number.

While there was considerable fluctuation from day to day in the percentage of seeds set to open-pollination, there were usually in any one day some heads that were elose to the maximum number, especially if five or more heads were involved. In this respect the plants $C$ and $\left(C \times E_{3}\right)$ no. 6 were quite uniform throughout the season.

In the case of the controlled pollinations, pollen from known 
sources was applied to all flowers of each head. In making com parisons between many such pollinations it is of importance to know if flowers produced on different parts of a plant and at different times in the season are relatively equally productive of seed; the tests reported in TABLES I 5 and 16 seem conclusive that they are sufficiently so for a fair comparison and also that when a low percentage of seed per head is set consistently there is a real condition of partial physiological self- or cross-incompatibility involved.

\section{OTHER INVESTIGATIONS}

Attention has been given to a study $(a)$ of the requirements for successful artificial germination of the pollen of Cichorium Intybus, (b) of the facts regarding the germination of pollen and of the relative rates of growth of the pollen tubes in self- and crossincompatibility as compared with self- and cross-compatibility, and $(c)$ of the more intricate cytological processes of fertilization and embryo development.

The artificial germination of the pollen was a special subject of investigation by Dr. Joseph C. Gilman under a scholarship grant from the New York Botanical Garden in the summer of I9I3. A large number of experiments were made employing chiefly agar plates and hanging drop methods of culture and using various strengths of various chemical solutions and of the juices of chicory plants. During I9I 5 in the studies made by the writer the pistils with pollen in contact were placed on slides and kept in a moist chamber for study.

On plates of I per cent agar with 25 per cent and 30 per cent sucrose a few tubes developed to a length two or three times the diameter of the pollen, but as the greater number of such tubes burst it is not certain that there was a real germination. Thus far no method of securing artificial germinations more successful than these has been discovered, and until much better germination can readily be secured there is no hope of determining by germination studies whether pollen of different plants shows differences in their physiology.

Preliminary studies along the other lines indicated above have been made and especially of the behavior of the pollen tubes in the pistils relative to fertilization, but none of these have at present writing reached the stage where they contribute any definite data 
on the phenomena of physiological self- and cross-incompatibility. To what degree the incompatibilities involve pollen-tube growth, irregular fusions of gametes, or embryo abortion has not been adequately determined.

\section{DISCLSSION}

There can be no doubt that in Cichorium Intybus the failure to set seed in the numerous cases of self- and cross-pollinations is due to some sort of physiological incompatibility operating in the interactions between the cells concerned with the processes of fertilization. Such sterility is to be sharply distinguished from that involving different types of impotence or anatonical incompatibility as defined above. It appears also that the sterility observed in chicory is quite the same as that exhibited by such plants as Cardamine (Correns '12, '13), tobacco (East' 15a), Reseda (Darwin '77, Compton '12, '13), Eschscholtzia (Darwin '77, Hildebrand '68, '69), and in cultivated varieties of the pear (Taite' 95), plum (Backhouse '11), apple (Lewis and Vincent'09), cherry (Gardner '13), and in strains of the blucberry (Coville '14, '15). Besides these cases which have been studied in some detail there is evidence which indicates the operation of similar phenomena in a considerable number of other species.

It seems that the causes of this sort of sterility are to be sought in the physiological processes which are operating in an organism quite independently of the anatomical differentiation of the sex organs. Upon this broad generalization practically all students of the subject are agreed. Nany have been inclined to assume also that in the higher plants the processes are concerned chiefly with that phase of fertilization which involves the completion of the growth of pollen tubes through the pistil to the eggs. In the more specific analysis, however, of the conditions, processes and causes, there is the widest diversity of opinion.

The more comprehensive of the theories, already discussed in this paper in some detail, fall quite naturally into three main classes as follows:

I. The view especially held by Darwin that "self-sterility" (physiological incompatibility), not including that in dimorphism and trimorphism, is incidental and a result of the direct influence of external environment, producing too great similarity in the germ cells. 
2. The conception that the causes of this type of sterility are purely individual and due solely to the fact that the two kinds of sex organs are produced by a single individual irrespective of any particular type of inherited nuclear or cell organization. Jost's conception of individual chemical stuffs that are similar in the sex organs of an hermaphrodite individual, and Morgan's view of similarity in so-called protoplasmic association inhibiting gametic union respectively. These conceptions emphasize internal environment.

3. The view that this sort of sterility is due to too great a similarity of nuclear constitution as regards certain definite hereditary units. (a) In a similarity involving the presence in the gametes of an hereditary unit solely associated with the production of a so-called line stuff: emphasis is placed on a particular germ plasm constitution; the view held by Correns, Baur, and Compton. (b) In the relative similarity of the male gametophyte only (in respect to any one or more hereditary units of any sort) to the hereditary complex of the sporophyte; East's view.

These divergent views are, for the most part, due to the particular emphasis which the one or the other investigator has given to certain phases of the phenomenon or to certain facts obtained in their particular experiments. They all agree in making similarity or lack of differentiation in sex organs responsible for the incompatibility.

Darwin considered that the constitution of sex elements may, to a considerable degree, be influenced directly by changed conditions of growth (theory of pangenesis). The persistent selfsterility of strains of plants like Eschscholtzia he considers a direct but rather incidental influence of external environment which reduces the sex differentiation that usually gives fertility. He attempted to distinguish this sort of influence from that which he thought operates through inbreeding in which the degree of relationship, as he believed, also influences the degree of compatibility of the sex elements. The cases of a markedly decreased fertility seen in cross-bred but self-sterile plants did not agree with Darwin's view that crossing increases fertility, hence Darwin rather unduly emphasized the fluctuating and sporadic nature of such sterility, ascribing its causes also to change in environment.

My plants of chicory are grown under as nearly uniform con- 
ditions as is possible under field treatment, but plants of the same line of descent growing side by side show such wide and fluctuating differences in the degree of their self-fertility that there seems to be no direct connection between these phenomena and the immediate conditions of growth. Yet it is entirely possible that the history of the varieties under cultivation and the spread of the species in new regions may have been, in quite the Darwinian sense, factors in inducing the physiological conditions that are associated with the present existence of self- and cross-sterility and fertility in the species. Careful and extended methods of pedigreed culture are necessary to enable one even to guess at the actual causes contributing to the development of such characters, especially in view of the possibility that they are epigenetic and intercellular in nature and manifest a wide range of fluctuating variability.

It is apparent, however, from the evidence accumulated since Darwin's time that the phenomena of self-sterility as seen especially in such cases as Eschscholtzia, Reseda, Cardamine, and $\mathrm{Ci}$ chorium are more than "incidental" as Darwin was inclined to believe, and may have a special biological significance in explaining the interrelations of living cells both in sex fusions and in vegetative growth, and the expression and heredity of such relations.

The conception of sterility as developed by Baur, Correns, and Compton, is manifestly too simple. They claim that such characteristics as fertility and sterility can be stated in terms of relatively fixed and constant units of germ plasm, and attempt to analyze the internal conditions involved in incompatibility on the hypothesis that these conditions are predetermined by the physical transmission of definite line stuffs as hereditary units which are directly responsible for certain specific and individual differences on the one hand and similarities on the other. The evidence in chicory is quite clear on this point. As described above, crosses between self-sterile plants gave an $F_{1}$ generation of 172 plants of which 15 showed some degree of self-fertility. The study of the progeny of these self-fertile plants as to sterility and fertility in self-fertilized line cultures gave results which are perfectly clear and definite. Both the $\mathrm{F}_{2}$ and $\mathrm{F}_{3}$ generations show that self-sterility and self-fertility are neither dominant nor recessive characters in any consistent sense, that the character of 
self-fertility appears in different degrees of intensity in different plants, and that there is very irregular and sporadic inheritance both of the character as such and of the degree of its expression, if the two can in any sense be separated. The character of selffertility (and that of cross-fertility as well) appears with different degrees of intensity whether in offspring from crossed self-sterile plants or from inbred self-fertile plants. That these differences are in many cases real and not due to the accidents of experimental conditions is, I believe, indicated by the results. The conclusion is inevitable that the quality of self-fertility is different in intensity in the various plants. That such differences are really expressive of internal constitutional conditions places the expression of selffertility quite on the same basis with the fluctuating variations observed in practically all characters which have been studied quantitatively.

The studies of the heredity of self-fertility in chicory show that plants most strongly self-fertile do not give offspring all of which are self-fertile, even after two generations of pedigreed culture. In other words, self-sterility, which is strongly in evidence in the parent strains and in Cichorium in general, tends strongly to reappear in spite of repeated selections of self-fertile plants. Neither is there a direct correlation between the degree of fertility exhibited by parents and their offspring.

It is very obvious that there can be no simple numerical expression descriptive of the hereditary behavior of fertility and sterility in chicory and, as I have shown, a careful study of Correns' data leads to the conclusion that his actual observations do not support the conclusions indicated in his formulae. The rather general statements of Lotsy ('13) regarding the $\mathrm{F}_{2}$ generation of Baur's hybrids between Antirrhinum molle and A. majus indicate great variation in regard to self-sterility as in all other characters. He states regarding the progeny of one of these, "Il y a des plantes auto-stériles et des plantes auto-fertiles, de sorte que l'on peut dire avec raison qu'il n'y a pas deux plantes identiques parmi les 255 individus obtenus en $F_{2}$ " (p. 420 ). In view of this fact, the opinions of Baur can hardly be considered, while those of Compton can not be seriously considered until the data are at hand. For the explanation of the causes of self-sterility in chicory, I am convinced that we must look most especially to the type or grade 
of sex differentiation operating in the individual rather than to racial or line characteristics or stuffs for the development of conditions, local or quite general for the plant, which determine its relative fertility.

This is fully realized by East, who states with reference to his own experiments with tobacco already discussed in the introduction, "When these experiments were begun, I expected to find that the facts would accord with a simple dihybrid Mendelian formula similar to that which Correns later proposed as an interpretation of his results. Iet only by considerable stretching and a vivid imagination will Correns' data fit such a hypothesis, and my own data do not fit at all " ('15a, p. 82). East's interpretation, although recognizing that there can be no hereditary factor directly representing fertility as such,' assumes that the direct conditioning substances are in the germ plasm. He considers that the physiological relations are mainly those of pollen-tube growth, involving interaction between the somatic cells of the pistils and the pollen tubes, and the favorable reaction is assumed to occur only when the haploid nuclei of the pollen tube possess at least some one factor which is not present in the nuclei of the diploid cells of the pistil. This relation, purely somatic at least on one side, he calls "gametic incompatibility," a term which hardly expresses the processes assumed to be involved.

It is especially to be noted that Darwin, Correns, and East seck the causes of sterility in a lack of differentiation of the gametes; it is too great a similarity that prohibits fertility. With Correns' no plant can be homozygous for any one line stuff: with East no plant should be self-fertile since its pollen grains can possess no element of the germ plasm which is not found in the somatic cells of the pistil of the plant on which the pollen grain is formed. The narrow applicability of East's theory is most erident. It ignores the facts which Burck has emphasized so strongly and the abundant evidence, discussed later in this paper, that it is similarity of germ plasm elements that favors fertility. According to East's view self-fertility should not occur in any plant, there should be no close approach to homozygosity such as he has previously pointed out is the rule in tobacco, and there should never be the development of self-fertile plants from self-sterile, unless the hereditary units of the germ plasm are subject to 
sudden and repeated changes in preparation for each self-fertilization. Any further modification of this general view which should assume that different grades or degrees of activity of single units or groups of assumed hereditary units can account for the phenomena of feeble fertility only makes more obscure the physiological processes, and, would not in any case enable one to. predict what the behavior will be in any species or strain.

East's observed results are of special interest in showing that even in interspecific hybrids the character of self-sterility may appear in all (or nearly all) of the offspring among which there is nearly complete cross-fertility. In his results cross-sterility is almost entirely absent; in Correns' results cross-sterility is strongly in evidence as it is in chicory. These apparent discrepancies emphasize the sporadic and fluctuating nature of self-sterility and demand a theory which shall account for the relations of crosssterility and self-sterility as they appear in breeding.

It is evident that there is much in the phenomena of self-sterility that favors the general basis of the conceptions of Jost and Morgan. It is most obvious that self-incompatibility, as indicated by the self-sterility of such hermaphrodite plants as Eschscholtzia, Cardamine, Reseda, Nicotiana, Beta, Cichorium, etc., and in such animals as Ciona intestinalis, has appeared, when from the nature of the case, the reproductive organs and gametes are of the closest possible physical relationship. In each individual they are produced by, and in large measure composed of, somatic tissues with the same hereditary complex, and when borne in the same flower with a close cytoplasmic and sap relationship. The evidence seems clear to Jost and Morgan that differences in the hereditary complex of spores, gametophytes, and gametes are not essentially involved, and that the causes of the incompatibility are to be sought in the conditions developing from the close physical relationship of the sex organs. In this sense the constitutional conditions present may involve lack of some sort of constitutional (sex) differentiation quite as Jost assumed. It appears that this condition also may even give various grades of gametic incompatibility as in Ciona intestinalis. This suggests that certain phases of fertilization are to be considered as influenced by the close relationship of the organs concerned. Whatever may be the affinities of the elements of the germ plasm in the act of cell fusion, certain phases of the 
processes of fertilization are no doubt conditioned by the physical relationship of the sexual organs especially when there is differentiation with respect to time of development.

A serious objection to the conceptions of Jost and Morgan is the very obvious fact that close relationship of the sex organs is equally present in all hermaplurodite plants, large numbers of which are self-fertile. In fact, in a single strain of plants, as in chicory, self-fertile and self-sterile individuals may exist. Furthermore, there may exist all degrees of cross-fertility and sterility among these self-sterile plants. These facts, especially, make it fully evident that there can be no general or very definite application of the doctrine either of individual stuffs or of purely individual cytoplasmic relations to the facts of relative sterility and fertility. These conceptions do not adequately distinguish self-fertile plants from self-sterile, and give no evident reason for the development of one or the other type.

SPECIAI, PHASES OF THE PIIENOMENA OF STERILITY AND FERTILITY

Before attempting to pass judgment on the very suggestive views already noted, or attempting to formulate any new conceptions, the different phases of the phenomena of sterility and fertility may be especially considered.

The relation of cross-incompatibility to self-incompatibility.-The results I have obtained with chicory indicate that the physiological processes involved in the self- and cross-incompatibility seen in this species are fundamentally of the same general nature.

The results are quite the same in both cases. As far as tested there seems to be a very general cross-sterility in those families whose individuals are mostly self-sterile. This is seen in the results with the $(A \times C)$ series and with the generations of the variety red-leaved Treviso. As far as known, at least some degree of physiological self-incompatilility always exists within a species or strain showing cross-incompratilility. Isually the phomomenas of self-incompatilility is much the more pronounced; in fact so much so that the phenomenon of cross-incompatibility between closely related plants of secel origin (not involving elimorphism, (etc.) Was not believerl to occur previens to ('orrens' report in 1912. Inless it can be shown that cross-incompatibility such as exists in Cardamine and Cichorium can exist without any self-incom- 
patibility, it would appear that the former is secondary to the latter and involves quite the same processes. That the two are not completely correlated is evident: plants of chicory that are self-sterile may or may not be mutually cross-sterile, and any two plants may exhibit different behavior when crossed with another sister plant, quite as Correns' data show in Cardamine. Furthermore, self-fertile plants are found with degrees of fertility varying from I to 70 per cent, which is quite analogous to the varying intensities of cross-fertility. The evidence indicates that in these cases cross-sterility is to some degree correlated with self-sterility.

The sporadic and fuctuating nature of steritity resulting from physiological incompatibility.-Darwin seems to have recognized quite fully the fluctuating nature of this sort of self-sterility at least in its appearance among different plants of the same race. His data, however, do not reveal such wide variations with various degrees of self-fertility as I have found in chicory. Correns' data show wide variations in the degrees of cross-fertility which, however, are ignored in his classification of results. Jost was fully aware that plants only feebly self-fertile are frequent. In Ciona different strains show different degrees of self-sterility. Neither Darwin, Jost, nor Morgan was aware of the wide variations that may appear in the degree of cross-fertility of self-sterile plants.

The behavior of sterility due to physiological incompatibility in different species further emphasizes the fluctuating nature and the marked individuality of the processes involved. Correns from self-sterile parents obtained one class of self-sterile offspring (though a few plants showed some indication of feeble self-fertility) which exhibited all degrees of cross-sterility and cross-fertility among themselves. East from self-sterile (?) plants of two different species of Nicotiana obtained only self-sterile offspring which, as far as tested, showed almost complete cross-fertility. In Cichorium Intybus, I obtained from self-sterile parents some self-fertile plants having the most sporadic and variable expressions of self-fertility and exhibiting all grades of cross-fertility among themselves. The difficulty of assuming that the causes are identical in all these cases and due to the activity of any simple chemical substances, either as to kind or intensity, is very evident.

That there are quite different grades and degrees even of complete self-sterility is indicated by the fact that two self-sterile 
plants may behave differently with a third self-sterile plant, one combination being fertile and the other sterile. The grouping of such interreactions was a point emphasized by Correns. The wide fluctuations in his results, howerer, fully indicate that the immediate cause of self-inconpatibility are strongly individual and are operating in different degrees of intensity in different plants. The group reactions, however, may be taken to indicate a degree of similarity with respect to the actual processes operating among certain plants. The results in chicory show that pollen of plants that are self-fertile may not be effective on other plants, and that reciprocal crosses may give different results, which is further evidence of the wide fluctuations in the interrelations involved in fertilization.

It is furthermore strongly indicated that the processes are fluctuating in a single plant. This is seen in Jost's assumption that the qualitative nature of the "individual stuff" is often different in different parts of the same plant, and in Correns" suggestion that a mosaic distribution of his assumed "line stuffs" might be involved in such irregular results as he obtained. In chicory, feeble fertility is exhibited by the development of a low percentage of seed in comparison with the total number of flowers pollinated. There is no evidence that in the oraries setting seed the processes of fertilization are identical with those in the cases of most successful cross-fertilization. The need here of carefully testing the relative vigor and fertility of individuals from seed so produced is obvious and experiments of this sort are in progress. Whether a low or a high percentage of seed is set, the processes in respect to each single fertilization involve no apparent incompatibility, or at least the incompatibility is not sufficiently strong to check fertilization. It should not be assumed, however, that seed-setting in and between different plants indicates an identical grade of compatibility. Self- or cross-fertilization that is of a weak grade of fertilization may be associated with the development of such weak or poorly developed plants and strains as do frequently appear in any sort of breeding. In a head of eighteen or twenty flowers, all were pollinated with the same mixture of pollen (in self-fertilization pollen of these flowers and pollen of the flowers of another head taken from the same plant and usually from the same main branch), but varying numbers of seed from 
one to the full complement may be produced. Cases of persistent low-fertility occur under the same conditions of chance experimental error. In such cases few seeds are set in a head of similar flowers all equally potent, and all seemingly subject to as nearly equal conditions of nourishment as is possible. The differences in compatibility exhibited by different flowers of the same head to mixtures of the same pollen are identically the same in the results (seed or no seed) as that seen in all the flowers in a head in the case of complete self- or cross-sterility as compared with marked high self- or cross-fertility. The differences can not be due to lack of pollination, as the method used, especially in selfpollinations, was equally ample for the distribution of pollen on all stigmas. These considerations seem to indicate that modifications of the same processes that produce complete self-sterility are also operating in the production of feeble self-fertility.

Further evidence of the fluctuating and individual nature of the processes and conditions involved in such cases may be gained by comparing the results of geitonogamy with those obtained by autogamy. The earlier experiments of Darwin ('77), Ulrich ('02), and Jost ('07) indicate that geitonogamy may in some cases be more productive of seed than autogamy. This question has never been adequately investigated in cases of physiological incompatibility where every sort of morphological incompatibility is eliminated. The results of Shaw ('16), indicate that in the proterandrous sugar beet autogamous fertilization is very nearly always sterile, while geitonogamous crossing is often successful, especially if the flowers are from distant branches. In these self-pollinations care was taken to preserve the pollen of the proterandrous flowers for use at the time when the stigmas were receptive, but it was not shown, however, that pollen of the same age was more effective in geitonogamy.

On the other hand, the marked persistence of self-sterility in varieties propagated vegetatively as seen in such plants as the pear, apple, plum, cherry, and blueberry is suggestive that the processes are quite uniform not only in the parts of a single plant but in the series of plants vegetatively derived from it. In such plants there is especial opportunity to test the degrees of bud variation and the relative fertility of plants of different lines of descent, and thus obtain accurate data on this important point. Thus far such studies have not been made. 
The relation of incompatibilities giving sterility to cell organization.-The particular types of cell organization which Correns and East assume to be involved in the cause of sterility have already been quite fully discussed. Quite a different view of the influence of cell organization may be considered and from at least two aspects. A particular type of somatic iclioplasmic constitution may be associated with the development of self-sterility in respect to the rôle of the nucleus, as a part of the whole, in the nucleo-cytoplasmic relationships determining the activities of cells and their intercellular relations in the individual organ or plant. A particular type of diploid nucleus may also be of significance in sterility through its influence on the differentiation of sex organs and of the gametes whose nuclei arise from them. In respect to these points it is to be noted, as East has emphasized in respect to the relations of the sporophytic style and gametophytic pollen tube, that the causes of sterility from physiological incompatibility are operating in a plant itself largely independent of such differences in the particular idioplasmic constitution of the sex organs as may result from reduction divisions.

Perhaps a better assumption which would provide for the sporadic occurrence of the differences which must be assumed to be responsible for self-sterility in the case of self-fertile offspring from self-sterile parents or, vice zersa, of self-sterile offspring from self-fertile plants, in which latter process all self-sterility doubtless originated, is that of new or differentiated cell organization resulting from such processes as Swingle ('13) has called zygotaxis. This is especially an emphasis of a new differentiated condition which may arise in the cytoplasm directly as a result of the relative distribution and position of the chromosomes in the nucleus. We must recognize a large amount of evidence that chromosomes have a fixed position in the nucleus as Boveri has so clearly shown in 1 scaris. But sporadic changes in the arrangement of chromosomes such as are assumed in the hypothesis of zygotaxis may well occur in nuclei where the number of chromosomes is larger, and thus provide for new cytoplasmic conditions of the sort which may be assumed to account for the phenomena of selfsterility.

In TABBLE, 3, data are griven for 58 plants of the cross $A \times$ E22: in these Fo hybrids, from parents which differed widely, the reduc- 
tion divisions undoubtedly gave in each plant many kinds of pollen with respect to the actual qualitative values of the germ plasm (irrespective of whether or not there may be purity of segregation). Fifty-three of these plants were fully self-sterile; all kinds of pollen produced by each plant were ineffective in selffertilization, though in respect to segregation the pollen of these plants must, it would seem, be as markedly different as that from the five sister plants that were, however, self-fertile in some degree. In the $F_{2}$ and $F_{3}$ generations, self-fertile and self-sterile plants appeared quite independently of the individual hereditary complex, so far as it could be judged by visible characters. The class of white-flowered segregates of the $F_{3}$, which were very uniform in appearance for each line, included both self-sterile and self-fertile plants. Likewise, the members of $F_{3}$ progenies grown from blue-flowered parents were self-sterile or self-fertile without respect to flower color or other characters. These results are quite the same as those obtained by Correns, East, and Morgan, which indicates that complete self-sterility may operate in individuals that are highly "heterozygous," and that in such cases the processes prohibiting self-fertility are operating on the pollen tubes or gametes from pollen of that plant irrespective of their idioplasmic differences, so far as the latter can be judged by visible characters. In cross-fertility or -sterility quite similar behavior is seen. It is on such evidence that the views of Jost and Morgan, that the processes are purely somatic and intercellular in the individual itself, are based and if self-sterility were universal in hermaphrodites this would be a very natural conclusion.

The marked persistence of self-sterility in varieties propagated vegetatively, already considered in the cases of the apple, plum, pear, cherry, and blueberry, is suggestive that the conditions giving self-sterility are perpetuated by bud propagation without any marked change due to growth under somewhat changed conditions. Carefully conducted experiments with such plants are greatly to be desired to determine whether wide variations can occur in the plants of the same clone irrespective of, or in association with, evidences of somatic variation in nuclear organization. If we may judge by the seed progeny of the cultivated rarieties just mentioned, the evidence is quite clear that they are vegetative types that propagate fairly true vegetatively and maintain a type 
of plant quite different from that which the great majority of the seed would give. Such varieties are to be regarded as "heterozygous" - at least the diploid organization of the somatic cells must be considered as far from "homozygous." The evidence here is therefore in favor of the existence of self-sterility in plants that are heterozygous and whose gametes possess a marked dissimilarity.

It must be noted, howerer, that plants that are apparently equally heterozygous may be either self-fertile or self-sterile. Fifteen plants of the total of 172 plants of the $F_{1}$ generation reported in TABLE 3 were self-fertile. It would seem that there is no evidence of a difference in the degree of heterozygosity between these and their self-sterile sister plants.

There is also evidence which seems to indicate that self-sterility may exist in plants that are less heterozygous than the $F_{1}$ hybrids just mentioned. In the inbred strain of the red-leaved Treviso variety of chicory, all plants thus far grown were self-sterile with one exception: the families of this strain have, however, showed wide variations in fasciation, in leaf-shape, and in the amount of anthocyanin developed, and are hence far from a pure race or the characters are showing sporadic variations of the eversporting type. Selection of self-fertile strains derived from the hybrid plants resulted in the segregation of certain $\mathrm{F}_{3}$ progenies that were very uniform in general appearance and in flower color, and were decidedly uniform in all their characters; in these plants, apparently the most homozygous of any of my chicory cultures, selffertility and self-sterility appeared with quite the same fluctuations as in the $F_{2}$ generation. We must conclude that complete or partial self-sterility and high self-fertility seem to occur without any direct or immediate relation to those degrees of homozygosity or heterozygosity that have thus far cleveloped in the cross breeding and inbreeding of these plants. It is such fluctuations as these, however, that may be masking the real relations of sterility and fertility to particular types of cell organization or differentiation.

It is clear that there is no decrease in respect to the self-fertility of strains produced by self-fertilization. The average fertility was quite the same for the $F_{3}$ as for the $F_{2}$, and in individual records two plants of the $\mathrm{F}_{3}$ gave a percentage fertility of 70 and 56 against the highest percentage of 52 for any $F_{2}$ plant. The pro- 
geny of $\mathrm{F}_{2}$ plants of feeble fertility gave an average fertility that showed marked regression to the mean fertility of all self-fertile plants. In these generations, considered as a whole, there was no apparent decrease of fertility due to self-fertilization. The results are quite in line with the exceptional cases of highly self-fertile strains which Darwin discovered in Ipomoea and Mimulus, and which were considered by Darwin as noteworthy exceptions to the general rule that inbreeding decreases fertility.

Thus far I have not been fully successful in isolating a race solely composed of self-fertile plants. As only two generations of self-fertile progeny have been grown there is the possibility that such races will be isolated. The data obtained indicate clearly that there is no decrease in fertility with increased homozygosity and self-fertilization. This fact suggests that a marked degree of similarity or homozygosity is at least not unfavorable to the development and perpetuation of self-fertility.

Further evidence on this point is to be had from the ancestry of the first self-fertile plants. With the exception of the one plant feebly self-fertile reported ir TABLE 7 , all the self-fertile plants derived from self-sterile parents are recorded in TABLE 3 . Of these ( $\mathrm{I} 5$ in number) all but one are progeny of plants rather distantly related. However, all my $F_{1}$ generation excepting 8 plants of the $A \times C$ cross were from crosses of rather widely separated types, hence the results of close crosses between self-sterile plants has not been very fully tested except in the red-leaved Treviso variety, and even here there is evidently much variability. A large majority of the sister plants were self-sterile; and wide crosses did not always give some self-fertile plants, as is seen in the case of the 17 plants from $A$ with $E_{3}$, and the 30 plants of series I4 (TABLE 3 ). In respect to the production of self-fertile plants, therefore, no general rule can be made that does not have exceptions. The judgment of cell organization on the basis of the expressed characters of parents, of sister plants, and of offspring may, as is generally recognized in many cases, be quite misleading.

The range and scope of cross-compatibility and -incompatibility has a bearing on the question of the relation of sterility to cell organization. Cross-pollinations between widely different and unrelated stocks do not always produce seed. The few crosses 
made between plants $A$ and $C$ and plants of the $E$ series were fertile, but not all wide crosses are successful, as the use of pollen from plant $A$ on various plants of the variety red-leaved Treviso shows. Also it should be noted that the cross-fertility of closely related plants as $A$ and $C$ (TABle 2), $A$ and $A 9, A$ and $A 27$ (TABle 9) may be quite as great as that between two more widely unrelated plants as $A$ and E22. The data for crosses within lines of known descent given in TABLES $\mathrm{I}-\mathrm{I}+$ seem to indicate that there are a large number of failures compared with those of crosses between widely unrelated stocks. Individual cases of high fertility occur quite the same in both, all of which emphasize the wide variations of the processes involved in incompatibility.

The occurrence of cross-sterility and cross-fertility between plants of different races or strains of chicory supports the view that such plants develop similar conditions in this respect independently of their possession of the germ cell elements that may be present. These facts emphasize that the conditions determining self-sterility or cross-fertility are in a high degree individual rather than purely related to racial differences, and suggest that the type of cell organization in any particular organ (the style) may be highly individual and relatively duplicated in widely different races on the hypothesis of zygotaxis. These considerations make it evident that the rôle of the particular content of the idioplasm in respect to the development of compatibilities and incompatibilities in fertilization is secondary to this more general cell organization that is affected by differentiation of sex organs.

Relation of vegetative vigor and fertility to inbrecding and crossbreeding.-Closely associated with the foregoing topic is the question of the influence of inbreceling and cross-breeding on vegetative vigor and on the degree of fertility or sterility (of all sorts).

Darwin sought to establish the law that "nature abhors selffertilization" and that cross-fertilization increases vigor and fertility while self-fertilization decreases vigor and fertility. This Darwin assumed to result because of increased dissimilarity through crossing as contrasted with decreased dissimilarity through selfing of sexual elements respectirely. Darwin approached the whole cuestion of cross- and self-fertilization from the standpoint of 
the scarch for the source of variations which might be the material for selective processes of evolution and the obvious fact that crossing as contrasted with selfing was considered to lead to greater variability made him the more willing to emphasize any evidence that the former process is beneficial in itself even independently of its relation to the increase of variability.

It is always to be remembered that even though self-fertilization is productive of more numerous and vigorous offspring, the increased variability resulting from crossing might make the latter a vastly more significant process from the standpoint of evolutionary progress. A study of Darwin's data shows clearly that the evil effects of self-fertilization in plants are not sufficiently in evidence to establish the point. In fact in the two cases (Ipomoea and Mimulus) continued longest in self-fertilization (ten generations) strains highly self-fertile and vigorous were maintained. Darwin fully admits not only that the supposed evil effects of inbreeding are scarcely apparent, but that "it is difficult to avoid the suspicion that self-fertilization is in some respects advantageous" ('77, p. 352). Darwin's whole contention on this point rests on the comparative increase in vigor and fertility which appeared in certain cases of crossing. Here, however, the results are far from consistent and convincing. Nearly half the cases considered show no such benefit. This was realized by Darwin who interpreted such negative results as due to the similarity of the crossed plants because of "having been self-fertilized and cultivated under nearly uniform conditions for several generations" ('77, p. 28I).

It is not always clear just what type of sterility is involved in Darwin's results. It is not fully evident that such differences as did appear between self-fed and cross-fed stocks are due to impotence as I have used the term. Darwin seems to ascribe cases of lower fertility in selfing to a combination of a weakened condition (a type of impotence) and a lack of differentiation in sex elements (a physiological incompatibility), which, however, he is careful to distinguish, as to its immediate cause at least, from complete self-sterility or, as I am calling it, well-developed self-incompatibility. At least in two genera, Eschscholtzia and Reseda, Darwin's data involve sterility due to physiological incompatibility. It is most significant that when self-fertility does occur in Eschscholtzia 
the resulting plants, as described by Darwin, were more vigorous than those of cross-bred origin. That they were less self-fertile than cross-fertile, however, is apparently in no way connected with their vigor.

The cases of plants reported by Darwin that were feebly selffertile but strongly cross-fertile suggest quite strongly that he may have been dealing with the same phenomenon of incompatibility that is frequent in the case of the self-sterility which he observed in Reseda and Eschscholtzia. A more extended study of these plants in pedigreed cultures might have convinced Darwin of this point.

The opposite view from that of Darwin on this particular question has been expressed by Burck ('08) who has very fully summarized Darwin's results, and much available data in connection with his own observations on various cleistogamous species. Burck especially points out that (I) plants that are regularly self-fertilized show no benefits from crossing, (2) that nowhere in wild species is there evidence of an injurious effect from selffertilization, and that there is abundant evidence of continued vigor and high fertility resulting from long continued selffertilization, and (3) that the advantage derived from crossing within or between garden varieties appears when there is doubtful purity, and is due to the fact that both vigor and fertility have already been decreased by hybridization, and that when crosses do give increased vigor and fertility the cross has restored in increased measure the original nuclear organization of the parent species.

Especial emphasis is given to the fact that Darwin worked with so-called impure varieties and that when continued self-fertilization resulted in a purer strain, as in the cases of Ipomoea and Mimulus greater fertility and vigor appeared from self-fertilization than resulted from cross-fertilization. Burck points out, as Darwin realized, that these facts are not in harmony with Darwin's general contention regarding the injurious effects of self-fertilization.

Burck considers that sexual affinity depends more upon similarity than clissimilarity; the degree of fertility depends upon the degree of harmony in respect to the total number of "anlagen" borne in the nuclei. The facts, Burck contends, support the view 
that full fertility is attained in self-fertilization between plants of strains that are most pure.

It must be noted that Burck does not further identify the type of sterility which he considers develops in cultivated varieties as a result of crossing. It is conceived to be due essentially to dissimilarity of gametes, although there may be, as it appears, also a decreased vigor. The question whether it may assume such marked types of self- (and cross?) incompatibilities as are seen in Eschscholtzia, Reseda, etc., is not considered. In fact this type of sterility was not discussed. Proper experimentation in such cases should show whether such sterility is in evidence. It is clear, however, that Burck is not considering a type of extreme impotence.

In marked opposition to the views of Burck and in general agreement with the conceptions of Darwin is the doctrine emphasized by Shull and more especially by East and Hayes ('12), that heterozygosity gives an increase of both vigor and fertility in proportion to the number of "heterozygous factors in the organism" and that inbreeding although "not injurious in itself" (p. 33) "tends to isolate homozygous strains which lack the physiological vigor due to heterozygosity" (p. 37).

The results of East and Hayes ('12) appear in two types of experiments; (a) those involving chiefly interspecific and intervarietal crosses in tobacco, which is usually highly vigorous and fertile in continued normal self-fertilization, and (b) those involving intervarietal crosses in corn, which is normally cross-fertilized because of the marked proterandry that exists.

In the interspecific crosses in tobacco 42 crosses were attempted (East and Hayes, '12, table 5): 9 of these failed to produce viable seed (the parent species were cross-incompatible); of the 33 different hybrid progenies grown, It showed decreased vigor, 2 were equal to parent species, and 17 were of increased vigor. It appears from the discussion that the percentage growth of hybrids, as given in the table just summarized, is based on the average of the parent species. Of the 14 hybrid progenies with decreased vigor one is reported as fertile and 2 as slightly fertile; of the 17 showing increased vigor 8 were fertile, 3 slightly fertile and 8 sterile. There was increased vigor in only I 7 cases, but there is no apparent reason why, if it is simply heterozygosity that increases vigor, more of the combinations should not show increased vigor. 
The low fertility (only 9 were classed as fertile and 5 as partly fertile) of the series is noticeable and clearly shows that the tendency of heterozygosity of interspecific rank is to give sterility. Evidently the sterility is largely of the type I am classing as impotence, although this is not certain, for at least one case (Nicotiana Forgetiana $\times N$. alata grandiflora) here reported fertile is later (East ' $15 a$ ) reported as self-sterile (physiological incompatibility) but cross-fertile. Eight of the cases classed as fertile are among hybrids that have increased vigor.

The evidence certainly fails to establish the point in question. One can claim equally well that in the cases of increased vigor and especially for those that are also fertile the results are due to a similarity in respect to the cell organization of parent species which admits of successful combination.

With the intervarietal crossing in tobacco the results are quite as fluctuating and variable as are those of Darwin, and here the writers are inclined to consider, as Darwin did, that when such intervarietal crosses show no increased vigor it is not because of simple relationship but because of similarity of gametic constitution. As Burck has pointed out, the general application of such a conception is untenable, and East and Hayes's results in tobacco are fully as unconvincing as are the results reported by Darwin.

The most striking results were obtained in corn, in which as a rule crossing between varieties increases both vigor and seed production over that of inbred and self-fertilized stock. At first glance the data seem most convincing and had such results been obtained in tobacco the case would seem well established. However, it must be remembered that many races of corn are difficult to self-fertilize on account of proterandry. Even with this difficulty East and Hayes found that "decrease in vigor lessened with inbrecding" and that "good and bad strains were isolated" (p. 22). Pedigreed line cultures, inbred, showed that no two gave the same results; one strain of Leaming dent remained vigorous and highly productive while another became nearly sterile. Strains apparently similar in lomozygosity show widest variation indicative of spontaneous variation in natural vigor, which is suggestive that in such highly cultivated varieties as corn extreme sporadic variations may be constantly occurring, a 
condition which is well shown by the numerous and well-known results of the so-called ear-to-row tests.

Further breeding work has shown that there are exceptions to the general rule that crossing between varieties of corn gives an $F_{1}$ with greater vigor than that of either parent and further that the yield may even be less than that of either parent (Hayes, '14, p. 364). Collins ('14) points out that in corn "some crosses give favorable results and others give little or no increase over the yield of parents" (p. 9I), and that there is a decidedly "abnormal behavior of self-pollinated maize plants" with also wide individual diversity in the yield of hybrids which make the satisfactory comparison of the yield of parents and hybrids difficult.

It must be recognized that it has not been fully shown that in corn the cross-pollination of plants of a good strain in such a manner as to eliminate the effects of proterandry does not continue the strain in inbreeding with high vigor and production. The conditions in corn hardly make the tests as adequate as in tobacco, but, considering all the data at their full value with proper consideration of the limiting conditions, the results, as pointed out by Burck for Darwin's data, can be interpreted as not at all inconsistent with the view that the best development and fertility is associated with greatest similarity.

The emphasis that East and Hayes place on nuclear organization in respect to presence or absence, or the presence of heterozygous allelomorphs of assumed hereditary units is based largely on the older conceptions that such units adequately represent characters and segregate with purity in sporogenesis; both conceptions are known not to be laws as these authors evidently realize ('11, p. +2). The marked increase in vigor which hybrids often show, especially when there is also fertility, may very well involve elements of similarity that pertain to a type of cell organization and sex differentiation that is far more fundamental than differences or similarities in purely nuclear organization such as may exist between varieties of the same species and such crosses may very well restore in increased degree a type of ancestral cell organization in much the manner that Burck has emphasized.

The evidence obtained in animal-breeding, in which inbreeding of pedigreed lines of descent is the nearest possible approach to self-fertilization of nearly homozygous plants, has been variously 
interpreted. Some have emphasized the fact that weak strains do thus arise, which is interpreted as evidence that inbreeding always results through its own influence in decreased vigor and fertility (see discussion and conclusion of Kraemer, '14). The very frequent cases of highly vigorous and fertile inbred strains or of intensive line-bred strains (Wilsdorf, '12), however, compel one to attribute the appearance of weakened inbred strains to causes other than inbreeding itself.

The results of experimental work with rats by King ('16) show that inbreeding of pedigreed lines of albino rats for 22 generations involving a total of 10,000 individuals has not led to any decrease in constitutional vigor, but that there has been instead an increase of body weight and fertility over that of stock albino rats. In these experiments selectionsfor size and fertility were quite secondary and incidental. Such results indicate that inbreeding is not of itself to be considered as injurious.

Relation of sterility from physiological incompatibility to vegetative vigor and production of sex organs. - The physiological incompatibility involved in the sterility exhibited in chicory is quite independent of any decrease in vegetative vigor, and it does not involve in any degree the number of flowers produced. Although the size of the plants and the relative number of flower heads varied considerably, there is no correlation between the number of flowers produced and the number of seed set either in self- or in cross-sterility or fertility, and in all cases the actual fertility bears no apparent relation to the potential fertility. It was estimated that during the summer of 1915 the self-sterile plant $A$ produced at least 1,00o flower heads, the self-sterile plant $C$ about 2,000, the self-fertile plant $(E 22 \times A)$ no. 10 about 2,200 , and the various self-sterile plants of the red-leaved Treviso variety about 2,500 each. Sister plants of the $F_{3}$ generation were most of ten quite alike in general vigor and habit of growth whether self-sterile or self-fertile. Evidently it was such results as these, together with the persistence of self-sterility even in plants necessarily cross-bred, that led Darwin to the vague suggestion that the causes of self-sterility of this type are sporadic and chiefly environmental.

The conditions in chicory in this respect are evidently similar to those reported for Eschscholtzia, Sccale, Cardamine, Nicotiana, 
and the various fruit-bearing plants generally described as selfsterile. In chicory the sporadic occurrence of plants self-fertile in varying degrees has given opportunity to observe the comparative vigor of self-fertilized and cross-fertilized progenies. There has been no consistent apparent decrease either of vegetative vigor or in the production of flowers in these self-fertilized lines. Different lines of descent differ widely in respect to habit of growth, size, and total number of flowers produced per plant. Some families of the $\mathrm{F}_{3}$ generation were uniformly small, scraggly, sparsely branched plants, others were short but very bushy and much branched, and still others were tall, vigorous, and much branched. These differences seem to be independent of any differences in the degree of homozygosity and in each family self-fertile and selfsterile plants were most of ten as nearly identical in habit of growth, vigor, and in number of flowers produced as it is possible for two plants to be. The evidence on this point is still accumulating and more complete statistical data will be published later.

The contrast between sterility from physiological incompatibility and sterility from impotence.-Sterility due to physiological incompatibility is quite different from that due to impotence as I have limited these terms above. The distinction has not generally been made and from the discussions given in the literature one can not always determine what sort of sterility actually prevailed. In such discussions of infertile hybrids as that by Wilson ('06) and by East and Hayes ('12), the different sorts are treated without any distinction. The sterility which East ('15a) reports for hybrids between Nicotiana Forgetiana and $N$. alata grandiflora is evidently due solely to a physiological incompatibility (germ cells all fertile in other connections), while that which he reports ('15b) for hybrids of $N$. rustica $\times N$. paniculata is evidently purely a matter of impotence (failure to produce spores or gametes). In I9I2 East \& Hayes reported the former hybrid as "fertile" and the latter "partially fertile." That a limitation in the use of terms is necessary is clearly apparent in such cases.

The causes of impotence which result in degeneration of spores, especially as seen in many interspecific hybrids, it would seem, are more essentially intracellular in that the incompatibility may involve a direct relationship within the cells between their idioplasmic elements, giving the so-called "chromatin repulsion." 
Numerous cytological studies of such cases show that the mechanical processes of the reduction division and the reorganization of the daughter nuclei of the spores are abnormal. What appears to be chromatin repulsion may be an expression of intra- and intercellular incompatibilities that arise in a hyl,rid from differences in the particular types of sex differentiation possessed by the two parents. Even when the parents exhibit close agreement in morphological differentiation a wide range of difference may exist in regard to the relative time of development of sex organs of which proterandry and proterogyny are marked types. Such parental differences may first clash when the processes of sex differentiation in a hybrid are set in motion, resulting in various grades and types of impotence. This is evidently, in part at least, what 'Tischler includes in his view (see especially '07) that the impotence of hybrids is the result of differences in the "Entwicklungsrichtung oder Tendenz" of the parental germ cells which interfere with the normal ontogeny of the hybrid especially during the critical time of the generative phase of the development.

The production of such conditions as the result of inbreeding or of continued self-fertilization is certainly very infrequent as compared with the development in the progeny of wide cross-fertilization. Such impotence on the part of plants was long considered as an evidence of hybridity, and as a direct result of dissimilarity in the cells involved, indicating the specific rank of the parents. Jeffrey ('14) has quite recently emphasized in special reference to the Oenotheras the familiar conception that such impotence is a sign of hyluridity.

Daris ('15b) has also pointed out the high degree of "zygotic sterility" (embryo abortion) and pollen and ovule sterility (impotence) that prevails in numerous Oenotheras and has suggested that a selective fertilization (physiological incompatibility) may also be in operation. He speaks also of "gametic sterility," hut it is not clear whether he refers solely to impotence or to physiological incompatibility (as I hare used the terms) or to both. His general conception that in these cases similarities are eliminated and dissimilarities are perpetuated is, however, purely an assumption which he lorings forward to assist in accounting for the sporadic and irregular inheritanes in the Oenotheras on more nearly Mendelian assumptions. His inrestigations are highly 
important in proving the frequency of impotence of various types and of embryo abortion, and is suggestive that much may be learned from work with the Oenotheras regarding the causes of these phenomena.

Not a few investigators have attributed the degeneration of microspores and macrospores to conditions arising from long and intensive cultivation. Thus Osawa ('13) considers that such is the case in Daphne, and Wakker ('96) has reported that cultivated races of sugar cane show various grades of such impotence which are not present in the wild or semi-wild races. In all such cases, however, the proof that hybridization has not been involved, as Jeffrey has pointed out for similar cases, is not conclusive.

Attempts to influence or change the degree of impotence in the case of almost completely impotent interspecific hybrids in tobacco (Goodspeed and Ayres, '16) have thus far been negative, which it would seem emphasizes the view that the causes of such impotence are intracellular and only subject to slight, if any, influences from the general nutrition or physiology of the plant as a whole. The results reported by Martin ('13) and of Westgate and Coe ('15) indicate that a plant may be impotent with respect to development of macrospores in one crop of flowers and potent in another crop as a result, they assume, of a difference in water supply determined by the season. Here, however, the impotence is not, it appears, a degeneration, but a condition in which the tissues of the pistil remain regetative. Coit ('15) has, however, reported that the degree of impotence of pistils in the Washington navel orange is changed to some extent by climatic conditions.

That impotence involving degeneration should often occur in the reduction divisions and not in the innumerable somatic divisions that precede, and that such impotent hybrids are often vegetatively very vigorous, may indicate that after all the socalled incompatibility may not involve chemical reactions so much as more purely mechanical relations. It is clear that fertilization may occur so far as cell and nuclear fusions are concerned and that diploid and of ten decidedly heterozygous organisms may continue life with vigor only to have the intranuclear processes, mechanical or chemical, or both, break down during the more intricate processes of spore formation. There is no clue in such behavior to the conditions operating in the production 
of such sterility as is in evidence in cases of physiological incompatibility in which spores and gametes are formed and in which the incompatibilities appear to be largely independent of any direct intracellular relations of the two parental elements in the germ plasm.

These cases suggest that the phases of fertilization involving cell fusion are more properly to be regarded as being conditioned by factors of cytoplasmic differentiation or general protoplasmic organization, while those of synapsis and reduction are conditioned by the mutual relations of the nuclear and cytoplasmic elements involved.

The general results of breeding indicate that when the cytoplasmic and nuclear relations are such that fertilization can occur, there is, as a rule, chance fertilization between all gametes irrespective of their particular hereditary complex. Such assumed behavior has been the fundamental basis of Mendelian doctrine. In the production of the so-called dominants and recessives from any $F_{2}$ hybrid, gametes that are alike (at least in respect to the characters involved) combine, while in the production of the impure members of the same generation gametes that are unlike are assumed to combine quite as in the production of the parent $F_{1}$ plants. Homozygosity and heterozygosity are generally assumed to occur with equal chance.

The only incompatibility, if we may call it such, that is assumed to occur in such cases is that between assumed hereditary units or factors at the time of the reduction division and here chemical or mechanical relations are assumed to give pairing and complete segregation of the elements of the pairs of allelomorphs whether they both are similar (represent the same character or fraction of a character), whether they are dissimilar, or whether they represent the presence and absence of a character. All have been assumed to segregate with quite their original integrity and value. While it is becoming very evident that the general doctrine of unit characters or unit factors and of purity of segregation have at most only a rather limited application, the general results of breeding have been assumed to indicate that to a certain degree similarity and dissimilarity of particular germ-plasm elements are not in themselves to be considered as definitely limiting fertility except perhaps in cases where impotence appears. The 
possibility that selective mating of gametes may occur in certain cases and constitute a factor in fertility and in segregation is, however, not to be excluded. The assumptions of those who would ascribe sterility from incompatibility to hereditary line stuffs or individual stuffs are plainly opposed to the general Mendelian assumption as to chance mating and pairing of the newly combined factors.

Further there would seem to be a natural presumption in favor of the view that chromosome incompatibility resulting in impotence is only the extreme stage of a series whose earlier stages are shown in the phenomena of gametic physiological and morphological incompatibility and that when in operation it is a very special grade of differentiation.

It must be recognized that impotence involving various grades of development of only one of the sex organs is less directly attributable to an intranuclear incompatibility than are the cases of nearly equal impotence of both sex organs as seen in numerous interspecific hermaphrodite hybrids. The various sex forms in Plantago lanceolata (Bartlett '13), for example, show gradations from fully potent hermaphrodites through various grades of anther and pollen impotence to plants that may beconsidered as pistillate only. Here the conditions suggest the operation of physiological processes in association with the differentiation of male sex organs, and that in respect to the degree of such impotence an entire plant is differentiated, much as is the entire organism in the case of strictly dioecious plants and animals. The occurrence of plants of Plantago exhibiting various grades of impotence among the flowers on a single plant (gynomonoecious) (Bartlett '13, p. I 74), indicates the sporadic nature of the physiological processes involved with this sort of differentiation, as do, likewise, the development of various grades of hermaphrodite forms in animals, as especially reported by Goldschmidt ('16).

The writer has simply suggested in the introduction and in the foregoing discussion some of the most obvious types of impotence of which degeneration of spores is a very marked type. Other types involving the failure in the formation of flowers or sporophylls, of one or the other kind or of both, or of a general physiological debility are equally in contrast to the conditions prevailing in the case of the incompatibility as seen in Cichorium, Cardamine, Reseda, etc. 
Significance of serum incompatibilities, etc.-It would seem that a clue to the processes involved in sterility due to physiological incompatibility might be found in the interactions between the tissues and the body fluids of different inclividuals as exhibited in the results of tissue grafting, in infection and immunity, and in hemolysis and isoagglutination. Such suggestions have been made especially by Jost ('07), Compton ('12, '13), Morgan ('10), and by Lillie ('13).

In tissue grafting, both in animals and plants, the degree of success depends on close relationship, and there are no eridences that in grafting there is any sort of tissue incompatibility comparable to that exhibited in self-sterility or in cross-sterility between closely related individuals. Here the results seem to present no analogies unless it can be shown that tissue grafting in the animals and plants which show self- and cross-sterility behaves differently from the rule and shows the same limitations as the fertilizations. This is a possibility, and in the absence of all evidence on this point must be held as such, although it should be noted that the self-incompatibility exhibited in cases of sterility in hermaphrodites is not indicated by any incompatibility of purely vegetative parts or even in general debility or decreased regetative vigor.

From the nature of the processes of fertilization in higher plants, it would appear that, as Jost ('07) has pointed out, any stimulating or inhibiting sulstances operating in the interrelations of the tissues involved must be diffusible and must be products of the cells involved. If this be true, the data regarding the incompatibility of normal body fluids of different individuals, as exhilited by the phenomena of agglutination, cytolysis, and precipitation should be studied with reference to its hearing on the phenomena of self- and cross-sterility. In agglutination phenomena, which have a distinct value in the elinical diagnosis of infectious cliseases, we see the visille effects of various types of so-callerl antigen-antihody reactions constituting a type of reaction between two organisms. Even in interspecific relations, however, there are exceptions to any general rule of operation: group reactions show that, even in sharply elefined species, specificity may not exist; "no two strains of harteria of the same species are exactly similar in the ir agglutinaloility in the same serum" (Zinsser 
'14, p. 229), and the agglutinative characteristics of various bacteria may be modified by life in different hosts (Smith and Reagh '04; Zinsser' '14, p. 23I). The quite general application of the principles of agglutination, however, suggests that similar reactions may be involved in compatibilities and incompatibilities. The appearance of agglutination reactions between the blood cells and the sera of different animals of the same species or strain (isoagglutination) suggests that at least in the higher animals types of antigen incompatibility may exist between closely related individuals. Such reactions have been studied especially in man, and it has been found (Ottenberg '11) that, in respect to the isoagglutination reactions between sera and red blood cells, individuals fall into four classes: class I, serum will agglutinate red cells of all members of all other groups, but the red cells of individuals of the group are not agglutinated by the serum of any individual of any class; class II, serum agglutinates in classes III and IV only, and red cells are agglutinated by serum of classes I and III only; class III, serum agglutinates in class II and IV only and blood cells are agglutinable by sera of classes I, II, and IV: class IV, serum will not agglutinate red cells of any class and has red cells that are agglutinable by every other class. These reactions within and between the four groups have been explained by the assumption of two pairs or sets of reacting substances; two different active substances (agglutinins $x$ and $y$ ), and two different agglutinable or sensitive substances ( $\mathrm{X}$ and $\mathrm{I}^{\top}$ ). The agglutination reaction is assumed to occur only when the two bloods that are mingled bring together at least one pair $\mathrm{x}$ and $\mathrm{X}$ or $\mathrm{y}$ and $\mathrm{Y}$. Between bloods of members of any one class there is no incompatibility in the form of agglutination. The reciprocal interactions between members of classes I and II, I and III, I and IV, II and IV are different. Two reciprocal pairs, II with III and III with IV', give the same reaction. Also individuals of the first class constitute about 50 per cent of all persons examined, and members of the fourth class are relatively rare. Nembers of the third group especially often show individual irregularities and deviations from the rule which it is assumed involves the presence of another substance, called hemolysin, which exhibits very sporadically the condition of activity or latency. 
Furthermore, the studies of isoagglutination phenomena in steers (Ottenberg and Friedman, '11) show that although there are groups of individuals with the same characteristics, some of these groups are different from those in man. In steers the interactions seem to involve but one pair of substances distributed in two classes only. The interreactions typical for the various classes in these different animals are given in TABLE $\mathrm{I} 7$, in which the differences noted are very apparent.

\begin{tabular}{|c|c|c|c|c|c|}
\hline & \multirow{2}{*}{ Class } & \multicolumn{4}{|c|}{ Sera } \\
\hline & & $I\left(x y^{\prime}\right)$ & $11\left(X_{y}\right)$ & $\mathrm{III}\left(\mathrm{xI}^{-}\right)$ & $\mathrm{W}(\mathrm{XY})$ \\
\hline$\stackrel{n}{\overline{0}}$ & $\begin{array}{l}x y \\
\text { Xy } \\
x Y^{\prime} \\
X Y\end{array}$ & $\begin{array}{l}\overline{+} \\
+ \\
+\end{array}$ & $\begin{array}{l}- \\
+ \\
+\end{array}$ & $\frac{\vec{t}}{t}$ & $\begin{array}{l}- \\
\bar{t} \\
-\end{array}$ \\
\hline \multicolumn{6}{|c|}{ IN STEERS } \\
\hline & $C_{1}$ & \multicolumn{4}{|c|}{ Sera } \\
\hline a & Class & $1(x)$ & $11(X)$ & III (o) & \\
\hline 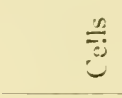 & $\begin{array}{l}\mathrm{x} \\
\mathrm{X} \\
\mathrm{o}\end{array}$ & \pm & $\begin{array}{l}- \\
\overline{-}\end{array}$ & $\begin{array}{l}- \\
\overline{-}\end{array}$ & \\
\hline \multicolumn{6}{|c|}{ IN CARDAMINE } \\
\hline & & $a b$ & $\mathrm{Ab}$ & aP, & $A B$ \\
\hline & $\begin{array}{l}a b \\
A b \\
a B \\
A B\end{array}$ & $\begin{array}{l}- \\
\overline{-} \\
-\end{array}$ & $\frac{\bar{t}}{+}$ & $\begin{array}{l}- \\
\bar{t} \\
+\end{array}$ & $\begin{array}{l}\bar{t} \\
+ \\
+\end{array}$ \\
\hline
\end{tabular}

The nomenclature and the grouping into classes especially in man are strikingly similar to those given by Correns in respect in the behavior of cross-sterility in Cardamine. In man, however, the incompatibility (judged by agglutination) is assumed to involve a reaction between two different substances, while in Cardumine the incompatibility (judged by cross-sterility) is assumed, doubtless falsely, to be a relation between two similar substances. No agglutination reactions occur between the bloods of individuals of any class, but in Cardamine only plants of the class " $a b$ " were cross-fertile anong themselves. Correns assumes that the sulustances may be also latent when they exhibit no 
interaction. In Correns' results cross-sterility is considered as a result of interaction of inhibiting substances and cross-fertility is an index that there was no action. These interactions expressed by + and - are represented in TABLE I7. A comparison of the behavior of cross-sterility between the various classes of Cardamine and the agglutination reactions between the various groups of man and steers shows that the only agreement is seen in the absence of reactions exhibited by class " $a b$ " in Cardamine, the class III in steers, and class $I$ in man. Only in classes in which all reacting substances are assumed to be either latent or absent is there any agreement.

There is as yet no evidence that these phenomena of isoagglutination have any relation to the cross-fertility of the animals concerned, for fertility between the individuals showing agglutination is apparently unimpaired. Thus it is evident that differentiations do occur, giving so-called incompatibility between blood cells and sera of animals of the same species which, as far as known, have no influence on the compatibility of the sex cells themselves. These observations suggest strongly that analogous reactions may operate in the cytoplasmic relations involved in the growth of pollen tubes during the early processes of fertilization, and that such interactions are not necessarily an index of the direct relations of the sex cells.

Physicians, however, fully recognize that cases of human sterility may involve particular incompatibilities which may be of the nature of those shown in immunity reactions either natural or acquired. The exact nature of these incompatibilities are, of course, at present no more understood than are the cases in plants (see discussion by J. B. De Lee of article by Edward Reynolds, '15), but De Lee believes that they may prove to be related to agglutination reactions.

That sterility may be a type of immunity and that the compatibility of the gametes themselves will depend on their constitutional similarity rather than their so-called sex differentiation is, however, very strongly indicated by the general evidence from agglutination reactions.

The observations made by Lillie ('12-'16) give strong support to the doctrine, rather generally discredited among zoölogists, of a specific chemotactic influence of egg secretions on sperms. His 
studies show that eggs of Arbacia and of Nereis give off substances that produce various visible effects on the sperm of the respective species. There is "stimulation of intense activity, which is of brief duration: (2) an orienting effect expressed in positive chemotaxis; (3) an agglutinating action; (4) following these effects more or less complete paralysis of sperm'" ('13, p. 554). The so-called agglutination, however, is held to be an indication of a chemical action that is necessary for union of ora and sperms. The particular " isoagglutinin " produced by eggs is called "fertilizin." Its action is regarded as similar to that of "amboceptors" in that it is considered a necessary link in fertilization, combining first with sperm receptors and then with the egg receptors. The function of fertilizin is not that of an antibody giving immunity, but rather that of a sensitizer which makes invasion and fertilization possible. It does not appear whether the agglutination phenomena here observed bear a close or a superficial resemblance to the agglutinations of immunity reactions.

In producing evidence in faror of the chemotactic influence of egg secretions involving the liberation of some such substance as fertilizin, Lillic has emphasized the importance of internal conditions determined by a particular and specific constitution of the individuals of a species which are fully self- and cross-fertile.

The discussion of self-sterility by Lillie ('13a, p. $573 ;$ ' 16, p. 5I) and his postulated causes of inhibition of fertilization ('136, p. 528) are hardly adequate for the known facts. Lillie is perhaps misled by a misunderstanding of the facts, for he states in reference to the phenomena of self-sterility "in species when this occurs the egg and sperm of the same individual are sterile inter se though fertile with those of all other individuals" ('16, p. 51 ). "That this is not necessarily the case has been well shown hy Correns whose data in respect to the variations of cross-sterility are quite like those which the writer has reported for Cichorimm. Furthermore, the specificity of fortilization according to Lillic involves complete cross-compatibility between all inclivicluals of a species, and also full self-compatilility of hermaphrodites. This is hardly comparable to the "individual specificity" of self-sterile hermaphrodites whose self-sterility involves an incompatibility of sex cells equal to that between two different and cross-sterile species. Sterility and fertility in and between individuals and species are in evidence and a theory of sperificity must provide for both. 
If fertilization depends on the production of fertilizin then selfsterile hermaphrodites that are cross-fertile with certain other individuals must produce a fertilizin which has selective chemotactic power due to some type or grade of relative physiological differentiation.

It is obvious that the facts as Lillie has found them require that the action of the so-called fertilizin must give various grades of isoagglutination ranging from complete paralysis to complete reversal and recovery paralleling the fluctuating conditions of fertilization quite generally emphasized by studies on Ciona, Cardamine, Cichorium, Primula, etc. Furthermore, the egg extracts of Arbacia are also agglutinative of sperms of Nereis with action that is violent and extremely toxic. Evidence is produced, however, to show that this so-called heteroagglutinin is another substance than the so-called isoagglutinin (fertilizin). The interrelations of these secretions of ova to fertilization and normal development after fertilization need to be fully investigated especially as the action of fertilizin, assumed by Lillie to be necessary for fertilization, is repeatedly spoken of as a type of incompatibility which "certainly lessens the fertilizing power of the sperm" ('13a, p. 556).

The phenomena of agglutination effects in these lower animals evidently afford a field for further careful investigation. The analysis of the chemotactic influence of egg secretion should be extended to such hermaphrodites as Ciona, of which different strains exhibit various degrees of self-fertility and also to such species as can be grown in pedigreed cultures in which the selfand cross-incompatibilities (judged by fertility) are as varied and fluctuating as are those in Primula, Lythrum, Cardamine, and Cichorium.

Von Dungern ('02) reports, previously to Lillie's studies, that so-called sperm heteroagglutinins are produced by certain species of Asterias and Echinus reciprocally, but not by other species. His studies were made with extracts from crushed eggs rather than from the secretions of eggs. He considers that the agglutinations check or inhibit interspecific fertilizations. He further injected ova and sperm of the same species separately into rabbits and found that both led to the production of sperm agglutinins in the blood of rabbits. The relation of such induced agglutinins to 
those normally existing in the eggs of another species is, of course, not determined, and their further relation to such isoagglutinins (fertilizin) as Lillie reports is an open question. The results, von Dungern points out, emphasize the obvious fact, which, however, has been somewhat disregarded, that the protoplasm of both sex cells are fundamentally of similar constitution. He further reaches the general conclusion at which I have arrived, that successful fertilization is not dependent on differences between ora and sperms, but on the similarity of their protoplasmic constitution.

Studies of precipitation have shown that the introduction of foreign proteins of any kind into the circulation of an animal will lead to the development in that animal of the property of causing precipitation when the serum of such an animal is mixed with clear solutions of the respective protein. Thus far, such studies emphasize the similarity of the proteid metabolic products of the individuals of a strain and have thus been concerned as tests of biological relationship not only of animals but of plants (Magnus and Friedenthal '06, '07a and $b$; Magnus '08).

As far as is now known, isoprecipitins, although present in some animals to some degree, are very irregular in appearance and power. Here, as in agglutination phenomena, there is no known reaction that could account for self-sterility, although it must be considered as possible that refined methods of technique may show similar reactions between the metabolic proclucts of two such organs as pistils and pollen tubes. The so-called "organ specificity" in which antigen antibody reactions depend on organs rather than on genetic relationship may furnish a clue to certain phases of the general problem of sex differentiation and the processes of fertilization especially in highly developed organisms. Herc, however, there is a constitutional and chemical similarity in large degree irrespective of anatomical structure quite as in cross-fertility in which specific anatomical identity is not a certain criterion for predicting cross-fertility. That a certain degree of similarity exists in the propertices of pollen of different species as woll as in the pistils is evident from the results of cultural studies of pollen-tule growth, and it is evident that this is not determined by particular and specific morphological characteristics.

It should be noted in this connection that Magnus and Friedenthat ('07) have presented data showing that in rye the extracts of 
seed, pollen, roots, and shoots give quite the same precipitations in the sera of animals previously treated with extracts of either shoots or pollen of rye. From these results they conclude that all cells of an individual possess the precipitation properties of the species.

However, there is some evidence that the general specificity of a species may be modified or limited to some degree by types of isoantibody reactions (isoprecipitations, isoagglutinations, isospermatotoxins, etc.). Also the specificity of the individual is limited by well-marked cases of organ specificity. These considerations certainly suggest that a further refinement of the precipitation method of analysis may reveal still more delicate but nevertheless important types of incompatibility in the interrelations between the cells of such highly specialized organs as pistils and pollen tubes or ova and spermatozoa, and which may be comparable to the cases of so-called autosensitization. In this respect the appearance of self-sterile plants and animals may perhaps involve the development of some type of acquired immunity, concerned with the metabolic products of closely related though specifically differentiated tissues. Still it must be admitted that high fertility and vigor, as Burck maintains, is present in naturally self-fertilized and in cleistogamous forms in which it would seem there would be greatest chance for the development of such immunity.

It is especially significant that the prevalent conceptions of the operation of antigen-antibody reactions are based upon the feeding or nutritive activities of the cells. The reactions are assumed to be cellular and, on the whole, individual. A newborn organism may acquire immunity or show various types of sensitization through the general property of its cells to react in much the same way as the parents were able to do. There is at least only an indirect heredity, in that characteristics of the species or race delimit the general range of its possible variations of intercellular reactions.

It is highly probable that an extension of the knowledge of colloidal relations may decidedly modify the older chemical conception of antigen-antibody reactions, at least for precipitation and other closely allied phenomena in which the relative concentrations of substances involved are important. In serum 
precipitation, for example, an excess of antigen frequently inhibits precipitation, a phenomenon quite analogous to the inhibition zones in colloidal flocculations in which the relative quantity is more important than the chemical nature of the substances. The whole theory of precipitation and agglutination phenomena rests on an assumed differentiation in the chemical or physical properties of the products of individuals or of different organs of the individual. The reaction occurs, it is assumed, because of dissimilarity. One could conceive of such conditions arising from the differentiation of sexual organs borne by the same plant and of fluctuations that would allow for such variations in self- and cross-fertility and sterility as do appear in chicory. Thus far, however, there are no well-marked or general data as to the behavior of isoagglutinins or isoprecipitins which are entirely parallel to the cases of incompatibility giving self-sterility. That the phenomena do indicate that sexual compatibility is proportional to similarity of the organisms or gametes rather than to dissimilarity or differentiation is, however, strongly suggested.

The phenomena of pollen-tube growth.-Extensive experiments have been conducted to determine the physiology of pollen tubes both in reference to direct growth in pistils and their extracts and to their behavior in different methods of artificial culture. The knowledge thus gained bears on the problems of sterility, especially from the standpoint of an understanding of (I) the requirements for germination, (2) the extent to which pollen-tube growth is determined by physical or local conditions or by its own initiative, in contrast to (3) the extent to which its growth is influenced by direct secretions of the ovule with its egg. The results with different species show such wide differences that it is difficult to establish any general rule of behavior in respect to any one of these questions.

The older opinion that specific chemical substances or conditions are necessary for germination of pollen is hardly tenable in view of the very general germination of pollen on pistils of widely different species (especially reported by Strasburger I 886, and by Tokugawa'14), and of the very freejuent observation that germination occurs in pure water (Molisch '93; Lidfor'ss'96), and that a proper control of the water supply is often all that is necessary to secure germination even in cases in which the difficulty of 
securing germination had been considered as an evidence of highly developed specificity in requirement (Jost '05, '07; Martin '13; Tokugawa '14).

It has been shown that pollen tubes of a species of ten make best growth in and show a marked chemotropism to a particular substance, and that in cultures usually a particular concentration gives the best growth. The limitations and uncertainties of the methods of artificial culture are most evident. The best results, as Jost points out, show a rather feeble growth; usually the tubes only reach a length that does not exceed a few diameters of the pollen grain. In corn, for example, the best growth reported by Andronescu ('15) was equal to $3^{-5}$ diameters of the pollen grain and was therefore only a very small fraction of the length of the style and stigma of corn. Many cases reported as germination may not be due to real growth but simply to swelling by tugor. The results of studies in germination are most of ten of questionable value owing to the lack of an adequate criterion of what constitutes natural germination and growth.

The best growth reported by Adams ('16) in his studies of the germination of pollen of the apple is $1336 \mu$ and of black currant is $688 \mu$, which in length is about 30 and $\mathrm{I} 2$ times the diameters of the respective pollen grains. Under the microscope this appears to be a vigorous growth, but when we consider that the growth is only $\mathrm{I} 1 / 3$ millimeters in length it is, in comparison, hardly sufficient to do much more than penetrate the stigma. The limitation of such results in explaining process of pollen-tube growth in the intricate relations of fertility and sterility is apparent.

In pistils themselves it has been shown that pollen tubes advance by mechanically penetrating through the pistil or by following stylar canals, that they may (in experiments) grow in the reverse direction from that which is natural, and that there is no marked difference in culture tests between the chemotropic power of different sections of the pistil.

Nearly all investigators have agreed that the growth of the tubes into the micropyle must be influenced by some sort of secretions of the egg itself, but it is not fully established just what this influence is or to what distance it acts.

The difficulty of establishing the fundamental facts regarding the relations of pollen-tube growth to the secretions and cell 
products of styles and of ovules in forms fully self- and cross-fertile is fully indicative that a decided refinement of method is necessary to determine the conditions operating in such fluctuating cases of fertility as are seen in self- and cross-incompatibilities.

It has, however, been quite generally shown, in agreement with Jost's ('07) results, that in self-sterility from physiological incompatibility the tubes grow more slowly and do not penetrate to the ovary in the time required for fertilization. This has been taken as eridence of the inhibitory action of specific stuffs (individual stuffs of Jost, line stuffs of Correns) or of the lack of proper nutritive substances (Compton '13; East '15a). Certain phases in the determination of this point admit of experimental proof and the writer is planning experiments in this particular. If pollen tubes admitted of ready growth in cultures, extracts of inhibitory or stimulating substances might be made and their action determined. Thus far, however, no essential differences have been found in the physiology of the pollen of self-fertile and self-sterile plants of the same species. It would seem that some such differences must exist comparable to the marked differences in the growth of pollen tubes in the ineffective and the effective pollinations. The difficulty of securing any sort of germination in chicory seems to prohibit this sort of study in this plant.

Some misunderstanding appears to have arisen in regard to the results of certain investigators. Jost's determination that a particular structure of the epidermis prohibits germination of pollen in Corydalis cara gives no clue to the causes of self-sterility in this species, as such a condition prohibits the germination of all pollen. After the epidermis is broken the plant's own pollen will germinate as will the pollen of other plants, but its growth is more feeble. The cause of self-sterility is here not concerned with the germination of the pollen. Likewise in Cytisus Laburnum the term solfsterility is used by Jost, inadvisedly, for here the structure of the epidermis seems to make the injury of stigmas necessary for the growth of any pollen and hence it is not self-sterility but complete sterility that is conditioned by an unlroken epidermal surface. These are interesting cases of very special adaptations that favor cross-fertilization.

Martin ('13) has drawn the highly suggestive conclusion that in red clover the necessity for a delicate regulation of water supply 
is so great that the excess supplied to pistils through the transpiration current of plants in wet seasons may be a cause of marked sterility in this species. It does not appear, however, that this is the actual cause of the self-sterility which seems to prevail in this species, for self-sterility is in evidence even under the conditions most favorable for cross-fertilization, and the marked sterility of a plant in the first crop seems to be more closely related to the impotence of pistils in that its tissues remain vegetative. Later in the season the same plant may produce a new crop of flowers with functional pistils but with the plants highly self-sterile from physiological incompatibility but highly cross-fertile as pollinated in the field.

Tokugawa's recent study gives no data that are directly concerned with the problems of self-sterility, although he worked with the pollen of several species known to be self-sterile. His results relate chiefly to a comparison of pollen-tube growth in cases of rather wide crossing and give no clue to the causes of self- and cross-sterility in such cases as chicory and Cardamine.

Favorable or unfavorable growth of pollen tubes may, to a considerable degree, depend quite as much on quantitative as on qualitative relations, not only in respect to such incompatibilities as are shown in the precipitation reactions but in the case of stimulating or inhibiting substances. Miyoshi ('94) has emphasized this point in presenting data on pollen-tube growth, which show that to divert tubes from one solution to another it is necessary to increase greatly the concentration of the second, as would be expected from Weber's law.

There can be no doubt that in the same strain different plants, and even different pistils on the same plant, possess variations in the total and relative amounts of materials that may serve for the nutrition and stimulation of pollen tubes, and that pollen grains possess considerable variations in their own supply of nutritive materials and in their requirements for growth. Such variations are operating in all cases of self-fertility. The causes of self- and cross-sterility are, however, quite independent of these.

The final stages of growth of pollen tubes in pistils should be more adequately determined with reference to the relative development of the macrogametophyte and the egg. It is highly essential to know the degree of development of the macrogameto- 
phyte in reference to what may be called the critical point in the growth of the pollen tube. It is highly possible that the style and stigma get their differential qualities by diffusion of secretions (hormones) from the gametophytes after reduction has occurred.

Types of sterility in dimorphic and trimorphic species.-Thus far we have considered the phenomena of sterility (chiefly physiological incompatibility) that appears in such non-dimorphic species as Eschscholtzia californica, Cardamine pratensis, and Cichorium Intybus, in which, as has been emphasized, there is no anatomical incompatibility in the relative differentiation of sex organs of the different plants. The evidence at hand, however, indicates that quite similar if not identical types of incompatibility also exist in various dimorphic and trimorphic species. Here, as Darwin ('62, '64, '65, '69) and Scott ('65) have especially pointed out, various morphological differences and similarities indicate in a general way the combinations that Darwin proposes to call legitimate and illegitimate, which are terms highly useful in a careful analysis of the relations in dimorphic and trimorphic species.

The real bearing of sex heteromorphism will become clearer if we summarize the general facts of sex differentiation. We eviclently need, in a consideration of all these conditions, a more accurate classification of the grades and types of differentiation that are in evidence. In respect to differentiations of sex that are either morphological or physiological, or correlations of both, we may quite readily distinguish in flowering plants such grades as the following:

I. Differentiation of organs within an individual plant.

I. General sex differentiation as ordinarily recognized, giving male and female sex organs with both exhibiting a certain degree of morphological and functional difference, but maintaining essential constitutional organization. Differences in time of development, giving grades of proterandry and proterogyny, especially when seen in perfect flowers, may be included here.

2. Differentiation between different flowers, giving grades of maleness and fentaleness to a flower as a unit (pistillate, staminate, perfect, or neutral as in monoccious, or polygamous, forms) or in various composite combinations. 
3. Differentiation between the male sex organs.

$a$. In clifferent flowers; from complete absence through various grades of development and function.

b. In a single flower giving heterodelphy of stamens; purely morphological (?), as in species of Labiatae, Cruciferae, and Scrophulariaceae; both morphological and physiological, as in Lythrum Salicaria; possibly cases purely physiological.

4. Differentiation between the female sex organs.

a. In different flowers; from complete absence through various grades of development and function.

$b$. In a single flower; no marked cases in evidence.

5. Differentiation within a reproductive organ, among the spores and gametophytes developed by or from any one sex organ; morphological or functional or both as a result of $(a)$ sporadic variation, $(b)$ of the intricate processes of reduction division, or $(c)$ from other unknown causes.

II. Differentiation between individuals as wholes.

I. In the degree of maleness or femaleness; in which entire plants differ in the total differentiation in one or more lines indicated under I; seen in dioecism, polygamodioecism, various grades of monoecism and intersexes such as Goldschmidt has described in moths.

2. In respect to male sex organs alone; giving various grades of development from presence to absence, or giving distinct types of stamens for different plants as in Primula, Lythrum, etc.

3. In respect to female sex organs; parallel with 2 above.

4. In respect to the particular combination of the various types of sex organs; (more involved and of different grade than I above), giving different plants with quite different types of perfect or imperfect flowers as also in Lythrum.

(In I, 2, 3, and 4 above, morphological differentiations are strongly in evidence; physiological correlations clearly in evidence in certain cases; purely physiological differentiations suggested by such cases as Cichorium.)

III. Differentiation between groups of individuals. 
$\mathrm{I}, 2,3,-\mathrm{x}$. The appearance within a species of one or more groups of individuals which are respectively similarily differentiated with regard to certain types, grades, or combinations of differentiation as indicated in $I$ and II.

The existence and interrelations of various types of these differentiations with reference to the questions of sterility may be illustrated by those cases in which incompatibilities giving sterility are best known.

In Linum grandiflorum (Darwin, '64) there is such anatomical differentiation that two groups (usually spoken of as forms) of individuals exist in respect to the type of pistil present in the perfect flowers. The flowers of all individuals of one form have long styles and short stamens; those of the other form have short styles and short stamens. Aside from this evident morphological differentiation there is a correlated functional differentiation. All plants show marked self-sterility, according to the evidence; thus within the indiviclual there is a degree of functional differentiation of the sex organs that gives self-incompatibility. It can not be too strongly emphasized that this is not correlated closely with anatomical differentiation, for long-styled plants are fertile with pollen from short stamens of plants of the other form, but sterile to its own short stamens. Also a short-styled plant is fertile with pollen of short stamens of a long-styled plant, but sterile with pollen of its own short stamens. This is quite identical with the behavior of cross-fertility and cross-sterility in Cichorium with the exception that in Cichorium the differentiation is purely physiological.

Darwin reports complete intra-form incompatibility in Limum; plants of the same form are cross-sterile; the two sex organs of different plants of the same form show the same incompatibilities exhibited by the two sex organs of the single plant. The morphological differences are certainly not indicative of the incompatibilities. Many highly self-fertile species show greater relative morphological differences than are here seen even in the longstyled form.

In several species of Primula (Darwin '62; Scott'65) there is a further anatomical differentiation hetween the wo forms in that they differ in the relative length of hoth sex organs: one form has long styles and short stamens, the other has short styles and long 
stamens. A third form may here arise with stamens and pistils of nearly equal length and intermediate between the lengths in the other two forms (see diagram by Scott '65, p. 109). Here also all plants are evidently more or less self-fertile, the plants of the non-dimorphic form being highly self-fertile. There is also marked fertility of intra-form crosses. The inter-form crosses are, however, more fertile; a condition that very clearly arises from the fact that the relative morphological and physiological differentiation of the sex organs involved is such that the greater degree of similarity exists between the male and female organs borne by plants of different forms.

Still another degree of morphological differentiation in hermaphrodites with perfect flowers is seen in Lythrum Salicaria (see diagram by Darwin, '65, p. 17I), in which three forms differ in regard to length of styles and in the particular combination of three different types of stamens. The forms are all different in respect to pistils but each is like another form in respect to one set of stamens. A special point of interest is the differentiation in the male sex organs in a single flower, which are relatively morphologically differentiated quite as are the two sets in various species of Labiatae and Cruciferae. Here, however, there are various physiological or functional differentiations, giving various grades of compatibility. All plants are apparently strongly self-sterile; there is marked sterility in intra-form cross-pollinations (all illegitimate); there is also marked sterility in interform pollinations, involving stamens and pistils of different lengths (illegitimate), but high fertility if legitimate pollinations are made. In inter-form crosses any one plant is both sterile and fertile to another plant according to the pollen used. IVe have here, perhaps, the most convincing evidence that in one individual the male sex organs may exhibit further differentiation, giving two sets of stamens in which the stamen as a whole, and each set as a whole, are differentiated quite independently of any differentiation that may exist between the spores produced by a stamen.

The degrees of functional differentiations that exist in such plants as those above mentioned are conspicuous because they exist in more or less marked correlation with structural differentiations. They are, however, revealed only in the degree of fertility and sterility that results. 
That functional differentiation may exist quite independently of morphological differentiation is equally conspicuous in the frequent cases of self-and cross-sterility where perfect anatomical compatibility is present. Furthermore, functional differentiation is subject to wide fluctuations and is by no means necessarily related to morphological differentiation. This is seen in the different grades and intensities exhibited by Linum grandiflorum, Primula sinensis, and Lythrum Sulicaria; by the different grades that exist in numerous species of Primula; and most especially by different grades and intensities of functional differentiation existing within a species or within a single form as judged by the immediate results of pollinations and the character and behavior of the respective offspring.

With Lythrum, for example, Darwin obtained various grades of fertility from illegitimate intra-form pollinations for all these forms, showing that various grades of physiological incompatibility exist independently of morphological differentiation. The illegitimate offspring exhibited a wide range of variation with respect to vigor, impotence, and fertility (the latter judged wholly by crosspollinations, mostly open and legitimate). Only in one set of I) plants (sisters?) was provision made for exclusive intra-form pollinations ('69, p. 398, 399). As these were all of the longstyled form they were illegitimate offspring illegitimately pollinated. Of these only three plants are fully reported: one produced a large crop of capsules and was decidedly fertile; one produced few capsules with less seed per capsule; the third flowered profusely, no impotence is mentioned, but the plant produced few capsules which, however, contained so many seeds that Darwin states "the average and the maximum are so remarkably high that 1 cannot at all unclerstand the case." No attempt was made to study controlled self-fortilization on any plants, and no attempt was made to make comparisons of the relative degrees of incompatibility which the data suggest must exist in and between various plants even of the same form. The studies of illegitimate offspring were also extended only to the first generation.

With Primulas, there is, it appears, a rather weak incompatibility in illegitimate self- or intra-form fertilizations. Darwin's most extencled experiments in inbreeding a form were with the long-styled form of $P$. ieris ('77, 1. 219), in which four gener- 
ations were grown (illegitimate). These were "healthy and fertile" and "their fertility even increased in the later generations as if they were becoming habituated to illegitimate fertilization" (p. 219). Such evidence shows that variations and fluctuations in self-compatibility and inter-form compatibilities may be so great that highly fertile strains may be derived just as an entire species may be non-dimorphic and either long-styled or short-styled (Scott '65).

Spontaneous variations involving in marked degree both morphological and functional differentiation are seen in the frequent appearance of highly fertile equal-styled strains in several species of Primula (Scotț '65; Darwin '69, '77).

The rather extended and more recent studies with Primula by Bateson, Gregory, and others have not been directed to such studies as give further light on the different grades of self- and cross-incompatibilities that exist in and between different lines of descent. From the general grouping of their data it appears (Gregory '11, p. 83) that legitimate fertilizations are more fertile than illegitimate fertilization. Gregory further notes that the short style is dominant over the long style, but that in $F_{2}$ generations from such a cross there are less short-styled plants than would be expected on the Mendelian conception of the integrity of characters as units. He suggests that this may be due to differences in the fertility of various gametic unions, giving real selective fertilization or selective embryo abortion, but he evidently recognizes that the degree or grade of fertility between the same types of gametes may differ in different races. In all these studies the relative fertility of pedigreed lines of self-fertilized long-styled or short-styled plants is not indicated, and it is not even clear that such lines were grown in the genetical studies.

The general behavior of these plants is of special significance in the consideration of whether physiological incompatibility involves too great or too little differentiation, and of the greater problem whether the success of fertilization is most dependent on similarities or dissimilarities. Darwin fully realized that illegitimate self- and cross-sterility can best be considered as due to "incompatibilities" that are more functional than morphological, and he even held that in self-fertilization and intra-form fertilization the incompatibility is in some cases of the same grade as that 
cxisting between species ('69, p. +36). The infertility even in selffertilization is here definitely considered as involving too great a dissimilarity that is essentially a physiological differentiation.

Jost's consicleration of the cross-incompatibilities of intra-form fertilization indicates that the doctrine of indiviclual stuffs does not adequately account for the results here obtained. He suggests that different concentrations of the assumed individual stuff may exist in organs of different length and from his discussion it appears that illegitimate cross-pollinations which should be fertile because involving different stuffs are not fertile because of a particular concentration. Thus certain degrees of concentration of the individual stuff in sex organs of two different plants are assumed to influence the degree of cross-fertility even to the extent of prohibiting cross-fertilization.

Darwin failed to see that the incompatibilities giving sterility in non-dimorphic species such as Eschscholtzia californica and Reseda odorata are undoubtedly of the same nature as those giving selfsterility in plants of dimorphic and trimorphic species. This was perhaps largely due to the fact that he clid not know of crossincompatibility in such plants as Cardamine and Cichorium, which give group reactions with reference to interrelations quite as do the dimorphic and trimorphic species. He further confuses the whole subject in his culminating work on self- and cross-fertilization by speaking of illegitimate pollinations of dimorphic forms as similar to self-fertilization of a non-dimorphic species (' 77, p. $3+3$; p. $35 \mathrm{I})$, largely on the conception that both were similar in respect to effect on fertility.

The evidence from the various species of dimorphic and trimorphic species clearly shows that morphological and functional differentiation of various grades and degrees of intensity are in evidence in and among plants of the same blood relationship; that the two are not necessarily closely related; that both are subject to fluctuations and sporadic variations; and that the incompatibilities giving sterility even in self-pollinations are to be considered, as Darwin evidently held, as resulting from too great a related differentiation of the organs and cells involved in fertilizations.

In the various dimorphic and trimorphic species each form is composed of inclivicluals whose thowers are morphologically differ- 
entiated as a whole from those of another form. Yet the differentiation, anatomical and physiological, between the two sex organs of a single flower or a plant as a whole is such that there is too great a difference for self-fertilization. The reciprocal differentiation, however, between sex organs of different forms is such that the two sex organs of the different plants are as a rule more compatible than are those on the same plant. Jost's conception of an influence of differences in the relative concentration of individual stuffs in organs of the same plant or of different plants is an attempt to analyze the physiological conditions of such differentiation.

\section{CONCLUSION}

Sex differentiation giving male and female plants, male and female organs, and male and female gametes, involves various obvious grades of anatomical and functional difference. This differentiation is what makes sex obvious and has led to an unwarranted emphasis of the view that the compatibility of sexes and the fusion of sex cells depends on such differences. The manifold limitations of cross-fertilization in the higher plants show that anatomical differences are to a large degree superficial, that there can be no doubt that constitutional dissimilarities are responsible for the great number of incompatibilities existing between individuals, and that the most fundamental principle of sexual fertility is that a marked degree of similarity in constitution is necessary.

The presence of self-sterility and intra-form sterility in such dimorphic and trimorphic species as Linum grandiflorum and Lythrum Salicaria might seem to indicate that the grade of visible differentiation between the sex organs and sex cells of a single individual has been carried so far that there is sufficient constitutional dissimilarity to give even self-incompatibility. But the presence of both self- and cross-sterility within a non-dimorphic species or strain as in Cichorium Intybus shows that incompatibility is fundamentally independent of visible differentiation.

On the whole, the evidence favors the doctrine that for successful fertilization the element of similarity in cell organization and in the physical, chemical, idioplasmic, and structural properties of all the cells and tissues involved is more important than any dissimilarity which can be associated with sex differentiation. 
Particular idioplasmic elements of the nucleus of the sex cells must, it would seem from the occurrence and only sporadic inheritance of self-sterility, have less direct influence on the possibility of successful fertilization than has the individually developed epigenetic cell organization of the parent individual and the grade of relative constitutional differentiation that may arise in the development of the two sexes even on a single individual.

Inbreeding and self-fertilization are often highy beneficial, as Darwin noted. Burck ('08) argues at length from good grounds, as noted above, that self-fertilization is the most effective means of reproduction. The evidence is clear that self-sterility prevails in plants that are necessarily cross-bred and that when self-fertile plants do appear inbreeding does not decrease the fertility. Speaking broadly, similarity favors gametic fusion.

Self-sterility due to differentiation giving dissimilarity, when it occurs, may have manifest advantages in evolution on the assumption of an increased number of variants that come from crossing and the direct increase of the intensity of variation that may thus appear over that in self-fertilized strains or that which arises by somatic variation. With the development of selfincompatibility a certain amount of cross-incompatibility comes unavoidably by heredity either between closely related (similar) or between more distantly related individuals. Types and grades of sex differentiation that are essentially physiological, if such are to be assumed as determining fertilization, have doubtless been acquired just as proteranchry or heterostyly, and other numerous anatomical incompatibilities have been acquired. Their transmission in out-crosses, howerer, is an unusually perfect example of sporadic inheritance in which vague tendencies only can be recognized.

The results in chicory show that the derelopment of self-incompatibility is not to be closely correlated with conditions in the immediate parentage. Every plant is, of course, the product of the fusion of two gametes, yet when self-sterile its gametes are inhibited from fusing. The apparent contradiction is equally present on any theory of sex. Such considerations, as already noted, emphasize the sporadic guality of the phenomenon of selfsterility.

Thus far the development of self-sterility, duc to physiological 
incompatibility, from strains previously fully self-fertile has not been observed in cultures or produced either by inbreeding or by wide crossing, showing that it is quite in the category of such deep-seated characters as those of heterostyly and proterandry, and such sex differentiation as that of individuals as wholes. East's ('15a) results with tobacco are most suggestive of the origin of self-sterility through crossing, but as he is inclined to consider the parent species as also somewhat self-sterile, this point is in doubt in this case. Still the production of types of impotence by wide crossing is proverbial, and we may find that the production of self-sterility due to physiological incompatibility is equally frequent. Impotence is no more directly and simply hereditary in outcrosses than is self-sterility. As in chicory, all known cases of sterility from physiological incompatibility have been studied only in species and strains in which it was already well developed, at least to the extent that some plants were thus self-sterile.

It must be fully recognized that the wide variations in the expression of incompatibility through sterility may, to a marked degree, mask the underlying tendencies of development. This is especially true when we consider the behavior of sterility and fertility in heredity. In my cultures of chicory self-fertile plants arose from self-sterile parents. The study of the offspring of such plants gives direct evidence on the heredity of the characteristic of self-fertility immediately after its appearance in a line of descent. The tendency is strong for complete self-sterility to develop among various individuals of the offspring of these self-fertile parents: but on the other hand there is a nearly equal tendency for selffertility to develop among such offspring. These two tendencies illustrate what may be called the inertia of cell organization as expressed in heredity. The particular somatic conditions in an individual and the particular grade of sex differentiation are not fully transmitted through spore formation and the formation of a new zygote. No doubt this sporadic nature of the character is chiefly due to the fact that the particular type of organization and differentiation which existed in the parent is not duplicated in the various offspring. The agreement is, however, sufficient to maintain a marked degree of fertility. On the other hand the variations are sufficient to give constant fluctuations in self-fertility about a rather fixed mode. To what extent the mode in chicory 
or in other plants can be shifted by continued inbreeding or selffertilization remains to be seen.

In the physiological incompatibilities that appear in the selfing and crossing of such non-dimorphic species as Cichorium Intybus and Cardamine pratensis, as well as in such dimorphic species as Primula sinensis, we see very clearly that the grade of sex differentiation within the individual may involve a relative dissimilarity sufficient to limit greatly or even prohibit successful fertilization. The nature of the differentiation in the sex organs of different plants can also be such that all grades of both self- and crosscompatibility and incompatibility may exist, as the results in Cichorium fully indicate. The phenomena, on the whole, seem most consistently interpreted on the general conception that the possibility of successful fertilization depends on constitutional similarities rather than dissimilarities.

\section{BiBLIOGRAPHY}

Adams, J. I916. On the germination of the pollen grains of apple and other fruit trees. Bot. Gaz. 6I: I3I-I+7.

Andronescu, D. I. I915. The physiology of the pollen of Zea Mays with special regard to vitality. Thesis, Univ. of Illinois.

Backhouse, W. O. 19I1. Self sterility in plums. Gard. Chron. 50: 299.

Bartlett, H. H. 1913. Sex forms in Plantago lanceolata. Rhodora 15: I 73-178.

Baur, E. I9II. Einführung in die experimentelle Vererbungslehre.

Burck, W. I908. Darwin's Kreuzungsgesetz und die Grundlagen der Blütenbiologie. Rec. Trav. Bot. Néerl. 4: I7-II8.

Castle, W. E. I 896. The early embryology of Ciona intestinalis Flemming (L.). Bull. Mus. Comp. Zool. Harvard Univ. 27: $201-280$.

Coit, T. E. I9I5. Citrus fruits.

Collins, G. N. I9I4. A more accurate method of comparing first generation maize hybrids with their parents. Jour. Agr. Rescarcli 3:85-1.

Compton, R. H. 1912. Preliminary note on the inleritance of selfsterility in Reseda odorata. Proc. Cambridge Phil. Soc. $7^{1}$.

I913. P'henomena and problems of sclf-sterility. New Phytologist 12: 197-206.

Correns, C. 19r2. Sellsstststerilität und Individualstoffe. Festsch. Med. Nat. Ges. z. 84. Versam. Deutsch. Naturf. u. Arzte. 
I9I3. Selbststerilität und Individualstoffe. Biol. Centralb. 33: $389-423$.

Coville, F. C. I9r4. Blueberry culture. In Bailey, L. H. Standard Cyclopedia of Horticulture I : 5 I $5^{-5}$ I 7 .

I9I5. Directions for blueberry culture, i9i6. U. S. Dept. Agr. Bull. 334.

Darwin, C. I862. On the two forms, or dimorphic condition, in the species of Primula and on their remarkable sexual relations. Proc. Linn. Soc. Bot. 6: 77-96.

- I864. On the existence of two forms, and on their reciprocal sexual relation, in several species of the genus Linum. Proc. Linn. Soc. Bot. $7: 69-83$.

__- I 865 . On the sexual relations of the three forms of Lythrum Salicaria. Proc. Linn. Soc. Bot. 8: 169-196.

I 868. Animals and plants under domestication. Vol. II. Edition by Orange Judd Co., New York.

- I869. On the character and hybrid-like nature of the offspring from illegitimate unions of dimorphic and trimorphic plants. Proc. Linn. Soc. Bot. 10: 393-437.

1877. Cross and self fertilization in the vegetable kingdom. Edition by D. Appleton Co., New York.

Davis, B. M. I9I5a. A test of a pure species of Oenothera. Proc. Am. Phil. Soc. 54: 226-245.

1915b. A method of obtaining complete germination of seeds in Oenothera and of recording the residue of sterile seed-like structures. Proc. Nat. Acad. Sci. I : 360-363.

Dorsey, M. J. I9I4. Pollen development in the grape with special reference to sterility. Agr. Exp. Sta. Univ. Minnesota Bull. I44.

Dungern, E. von. I902. Neue Versuche zur Physiologie der Befruchtung. Zeit. Allgem. Physiol. I : $3+-55$.

East, E. M. I9I5a. The phenomenon of self sterility. Am. Nat. 49: $77-87$.

- I9I5b. An interpretation of sterility in certain plants. Proc. Am. Phil. Soc. 54: 70-72.

East, E. M., \& Hayes, H. K. I9I I. Inheritance in maize. Connecticut Agr. Exp. Sta. Bull. 167.

-. I9I2. Heterozygosis in evolution and in plant breeding. U. S. Dept. Agr. Bur. Pl. Ind. Bull. 243.

Focke, W. O. I 890 . Versuche und Beobachtungen über Kreuzung und Fruchtansatz bei Blütenpflanzen. Abh. Nat. Ver. Bremen II: 4I $3-42$ I.

__. I893. Über Unfruchtbarkeit bei Bestäubung mit eigenem Pollen. Abh. Nat. Ver. Bremen I 2: fo9-416. 
Fruwirth, C. I909. Die Züchtung der landwirtshaftlichen Kulturpflanzen 2: I 52-I 56 . [Ed. 2.]

Fuchs, H. M. 1915. Studies in the physiology of fertilization. Jour. Genetics 4:215-30I.

Gardner, V. R. I913. A preliminary report on the pollination of the sweet cherry. Oregon Agr. Exp. Sta. Bull. i 6.

Goldschmidt, R. I9I6. A preliminary report on further experiments in inheritance and determination of sex. Proc. Nat. Acad. Sci. 2: $53-58$.

Goodspeed, T. H. I915. Parthenogenesis, parthenocarpy and phenospermy in Nicotiana. Univ. California Pub. Bot. 5: 249-272.

Goodspeed, T. H., \& Ayres, A. H. I916. On the partial sterility of Nicotiana hybrids made with $N$. sylestris as a parent-II. Univ. California Pub. Bot. 5: 273 (in press).

Gregory, R. R. I9I. Experiments with Primula sinensis. Jour. Genetics $I: 73^{-1} 32$.

Harris, J. A. I9I0. The arithmetic of the product movement of calculating the coefficient of correlation. Am. Nat. 44: 693-699.

Hayes, H. K. 19I4. The corn plant and seed selection. Report of the plant breeder. Ann. Rep. Connecticut Agr. Exp. Sta. 37: $353-384$.

Hildebrand, F. I 868 . Notizen über die Geschlechtverhältnıse brasilianischer Pflanzen. Aus einem Briefe von Fritz Müller. Sta. Catharina, I2 Sept. 1867. Bot. Zeit. 26: I I3-I I6.

Jeffrey, E. C. 191. Spore conditions in hybrids and the mutation hypothesis of de Vries. Bot. Gaz. 58: 322-336.

Jost, L. 1905. Zur Physiologie des Pollens. Ber. Deutsch. Bot. Ges. 23: 504,505 .

- I 907 . Ueber die Selbststerilität einiger Blïten. Bot. Zeit. 65: 77-II7.

King, H. D. 19I6. Experimental inbreeding. Jour. Heredity $7: 70-76$.

Kraemer, H. 1914. Effects of inbreeding. Jour. Heredity 5:226-234.

Kraus, E. J. 1915. The self-sterility problem. Jour. Heredity 6: 549557 .

Lewis, C. I., \& Vincent, C. C. I909. Pollination of the apple. Oregon Agr. Exp. Sta. Bull. Iof.

Lidforss, B. I 896. Zur Biologiedes Pollens. Jahrb. Wiss. Bot. 29: 1-38.

Lillie, F. R. 1912. The production of sperm iso-agglutinins by ova. Science II. 36: 527-530.

-. 1913a. Studies of fertilization. V. Jour. Exp. Zool. 14: 515$57+$.

- I9I3b. The mechanism of fertilization. Science II. 38: 524528. 
19I6. The history of the fertilization problem. Science II. $43: 39-53$.

Lotsy, J. P. I9I3. Hybrides entre espèces d'Antirrhinum. IVe Conférence Internationale de Génétique 416-428.

Magnus, W. 1908. Weitere Ergebnisse der Serum-Diagnostik für die theoretische und angewandte Botanik. Ber. Deutsch. Bot. Ges. 26a: $532-539$.

Magnus, W., \& Friedenthal, H. I906. Ein experimenteller Nachweis natürlicher Verwandtschaft bei Pflanzen. Ber. Deutsch. Bot. Ges. 24: 60I-607.

- 1907a. Über die Specificität der Verwandschaftsreaktion der Pflanzen. Ber. Deutsch. Bot. Ges. 25: 242-247.

- I I907b. Über der Artspecificität der Pflanzenzelle. Ber. Deutsch. Bot. Ges. 25: 337-340.

Martin, J. N. I9I3. The physiology of the pollen of Trifolium pratense. Bot. Gaz. 56: I I2-126.

Molisch, H. I893. Zur physiologie des Pollens. Sitzungsber. Akad. Wiss. Wien. I02: 423-448.

Morgan, T. H. I904. Some further experiments on self fertilization in Ciona. Biol. Bull. 8: 313-330.

-. 1910. Cross and self fertilization in Ciona intestinalis.' Arch. Entwickelungsmech. Organ. 302 : 206-234.

-. I9I3. Heredity and sex. Chap. VII.

Miyoshi, M. r894. Ueber Reizbewegungen der Pollenschläuche. Flora $78: 76-93$.

Müller, F. I869. Ueber einige Befruchtungserscheinungen. Aus einem Briefe an F. Hildebrand. Bot. Zeit. 27:224-226.

Oliver, G. W. r910. New methods of plant breeding. Bur. Pl. Ind. U. S. Dept. Agr. Bull. I67.

Osawa, I. I9I3. On the development of the pollen grain and embryo sac of Daphne with special reference to the sterility of Daphne odora. Jour. Coll. Agr. Imp. Univ. Tokyo 34:237-264.

Ottenberg, R. I9I. Studies in isoagglutination. I. Jour. Exp. Med. I3: 425-438.

Ottenberg, R., \& Friedman, S. S. Studies in isoagglutination. II. Jour. Exp. Med. I3: 53 I-535.

Reynolds, E. 1915. Prognosis of sterility. Jour. Am. Med. Asso. 65: II II-II56.

Scott, J. 1865. Observations on the functions and structure of the reproductive organs in the Primulaceae. Proc. Linn. Soc. Bot. 8: 78-126.

Shaw, H. B. I916. Self, close and cross fertilization in beets. Mem. N. Y. Bot. Gard. 6: 149-152. 1916. 
Smith, T., \& Reagh, A. L. I904. The agglutination affinities of related bacteria parasitic in different hosts. Stud. Rockefeller Inst. I: $270-300$.

Strasburger, E. 1886. Ueber fremdartige Bestäubung. Jahrb. Wiss. Bot. I7: 50-98.

Swingle, W. T. I9I3. Variation in first generation hybrids (imperfect (ominance): its possible explanation through zygotaxis. IVe. Conférence Internationale de Génétique 38I-395.

Tischler, G. I907. Weitere Untersuchungen über Sterilitätsursachen bei Bastardpflanzen. Ber. Deutsch. Bot. Ges. 25: 376-383.

Tokugawa, Y. I9I4. Zur Physiologie des Pollens. Jour. Coll. Sci. Imp. Univ. Tokyo 35: I-53.

Ulrich, K. I902. Die Bestäubung und Befruchtung des Rogges. Diss. Halle.

Vries, H. de. I9I0. Intracellular pangenesis. Trans. by C. Stuart Gager. Open Court Pub. Co.

Waite, M. B. I 895 . The pollination of pear flowers. U. S. Dept. Agr. Div. Veg. Path. Bull. 5.

Wakker, J. H. I896. Die generative Vermehrung des Zuckerrohrs. Bot. Centralb. $65: 37-42$.

Westgate, J. M., \& Coe, H. S. I9I5. Red-clover seed production: pollination studies. U. S. Dept. Agr. Bull. 289.

Wilsdorf, G. 1912. Tierzüchtung.

Wilson, J. H. 1906. Infertile hybrids. Rep. 3rd Int. Conference on Genetics. Roy. Hort. Soc. I 83-209.

Zinsser, H. I9I4. Infection and resistance.

\section{Explanation of plate 30}

\section{Cichorium Intybus}

I. Head with petals fully expanded; stigmas beginning to protrude.

2. Stigmas extended and recurved.

3. Closed head; about two hours later than fig. 2.

4. As no. I, with petals cut away.

5. As no. 2, with petals removed, showing pollen masses more plainly.

6 to II. Individual flowers showing stages in the development of stigma from time of opening (no. I) to closing (no. 3) of heads. 


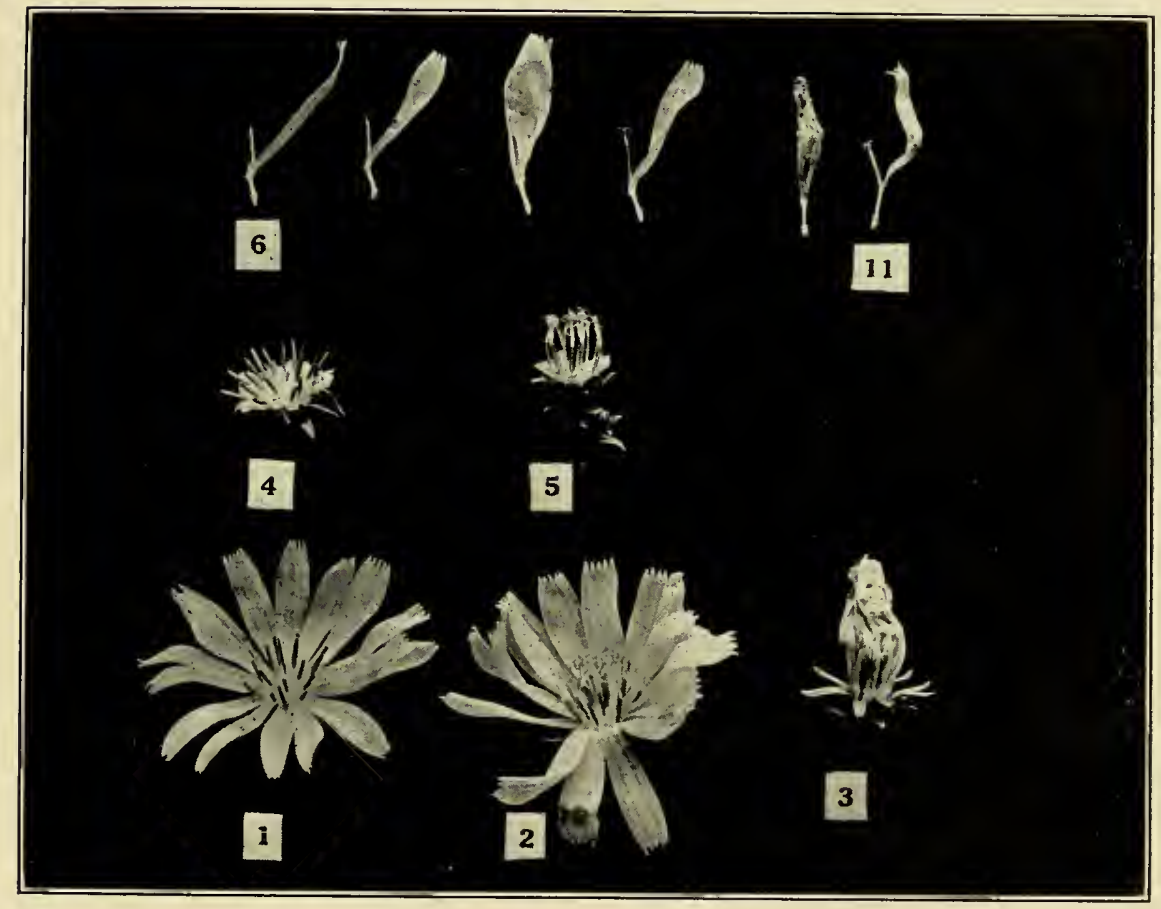

Stout: Pollinations in Cichorium Intybus 



\title{
VARIATION IN TITHYMALOPSIS
}

\author{
J. B. S. Norton \\ Maryland Agricultural College
}

In studying the species of Euphorbiaceae around Washington, D. C., for the District Flora, it became necessary to determine more carefully the status of the species of Tithymalopsis found there. T. corollata (L.) Klotsch \& Garcke and T. Ipecacuanhae (L.) Small, both generally recognized as very variable species, are very common in this region, and in recent years two others, $T$. arundelana (Bartlett) Small and T. marylandica (Greene) Small, intermediate between the other two, have been described and rarely found.

In analyzing the plants of these species found this year I have plotted the characters of all the plants seen (over 400) in the accompanying tabulation which I think will show the relation of the several species and the relative number of each conspicuous variation in the total population. I would like to commend to others the method of analysis of variable species which I have used, as an easy means of forming a clear picture of the above relations.

The plants studied have not been selected entirely at random, though mostly so, and the more unusual kinds will appear a little more frequent in the tabulation than they should by chance.

The progressively subdividing arrangement of the tabulation, allowing for all possible combinations of the variable characters, is explained in the following notes: The first column divides the plants on whether a distinct white appendage is present or not on the involucral glands. All of typical T. Ipecacuanhae is included in the "appendages none" group, though on almost every one of the hundreds I have seen, there is a narrow appendage easily seen with a magnification of Io diameters. I might also add here that every specimen of any species of Tithymalopsis which I have examined has distinct, though minute, stipules.

The second column includes under "none" those forms where the first cyathium arises from the ground or below. The short- 
stemmed are those with the main stem below the inflorescence less than 6-Io inches long and generally shorter than the mature umbel. The later flowering begins, the longer the stem.

The third column includes under "pubescence o" plants without hairs outside the involucre or so rare that they cannot be found without some search. Under "pubescence - " are those essentially glabrous, but with hairs easily found on some parts. The \pm and + indicate pubescence medium or abundant. The hairiness seems to vary largely with some external condition, plants being sometimes glabrous below and hairy above, sometimes the opposite.

The leaf-form column includes under I, leaves broadest below the middle; under II, leaves broadest at the middle; and under III, leares broadest above the middle.

The subdivisions have been carried out further on leaf width, red color of herbage, width of appendage, length of petiole, angle of divergence of hairs, length and thickness of peduncle, number of times the inflorescence branches, etc. It was found, however, that a number of these characters and others that have been used in separating species are dependent entirely on the stage of development. A thorough study of the southern species in both early and late stages will be necessary before they can be accurately classified, so I have not included specimens from south of Maryland, though I have listed a few western plants for comparison. Plants of $T$. arundelana at the time of first blooming and in midsummer would hardly be recognized as the same species.

The amount of red color in stems and leaves, although it varies somewhat with the environment, is unquestionably largely governed by hereditary factors.

I have classified about 200 distinguishable forms but for lack of space can only show the more easily recognized kinds on the diagram.

The numbers following each minor subdivision show the number of plants in the respective group indicated by the associated letter as follows:

A. Plants from the type locality of $T$. arundelana.

B. Type of T. arundelana.

C. Plants with very narrow appendlages but broader than the usual T. Ipecacuanhae type. 
D. A plant of $T$. Ipecacuanhae flowering at the same time as the earliest blooming $T$. corollata, found at the type station for T. arundelana.

E. Type of T. marylandica.

F. Plants from two colonies showing relation to $T$. zinniiflora Small.

G. Plants from the central U. S. prairie region.

H. Plants from dry, open woods.

J. Plants from northern U.S.

K. Plants from eastern U. S. not otherwise designated, nearly all from Maryland.

Seventy-two possible combinations of the variations in presence and absence of appendages, length of stem, pubescence, and leaf form are given in the tabulation. Thirty-three of these were found in the field. But it will be seen that over one half the plants fall into 3 or 4 of the ultimate divisions of the scheme.

Though there are 6 groups in the T. Ipecacuanhae series, distinguished by the practical absence of stem, appendages or hairs, most of the plants fall into the glabrous form with leaves broadest above the middle. This might then be taken as the dominant or typical form of this species in the region under discussion.

No plants have yet been found in the next two series, those without appendages and with long or short stems.

The $T$. arundelana series, characterized by acaulescent plants with white appendages on the glands, has 8 ultimate groups. There are no very hairy ones and only 2 perfectly smooth plants, though practically all fall into the essentially glabrous group. One of the hairless individuals is the single specimen of T. marylandica which I have seen, the plant from Dr. Greene in the New York Botanical Garden herbarium. I do not know of any one else other than Dr. Greene who has ever seen this species growing. It differs further from any of its relatives in Maryland in having unusually narrow linear leaves. A few plants otherwise similar to this group and from the type locality of $T$. arundelana have short stems and fall into the next series. There is a possibility that $T$. arundelana originated as a hybrid between $T$. Ipecacuanhae and $T$. corollata, as all three occur together at the type station in some abundance and variety and rarely all blooming at the same time and are also found at every other place where I have dis- 
covered $T$. arundelana. There are intermediates in appendage width and hairiness but as indicated before some of the intermediate series are lacking.

The short-stemmed, appendaged series consists chiefly of a lot of plants found only in two or three colonies. They tend to have lanceolate, ovate, or oblong leaves. They are generally broaderleaved and less hairy than $T$. corollata and seem to be nearest related to $T$. zinniiflora, some specimens being very close to the T. zinniiflora type. Some otherwise similar are later-blooming and longer-stemmed and so included in the next series.

The $T$. corollata series, characterized by appendages and long stems, has several rather clearly marked groups. Nearly all the plants from the central prairie region fall into the group with hairless stem and leares. They also have thick, ascending leaves and tend to be pubescent on the involucre or capsule, thus forming a rather distinct morphological as well as geographical form. Nearly all this series are in the four oblong-or oblanceolate-leaved groups, with more or less pubescence, which may then be considered the dominant form of the species locally. There is, however, a marked variation in the open woodland form which tends to be more hairy and to have oblanceolate leaves. 


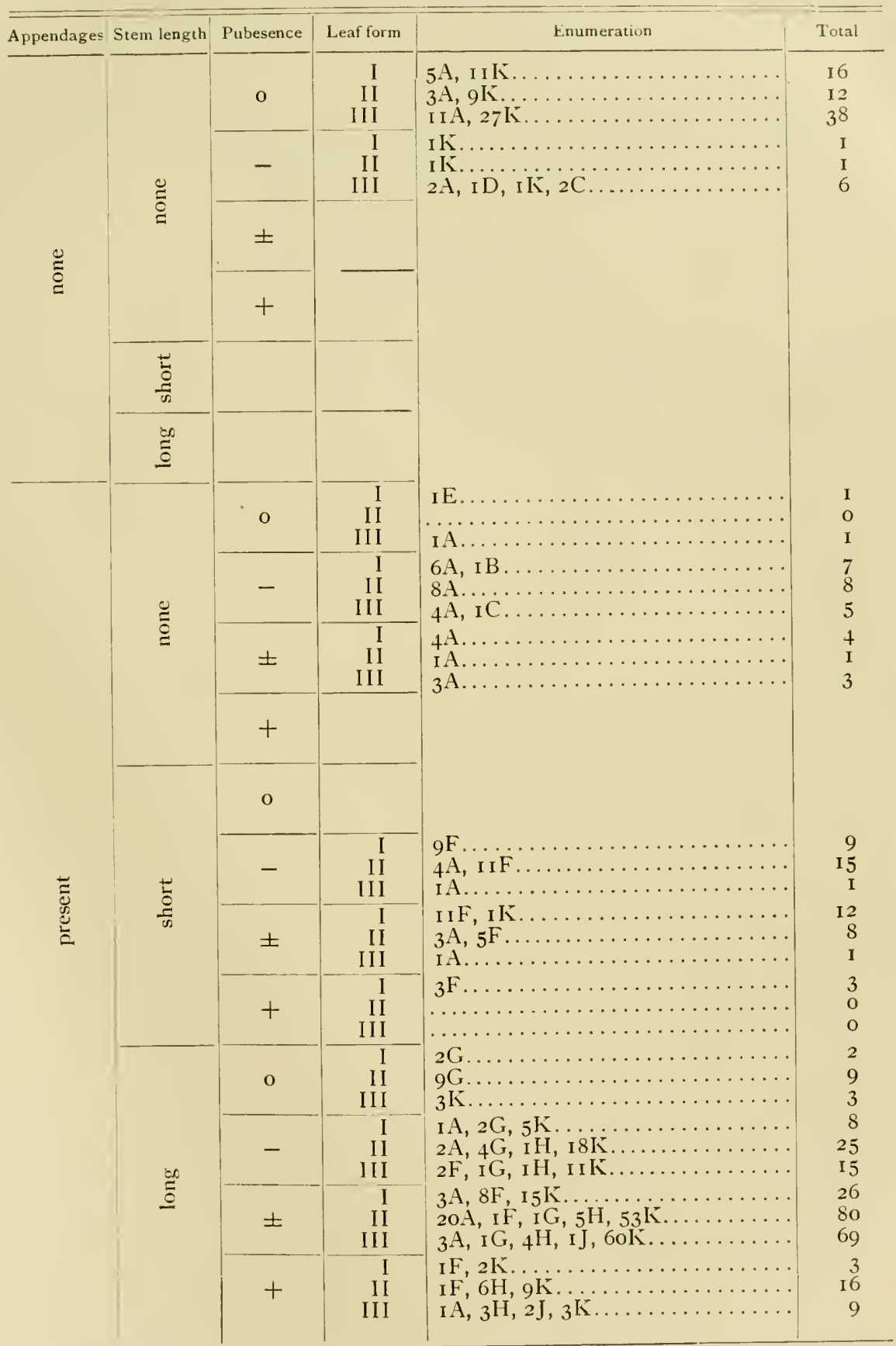





\title{
THE GENUS HIPPOCHAETE IN NORTH AMERICA, NORTH OF MEXICO
}

\author{
Oliver Atkins Farivell \\ Parke, Davis and Company, Detroit
}

My attention was specifically drawn to these plants through the monograph of the genus Equisetum by Mr. A. A. Eaton, which appeared serially in the Fern Bulletin, and in which the exclusion of E. laevigatum and E. robustum from Michigan was so opposed to my field studies of these species, as I understood them, that I concluded to give the subject further and more careful attention in order to confirm my earlier views or to reject them. Mr. Eaton, it is true, credited E. robustum to Sarnia, Michigan, but Sarnia is in Ontario, Canada. These two species are unquestionably found in Michigan.

The following notes are based primarily on field studies, supplemented by studies of material distributed by Eaton and of that in the herbarium of Parke, Davis \& Co.

Mr. Eaton said there were no true varieties, with perhaps the exception of E. arvense var. boreale, in the genus Equisetum; and then listed a large number, many of them new, but specifically made no claims for their constancy. A goodly number of these so-called varieties are based entirely on an injury to the individual plant, and therefore are no more deserving from a systematic point of view, of a special name and the dignity which is always conferred by the elevation of a form to one of the named nomenclatorial categories, than is, in the higher plants, a willow stump that has sent out innumerable branches to prolong its existence; or if it pleases you to have the subject matter brought a little nearer home, than is a man with an artificial limb to be ranked as a new species in the genus Homo. All these so-called varieties may be produced at will from the same evergreen stalk. The apex of a normal evergreen stem may be broken off and labeled under its specific name; the following year another section, now with long branches, may be broken off and labeled var. ramigerum; 
the next year what is left of the stem may be bearing the short spiciform branches of the var. ramosum; and the next season will see numerous stems surrounding the base of the old one, whence we have the var. caespitosum. 'To apply names of specific or other rank to such forms is the climax of folly. On the other hand, when a species is normally unbranched, if a form of it is found that constantly produces branches naturally, i. e., not due to an injury, such a form is a normal variety; such a form can not be found on the same rhizome with another of different character, while all the so-called varieties due to an injury may be found along with the normal stem emanating from the same rhizome and sometimes two or more such forms may be found on the same crown! I have observed several forms due to an injury, that do not come within the description of any variety enumerated by Mr. Eaton; but they are as much deserving of recognition as any such that he has named.

With special reference to the bast and green parenchyma, there are two very distinct types of anatomy in the genus Hippochaete: one with abundant vallecular bast completely cutting the green parenchyma while the carinal bast is slight and does not completely cut the parenchyma, thus dividing it into $Y$-shaped blocks; the other is just the reverse of this, the vallecular bast, being of small amount, does not divide the parenchyma, while the carinal is plentiful and does divide it, or nearly so, thus splitting the green parenchyma into blocks shaped somewhat like a carpenter's drawing knife $I I$. laevigata best exenplifies the former, while $H$. prealta is typical of the latter. Similar to $H$. leevigata are $I I$. v'ariegata and $I I$. hyemalis var. alaskana. Like $H$. prealta are $H$. prealta var. affinis, H. hyemalis var. californica, II. scirpoides, and the European H. hyemalis. The other species and varieties are either intermediate in character or they combine both types in greater or less degree. In the intermediate forms the parenchyma is continuous under both the vallecular and carinal basts, the outer surface being even, or more or less indented but not divided by the basts. When the two types are combined the Y-shaped parenchyma may alternate with the other type, or the parenchyma may be divided by both the vallecular and carinal basts splitting it up into irregularly triangular b.ocks. 'The central cavity is also variable, ranging 
form obsoleteness in $H$. scirpoides to $4 / 5$ the total diameter of the stem in $H$. prealta and $H$. laevigata. It has been suggested that all variations from the two types above mentioned, in the anatomy of some forms, are due to hybridization. This may be so but it has yet to be proved by exact laboratory work. On the other hand, varieties combining these intermediate or variable anatomical characters, such as $H$. variegata var. anceps and $H$. hyemalis var. Jesupi are sometimes found where the supposed parents have never been detected; the former on Parkedale Farm and the latter on Belle Isle, an island in the Detroit River, which has 5 or 6 miles of shore line with the nearest point of mainland I/2 a mile away. It is the only Hippochaete that has ever been detected on the island.

In certain Californian plants Mr. Eaton ascribes to Hippochaete ramosissima (Desf.) comb. nov. (Equisetum ramosissimum Desf. Fl. Atl. 2: 398. I800) an anatomy like that of $H$. laevigata. According to Luerssen the parenchyma of this species is continuous thus being intermediate but more similar to that of Hippochaete hyemalis (L.) comb. nov. (Equisetum hyemale L. Sp. Pl. 1062. 1753) than to $H$. laevigata. If Luerssen is correct in regard to the anatomy of $H$. ramosissima, then the Californian plants are not of that species and it should be excluded from the American flora. Notwithstanding that Sadebeck gives it a range on the American continents from $49^{\circ}$ north latitude to $30^{\circ}$ south latitude, it is highly improbable that it occurs north of central Mexico. Judging from the anatomy, as described by Mr. Eaton, the plants he referred to $H$. ramosissima should be referred to some form of $H$. laevigata, probably to var. Funstoni.

From an intimate study of these plants in the field, extending over many years, I have become thoroughly imbued with the conviction that they constitute a valid genus distinct from Equisetum. The habit and other characters by which Hippochaete differs from Equisetum are as constant and of as much significance as those which separate Aster from Solidago in the higher plants, and many other closely allied genera which could just as readily be named. Generally speaking their differences may thus be expressed.

Stems annual, often dimorphous, the sterile always with regular verticils of acutely angled branches at the nodes; spikes rounded at apex; stomata scattered.

Equisetum. 


\section{MEMOIRS OF THE NEW YORK BOTANICAL GARDEN}

Stems generally evergreen, not dimorphous, usually simple; branches when present, similar to the stem; spikes usually apiculate; stomata in regular rows.

Hippochaete.

Of the genus Equisetum (Tourn.) L., the type species is E. arvense; of Hippochaete Milde, H. hyemalis. I have not been able to verify Milde's authorship of the genus but according to Ascherson and Graebner, Milde published it in the Botanische Zeitung for 1865, p. 297. The genus is readily subdivided into two sections. The species with evergreen stems and apiculate spikes form a group that may be known as section EuHIPPOCHAETE; those with annual stems and generally obtuse spikes may be known as section AMBIGUA.

The chief character separating the sections is the duration of the stem; those separating the species are to be found in the ridges and sheaths, whether concave and biangulate, or convex and banded, campanulate or cylindrical. Following out these lines of differentiation, the species will be assembled in a more natural grouping than by any other method.

\section{Key to the species}

Stems evergreen, spikes apiculate (EvHIPPOCHAETE).

Ridges concave, biangulate.

Ridges narrowly concave, numerous.

Sheaths cylindrical, tight.

Centrum $3 / 4$ the diameter of the stem, teeth deciduous or more or less persistent.

H. hyemalis var. californica.

Centrum, I/2 the liameter of the stem; teeth and awns persistent.

Centrum $1 / 3$ the diameter of the stem; awns decicluous.

II. hyemalis var. Jesupi.

II. hyemalis var. alaskana.

Sheat hs campanulate, loose.

Centrum I $/ 3$ the diameter of the stem; teeth persistent, awns deciduous.

Centrum $1 / 6$ the diameter of the stem to obsoleteness.

Ridges broadly and deeply concave, these and the teeth three.

Ridges rounded, not biangulate.

II. zariegata.

II. variegata var. anceps.

II. scirpoides.

Sheaths cylindrical, tight.

Stems simple.

Sheaths broader than long, teeth persistent.

Sheaths longer than broad, teeth caducous.

II. prealta.

II. preallu var. affinis. 
Stems normally branched; branches spike bearing.

H. prealta var. Suksdorfi.

Sheaths more or less ampliate and loose, but not campanulate.

Teeth caducous.

H. prealta var. intermedia.

Teeth deciduous or persistent.

II. prealta var. scabrella.

Stems annual, spikes obtuse or apiculate, ridges rounded (Ambigua).

Sheaths cylindrical, tight; teeth persistent.

H. Nelsoni.

Sheaths campanulate and loose; teeth caducous.

Stems smooth to the touch.

Stems rough, simple.

Bases of teeth straight.

Bases of teeth, incurved.

Stem rough, branched.

H. laevigata.

H. laevigata var. Eatonii.

H. laevigata var. Funstoni.

H. laevigata var. polystachya.

Hippochaete hyemalis var. californica (Milde) comb. nov.

Equisetum hyemale var. californicum Milde; A. A. Eaton, Fern

Bull. 11: I I3. I903, as to the biangulate plants only.

Equisetum hiemale var. Doellii Milde; A. A. Eaton, Fern Bull.

11: I I4. I903. Not Milde, I863.

Typical $H$. hyemalis with caducous teeth has never been collected in America. The Pacific coast plants differ in having the teeth deciduous or more or less persistent. The plants referred by Mr. Eaton to the var. Doellii Milde cannot belong there as that European variety has the centrum only one fourth or one third the diameter of the stem, while the British Columbia plants have a centrum four fifths the diameter of the stem and the teeth are not wholly persistent as described, at least on specimens distributed which show them to be generally deciduous. California to British Columbia.

Hippochaete hyemalis var. Jesupi (A. A. Eaton) comb. nov.

Equisetum variegatum var. Jesupi A. A. Eaton, Fern Bull. 12: 24. 1904.

This variety has some of the characters of $H$. variegata, towards which it trends. The teeth have long, generally persistent awns and the anatomy is variable, sometimes of one type, sometimes of the other. The size and aspect are intermediate but the tight, cylindrical sheaths place it with $H$. hyemalis rather than with H. variegata.

Belle Isle, Mich., Farwell 2I Ia, June 4, I895; Rochester, Mich.,

Farwell $21 \mathrm{I} b$ July 4, I896. Mr. C. K. Dodge has collected it at Port Huron, Mich. Its general distribution is from Illinois to Connecticut, northward into Canada. 
Hippochaete hyemalis var. alaskana (A. A. Eaton) comb. nov.

Equisetum variegatum var. alaskanum A. A. Eaton, Fern Bull. 12: 39. 1904 .

Somewhat similar to the last variety but larger, yet with a relatively smaller centrum, awns deciduous, and anatomy much like that of $H$. variegata. 'The cylindrical, tight sheaths place it here rather than with the species just named. In dried plants the sheaths are liable to be slightly ampliated. Washington to Alaska.

Hippochaete variegata (Schleich.) comb. nov.

Equisetum variegatum Schleich. Cat. Helvet. 27. I807.

This species, in its typical form, is common on sandy or gravelly shores on the Keweenaw Peninsula, a tongue of land 60 miles in length, stretching northeasterly into Lake Superior. It is associated with $H$. laevigata and Equisetum limosum. I have seen no indications that either this or the variety anceps is injured by frost in this state and they are certainly evergreen.

Keweenaw Peninsula, Mich., Farwell 2II, May 30, I885. This species may be looked for north of $42^{\circ}$. It prefers the borders of cold streams and ponds.

HipPOCHAETE VARIEGATA var. anceps (Milde) comb. nov.

Equisetum varicgatum var. anceps Milde, Ann. Mus. Lugd. Bat. 1: 7 I. I 863.

This variety is intermediate in aspect between the species and $H$. scirpoides and approaches the latter in habit. The stems are evergreen $30 \mathrm{~cm}$. or less in height by $\mathrm{I} \mathrm{mm}$. or less in diameter and are massed in a mat-like growth. The centrum is from obsolete to one sixth the diameter of the stem and does not exceed the vallecular cavity; the anatomy is variable. The ridges and leaves are $4^{-8}$, the teeth persistent, and theawns deciduous. Thebranches have the same number of ridges and leaves as the stems or fewer and in some instances they have five leaves while the stem has four; the only instance, so far as I am aware, where a branch has more ridges and leaves than the stem from which it springs. It grows on grassy borders of marl under willow thickets associated with moss and sedges. Parkedale Farm, Mich., Farwell 2921 , July 28, I9I 2. 
Hippochaete scirpoides (Michx.) comb. nov.

Equisetum scirpoides Michx. Fl. Bor.-Am. 2:28I. I803.

Our smallest species, forming dense mats along old logs and stumps in open fields, cedar swamps, etc. Well characterized by its three leaves and ridges, the latter so deeply and broadly concare that the stem apparently is 6-ridged.

Keweenaw Peninsula, Mich., Farwell 212, May 30, I885. This has much the same range as $H$. variegata but extends about $2^{\circ}$ further south.

Hippochaete prealta (Raf.) comb. nov.

Equisetum prealtum Raf. Fl. Ludovic. I3. I8I7.

Equisetum robustum A. Br. Am. Jour. Sci. 46, 88. I843.

Equisetum robustum var. minus Engelm. in A. Br. Am. Jour.

Sci. 46, 88. I 843 .

Equisetum hyemale var. Drummondi Milde, Mon. Equit. 593. I 865 (?).

Equisetum hiemale var. robustum A. A. Eaton, Fern Bull. 11: I I2. 1903 .

Equisetum hiemale var. californicum Milde; A. A. Eaton, Fern Bull. 11: I I3. I903, as to the plants with rounded ridges.

Equisetum hyemale var. prealtum (Raf.) Clute, Fern Bull. 16: I8. I 908.

This is our largest and most widely spread species and probably our most common one. It is well characterized by its cylindrical, tight sheaths, which are as broad as long or sometimes a little broader or narrower than long, its persistent teeth, and very numerous, rounded ridges. It may be found on sand banks, in poor soil, in swamps and bogs; generally near water. Mr. C. K. Dodge has collected it near Port Huron, Mich., and near Sarnia, Ontario.

Keweenaw Peninsula, Mich., Farwell 2091/2, May 30, I885; 572, Aug. 29, I887. Rochester, Mich., Farwell 2975, Aug. 4, I9I2; 3696 and 3710, June 28, I9I4; 3722, July 19, I9I 4 ; 3922 and 3927, October 25, 1914. Parkedale Farm, Mich., Farwell $39881 / 2$, June 20, 19I5. May be found from the Atlantic to the Pacific but rare east of the Mississippi basin.

Hippochaete prealta var. affinis (Engelm.) comb. nov.

Equisetum robustum var. affine Engelm. in A. Br. Am. Jour. Sci. 46: 88 . I 843 . 
Equisetum hiemale var. pumilum A. A. Eaton, Fern. Bull. 11: I09. 1903.

Equisetum hiemale var. affine (Engelm.) A. A. Eaton, Fern. Bull. 11: I I . I903.

Differs from the species in its longer sheaths which are $1 / 3^{-2}$ times as long as broad, and in the teeth, which are caducous. Where this variety and the species overlap they intergrade and pass insensibly one into the other, indicating that there is but one species, although the extremes seem distinct enough.

Keweenaw Peninsula, Mich., Farvell 209, May 30, I 885. Palmer Park, Mich., Farwell 209a, July I5, I902. Rochester, Mich., Farwell 3694 and 3695, June 28, I914; 3925, 3926, October 25, I914; 39291/2, October 29, I9I4. Parkedale Farm, Mich., Farwell 39221/2, October 25, 1914;39841/2, June 20, 1915. From the Atlantic to the Pacific but most common east of the Mississippi River.

Hippochaete prealta var. Suksdorfi (A. A. Eaton) comb. nov. Equisetum hiemale var. Suksdorfi A. A. Eaton, Fern. Bull. 11: I IO. 1903.

Somewhat similar to the variety affinis but has whorled branches from the upper nodes, which are spike-bearing simultaneously with the central stem; Mr. Eaton described it as with the anatomy of $E$. hiemale but material distributed by him shows the green parenchyma cut by the vallecular bast which, with the branching habit, indicates a tendency toward $H$. laevigata, while the rosulae in the groove show a trend toward $I I$. hyemalis var. californica. Collected by $\mathbf{W}$. N. Suksdorf, September 3, I902, at Bingen, Washington.

HIPPOCHAETE PREALTA var. intermedia (A. A. Eaton) n. comb.

Equisetum hiemale var. intermedium A. A. Eaton, Fern. Bull.

10: I20. I902, pp., and in Gray's New Manual, 53. Igos.

The sheaths are ampliated but not campanulate, and the teeth are caducous. Described by Mr. Eaton as with the anatomy of Equisetum hiemale but material distributed by him shows a variable anatomy, sometimes that of $I I$. prealta sometimes that of $H$. laevigata. Collected at Port Huron, Michigan, by Mr. C. K. Dodge. It has been found in various localities from the Atlantic to the Pacific and may be looked for whenever $H$. laevigata and II. prealta var. affinis may be found in close association. 
Hippochaete prealta var. scabrella (Engelm.?) comb. nov.

? Equisetum laevigatum var. scabrellum Engelm. in A. Bi. Am. Jour. Sci. 46: 87 . 1843 .

? Equisetum hiemale var. texanum Milde; A. A. Eaton, Fern Bull. 11: 108. 1903.

Similar to the preceding variety but the sheaths are proportionably broader and the teeth deciduous or persistent, indicating a cross between $H$. laevigata and $H$. prealta, if these intermediate forms are to be considered as the result of hybridization. I do not know if this is Engelmann's variety or not but it agrees in every particular with Eaton's description of Equisetum laevigatum var. scabrellum in Fern. Bull. 11:42. 1903. The stems of the season have the general aspect that $H$. laevigatum would have if its sheaths had persistent teeth; the stems of the preceding year have the general markings of $H$. prealta. The anatomy is now of the one species, now of the other.

Rochester, Mich., Farwell 37121/2, July 4, I9I4.

Hippochaete laevigata (A. Br.) comb. nov.

Equisetum laevigatum A. Br. Am. Jour. Sci. 46: 87. 1843.

This species in its typical form is well characterized by its simple or branched, annual, stems, which are smooth, at least to the touch, its rounded spikes, and campanulate sheaths with caducous teeth. Those varieties which are intermediate between this and other species generally will have rough stems and spikes that are either obtuse or apiculate. It may be found in clear sand or gravel, or a similar soil covered with a sparse growth of grass and other vegetation and generally not far from water.

It may be found in colonies by itself, or it may be associated with $H$. prealta and its variety affinis, $H$. variegata, and Equisetum limosum. The vallecular bast divides the green parenchyma into $y$-shaped divisions. Eaton restricted this species east of the Mississippi to Ohio, Indiana, Illinois, and Wisconsin; but I have found it in southeastern Michigan, where it is common, and on the Keweenaw Peninsula, where it cannot be said to be scarce. Probably it is to be found throughout the state. The annual stems begin their growth about the first of May, are fruiting in June, and perish in July or August. New stems are appearing continuously until the middle of the summer but all have perished 
before winter has set in. It may be noted here that growth in the evergreen species begins, in Michigan, about the middle of May and continues through the summer.

Keweenaw Peninsula, Mich., Farwell 39941/2, June 29, 1915. Algonac, Mich., Farwell $3640,3684 \frac{1}{2}, 3685$, June 2I, I9I4. Detroit, Mich., Farwell 210e, June 24, 1902. Rochester, Mich., Farwell 2IOc, July 4, I896; $37211 / 2$, July I9, I9I4. Stony Creek, Mich., Farwell 34381/2, June 8, 1913. Parkedale Farm, Mich., Farwell 270I, June II, I912; 36771/2, June II, I9I4; 3705, June 28, I9I4. Common west of the Mississippi and in the "Lake States."

\section{Hippocinete laevigata var. Eatonii var. nov.}

Equisetum hiemale var. intermedium A. A. Eaton, Fern. Bull. 10: I20. I902, as to the annual plant.

Externally, this variety can be distinguished from the typical species only by the roughness of the stem and the occasionally apiculate spikes. The anatomy is very variable, sometimes that of the species, sometimes that of $H$. prealta var. affinis; now intermediate when the parenchyma is continuous, and now combining both types when both the carinal and vallecular basts divide the green parenchyma, splitting it in to irregularly triangular blocks. It may be found alone, associated with $H$. laevigata, $H$. prealta, or its var. affinis, or with all of these. In the original description of Equisetum hiemale var. intermedium, Eaton included annual and evergreen plants with teeth that were caducous, deciduous, and persistent. In the seventh edition of Gray's Manual he had restricted the variety to the evergreen plant with caducous teeth. This left the evergreen plant with broader sheaths and persistent teeth and the annual plant with caducous teeth without names. For the former I have adopted Engehmann's varietal name of scabrella; to the latter I give the varietal name Eatonii. The first stems of the season fruit in June and perish in July and August when the later stems are fruiting and others just coming up. At this time it simulates $H$. prealta var. intermedia but is cuickly and readily differentiated by its annual stems, which have not the bright green of that variety. Some plants have completely perished before winter sets in while others in greater or less degree survive the winter but these parts have perished before the new 
growth of the season begins in May. Where this variety grows in profusion it is not an uncommon thing to see in March, just after the snow has disappeared, its long stems chalk-white and intact lying flat upon the ground, crossed in all directions. W'hen disturbed, however, they will fall apart and crumble into powder. The stems like those of the species may be single or caespitose, simple or branched, and often four feet in height. I have not seen any with spike-bearing branches.

Wiards Siding, Mich., Farwell 21591/2, $2159 \frac{1}{3}$, June 25, I910. Rochester, Mich., Farwell 27061/2, 27101/2, June II, 1912; $3643 \frac{1}{2}$, May 26, I9I4; 36941/2, June 8, 1914. Algonac, Mich., Farwell 3640a, July 26, I9I4.

Hippochaete laevigata var. Funstoni (A. A. Eaton) comb. nov. Equisetum Funstoni A. A. Eaton, Fern. Bull. 11: I0-I2. 1903 (excluding forma polystachyum).

Equisetum laevigatum f. variegatoides A. A. Eaton, Fern Bull. 11: 43. 1903.

? Equisetum hiemale var. herbaceum A. A. Eaton, Fern. Bull. 11: 108-9. I903.

Similar to the specific type but very rough and the bases of the caducous teeth are more strongly incurved. Eaton described the spikes of E. Funstoni as "not apiculate as in the rest of the subgenus." H. laevigata has non-apiculate, i. e., rounded, spikes and E. Funstoni as distributed by Eaton has some of the spikes apiculate. The parenchyma is sometimes divided by the vallecular bast, sometimes not. Equisetum laevigatum f. variegatoides and Equisetum Funstoni f. caespitosum as distributed by Eaton are to be differentiated by only one character; the stems of the former are prostate, ascending, or erect, while those of the latter are ascending or erect-a distinction without a difference. Both have prominently white-bordered teeth fading to white throughout. There seems therefore to be no good reason for keeping Funstoni separate from laevigata. It has been collected in IVisconsin, Nebraska, Kansas, Wyoming, Utah, and California.

Hippochaete laevigata var. polystachya (A. A. Eaton) comb. nov.

Equisetum Funstoni f. polystachyum A. A. Eaton, Fern Bull. 11: I2. I903. 
Equisetum laevigatum f. polystachyum A. A. Eaton, Fern Bull. 11: 44. I903.

A form in which the stem and its branches (not due to an injury) are simultancously spike-bearing.

Hippochaete Nelsoni (A. A. Eaton) comb. nov.

Equisetum variegatum var. Nelsoni A. A. Eaton, Fern. Bull. 12: 4I. 1904 .

Intermediate between $H$. laevigata and $H$. hyemalis var. Jesupi but more like the latter in appearance than the former. The rounded ridges and annual stems, however, place it more appropriately in the section Ambigua than in the Euhippochaete. The parenchyma is frequently divided by the vallecular bast but not regularly so. The sheaths in dried plants are liable to be slightly ampliated. It has been collected in New York, Michigan, and Illinois. 


\title{
A FOSSIL FERN MONSTROSITY
}

\author{
Arthur Hollick \\ Staten Island Association of $A, t$ s and Sciences
}

(With PLATES 31 AND 32)

A short time ago I received from Dr. F. H. Knowlton of the United States National Museum a number of specimens, apparently representing fragments of a fossil fern, which are unlike any fossil fern remains heretofore described or figured, so far as I am aware. Superficially nearly every specimen presents the appearance of a sport or monstrosity, strikingly similar to some of those which have been developed in cultivated forms of the Boston fern, Nephrolepis exaltata (L.) Schott. On PLATE 3I are figures of three of the specimens, reproduced natural size, and on PLATE 32 are two photographs of portions of fronds of $N$. exaltata, recently selected for purposes of comparison from plants growing in the conservatory of the Brooklyn Botanic Garden.

If the specimens represent a species, it was a unique and peculiar one. If, on the other hand, they represent a freak or monstrosity, this is equally remarkable. In any event it is apparently a fern, and the probability is that it belongs in a living genus; but the critical characters are too imperfectly preserved for satisfactory comparison. Nevertheless, the species, or variety, or form, whichever it may be, is certainly of sufficient interest to be figured and to be described as accurately as possible, even if with no other result than to invite criticism.

The preservation of plants as fossils is and always must have been a matter of fortuitous conditions. The number of specimens thus preserved during any period in the earth's history must represent merely a very small fraction of the vast host that lived and died during the same period and left no trace behind. We may, therefore, assume that a rare or local species, represented by a relatively small number of individual plants or confined to a limited region, would have had but little chance of being preserved 
in the fossil condition; and a sport or monstrosity, confined presumably to a small group of individuals or perhaps to a single one, would have had a yet smaller chance. On general considerations, therefore, it would scem most consistent to regard our specimens as representing a species, and to apply a generic name that will indicate merely a probable relationship with the ferns.

Anomalofilicites monstrosus gen. et sp. nov.

Size and shape of frond not known, the parts irregularly pinnate; pinnae diverse in shape and size, mostly pinnatifid or obscurely pinnate, linear-lanceolate in outline and tapering to the tips, but occasionally expanded and pinnate except toward the base, the pinnules pinnatifid.

Tertiary (Fort Union Formation), Kern Ranch, Dawson County, Montana. Collected by A. G. Leonard, George Holgate, and IV. H. Clark, September 28, I906.

Those who may be interested in the line of investigation suggested by the peculiar surficial characters of these specimens will find the following works of assistance:

E. J. Lowe, Our native ferns, etc., vols. I and 2. London, I 867, I 869 .

Robert G. Leavitt, A vegetative mutant and the principle of homeosis in plants. Bot. Gaz. 47:30-68. f. I-19. Ja, I909.

R. C. Bencelict, Some modern varieties of the Boston. fern at their source. Jour. N. Y. Bot. Gard. 16: I94-I97. pl. I6I, I62. S I9I5.

Explanation of plates 31 and 32

Plate 3I. Anomalofilicites monstrosus Hollick, natural size. I from U. S. Nat. Mus. no. $34987 ; 2$ from U. S. Nat. Mlus. no. $34988 ; 3$ from U. S. Nat. Mus. no. 34986.

Plate 32. Nephrolepis exaltata (L.) Schott. Portions of heteromorphous fronds from living plants growing in conservatory of the Brooklyn Botanic Garden, natural size. 


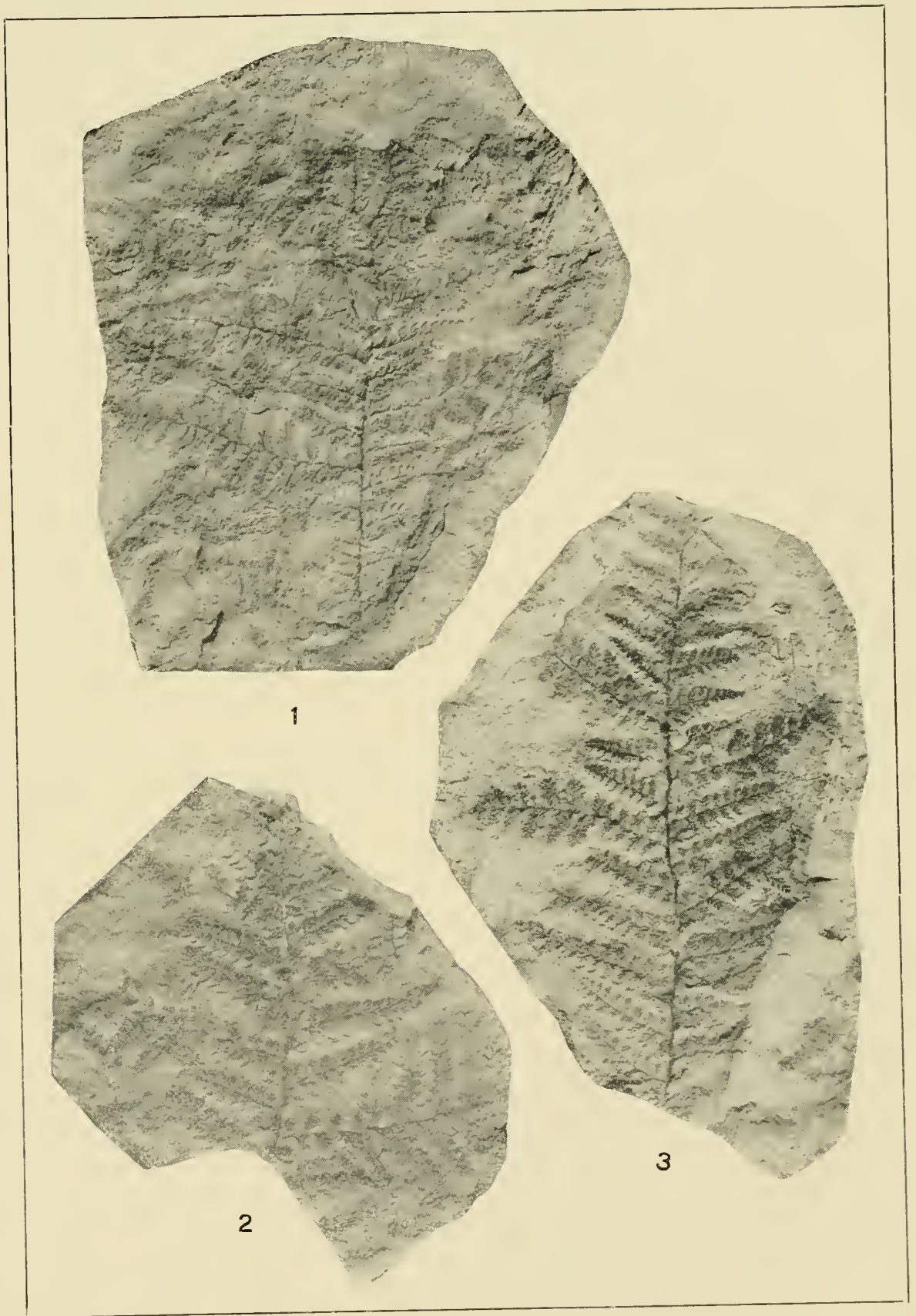

Axomingofilicites monstroses Hollick 


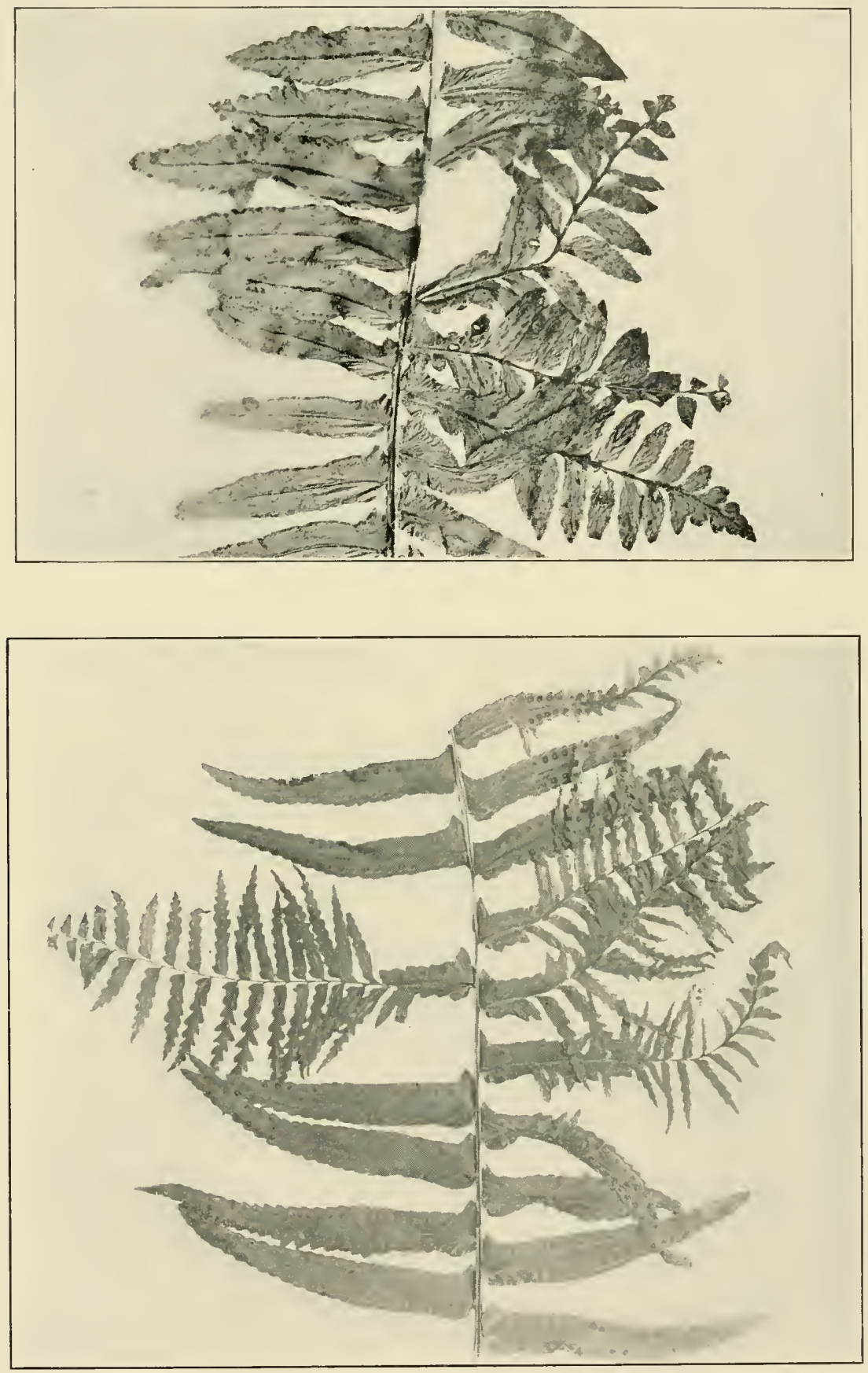

Heteromorphots froxds of Nephrolepis exaltata (L.) Schott 



\title{
RECENT EXPLORATION IN SOUTHERN FLORIDA ${ }^{1}$
}

\author{
John K. Simall \\ The New York Botanical Garden
}

Previous to 1903, when we began botanical exploration in southern Florida, the country southwest of Cutler and Perrine, then the frontier settlements on the eastern coast of Florida, was almost a terra incognita. A wagon road to the south of Miami, or Fort Dallas, as it was at one time called, connected that place with Cocoanut Grove and Cutler and terminated at Perrine, which was an old but scarcely at all developed settlement in the pine forest, situated about three miles west of Cutler and Bay Biscayne. Near Perrine the surveyor's trail entered the pine forest and extended toward the southwest through the unbroken wilderness until it met the open Everglades at a point called Camp Longview. Later, another trail developed parallel to the proposed railroad route to Cape Sable and met the Everglades between three and four miles south of Camp Longview.

Notwithstanding the inaccessibility of this region during the early period of exploration, except by the trails just referred to, we found scores of plants, either new to science or typically West Indian and Central American, not before known to occur naturally in the United States, not even on the tropical Florida Keys, and learned that these islands in the Everglades which we have designated the Everglade Keys are, so far as their vegetation is concerned, a portion of the West Indies isolated on the Florida peninsula.

The following table will indicate the geographical extent of our recent operations and the character of the points visited.

$\begin{array}{cl}\text { Everglade Keys } & \text { Brickell (twice) } \\ \text { Pineland hammocks and ad- } & \text { Brogdon } \\ \text { jacent pineiands, Miami } & \text { Cocoanut Grove } \\ \text { and southwestward } & \text { Costello (thrice) } \\ \text { Addison } & \text { Cox } \\ \text { Black Point Creek (twice) } & \text { Goodburn (twice) }\end{array}$

${ }^{1}$ Abstract. For a more extended report, see Jour. N. Y. Bot. Gard. 17: 37-45. pl. I66-I68. I9I6. 
Hattic Baner (thrice)

Murden

Nelson

Nixon-Lewis (thrice)

Ross (thrice)

Royal Palm (twice)

Shiclds

Snapper Creek

Sykes (thrice)

Timms (twice)

Everglades

Prairie hammocks north of Miami

Freeman (twice)

Merritt's Island

Humbugus (twice)

Prairies north of Miami.

Humbugus (twice)

Little River

Arch Creek

Prairies south of Miami.

Cutler to Black Point
Vic. Long Prairie

Vic. Murden hammock

Vic. Nixon-Lewis hammock

Vic. Tinims hammock

Vic. Silver Palm

Vic. Larkins

SANd-Dunes

Near Crocodile Hole

Opp. Lemon City

Opp. Miami (twice)

Key Biscayne

FLORIDA KEYS

Sands' Key

Old Rhodes' Key

Caesar's Rock

Adams' Key

Pumpkin Key

Elliott's Key

Big Pine Key

Key West

These comprise distinct phytogeographical areas. They are as follows:

Everglade keys-Pineland hammocks and adjacent pinelands.

Everglades-Prairie hammocks and prairies.

Coastal Sand-dunes-Hammocks.

Filorida Keys-Hammocks and pinelands.

A brief summary of the more interesting discoveries in the collection of about I I,O0o specimens, so far as studied, is as follows: First, over forty species of flowering plants comprising naturalized exotics and heretofore unobserved natives, added to the known flora of the Everglade Keys and vicinity. Second, additions to the known flora of the United States: Mushrooms, two V'est Indian species and several new endemic species; liverworts, four West Indian species and three new species; mosses, several IVest Inclian species; ferns, a West Indian species; flowering plants, ten West Indian species and screral new endemic species. 


\title{
VEGETATIVE LIFE ZONES OF THE ROCKY MOUNTAIN REGION
}

\author{
P. A. Rydierg \\ The New York Botanical Garden
}

It was twenty years ago last June that I had my first introduction to the flora of the Rocky Mountains proper. Even before that time I had spent three summers in the foothills in western Nebraska and in the Black Hills of South Dakota. While being principally occupied in a botanical survey from a taxonomic standpoint, during the eleven summers spent in the Rocky Mountain region, I could not help making some observations on the general phy togeography of the country. As very little has been published on this subject, and as some of that little is quite misleading, I thought it advisable to place on record these observations of mine, however incomplete they may be. They were made rather incidentally, and could not be otherwise. I therefore began publishing in the Bulletin of the Torrey Botanical Club a series of articles under the heading "Phytogeographical notes on the Rocky Mountain region." The present paper should in reality have been the first of these articles as an introduction to the more specialized topics already begun.

The Rockies extend from the neighborhood of Santa Fé, New Mexico (about Lat. $35^{\circ} 30^{\prime}$ ), to near Lat. $65^{\circ}$ in the Yukon Territory, and the different parts must show great variations in the flora. The flora of the region north of Lat. $55^{\circ}$ is practically unknown to me, and that of the Canadian Rockies south of $55^{\circ}$ I know only from the collections made by others, but such are well represented in the herbarium of the New York Botanical Garden, as the Geological Survey of Canada has let us have the first set of their duplicates for years.

As I have already pointed out in one of my articles printed last January, the Rockies south of Lat. $55^{\circ}$ can be divided into two parts: The Southern Rockies from the Santa Fé Mountains in New Mexico to the Medicine Bow Mountains in southern 
Wyoming; and the Northern Rockies from the Wind River Mountains in central IVyoming northward. To the former may be ascribed also the Uintah, Wasatch, and several other smaller ranges in L tah. As belonging to the floral district of the Northern Rockies are to be counted several more or less isolated mountains in Idlho, Mlontana, and Wyoming. The Cypress Hills in Saskatchewan and the Black Hills of South Dakota and Wyoming may also be included therein, though both contain many eastern elements.

The division between Northern and Southern Rockies is not made wholly because there is a break in the high mountain chain, about where the Union Pacific Railroad crosses Wyoming, but because many plants are restricted to either region and do not cross the gap. The floras of the two regions show many differences, especially is this the case of the more characteristic species of the wooded areas. It is true that many of the trees, as Picea Engclmanni, Pinus scopulorum, P. Murrayana, and P. flexilis, Pscudotsuga mucronata, Abies lasiocarpa, Sabina scopulorum, Betula fontinatis, Almus tenuifolia, and several species of Crataegus, Salix, and Populus are common to both regions, but others are not. Pinus aristata, P. edulis and P. monophylla, Picea Parryana, Sabina monosperma and S. utahensis, Populus Wislizeni and P. Fremontii, Fraxinus anomala and the oaks of the Quercus Gambelii and Quercus undulata groups are practically restricted to the southern Rockies. Of these only Picea Parryana has been collected in what I consider as belonging to the Northern Rockies, namely in the Teton Mountains of Western Wyoming. It is between these mountains and the Bear River Mountains of southern Iclaho (an extension of the Wasatch), not along the continental divicle in central Wyoming, that an interchange of species between the two regions takes place. Hence some northern species are found in southern Idaho and northern Utah, but not in southern Wyoming, and a few southern ones in the Tetons.

The wooded flora of the Sierra Madre shows stili more striking differences, lut this would lead us outside the present discussion.

In the Rocky Mountains proper I am inclined to recognize the following zones: (1) Mlpine; (2) Subalpine; (3) Montane; (4) Submontane or Foothills; (5) Upper Sonoran. Whese correspond practically to Dr. Merriam's life zones: Arctic, Hudsonian, 
Canadian, Transition, and Upper Sonoran. I have preferred the names given above rather than those of Merriam, because the former have been used by many authors in Europe in articles on the phytogeography of the Alps and other mountain regions. Furthermore, I do not like the names Hudsonian and Canadian as applied to the Rocky Mountains, for the Rockies have none of the characteristic forest trees in common with the Hudson Bay Region or Canada proper. The only ecologically important tree common to both regions would be the quaking aspen, which is not a tree characteristic of either zone, and some botanists regard the western aspen as distinct from the eastern. When the life zones are so unlike as they are in the East and in the Rockies, I think that they should have different names. It would be as misleading to call our Austro-riparian zone of the Southern States the Lower Sonoran zone, which is the name of the corresponding zone of the West.

The Rockies are surrounded by plains or tablelands, either grasslands or desert regions, some belonging to the Submontane and others to the Upper Sonoran.

Besides these zones long tongues of others intrude into the Rocky Mountain region, viz. several of the Prairie regions, especially along the Arkansas, Platte, and Missouri rivers and one from the Lower Sonoran along the Colorado of the IVest. The true Hudsonian and Canadian zones also touch the Rockies at the headwaters of Athabasca River and northward.

\section{Arctic-Alpine Zone}

This is represented in the Rockies by numerous islands along the mountain chain and shows very little variation in composition throughout the whole range. It is true that the Northern Rockies contain more of the circumpolar arctic plants, and the percentage of endemic species is somewhat larger in the Southern Rockies, but the general make-up is practically the same. The arcticalpine zone comprises the tops of the higher mountains above the timber line. The altitude of the latter varies a good deal even in the same locality, but is found in Colorado between II,O0O and I 2,000 feet, in Montana between 7,500 and 9,000 feet altitude, and in the Canadian Rockies still lower. In the north the timberline comes down practically to the sea-level near the arctic coast 
at the mouth of Mackenzie River (Lat. $69^{\circ}$ ), but it swings southward going east, so that it meets the Hudson Bay about $10^{\circ}$ further south. On the Labrador Peninsula the most northern point is also about Lat. $59^{\circ}$. The flora consists mostly of low perennial herbs and a few depressed shrubs. There is no distinct shrub-belt as in the Alps or the Scandinavian Mountains. I have already discussed the composition, distribution, and origin of its flora in three articles published in the Bulletin of the Torrey Botanical Club.

\section{Subalpine Zone}

This is practically the same as Dr. Merriam's Hudsonian Zone and corresponds to the true Hudsonian Zone of the East, to the dwarf birch region of the Scandinavian Mountains or the subalpine regions of Switzerland with Pinus montana, Almus viridis, and species of Rhododendron. It resembles most that of the eastern Hudsonian, as the forest consists of spruces, balsams, larches, and aspens, but of these the only species in common is Populus tremuloides. The characteristic trees of the eastern Hudsonian are Picea canadensis and P. Mariana, Abiesbalsamifera, and Larix laricina; those of the Subalpine Zone of the Rockies are Picea Engelmanni, Abies lasiocarpa, and Larix Lyallii, the last only in the Northern Rockies. These three trees are also found in the Cascades, i. e., the northern part of the Pacific highlands. On the more exposed and drier ridges, especially on the southern side of the mountains, two pines are found, viz. Pinus albicaulis in the Northern and $P$. aristata in the Southern Rockies, but neither is of any great importance.

Merriam ${ }^{1}$ in his life zones of Idaho distinguishes between a Subalpine or 'Timberline Zone and a Hudsonian or Spruce Zone; the former being the region between the upper and lower timber lines. Such a zone can not be upheld from a botanical viewpoint and evidently 1)r. Nerriam has given up the idea. The open grass-covered areas of this region are essentially Alpine-arctic, while the wooked spots belong to the Subalpine or so-called Hudsonian Zone. Mr. Vernon Bailey, ${ }^{2}$ who follows Merriam very closely, in his Life Zones and Crop Zones of New Mexico seems to have limited the Hudsonian Zone nearly to what Merriam at

1 North Ancrican Fauna 5:22. 1891.

"North American_Fiuna 35: 11. 1913. 
the place cited called the Subalpine Zone, for he states: "Hudsonian, the zone of dwarf spruces, occurs as a narrow belt of the scrubby timber line trees around the high peaks." I am inclined to make the zone broader, including Dr. Merriam's whole spruce zone, or of about the same extent as the Hudsonian Zone of Piper's Flora of Washington. ${ }^{1}$ I have regarded this zone as extending from the timber line to the average lower limit of the subalpine fir (Abies lasiocarpa) or in Colorado at the upper limit of the bull pine (Pinus scopulorum), i. e., down to about Io,ooo feet in Colorado, 8,000 in the Yellowstone Park, 6,500 feet in northern Montana, and still lower in the Canadian Rockies and the Selkirks. It would not do to set it at the lower limit of Engelmann spruce or the aspen, for both are found far down into the Montane Zone. As Picea Engelmanni is the most characteristic species this zone may be called the Spruce Belt.

As to the differences between the floras of the Northern and Southern Rockies, they are not very conspicuous in the Subalpine Zone. As stated before, Larix Lyallii is lacking in the Southern Rockies. So are also Tsuga heterophylla and Pinus albicaulis, whose place on the dry ridges is taken by $P$. aristata. The undergrowth is practically the same, consisting of Arctostaphylos Uva-ursi, Lepargyraea canadensis, Linnaea americana, species of Sambucus, Pyrola, Aquilegia, Vaccinium, etc. Some of these are also common to the Hudsonian Zone of the East or to the Montane Zone of the Rockies.

\section{Montane Zone}

This corresponds to the Canadian Zone of Merriam, but it is not like the Canadian Zone of the East. The two important pines of the Canadian forests, Pinus Strobus and P. resinosa, and the Arbor Vitae, Thuya occidentalis, do not go further west than Lake Winnipeg and only Pinus Banksiana (with the spruces mentioned under the subarctic zone) reaches the foothills of the Rockies. Of the deciduous trees, only Populus tremuloides, P. balsamifera, Betula papyrifera, and a few willows are common to the East and the Rockies. It is true that some of the undergrowth consists of plants common to both regions, but most of the species of such genera as Vaccinium, Lonicera, Symphoricarpos, etc. are different.

${ }^{1}$ Contr. U. S. Nat. Herb. I I : 1906. 
Yothing in the East corresponds to the characteristic and conspicuous Odostemon (Berberis) Aquifolium and Pachystima Myrsinites of the Rockies, and Echinopanax horrida is found only as a waif at the western end of Lake Superior. The conspicuous genera Castilleja, Pentstemon, Aquilegia, Arnica, represented by numerous species in the Rockies, are poorly represented in the Canadian flora. Dr. Merriam has made the statement, " In a communication already referred to, I stated the conclusion that the commonly accepted division of the United States into Eastern, Middle, and Western Provinces had no existence in nature and that the whole extra-tropical North America consists of but two primary life regions, a boreal region which is circumpolar, and a Sonoran or Mexican Tableland region which is unique." These statements are far from correct when the plants are considered. It may be that the animals, which are less dependent on soil, moisture, and other conditions, and are endowed with locomotion, might be the same in the western part of the northern woods (Hudsonian and Canadian Zone) and the forested region of the Rockies, but as far as the flora is concerned it is not the same. Though the two regions touch at the headwaters of the Athabasca River and north, there is not a single of the characteristic forest trees in common. The only tree of general distribution common to the two regions is, as mentioned before, the aspen, and some botanists, Tidestrom, Wooton and Standley, etc., regard the western a distinct species, Populus aurea; and others, Daniels, etc., as a distinct variety. The boundary line between the eastern woods and those of the Rockies is more clistinct than between the different life zones of the Rockies. Many species, as for instance the sage brush and several species of poplars and willows, are found both in the Montane (Canadian of Merriam) Zone and the (pper Sonoran, not to speak of all that are common to Merriam's Canadian and Transition or his Transition and Lpper Sonoran.

If we compare the Montane zone of the Rockies and that of the Pacific Coast mountains, we find that they have many more species in common. This is due partly to the fact that the Cascades and the Northern Rockies are connected by many mountain ranges. Many of the Rocky Monntain plants have migrated into the Casciades, and sercral of those helonging to the Pacific

1 hee Proc. Biol. Soc. Natsh. 7: 58. 1892. 
Mountains are found on the western slope of the Northern Rockies. Some have also migrated across the Great Basin from the Sierra Nevada to the Southern Rockies, or vice versa from mountain to mountain. Of the forest trees may be mentioned the following categories: (I) Species of general distribution in both regions: Pinus Murrayana, $P$. flexilis, $P$. albicaulis, Pseudotsuga mucronata, Alnus tenuifolia, Populus tremuloides, and Pinus ponderosa, if Pinus scopulorum is included in it as a variety. (2) Species common to the Sierra Nevada and the Southern Rockies: Abies concolor and Pinus aristata. (3) Western species, whose ranges extend to the western slopes of the Rockies: Larix occidentalis, Abies grandis, Tsuga heterophylla, Thuya plicata, Pinus monticola, Taxus brevifolia, Populus trichocarpa, Betula occidentalis, etc. These may all be regarded as immigrants. (4) Rocky Mountain species which have migrated into the Cascade Mountains but which are not found in the Sierra Nevada, as Picea Engelmanni and Abies lasiocarpa. (5) The endemic species confined to the Rockies only are: Picea Parryana, P. albertiana, Populus angustifolia, Betula fontinalis, etc. From this it may be inferred that the difference between the Montane Zone in the Rockies and the Pacific Mountains is much less than between the former and the Canadian Forest. The mountains of the Pacific slope and the Rockies might be included in the same province, were it not for the lack in the latter of many of the most characteristic trees of the former, as for instance, the sugar and other Californian pines, the redwoods and "big trees," the cypresses, etc.

Many differences are found between the Montane Zone of the Northern and of the Southern Rockies. Here it may suffice to give a summary of the differences in the composition of the forest trees from an article already published. (I) Trees common to the both divisions are Pinus Murrayana, P. scopulorum, P. flexilis, Pseudotsuga mucronata, Picea Engelmanni, Sabina scopulorum, Populus tremuloides, $P$. balsamifera, and P. angustifolia, Betula fontinalis, Alnus tenuifolia, and several willows. (2) Trees found in the Southern but not in the Northern Rockies are: Picea Parryana, Abies concolor, and Betula utahensis. (3) Those found in the Northern Rockies but not in the Southern: Picea albertiana, Pinus albicaulis, several species of Betula, Populus, and Salix, and the conifers mentioned above as immigrants from the Cascade Mountains. 
As the flora of the Montane Zone is mostly made up of different pines and Pseudotsuga mucronata it may be called the Belt of Pines and Red Fir.

The upper limit of this zone I have placed at the upper limit of the Bull Pine in Colorado, for here the Douglas Spruce and Lodge Pole Pine extend far up into what I regard as the Subalpine Zone. In the Northern Rockies it may be placed at the upper limit of the Rel or Douglas Fir and that of most of the immigrants from the Cascades. This means an altitude of about 10,000 feet in Coloraclo, 8,00o in the Yellowstone Park and 6,500 feet in northern Montana. The zone so limited would extend north to Lat. $55^{\circ}$, though the Lodge-Pole Pine extends about $10^{\circ}$ further north. Of the trees belonging to the Canadian Zone of the East, the Banksian Pine extends in a similar way further north than the other members. The lower limit has been placed at the lower limit of the Lodge-Pole Pine. This is also near the lower limit of the Limber Pine and that of the Douglas Spruce, east of the mountains. The lower limit of the Montane Zone is therefore about an altitude of 7,500 or 8,000 in Colorado and 5,000 feet in southern Montana. It is rather lower on the western side, about 4,000 fect in western Idaho. For some reasons to be mentioned later it might have been better to have set the lower limit further down, perhaps at the lower limit of the Douglas Spruce, which would carry it I, 500 feet further down.

\section{SubMontane Zone}

This corresponds mainly to Dr. Merriam's 'Transition Zone. It has scarcely any thing in common with the Transition Zone of the East, the Alleghanian hardwoods, with oaks, chestnuts, walnuts and hickories; but even Dr. Merriam did not regard it as a life zone proper, but a transition belt between the boreal and austral zones. Seen from such a view it is a transition zone between the wooled monntains and the grass-covered plains or between the Rocky Mountains proper and the Sonoran highland.

Merrian included also in his Arid Transition Zone the plains of the western Dakotas, northern Montana, part of Saskatchewan and Allerta. He was correct so far, but clicl not extend it far enough south. I shall discuss this further on under the headings of the Creat Plains. 
The foothills are far from uniform, depending partly on the region on which they border; those of the eastern slope are very different from those of the western, those in the south different from those in the north. In the foothills are included both the lower mountains of the Rockies, the high mesas and plateaus of ten bordering on the same, and the isolated mountains, hills, and bluffs in the neighboring region.

\section{Foothills of the eastern slope of the Northern Rockies}

The foothills are here usually covered with scattered growth of Bull Pine, Pinus scopulorum, and on the steeper hillsides by Sabina scopulorum, and to a great extent covered with the common grasses and other herbs of the plains. In the upper portion of the hills, Pseudotsuga mucronata and other trees of the Montane Zone are often found in the valleys. The river bluff and hillsides with richer soil are covered by groves of Prunus melanocarpa, Grossularia setosa, Ribes odoratum, $R$. inebrians, Acer Douglasii, Rhus trilobata, Symphoricarpos occidentalis, Amelanchier alnifolia, and related species. In the canyons and valleys are groves of Populus angustifolia, P. Sargentii, P. acuminata, some willows and birches, Negundo interior, and in the drier part of the same Prumus americana and several species of Crataegus. Many of these trees and shrubs really belong to the flora of the Plains or even to prairie-division of the Upper Austral Zone, and have followed the rivers up. In the Black Hills of South Dakota and in some of the hills and ridges in western Nebraska to these are added, Quercus macrocarpa, Ostrya virginica, Celtis occidentalis and $C$. crassifolia, Ulmus americana, Fraxinus campestris, and Cercocarpus montanus, all except the last belonging to the eastern flora. The lower hills, as well as tablelands and flats, are often covered by sage brush, principally Artemisia tridentata and A. cana, and rabbit brush, i. e., various species of Chrysothamnus.

Although the foothill region in central Montana covers large areas, the zone is really rather narrow in altitude and becomes still narrower further north. As far as I can understand, it has disappeared in the Canadian Rockies. At least, the hills sparingly covered by Pinus scopulorum so characteristic of the belt in Montana, northern IVyoming, and western Nebraska are not there. Even the tree itself seems to be lacking north of latitude 
$49^{\circ}$ east of the mountains. The most northern record is in the Bear Paw and Little Rocky Mountains in Northern Montana, a little north of Lat. $48^{\circ}$.

\section{Foothills of the northeastern slope of the southern Rockies}

In 11 yoming and northern Colorado the eastern foothills of the Southern Rockies are much the same as those of the Northern Rockies already described, but Pseudotsuga mucronata is perhaps a little more common and the sage brush is rare. In some cases the mesas and hills are covered by shrubs, as Cercocarpus montanus, Rhus trilobata, Ribes inebrians, june-berries and roses, occasionally also Celtis rugosa. This description may apply to the foothills north of South Platte River. In this region the pinons and shrub oaks are rare, but south of said river the foothills take on a different aspect. In other words, the division line between the northern and southern foothills is on the eastern slope of the Rockies over two degrees further south than the line between the northern and southern division in the Montane Zone.

\section{Foothills of the southern and western slopes of the southern Rockies}

This division takes in the eastern slope south of the South Platte River (about Lat. $39^{\circ} 30^{\prime}$ ), the whole southern slope and the western slope, at least as far north as the Grand River, probably as far north as Jampa River (Lat. $40^{\circ} 30^{\prime}$ ), and very likely the southern slope of the Lintahs and the eastern of the Wasatches. In these are included the isolated La Sal and Abajo Mountains of southeastern ['tah, but the Henry Mountains and other mountains west of the Colorado of the IVest belong to the Great Basin. The flora in the zone is by no means uniform. Often it consists of sereral belis one above the other, sometimes the species of the different belts are intermixed. If the zonation is present, the belts are often in the following order: (1) Pine Belt, highest; (2) Chaparral Belt; (3) Piñon-Cedar Belt.

\section{a. Pine Belt}

The Pine Bele is mostly made up of an open stand of Pinus scopulorum, mixed with some Sabina scopulorum and Pseudotsugu mucronatu, and arboresent oaks, with Padus melanocarpa and $P$. i'alidn, Acer glabrum, Robinia neomevicana, and species of Crataegus in the moister places. 


\section{b. Chaparral Belt}

The Chaparral is mostly made up of shrub oaks, principally of the Quercus Gambelii group, with deciduous leaves. The evergreen oaks mostly belong to the Upper Sonoran flora. The oaks often grow in pure stand in dense thickets, but often are mixed with species of Amelanchier, Rosa, Symphoricarpos, Cercocarpus, Ribes, and other shrubs.

The valley and canyon flora of both these belts consist of Populus Sargentii, P. Wistizeni, P. acuminata, P. angustifolia, Betula fontinalis, Alnus tenuifolia, and willows.

\section{c. Piñon-Cedar Belt}

This belt is characterized by an open stand of Pinus edulis and Sabina monosperma and on the western side also of $S$. utahensis. It may be counted to the foothills, but Merriam, ${ }^{1}$ Vernon Bailey, ${ }^{2}$ and Wooton \& Standley, ${ }^{3}$ refer this to Upper Sonoran Zone. Although the undergrowth in it is much the same as that of the Pine Belt, and though the vegetation is quite different from that of the Great Basin proper, which also belongs to the Upper Sonoran, and plant societies from the three belts often $\mathrm{mix}$, it is better to leave it in the Upper Sonoran Zone as they have done. It will be discussed fuller later.

\section{Western foothills of the Wasatches}

This slope is much like that of the western slope of the Southern Rockies, though the Pine Belt is poorly developed, perhaps destroyed by man, and in the other belts there are found many immigrants from the Great Basin Mountains. The Chapparal extends north to about Lat. $43^{\circ}$. If the Piñon-Cedar Belt is included in the foothills an important element is added, viz. Pinus monophylla.

\section{Foothills of the Green River Basin}

Here the Chaparral Belt has wholly disappeared and of the Piñon-Cedar Belt, Sabina utahensis is the only one of the characteristic trees left.

${ }^{1} \mathrm{~N}$. Am. Fauna 3: 20. I890.

${ }^{2}$ N. Am. Fauna 35: 35. I9I3.

${ }^{3}$ Contr. U. S. Nat. Herb. I 9: 3I, 37. 19 I 5. 


\section{Southwestern foothills of Northern Rockies}

In central Idaho the foothill flora is very meager as far as woody plants are concerned. Bull Pine is practically wanting, and both the oaks and junipers have disappeared. The woody regetation of the drier hillsides is mostly made up of shrubs, such as species of Artemisia, Chrysothammus, Tetradymia, Eurotia, etc. The mountain mahoganies, Cercocarpus ledifolius and $C$. hypoleucus, are also found there. Along the water courses are found species of Populus, Salix, Crataegus, Amelanchier, Betula, and Almus.

\section{Western foothills of the Northern Rockies}

In British Columbia there are no foothill regions of the Rockies, for, as said before, they connect here through several mountain ridges with the Cascades. I have not visited personally the west side of the Bitter Root Mountains, but have received the impression from what I have read that there is a broad belt of Yellow Pine, Pinus ponderosa, on the higher plains bordering these mountains. These woods Piper includes in the arid portion of the Transition Zone. Judging from the little I have seen of the Flathead Basin between the Rockies proper and the Bitter Roots, one may scarcely speak of any distinct foothills, as no other transition flora exists there than what we find in any mountain valley between the hillsides and the bottomlands.

As seen from above, the Pine Belt only, consisting of scattered Pinus scopulorum and Sabina scopulorum, is present on the eastern slope of the Northern Rockies and the northeastern slope of the Southern. In the southern part of the western slope of the Northern Rockies where the Bull Pine is absent the belt is also alsent as a Pine Belt and in the northern part its place is taken by P. ponderosa. As Pinus scopulorum is the one of the mountain trees that grows at lowest altitudes, it naturally is the tree that runs further down on the hills or further out on the plains, and is the one that really is concerned in the strife between the mountain forest and the grasslands of the plain, or between the Montane evergreens and the Sulmontane deciduous trees. It is one of the important components of the Mlontane flora and should be counted there, but as it encroachess so much on the Submontane floral districts, and its close relative, Pinus ponderosa, is the charac- 
teristic tree of the Submontane forest of eastern Washington, it is better to treat the region of scattered Bull Pines as a zone by itself, although in reality it is only a transition belt between two life zones.

The belt of chaparral is really the true representative of the hardwood forest of the Alleghanian Zone of the East and the Submontane zone of oaks, chestnuts, and walnuts of Europe. It is true that it is a poor representative thereof, not only as to the size of the trees (or rather shrubs), but also as to the extent of the zone itself. Marcus E. Jones, who has studied the flora of Utah, California, and Arizona, has come to the same conclusion, though other ideas of his regarding limitations of zones and provinces are somewhat faulty. A little north of the Arkansas Divide (about Lat. $39^{\circ}$ ), this belt disappears on the east side of the Rockies. It reaches there its northern limit at the altitude at which the grass-covered plains reach the mountains. The life zone is evidently here continued on the plains as grasslands, and naturally the oaks disappear. The hardwood belt reappears partly in the foothills of the Black Hills, but here it contains only eastern species, such as Quercus macrocarpa, Ulmus americana, Ostrya virginica, etc.

\section{The Great Plains}

The Rockies are bordered on the east by the Plains. These slope, in Colorado and Kansas, about 3,500 feet in 5 degrees of longitude or Io feet to the mile, i. e., decreasing in altitude from about 6,000 feet to 2,500 feet. In the north the slope is still more gentle, in northern Montana and North Dakota about 2,000 feet in I 3 degrees or Io feet in $4 \frac{1}{2}$ miles from about 4,000 to 2,000 feet altitude. From this can also be seen that the plains are higher in the south and lower in the north, i. e., that the slope is southwest to northeast. The northern part of the plains Dr. Merriam included in the arid division of the Transition Zone, the southern part in the Upper Sonoran. In this I agree, but I do not agree as to the limitation of these zones. The maps which Dr. Merriam has issued at different times vary a good deal, but in all I have seen the Upper Sonoran Zone is carried to the nor th in to western South Dakota and southeastern Montana and in the one published in I898, with his "Life zones and crop zones of the United States," it includes even one third of Montana, Wyoming, and

${ }^{1}$ U. S. Dept. Agr. Div. Biol. Surv. Bull. Io: 1898. 
Nebraska and part of South Dakota. In my opinion, these parts do not belong to the Cpper Sonoran Zone. In the Bulletin mentioned, I can not find any statement giving the reason why this region is included in the Upper Sonoran Zone, and why the northern part, viz. northeastern Montana, eastern Alberta, Saskatchewan, and western North Dakota, is excluded. Perhaps the zone is based wholly on animal distribution, for the flora does not warrant such a division. Maybe the occurrence of austral types in this region has lead to the error. But then the question arises, were these austral types Sonoran or were they from the eastern Ipper Austral Zone. The true prairie region belongs to that zone and it extends along the Missouri Valley through South Dakota into Montana and along the North Platte and Cheyenne River valleys into Wyoming.

The flora of the Great Plains from the Arkansas Divicle in Colorado to the divide between the Saskatchewan and Athabasca rivers in the north, and from about the $100^{\circ}$ meridian to the foothills of the Rockies, is practically the same. The characteristic grasses, Koeleria nitida (vernal facies), and the two gramas, Bouteloua oligostachya, B. hirsuta (autumnal facies) on the plains proper, Andropogon scoparius and Bouteloua curtipendula on the hills, and Agropyron Smithii, A. molle, etc., in alkaline soil, are found from southern Colorado to Saskatchewan, and the Buffalo grass, Bulbilis dactyloides, is scattered over the region, except in the northern portion. The common trees and shrubs of the hillsides, Padus melanocarpa, Rhus trilobata, Toxicodendron Rydbergii. Grossularia odorata, and Symphoricarpos occidentalis, extend north to northern Montana or Alberta. It is true that some of these, as for instance Bouteloua oligostachya, B. curtipendula, and $B$. hirsuta are also found in the Sonoran Region, but they are the only ones among their numerous relatives which are found on the plains north of the Arkansas Divide. Of the cactuses, Opuntia polyacunthe and Cactus viviparus range from Colorado to Saskatchewan and Opuntia fragilis and Cactus missouriensis to northern Nontana.

South of the Arkansas Divide are found many plants either not found north thereof or not extending far north thereof. Among the grasses may be mentioned Amphilophis Torreyanus, Bouteloua poly'stachy'a, B. criopoda, B. prostratu, Scleropogon brevifolius, and 
Erioneuron pilosum, which are found in Colorado only south of the divide. The cactuses also are here represented by genera not found north of the divide, as Echinocactus, Echinocereus, and the section Cylindropuntia of Opuntia. The tree cactus, Opuntia arborescens, is found on the Arkansas Divide, but not north thereof. Even the other sections of Opuntia and the genus Cactus are mostly represented by different species. The yuccas so common in the Upper Sonoran Zone are represented north of the divide by only one species, Yucca glauca, which ranges north to South Dakota. The genera Dasylirion and Nolina are found only on the south side. Several species of Padus and Rhus are added south of the divide. Genera characteristic of the plains, such as Lesquerella, Eriogonum, etc. are mostly represented by different species south of the line. Atriplex confertifolia, the Shad-Scale of the Great Basin, is not uncommon south of the divide, but is not found north thereof.

It is therefore evident that the line between the northern plains and the southern should not be drawn in Montana but in Colorado. Looking at Dr. Merriam's map of 1898 , one may wonder how it happens that the Upper Austral Zone should swing northward towards the Rockies where the plain becomes higher and that northern Iowa and northern Illinois should be counted to the Transition Zone, while eastern Montana $4^{\circ}$ or $5^{\circ}$ further north and 2,000-3,00o feet higher, or central Wyoming on the same latitude and over 4,000 feet higher, should be counted to the Upper Sonoran, the zone next below it.

If we let the plains as far south as central Colorado belong to the Transition Zone, i. e., if we let a region $3^{\circ}$ or $4^{\circ}$ degrees further south and 4,000 or 4,500 feet higher than northern Iowa and northern Illinois be on the southern boundary line of the same life zone, it seems much more reasonable. When my observations relative to the native flora and the generally accepted relation between latitude and altitude point to the same conclusion, I can not see any reason why we should not draw the line between the so-called Transition Zone and the Upper Sonoran on the plains where I have drawn it.

I know very little about the distribution of animals, but I think that several illustrations may be found supporting my theory. I know at least of one, viz. the distribution of the two species of 
jack-rabbits, of which the northern species, the common jack-rabbit or prairie hare, ranges from Saskatchewan to southern Colorado, i. e., a little south of the Arkansas Divide, and the southern species, the black-tailed jack-rabbit, from Mexico and Texas on the eastern side to northern Colorado, a little north of the divide.

The plains east of the Rockies may therefore be divided into two life zones as far as the native flora is concerned.

I. The Great Plains, north of the Arkansas Divide, and belonging to the Subboreal or Transition Zone.

2. The Staked Plains, south of the divide and belonging to the Lpper Sonoran division of the Austral Zone.

\section{Columbia Plains}

The upper part of the Columbia Plains belongs also to the Submontane Zone. For a description I shall only refer to Piper's Flora of Washington. ${ }^{1}$

\section{Upper Sonoran Zone}

Just as the Submontane Zone runs across the mountains and forms the bottom of the saddle between the Northern and Southern Rockies, so does the Upper Sonoran Zone in the saddle between the Southern Rockies and Sierra Madre of northern Mexico. Just as the Submontane Zone is made up of two principal divisions, (I) The wooded hilly or broken country, and (2) The grass-covered plains, so is also the U'pper Sonoran region bordering the Southern Rockies, but the plains are not always covered by grasslands. This is especially the case on the western side of the mountains. The Upper Sonoran division of the Rocky Mountain region may be divided into the following divisions:

I. Piñon-Cedar Belt.

2. Staked Plains.

3. Creat Basin, including the basins of the Colorado and Snake Rivers.

4. Columbia Plains.

\section{Piñon-Cedar Belt}

This has already been mentioned under the Foothills. It is marle up of hills or tablelands mostly covered by an open stand of 
Pinus edulis and Sabina monosperma, and, on the western side, Sabina occidentalis also. It extends on the eastern side over the Arkansas Divide to South Platte River (Lat. 39 ). North of that river both the piñon and the cedar are only local and soon disappear altogether. On the western side it forms foothills of the Rockies and a few isolated mountains, as well as low plateaus apparently as far north as the Yampa River. On the western slope of the Wasatch Mountains and in the mountains south thereof as far east as the Henry Mountains, Pinus edulis is mixed with $P$. monophylla, which takes its place in the isolated mountains of the Great Basin as far north as southern Idaho. In the part bordering the deserts the Piñon-Cedar Belt is often broken and intermixed with patches of sage brush, Artemisia tridentata, as for example, on the mesas between the Elk Mountains and San Juan River in southeastern Utah.

On the western slopes of the La Sal Mountains the Piñon-Cedar Belt reaches the top of Wilson's Mesa, nearly 8,000 feet in altitude, and is separated by a narrow belt of chaparral only a few hundred feet high, from the Spruce Zone above, both the foothill Pine Belt and the Montane Forest Zone being lacking. The PiñonCedar Belt, furthermore, was there separated from the valley below with the Upper Sonoran flora by a belt of low shrubs of Amelanchier utahensis, Cercocarpus, Coelogyne, Petradoria, Yucca, Fendlera, Ephedra, Cowania, Fallugia, and Quercus, some of which belong to the Upper Sonoran flora, and some to that of the chaparrals.

The undergrowth of the Piñon-Cedar Belt is often the same as in the Transition Pine Belt, but often many southern plants are added, as for instance Arctostaphylos platyphylla, Ceanothus Greggii, Berberis Fremontii, etc. In southeastern Utah large stretches are covered by Amelanchier utahensis and other shrubs. Towards the San Juan River the mesas are sparingly covered by Coelogyne, which, if I am not mistaken, associates further south with Covillea, one of the characteristic plants of the Lower Sonoran Zone. In southern Utah, Arizona, and New Mexico, the place of the pinons and cedars is often taken by live oaks, especially on the sides of cañons. In the cañons, Fraximus anomala is common. In southern Arizona and New Mexico many other trees and shrubs are added to the belt, but as that region belongs 
to Sierra Madre rather than to the Rockies, it will not be discussed here.

The eastern representative of the Upper Sonoran Zone is the wooded division of the Upper Austral Zone or the Carolinian Zone. This is also characterized partly by evergreen forests of conifers, as the short-leaved pine, partly of deciduous broad-leaved trees, as rose-magnolia, tulip-tree, persimmon, hickory, oak, and walnut. The lire-oaks seem lacking. This zone corresponds to the Mediterrancan region with evergreens of both classes, as pinons, cypresses, and junipers, as well as live-oaks, olives, laurels, etc. The true prairies are probably the grass-covered portion of this zone in the Middle West.

\section{Staked Plains}

These are discussed already under the Great Plains.

\section{Great Basin}

The Great Basin comprises the larger part of Utah and Nevada, northern Arizona, southern Idaho, and small parts of New Mexico, Colorado, Wyoming, Oregon, and California. In it is included the Great Basin proper, without outlet, and the upper basins of the Colorado of the West and Snake River. The flora of the basin is a desert flora, characterized by such shrubs as Atriplex. confertifolia and other species of that genus. Artemisia tridentata and its relatives, Sarcobatus, Graya, Tetradymia, Yucca, and numcrous species of Eriogonum (both shrubby and herbaceous).

\section{Columbia Plains}

These I have not risited personally and shall only refer to the description in Piper's Flora of Washington.

\section{LOWER SONORAN \%ONE}

The Lower Sonoran Zone consists mostly of desert lands. The worly vegetation is characterized ly the Creosote Bush (Covillea), mespluites (Prosopis), acacias, cactuses, yuccas, and agaves. In the Midklle Province, it may be divided into two divisions, the Texano-Mexican Region east of the mountains, and the true Sonoran Region west thereof. The former send up two tongues northward along the valley's of the Rio Grande and the Pecos, 
but neither reaches the Rockies proper. The latter sends up three such tongues, one along the Colorado of the West, another along the Virgin River, and the third along the eastern slope of the Sierra Nevada. Only the first of these may be considered in connection with the Rocky Mountains, as a few plants belonging to this zone reach the foot of the mountains along the Grand and the San Juan, two rivers of the Colorado River system. On the Pacific Coast there are two other regions belonging to the Lower Sonoran Zone, viz. the Sacramento-San Joaquin Valley and the Lower Californian region. In the East this is represented by the humid Austro-Riparian Zone. It is the region of the Long-leaf and Loblolly pines, magnolias, cypress, tupelo, and live-oaks. It corresponds to the regions of oranges and date palms in the Mediterranian Region.

\section{SUMMARY}

The results of my investigations show, as far as the native flora is concerned:

I. That the United States may be divided into three floral provinces, an eastern or Alleghanian, a middle or Rocky Mountain, and a western or Pacific. As far as the native flora is concerned, Dr. Merriam is wrong in his contentions that no such a division exists in nature.

2. That going north and south or down the mountains one may recognize six life zones in the Rocky Mountains. My observations in that respect agree with those of Dr. Merriam, but I have used different names, names that have been used by phytogeographers in Europe. They are:

I. Alpine-Arctic.

2. Subalpine-Subarctic, or Hudsonian of Merriam.

3. Montane-Boreal, or Canadian of Merriam.

4. Submontane-Subboreal, or Transition of Merriam.

5. Upper Austral or Upper Sonoran.

6. Lower Austral or Lower Sonoran.

3. That the Arctic-Alpine Zone is practically the same in all three divisions, as it is essentially all over the world.

4. That the composition of the flora of the corresponding life zones of the eastern and middle divisions otherwise show greater differences than even the parallel zones of the same division, and 
scarcely less than the corresponding zones of Europe and North America.

5. That the Sulnarctic and Boreal zones of the eastern and midclle divisions, although they meet in the north without a barriers, have practically none of the characteristic plant species in common; the common plants consisting mostly of transcontinental plants, many of which are also found in the Old IVorld or in other life zones.

6. That the same zones of the middle and western divisions because of the connections in the north between the Cascades and the Rockies have many of the characteristic species in common, especially in the north, and that there is less reason for keeping these two divisions distinct. They could be regarded as one division, if it were not for the absence of spruce and balsam in the southern part of the western division, and the total absence of redwoods, cypresses, sugar pines, and several other western pines in the middle division.

7. That the Submontane, Upper and Lower Sonoran zones of the Rockies have practically no elements in common with the corresponding zones of the Atlantic Coast, being separated from that region by the grass-covered plains.

8. That the Submontane zones of the middle and western division, i. c., of the Rockies and the Sierra Nevada, have rather few plants in common, as they are separated more or less by the Great Basin.

9. That the Upper and Lower Sonoran zones of these two divisions merge, more or less, as there is no real effective barrier.

Io. That the Arctic-Alpine region naturally has no wooded division, that the Subarctic or Subalpine and the Boreal or Montanc zones in America have no grasslands of any extent and that the Subboreal, Ipper and Lower Austral zones have both wooded regions and grasslands or deserts.

I I. That the Subarctic-Subalpine zones of both the eastern and midcle divisions are characterized by a spruce-balsam forest, through the species are different. That this forest is lacking in the western division, excent in the Cascades, where the species of the middle division have invarlerl the zone. In Europe the zone is represented by the dwarf hirel belt in the Scandinavian mountains, and the region of Pimus monticola, Aluus viridis, and ericaceous shrubs in the $A l_{p}$ s. 
I2. That the Boreal or Montane Zone is characterized by a pine forest in all three divisions in North America, as well as in Europe, where, however, there are also steppe-lands, especially in Russia.

13. That the woods of the Subboreal Zone (Transition Zone of Merriam) in all three divisions as well as in Europe are characterized by deciduous trees, mainly oaks and other nut-bearing trees, and that this zone is but poorly developed in the Rockies, consisting mostly of chaparrals of scrub oaks, Amelanchier, Cercocarpus, etc.

I4. That the woods of the Upper Austral zones (in the West called Upper Sonoran) in all three divisions in America are mostly made up of evergreens, partly of broad-leaved trees and shrubs, principally live oaks, partly of conifers, as, for instance, pines, junipers, and cypresses. The same is the case in Europe.

I5. That the Lower Sonoran Zone, characterized further south in the middle and the western divisions by the mesquite, creosote bush, giant cactuses, and tree yuccas, is poorly represented in the Rockies, and there only in the cañons and valleys of the Colorado of the West and its tributaries. It corresponds to the AustroRiparian district of the East with pines, magnolias, cypresses, and live oaks, and to the region of oranges and date palms of the Mediterranean.

I6. That going north or up the mountains we find no sharp lines between the parallel zones, or going east and west between grasslands or desert and forest, but everywhere we find transition belts or zones of strife between neighboring floras.

I7. That the original Subalpine or Timber Line Zone of Dr. Merriam, which he has abolished, is merely such a transition belt or zone of strife between the Alpine Zone and what I have called the Subalpine Zone, or Dr. Merriam's Hudsonian Zone.

I8. That the Subalpine Zone, or so-called Hudsonian, gradually emerges into the Montane or Canadian Zone. As both contain coniferous woods, the transition is gradual and no distinct transition belt is evident.

I9. That Dr. Merriam's original Transition Zone as designated in his survey of the San Francisco Mountains does not in my opinion correspond to his Transition Zone of the East, viz., the Alleghanian Zone of hardwood forest. The open woods of Pinus 
scopulorum represent the zone of strife either between the montane pine forests and the grassy plains, as for instance in western Nebraska and northern Colorado, or between the former and the chaparral belt in southern Colorado. Sometimes the latter disappears and the strife is between the Montane and the Upper Sonoran.

20. That the Chaparral Belt is the true representative in the Rockies of the Alleghanian Zone or submontane hardwoods of Europe.

2I. That the Great Plains north of the Arkansas Divide represent the grasslands of this zone and not of the Upper Austral or Lpper Sonoran, as partly claimed by Dr. Merriam. They begin at about the same latitude as that at which the chaparral disappears. That the higher part of the Columbia Plains also belongs to this life zone.

22. That the Staked Plains south of the Arkansas Divide should be counted in the Upper Sonoran Zone as well as the Great Basin and a part of the Columbia Plains. In this I agree with Dr. Merriam.

23. That Dr. Merriam is right in counting the Lower Sonoran to the warm temperate zones and Marcus E. Jones wrong in placing it among the tropical.

24. That the prairie region of the Upper Austral Zone of the East sends long arms along the valleys of Missouri, Platte, Arkansas, and other rivers into the Great Plains, which arms carry some of the prairic plants to the foot of the Rockies.

25. That the Lower Sonoran sends up similar arms along the Coloratlo of the 1 est and its tributaries and the Rio Grande.

26. That the mountain regions of the middle division may be divided into three parts which show some differences in the composition of the flora, viz., the Northern Rockies, the Southern Rockies, and the Sicrra Madre. The division lines in the Montane \%one between these are the saddles in central $17 y$ yoming and New Mexico, not near the C'madian and Mexican houndaries as Harshberger has inclicated. In the Submontane \%one the division line on the eastern slope is further south alout the headwaters of the South Platte River, and the Luper Somoran on that sicle stops on the Arkansativide. (On the west sicke the latter extends north to the Columbia Plains. 
27. The approximate altitudinal limits of the different zones in the south are given below. So also the northern latitudes at which they meet the lowlands, the plains, or the level basins.

Zones

Alpine-arctic

Altitude in New Mexico, approximately

Subalpine............... I0,500-12,000 "

Montane................99,000-I0,500" "

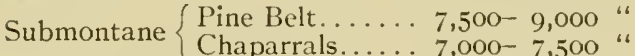

Upper Sonoran............ 4,500-7,000"

Lower Sonoran............ $\quad-4,500 "$
Northern latitude East Side West Side Lat. $69^{\circ}-90^{\circ}$ $55^{\circ}-69^{\circ}$ $+8^{\circ}-55^{\circ}$ $39^{\circ} 30^{\prime}-48^{\circ}$ $38^{\circ} 30^{\prime}-39^{\circ} 30^{\prime}$ $35^{\circ}-38^{\circ} 30^{\prime}$ Lat. $69^{\circ}-90^{\circ}$ $55^{\circ}-69^{\circ}$ $50^{\circ}-55^{\circ}$ $43^{\circ}-50^{\circ}$ $42^{\circ}-43^{\circ}$ $35^{\circ}-42^{\circ}$ 



\title{
BERMUDA FUNGI
}

\author{
Fred J. Seaver
}

The New York Botanical Garden

It is often stated by those who have visited the islands that there are no fungi in Bermuda, at least none to speak of. It is difficult to account for the prevalence of this idea unless it be that many of the larger forms which one is accustomed to see in other places are conspicuous by their absence in Bermuda, or if they do occur, being short-lived, they are overlooked by visiting botanists. Many of the fungi are at best so evanescent in their occurrence that it is difficult to form an adequate conception of the fungous flora of any region unless the place is visited frequently at different seasons of the year or for an extended period of time. Even then the region must be gone over with a "fine comb" in order to get a fair representation of the smaller and more inconspicuous species.

Whatever explanation may be offered, on account of the reputation which these islands have had, so far as their fungous flora is concerned, they seem to have offered no inducement to mycologists. Or perhaps this phase of their natural history has been overshadowed by the opportunities which are afforded for the study of other cryptogams such as marine algae; at any rate the fungi have received very little attention. Twenty-four species were recorded in the report of the Challenger Expedition in I883. Professor Farlow has collected and described a few species. In addition to these published records about forty species were collected by Dr. and Mrs. B. O. Dodge during a recent visit, many of which were duplicated during our own visit to Bermuda at a later date.

The parasitic fungi, which on account of their economic importance are the first to attract attention, are quite abundant and their number is gradually increasing, largely by importation, as the work of agriculture and horticulture is becoming more extended in this region. From the observations based on a two weeks' collecting trip (November 29-December I4, I9I2), the writer is 
inclined to believe that the fungous flora of Bermuda, so far as the number of species is concerned, compares very favorably with that of any other region of equal extent, notwithstanding the fact that many of the familiar forms seem to be lacking. Of the one hunclred and fifty species collected during our two weeks' visit to the islands, many are still undetermined and as this collection must necessarily represent a very small percentage of the species which actually occur, any report which may be presented at the present time must at best be regarded as only preliminary to the study of the fungi of these interesting islands.

Only three species of the Phycomycetes were found. Among the Peronosporales, or white rusts, Albugo candida (Pers.) Roussel, was the only species collected. This species, as might be expected, was found to be common on leares and stems of cultivated radish. The Mucorales were found to be represented by Pilobolus crystallimus (IVigg.) Tode and an unnamed Mucor.

Four species of the Helvellales were collected. Of these one species, Geoglossum nigritum Cooke, was found to be abundant on rocky hillsides among mosses. Trichoglossum hirsutum Wrightii Durand was also found. This variety of "hairy earth-tongue" was described by Durand in his recent monograph of the Geoglossaceac. The variety was based on two collections made in Cuba by Wright. At the time of the original description of the variety it was predicted by the author of the variety that it would probably prove to be a distinct species. The material collected in Bermuda according to a communication from Durand has served to confirm this suspicion. Trichoglossum hirsutum (Pers.) Boud. was reported by the Challenger Expedition as occurring in Devonshire Marsh. Although this region was searched diligently we were unable to cluplicate the collection of this species. The fourth species collected consisted of only two plants about I $\mathrm{cm}$. in height. While this minute species is distinct from either of the other three collected, the species is in cloubt and will probably remain so until more abundant material can be collected.

Twenty-one species of the Pezizales were collected which have been assigned specific names. Of these one species, Ascophanus bermudensis, is clescribed as new. 'This species is most closely related to Ascophamus surcobius Boud., a species which was also found to be common in the Permudas, but the two appear to be 
distinct in spore characters. Perhaps the most interesting fact in regard to the discomycetes of the Bermudas was the collection of several European species, which so far as the writer is able to learn have not previously been known from North America.

One of the most interesting of these is Detonia Planchonis Boud. a small purple cup-fungus about $\mathrm{I} \mathrm{cm}$. in diameter. This species was found on damp soil by roadsides and on bare soil in fields throughout the Bermudas. While this is the commonest cupfungus in the islands and is large enough to be easily seen, there is no record of the species having been previously collected either in Bermuda or elsewhere in North America.

Another species of equal interest is Sarcoscypha minuscula Boud. On account of its small size this species might easily be overlooked. The species was originally described from material collected in Portugal on dead foliage of cedar. The species while not abundant was frequently collected and there is no record of the species having been previously collected in North America. Among the peculiarities of this species are the asci, which are marked by an external thickened ring near their apices. This gives to the asclis when seen in profile the appearance of having two minute ears. This structure of the ascus is very different from that of Streptotheca, in which genus the thickened ring about the ascus projects inward instead of outward.

Of the more common species of discomycetes, we were interested in noting the occurrence of Pyronema omphalodes (Bull.) Fuckel on burnt places. This species, which has proved to be of unusual interest to morphologists, appears to have a very wide distribution. The coprophilous discomycetes were found to be common and quite abundant. A number of species of the Hysteriales and Phacidiales were collected, five of which have received specific names.

The Perisporiaceae or "sooty moulds," which are essentially tropical fungi occurring as parasites or epiphytes on the leaves and stems of the higher plants, were found to be quite abundant. Since in many cases the mycelium occurred without any trace of perithecia, it was impossible in such cases to make specific determinations. Four species have been definitely deter mined.

Eight species of the Hypocreales were collected, three of which are described as new. One of the new species is Nectria Lantanae, a minute species which was found to be common on the dead leares 
of Lantana odorata. Whether the mycelium of this fungus attacks the leaves while living, it was impossible to determine from field observations. The other two new species were Calonectria Umbelliferamm and Calonectria gramulosa, the former occurring on dead stems of Foeniculum and the latter on dead stems of Jasminum. Both appear to be saprophytes.

The Fimetariales or coprophilous pyrenomycetes were found to be represented by seven species which have been found to be determinable, and the Sphaeriales by thirteen species, none of which are of any especial interest.

The fungi imperfecti were found here as elsewhere to be very abundant and on account of the parasitic habits of the group will doubtless prove to be of considerable economic importance. Fourteen species have been specifically determined and a considerable number referred to the genera only.

Two species of the Ustilaginales or "smuts" have been reported, Ustilago Zeae (Beckn.) Unger, collected by Dr. Dodge, and Ustilago Carbo Tul., reported by the Challenger Expedition.

The Uredinales or plant "rusts" are known to be represented by nine species, some of which have been introduced with cultivated crops. Of this number one species, Puccinia Cladii Ellis \& Tracy, has proved to be of especial interest according to Dr. J. C. Arthur, who very kindly determined the plants of this group. This species was formerly known only from the type collection which was made in Mississippi several years ago. 'The Bermuda material has added a new host and locality and also furnished material which has enabled Dr. Arthur to complete the description of the species in a much more satisfactory manner than would otherwise have been possible.

The Basidiomycetes, or so-called higher fungi, although not so abundlant as in other regions, were found to be fairly well represented. The group has not been intensively studied and only thirty-two species have been assigned specific names, including sereral of those reported by the Challenger Expedition. The plants of this group were determined by Dr. II. A. Murrill.

The slime moulds, which are often included with the fungi, were found to be represented by a number of species, most of which have not been critically studied.

From the studies which have been recently made on the fungi 
of Bermuda, four species of ascomycetes and two basidiomycetes have been revealed which are described as new, one variety has been raised to specific rank and a number of European species have been found which were not previously known from North America. The following is a list of the species collected, so far as they have been named:

\section{PERONOSPORALES}

Albugo candida (Pers.) Roussel. On living leaves of cultivated radish.

\section{Mucorales}

Pilobolus crystallinus (Wigg.) Tode. On horse dung.

Mucor sp. On heavily fertilized soil.

\section{Helvellales}

Geoglossum nigritum Cooke. On rocky hillsides among mosses.

Trichoglossum hirsutum (Pers.) Boud. Reported from Devonshire Marsh.

Trichoglossum hirsutum Wrightii Durand. On rocky hillsides among mosses.

Geoglossum pumilum Winter? On damp soil in woods.

\section{Pezizales}

Lamprospora Planchonis (Dun.) Seaver. On damp soil. Common.

Pithya Cupressi (Batsch) Rehm. On dead foliage of Bermuda cedar.

Lachnea pulcherrima ( $\mathrm{Cr}$.) Boud. On excrement of cows.

Lachnea theleboloides (Alb. \& Schw.) Gill. On excrement of cows. Ascophanus sarcobius Boud. On the excrement of cows.

\section{Ascophanus bermudensis Seaver sp. nov.}

Apothecia gregarious or scattered, at first subglobose, expanding and becoming subdiscoid, reaching a diameter of $\mathrm{I}-2 \mathrm{~mm}$., white or more often with a delicate pinkish tint; hymenium at first slightly concave, becoming plane, finally convex, roughened by the protruding asci, similar in color to the outside of the apothecium; asci clavate, reaching a length of $325 \mu$ and a diameter of $35-40 \mu$, 8-spored; spores I-seriate or partially 2 -seriate, or occasionally irregularly disposed, at first smooth, becoming rough, $33-38 \mu \times 23-25 \mu$; spore-roughenings assuming the form of scat- 
tered protuberances which are enlarged outwards and giving the appearance of protruding nail-heads, $2-3 \mu$ long and $2 \mu$ broad; paraphyses strongly enlarged above.

On cow dung.

Type locality: Near Harrington Sound, Bermuda.

Distribution: Known only from the type locality.

The present species seems to differ from $A$. sarcobius Boud. in the larger size of the spores and the difference in their markings. Both species were collected in the same region. It is possible that further field study will show the present species to be only an extreme form of $A$. sarcobius. If so, the description and illustrations of that species are incorrect.

Ascophanus gramuliformis ( $\mathrm{Cr}$.) Boud. On excrement of cows. A scobolus stercorarius (Bull.) Schröt. On the excrement of cows. Ascobolus immersus Pers. On the excrement of cows and horses. Saccobolus Kerverni (Cr.) Boud. On the excrement of cows and horses.

Lasiobolus equinus (Müll.) Karst. On excrement of various kinds. Thecotheus Pelletieri (Cr.) Boud. On excrement of horses. Pyronema omphalodes (Bull.) Fuckel. On damp soil where fires have been.

Sarcoscypha minuscula Boud. \& Torrend. On dead foliage of Bernuda cedar.

Erinella rhaphidophora (Berk. \& Curt.) Sacc. On old wood. Gorgoniceps Pumilionis Rehm. On decaying wood.

Orbilia chrysocoma (Bull.) Sacc. On an old pasteboard box.

Dasyscypha earoleuca Berk. \& Br. On decaying wood.

Patellaria atrata (Hedw.) Fries. On dead and decaying cornstalks.

Karschia lignyota (Fries) Sacc. On decaying wood.

\section{Hysteriales}

Hysterographium lineolatum (Cooke) Sacc. On old trunks of Sabal Blackburnianum.

IIysterographium praelongum (Schw.) Sacc. On dead wood.

\section{Pinacidiales}

Propolis faginea (Schröt.) Karst. On old wood of various kinds. Stictis radiata (L.) Pers. On old wood and herbaceous stems. Stictis graminum Desm. P'arasitic on stems of rarious grasses. 
Perisporiales

Dimerosporium melioloides (Berk. \& Curt.) Ellis \& Ev. On living leaves of Baccharis.

Meliola Cookeana Speg. On living leaves of Lippia .

Meliola circinans Earle. On living leaves of saw-grass, Mariscus jamaicensis.

Asterina pelliculosa Berk. Reported by the Challenger Expedition on coffee leaves.

\section{HyPocreales}

Cordyceps militaris (L.) Link. On the pupa of an insect.

Hypocrea patella Cooke \& Peck. On dead twigs of Bermuda cedar.

Sphaerostilbe flammea (Berk. \& Rav.) Tul. On bark associated with scale insects.

Stilbocrea hypocreoides (Kalch. \& Cooke) Seaver. On bark of various kinds.

Nectria sanguinea (Bolton) Fries. On dead wood.

Nectria Lantanae sp. nov.

Perithecia superficial, minute, scattered, at first globose, collapsing when dry, smooth or only minutely rough, pale orange, often fading to nearly white in dried specimens; asci cylindric or subcylindric, 8-spored; spores ellipsoid, I-septate, hyaline; paraphyses indistinct.

On dead leaves of Lantana odorata.

Type locality: Near Harrington Sound, Bermuda.

Distribution: Known only from the type locality.

\section{Calonectria Umbelliferarum sp. nov.}

Perithecia superficial, scattered or gregarious, occasionally slightly crowded, globose or subglobose, collapsing when dry and becoming pezizoid, bright reddish, often becoming dull when dry, smooth or minutely rough; asci clavate, reaching a length of $75 \mu$ and a diameter of $10 \mu, 8$-spored; spores usually slightly curved, attenuated at the ends, becoming 3 -septate, reaching a length of $20-25 \mu$ and a diameter of $4 \mu$; paraphyses indistinct.

On dead stems of Foeniculum Foeniculum.

Type locality: Near Harrington Sound, Bermuda.

Distribution: Known only from the type locality. 


\section{Calonectria granulosa sp. nov.}

Perithecia scattered, gregarious or occasionally crowded together in small clusters, minute, globose or subglobose, occasionally collapsing, strongly granulose, bright red, finally fading to pale yellow; asci clavate, S-spored, reaching a length of $60 \mu$ and a diameter of $10 \mu$; spores partially 2 -seriate, ellipsoid, with the ends strongly narrowed, hecoming I-septate, finally 3-septate, hyaline, reaching a length of $14^{-15} \mu$ and a diameter of $4^{-6} \mu$, occasionally slightly constricted at the middle septum.

On dead stems of Jasminum.

Type locality: Near Harrington Sound, Bermuda.

Distributiox: Known only from the type locality.

\section{Fimetariales}

Fimetaria fimicola (Rob.) D. Griff. \& Seaver. On excrement of cows.

Fimetaria hyalina (D. Griff.) D. Griff. \& Seaver. On the excrement of cows.

Pleurage fimiseda (Ces. \& De-Not.) D. Griff. On the excrement of cows.

Pleurage anserina (Ces.) Kuntze. On the excrement of cows. Pleurage vestita (Zopf) D. Griff. On the excrement of cows. Sporormia minima Auersw. On the excrement of cows. Sporormia intermedia Auersw. On the excrement of cows.

Chactomium sp. On the excrement of rats.

\section{SPHAERIALES}

Rosellinia mammaeformis (Pers.) Ces. \& De-Not. Reported by the Challenger Expedition.

Rosellinia subiculata (Schw.) Sacc. On old wood of various kinds. Lasiosphaeriu pezizula (Bcrk. \& Curt.) Sacc. On decaying wood. Iypoxylon mulliforme Fries. Reported by the Challenger Expedition.

IIypoxylon inestiens (Schw.) Berk. On rotten wood.

IIypoxylon fuscum (Pers.) liries. On decaying wood.

IIypoxylon fuscopurpurcum (Schw.) Berk. On old wood.

Vummularia Bulliardi Tul. On rotten wood.

Daldinia concentrica (Bolton) ('es. S Be-Not. Reported by the Challenger Expedition.

Xylaria filiformis (.111). \& Sichw.) Fries. On dead leaves of Jasminum. 
Xylaria arbuscula Sacc. On sticks and rotten wood.

Poronia Oedipus Mont. On the excrement of cows.

Ophiobolus acuminatus (Sow.) Duby. On old corn-stalks.

\section{Fungi Imperfecti}

Helminthosporium Ravenelii Berk. \& Curt. Parasitic on Sporobolus angustus.

Septoria oleandrina Sacc. Parasitic on leaves of Oleander.

Phyllosticta Ipomoeae Ellis \& Kellerm. Parasitic on leaves of Ipomoea.

Phyllosticta Opuntiae Sacc. \& Speg. Parasitic on Opuntia.

Phoma Fourcroyae Thüm. Parasitic on leaves of Fourcroya macrophylla.

Phoma leguminum West. On old pods of Lonchocarpus violaceus.

Phoma Musarum Cooke. On petioles of banana leaves.

Pestalozzia Guepini Desm. Parasitic on leaves of Rhizophora Mangle.

Macrosporium Solani Ellis \& Martin. On old stems and leaves of potato, Solanum tuberosum.

Sclerotium Semen Tode. On dead leaves of some grass.

Isaria felina (DC.) Sacc. On excrement of rats.

Stysanus Stemonites fimetarius Karst. On excrement of rats.

Tetraploa aristata Berk. \& Br. On old wood.

Helicoma larvula Morgan. On old stems of Sabal Blackburnianum.

\section{Ustilaginales}

Ustilago Zeae (Beckm.) Unger. On corn, Zea Mays.

\section{UREDINALES}

Nigredo proeminens (DC.) Arthur. On leaves of Poinsettia heterophylla, Chamaesyce Blodgettii, Chamaesyce hyssopifolia, Chamaesyce prostrata.

Nigredo Medicaginis (Pass.) Arthur. On leaves of Medicago denticulata.

Puccinia Lantanae Farlow. On leaves of Lantana odorata.

Puccinia Dichondrae Mont. On leaves of Dichondra carolinensis.

Puccinia Cladii Ellis \& Tracy. On leaves of saw grass, Mariscus jamaicensis.

Puccinia Polygoni-amphibii Pers. On leaves of Persicaria punctata. 
Puccinia purpurea Cooke. On leaves of sugar cane, Saccharum officinarum.

Tranzschelia punctata (Pers.) Arthur. On leaves of cultivated peach.

Gymnosporangium bermudianum (Farlow) Earle. On foliage of Juniperus barbadensis.

\section{AGARICALES}

Agaricus alphitophorus Berk. On small twigs. Reported by the Challenger Expedition.

A garicus ariensis Schaeff. On the ground in pastures.

Agaricus corticola Schum. On dead wood. Reported by the Challenger Expedition.

Agaricus helictus Berk. On rotten leaf mould. Reported by the Challenger Expedition.

A garicus rhodocylix Lasch. On the ground. Reported by the Challenger Expedition.

Agaricus tener Schaeff. On the ground. Reported by the Challenger Expedition?

Coprinus ephemerus Fries. On the excrement of animals.

Coprinus fimetarius Fries. On the excrement of animals.

Coriolus pavonius (Hook.) Murrill. On deciduous loge.

Coriolus sericeohirsutus (K'lotzsch) Murrill. On dead branches of cedar.

Crinipellis stupparia (Berk. \& Curt.) Pat. On fallen dead sticks. Daedalea Aesculi (Schw.) Murrill. On dead trunks of deciduous trees.

Fomes Sagraeamus (Mont.) Murrill. On dead logs and stumps.

Gymnopilus penetrans (Fries) Murrill. On dead wood.

IIirneola coffeicolor Berk. On coffee bark. Reported by the Challenger Expedition.

Hydrocybe Cantharellus (Schw.) Murrill. On the ground.

IIydrocybe conica (Scop.) P. Karst. On the ground.

Lepiota naucina (Fries) Quél. On the ground.

Marasmius bermudensis Berk. On dead coffee wood. Reported by the Challenger Expedition.

Murasmius mimutus Peck. On fallen leaves.

Marasmius obscurus Berk. \& Br. Reported by the Challenger Expedition.

Marusmius Subali Berk. On leaf-stalks of Sabal. Reported by the Challenger Expedition. 
Marasmius praedecurrens Murrill. Among mosses and sticks. Panaeolus campanulatus L. On the excrement of animals. Pleurotopsis niduliformis Murrill. On fallen twigs of cedar. Polyporus obliquus Fries. On dead sticks. Reported by the Challenger Expedition.

Polyporus arcularius Fries. On dead sticks. Reported by the Challenger Expedition.

Schizophyllus alneus (L.) Schröt. On dead wood.

Stereum hirsutum (Willd.) Fries. On dead branches.

Stereum radians Fries. On old wood.

Tyromyces graminicola Murrill. On a tuft of grass.

LyCOPERDALES

Clathrus sp. On the ground.

Geaster saccatus Fries. On the ground. 



\title{
SOME THINGS LEARNED IN MANAGING A BOTANIC GARDEN
}

\author{
W. J. BEAL \\ Emeritus professor of botany, Michigan Agricultural College
}

Instead of waiting for the endowment of a botanic garden to be managed by him, the writer, a man with no experience in such matters, began in 1877 in a very small way to carry some of his ideas into practice, making many mistakes, especially in reference to treatment of hardy plants as suggested by English writers. The mistakes were inexpensive, because the experiments were made on a small scale; but he kept learning. To begin with, the writer possessed some knowledge of landscape gardening, horticulture and systematic botany and a desire to produce a garden which should attract the public and especially be useful to serve as a laboratory for students. He kept studying all phases of the subject, visiting several gardens of this country, talking with directors and reading reports.

As the garden grew, the authorities of the college became interested, and were willing to furnish more needed money and labor.

At its best, the garden consisted of two areas, one of them on both sides of a brook containing about two acres and a half, the other of one acre on a gentle slope for growing grasses and other forage crops and weeds, a total area of about three and one half acres; the highest number of species reached was 2,500 .

During an experience of thirty-three years, the following are some of the most important things learned: labels are made of iron galvanized, the top portion placed with one edge up instead of sloping, this to prevent the birds from soiling them.

Now comes a very important and convenient addition to the system of labels: a. strip of zinc with a number punched on the upper end is thrust full length into the ground adjoining and on the back side of the standard of the label; the numbers on the strip of zinc are recorded in a book opposite the corresponding name of the plant. 
For about six months of the year these labels are gathered up in bundles, each family kept by itself. When each label is taken out a small stake is put in its place, for convenience in returning the labels.

The label for a family is larger and the text somewhat extended. It did not seem possible to arrange the families in order of rank, for most of them need a change every few years. For each family a spot was selected of suitable size and exposure to sun and shade. For instance, there was only one place just suited to ferns and that could not be at one end of the list if placed to show the relative rank. Preferably each species was given room enough to fill the eye, a patch three feet in diameter not only for appearance, but there is less risk of losing all of the plant in case of severe cold weather or hot, too wet or too dry.

In some families a few trees were planted, and these were occasionally cut back or a small tree substituted for a large one.

The writer soon learned that to grow violets and keep them true to label they must be scattered not nearer than eight feet of each other, because when mature they shoot their seeds in every direction, some of them to a distance of ten feet. The same is true of some species of plants of the family Euphorbiaceae, Geraniaceae, and species of oxalis, balsam and others.

Poison ivy and poison sumach are grown on an island not far from the path that visitors may not touch them.

Aquatics placed in the larger pond were not equally content with a reasonable amount of space. The most rampant one of the lot was Cabomba from the south. We had to draw off the water, clean out the surplus plants and prepare a separate place for Cabomba.

On the banks of the brook tarred paper subdued quack grass, proving much superior to common salt.

Noles and quack grass frequently invaded the garden from the surrounding campus. This was most successfully prevented by the following device: dig down a narrow trench about eighteen inches deep, leaving one wall smooth and sloping a trifle; on this wall we placed a coat of cement mortar an inch to an inch and a half thick, carefully filling in the dirt. Quack grass stopped then and there; cement was preferable to hemlock boards and lasted longer. 
Occasionally a plant, like Indian hemp or bind-weed is inclined to roam about instead of remaining where it is given a place. An inclosure of cement is efficient.

By repeated trials the writer has learned that rhododendrons, azaleas, kalmias, and bluets will not flourish in the garden on account of lime in the soil.

After three to five years, some species of Helianthus and most kinds of mint seemed to dwindle or poison the soil. The plants or the soil had to be changed.

After ten years, in spite of all we could do, insects disfigured or killed nearly all umbellifers. WTe had to give them a rest or a shift. Darwin and Wallace refer to similar incidents.

Why not cover top and sides over a bog with a screen and grow a nice assortment of mosses? The writer tried it for two years and had to admit the effort was not a success.

Spring is a busy time; for this reason we did as much work as possible in the fall previous. At this time we would mulch with coarse sedges and avoid scattering seeds which make trouble the next season.

With few exceptions, unless the writer knew exactly what he wanted, he found little satisfaction in exchanging or buying seeds; it is very much more satisfactory to visit nurseries and gardens when the display is good and secure living plants.

For growing weeds, grasses, and other forage plants, the writer adopted a formal style of squares or parallelograms, five or six feet across, where he grew about three hundred species. What seems nicer than to grow for comparison numerous species of a genus side by side, as for instance species of Poa, Agrostis, Polygomum, Brassica, and Trifolium? Don't do it, or you will soon learn how much misery and perplexity can be got out of a small piece of ground.

Of weeds, grow those unlike each other in adjoining plats; mix in, as clover between grasses, or place a Poa, or Panicum, or Aristida, a Bromus, a Festuca, the small kinds among those which are coarser.

The writer has helped half a dozen or more professors who had admired his plats to start a weed garden or a grass garden. In no case was it worth while, for the species were soon in hopeless confusion. Where kept pure and well grown, plats are very interesting, but a few things out of place destroy confidence. 
Before seeds begin to scatter, cut off the tops excepting a few for seed and study.

In his weed garden, the writer made a start in growing some parasitic fungi. As Gymnosporangium macropus does not grow on red cedar in central Michigan, the writer induced our mutual friend, Dr. Byron D. Halsted, to send him from New Jersey a few young cedars infested with the coveted cedar apples. For two years he made an unsuccessful attempt to infest the young leaves of a red astrachan apple tree, demonstrating the fact that this variety of apple is immune to this pest.

Securing red cellars from New Jersey reminds me of an incident worth mentioning at this time: some years ago Dr. Britton, the honored director of the New York Botanical Garden, visited the wilds of central Michigan and noticed that the red cedars there had bushy tops, unlike the conical tops of those in New Jersey and surrounding country. Beside the cedars received from Dr. Halsted were planted half a dozen cedars from the river bank at Michigan Agricultural College. The two lots of cedars have grown side by side and are now twelve feet high. The tops of all are alike bushy, not appearing as though sheared to a conical shape.

In conclusion, this small garden was much frequented by visitors from far and near. The writer recalls a single comment made by each of two men, B. T. Galloway, long the successful chief of the Bureau of Plant Industry, "I want a garden at Washington like this and larger." The other was Robert W'arington, director of the experimental farm so long famous for the work of Lawes and Gilbert of England, in looking at the plats of grass, Mr. Warington said: "How pure they are."

The writer had the oversight of this garden for thirty-three years; it took less than three years for his successors to reduce the number of species one half or more. 


\title{
COOPERATION IN THE INVESTIGATION AND CON- TROL OF PLANT DISEASES ${ }^{1}$
}

\author{
KARL F. KeLLERMAN \\ Bureau of Plant Industry, U.S. Department of Agriculture
}

Systematic botanists and mycologists can render material aid to the attempt to control the spread of destructive plant diseases by more widespread distribution of information concerning the unexpected occurrence of diseased plants in regions remote from their usual range, and the occurrence of new plant diseases. Cooperation among specialists now exists to a certain degree and with the further specialization of each branch of science it will probably become more and more the practice of the specialist in any one field to refer related questions and material to specialists in other fields.

This tendency, however, unfortunately overlooks the increasing responsibilities of the federal, state, and local officials responsible for effective inspections and the maintenance of established quarantines. Through more intimate contact with these officials specialists not only contribute greatly to the efficiency and economic value of quarantines against plant diseases, but also open to themselves new avenues for receiving immediate information regarding the occurrence of new diseases. The citrus canker disease is the most striking recent example of the introduction, gradual increase; and destructive prevalence of a distinctive disease before its existence was recognized by plant pathologists. Intimate contact between inspectors and pathological specialists would render such an occurrence impossible.

The establishment of a more thorough plant disease survey is desirable as well as the development of a clearing house for information regarding the occurrence and prevalence of diseases and insect pests, but such a development will not be feasible until the specialists themselves recognize their economic responsibility in this work.

\footnotetext{
${ }^{1}$ Abstract.
} 



\title{
THE NATURE OF THE INFLORESCENCE AND FRUIT OF PYRUS MALUS
}

\author{
Caroline A. Black \\ New Hampshire Agricultural Experiment Station
}

(WITH PLATES 33-40)

The literature concerning the nature of the inflorescence and fruit of Pyrus Malus is not in accord. The inflorescence is considered both determinate and indeterminate. The different parts of the mature fruit have been variously identified and the fruit is described under the inclusive term, pome, as originating in the calyx, receptacle or stem, and accompanied by more or less carpellary activity. The desirability of further study on this subject being evident, the present work was undertaken by the writer.

The material for this study was collected entirely from Baldwin trees in an orchard used for experimental purposes by the New Hampshire Agricultural Experiment Station, the collection covering a period of more than two years in order to furnish data for more than one growing season. From March, I9I3, to July, I9I5, collections were made at intervals varying from twice a week when vegetation was most active to every two or three weeks when the trees were dormant. The material was fixed in chromacetic acid and in the chrom-osmic-acetic acid solution prepared according to the formula of Mottier (1), washed, dehydrated, and embedded in paraffin. It was necessary to remove the outer scales and immerse the buds for a few seconds in a $5^{\circ}$ per cent. solution of alcohol to remove the film of air on the hairs on the inner scales in order to secure penetration of the fixative. Sections were cut from I 7 to $25 \mu$ and stained with Flemming's triple stain or with Haidenhain's iron-alum haematoxylin. The triple stain was preferable for detail of structure.

The following morphological study on Pyrus Malus includes the origin and development of the flower from the incipient shoot and the subsequent formation of the fruit. The subject matter is 
divided into topics which are cliscussed in sequence as far as possible, under the following headings:

The flower bud and its position

The inflorescence

The flower and its essential parts

Pollination and fertilization

The development of the fruit.

\section{THE FLOWER BUD AND ITS POSITION}

The flower bud in the Baldwin apple is a mixed bud and develops either terminally or axillarly, more frequently in the former manner. Many so-called axillary buds are found to be terminal upon one or more years' growth of wood (PLATE 33, FIGURES I and 2). The small amount of wood developed is inconspicuous and has led to a rather general use of the term axillary as applied to such buds in horticultural literature. The true axillary bud as a rule is a very small bud found directly in the axil of the leaf scar, and usually develops a few leaves only, if the bud is potentially fertile. Typical axillary buds are also shown in PLATE 33, FIGURES 1, 2, and 3. A few so-called axillary flower buds were found but the flowers formed in such buds were few in number and of no vigorous growth, developing a little later than the usual terminal flower buds (PLATE 33, Figure 7). The few scars at the base of this inflorescence indicate that it is really terminal and not axillary. Buds terminating long and short shoots are shown in PLATE 33, FIGURES I, 2, and 3, as are also the axillary buds. The difference in size between terminal buds on one year's growth of wood and true axillary buds is quite apparent.

The term fruit bud is well established in horticultural literature as applying to the bud which will eventually produce fruit. The question of distinguishing between a fruit bud and a leaf bud naturally presents itself. The size and position of the buds may inclicate the different kinds in some fruit trees, fruit buds as a rule being larger than leaf buds. Sometimes size indicates the nature of the burl, as in the peach; in other cases neither size nor relative position is indicative, as in the plums and cherries. The size of the bud in the Baldwin is not a distinguishing character, as a comparison of the terminal buds in I'LATE 33, IFGURES I and 2, which are leaf buds and riciures 3, 4,5 , and 6 which are 
fruit buds, will show. The identification of these buds was determined by dissection. A fruit bud terminates a long shoot occasionally, as shown in PLATE 33, FIGURE 3. Usually this bud is a leaf bud, as are the terminal buds in PLATE 33, FIGURES I and 2.

Flower buds develop on a variety of types of branches, which have been given special names in the horticultural literature of continental Europe. These types have been described and figured by Eneroth (2) and Forney (3), as their recognition and proper treatment is necessary to the successful culture of espaliergrown trees. The various kinds of fruit-bearing branches recognized by these authors are as follows: The brindille, a moderately long slender shoot with flower buds only in the axils of the leaves; the dard, a short stiff spine-like shoot with smooth bark and bearing a terminal flower bud and axillary leaf buds; the lambourde (FIGURE 6, PLATE 33), a short shoot with much wrinkled bark and a terminal flower bud; the branche a fruits (FIGURES 4 and 5, PLATE 33), a lambourde or dard that has developed for several seasons, in other words, our fruit spurs; the rameau a fruits, an ordinary branch bearing axillary flower buds. In the apple the brindille and rameau a fruits are rare, for the simple reason that the floral buds are most usually terminal buds. The flower buds in the apple are produced mostly on lambourdes or branches à fruits (PLATE 33, FIGURES $4,5,6)$. Figure 6 shows the beginning of the development of a typical fruit spur, a flower bud upon one year's growth. FigURE 5 shows a four-year old fruit spur and FIGURE 4 a nineyear old fruit spur with two three-year old branches. It is evident that a fruit spur develops from the tendency of a bud to produce fruit and to continue producing flower buds, hence the very small wood development. The branched, wrinkled twig becomes a fruit-bearing spur.

The growth of a flower bud is marked by an elongation of the axis, in which more or less wood is formed and upon which the flowers, leaves, and buds develop. This growth of stem which was described by Forney as a bourse or "purse" is identified by the numerous scars from the fruit stalks and becomes a characteristic part of the fruit spur. The appearance presented in FIGURE 2 is really due to a flower bud having developed in place of a terminal leaf bud. The "purse" which developed from this flower bud is very conspicuous and bears the scars of the fruit 
stalks. A small, dormant axillary bud is present on the "purse" as well as on the shoot with the terminal leaf bud. This shoot had developed from a leaf bud produced on the "purse" the preceding year. The development of this so-called purse is shown in its formation in FIGURE 8, PLATE 33, and FiguRE I, PLATE 34, and in its maturity in FIGURES 2, 4, and 5, PLATE 33. These drawings show that a fruit bud not only produces the flower cluster with its subtending leares but a small amount of wood, which varies in different buds and becomes the "purse." From this it will also be seen that the fruit is produced upon wood of the same year, i. e., the stem development known as the "purse."

It has been stated that the identification of the buds in FIGUREs I to 6, PLATE 33, was based upon their dissection. After removing the outer scales of the buds the shape of the bud was found to vary. If the flowers were formed, they were at once conspicuous and altogether gave a rounded or dome-shaped appearance to the bud, while, if only leares were present, the end of the bud was decidedly pointed. In longitudinal sections of very young buds the flower bud was found to have a broad summit to accommodate the somewhat simultaneous development of a number of parts while the leaf bud had a more conical apex. This is shown in PLATE 35, FIGURES I and 2 which are sections respectively of fruit and leaf buds. Fruit buds in the Baldwin may be anticipated by their position on the fruit spur but are identified with certainty on!y by dissection.

The bud of the apple is found to be a scaly bud according to the nature of $i$ ts protection. The number of scales varies considerably, depending upon the size of the bud and the stage of derelopment. Figures 2 and 3, PLATE 34, give in outline the scales of leaf and flower buds respectively, showing the average number and the form of the scales. Beginning with the outer, smooth, reddish scales uscel for protection only, there is a gradual transition from these to green, hairy scales with well-elefined growing regions as their apices. The growing region is seen to be flanked with two small lobes in IFIGUREs $3, f, g$, and $h$, while it has become a blade with distinct stipules in FIrURE $2, g$ and $h$. The bud scale in the apple is therefore a modified petiole, the innermost scales becoming true leaves as the bud opens. The flower bud is usually protected by more scales than the leaf bud. Buds are classified by Gray (4) 
according to structure as leaf, flower, and mixed buds. The flower bud of the apple contains both flowers and leaves and is therefore, properly, a mixed bud, as shown in the expanded buds in PLATE 33, FigURES 7 and 8, and PLATE 34, FIGURE I.

The time of flower bud formation is somewhat variable according to the general conditions of growth and the state of the apple tree and is either in the spring when growth is resumed or the buds may develop on the second growth of the season if such growth occurs. An interesting article on the conditions affecting the flowering of fruit trees by Sandsten (5) states that a physiological constant can be formulated from the climatic conditions during the ten months preceding flowering. He concludes that: ${ }^{1}$ "The time of flowering in the spring of a certain variety of fruit is dependent upon a number of causes or conditions chief among them being, first, the number of positive temperature units received in the spring preparatory to flowering; second the stage of development of the flower buds as dependent upon the climatic conditions of the summer and fall preceding the flowering; third the fruiting of the trees, - whether light or heavy the year previous to flowering; fourth, soil conditions and the amount of plant food present in the soil; and fifth, the individual characteristics and state of health of the tree and plant." By the time the flowers have advanced to the stage shown in PLATE 33, FIGURE 8 , and PLATE 34, FIGURE I, one or more well-established growing points may be found in the axils of the lower leaves on the "purse." These growing points are the primordia of the buds for the following year. An examination of trees in the middle of July revealed apples approximately two inches in diameter on a well-developed "purse." The bud for the next year was well established. It was partially surrounded by the petioles of two or more leaves.

The time of the differentiation of flower buds has been suggested by Kraus (6) for Oregon by the statement that the microsporangia pass the winter in the mother-cell stage. Drinkard (7) for Virginia states that the primordia of the flowers were found in July and by December the flower parts were completely formed. In February, resting pollen-mother-cells were found. In Wisconsin Goff (8) gives the date of June 30 for the earliest evidence of flower production. He states that in the apple a longer time apparently

1 Page 6. 
is consumed in preparing flowers than in preparing wood, and that the flowers commenced growth about the time the wood ceased forming.

In New Hampshire buds collected March I8, I9I3, show wellestablished flower parts, as seen in PLATE 35, FIGURES 3, 4, and 5 . The sporogenous tissue however was not distinct in the anthers. By April 14, 1913, the anther wall, sporogenous tissue, and tapetum were differentiated, as shown in I'LATE 36 , FIGURES 3 and 4 . The following season, I9I4, the buds were a little later in their development. The sections shown in PLATE 35, FIGURES I and 2, were taken from buds collected April 23, I9I5. No differentiation other than the shape of the growing apex was observed, showing that very little growth had taken place during the preceding season. The buds for I9I6 dissected on July 3, I9I5, and July 20 , I9I5, showed no differentiation into leaf or mixed buds. If second growth occurred in the late summer of I9I5 some of these buds might have produced floral parts, as flowers can develop on second growth. It is evident that the time of bud differentiation and flower formation in New Hampshire is somewhat variable. The primordia of the flowers may or may not be established in one growing year.

\section{THE INFLORESCENCE}

The inflorescence of the apple has been described by different writers as a cyme, an umbel, a corymb, a corymbed cyme, and an umbel-like cyme. Loudon (9) in $18+4$ states that the flowers in the apple are in corymbs and in the pear in umbels on simple pediccls. In the description of the genus Pyrus by Bentham and Hooker (10) the inflorescence is given as a cyme and rarely a corymb. Decaisne (11) uses the term corymb and calls the flower stalks perluncles in his Memoir on the families of the Pomaceae. The first six editions of Gray's (12) Manual of Botany describe the inflorescence in the section Malus as a cyme simple and umbel-like. In the seventh edition of the Manual (13), the inflorescence is given as a corymbed or umbel-like cyme for the genus Pyrus and the flowerstalks of Pyrus Malus are called pedicels. In the Field, Forest, and Garden Botany by Gray (14) the inflorescence is called a simple cluster or simple umbel and the flowei stalks are termed peduncles. In a revised edition of the Field, Forest, and Garden Botany (15) the flowers are 
described as occurring on short, woolly peduncles. Sargent (16) in his Manual of the Trees of North America states that the flowers occur in simple terminal cymes with filiform deciduous bracts and bractlets. In North American Trees by Britton (17) the flowers are said to be clustered in simple, terminal cymes on stout, woolly pedicels. In Britton and Brown's (18) Flora of the Northern United States, the flowers are described as borne in simple, terminal cymes upon pedicels.

In Gray's Structural Botany (4) the inflorescence is divided, according to kind, into Determinate and Indeterminate. In a determinate flower cluster, the axis is terminated by a flower which corresponds to a terminal bud. If more flowers appear they spring from axils, preferably from the highest axils and develop later. The order of evolution is indicated by the size of the flower buds. This type of inflorescence is also called Cymose and in a cymose cluster the flowering is centrifugal or descending. The terms corymbiform cyme, corymbed cyme, and umbel-like or umbelliform cyme originate in combining qualities of indeterminate inflorescences with determinate. The corymb and umbel are both examples of the indeterminate inflorescence and differ chiefly in the length of the axis or peduncle and the equality or inequality of the pedicels.

The words peduncle and pedicel have been used interchangeably as will be observed in the above descriptions. A peduncle is the general name of a flower stal or branch directly terminated by a flower. The name is also given to a more or less branched flowering axis, the ultimate divisions of which are called pedicels. The term pedicel is given to distinguish a partial flower stalk or, more strictly, the stalk of each individual flower of an inflorescence. In LeMaout and Decaisne's (19) Descriptive and Analytical Botany, the following definition of an inflorescence is found. " "An inflorescence in its restricted sense consists of a group of pedicelled flowers, bracteate or not, all springing from a common peduncle which bears no true leaves."

Upon dissecting the inflorescence of the apple as shown in PLATE 34, FIGURE 4, each lateral flower is found in the axil of a leaf or bract. The lower flowers are in the axils of leaves and the upper are found in the axils of modified structures, or bracts,

\footnotetext{
${ }^{1}$ Page 34 .
} 
as the series from $a$ to $e$, FIGURE 4 , indicates. There may be a gradual change between successive flowers in the subtending structure from a well-developed leaf with stipules to a very small filiform bract, or the change may be quite abrupt. Occasionally at the base of the terminal flower a rudimentary bract was found. This bract sometimes contained a bud and evidently represented a flower which failed to develop. 'The normal type of inflorescence in Pyrus Malus is shown in PLATE 33, Figure 8. Each flower is borne upon a pedicel, the pedicels having their origin in the common axis or peduncle. The distinction between a pedicel and a peduncle is made clear by the irregularity shown in PLATE 34, FIGURE I, where a peduncle, here a partial peduncle, is branched bearing two flowers which are pedicelled. If the inflorescence shown in PLATE 33, FIGURE 8 is lengthened so that the flowers are placed on an elongated axis instead of crowded on a very short axis, a figure such as is shown in PLATE 34, FIGURE 7 would be constructed. The dotted line represents the axis of the inflorescence or the peduncle. It is terminated by the pedicel of the oldest flower. The pedicels of the lateral flowers are found in the axils of bracts or leaves. A solitary bractlet or a pair of bractlets usually may be found upon the pedicels. 'They may be at the base of the pedicel or irregularly placed at any point on the pedicel. These bractlets are deciduous as are the bracts subtending the pedicels. The number of flowers in an inflorescence varies usually from 4 to 7 .

It will be noted on old twigs at the end of the "purse" where four or five scars have been made by the loss of the apple stems or pedicels, that a new scar has formed just beneath them. This shows very clearly in twigs where the apples have failed to develop and persist as shrunken mummies attached to the stem. This condition is shown in PLATE 34, FIGURE 5. The edge of the new scar is seen beneath the little cluster of undeveloped fruits. With very little pressure such a cluster may be removed. FigurE 6, I'LATE 34, shows the cluster removed and still united by the conmon tissue beneath. 'This may be considered the complete inflorescence and the axis or peduncle becomes with age somewhat disc-shaped.

Mention has been made of the abor wive bract with its bud, occasionally found at the base of the terminal flower. It might 
appear that the terminal flower was in the axil of this bract and by its more vigorous development had caused the abortion or complete suppression of the bract and its potential bud. From the basis of the definition, a terminal flower can not be a lateral structure. Therefore a terminal flower can not be axillary, because an axillary flower becomes, ipso facto, a lateral structure. A comparison of sections of developing flowers, however, shows the unmistakable terminal character of the oldest flower from the time of its inception to its maturity. In PLATE 35, FIGURES 4, 6, and 7 are of the terminal flower and show that it is a direct continuation of the axis. It is more logical, from the centrifugal type of flowering and from microscopic observation, to conclude that the axis is terminated by the oldest flower and is therefore a type of cymose inflorescence and may correctly be called a cyme.

\section{ThE FLOWER}

The development of the flower of the apple is of two-fold interest. It is a foundation for the subject of pollination and for the subsequent formation of the fruit. Progressive stages in the development of the apple flower have been described and figured by many writers-Goff (8) has discussed the origin and time of flower formation in the apple, as well as in the pear, plum, and cherry. Drinkard (7) by means of a series of photomicrographs presents stages in the development of the flower in the apple, plum, pear, peach, and cherry. Quaintance (20) gives a few figures in the development of the peach flower. Kraus (6) describes different stages in the development of apple flowers with particular reference to the origin and nature of the fruit and Bradford (21) shows very early stages in the flower formation of a number of varieties of apples.

The bud in PLATE 35, FIGURE 2, shows the broad growing region upon which the inflorescence will develop. This region consists of ten or twelve rows of small, dense cells. These cells have large nuclei and may be observed in various stages of cell division. Below this meristematic tissue the cells are gradually differentiated by their large size, irregular arrangement, and cell content. This tissue is the pith and is characterized by many intercellular spaces formed partly by the breaking down of one or more cells. The density of the cells in this region varies considerably according to 
the nature of the cell content. The circle of vascular tissue surrounds this dome of pith and, branching near the summit, sends new strands into the different structures as they are formed. This is shown in the section in the strands on each side of the pith. The end of the axis is early identified as a small blunt elevation and below it are found other excrescences in the axils of small bracts. These slight elevations are the primordia of the flowers. The description of the development of a single flower of the inflorescence follows.

The parts of a flower develop from the end of the stem or the receptacle and a typical receptacle is a rounded or flat surface on which the floral members develop. The small elevation destined to become a flower in the apple, is found to consist at first of a dome of tissue which however soon becomes cup-shaped and presents a hollowed appearance. The tissue lining this cup is meristematic. The cells beneath this meristematic layer are a continuation of the axis or stem on which the flower is produced. Within this structure a vascular system is differentiated, demarking the cortex and pith. Growth occurs on the periphery of this cup and particularly at five points, marking the primordia of the sepals. The origin of the sepals is of interest in relation to the development of the fruit.

Le Maout and Decaisne (19) state that in many plants the receptacle dilates into a cup which represents a calycinal tube, better called receptacular cup, over which the torus is spread and that hypertrophy of the receptacle is particularly striking in orchard fruits. The torus is considered the periphery of the receptacle but the term for most authors is synonymous with the receptacle and is so considered here. The sepals then begin their growth as five outgrowths of the torus. According to this view the apple flower does not possess a calyx tube, the calyx being limited to the five sepals. The calyx therefore does not form any part of the flesh of the apple and changes but slightly if at all as the fruit develops.

The torus grows rapidly by intercalary growth beneath the sepals and as growth proceeds the receptacular cup becomes more highly developed, producing next the petals, then the stamens, and finally the pistils. In PLATE 35 different stages in the development of the flower are shown. FIGURE 3 is of a very young flower 
with well-developed sepals. The primordia of the petals and stamens are also shown. The intercalary growth of the torus as well as the terminal growth of the members produced upon it emphasizes the cup-shaped appearance, so that the floral members are elevated considerably above the apex of the axis, which persists in the center of the flower. In FIGURE 4 the petals, stamens, and pistils are formed. FIGURE 5 shows two buds from an inflorescence with the primordia of all parts established. The petals develop in a circle within the sepals and alternate with them. In a young flower the tips of the scale-like petals curve over the torus, as shown in PLATE 35, Figures 6 and 7, and PLATE 36, FIGURE I. In the mature flower the tips overlap as found in PLATE 36, FIGURE 2 , forming an arch over the stamens and pistils. The sepals are lined with hairs, whereas the petals are practically free from hairs.

The stamens next develop in three circles. The stamen first appears as a blunt outgrowth of the torus. As the successive circles develop, the stamen is differentiated into anther and filament. The filament varies in length, according to the position of the stamen. Sections of stamens in position are shown in Plate 35, Figures 3 to 7 , and in Plate 36 , Figures $\mathrm{I}$ and 2 . It will be seen that the anther is conspicuous from the first. The anther develops as a four-lobed structure as shown in PLATE 36 , FIGURES 3 and 4 , which are cross sections of anthers in slightly different stages of development. The vascular strand in the connective appears denser than the surrounding tissue and in each lobe of the anther a few cells are found which are larger than the others and have dense contents. This is the primary sporogenous tissue in which the tapetum is early recognized. The cells within the tapetum become the microspores or pollen grains. The anther in FIGURE 4, PLATE 36, is a little older than that in FIGURE 3 and a little more specialization is shown in the anther wall in the region where the longitudinal dehiscence will occur. The cells in this portion of the epidermal layer are smaller with dense cell contents and inconspicuous cell walls.

As the anther may not be formed by the end of the first year, the pollen does not necessarily pass the winter in the pollenmother-cell stage as reported by Drinkard (7) for Virginia or by Kraus (6) for Oregon. If the anther is not formed the first year there is no resting period following the pollen mother cell stage, 
as has been described for so many plants, and the development is one of steady progression.

Within the innermost circle of stamens five small rounded protuberances are formed. This last circle consists of the primordia of the five carpels or pistils. Each protuberance soon becomes lobed as growth occurs in a circle that is not quite complete, leaving a small groove. This is well expressed by $\operatorname{Kraus}^{1}{ }^{\prime}(6)$ as follows: "Directly after this very early beginning, growth does not procecd equally in all directions from the center and form a solid cone-like or spherical structure, but instead, about the circumference of a circle which is not quite closed, thus forming as further growth takes place, a narrow hood-like scale with infolded edges." The five open or cleft pistil primordia are now found with their openings toward the center or facing each other. The cross section in PLATE 37, FIGURE 2, shows the position of the pistils and the narrow opening or groove leading in to the enlarged ovarian cavity of each pistil. A longitudinal section of this stage is found in PLATE 37, FIGURE $\mathrm{I}$. The apices of the pistils appear a little above the torus, which surrounds them. This common tissue of the torus runs up the lengthening styles a short distance, thus causing their apparent union, as shown in PLATE 39, FIGURE 3. The five free styles are shown in a cross section in PLATE 38, FIGURE 6. This section is made just below the origin of the sepals and petals and shows the relative position of the styles and stamens surrounded by the torus. Later development of the pistils is shown in PLATE 38, FIGURE 4 . The simultaneous development of the torus surrounding the pistils prevents the identification of the pistil as a distinct structure except at the inner surface, where a small indentation demarks one pistil from another. The gradual development of the pistil is shown in PLATE 35, Figures, 4 to 7 , and PLATE 36, Figures I and 2 . The openings of the pistils extend from the apex to the base, enlarging at the base to form the ovarian cavity. The edges of the openings become almost closed and upon these infolded edges or placentae the ovules are produced. The five pistils are the last structures developed by the torus and a very small portion of the end of the axis remains. The five pistils become adjacent as growth proceeds and the inturned edges form the boundary of a cone-like

1 Page 7. 
space directly over the remaining part of the apex of the axis. The fact that the vegetative point of the flower-axis is not entirely used up is observed and figured by Goebel (22) who places some of the flowers of the Pomaceae in a "transitional position between the perigynous to hypogynous." 1 He states that "the five carpels appear as papillae upon the hollowed-out inner surface. They take up the whole inner margin of the cavity, but at the base there is visible, and even at later stages it is so, the flattened vegetative point of the flower." It will be observed in PLATE 36 , FIGURE I, that the unused portion of the axis has become slightly elevated so that the apex is above the base of the ovarian cavities. This elevation is caused by a slight growth of the apex of the axis after producing the last circle of floral members, $i$. e., the pistils. Cell division was frequently observed in this region. In a median longitudinal section the unused apex of the axis presents a flattened appearance. Around this flattened area the inner surfaces of the carpels arise somewhat gradually. The section shown in PLATE 36, FigURE I, Or PLATE 38, FIGURE 2, is not a median section and the slight notch in the center is due to the ovarian groove of the adjacent carpel. A flower is shown just before expanding in PLATE 36, FIGURE 2. The sepals and petals arch over the stamens and pistils. The pollen is mature in the anthers. The styles have elongated and carry up with them the groove to the stigma. The papillose stigmatic surface is apparent before the flower opens. A young ovule is shown in the ovary of one pistil. The continued growth of the torus elevates the sepals, petals, and stamens so that they are above the ovaries. The ovaries thus become epigynous.

One ovule develops upon each placenta of the ovary, thus two ovules are usually found within an ovary. Early stages in the development of the ovule are seen in PLATE 36, FIGURES I and 2, and Plate 38 , Figures I, 2, 3, and 5. Figure i, Plate 38 , shows a very slight elevation upon the placenta. This rounded protuberance increases in size as shown in the next figure (FIGURE 2). Here the section is so cut that two similar ovules are seen in different ovaries. Below the ovule a very slight projection, the obturator is observed, similar to that shown by Péchoutre (23) for the pear (FIGURE 3, PLATE 38). This elevation does not appear ${ }^{1}$ Page 568. 
to be caused by the growth of any special cell but is due to the growth of several cells. It results in a somewhat rounded protuberance just below the micropylar end of the ovule (PLATE 39, FIGURES I and 5). The nucellus of the orule is conspicuous from the first. The ovule shows its anatropous character at an early stage. This is seen in PLATE 38 , FIGURE 3 , as are also the integuments. Both inner and outer integuments show on the free surface of the orule. The macrospore is apparent as a large cell two or three cell rows below the surface in farorable sections of ovules of this stage. A mature ovule is shown in PLATE 39, FIGURE I. The integuments have closed over the nucellus, leaving a narrow micropyle. A well-developed nucellar tissue surrounds the embryo-sac, which is situated six or seven cell rows below the nucellar cap. The integument on the inner side of the ovule is adjacent with the funiculus and the latter arises just above the spongy obturator. The fibro-vascular strand in the funiculus terminates in a well-marked chalaza, which is particularly prominent as the ovule matures. The chalaza is conspicuous in the three ovules in FIGURE 2, PLATE 39, as shown in the cross section at the base of the integument.

The macrospore gives rise to a seven-celled embryo-sac, the micropylar end of which is broader than the opposite end. The egg apparatus is well developed. The three antipodal cells are found in the somewhat pointed end of the embryo-sac. The micropylar polar nucleus and the antipodal polar nucleus fuse, forming the endosperm or fusion nucleus.

\section{Pollination AND fertilization}

The pollination of members of the Pomaceae has been described in two articles by IVaite $(24,25)$ and in the apple by Lewis $(26)$. The subject of pollination has been studied from various points of view and there is an extensive literature upon the subject. A discussion of it here seems unnecessary. Flowers were hand-pollinated with pollen from Baldwin flowers and with the pollen from other varieties. 'The Baldwin is evidently nore or less self-sterile, as a greater percent of fruit was securerl from the flowers pollinated with pollen from other trees than with Baldwin pollen. Pollination in the Baldwin apple is dependent more upon bees and insects than the wind. This was indicated by the greater number of fruits set in 
hand-pollinated flowers than in the flowers left to chance. A recent article by Chittenden (27) emphasizes the economic importance of the subject of pollination as well as the biological significance of the problems presented by its phenomena. The stigmatic surface is papillose and when it is in a receptive state is moist. Germination of the pollen grain takes place immediately after pollination, and fertilization quickly follows. Fertilization was observed in several cases. The pollen tube, which is slender, enters the micropyle of the ovule, and apparently does not break down tissue to reach the egg cell. Seventy-two hours after pollination small embryos were found, consisting of four or more cells.

There is great activity immediately following fertilization. The embryo-sac enlarges considerably, sometimes extending almost the entire length of the ovule. The endosperm nucleus divides and in the free nuclear division which follows, cell walls are laid down and a well-developed endosperm tissue is formed. At the micropylar end the cylindrical embryo is found on a short suspensor. The embryo at first is rather short and thick, but soon elongates, and is always straight. Figures I and 2 in Plate 40 show two embryos in different stages of development. Figure I shows the younger embryo, surrounded by the endosperm, well up in the micropylar end of the ovule. The small uniform cells in the periphery of the endosperm are clearly differentiated from the more irregular interior tissue. The cotyledons and root are well defined in the embryo. The cotyledons, which are thin and elongated in FIGURE 2, show a well-defined vascular system. In the root the central cylinder, cortex, and root cap are early distinguished. The blunt end of the embryo in FIGURE 2 indicates the position of the suspensor. With the development of the embryo, changes have been taking place in the integuments to form the brown satiny coat of the ripe seed. Péchoutre in describing the development of the seed in the pear observes that the nucellus and both inner and outer integuments take part in the formation of the seed coat. He gives in detail the changes which occur in these tissues and states that the outer integument becomes organized into an inner and outer zone. A comparison of the ovule in PLATE 39, FIGURE I, and the two ovules in PLATE 40, FIGURES I and 2, indicates the gradual change in the nucellus and integuments of the ovule to the seed coats. While no particular 
study was made of the seed coats in the apple, it is cvident that the nucellus and the inner integument are not as important as the outer integument. The zoned appearance in the latter is shown in FIGURE 2. The outermost zone is composed of cells which are considerably elongated and flattened. The inner integument, consisting of two or three rows of cells in the ovule, can not be distinguished in the seed. The nucellus in the orule occupies all of the area within the integuments except the embryo-sac but in the seed becomes quite inconspicuous due to the enlargement of the embryo sac and the amount of endosperm formed. Péchoutre describes the nucellus as recognizable by a cutinized strip or band. This is conspicuous in the apple as the dark wavy line in FIGURE 2, PLATE 40, and its origin can be distinguished in FIGURE I, PLATE to. The endosperm is practically exhausted by the time the seed is mature.

\section{The develorment of the fRUit}

The activity following fertilization is not confined to the embryo and ovule but extends to the ovary and torus, the further development of which gives rise to the fruit called in the case of the apple, a pome. The word pomum is used several times by Pliny (28) but referred then to many kinds of fruit, such as apples, cherries, nuts, berries, figs, and dates. Its application was apt only for round fruits. The fruit of the apple is now called a pome. Hence there is the Pomaceae or apple family or tribe. Conversely, the definition for a pome in general terms as found in the glossary" of Gray's Manual 7 th ed. reads, "Pome,- - a kind of fleshy fruit of which the apple is the type," or in Jackson's Glossary $^{2}$ of Botanic Terms (29) "Pome,- - an inferior fruit of several cells of which the apple is the type." More specific descriptions are given by Gray in the text of the 7 th edition of the Manual ${ }^{3}$ as-" "Fruit a large, fleshy pome with 2-5 papery or cartilaginous cells imbedded in the flesh." The genus Pyrus in Gray's Ficld, Forest and Garden Botany" is characterized as "a genus made to include a great variety of plants, agreeing in the cartilaginous parchment-like or thin-wallerl cells that contain the seeds. In the

\footnotetext{
1 Jage 881 .

2 Page 206.

${ }^{3}$ Page 457.

4 Page 161.
} 
apple the fruit is umbilicate at both ends. It is various, but always holding the calyx lobes upon its apex."

It is evident from the literature that the structure of the apple, pear, and quince has been the object of much study. Lindley (30) describing the Pomaceae states that as the fruit ripens, the calyx and ovaries increase simultaneously in size. The carpels become fleshy and form with the calyx a five-celled fruit with cartilaginous or chartaccous endocarp in Pyrus and osseous endocarp in Mespilus -and to these the term pomum may be strictly applied. The fruit is absolutely inferior, the carpels cohering with the calyx and each other by their whole surfaces.

De Candolle (31) describes the fruit of the Pomaceae as reenforced or consisting of the union of the calyx tube and carpels. Decaisne (32) gives a longitudinal section of the fruit, showing the position of the receptacular cup and ovaries. Carrière (33) gives a cross section of the fruit in reference to the core. Barry (34) describes the pomes or kernel fruits as accessory fruits. In Le Maout and Decaisne (19) directions are given to halve an unripe pear or apple when five carpels are found, forming 5 twoovuled cells, surrounded by a fleshy mass. The so-called calycine tube (better called receptacular cup) has closely enveloped them, and agglutinated them by their lateral faces, but has left their inner faces free. The parenchyma of the receptacle is enormously increased in bulk to envelop the ovaries; the remains of the sepals and stamens are carried up by the expansion of the receptacle. The receptacular tube encloses the carpels. A pome is considered an accessory fruit and is defined as a berry composed of many, usually five, cartilaginous carpels, forming five cells and united to the receptacular tube;-examples are the apple, pear, and quince.

The word receptacular cup gives way to perhaps a better terminology in the use of the word hypanthium or hypanthial receptacle, which is a flower axis or receptacle developed mainly under the calyx-according to Gray (4). He states in describing the flower of Calycanthus that" "the receptacle, instead of convex or protuberant is here concave, and has grown up around the ovary which is free from the cup but immersed in it, as in the hawthorn. A comparison with a rose-hip, an apple and a pear much strength-

\footnotetext{
${ }^{1}$ Page 2 I 4.
} 
ens this interpretation which is rather largely adopted at this day, at least theoretically. It was perhaps first proposed by Link who introduced the appropriate name of Hypanthium." Sturtevant (35) sums up the fruit of the apple as the core, consisting of the carpels, and the edible portion, or the calyx, which is adherent to the exterior of the orary. Bessey (36) defines a pome as the enlarged and fleshy calyx cup enclosing the papery carpels. Strasburger (37) describes the apple as a form of berry and considers it a spurious fruit composed of the carpels which are adnate to the wall of the receptacle. In the Handbook of Practical Botany (38) he clescribes the apple as a fleshy indehiscent fruit. The ovary is considered five-celled and is immersed in a hollowed flower stalk, a so-called hypanthium, or receptacular tube and is adnate to this. The thickening in the endocarp is compared with the shell of a plum stone. Van Tieghem ${ }^{1}$ (39) describing the fruit of the Rosaceae says: "The floral receptacle develops sometimes at maturity into a fleshy and edible substance (strawberry). In other cases it is the tube resulting from the concrescence of the three external parts which grows and forms around the fruit, a dry cnvelope (sanguisorba, agrimonia, etc.), or fleshy (rose); in the latter case if the carpels are concrescent with this fleshy tube and if they themselves become drupes, we have a fruit of which the fleshy portion has a double origin, belonging as regards the external part to the tube formed by the concrescence of the external parts and as regards the internal part to the pistil itself; it is in part a false fruit (pear, quince, hawthorn, etc.)." Sorauer (40) has a diagram of a young flower of the apple on page 2 I9 of the Popular 'Treatise on the Physiology of Plants, and in the text states that the edible portion of the apple consists of the hollowed axis or receptacle and that the apple is the cortical tissue of a succulent shoot.

The exact nature of the structure of the fruit of the apple is obtained from a study of the development of the parts, as has recently been done by Kraus in his paper, The Gross Morphology of the Apple. Krans states in his summary on page io "that the initial development of an epigynous fruit as typificd by the apple (Malus), and of a perigynous fruit such as the plum (Prumus), are the same. Subsecpuent growth in the former, proceeds across

1 Page 1663. 
the entire torus and carpels conjointly; in the latter, such growth is intercalary; the carpels and that part of the torus which bears the sepals, petals, and stamens, maintain an independent growth." A conclusion substantially similar to that of Kraus has been reached by the writer with the exception of the interpretation of the term intercalary.

Jost (41) defines intercalary growth as the interpolation of a new region between two zones which are already fully developed, giving as an example, Oedogonium. Sachs (42) cites the growth at the base of the internodes of grasses, the production of new laminae in Laminaria and the development of the inflorescence in the fig as examples of intercalary growth.

In discussing terminal and intercalary growth, Van Tieghem ${ }^{1}$ states that if growth is exclusively terminal, the parts of the structure are superposed gradually from base to summit according to age. The formation is thus basifugal. When growth is exclusively intercalary it may occur equally in all parts of the structure at the same time or it may be localized in a certain transverse zone. In the first place all parts are of the same age, their formation is simultaneous. In the second case the parts are of different ages and successive. Depending on the position of the intercalary growth, we may have: growth towards the apex, or basifugal growth; growth towards the base, or basipetal growth; or, growth may be intermediate, when it is said to be mixed. Finally if both terminal and intercalary growth occur at the same time, which is very frequent, the two results are superposed. The apex produces the parts at first in basifugal order, then, in these parts are intercalated the new ones which have formed following the simultaneous method or one of the other three.

Different zones of growth may be distinguished in very simple

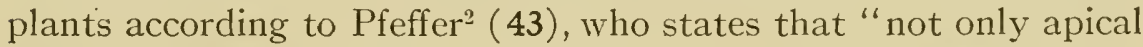
and intercalary vegetative zones, but also zones in which only growth in length is active, may be present in trichomes, and also in the filaments of algae and fungi. Moreover, the remarkable forms assumed by unicellular diatoms and desmids suffice to indicate that localized differences in growth are possible even in cells which retain their embryonic character."

1 Page 34.

${ }^{2}$ Page 10. 
Vines (44) on page 17 of his Textbook on Botany states: "One of the most remarkable instances of an intercalary growing-point is that occurring in connection with the development of hollow, more or less tubular structures (e.g., inferior ovaries, 'calyx-tube' of Rosaceae, gamopetalous corollas, inflorescence of the fig, pitchered leaves of Nepenthes, Utricularia, etc.). Taking the case of a hollow floral receptacle (whether inferior ovary or 'calyx-tube') when the apical growth of the axis is arrested, a zone of embryonic tissue lying close behind the apex gives rise to a projecting ring of tissue, which by continued basal growth, becomes a tube enveloping the apex of the shoot." And again on page 495: "In a great number of plants the perianth and androecium are raised by the intercalary growth of a lower portion of the axis (as represented by the outer portion of the torus) and stand on a circular rim surrounding the apex of the axis which lies at a lower level. Of this condition two different forms occur: in the one, the carpels are inserted in the depression at the apex of the axis, and there form one or more ovaries free from it, primarily at least, though they may subsequently become adherent to it; in such cases as in the rose and apple, the flower is said to be perigynous."

Goebel in describing the development of the fruit in the apple states that an ordinary perigynous flower would develop if the carpel alone, by intercalary growth produced the ovary. He attributes the formation of the ovarian cavity to growth involving "both the flower axis and the base of the carpels which quite cover its insides." 1

The growth of the carpel in the apple as an established organ has no relation to the further growth of the structure which produced it, save as they may develop conjointly. Intercalary growth occurs in both simultaneously. Following then the principles claborated by Van Tieghem and the various examples given by other authors, intercalary growth may be distinct with the interpolated tissue clearly limited by zones of mature tissue or it may occur with terminal growth and according to either the simulaneous or successive development complex growth relationships result. The development of the flower of the apple is the result of both terminal and intercalary growth. The excessive growth resulting in the fruit is due chiefly to the intercalary growth of the torus.

1 Page 568. 
The apple fruit is the result of a combination of the growth of the inferior ovaries and the torus of the receptacle. The identification of the various parts of a mature fruit is made by comparison with the origin and development of these parts in the flower and immature fruit. It has been shown that the sepals, petals, stamens, and pistils arise successively from the meristematic surface of the concave torus. The great growth of the torus and underlying parenchyma elevates the circles of sepals, petals, and stamens in succession, so that they gradually assume a position above the pistils-PLATE 35, FIGURES 3 to 7 ; PLATE 36 , FIGURES I and 2. The pistils thus become inferior. A comparison of the developing flower and the immature fruit (PLATE 37 , FIGURES I and 2; PLATE 38 , FiguRES I to 6; PLATE 39, FIGURES I to 5) furnishes the basis for the following description of the formation of the fruit. The five pistils in the flower (PLATE 35, FIGURES 3 to 7 ) arise from the embryonic tissue of the torus around the apex of the axis which is not entirely used up. Each pistil is united to its neighbor by the tissue of the torus, thus forming a continuous ring, except that part becoming the style. Sections cut near the apex of the fruit show the styles still united peripherally, but distinct centrally, with the grooves ${ }^{1}$ leading to the ovarian cavities (PLATE 39, FIGURE 3). Sections cut at a higher point show the five now distinct styles with their grooves centrally faced (PLATE 38, FIGURE 6).

The parenchymatous tissue just beneath the meristematic end of the axis and the organs produced upon it becomes the pith. As the torus becomes more concave the pith area also conforms to this shape. This has been shown in a diagrammatic way by Kraus. The developing pistils thus become enveloped by the increasing torus with which they have always remained united (Plate 36, Figures I and 2; Plate 37, Figures I and 2; Plate 38 , FIGURES 4 and 5). That part of the section properly pistil is clearly distinct from that which is torus as shown by the finer cells and by the network of small vascular bundles outlining each carpel as found in FIGURES 4 and 5, PLATE 38.

Growth proceeds rapidly in the pistil and torus, following the

\footnotetext{
${ }^{1}$ In the apple the gynoecium is more sensitive to frost than the other floral organs. This greater susceptibility to cold has frequently been attributed to the sensitiveness of these parts, whereas it seems more reasonable to explain it as due to the exposure occasioned by the structure of the pistils.
} 
stimulus of fertilization. The wall of the ovary develops as two distinct layers. The inner, or endocarp, composed of relatively few cells, becomes firm and leathery or, as frequently described, cartilaginous. The outer, consisting of mesocarp and exocarp remains soft and pulpy, and is traversed by numerous small fibro-vascular bundles. The innermost edges of the carpellary wall come together forming a drupe-like suture, while the outer tissues lose their identity and become indistinguishable from the torus. Thus the conditions of a drupe are fulfilled and if the ovary of the apple were superior, developing free from the torus, the resulting fruit would be a close approach to a true drupe. Is it is, the ovaries are inferior and are embedded in the torus which grows with the carpels. This is shown in the three sections of fruits in FIGURES 2, 4, and 9, PLATE 39. The demarcation of the various tissues can be seen in FIGURE 2 with the exception of the endocarp, which is only distinguished as the darkened border of the ovarian cavity. The exocarp is limited by the series of small fibro-vascular bundles appearing in the figure as a row of small dots. The tissue next in position extending from the exocarp to the primary vascular bundle is conspicuous by the absence of all vascular tissue. This zone of tissue may be called the pith of the apple and is continuous with the pith of the stem. The cortex or remaining tissue is separated from the pith by ten prinary vascular bundles.

The vascular structure of the apple has long been studied. Ten primary strands are described in Miller's (45) Garden Dictionary as occurring very regularly in the apple, one at the point of each cell of the "capsule" and one in the middle between the other five. Loudon (9) makes a somewhat similar statement, adding that the bundles tend toward the calyx. Decaisne (11) in a figure of a longitudinal section of the apple shows the primary vascular strand with the dorsal strand of the carpel arising from it. Recently Mc.llpine $(46,47)$ has worked out the fibro-vascular system of the apple and pear. In the apple McAlpine shows ten primary vascular bundles supplying the "flesh" and secondary branches supplying the "core." In the pear, he states that as each one of the five primary bundles approaches its corresponding carpel, it gives rise to an internal branch which passes along the dorsal or outer face of the carpel, while the main portion of each 
bundle is continued beyond to the blossom-end of the fruit. There are also five alternating bundles which diverge a little higher up than those in the preceding and each one passes between two carpels, giving off an internal branch to the inner or ventral face of the carpel. The vascular system in the apple is shown diagrammatically in PLATE 33, FIGURES 9 and IO. Ten primary vascular bundles demark the cortex and pith regions in the apple. Five of these bundles are found directly opposite the carpels and the other five alternate with them. The carpellary vascular system arises from these primary strands. A dorsal strand supplying the exocarp arises from each of the primary bundles opposite a carpel. A ventral strand which eventually branches, producing two strands, arises from the alternating primary bundle. These strands pass through the placentae of the carpels and again branch to supply the ovules. The dorsal and ventral strands eventually anastomose in the region of the style. The primary strands branch repeatedly to supply the sepals, petals, and stamens, and the tissue of the cortex. The ten primary bundles finally anastomose in a very small ring at the apex of the greatly enlarged fruit. In the longitudinal section in FIGURE 9 one of the primary vascular bundles is shown with the dorsal bundle of the carpel which arises from it. One of the ventral strands extends along the inner surface of the carpel and sends a branch to the ovule. The anastomosing of the dorsal and ventral strands is indicated. The different regions of the fruit may be identified in the drawing as follows (a) representing the unused portion of the axis of the flower; $(b)$ the exocarp of the carpel separated from $(c)$ the pith, by the dorsal vascular bundles; and $(d)$ the cortex, which is distinct from the pith and is outlined by the primary vascular bundles. The same regions are indicated by similar letters in the cross section in FIGURE IO. It will be observed that the five primary vascular bundles opposite the carpels are in a circle of a slightly larger diameter than the circle of the intermediate bundles. The small row of dots demarking the exocarp of the carpel represents the distribution of branches from the large dorsal bundle of the carpel. The two ventral bundles in each carpel are inconspicuous. Within each carpel two ovules are shown. The dorsal primary bundle and the suture formed by the infolded edges of the carpel lie on radii passing through one of the outermost primary vascular 
bundles. 'Radii passing through one of the inner primary vascular bundles would lie in the small strip of pith tissue separating one carpel from another, and would pass between the two ventral vascular bundles.

In conclusion, it will be observed from the literature that the identification of a pome has been along two lines. One was to determine the origin and nature of the fleshy portion and the other was to determine the rôle of the carpel in the formation of the fruit. The receptacular origin of the fleshy portion has been quite generally accepted. The derelopment of the carpel has not been so generally discussed, although the coherence of the receptacle and carpels has been emphasized. It will be recalled that Ian Tieghem described the similar fruit of the pear and quince as a false fruit and considered the carpels drupes. Kraus ${ }^{1}$ defines the fruit as follows: "A pome is to be regarded as consisting of one to several drupe-like fruits more or less intimately connected with a fleshy torus, on and within which they are borne." The apple is thus shown to be the result of excessive growth on the part of the torus, surrounding and embedding in it the carpels. The torus originates in the receptacle of the flower and results in the flesh of the fruit. The carpels taken singly correspond to drupes. The fruit of the apple may then be considered as a reenforced or composite fruit consisting of one to several drupe-like fruits embedded in a fleshy torus and is called a pome.

\section{SUMMARY}

I. The size of the fruit bud in the Baldwin apple is not a distinguishing character.

2. Fruit buds may occur in various positions such as terminating a long or short shoot or on a structure known as the fruit spur. The fruit bud is rarely axillary.

3. Fruit buds in the Baldwin apple may be anticipated by their position on the fruit spur, but are identified with certainty only by dissection.

4. The growth of the fruit bud is characterized by an elongation of the axis called the "purse," in which more or less wood is formed and upon which the flowers, leaves, and buds develop.

5. The bud scales are modified petioles.

J'lage 9. 
6. The time of bud differentiation and flower formation in New Hampshire is somewhat variable. The primordia of the flowers may or may not be established at the end of the growing season.

7. The inflorescence in the apple is a simple cyme, consisting of usually four to seven pedicelled flowers upon a very short peduncle.

8. The parts of the flower develop in succession from the torus. The greater growth of the cells in the periphery of the torus results in a cup-shaped structure, thus elevating the sepals, petals, and stamens above the epigynous carpels. The apex of the axis is not completely used up in the production of the flower parts.

9. The inferior ovaries in the apple are embedded in the torus, which grows with the carpels. The mesocarp and exocarp of the carpel become fleshy, whereas the endocarp becomes cartilaginous or papery.

Io. The torus is the receptacle of the flower and by excessive growth produces the flesh of the fruit, in which a well-defined pith and cortical layer can be seen.

II. Ten primary vascular bundles demark the cortex and pith regions in the apple. The carpellary vascular system arises from these strands.

I2. The fruit of the apple may be considered a reenforced or composite fruit consisting of one to several drupe-like fruits embedded in a fleshy torus and is called a pome.

For valuable help and criticism, the writer wishes to express her sincere appreciation to Dr. O. R. Butler, who suggested this study, and whose constant advice and assistance made the photomicrographs possible.

\section{LITERATURE}

I. Mottier, D. M. Beiträge zur Kenntniss der Kerntheilung in den Pollen-Mutterzellen einiger Dikotylen und Monocotylen. Jahrb. Wiss. Bot. 30: 169-204. I897.

2. Eneroth, O. Handbok I, Svensk Pomologi, I72-I80. I864.

3. Forney, E. La taille des arbres fruitiers. I: 2I-23. 1907 .

4. Gray, A. Structural botany, I: 40, I44, 2 I 4. I879 [ed. 6].

5. Sandsten, E. P. Conditions which affect the time of the annual flowering of fruit trees. Wisconsin Exp. Sta. Bull. 137: I-7. I906.

6. Kraus, E. J. Gross morphology of the apple. Oregon Agr. Coll. Exp. Sta. Res. Bull. no. I, part I. I9I3. 
7. Drinkard, A. W. Fruit-bud formation and development. Ann. Rep. Virginia Agr. Exp. Sta. I909-I910: I 59-205.

8. Goff, E. S. The origin and early development of the flowers in the cherry, plum, apple and pear. Ann. Rep. Wisconsin Agr. Exp. Sta. I6: 289-303. I 899 .

9. Loudon, J. C. Arboretum et fruticetum britannicum. 2: 880-894. I $8+t$ [ed. 2].

I0. Bentham, G., \& Hooker, J. D. Genera plantarum. I : 626. I865.

I I. Decaisne, J. Mémoire sur la famille des Pomacées. I53. I875.

I2. Gray, A. Nanual of botany. 18+8-I890 [ed. I-6].

I3. Robinson, B. L., \& Fernald, M. L. Gray's New manual of botany. I 908 .

I4. Gray, A. Field, forest, and garden botany. I869.

I5. Gray, A. Field, forest, and garden botany. I 895.

16. Sargent, C. S. Manual of the trees of North America. I905.

17. Britton, N. L. North American trees. I908.

18. Britton, N. L., \& Brown, A. An illustrated flora of the Northern United States, 2: 1913 [ed. 2].

I9. Le Maout, E., \& Decaisne, J. Descriptive and analytical botany. I 876 [Eng. trans.].

20. Quaintance, A. L. The development of the fruit buds of the peach. Thirteenth Ann. Rep. Georgia Exp. Sta. I3:349. 1900.

2I. Bradford, F. C. Fruit bud development of the apple. Oregon Agr. Coll. Exp. Sta. Bull. I29. I9I5.

22. Goebel, K. Organography of plants, Part 2. English edition by Balfour, 568. 1905.

23. Péchoutre, F. Contribution à l'étude du développement de l'ovule et de lil graine des Rosacées. Ann. Sci. Nat. Bot. VIII. I6: I-I 58 . I 902.

24. Waite, M. B. The pollination of pear flowers. Dir. Veg. Path. U. S. Dept. Agr. Bull. 5. I 895 .

25. Waite, M. B. Pollination of pomaccous fruits. Yearbook Dept. Agr. I 898: 167. I809.

26. Lewis, C. I., \& Vincent C. C. Pollination of the apple. Oregon Agr. Coll. Exp. Sta. Bull. I0f: I-1 fo. 1909.

27. Chittenden, F. J. Pollination in orchards. Ann. Applied Biol. I: $37+2$. II) It.

28. Pliny, C. Naturalis historia.

29. Jackson, B. D Clossary of botanic terms. I905 [ed. 2].

30. Lindley, J. Observations on the natural group of plants called the P'omarciac. 1820.

31. Candolle, A. de. Introduction à l'étude de la botanique. i 835 . 
32. Decaisne, J. Le jardin fruitier du Muséum, I: $39 . \quad$ I 858.

33. Carrière, E. A. Étude générale du genre pommier et particulièrement des pommiers microcarpes ou pommiers d'ornement. I883.

34. Barry, P. The fruit garden. I 852 and I 889.

35. Sturtevant, E. L. Seedless fruits. Mem. Torrey Club I: I4I-I 85 . I 890 .

36. Bessey, C. E. The botany of the apple tree. Ann. Rep. Nebraska State Hort. Soc. I 894 .

37. Strasburger, E., Noel, F., Schenck, H., \& Schimper, A. F. W. A textbook of botany, 563-564. I 903 [Eng. trans.].

38. Strasburger, E., \& Hillhouse, W. Handbook of practical botany. 425. I9I I [ed. 7].

39. Van Tieghem, P. Traité de botanique, 34 and I663. I 891 [ed. 2.] 40. Sorauer, P. A popular treatise on the physiology of plants. I895 [Eng. trans.].

4I. Jost, L. Plant physiology, 26I. I907 [Eng. trans.].

42. Sachs, J. v. Physiology of plants, 467. I 887 [Eng. trans.].

43. Pfeffer, W. Physiology of plants, 2: Io. I903 [Eng. trans.].

44. Vines, S. H. A students' textbook of botany, I7 and 495. I 896.

45. Miller, P. The gardener's and botanist's dictionary. I 807 .

46. McAlpine, D. The fibro-vascular system of the apple (pome) and its functions. Proc. Linn. Soc. New South Wales 36: 6I3-625. I9I I.

47. McAlpine, D. The fibro-vascular system of the pear (pome). Proc. Linn. Soc. New South Wales 36: 656-663. I9I I.

\section{Description of plates $33-40$}

\section{Plate 33}

I. Shoot with two short lateral branches. The terminal buds are leaf buds. A typical axillary bud is present.

2. Three-year-old shoot, the axis of which has ceased to elongate owing to the development of a flower bud the second year. A strong lateral shoot has grown out of the "purse" and a weaker one from the three-year-old wood. The terminal buds and axillary bud are leaf buds.

3. Shoot with a terminal flower bud.

4. Nine-year-old fruit spur bearing three-year-old branches. The scars from the pedicels of the fruit may be seen upon the "purses."

5. Four-year-old fruit spur.

6. A fruit bud is shown upon one year's growth, the beginning of a typical fruit spur.

7. So-called axillary flower bud. In the specimen figured the flowers were few in number and lacked vigor, developing late.

8. Typical apple inflorescence. 


\section{$5+6$ MENOIRS OF TIE NEW YORK BOTANICAL GARDEN}

9. Diagrammatic longitudinal section of the fruit, showing the vascular system. (a) The unused portion of the axis of the flower, $(b)$ the exocarp and mesocarp of the carpel, (c) the pith, $(d)$ the cortex.

IO. Diagrammatic cross section of the fruit, lettering as in FIGURE 9. The rows of small fibro-vascular bundles surrounding the carpels on their outer faces form the boundary line between carpellary and torus tissue. The primary fibro-vascular bundles occur in two circles of five each. The bundles of the outermost circle occupy positions opposite the carpels, thase on the inner circle positions between the carpels.

\section{P'LATE $3+$}

I. A slightly irregular inflorescence showing the distinction between a pedicel and a peduncle which in this case is a partial peduncle.

2. A series of lud scales from a leaf bud showing the petiolar origin of the scale. $a$, Outermost scale to innermost scalc, $h$.

3. A series of lucl scales from a flower bud. $a$, Outermost scale to innermost scale, $h$.

4. Individual flowers of an inflorescence with the leaves or bracts which subtend them. $a$, Oldest llower to youngest flower, e.

5. A cluster of mummicl fruits. The peduncle is becoming separated from the stem which bore it.

6. The cluster shown in FIGURE 5 removel. The inflorescence is abjointed as a whole by the common tissue, the peduncle.

7. Diagrammatic drawing of an inflorescence. The dotted line is the axis of the inflorescence or peduncle from which arise the pedicelled flowers.

\section{Plate 35}

I. Longitudinal section through the apex of the leaf bud with the same general structure as the fruit bud.

2. Longitudinal section of the growing apex of a flower bud. The pith is crowned by the layer of meristematic tissue.

3. Longitudinal section of a young flower with the calyx well developed and the primorlia of the petals and stamens established.

4. Longitudinal section, showing the primordia of all parts present. The pistils are the last organs developerl.

5. Longitudinal section of two young flowers, showing the ovarian cavity in two carpels and the unused central portion of the axis.

6. Longitudinal section of a flower. This section shows clearly how the torus becomes hullowed as the successive circles of the flower parts develop. The unused portion of the apex of the axis is shown. The ovarian cavity is seen in two carpels.

7. A little later stage than the preceding. The styles have developed and extend slightly alsove the torus. A primary vascular strand is shown on either side, supplying the sepal!s, petals, and stamens.

\section{Plate 36}

I. Longitudinal section of a flower, showing petals arching over the stamens. The well-developerl anthers and young ovule primordia are shown. The unused portion of the axis is conspicuous.

2. Longiturlinal section of a flower just before expanding.

3. Cross section of a young anther, showing the differentiation of the sporogenous tissus:

4. Cross sertion of a young anther. The print at which dehiscence will occur is clearly indicatted between the pollen sacs. 


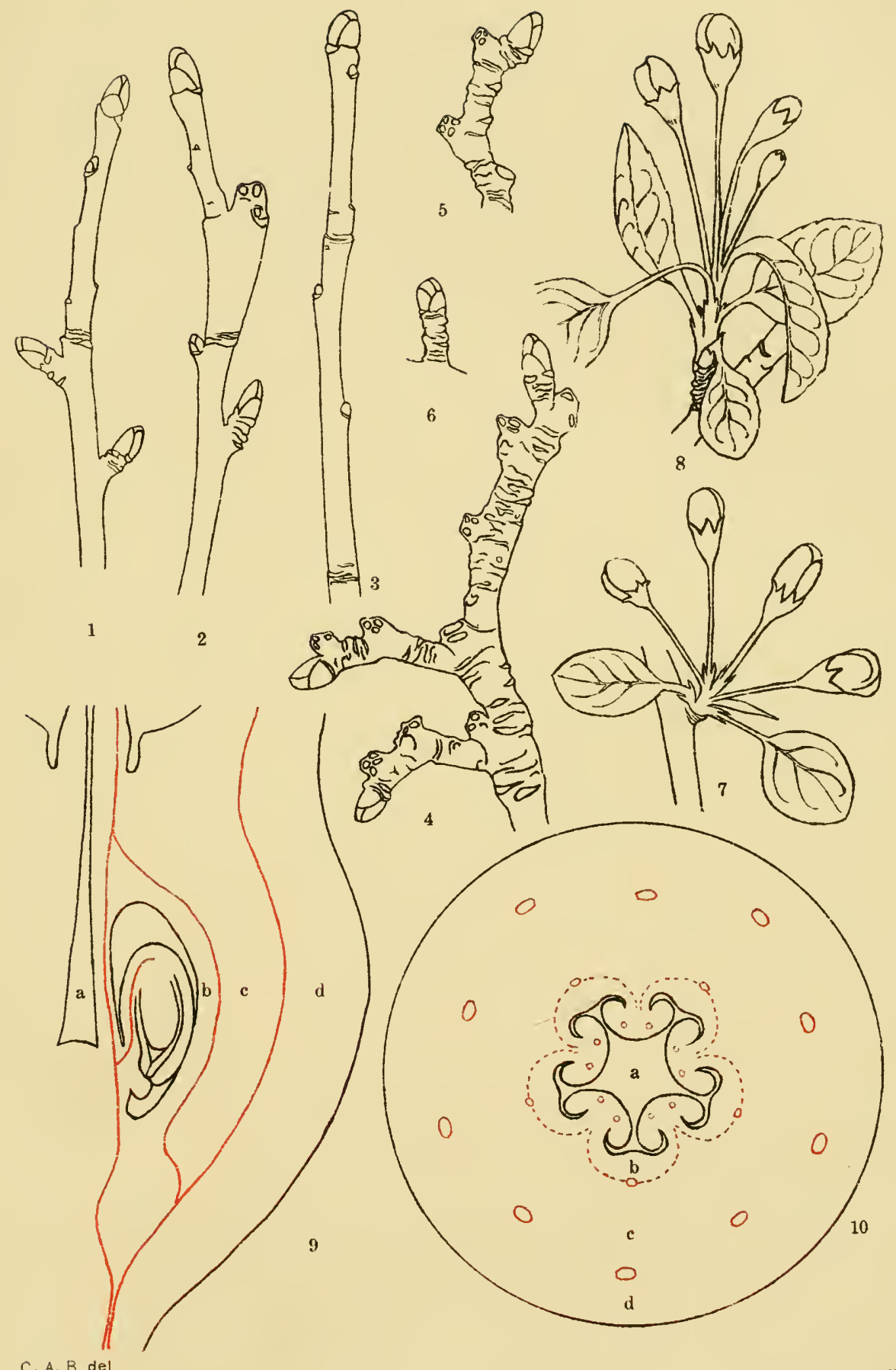




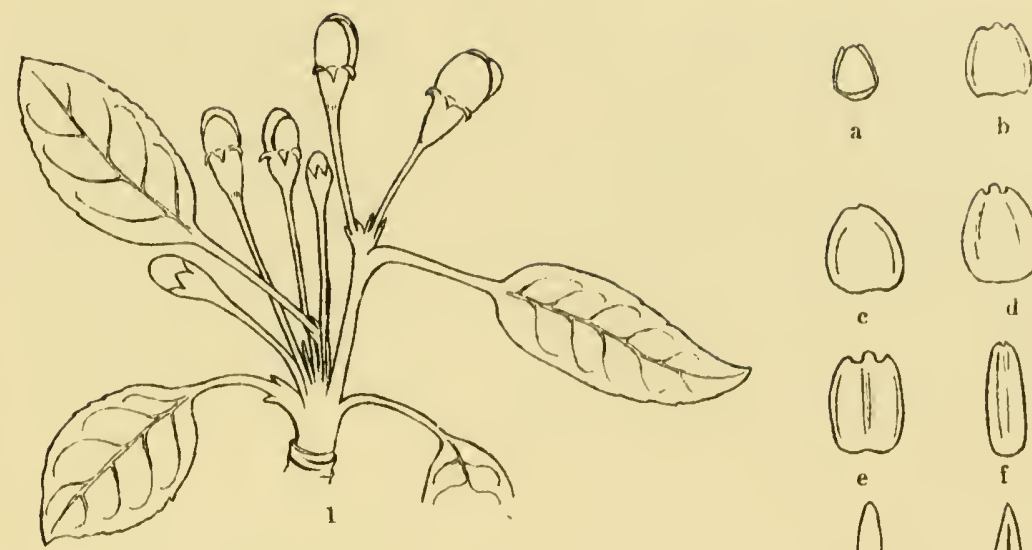

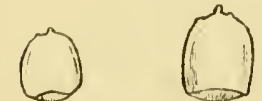

b)

a

$(1$

e

$\sqrt{3}$

a

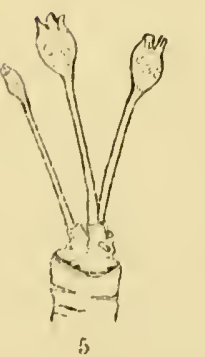

C A. B del

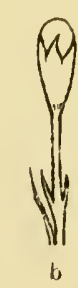

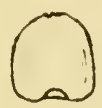

c
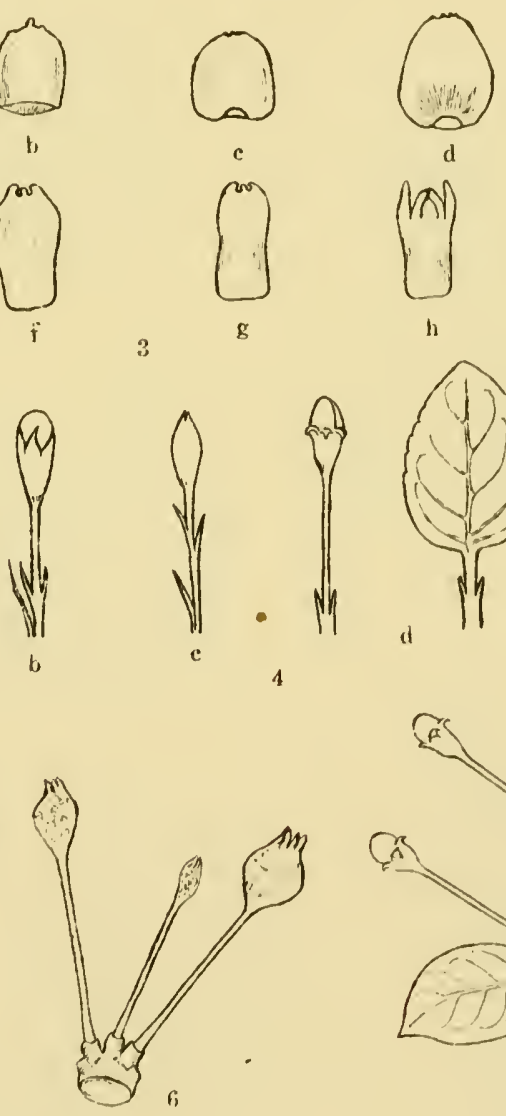

d

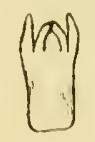

h
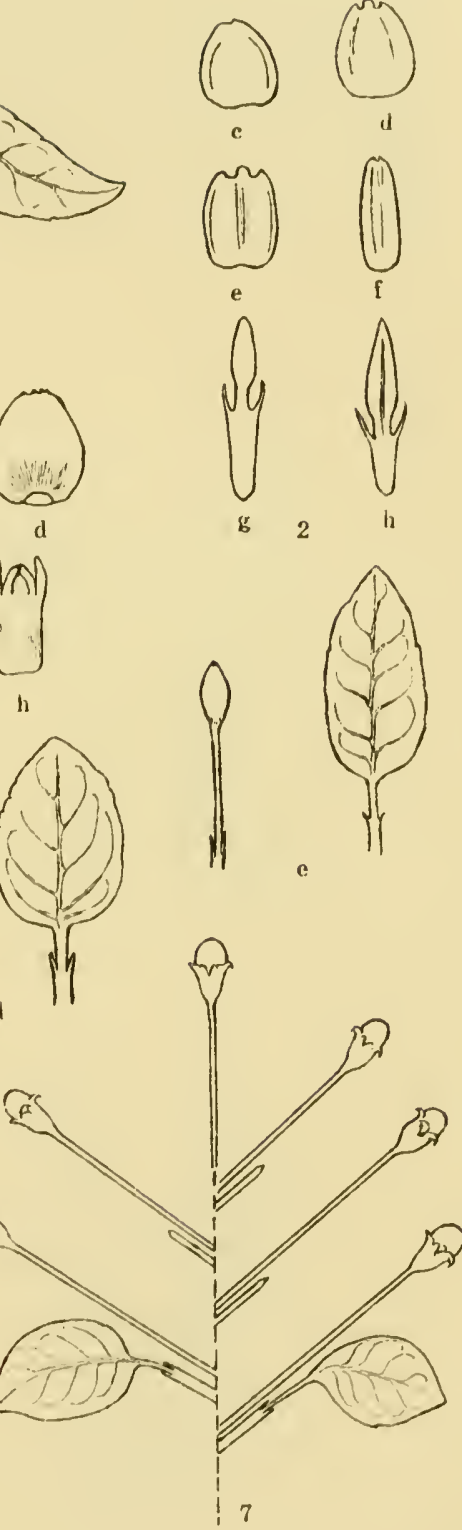

BHACK: PyrUS MALUS 


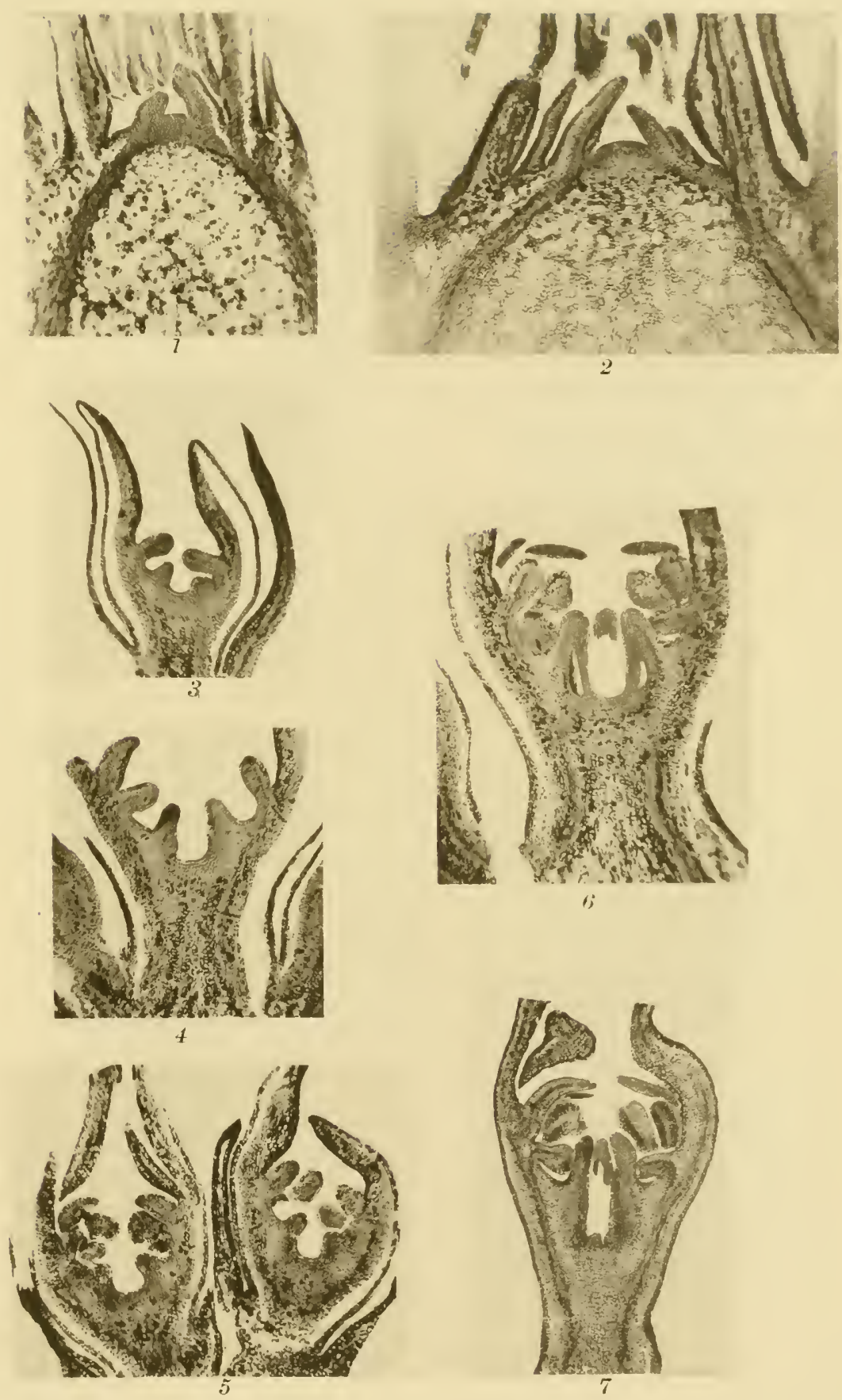


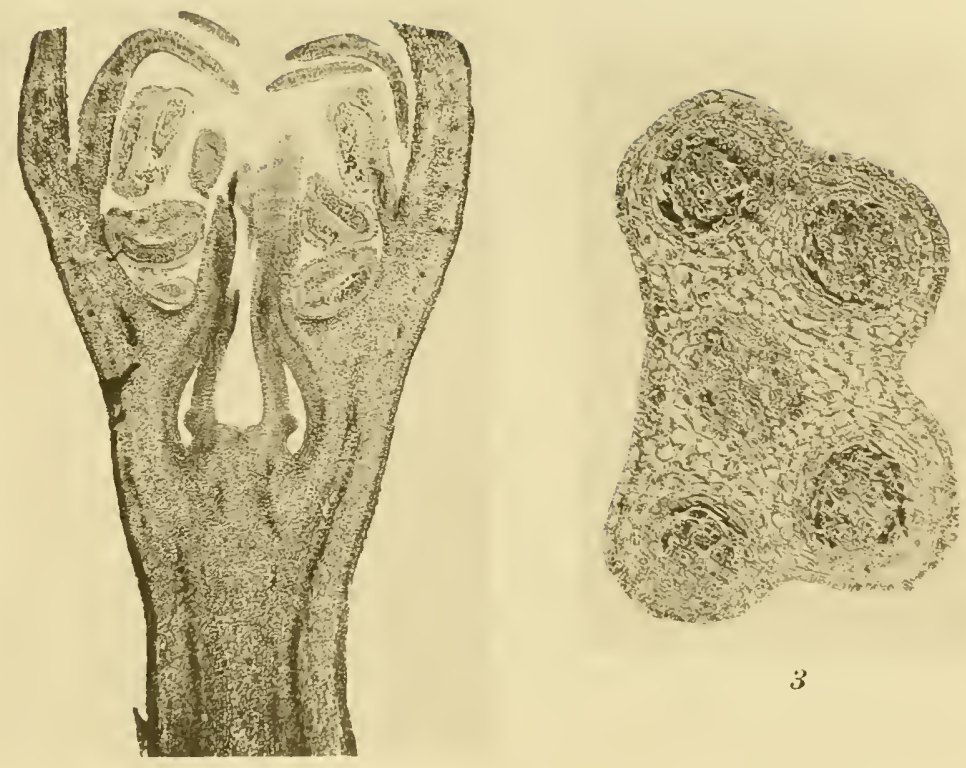

3

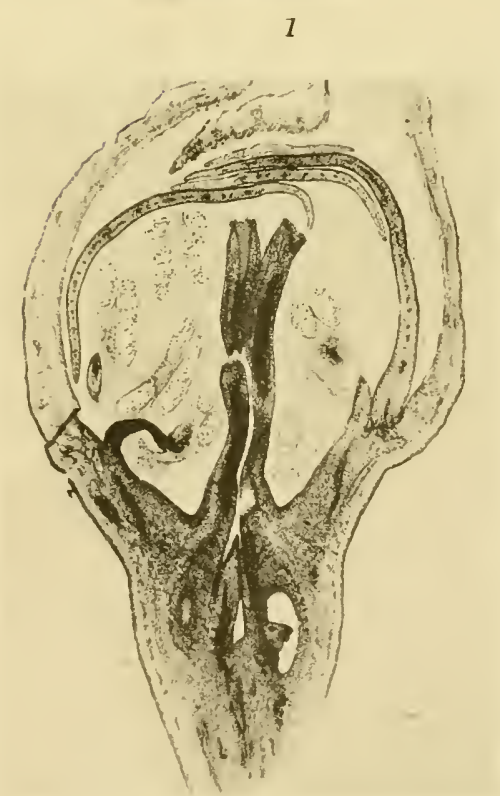

2

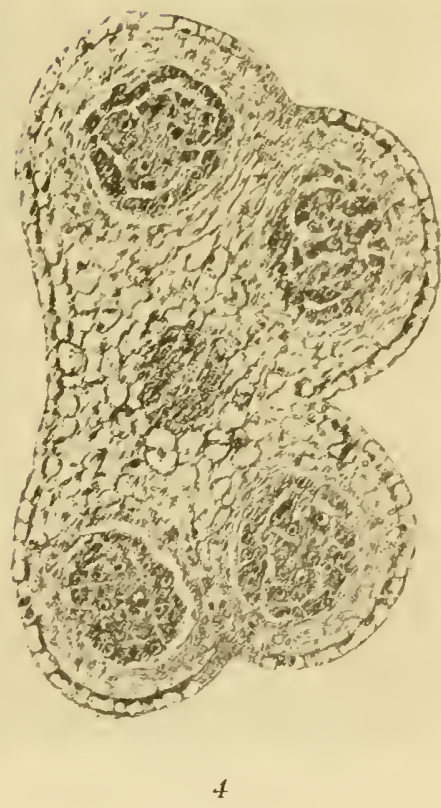

HELIOTYPE CO., BOSTCN

Black: Pyrus Malus 


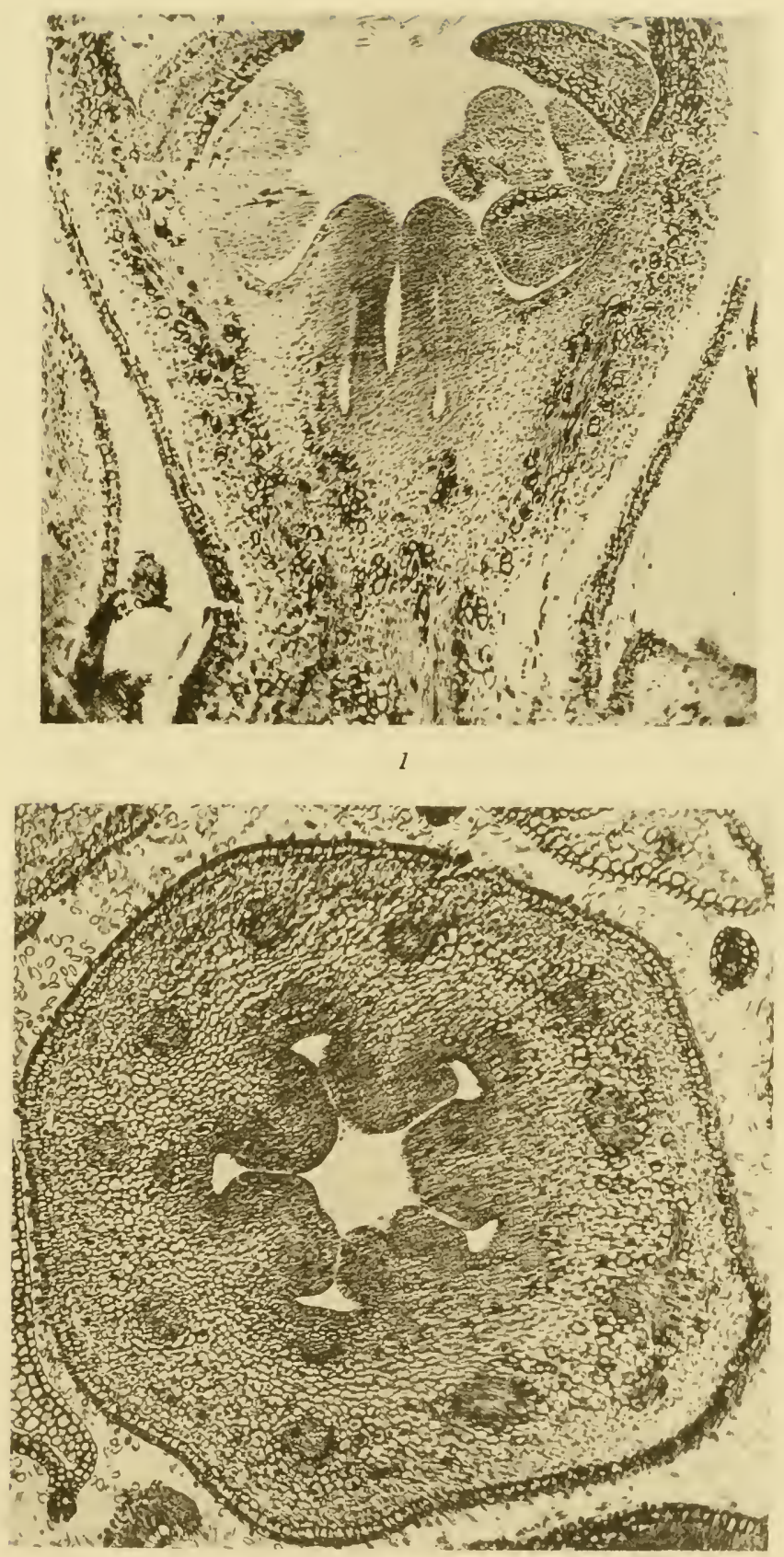


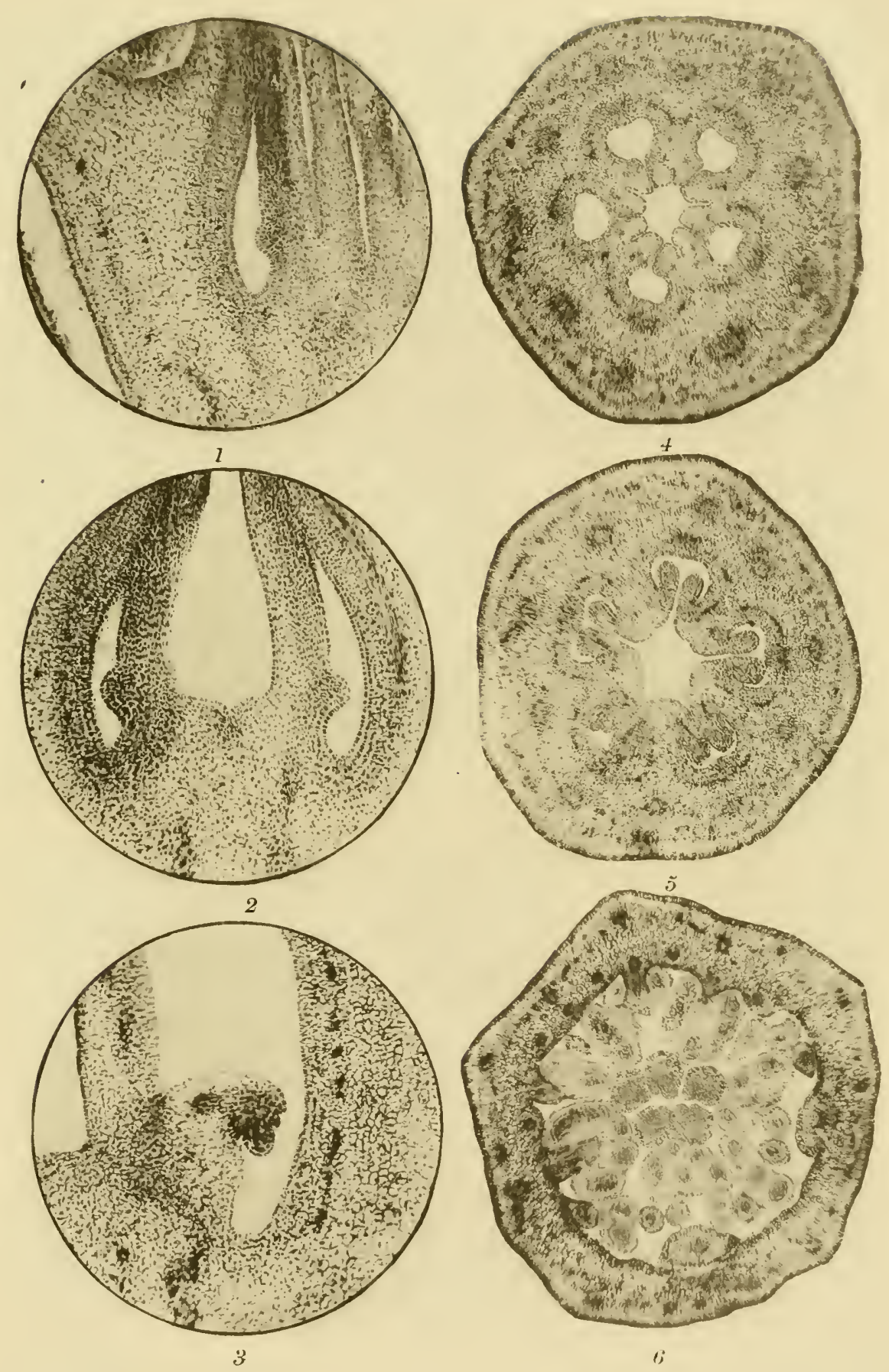

C. A. B. photo 



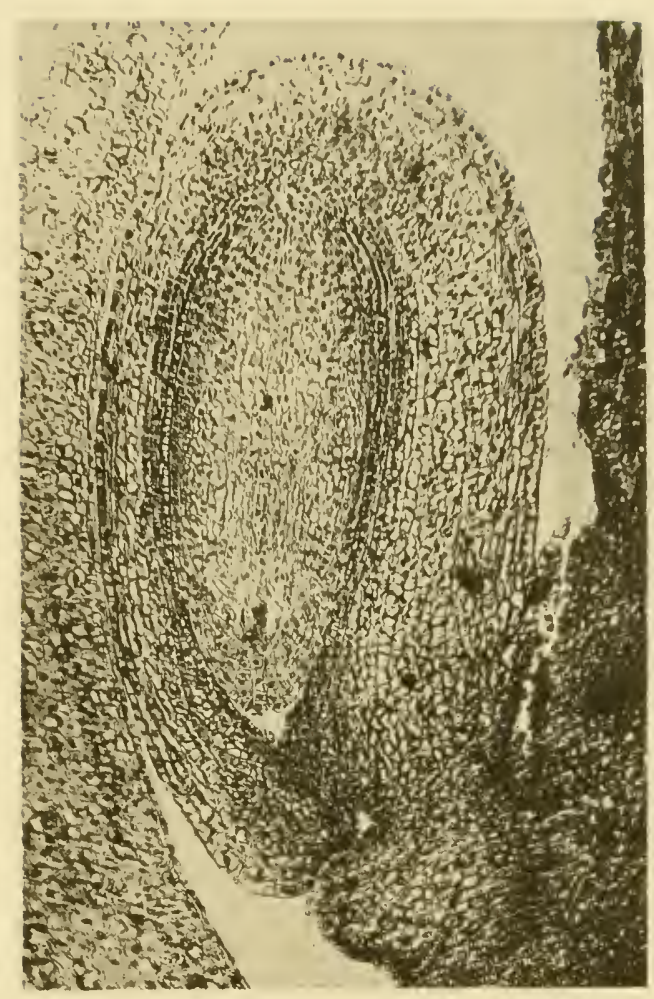

1

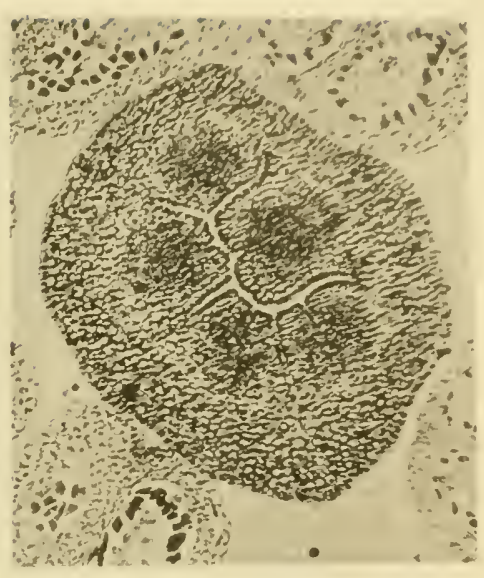

3

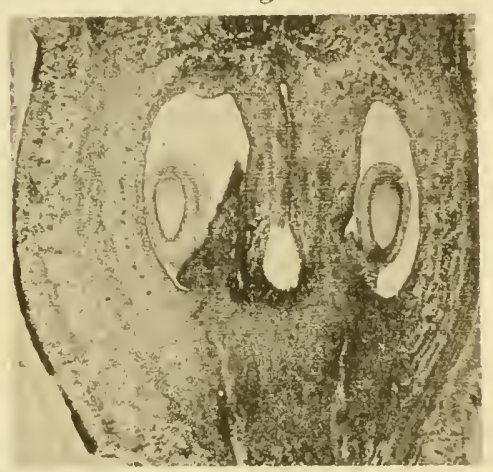

4

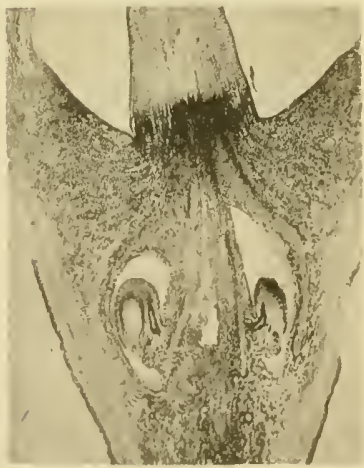

j

HELIOTYFE CO. BOSTON

Bhack: Pyrus Maleis 


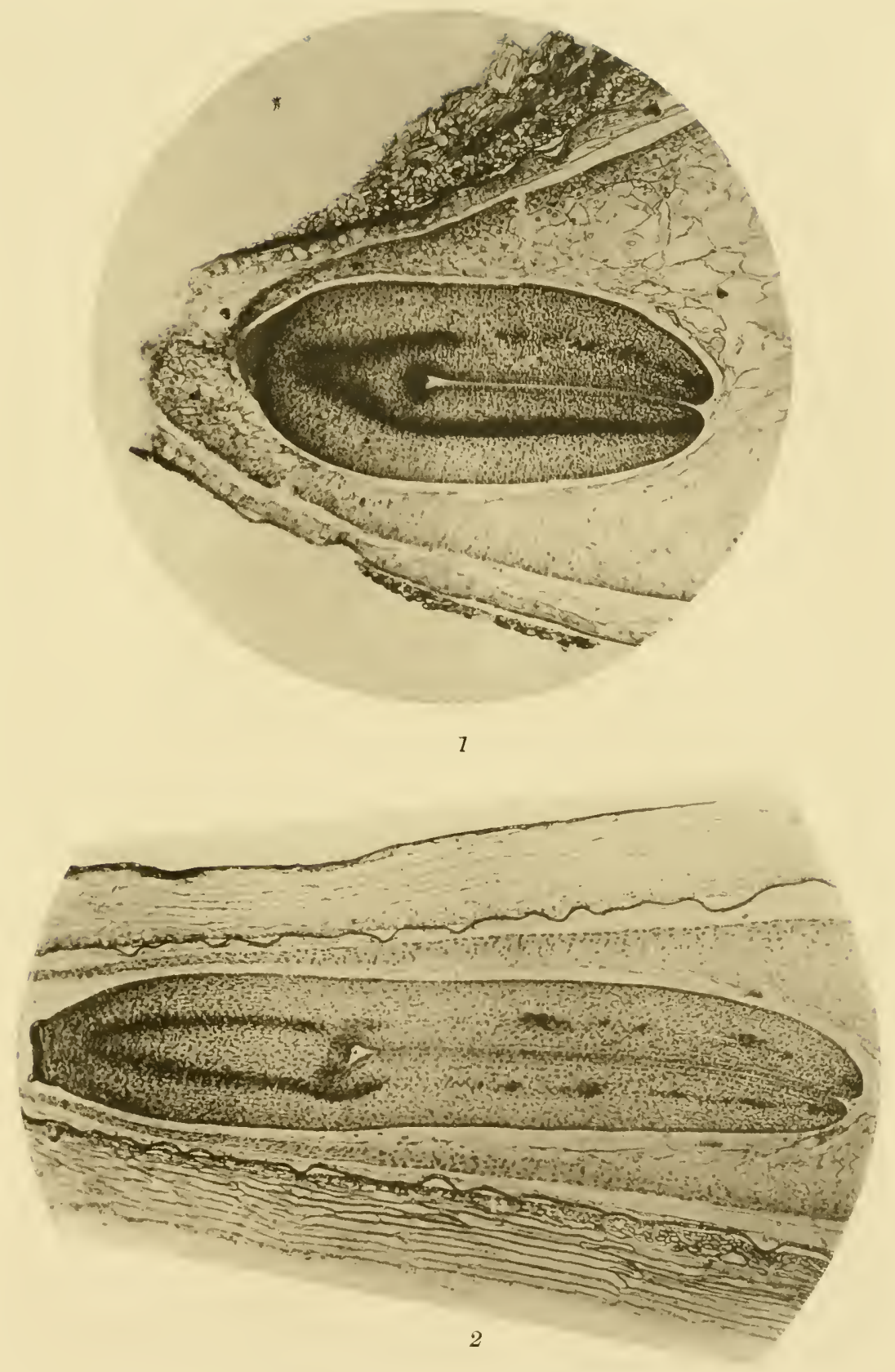

C. A. B. photo

HELIOTYPE CO., BOSTON

Black: Pyrus Malus 



\section{Plate 37}

I. Longitudinal section of a young flower, showing the sepals, petals, and stamens elevated above the carpels which are embedded in the torus. The ovarian cavities are indicated.

2. Cross section of a young flower showing the five carpels and the ovarian cavity in each formed by the infolding of the edges of the carpel. The small dense cells demark the carpellary tissue from the tissue of the torus. The ten primary vascular strands are found in the latter.

$$
\text { Plate } 38
$$

1. Longitudinal section of a young flower, showing the origin of the ovule.

2. Median longitudinal section, showing the unused portion of the apex of the axis of the flower with a developing carpel on either side of it.

3. Longitudinal section, showing the anatropous ovule and the inner and outer integuments.

4. Cross section of a young fruit. The demarcation of the carpels is shown by the outline of small vascular strands around each one. A slight indentation is present in the common tissue between two carpels in which the ventral vascular strands lie em. bedded. The dorsal strand of each carpel is also shown as well as the ten primary strands demarking the pith and cortex regions.

5. Cross section similar to FIGURE 4, but showing two ovules in each ovary.

6. Cross section of fruit, showing the position of the parts above the torus. The five styles are free.

\section{Plate 39}

I. Longitudinal section of a mature ovule, showing the integuments, nucellus and embryo-sac. The obturator is the projection just below the ovule.

2. Longitudinal section of a fruit approximately $3 / 8$ inch in diameter. The great increase in the torus is marked. The cortex contains fibro-vascular bundles, the pith is free from them.

3. Cross section of fruit, showing the union of the styles to the tissue of the torus.

4. Longitudinal section of the fruit, showing the unused portion of the end of the axis of the flower and the prolongation into the fruit of the pith tissue of the stem.

5. Longitudinal section of young fruit, showing one ovule cut in position. The obturator is prominent.

\section{Plate $4^{\circ}$}

I. Longitudinal section of a young embryo in the micropylar end of the ovule. The endosperm tissue is well developed.

2. Longitudinal section of an older embryo than shown in FIGURE I. The embryo is elongated, straight, and shows a well-developed vascular system. The formation of the seed coat is well advanced. 



\title{
A CONTRIBUTION TO OUR KNOWLEDGE OF SILVER SCURF (SPONDYLOCLADIUM ATRO- VIRENS HARZ) OF THE WHITE POTATO
}

\author{
J. J. Taubenhaus \\ Texas Agricultural Experiment Station ${ }^{1}$ \\ (IVITH PLATES 4I-43)
}

The white potato is one of the staple foods in the United States. With the increased cost of living, it is natural that more interest should be directed to investigations of the diseases of that important crop. Silver scurf is a trouble which of late years has attracted considerable attention from American plant pathologists. Although much has been written, scientific data on the nature of the disease as well as on the taxonomic relationship of the causative organism are still wanting. The present paper is the result of two years' investigation carried on at the Laboratory of Plant Pathology of the Delaware Agricultural Experiment Station.

Historical.-Harz (2), in I87 I, was the first to describe the fungus Spondylocladium atrovirens, without, however, suspecting it to be the cause of silver scurf. In I 897 , Frank (5) described a spot disease of the white potato, which he attributed to a new fungus, Phellomyces sclerotiophorts Frank. The same disease, which was fully described a year later (6), is now known to American pathologists as silver scurf. In r903, Johnson (9) called attention to Frank's Phellomyces disease as being serious in Ireland, and causing there a scab and dry rot of the tubers. That Johnson was dealing with what we now know as silver scurf is certain. However, it is difficult to account for his naming the disease a "scab," unless the material with which he dealt was scabby.

From I 897 to I904, nothing new was added to our knowledge of silver scurf. However in 1905-1907, Appel and Laubert (10) and (11), in their work on silver scurf claimed that the sclerotia of the fungus Phellomyces sclerotiophorus are merely the stromata of

\footnotetext{
${ }^{1}$ Of the staff of the Delaware Agricultural Experiment Station at the time of the presentation of this paper.
} 
the fungus fruitings of Spondylocladium atrovirens. This view is accepted by Clinton (12), Eichinger (13), Massee (14, 16), Bohutinsky (17), Erikson (19), Orton (21), Melhus (22), Bailey (23), O' Gara $(24,25)$, and others. As we shall soon show, the results presented in this paper are at variance with the views presented above.

PRESENT WORK.-In this investigation the writer wished to determine definitely, (I) The true relationship of the sclerotia of the fungus Phellomyces sclerotiophorus Frank with Spondylocladium atrovirens Harz. (2) The pathogenicity of $S$. atrovirens as determined by pure culture inoculations. To settle I and 2 , it was necessary to grow the organism in pure culture. Of all the writers here quoted, Johnson (9) is the only one who claims to have grown it on artificial media, as he says, "Under artificial culture (gelatin, agar and potato) I have found that the sclerotia are readily produced, but up to the present time, neither in nature nor by culture, has any typical fungal fructification been observed." As will be shown later, Johnson was not dealing with S. atrovirens. Appel and Laubert (10) do not report having grown the organism on artificial media. They obtained the fructification of $S$. atrovirens by placing affected tubers under moist conditions. They decided this fungus to be the fruiting stage of Phellomyces sclerotiophorus. The conclusion for this relationship was drawn from the fairly constant presence of the sclerotia of $P$. sclerotiophorus on spots of potatoes affected with silver scurf.

In the fall of I9I3, the writer collected a large quantity of tubers which showed typical silver scurf (FIG. I). The spots on each tuber were carefully examined with a hand lens. These tubers were all fresh and recently harvested. The sclerotia of Phellomyces sclerotiophorus were present on 99 per cent of the silver scurf spots. The remainder of the spots did not show any sclerotia, and none of the spots in all the material showed any fruitings of Spondylocladium atrovirens. A few of the infected tubers were placed in moist chambers, while the remainder of the material was used for cultural work. The method of isolation was as follows: The tubers were first washed and cleaned in the usual way. With a sharp knife, pieces of the spots were cut out, one fourth of an inch deep. These pieces were then dropped in a test tulx, sterilized for one minute in a solution of $\mathrm{I}-\mathrm{I}, \mathrm{OoO}$ (alcohol 
50 per cent.) mercuric bichloride, then rinsed five times in sterile water to wash off all traces of the disinfectant. Tubes with agar medium were liquefied and cooled down to the proper temperature. With a flamed and cooled scalpel, a piece of the potato material was placed at the mouth of the tube and thoroughly crushed, and then shaken up with the medium. The content of the tube was poured into a petri dish and allowed to cool. The first series of cultures consisted of some fifty plates; the spots cultured in this case all showed sclerotia of Phellomyces sclerotiophorus but not the fruitings of Spondylocladium atrovirens. In four to five days, all the plates showed a sclerotium-producing fungus, together with a species of Fusarium. In some plates the latter predominated, while in others the sclerotium-producing fungus predominated (FIG. 3). These two organisms were transferred pure, to slants on agar medium. More isolations were made to the extent of crushing 800 different spots of silver scurf and culturing in the same number of plates. Of the spots selected in this case, 80 per cent showed sclerotia in varying number, while the remainder were free from it, free in so far as that none could be seen with a hand lens. In all the plates, with but one exception, the sclerotium-producing fungus, together with the species of Fusarium, appeared after four days. From these results, it appeared that the sclerotium-producing fungus, that is, Phellomyces sclerotiophorus was the predominating stage in silver scurf, and that the fruitings of Spondylocladium atrovirens appeared very rarely or under certain cultural conditions, yet to be determined. None of the plates were discarded at once. In many instances, either the Fusarium colonies or Phellomyces were so numerous that they overran the plate, thus giving no chance for slower growing organisms to appear. Fifty per cent of such plates were discarded and the remainder kept for further observation. After about two weeks, other minute fungus colonies appeared in about one per cent of the plates (FIGS. 4 and 5). In the one petri dish where no growth had previously appeared, there now showed the same minute furgus colonies practically pure. These plates were watched and transfers made on slants of agar. In five to six days the fungus under observation produced the typical fruitings of Spondylocladium atrovirens. Pure cultures (FIG. 6) were now easily obtained of this fungus, as well as of Phellomyces sclerotio- 
phorus. It was at once evident and certain that they were distinct fungi. Although the spore measurements varied considerably when the fungus was grown on different media, yet, on the whole, it agreed well with Spondylocladium atrovirens Harz. Careful studies of the fungus Phellomy'ces sclerotiophorus revealed some very interesting things. It was found that while the fungus produced an abundance of sclerotia which are plainly visible to the naked eye, yet under the microscope they are seen to be provided with setae (FIG. I9). These setae were first thought to be abortive conidiophores of Spondylocladium atrovirens. However, further studies showed hyaline one-celled spores, sparingly formed, in typical acervuli but not on the sclerotia (FIGS. 20 and 2I). This would place the fungus in the genus Colletotrichum.

It may be contended that the fungus Phellomyces sclerotiophorus was not pure and that in our culture it was merely contaminated. In order to settle this, dilution cultures of the spores were made. In three to eight days, typical colonies of the Colletotrichum sclerotium-producing fungus appeared (FIGS. 7 and 9). In manner of growth, these isolation colonies were identical with the sclerotiumproducing fungus obtained from the spots of silver scurf of the white potato (FIGS. 8 and Io). Cultural work carried out in the fall of I9I4 and I9I 5 duplicated the results obtained the previous year. This proved conclusively that Spondylocladium atrovirens was in no way connected with Phellomyces sclerotiophorus, and that the genus Phellomyces was not valid. Recently O'Gara (25) described a new species of Colletotrichum which he isolated from portions of underground stems of the white potato, and which he named C. solanicolum O'Gara. Dr. O'Gara was kind enough to send me a pure culture of his new Colletotrichum as well as sectioned and stained slides of the fungus, as it appears natural on the host and in pure culture. The writer observed at once the resemblance of Dr. O'Gara's Colletotrichum to the Colletotrichum-like fungus isolated from silver scurf spots. Cultures of our strain were submitted to Dr. O'Gara, who pronounced it the same or similar to his new Colletotrichum solanicolum. .

It will be remembered that Frank (5), in describing Phellomyces sclerotiophorus dicl not carry out pure cultures of his new genus and species. It should further be added that the sclerotia on the living host often fail to produce setae, and that in pure culture 
the former are either abortive, imperfectly developed, or not very abundant. It will be readily seen, therefore, why Frank was led to create the new genus Phellomyces, and overlooked its resemblance or relationship to the genus Colletotrichum. Moreover, Frank's Phellomyces is not a sterile fungus, since it produces Colletotrichum-like spores. Hence, the genus Phellomyces is not valid.

Recently the writer (20) described the charcoal rot of sweet potatoes, which is attributed to the fungus Sclerotium bataticola Taub. This organism greatly "resembles Phellomyces. However, it produces neither setae nor spores but sclerotia only. Hence the writer placed this fungus in the genus Sclerotium. It matters little whether sclerotia are minute or large, free or buried in the tissue; as long as they are sterile bodies, they should be placed in the genus Sclerotium. In such cases, the less genera we have, the better. It is evident then, that the Phellomyces of Frank, which is found associated with silver scurf, is a Colletotrichum. It is probably also the same fungus as Vermicularia atramentaria Berk. \& Br. (1). Halsted, (3) in I894, while working on a stem blight of the white potato, met with this fungus; he says: "The fungus in question seems to be Vermicularia atramentaria Berk. $\&$ Br., but the amount it has to do with causing the destruction of the crop is an open question." The species $V$. atramentaria is recognized by Saccardo (8), Rabenhorst (7), and Clements (15). However, the species is poorly described and no measurements of spores are given. Studies were made by the writer, of the various specimens of Vermicularia atramentaria found at the herbarium of the New York Botanical Garden. From these studies, it seemed evident that Vermicularia atramentaria is not a Vermicularia. The bodies which may be taken for pycnidia of Vermicularia seem to be sterile sclerotia; these may be with or without black setae (FIGS. I9-2I). The spores of $V$. atramentaria as stated above, are not borne in the sclerotia, but in typical acervuli with setae near the sclerotia (FIGS. 2 I and 20). Of the collections of Vermicularia atramentaria at the New York Botanical Garden, one specimen is of particular interest. It reads as follows:

"C. Roumegère.-Fungi Gallici exsciccati.

"2968. Vermicularia atramentaria Bk. et Br. Fung.

"n. 430, forma sclerotioides." 
"Après l'expulsion des spores et la chute des soies, le périthèce. (rappelant par sa consistance et son aspect le Sclerotium durum) persiste sur les tiges desséchées du Solanum tuberosum."

"Plomereuc (Seine-Inférieure, Mars I884)."

$$
\text { "Abié Letendre." }
$$

From our own studies and as already stated, what is taken for pycnidia are only sterile sclerotia, since studies made of these pycnidia at different stages of development in pure culture and on the host proved them to be sterile bodies. The fungus therefore is perhaps an intermediate form between Vermicularia and Colletotrichum, although it fits in better in the latter. There are no described species of Colletotrichum which are known to produce sclerotia. However, there seems no doubt but that many of the species of Vermicularia, upon culturing, would show characteristics of the former genus.

It seems evident that Phellomyces sclerotiophorus Frank is the same as Vermicularia atramentaria Berk. \& Br. and also the same as Colletotrichum solanicolum O'Gara. However, in following the rule of priority, the fungus becomes Colletotrichum atramentarium (Berk. \& Br.) Taubenhaus. Syn. Vermicularia atramentaria Berk. \& Br., I850; Phellomyces sclerotiophorus Frank, 1897 ; Colletotrichum solanicolum O'Gara, I9I5. The fungus needs no further description, as it has been fully described by O'Gara. However, it should be added that the spore measurements as given by him $\left(3 \cdot 5^{-5} \mu \times 17 \mu\right)$ are found to be much more variable in length (FIGS. 24 and 25 ).

The fungus Colletotrichum atramentarium does in no way resemble Periola tomentosa Fr. occurring on dead potato vines in Europe. Further studies of this genus will show that it is probably invalid.

Pathogenicity.- It has already been pointed out that in culturing silver scurf spots, the great majority of the plates yiclded the fungus Colletotrichum atramentarium (FIG. 3). One would therefore be tempted to suppose that the latter fungus was the cause of silver scurf. Moreover, no previous workers reported infection with spores of pure cultures of Spondylocladium atrovirens. Appel and Laubert (11) in their infection experiments merely used spores of this organism obtained from infected tubers which were kept in a noist chamber. These spores were diluted 
in water and the liquid used for inoculation. In order to determine definitely the pathogenicity of Spondylocladium atrovirens, spores from a pure culture of the latter were suspended in sterile water and sprayed on healthy white potatoes. Before inoculation these tubers were washed and disinfected for ten minutes in a solution of 5 parts of formaldehyde in 95 of water. They were then kept two weeks in sterile moist chambers to see if any disease would appear. In making microscopic mounts twenty-four hours after infection, the spores of Spondylocladium atrovirens were seen to germinate (FIGS. 27, 28, and 29) and to break through the epidermis (FIG. 26). This agrees with the observations of Appel and Laubert (11). In about two to four weeks, typical spots of silver scurf appeared. This was repeated several times with the same results. The symptoms of the artificial infection were identical with those seen in nature, with the exception, however, that the sclerotia of Colletotrichum atramentarium were absent.

A series of inoculations was also carried out with spores from fresh cultures of Colletotrichum atramentarium. At no time did infection appear. Inoculations were also made by inserting bits of mycelium and sclerotia of the above fungus into slits made in the epidermis of the tuber. In no case did infection appear. This clearly shows that Spondylocladium atrovirens Harz and not Colletotrichum atramentarium (Berk. \& Br.) Taub. is the cause of silver scurf. Nevertheless, and as previously pointed out, Frank (6) and Johnson (9) recognize a form of dry rot due to Colletotrichum atramentarium. The writer agrees with Appel and Laubert (11) that the dry rot of Frank and of Johnson above mentioned was probably caused by another organism, perhaps Fusarium. It has already been pointed out that Halsted (3) did not consider Colletotrichum atramentarium, to be the cause of the stem wilt of white potatoes which he studied. Stewart (4) in working with an apparently similar stem blight of potatoes attributes the probable cause to Oospora rosea (Preuss.) Sacc. \& Vogel, or to Melanospora ornata Zukal. Stewart could not find the association of Colletotrichum atramentarium with his stem blight, as previously noted by Halsted. It is very probable that both Halsted and Stewart were then dealing with a stem blight caused by some species of Fusarium. Dr. Manns ${ }^{1}(18)$ in his work

\footnotetext{
${ }^{1}$ Dr. Manns has pronounced his Vermicularia identical with Colletotrichum atramentarium (Berk. \& Br.) Taub.
} 
on dry rot of the white potato has also met with the fungus Colletotrichum atramentarium, as he says: "It is common to find associated with the Fusarium and likewise penetrating the tuber, sometimes to a depth of one-fourth to one-half inch, a fungus of the genus Vermicularia... The Vermicularia was present to an extent of 10.3 per cent, .... When used alone it brings about no disease symptoms. If it assists any in bringing about the disease, its work is that of a semi-parasite which follows the openings made by Fusarium." It is very probable that Frank (6) and Johnson (9) originally dealt with the dry rot caused by several Fusaria, which were obscured and overrun by Colletotrichum atramentarium. The probability of the latter fungus being a saprophyte is also admitted by O'Gara, ${ }^{1}$ who writes: "I do not think that the Colletotrichum is a very active parasite." It is safe to assume that Colletotrichum atramentarium is a common saprophytic soil organism. The writer has found it time and again on dead and dying stems of white potato, especially if the hills were fully mature. It is noteworthy to add that on dead stems the sclerotia are larger than they are when found following the silver scurf fungus (Spondylocladium atrovirens) or on partly dying potato vines. However, when these larger sclerotia are dropped on an agar medium, the resulting growth is identical with Colletotrichum atramentarium. This would seem to indicate that the organism is only at best a semi-parasite under certain climatic conditions, since there must be some element in the living host which is unfavorable to the fungus. It is also interesting to add that the setae of the acervuli are much more abundant in pure culture on an agar medium and on steamed potato vines than they are found in nature. When found accompanying the silver scurf fungus, the setae are almost wanting. Species of Colletotrichum, as a rule, are not known to produce sclerotia, nor to reproduce by means of such bodies. Colletotrichum atramentarium, however, is an exception, since, in the former, the sclerotia seem even to be a more important phase of reproduction than are the spores; the latter are formerl only in young cultures and very sparingly on the host. As the organism increases in age, spore formation in pure culture is dispensed with, and an abundance of sclerotia with or without setae are formed in layers of concentric

\footnotetext{
${ }^{1}$ Correspondence dated August 17, 1915.
} 
zones (FIGS. 9 and Io). The organism too, is a vigorous grower, compared to Spondylocladium atrovirens, the latter of which forms small colonies which are seldom larger then one third of an inch in diameter (FIG. 6). Colletotrichum atramentarium will grow and increase in zonation as far as space permits in the petri dish (FIGS. 9 and IO).

HOW SILVER SCURF IS CARRIED OVER.--Silver scurf is carried with the seed and with the soil. To prove this, a number of tubers which were infected with silver scurf were planted in a clean soil in the greenhouse. In another lot, a pure culture of the fungus Spondylocladium atrovirens Harz was mixed with clean soil, and healthy disinfected tubers planted therein. Healthy and disinfected tubers were also planted in clean soil to serve as checks. The plants in all the lots grew well, and in four months mature hills of potatoes were formed in each lot. The results showed that the lot infected with a pure culture of S. atrovirens produced Ioo per cent diseased tubers. Where infected seeds were used, the new tubers showed 60 per cent infection. All the checks were free from the disease. A second crop of potatoes was grown on the same plots. In this case, however, only healthy disinfected seeds were planted. At the end of the experiment, the tubers in the check plot were all healthy, while those in the other two plots were infected with silver scurf. This clearly shows that the seed as well as the soil, is a carrier of the disease. There is no doubt but that the fungus Colletotrichum atramentarium, like Spondylocladium atrovirens, is also carried by the above two agencies. In the plot where only infected tubers were planted, Colletotrichum atramentarium was also present on the spots of the new crop as well as on the dying vines.

PATHOLOGICAL MORPHOLOGY.-Silver scurf is only an epidermi disease (FIG. II). At no time has the writer been able to find evidence that the fungus Spondylocladium atrovirens Harz is capable of producing a scab, or a dry rot. Wherever such cases came to our attention, the material was immediately cultured, and the resultant flora was rich in Actinomyces, Fusaria, and other Hyphomycetes, but not with Spondylocladium atrovirens. The same is also true for Colletotrichum atramentarium (FIGS. I2, I9, 20 , and $2 \mathrm{I}$ ), with the exception however, that the latter is capable of entering deep into tubers which have previously rotted by other organisms, such as Fusaria. 


\section{SumMary}

I. It has been proved that Spondylocladium atrovirens Harz is the cause of the disease known as silver scurf.

2. The fungus Phellomyces sclerotiophorus Frank is not in any way connected with Spondylocladium atrovirens Harz.

3. The fungus Phellomyces sclerotiophorus Frank, although very prevalent on the silver scurf spots, is merely a secondary invader.

4. It has been shown that the genus Phellomyces is not valid, since the genus belongs to Colletotrichum.

5. Phellomyces sclerotiophorus Frank is the same as Vermicularia atramentaria Berk. \& Br. and the same as Colletotrichum solanicolum O'Gara.

6. Following the rules of priority Colletotrichum solanicolum O'Gara becomes Colletotrichum atramentarium (Berk. \& Br.) Taub.

7. Colletotrichum atramentarium is apparently a saprophyte or at best, a very weak parasite.

8. Silver scurf is carried with the seed and soil.

9. Silver scurf is only a skin disease.

\section{BIBLIOGRAPHY}

I. Berkeley, M. J., \& Broome, C. E. Notices of British fungi. Ann. and Mag. Nat. Hist. II. 5:378-379. I 850.

2. Harz, C. O. Einige neue Hyphomyceten Berlin's und Vien's nebst Beiträgen zur Systematik derselben. Bull. Soc. Imp. Nat. Moscow 44: I29-I30. I87I.

3. Halsted, B. D. Seventh annual report 352-354. 1894 .

4. Stewart, F. C. Potato diseases on Long Island in the season of 1895. N. Y. (Geneva) Agr. Exp. Sta. Bull. Ior : 83-84. I895.

5. Frank, A. B. Die Fleckenkrankheiten der Kartoffelschale mit dem Phellonyces sclerotiophorus Frank. Kampfbuch gegen die Schädlinge unserer Feldfrüchte I 82-I85. I897. (Berlin.)

6. Frank, B. Die Phellomyces Faule. Ber. Deutsch. Bot. Ges. I6: $280-281.1898$.

7. Allescher, A., in Rabenhorst, L., Krypt. Fl. I ${ }^{6}: 512 . \quad 1901$.

8. Saccardo, P. A. Syll. Finng. 4: 68I.

9. Johnson, T. Phellonyces sclerotiophorus, a cause of potato scab and dry rot. Econ. Proc. Roy. Soc. Dublin I: 16I-I65. 1903.

Iо. Appel, Otto, \& Laubert, R. Die Konidienform cles Kartoffelpilzes, Phellonyces sclerotiophorus Frank. Ber. Deutsch. Bot. Ges. 23: 218-220. I 905 . 
I I. Appel, Otto, \& Laubert, $\dot{\mathrm{R}}$. Die Konidienform und die pathologische Bedeutung des Kartoffelpilzes Phellomyces sclerotiophorus Frank. Arbeit. Kaiserl. Biol. Anst. für Land- und Forstw. 5: 435-44I. 1907.

12. Clinton, G. P. Scurf, Spondylocladium atrovirens Harz. Conn. Agr. Exp. Sta. Ann. Rep. 3I-32: 357-359. I 908.

13. Eichinger, A. Zur Kenntnis einiger Schalenpilze der Kartoffel. Ann. Myc. 7:356-364. I909.

14. Massee, George. Dry scab of potatoes. Spondylocladium atrovirens Harz. Roy. Bot. Gard. Kew. Bull. I: I6-I8. 1909.

I5. Clements, F. E. The genera of fungi, I60. I909.

I6. Massee, George. Diseases of cultivated plants and trees, $478-480$. I9Io (London).

I7. Bohutinsky, G. Beiträge zur Erforschung der Blattrollkrankheit. Zeits. Landw. Versuchsw. in Oesterreich I3: 607-633. I9Io.

I8. Manns, Thos. F. The Fusarium blight and dry rot of the potato. Ohio Agr. Exp. Sta. Bull. 229: 3I5-316. I9I I.

19. Erikson, Jakob. Fungoid diseases of agricultural plants [Tr. from the Swedish by Anna Molander], II2. I9I2 (London).

20. Taubenhaus, J. J. The black rots of the sweet potato. Phytopathology 3: I59-I65. I9I3.

2 I. Orton, W. A. Potato tuber diseases. Farmers' Bull. 544: 3-I6. I9I3.

22. Melhus, I. E. Silver scurf, a disease of the potato. U. S. Dept. Agr. Bur. Pl. Ind. Circ. I27: I5-24. I913.

23. Bailey, F. D. Notes on potato diseases. Phytopathology 4: 32 I322. I9I4.

24. O'Gara, P. J. Occurrence of silver scurf of potatoes in the Salt Lake Valley, Utah. Science II. 4I : I3I-I32. I9I5.

25. O'Gara, P. J. New species of Colletotrichum and Phoma. Mycologia $7: 38-4$ I. I9I5.

\section{Explanation of plates $41-43$}

FIG. I. Spots of silver scurf (Spondylocladium atrovirens Harz) of the white potato.

FIG. 2. Tuber infected with silver scurf, showing shrinkage due to the disease.

FIG. 3. Crush culture of a silver scurf spot of white potato. The resultant is a pure growth of Colletotrichum atramentarium (Berk. \& Br.) Taub. and not Spondylocladium atrovirens Harz, the cause of the disease. S. atrovirens is a slow grower and hence easily overrun by more vigorous saprophytes.

Figs. 4 and 5. Two of the few plates which yielded a culture of Spondylocladium atrovirens from cultured spots of silver scurf. Notice the small colonies of $S$. atrovirens intermingled and overrun with Fusaria and Colletotrichum atramentarium.

FIG. 6. Pure culture of Spondylocladium atrovirens Harz. 
FIG. 7. Pure culture, three day's old, of Colletotrichum atramentarizm isolated from silver scurf spots of white potato.

FIg. 8. Pure culture three days old of Colletotrichum atramentarium obtained from Dr. O'Gara.

Figs. 9 and Io. Colletotrichum atramentarium transfers from FIGS. 7 and 8, showing zonations of sclerotia and the abundance of the latter in pure culture.

FiG, II. Cross-section of a spot of silver scurf of white potato to show relationship of the fungus Spondylocladium atrovirens Harz to the host tissue. Notice the fungus is confined to the epidermis of the tuber.

FIG. I2. Cross-section of a silver scurf spot of a white potato tuber showing sclerotia of Colletotrichum atramentarium (Berk. \& Br.) Taub.

FIG. I3. Conicliophores and conidlia of Colletotrichum atramentarium.

FIGS. I-16. Germinating spores of Colletotrichum atramentarium.

FIGs. I 7 and I 8. Germinating spores of Colletorichum atramentarium, showing formation of appresoria at tip of germ tube.

FIG. 19. Single sclerotium with setae of Colletotrichum atramentarium, showing its relationship to the epidermis of a killed white potato vine.

FIGS. 20 and 21. Sclerotia and ascervuli of Colletotrichum atramentarium on dead potato vines.

FIG. 22. Surface black mycelium of Colletotrichum atramentarizm in pure culture.

FIG. 23. Hyaline deep-growing mycelium of Colletotrichum atramentarium in pure culture.

Figs. 24 and 25. Showing variations in sizes of spores of Colletotrichum atramentarium in pure culture.

FIG. 26. Germinating spore of Spondylocladium atrovirens breaking through the epidermis of the host.

FIGs. 27-29. Germinating spores of Spondylocladium atrovirens Harz. 

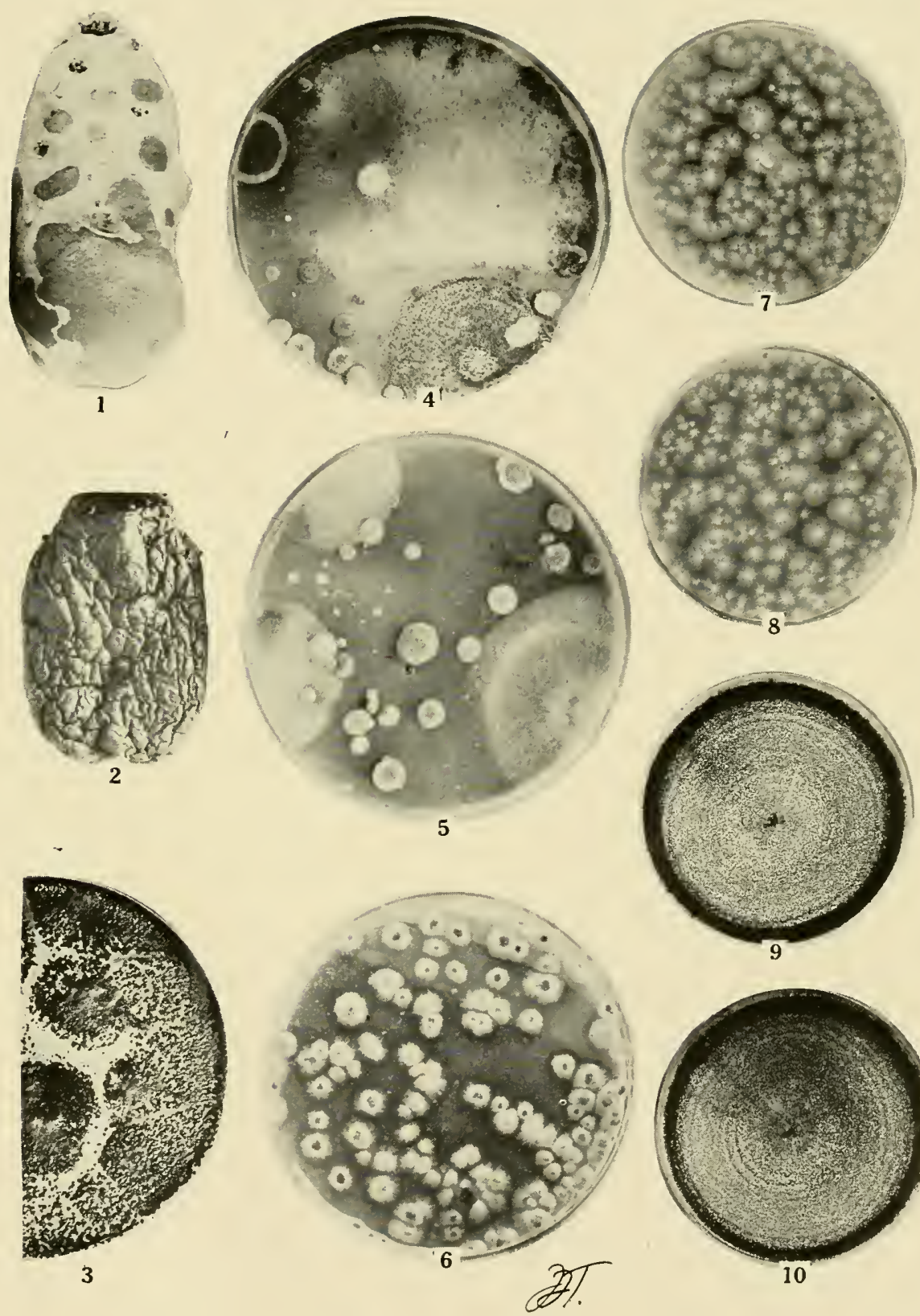

3

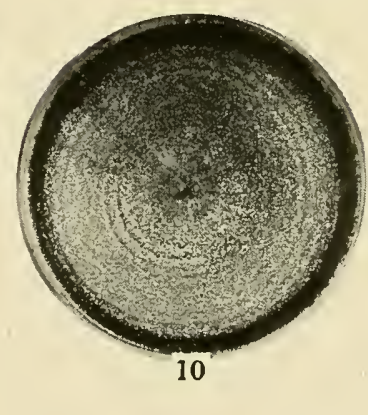

TAUBENHAUS: SILVER SCURF OF THE WHITE POTATO 



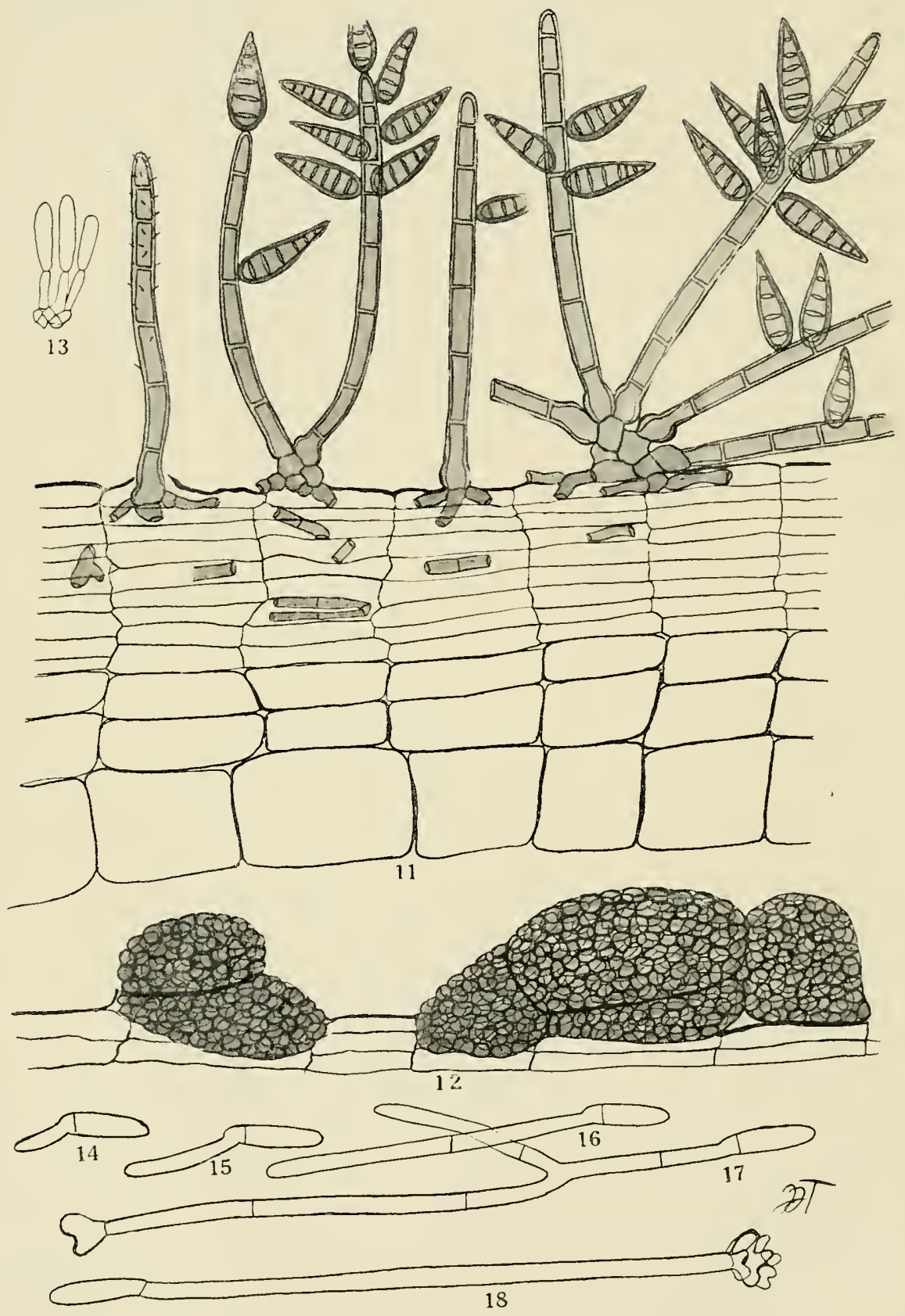

TALBENHALS: SILVER SCLRF OF THE WHITE POT.ITO 


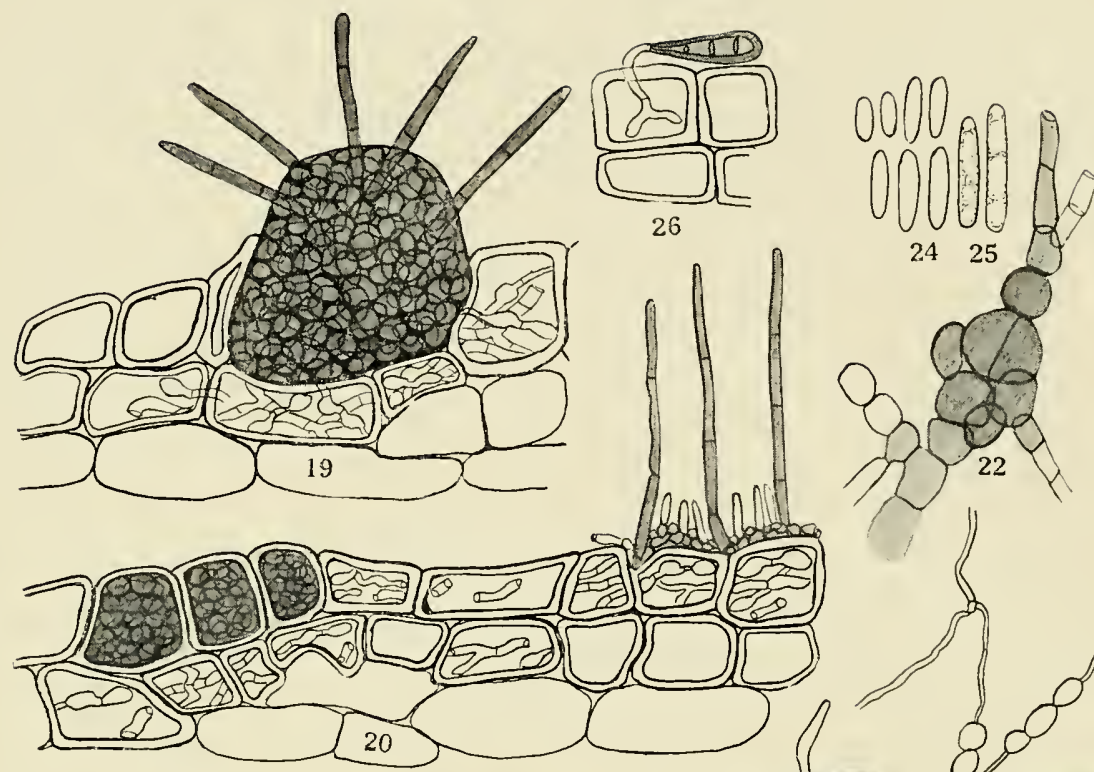

26
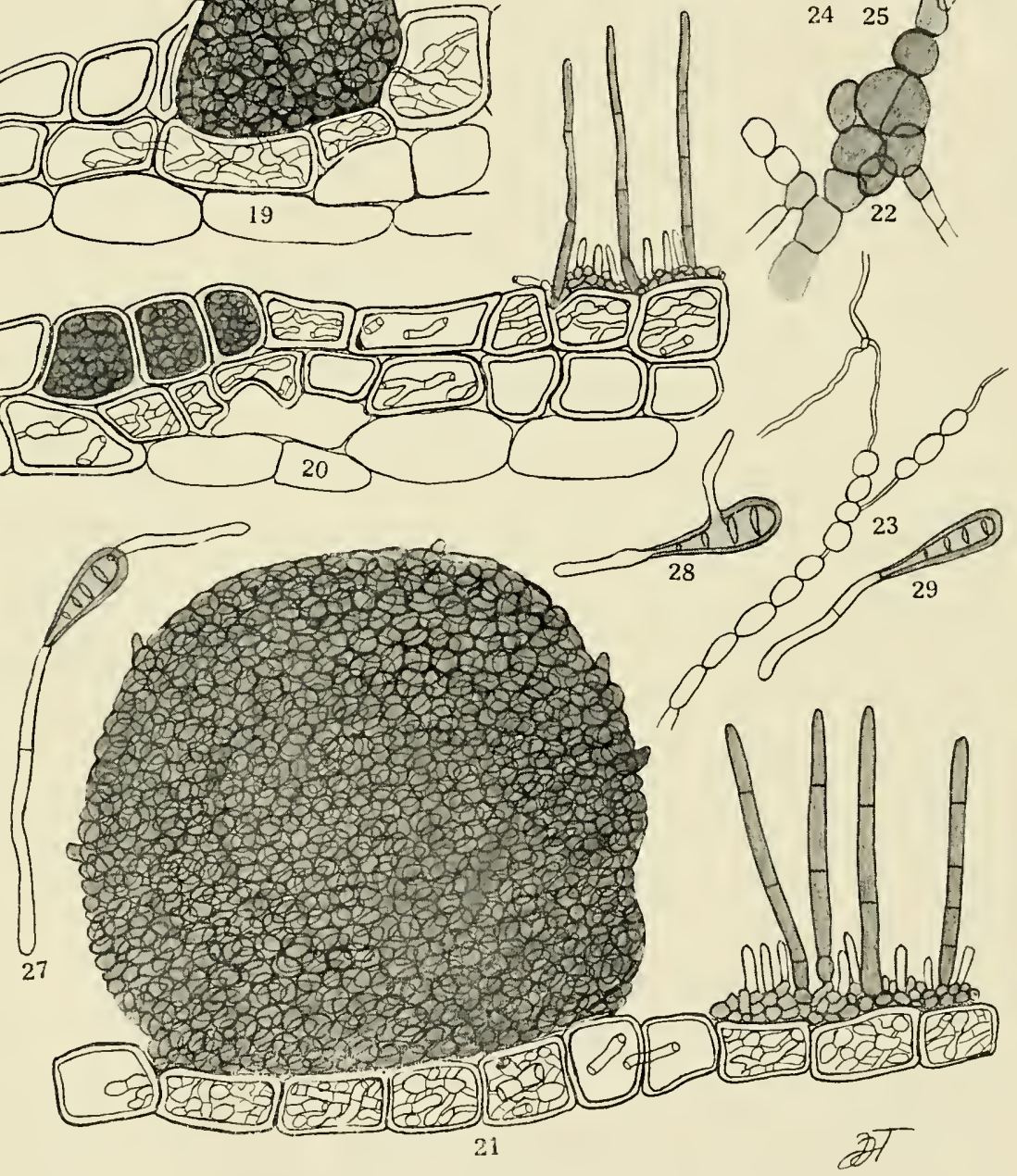

TAUbeNhal's: Silyer sClRF OF the wiHte potato 


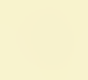




\title{
THE EMBRYO-SAC AND POLLEN GRAIN AS COLLOIDAL SYSTEMS
}

\author{
Francis E. LLOYD \\ McGill University
}

One of the most insistent problems of the present time in the field of biology is the relation of growth to the behavior of colloids, especially those known as emulsion-colloids. ${ }^{1}$ These bodies show the phenomena of swelling at low concentrations of acids and alkalis, and of shrinkage in salts. Certain of them (albumin, etc.) coagulate irreversibly at high temperatures, with concentrations of acids in wide amplitudes, possibly (as indicated by my own experiments) at certain concentrations of alkalis, by mechanical disturbance (shaking, pressure); and to this group of bodies protoplasm belongs. It seems now clear that protoplasm is a hydrophile emulsion colloid, the hydratation capacities of which are functions of the solutes in the watery medium which bathe it. Any change in the concentrations of the solutions must cause corresponding changes in the amount of water within the protoplasm, and this must change the spacial relations of the water-poor dispersoids and water-rich disperse medium, evidenced in swelling or shrinkage. Changes in surface tensions, electrical charge, etc., may be mentioned as indicating the vast possibilities which can result. One possible and important result is the change in permeability which can be readily conceived as being a function of the changes in spacial relations above mentioned. When the antagonistic effects of mixed solutes, the coagulating effects of various reagents, and the possible dissolution of substances (such as lipoid), either proper to or associated with protoplasm by appropriate solvents, are added as further possibilities of affecting the internal relations, it becomes at once evident that the problems in this field are both complex and difficult.

For the present purpose, one such difficulty which confronts the experimental cytologist is the presence of water vacuoles in the majority of growing plant cells. It has indeed been assumed, by

I Such as jelly of any kind, protein bodies in unpeptized condition, such as protoplasm. 
Borowikow, ${ }^{1}$ that the agents which cause swelling in emulsion colloids would increase growth, and, for the moment, it is not possible to discount his results, which he holds substantiate his assumption. He concerned himself with the period of elongation (Streckungsphase), that period, namely, when the growing cells take on a maximum water volume by adding to the number and size of vacuoles. And it is this fact which forces the criticism that we have no knowledge at the present moment of how swelling, shrinking, and coagulating reagents affect the relation of changes of hydratation to the capacity of protoplasm to secrete and to hold water within the vacuoles. And when it is pointed out that the water in the vacuoles is not by any means a simple solution of electrolytes, but contains albumin (Loew) and mucilages, and frequently also suspension colloid bodies (tannins, etc.), substances which must act in antagonism to the protoplasm in so far as they will compete with it in the hydratation processes, as also must investing membranes (cellulose and pektose walls, derived mucilages, such as that of mallows and cacti), we see the need of investigation which is directed toward forming some conception of how these interactions proceed.

The embryo-sac and pollen grain exemplify the abore. The former is a group of cells invested by very delicate cellulose membranes, and in which the development of vacuoles reaches a maximum. The resulting mechanism of endosperm-cell and eggapparatus (in Torenia) is so delicately equilibrated that the whole is thrown out of order by the plasmolytic effects of a solution of the concentration of slightly over o.IN potassium nitrate. It is difficult to conceive the effects of reagents to be identical when operating upon such a system as in the case of the protoplasts of the pollen grain, ${ }^{2}$ from which all water vacuoles (some pollens, such as that of Calla, do not conform to this description) are absent. In this case, the emulsion colloid complex which we call protoplasm shows at once the changes in hydratation due to reagents. Preliminary studies have shown that the protoplasts can swell after previous shrinkage in concentrated glycerine, salts, sugars, and indeed burst ${ }^{3}$ at surprisingly high concentrations of these

I Ueber die Ursachen des Wachstums der Pflanzen. I. Bot. Inst. Unir. Odessa.

${ }^{2}$ Pollen grains of Eschscholizin, Lupinus, and many others are cxamples.

Pollen of cotton bursts in 50 per cent. glyecrine, 25 per cent. cane sugar, $0.45 \mathrm{~N}$ $\mathrm{K}_{\mathrm{NO}}$. That of Eschschollzia frequently bursts in the course of twenty-four hours in very strong glyccrine. 
and other reagents (acids and alkalis). This and other behaviors ${ }^{1}$ preclude a contributing rôle of water vacuoles, while they indicate strongly the value of the suggestion that the hydratation effects alter the permeabilities of the protoplasm, which themselves can be momentarily altered. Thus, the amount of water already in the protoplasm affects the hydratating power of a given reagent, as shown by pollen with different initial quanta of water (imbibed). It is hoped that this brief report will serve to indicate the importance of directing research toward the behavior of the congeries of colloids constituting protoplasm as such, as distinguished from systems in which complications arise from such disturbing factors as water-vacuoles, mucilages, etc., without however underrating the importance of understanding the interrelations of these and the protoplasm.

${ }^{1}$ Swellings and coagulation effects caused by acids and alkalis and the characteristic forms so produced; change in size of dispersoids, as in the case of oil. 



\title{
THE VEGETATION OF ANEGADA
}

\author{
N. L. Britton \\ New York Botanical Garden
}

I visited the little-known island Anegada ${ }^{1}$ in February, I9I3, in company with Mr. W. C. Fishlock, then Agricultural Instructor for the Virgin Islands, and in charge of the Botanical Station at Roadtown, Tortola. The trip was made during our botanical exploration of the Virgin Islands, which included the examination of St. Thomas, St. Jan, Tortola, Virgin Gorda, and Anegada, and landings upon a number of the smaller islands of the archipelago. ${ }^{2}$ Anegada is the most northern and eastern island of the group, and lies north of the eastward prolongation of the axis of the archipelago. It is separated from Virgin Gorda, which lies nearly south of it, by about I 3 miles; the greatest depth of water between the two is about II fathoms. Anegada is about io miles long and a little more than 2 miles wide at its broadest part, which is near the middle of the island; its highest point, which is given at 30 feet on the sailing chart, is a little east of the center. Deep water occurs within a few miles to the north and west, I, IOO fathoms being reached about I2 miles to the southwest. The eastern and central portions of the island are a nearly level limestone plain, slightly eroded, but the western part is a sand plain, with large saline areas and many salt ponds. There are small areas of arable land, originating, in part, from the decay of the limestone, more or less mixed with calcareous sand. The population at the time of our visit consisted of several hundred negroes.

While situated on the same bank as the other Virgin islands, Anegada is totally different from any of them, in being wholly composed of limestone and sand and rising only a little above the water, the other larger Virgin islands being hills which rise to elevations of 500 to 600 meters and are mostly composed of eruptive rocks, although some stratified series were locally ob-

1 Also written Anagada.

${ }^{2}$ Jour. N. Y. Bot. Gard. 14: 99-102. I9I4. 
served, but there is scarcely any limestone recorded. The origin of Anegada is therefore wholly different from the rest of the group and its limestone very much resembles that of the Bahamas, Bermuda, and other acolian islands. Its soil is therefore quite different from that of the other Virgin islands, and some of its plants are not known to grow on them.

The only detailed published account of Anegada known to me is that of Robert Hermann Schomburgk, printed on pages I 52-1 70, with a map, in the second volume of the Journal of the Royal Geographical Society of London, published in I832. In these years, and previously, the island was noteworthy for the number of wrecks of sailing vessels which occurred there, and wrecking was the principal occupation of the inhabitants and was evidently quite lucrative. Schomburgk surveyed the island in I83I; his paper. contains descriptions of its geography, oceanography, geology, and climate, with notes upon its plants and animals, and a list of 53 vessels wrecked on its reefs within the memory of its inhabitants up to that time. He does not appear to have made any collections, although, as a member of the Horticultural Society of Berlin, he might have been expected to have brought out some botanical specimens; Professor Urban remarks, "Plants do not appear to have been collected on this island." burgk records the discovery of a definite northwesterly current about the island and accredited certain deposits which he observed on its southern side to drift-matter in this current, originating as part of the sediment brought down by the Orinoco River. He remarks, "This explains the reason why there are many plants to be met with on the island which do not exist in any of the other Virgin islands, but are peculiar to South America." He states the greatest width of the island as 4.25 miles, but his map shows this to be excessive, and he gives the greatest height as 60 feet above the sea, at a point just east of the settlement, but we saw no such altitude.

The plants mentioned by Schomlurgk are:

Arundo, on sand hillocks, northwestern side. We saw no large grass on the island, but we did not explore the whole of the northwestern coast.

'Symb. Ant. I: 152. I898. 
Suriana maritima. This we found abundant in sandy parts of the west end.

Bignonia Leucoxylon, on islands in the Flamingo Pond. This is evidently Tabebuia heterophylla, which we saw at several points.

Species of Malpighia, Mimosa, Eugenia, Croton, Agave, and Epidendrum are mentioned as plants not observed by him on the other Virgin islands. His Mimosa may be the tree here described as a new Acacia; we found species of the other four genera.

Malpighia angustifolia, which he records as in great abundance about the settlement, is evidently $M$. linearis.

Malpighia urens, west of the settlement.

Malpighia (perhaps coccifera), growing with M. urens.

Laurus Culilaban.- We saw no Lauraceae.

Coccoloba Uvifera, in great quantities at the west end, where we also found it abundant.

Rhizophora Mangle, which is abundant.

Scaevola Lobelia, which is what we call Scaevola Plumieri and is plentiful on coastal sands.

Robinia squamata "with showy yellow flowers," is evidently Pictetia aculeata.

Agave vivipara, probably Furcraea.

A Croton, "which, amongst the Virgin Islands, is peculiar to Anegada, seems to extend over the whole island." IVe saw only Croton discolor.

A red Ulva, on margins of ponds.

During our visit of two days, specimens of 123 species of land plants were obtained; the collection is probably insufficient to base any general conclusions upon, because, presumably, there are more species growing there; we took a specimen of every species we saw, examined at least a square mile of the sandy plain toward the west end and an equal area of the rocky plain toward the east end, and the surface conditions are very uniform, but we did not have time to traverse the whole island. I hope that a collector may be located there for a considerable period of time and the entire flora ascertained.

It is probable that some of the species of trees and shrubs originally growing on Anegada have been exterminated. Schom- 
burgk, in 1832 , refers to "the sale of the underwood, which was progressively cleared away, and which, being full of gum, had a preference in the market of St. Thomas."

There are apparently four endemic species in our collection, these being an Acacia, forming a small tree, here described; a Chamaesyce, pronounced by Dr. Millspaugh to be undescribed (C. anegadensis Millsp. Field Mus. Bot. 2: 394. I9I4); an Astephanus, regarded as new by Dr. Schlechter, and to be described by him, and a new Arthonia, here described by Professor Riddle. All the other species of our collection are found in one part or another of the West Indies, none being characteristic of South America, though many reach South America in their southward distribution. That a number of the Anegada species do not occur in the other Virgin islands was to have been expected, because there is no similar limestone area anywhere else in the archipclago.

No evidence former land connection of Anegada in any direction has been adduced; all the species observed by us may well have been brought there by oceanic or transoceanic distribution.

\section{LIST OF SPECIES}

Panicum geminatum Forsk.

In a water hole near the settlement. St. Thomas:-Florida; Bahamas; W'est Indies south to Martinique and Aruba; continental tropical America; tropical Asia and Africa.

SPOROBOlus ARGUTUS (Nees) Kunth.

Border of marsh. St. Croix:- southern United States; Bahamas; Jamaica; Cuba to Porto Rico; Bonaire; Curaçao; Mexico. Sporobolus virginicus (L.) Kunth.

Border of marsh. Virgin Gorda; St. Jan; Tortola; Vieques:southeastern United States; Bermuda; Bahamas; West Indies; continental tropical America; tropical Africa and Australasia.

Dactyioctenium AEgYptiun (L.) Willd.

Waste grounds. Tortola; St. Jan; St. Thomas; Vieques; St. Croix:- Southern United States; Bahamas; West Indies; continental tropical America and Old World tropics.

Eragrostis ciliaris (L.) Link.

Frequent on the rocky plain. Virgin Gorda; Tortola; St. Jan; St. Thomas; Culebrita; Vicques; St. Croix:--southern United 
States; Bermuda; Bahamas; West Indies; tropical continental America; Old World tropics.

Paspalum Helleri Nash.

Sandy plain, West End, and occasional on the rocky plain. Culebra; Vieques; St. Thomas; St. Jan; Tortola:-Florida; Bahamas; West Indies south to Barbadoes.

Eragrostis Urbaniana Hitchc.

Sandy plain, West End. Bahamas; Porto Rico; Bonaire; Curaçao; Aruba.

Cyperus cuspidatus H.B.K.

Occasional on the rocky plain. Florida; Bahamas; Cuba; continental tropical America.

Cyperus brunneus Sw.

Sandy plain, West End. Virgin Gorda; St. Thomas:--Florida; Bermuda; West Indies south to St. Vincent; Central America; Fernando de Noronha.

Cyperus elegans L.

In a water hole near the settlement. St. Thomas; St. Jan:Florida; West Indies and tropical continental America.

Cyperus fuligineus Chapm.

Occasional on the sandy plain, West End. Florida; Bahamas; Cuba; Bonaire; Curaçao.

Fimbristylis inaguensis Britton.

Frequent on the sandy plain, West End. Cuban Cays; Bahamas.

Thrinax Morrisir Wendl.

Occasional on the sandy plain, West End. Anguilla. Only small barren trees were observed at the time of our visit but Mr. Fishlock subsequently obtained young fruiting inflorescence.

SABAL.

A few trees on the sandy plain, West End. None of them were in flower or in fruit at the time of our visit, and I am therefore unable to determine the species.

Tillandsia utriculata L.

On a tree near the settlement. Tortola; Culebra; Vieques:Bahamas; Jamaica; Cuba to Trinidad; continental tropical America. 
Commelina elegans H.B.K.

Frequent on the rocky plain. St. Thomas:-Florida; Bermuda; IVest Indies and continental tropical America.

Furcraea tuberosa Ait. f.

On the rocky plain near the settlement. Probably introduced. Porto Rico; Vieques; Culebra; St. Croix:-St. Kitts.

Agave missionum Trelease.

Frequent on the rocky plain. Virgin Gorda; St. Jan; St. Thomas; Culebra.

IBIDIUM LUCAYANUM Britton.

Occasional under bushes on the rocky plain. Florida; Bahamas; Porto Rico.

Epidendrum papilionaceum Tahl.

Frequent on low trees and shrubs. Virgin Gorda; Tortola; St. Thomas; Culebra; Vieques:-Hispaniola; Mona; Porto Rico; St. Barts. Recorded from the Bahamas and St. Croix.

Tetramicra eiegans (Hamilt.) Cogn.

Frequent on the sandy plain, West End. St. Jan; St. Thomas; St. Croix:-Porto Rico; Antigua; Guadeloupe.

BATIS MARITINA L.

Common in salinas, West End. St. Thomas; Culebra; Vicques; St. Croix:-southeastern United States; southern California; Bahamas; Jamaica; Cuba; Hispaniola; Porto Rico; Anguilla; Martinique; Margarita; Bonaire; Curaçao; continental tropical America; Sandwich Islands.

Pilea tenerrima Miquel.

Occasional on the rocky plain. Florida; Bahamas; Cuba; Jamaica.

Pilea triantinemoides (Sw.) Lindl.

Occasional on the rocky plain. West Indies.

DENuROPEMON CARIBAEUS Krug \& LTrban.

On a tree near the settlement. St. Jan; St. Thomas; St. Croix:Porto Rico; Antigua to St. Vincent.

Schoenfia obovata C. Wright.

Occasional on the sandy plain, IVest End. Bahamas; Cuba; Porto Rico. 
Coccolobis Uvifera (L.) Jacq.

Frequent on the sandy plain, West End; also in coastal thickets. Virgin Gorda; St. Thomas; St. Jan:-Florida; Bermuda; West Indies and tropical continental America.

Coccolobis KrugiI Lindau.

Occasional, both on the sandy plain, West End, and on the rocky plain. Bahamas; Jamaica; Porto Rico; St. Martin; Barbuda.

SAlicornia PERENnis L. (Salicornia ambigua Michx.)

Saline soil, West End. West Indies; eastern United States.

ACHyRANTHES PORTORICENSIS (Kuntze) Standley. (Alternanthera portoricensis Kuntze.)

Under small trees and shrubs on the rocky plain. Culebra:Porto Rico; Little St. James Island, St. Jan.

Lithophila muscoides Siv.

Occasional on the rocky plain. St. Martin:-Bahamas; Cuba to Martinique; Bonaire; Curaçao; Aruba.

Philoxerus vermicularis (L.) R. Br.

Common in salinas, West End. St. Thomas; Virgin Gorda:Florida; Bahamas; Jamaica; Cuba to Trinidad; Cayman Islands; Curaçao; northern South America.

Pisonia subcordata Sw.

Occasional on the sandy plain, West End. Tortola; St. Thomas; Culebra; Vieques:- Porto Rico to Martinique.

Cypselea humifusa Turpin.

Occasional on the rocky plain. Florida; Cuba; Hispaniola; California.

Portulaca malimoides L.

Frequent on the rocky plain. St. Jan; St. Croix:-Jamaica; Cuba; Hispaniola; Porto Rico; St. Barts and St. Eustatius to Martinique; Bonaire; Curaçao; Aruba.

Portulaca oleracea L.

Frequent on the rocky plain. St. Thomas; St. Jan:-conti; nental temperate and tropical America; Bermuda; West Indiestemperate and tropical regions of the Old World.

Bryophyllum Pinnatum (Lam.) Kurz.

Waste grounds near the settlement. Florida; Bermuda; West Indies. Native of the Old World tropics. 
Pithecolobium Unguis-cati (L.) Mart.

Frequent on the rocky plain. St. Thomas; St. Jan:-Florida; West Indies; Yucatan; northern South America.

Acacia anegadensis Britton, sp. nov.

An intricately branched tree, up to $8 \mathrm{~m}$. high, the main branches wiclely spreading, the slender twigs tortuous, glabrous. Stipules a pair of rigid, acicular, persistent spines $5^{-15} \mathrm{~mm}$. long; leaves 2-3 cm. long; petiole glabrous, or sparingly pubescent, $3-6 \mathrm{~mm}$. long, channeled above, bearing a sessile, saucer-shaped gland about $0.5 \mathrm{~mm}$. in diameter at the top; pinnae I-pair; petiolules a little longer than the similar petiole, with a smaller, similar gland between the leaflets; leaflets I-pair, rarely 2 -pairs, sessile, obliquely oblong or oblong-obovate, coriaccous, glabrous, I0-16 mm. long, strongly and loosely reticulate-veined, rounded or emarginate at the apex, obliquely obtuse at the base, lustrous on both sides; peduncles solitary or $2-4$ together in the upper axils, slender, loosely pubescent, shorter than the leaves; heads globose, in flower $5^{-6} \mathrm{~mm}$. in diameter; flowers yellow; calyx minutely toothed, about $0.6 \mathrm{~mm}$. long; corolla narrow, its teeth ciliolate, much shorter than the tube; stamens about $20,3-4 \mathrm{~mm}$. long, the filaments filiform, the anthers minute; pod short-stipitate, linear, curved, apiculate, glabrous, veiny, $3-4 \mathrm{~cm}$. long, swollen, the dry, subcoriaccous valves very tardily dehiscent; seeds compressed, suborbicular, brown, clull, 3-4 $\mathrm{mm}$. in diameter, $1.5 \mathrm{~mm}$. thick.

Abundant on the rocky plain, and occasional on the sandy plain near the IVest End. (Type, Britton \&o Fishlock 9go.)

Acuan virgatum (L.) Medic.

Frequent on the rocky plain. Virgin Gorda; St. Thomas; St. Croix; Culebra; Vieques:-Bermuda; West Indies; continental tropical America.

Cassia micapsularis L.

Occasional on the rocky plain. St. Thomas; St. Jan; Tortola; Culebra; Vieques:-IVest Indies; continental tropical America.

Cassia polyeriylla Jacq.

Occasional on the rocky plain. St. Thomas; St. Croix:-Porto Rico; Hispaniola.

Cassia Sofhera L.

Roadside, near the settlement; apparently introduced. IV'est Indies; continental tropical America and Old World tropics. 
Sophera tomentosa L.

Frequent on the sandy plain, West End. St. Thomas; St. Croix:-Florida; Bermuda; West Indies south to St. Vincent; Aruba; continental tropical America and Old World tropics.

Pictetia aculeata (Vahl) Urban.

Occasional on the rocky plain. Virgin Gorda; St. Jan; St. Thomas; Culebra; Vieques:--Porto Rico; recorded from St. Croix and, doubtfully, from Hispaniola.

Stylosanthes hamata (L.) Taubert.

Frequent on the rocky plain. Tortola; St. Thomas; St. Jan; St. Croix:-Florida; West Indies south to Barbados; Mexico to Colombia.

Bradburya virginiana (L.) Kuntze.

Frequent on the rocky plain. St. Thomas; Culebra; Vieques:southeastern United States; West Indies; continental tropical America. Recorded from Bermuda.

Byrsonima lucida (Sw.) DC.

Frequent on the sandy plain, West End, and on the rocky plain. St. Thomas; Vieques:-Florida; Bahamas; West Indies south to Barbados.

Malpighia linearis Jacq.

On the rocky plain near the settlement. St. Jan; St. Thomas:south to Guadeloupe and Montserrat.

Stigmaphyllon lingulatum (Poir.) Small.

Frequent on the rocky plain. Tortola; St. Jan; St. Thomas; Culebra; Vieques:- Hispaniola and Porto Rico to Martinique.

AMyris ELEMIFERA L.

Frequent on the rocky plain. St. Thomas; St. Jan; St. Croix; Culebra; Vieques:-Florida; West Indies; Central America.

SURIANA MARITIMA L.

Frequent on sand dunes, West End. Virgin Gorda; St. Thomas; St. Croix; St. Jan; Vieques:-Florida; Bermuda; West Indies; continental tropical America and Old World tropics.

Polygala hectacantha Urban.

Frequent on sand dunes, West End. Hispaniola; Porto Rico. Phyllanthus polycladus Urban.

Occasional on the rocky plain. Porto Rico; Hispaniola; Bonaire; Curaçao. 
Argithamia Stahli Urban.

Occasional on the rocky plain. Porto Rico.

Croton discolor Willd.

Frequent on the sandy plain, West End, and occasional on the rocky plain. Vieques; St. Thomas; St. Croix:-Hispaniola; Mona; Porto Rico.

Cimanaestce buxifolia (Lam.) Small.

Sand dune, near East End. Virgin Gorda; St. Thomas; St. Croix; St. Jan; Tortola:-Florida; Bermuda; West Indies; continental tropical America.

Chamaestce serpens (H.B.K.) Small.

Rocky plain near the settlement. Porto Rico; St. Thomas:Antigua to Barbados; continental tropical America, north to South Dakota.

Chamaesyce Blodgettii (Engelm.) Small.

Rocky plain near the settlement. Florida; Bermuda; Bahamas; Cuba; Jamaica.

Chamaestce anegadensis Millsp. Field Mus. Bot. 2: 394. I9I4.

Frequent on the rocky plain. Endemic.

Chamaesyce articulata (Aubl.) (Euphorbia articulata Aubl.)

Frequent on the sandy plain, West End. Tortola; St. Jan; St. Thomas; Culebra; Vieques:-Porto Rico to St. Vincent.

Akleira petiolaris (Sims) Millsp.

Frequent on the rocky plain. Tortola; St. Jan; St. Thomas; Culebra; Vieques:- Hispaniola to St. Martin and Guadeloupe.

Rhacoma crossopetalum L.

Frequent on the sandy plain, West End. Virgin Gorda; Tortola; Culebra; St. Thomas; St. Jan:--Florida; Bermuda; West Indies; Colombia.

Gyminda matifolia (Sw.) Urban.

Frequent on the sandy plain, West End. St. 'Thomas; Vieques:

-Florida; West Indies; Mexico.

Elaeodendron xylocarpum (Vent.) DC.

Frequent on the sandy plain, West End. Tortola; St. Jan; St. Thomas; St. Croix; Vieques; Culebra:--Porto Rico. 
SERJANiA POLyPhylla Radlk.

Frequent on the rocky plain. Tortola; St. Jan; St. Thomas; Vieques; St. Croix:--Porto Rico; Hispaniola. Recorded from Colombia.

Dodonaea Ehrenbergit DC.

Common on the sandy plain, West End. Bahamas; Cuban Cays; Hispaniola; Mona.

SARComphalus domingensis (Spreng.) Urban.

Occasional on the rocky plain. Virgin Gorda; Tortola; Vieques:

-Hispaniola; Porto Rico; Anguilla.

Colubrina Colubrina (L.) Millsp.

Occasional on the rocky plain. Virgin Gorda; Tortola; St. Thomas; St. Jan; St. Croix; Vieques; Culebra:-Florida; West Indies south to Antigua; recorded from Barbados; Yucatan.

Reynosia UNCINATA Urban.

Frequent on the rocky plain. Tortola:-Porto Rico; Mona; Anguilla.

Cissus trifoliata L.

Frequent on the rocky plain. St. Jan; St. Thomas; St. Croix; Vieques:- IVest Indies south to Martinique; northern South America.

CORCHORUS HIRSUTUS L.

Frequent on the sandy plain, West End. Virgin Gorda; Tortola; St. Jan; St. Thomas; St. Croix; Vieques:-IVest Indies south to St. Eustatius; Bonaire; Curaçao; Aruba.

SIDA CILIARIS L.

Occasional on the rocky plain. Virgin Gorda; Tortola; St. Jan; St. Thomas; St. Croix:-Florida; West Indies, south to Bequia; Margarita; Curaçao; Aruba; continental tropical America.

PASSIFLORA SUBEROSA L.

Occasional on the rocky plain. St. Thomas; St. Croix; St. Jan; Culebra; Vieques:-Florida; Bermuda; West Indies; continental tropical America.

Cactus intortus Mill.

Occasional on the rocky plain. Virgin Gorda; Tortola; St. Jan; St. Thomas; St. Croix; Vieques:-Bahamas; Mona; Porto Rico to Montserrat and Antigua. 
Cephalocereus Royeni (L.) Britton \& Rose.

Frequent on the rocky plain. Virgin Gorda; Tortola; St. Jan; St. Thomas; St. Croix; Culebra; Vieques:-Porto Rico; Mona; Desecheo.

RHIZOPHORA MANGLE L.

Mangrove swamps, West End. St. Thomas; St. Croix; St. Jan; Vieques:-Florida; Bermuda; IVest Indies; tropical continental America; west tropical Africa.

CoNocARpus ERECTA Jacq.

Mangrove swamps, IVest End. Virgin Gorda; Tortola; St. Thomas; St. Jan; St. Croix; Vieques:-Florida; Bermuda; West Indies and continental tropical America.

Laguncularia RaCemosa (L.) Gaertn. f.

Mangrove swamps, West End. St. Thomas; St. Jan; St. Croix; Vieques:-Florida; West Indies; tropical continental America.

Eugenia Axillaris (Sw.) Willd.

Sandy plain, West End. St. Croix; Vieques:-Florida; Bermuda; IVest Indies, south to Guadeloupe.

The determination is based on specimens showing foliage only. The species is not recorded from Tortola, St. Jan, or St. Thomas. Bumelia obovata (Lam.) A. DC.

A narrow-leaved race. Occasional on the sandy plain, West End. Virgin Gorda; Tortola; St. Jan; St. Thomas; St. Croix:Hispaniola to Santa Lucia; Bonaire; Curaçao; Aruba. Recorded from Jamaica.

JACQUiniA BARBASCo (Loefl.) Mez.

Frequent on the sandy plain, West End. Tortola; St. Jan; St. Thomas; St. Croix; Culebra; Vieques:-Jamaica; recorded from Cuba; Porto Rico to Tobago; Curaçao.

Centaurium Brittonit Millsp. \& Greenm.

Shaded saline soil, WVest End. Bahamas.

Plumiera alba L.

Occasional on the rocky plain. Virgin Gorda; Tortola; St. Jan; St. Thomas; St. Croix; Culebra; Vieques:-Porto Rico to Grenada.

URECHITES LUTEA (L.) Britton.

Occasional on the sandy plain, West End. Tortola; St. Jan; 
St. Thomas; St. Croix; Vieques:-Florida; West Indies, south to St. Kitts, and recorded from St. Vincent.

Astephanus.

Sandy plain, West End. Endemic.

Evolvulus glaber Spreng.

Frequent on the rocky plain. Virgin Gorda; Tortola; St. Jan; St. Thomas; St. Croix:-Florida; West Indies; tropical South America.

Evolvulus SERICEUS Sw.

On the rocky plain near the settlement; a short-leaved, shortsepaled race, occurring also on Anguilla, St. Martin, and Porto Rico.

Evolvulus squamosus Britton.

Occasional on the rocky plain. Bahamas.

Jacquemontia reclinata House.

Sandy plain, West End. Florida; Bahamas.

Mallotonia gnaphalodes (L.) Britton.

Frequent on sand dunes, West End. Virgin Gorda; St. Jan; St. Thomas; St. Croix; Vieques:-Florida; Bermuda; West Indies; Central America.

Varronia bahamensis (Urban) Millsp.

Frequent on the sandy plain, West End. Bahamas.

LANTANA INVOLUCRATA L.

Common on the sandy plain, West End. Tortola; St. Jan; St. Thomas; Culebra; Vieques; St. Croix:-Florida; Bermuda; West Indies; Mexico; Galapagos Islands.

VOLKAMERIA ACULEATA L.

Frequent on the rocky plain. Virgin Gorda; Tortola; St. Jan; St. Thomas; St. Croix; Culebra:-Vieques; Bermuda; West Indies, south to Martinique; continental tropical America.

Citharexylum Fruticosum L.

Occasional on the rocky plain. Virgin Gorda; Tortola; St. Jan; St. Thomas; Culebra; Vieques:-Florida; Bahamas; Jamaica; Cuba; Hispaniola; Porto Rico to Dominica and Guadeloupe.

Salvia serotina L. (S. micrantha Vahl.)

Rocky plain, near the settlement. Tortola; St. Jan; St. Croix:Florida; Bermuda; West Indies; Yucatan. 
Solanum persicifolium Dunal.

Occasional on the rocky plain. Virgin Gorda; Tortola; St. Jan; St. Thomas; St. Croix; Culebra; Vieques:-Porto Rico.

LYCIUM AMERICANUM Jacq.

Occasional on the rocky plain. Anguilla; Hispaniola; Cuba. Physalis angulata L.

Occasional on the rocky plain. Tortola; St. Jan; St. Thomas; St. Croix; Culebra; Vieques:- - southern United States; Bermuda; West Indies; continental tropical America.

Tabebuia heterophylla (DC.) Britton.

Occasional on the rocky plain. Virgin Gorda; St. Jan; St. Thomas; St. Croix; Culebra; Vieques:-Porto Rico.

Randia aculeata L.

Frequent on the rocky plain. St. Jan; St. Thomas; St. Croix; Vieques:-Florida; Bermuda; West Indies; Mexico.

ERITHALIS FRUTICOSA L.

Common on the sandy plain, IVest End. Virgin Gorda; Tortola; St. Jan; St. Thomas; St. Croix; Culebra; Vieques:-West Indies; Central America.

StrumpFia Maritima Jacq.

Common on the sandy plain, West End. Tortola; Vieques:Florida; West Indies; south to Guadeloupe; Bonaire; Curaçao; Aruba; Yucatan.

ERNODEA LitToralis Sw.

Sandy plain, West End. Tortola; St. Jan; St. Thomas; St. Croix; Culebra; Vieques:-West Indies, south to Guadeloupe; Central America.

SPERMACOCE TENUIOR L.

Frequent on the rocky plain. St. Jan; St. Thomas; St. Croix; Culebra; Vieques:- southern United States; Bermuda; IVest Indies; continental tropical America.

Cucumis Axguria L.

On the rocky plain near the settlement. St. Jan; St. Thomas; St. Croix; Culebra; Vieques:-Florida; West Indies; continental tropical America.

Scaevola Plumieri (L.) Vahl.

Frequent on sand dunes, West End. Virgin Gorda; Tortola; 
St. Thomas; St. Croix; Vieques:-Florida; Bermuda; West Indies; Mexico; tropical Africa.

Gundlachia corymbosa (Urban) Britton.

Abundant on the sandy plain, West End. Bahamas; Porto Rico to Guadeloupe; Curaçao. Not known from the other Virgin Islands, but found on Saba.

Pluchea purpurascens (Sw.) DC.

Moist places on the rocky plain. St. Thomas; St. Croix:southeastern United States; Bermuda; West Indies, south to Guadeloupe; continental tropical America.

Borrichia arborescens (L.) DC.

Abundant in salinas, West End. St. Thomas; St. Croix; Culebra; Vieques:- -southeastern United States; Bermuda; West Indies and continental tropical America.

Wedelia Parviflora L. C. Rich.

Frequent on the rocky plain. Tortola; St. Jan; St. Thomas; St. Croix; Vieques; Culebra:--Porto Rico to Trinidad.

Bryum MiCrodecurrens E. G. Britton.

On the rocky plain near the settlement. Mona.

Hymenostomum Breutelii (C. Muell.) Broth.

On the rocky plain near the settlement. Tortola; St. Jan; St. Thomas.

Chara.

In a water hole near the settlement.

\section{LiCHENS}

(Determined by Professor Lincoln IV. Riddle.)

Arthonia interducta Nyl.

On Acacia anegadensis.

Arthonia anegadensis Riddle, sp. nov.

Thallus epiphloeodes crustaceus sat crassus rimulosus laevigatus niveus. Apothecia dispersa, rotundato-difformia aut subelongata, diam. $0.2-0.5 \mathrm{~mm}$., primum immersa vestitaque demum aperta thallum subaequantia, disco plano epruinoso, sicco nigro, madefacto badio, materias $\mathrm{KOH}$ reagentes haud continentia. Epithecium fulvum; hymenium et hypothecium decoloratum; hymenium iodo vinose rubens. Asci late ovales, octospori. Sporae decolores vel subfuscescentes, oblongae, 6-loculares, cellulis subaequalibus, I $5^{-1} 8 \mu \times 5^{-6} \mu$. 
This is a striking and distinct species, belonging to the section Euarthonia, and marked by the comparatively thick, rimulose, very white thallus, in which are immersed the dark, difform apothecia, with the disk slightly sunken below the surface of the thallus.

Type: on bark of Pisonia subcordata, Anegada Island, West Indies; coll. N. L. Britton and W. C. Fisklock, Feb. I9-20, I9I3; no. 987 ; in herb. L. W. Riddle. Duplicate in herb. New York Botanical Garden.

Ramalina denticulata (Eschw.) Nyl.

On a twig.

Buellia parasema var. aeruginascens (Nyl.) Muell. Arg. On a twig.

Anthracothecium libricolum (Fée) Muell. Arg.

On Acacia anegadensis.

Arthopyrenia fallax (Nyl.) Arnold.

On Pisonia subcordata.

Pyxine Meissneri Tuck.

On a twig.

Glyphis cicatricosa Ach.

On a twig. 


\section{INDEX}

Abies balsamifera, 480 ; concolor, 483 ; grandis, 483; lasiocarpa, 478, 480, 481,483

Abutilon Darwinii, 339, 340

Acacia, 306, 567, 568; a negadensis, 572, 579,580 ; paradoxa, 274

Acer carolinianum, $80,82,84$; Douglasii, 485; glabrum, 486 ; rubrum, 80

Achyranthes portoricensis, $57 \mathrm{I}$

Aconitum, 276

Acrochaetium, I $13, \pm 16,120,123$; affine, I06, I08, I I0, I I I, I I 5-120, I 22; Hoytii, I I2, I I6-I20, I22; Hyyneae, I 20 ; infestans, II6, II7, I22; robustum, I 1 8, I 20; unipes, I I 8-1 20

Aconitum, 557

Acuan virgatum, $\mathbf{5 7 2}$

Address of welcome, I

Aecidium Cerastii, I99; convolvulatum, 197; Galii ambiguum, 203; Giliae, I99; gnaphaliatum, 205; graminellum, I80; intermixtum, 204; Ipomoeae, r95; Ipomoeae-panduranae, 197 ; Leptotaeniae, I90; Ludwigiae, I89; monoicum, I88; Nesaeae, I89; Phlogis, I99; Podophylli, I 86; Pourthiaeae, 250; Sorbi, 25I; Swertiae, I95; Wilcoxianum, I99

Agalinis maritima, 86

Agaricus, 213, 215; alphitophorus, 5I0; arvensis, 22I, 222, 510; campestris, 22I; corticola, 5IO; helictus, 5IO; rhodocylix, 510; Rodmani, 212, 218 , $22 \mathrm{I}$; tener, 5 IO

Agastache, 163

Agave, 272, 305, 567; attenuata, 126; missionum, 570; vivipara, 567

Agropyron molle, 490; Smithii, 490

Agrostis, 5I 5

Akentra, 6I

Aklema petiolaris, 574

Albugo, I97; candida, 502, 505

Alcyonidium gelatinosum, i 7

Allium, I82, 254, 27 I, 305; reticulatum, I 8 I

Allodus, I 73-I 78, I 8I, I 82, I96; ambigua, 177 , I80, 203; a reolata, I 80, I 86; asperior, I79, I93; Batesiana, I 77, I80, 204; Bouvardiae, I79, 202; Calochorti, I79, I8I ; Carnegiana, I79, I82, I83; Chamaesarachae, I77, I 79, 20I ; claytoniata, I77, I79, I 84 , I85; commutata, I80, 203; consimilis, I77, I80, I87; crassipes, I79, I96; Desmanthodii, I80, 206; Dichelostemmae, I80, I83, I84; Douglasii,
177, I80, I98; effusa, I74, I79, I88; Erigeniae, I79, I9I; gigantispora, I80, I 85; Giliae, I77, I 79, I99; gnaphaliata, I80, 205; graminella, I78, I80; imperspicua, I80, I89; insignis, I79, I97; intermixta, I77, I79, 204; Jonesii, 179, I90; lacerata, I79, 194; Lindrothii, I 79, I92; Ludwigiae, I 80, I89; megalospora, I79, I98; melanconioides, I 80, I94; mellifera, I80, 200; microica, I 80, I92; Moreniana, I 79, I82; Musenii, I79, I93; Nesaeae, I89; nocticolor, I79, I97; opposita, I 80, I85; opulenta, I79, I95; oregonensis, I93; pagana, I79, I8I ; Palmeri, I79, 202; plumbaria, I99; Podophylli, I78, I79, I86; rufescens, I 79, 202; Senecionis, 207; subangulata, I79, I 83, I84; subcircinata, I80, 206; superflua, I79, I98; Swertiae, I80, I95; tenuis, I80, 205; vertisepta, I 79, 201

Allodus, North American species of, I73 Allosorus crispus, I 70

Alnus, 488; rugosa, 81 ; tenuifolia, 478 , 483,487 ; viridis, 480,496

Aloe, 27 I, 305

Alstroemeria, 255

Alternanthera portoricensis, $57 \mathrm{I}$

Althaea, 274, 276, 306, 307; rosea, 273, 274

Amanita, 215 ; rubescens, 22 I

Amanitopsis, 215; vaginata, 22 I

Ambrosia, 284, 307; artemisiifolia, 284, 302

Amelanchier, 246, 487, 488, 497; alnifolia, 485 ; asiatica, 245; utahensis, 493

Amphilophis Torreyanus, 490

Amyris elemifera, 573

Andropogon scoparius, 490

Anegada, The vegetation of, 565

Anemone cylindrica, 185; globosa, I 85 , I86; narcissiflora, I 85; nemorosa, I70; patens Nuttalliana, I 85

Aneura, 266, 288, 304

Anomalofilicites monstrosus, 474

Anona, 27 1, 278, 28I

Anophthalmus, 66, 68

Antennaria dioica, 170

Anthericum, 257, 271, 305

Anthoceros, 255, 266, 267, 269, 274, 304

Antholyza, 27 I

Anthracothecium libricolum, 580

Antiquity among plants, Endemism as a criterion of, I6I

Antirrhinum majus, 358, 405; molle, 358,405 
Apicra, 271, 305

Apocynum, 271, 276, 281, 306

Aquilegia, 481,482

Aranella, $43,48,49,64$; fimbriata, 48,49

Arbacia, 432,433

Arcella, I to

Arctostaphylos platyphylla, 493; Lraursi, $48 \mathrm{I}$

Arenaria verna, 169

Are Tetracentron, Trochodendron and Drimys specialized or primitive types?, 27

Argythamnia Stahlii, 5it

Arisaema, 8; triphyllun, 81

Aristida, 515

Aristolochia, 271, 278, 306

Armeria vulgaris, 170

Armillaria mellea, 2 I 5, 22 I ; mucida, 222

Arnica, 482

Aronia arbutifolia, 8I; atropurpurea, 8I

Arracacia Hartwegii, I92; multifida, I89, 190

Artemisia, 488 ; cana, 485 ; triclentata, $485,493,49+$

Arthonia, 568; anegadensis, 579; interducta, 579

Arthopyrenia fallax, 580

Arundo, 566

Ascaris, 412

Asclepias, 270, 271, 276, 281, 282, 305

Ascobolus immersus, 506; stercorarius, 506

Ascophanus bermudensis, 502, 505; granuliformis, 506; sarcobius, 502, 505, 506

Asimina, 163

Askofake, 54

Asphodelus, 27 I, 305

Asplenium viride, 170

Astephanus, 568, 577

Aster, +63

Asterias, 433

Asterina pelliculosa, 50\%

Asterocarpus falcatus, 76 ; virginiensis, 76

Atkixsos, Geo. F. The development of Lepiota cristata and Lepiotil seminuscla, 209

Atriplex confertifolia, 49I, 494; hastata, 86

Audibertia incana, 200; granditlora, 200; stachyoides, 200

Aulospermum Betheli, 190; purpureum, 190

Avena sativa, 8

A'esicaria, 42, 56, 57, 64; neottioides, 56

Azalea mudillora, $8 \mathrm{I}$; viscosil, $8 \mathrm{I}$

Baccharis, 84,507

Bacria, 163

BAILISY, I. IV., IV. P'. THOMmpos and. Are Tetracentron, Trochodendron and Drimys specialized or primitive types?, 27

BARNIART, JOIN HENHLEY, Segregattion of genera in Lentilublariaccae, 39

\section{YORK BOTANICAL GARDEN}

Batis maritima, $57^{\circ}$

BEAL, IV. J. Some things learned in managing a botanic garden, 513

Beaufort, North Carolina, Notes on some marine algae from the vicinity of, 105

Beets, Self, close and cross fertilization of, 149

Benjaminia, 63

Benzoin aestivale, $8 \mathbf{I}$

Berberis Fremontii, 493

Bermuda fungi, 501

Beta, 407

Betula, 483,488 ; fontinalis, $478,483,487$ : occidentalis, 483 ; papyrifera, 481 ; utahensis, 483

Bigelovia, 163

Bignonia, 306, 307; Leucoxylon, 567

Biovularia, $41,57,58,64 ;$ cymbantha, 59 ; olivacea, 57,59

BLACK, CAROLINE A. The nature of the inflorescence and fruit of Pyrus Malus, 519

Blakeslee, Albert F. Inheritable variations in the yellow daisy (Rudbeckia hirta), 89

Borrichia arborescens, 579

Botanical trip to North Wales in June, A, 167

Botanic garden, Some things learned in managing a, 513

Botany, Directing factors in the teaching of, 33 .

Botrychium, 267, 304

Botrytis cinerea, 325

Boudiera, 68

Bonteloua curtipendula, 490; eriopoda, 490; hirsuta, 490; oligostachya, 490; polystachya, 490; prostrata, 490

Bouvardia triphylla, 203

Bradburya virginiana, 573

Brandonia, 47

Brassica, 5 55

Brickellia, 163

BRITTOx, N. l. The vegetation of Anegada, 565

Brodiaca, I74; capitata, I82; capitata pauciflora, 183 ; congesta, $18_{3}, 184$

Bromins, 515

Bryonia, 127, 137, 273, 276, 279, 306; alloa, 69, 70, 74 ; dioica, 69, 70, 74

Bryophyllum pinnatum, 57 I

Bryum microdecurrens, 579

Buellia parasema aeruginascens, 580

Bullilis dactyloides, $49^{\circ}$

Bullaria, $17+$ I 76

Bumelia obovatil, 576

By.blis, 63

Byrsonima lucida, 573

Calomba, 514

Cactus, t91; intortus, 575; missouriensis, f(0); viviparus, 490

Cacoma (Aecirlium) claytoniatum 18.; poclophyllatum, 187 ; tenue, 205 
Calla, 562

Call, Richard Ellsworth. Observations on the flora of Mammoth Cave, Kentucky, 65

Calluna vulgaris, I 70

Calochortus albus, I 82; elegans, I82; flavus, I 82; Gunnisonii, I 82; longebarbatus, I 82 ; nudus, I 82 ; Nuttallii, I 82

Calonectria granulosa, 504, 508; Umbelliferarum, 504, 507

Calpidisca, $44,54-56,64$; capensis, 56 ; denticulata, 55,56

Caltha biflora, I 86; palustris, 17 I

Calycanthus, 535; floridus, I32

Calycocarpum, I63

Calyptospora, I 78

Campanula rotundifolia, 170

Cardamine, $340,350,353,384,393,402$, $404,407-409,422,427,430,43 \mathrm{I}, 433$, $439,44^{6}$; pratensis, $353,440,45^{\circ}$

Carex, 273, 305; Collinsii, 81; Howei, $8 \mathrm{I}$

Carya, 163

Cassia bicapsularis, 572 ; polyphylla, 572 ; Sophera, 572

Castilleja, 163,482

Ceanothus, I63; Greggii, 493

Celt is crassifolia, 485 ; occidentalis, 485 ; rugosa, 486

Centaurium Brittonii, 576

Cephalocerus Royeni, 576

Ceratophyllum, 27I, 276, 281, 282, 305

Ceratozamia, 268, 304

Cercocarpus, I64, 487, 493, 497; hypoleucus, 488 ; ledifolius, 488 ; montanus, 485,486

Chaetomium, 508

Chamaecyparis, $79,80,82,83,86$; nootkatensis, 25I; pisifera, 252; thyoides, 79

Chamaesaracha nana, 20 I

Chamaesyce 568; anegadensis, 568, 574; articulata, 574; Blodgettii, 509, 574; buxifolia, 574; hyssopifolia, 509; prostrata, 509; serpens, 574

Chantransia endozoica, I I 7

Chara, 579

Chemotropic reactions in Rhizopus nigricans, 323

Chivers, Arthur $H$. Directing factors in the teaching of botany, 33

Chrysanthemum, 285, 299, 302, 307, 485, 488 ; frutescens, 284,302

Chrysosplenium americanum, 172; oppositifolium, I 72

Chrysothamnus, 488

Chylocladia, 260, 265

Cichorium, $340,363,364,367,384,404$, $405,407,408,427,432,433,44 \mathrm{I}, 442$, 446,450 ; Intybus, $360,364,397,401$, $402,409,440,447,450,454$

Cichorium Intybus with reference to sterility, Self- and cross-pollinations in, 333
Ciona, 348-35I, 409, 433; intestinalis, $337,348,350,407$

Cissus trifoliata, 575

Citharexylum fruticosum, 577

Citrus, 335

Cladophora, 107, 258, 269, 277

Clathrus, 5I I

Claytonia asarifolia, I84; caroliniana, I 84; megarrhiza, I 85; siberica, I 84; virginica, I 84

Clethra alnifolia, $8 \mathrm{I}$

Cobaea, 279, 306, 307

Coccolobis Krugii, 57I; Uvifera, 567, 57 I

Coelogyne, 493

Coemansia, 68

Cogswellia foeniculacea, I90; Grayi, I90; macrocarpa, I90; nevadensis, I90; orientalis, I90; platycarpa, I90; Suksdorfii, I90; triternata, 190

Colaconema, I I3, I I4; Bonnemaisoniae, I 13 ; reticulatum, I I 4

Colacopsis, I I 3

Colletotrichum, 552-55t, 556, 558; atramentarium, 554-560; solanicolum, 552, 554,558

Colloidal systems, The embryo-sac and pollen grain as, $56 \mathrm{I}$

Collomia gracilis, 200

Colubrina Colubrina, 575

Commelina elegaris, 570

Conferva stellulata, i io

Conocarpus erecta, 576

Conocephalum, 266

Convallaria, 272, 305

Convolvulus, 273,306

Cooperation in the investigation and control of plant diseases, 517

Coprinus, 22I, 224; ephemerus, 510; fimetarius, 5I0; micaceus, 67, $22 \mathrm{I}$; radians, $22 \mathrm{I}$

Corchorus hirsutus, 575

Cordyceps militaris, 507

Coriolus pavonius, 5IO; sericeohirsutus, 510

Corydalis, $34^{6}$; cava, $346,43^{8}$

Cosmiza, $41,48-50,64 ;$ coccinea, $49 ;$ multifida, 48,49

Covillea, 493,494

Cowania, 493

Crataegus, $478,485,486,488$

Craterospermum, 260, 265

Crepis, 283, 284, 307; taraxacifolia, I 29, 283; virens, I 29

Crinipellis stupparia, 5 Io

Cristatella, 45

Criterion of antiquity among plants, Endemism as a, I6I

Cross-pollination in Cichorium Intybus with reference to sterility, Self-and, 333

Croton, 567; discolor, 567, 574

Cryptanthe, I63

Cryptotaenia canadensis, I92

Cucumis, 276, 306, 397; Anguria, 578

Cucurbita, 306; Pepo, 273 


\section{8+ MEMOIRS OF THE NEW YORK BOTANICAL GARDEN}

Cyathus vernicosus, 68

Cycadeomyelon, 77

Cydonia, 246, 249, 250; japonica, 249; vulgaris, $246,247,2+9$

Cylindropuntia, 49I

Cymopterus acaulis, I90; Fendleri, I90; montanus, I9I; purpureus, I90; terebinthus, I9I

Cynomarathrum Eastwoodii, I90

Cyperus brunneus, 569; cuspidatus, 569; fuligineus, 569 ; elegans, 569

Cypripedium, 27I, 305

Cypselea humifusa, $57 \mathrm{x}$

Cystopteris fragilis, 170

Cytisus Laburnum, +38

Cytokinesis of the pollen-mother-cells of certain dicotyledons, 25.3

Dactyloctenium aegyptium, 568

Daedalea Aesculi, 5 Io

Dahlia, 281, 306

Daldinia concentrica, 508

Daphne, 282, 306, +25

Darlingtonia, 163

Dasylirion, 491

Dasy'scypha earoleuca, 506

Dasyspora, I 73-175, I 85, I 88, 192; Anemones-virginianae, 185

Delphinium, 276

Dendropemon caribaeus, 570

Derbesia repens, 107; turbinata, 106-108, I2 I ; vaucheriaeformis, 107,108

Deringa canadensis, 192

Desmanthodium fruticosum, 206; ovatum, 206

Desmarestia Dudresnayi, II 4

Detonia Planchonis, 503

Development of Lepiota cristata and Lepiota seminuda, The, 209

Deweya arguta, 192

Dicaeoma, I74, I75, 188, I94, I95: anachoreticum, I8I; arabicola, I99; areolatum, 186; asperius, 193; claytoniatum, 184 , Clematidis, I 85 ; consimile, 187; crassipes, 196; Cymopteri, 190; Douglasii, 198; fragile, 199; Holwayi, I8I; intermixtum, 204; investitum, 205; Ipomocae, I06; Jonesii, 190; melanconioides, 194; microicum, 192; Nesaeae, I89; opulentum, I95; plumbarium, 199; Podophylli, 187; rufescens, 202; subcircinatum, 206 ; Swertiae, 195; Violae, I88; tenue, 205

Dichelostemma congestum, 183,184

Dichondra carolinensis, 509

Dicotylerlons, Cytokinesis of the pollenmother-cells of certain, 253

Dict yopteris polypodioides, 108

Dictyota, I08, 122, 123, 255, 259, 260; dichotoma, 105, I06, I08-112, 115 , I 6 , I I 8 ; linearis, I 8

Didymium, 26 I

Dimerosporium melioloides, 507

Diorchidium Tracyi, 201
Dipterostemon capitatus, 182,183 ; pauciflorus, 183

Dirca, 163

Directing factors in the teaching of botany, 33

Distichlis spicata, 85,86

Diurospermum, 50

Dodecatheon, 195; cruciatum, 195; Hendersonii, I95; latifolium, 195; "Mleadia," 195

Dodonaea Ehrenbergii, 575

Drimys, 27-30; axillaris, 29-3I ; colorata, 29-31; Muelleri, 27; vascularis, 27; IVinteri, 29-3I

Drimys specialized or primitive types? Are Tetracentron, Trochodendron and, 27

Drosera, $134,137,142,282,306$; binata, I30, I38; filiformis, 130, I32-134, 136I 38 , I 46 ; intermedia, I30, I32, I34, 137, I 38, I41, I46; longifolia, 125, 129I33, I38, I I, I 47 ; obovata, I25, I26, 128 , I +1 ; rotundifolia, I25, I30-132, $134,137,138,141,146,172$

Drosera, Somatic and reduction divisions in certain species of, 125

Drudeophytum Hartwegii, 192

Dryas octopetala, 170

Dryopteris simulata, 81

Echinis, 433

Echinocactus, 49I

Echinocereus, 49I

Echinopanax horrida, 482

Ecology and the new soil fertility, Plant, 319

Ectocarpus solitarius, 108

Elachistea, I08; stellulata, I06, 108 I $10-112$, I I 5, I 18

Elaeodendron xylocarpum, $57 t$

Embryo-sac and pollen grain as colloidal systems, The, $56 \mathrm{I}$

Empetrum nigrum, I 70

Endemism as a criterion of antiquity among plants, 161

Enskide, 54

Ephedra, 254, 269, 493

Epidendrum, 567; papilionaceum, 570

Epigaea repens, 139

Epilobium, 272, 305

Epipactis, 254, 305

Equisetum, 267,304, 308, 46I, 463,464 arvense, 464; arvense boreale, 46I; Funstoni, 47r; Funstoni caespitosum, 471 ; Funstoni polystachy'um, 47 I hyemale, 463, 468; hyenale affine, 468 ; hyemale californicum, 465, 467; hyemale Doellii, 455 ; hyemale Drummondi, 467; hyemale herbaceum, 47 I ; hyemale intermedium, 468, 470 ; hyemale prealtum, 467 ; hyemale pumilum, 468; hyemale robustum, 467 ; hyemale Suksdorfi, 468; hycmale texanum, 469 ; laevigatum, 461, 469; laevigatum poly- 
stachyum, 472; laevigatum scabrellum, 469; laevigatum variegatoides, $47 \mathrm{I}$; limosum, 466, 469; prealtum, 467; ramosissimum, 463; robustum, 46I, 467 ; robustum affine, 467 ; robustum minus, 467 ; scirpoides, 467 ; variegatum, 466; variegatum alaskanum, 466; variegatum anceps, 466; variegatum Jesupi, 465; variegatum Nelsoni, 472

Eragrostis ciliaris, 568; Urbaniana, 569

Erigenia bulbosa, I9I

Erinella rhaphidophora, 506

Eriogonum, I 63, 49I, 494

Erioneuron pilosum, 49I

Eriophyllum, I63

Erithalis fruticosa, 578

Ernodea littoralis, 578

Erythrocladia, II3, II4, I20; irregularis, I I 2, I I3; recondita, I I, I I 4-I I 6, I 20-I 22; vagabunda, I I 5, I I 6, I I 8 , I 20-I 22

Erythrotrichia, I I3, I I4; carnea, I I4; obscura, II 4

Eschscholtzia 34I, 342, 402-404, 407, 417-4I9, 422, 562; californica, 339, $344,440,446,562$

Euarthonia, 580

Eubotrys racemosa, 8I

Eugenia, 567; axillaris, 576

Eupatorium ageratoides, 205; urticaefolium, 205

Euphorbia articulata, 574; corollata, I 26

Eurotia, 488

Evolvulus glaber, 577; sericeus, 577; squamosus, 577

Exogonium arenarium, I96

Exploration in Southern Florida, Recent, 475

Fallugia, 493

Farr, Clifford Harrison. Cytokinesis of the pollen-mother-cells of certain dicotyledons, 253

Farwell, Oliver Atkins. The genus Hippochaete in North America, north of Mexico, 46I

Fegatella, 266, 304

Fendlera, 493

Fern monstrosity, A fossil, 473

Fertility, Plant ecology and the new soil, 3 I 9

Fertilization of beets, Self, close and cross, I 49

Ferula dissoluta, I93; multifida, I9I; purpurea, I9I

Festuca, 515

Fimbristylis inaguensis, 569

Fimetaria fimicola, 508; hyalina, 508

Flora of Mammoth Cave, Kentucky, Observations on the, 65

Flustra foliacea, I I4

Foeniculum, 504; Foeniculum, 507

Fomes applanatus, 67; Sagraeanus, 510

Fossil fern monstrosity, A, 473
Fossombronia, 266

Fourcroya macrophylla, 509

Fraxinus anomala, 478 , 493; campestris, 485

Freesia, 27 I, 305

Fritillaria, 27I, 305

Fruit of Pyrus Malus, The nature of the inflorescence and, 5 I9

Fuchsia, I 26

Fucus, I06, 256, 260, 264

Fuligo, 26I

Funaria, 267, 304

Fungi, Bermuda, 50 r

Funkia, 272, 305

Furcraea, 567; tuberosa, 570

Fusarium, 551, 555-557, 559

Gager, C. Stuart. Present status of the problem of the effect of radium rays on plant life, I 53

Galium Aparine, I77, 203; boreale, I70

Galtonia, 27 I, 272; candicans, 129

Garrya, I63

Gasteria, 27 I, 305

Gaylussacia frondosa, 8I

Geaster saccatus, 5 I I

Genlisea, 4I, 48, 64; aurea, 48; filiformis, 48

Geoglossum nigritum, 502, 505; pumilum, 505

Gilia californica, 200; ciliata, I99; gracilis, 200; Nuttallii, 200

Ginkgo biloba, 29, 31

Gladiolus, 35 I

Glaucium, 276

Glyphis cicatricosa, 580

Gnaphalium californicum, 206; decurrens, 206; leptophyllum, 206; leucocephalum, 206; margaritaceum, 206; obtusifolium, 206; oxyphyllum, 206; polycephalum; 206; semiamplexicaule, 206

Gnetum, 27

Goniotrichum, I I4

Gonium, 300

Gorgoniceps Pumilionis, 506

Gossypium, 307

Graves, Arthur H. A botanical trip to North Wales in June, I67; Chemotropic reactions in Rhizopus nigricans, 323

Graya, 494

Grossularia odorata, 490; setosa, 485

Growth, The mechanism and conditions of, 5

Gundlachia corymbosa, 579

Gyminda latifolia, 574

Gymnoascus setosus, 68

Gymnopilus penetrans, 510

Gymnosporangium, I 78, 245-249, 25I ; asiaticum, 247, 249; bermudianum, 5I0; Blasdaleanum, 250, 25I; chinense, 247, 249; fraternum, 249; Haraeanum, 247,249 ; japonicum, 245-247, 249; koreaense, 248-250; macropus, 516; 
Miyabei, 252; Nidus-avis, 246; nootkatense, 178; Photiniae, $246,247,249$, 250 ; spiniferum, 246; solenoides, 252 ; Yamadae, 250

Gymnosporangium, Japanese species of, 245

Hamamelis, 283,307 ; virginiana, $8 \mathrm{I}$

Hamulia, 60

HARPER, R. A. On the nature of types in Pediastrum, $9 \mathrm{I}$

HARRIS, J. ARTHUR. A tetracotyledonous race of Phaseolus vulgaris, 229

Haworthia, 27I, 305

Helianthus, 8, 25, 285, 302, 307, 515; annuus, 284; globosus, 8

Helicoma larvula, 509

Helicopsis helianthoides, 205; scabra, 205

Helleborus, 269

Helminthosporium Ravenelii, 509

Helvella crispa, 129

Hemerocallis, 258, 27I, 273, 302, 305; flava, 347 ; fulva, 126,127

Hemizonia, I63

Hesperis, 306; matronalis, $28 \mathrm{I}$

Heuchera, 163

Heyderia, 25I; decurrens, 250

Hieracium, 306; venosum, 282

Hippochaete, $462-464$; hyemalis, 462465; hyemalis alaskana, $462,464,466$; hyemalis californica, 462, 464, 465, 468; hyemalis Jesupi, 463-465, 472; laevigata, 462, 463,465, 466, 468-472; laevigata Eatonii, 465, 470; laevigata Funstoni, $463,465,471$; laevigata polystacliya, 465,471 ; Nelsoni, 465 , 472 ; prealta, $462-464,467-470$; prealta affinis, $462,464,467-470$; prealta intermedia, $465,468,470$; prealta scabrella, 465,469 ; prealta Suksdorfi, 465,468 ; ramosissima, 463 ; scirpoides, $462-464,466,467$; variegata, 462, $464-467,469$; variegata anceps, 463 , 464,466

Hippochacte in North America, north of Ilexico, The genus, 461

Hirneola coffeicolor, 510

Hollick, Arthur. A fossil fern mon. strosity, 473

Hookera pulchella, $\mathbf{1} 83, \mathbf{1} 84$

Houttuynia, 278, 306

Howe, MARSHALL Avery, and WilliaM DANA Hoyt. Notes on some marine algae from the vicinity of Beaufort, Vorth Carolina, 105

Hoyt Wr Wliam DaNa, Marsilall Avery Hows: and, Notes on some marine algae irom the vicinity of Beaufort, North Carolina, 105

HuMPIIEYS, EDwix IV. Triassic plants from Sonora, Mexico, including a Veocalamites not previously reported from North America, 75

Hydrion, 61,63
Hydrocybe Cantharellus, 510; conica, 510

Hymenopappus, 163

Hymenophyllum IVilsoni, I 70

Hymenostomum Breutelii, 579

Hypholoma fasciculare, $22 \mathrm{I}$; sublateritium, 22 I

Hypocrea patella, 507

Hypoxylon fuscopurpureum, 508; fuscum, 508; investiens, 508; multiforme, 508

Hysterographium lineolatum, 506; praelongum, 506

Ibidium lucayanum, 570

Ilex glabra, 81 ; laevigata, 81 ; verticillata, $8 \mathrm{I}$

Ilicioides mucronata, 8 I

Inflorescence and fruit of Pyrus Malus, The nature of the, 519

Inheritable variations in the yellow daisy (Rudbeckia hirta), 89

Investigation and control of plant diseases, Cooperation in, 5 I 7

Ipomoea, I 73, 196, 197, 284, 306, 342, 415, 417, 418, 509; acuminata, 196; arborescens, I98; arenaria, I96; carolina, 196, I98; caroliniana, 196; cathar tica, 196; commutata, 196; fastigiata, 196; fistulosa, 197; intrapilosa, 197. 198; Jalapa, 196; murucoides, 198; purga, 196; purpurea, 196; Steudeli, 196; tiliacea, 196; trichocarpa, 196; tricolor, 281; triloba, 196; Wolcottiana, 197

Iris, 270, 271, 275, 305; pumila, 126

Isaria felina, 509

Isoetes, 268, 269, 304, 308; lacustris, I 7 I

Isoloba, 46,47

Iva, 84; axillaris, 204

Ixia, 27 I, 305

Jacquemontia reclinata, 577

Jacquinia Barbasco, 576

Japanese species of Gymnosporangium, $2+5$

Jasminum, 504, 508

Juncus Gerardi, 85

Juniperus, 247; barbadensis, 510; chinensis, 245-250; communis, I70; communis montana, I 70 ; virginiana, 84

Karschia lignyota, 506

Kellerman, Kard F. Cooperation in the investigation and control of plant cliseases, 517

KERN, FRANK D. Japanese species of Gymnosporangium, $2+5$

Knowlerlge of silver scurf (Spondylocladium atrovirens Harz) of the white potato, $A$ contribution to our, 549

Kioeleria niticla, 490

Krigia, I63

Laboullenia, 68; subterranea, 66, 68 
Lachnea pulcherrima, 505; theleboloides, 505

Laguncularia racemosa, 576

Laminaria, 537

Lamprospora Planchonis, 505

Lantana involucrata, 577; odorata, 504, 507,509

Larix, 256, 284, 305; laricina, 480; Lyallii, 480,481 ; occidentalis, 483

Lasiobolus equinus, 506

Lasiosphaeria pezizula, 508

Lathyrus, 283, 306; odoratus, 28 I

Laurus Culilaban, 567

Lavatera, 279, 306, 307

Leavenworthia, 163

Lecticula, $44,57,58,64$; resupinata, 57 , 58; Spruceana, 58

Lentibularia, 39,60

Lentibulariaceae, Segregation of genera in, 39

Lepargyraea canadensis, 48 I

Lepiactis, 60

Lepiota, 2I4, 222; clypeolaria, 2I5, 222; cristata, 2 IO $, 2 \mathrm{I} 3,2 \mathrm{I} 6,22 \mathrm{I}-224,226$; naucina, 510 ; seminuda, $210,213,216$, 2 I $8,222-224,226,227$

Lepiota cristata and Lepiota seminuda, The development of, 209

Lepiota seminuda, The development of Lepiota cristata and, 209

Leptodactylon californicum, 200; Nuttallii, 200

Leptotaenia, I93; dissecta, I93; Eatonii, I90; multifida, I9I ; purpurea, I9I

Lesquerella, I63, 49I

Levine, Michael. Somatic and reduction divisions in certain species of Drosera, I25

Libocedrus decurrens, $25^{\circ}$

Lilium I 34, 255, 269, 27 I, 272, 280, 284, $305,336,442$; bulbiferum, 351 ; canadense, 8I, I28; candidum, I29

Limax, 262

Limonium carolinianum, 85,86

Limosina stygia, 67

Linanthus ciliatus, 200

Linnaea americana, 48I

Linum catharticum, I55; grandiflorum, $442,444,447$

Lipuan, ChAs. B. Plant ecology and the new soil fertility, 3 I9

Lippia, 507

Liriodendron, 27 I, 277

Litanthus, 42

Lithophila muscoides, $57 \mathrm{I}$

Littorella lacustris, I7I

Lloyd, Francis E. The embryo-sac and pollen grainas colloidal systems, 56I

Lloydia serotina, I 7 I

Lobelia Dortmanna, I7 I

Lomatium foeniculaceum, I90; Grayi, I90; macrocarpum, I90; orientale, I90; platycarpum, I90; Suksdorfii, I90; triternatum, I90
Lonchocarpus violaceus, 509

Lonicera, $48 \mathbf{I}$

Ludwigia alternifolia, 189; glandulosa, I 89 ; hirtella, r 89 ; palustris, I89; polycarpa, I89; sphaerocarpa, I89; virgata, I 89

Lychnis dioica, I69

Lycium americanum, 578

Lycopodium, 268

Lygodesmia, I63

Lymantria dispar, 72

Lythrum, 336, 433, 44I, 444; Salicaria, $44 \mathrm{I}, 443,444,447$

MacDougal, D. T. The mechanism and conditions of growth, 5

Maclura, 163

Macroceras, 53

Macrosporium Solani, 509

Macrotaeniopteris, 76 ; magnifolia, 76

Madia, 163

Magnolia, 80, 8I, 27 I , 277, 278, 28 I

Mallotonia gnaphalodes, 577

Malpighia, 567; angustifolia, 567; coccifera, 567 ; linearis, 567,573 ; urens, 567

Malus, 250, 536; Malus, 250; spectabilis, 250; Toringo, 250

Mammoth Cave, Kentucky, Observations on the flora of, 65

Managing a botanic garden, Some things learned in, $5 \mathrm{I} 3$

Marasmius, 222; bermudensis, 5 ro; minutus, 510; obscurus, 510; praedecurrens, 5I I; Sabali, 5 Io

Marine algae from the vicinity of Beaufort, North Carolina, I05

Mariscus jamaicensis, 507, 509

Marsilea, 268, 304

Matricaria Chamomilla, I29, 283

Matthiola, 335

Mechanism and conditions of growth, The, 5

Medicago denticulata, 509

Megozipa, 60

Meionula, 50, 52

Melanospora ornata, 555

Meliola Cookeana, 507 ; circinans, 507

Meloneura, 42, 43, 45, 50, 5I, 64; purpurea, 50; striatula, $50,5 \mathrm{I}$

Menyanthes trifoliata, I 7 I

Mercurialis, 7I, 73, 74; a nnua, 70-74

Mercurialis annua, Observations on inheritance of sex-ratios in, 69.

Merrick, Long Island, and its significance, A white-cedar swamp at, 79

Mertensides, 76 ; bullatus, 76

Mespilus, 535

Micranthemum, 63

Microascus longirostris, 68

Microchaete nana, I05, I06, III, II5, I 8 , I 22; purpurea, I06; vitiensis, I06

Microseris, I63

Microsteris gracilis, 200; humilis, 200; micrantha, 200 
Mimosa, 567

Mimulus, $342,+15,417,418$

Mirabilis, 279, 306; Jalapa, 336; longiflora, 336

Mitchella repens, $8 \mathrm{I}$

Momordica, 306; Elaterium, 273

Monbretia, 271, 305

Monstrosity, A fossil fern, 473

Montia asarifolia, I84; siberica, 184

Mougeotia, 260, 265

Mucor, 66, 502, 505; Mucedo, 66, 68

Musa, 273; 305; sapientum, I27

Musenion tenuifolium, 194

Musineon divaricatum, I9I ; Hookeri, 19r ; tenuifolium, I94; trachyspermum, I9I

Myriact is stellulata, i Io

Myrica carolinensis, 84 ; Gale, I 72

Myriophyllum, 63

Naias, 305; major, 270

Nature of types in Pediastrum, On the, 9I

Navicula, 66

Nectria Lantanae, 503, 507; sanguinea, 507

Neevea, IIt

Negundo interior, 485

Nelipus, 54

Nemopanthus, I63; mucronata, 81

Neobeckia, 6; aquatica, 6

Neocalamites Carrerei, 77,78

Neocalamites not previously reported from North America, Triassic plants from Sonora, Mexico, including a, 75

Neotoma, 66

Neottia, 305; ovata, 270

Nepenthes, 538

Nephrolepis exaltata, 473,474

Nereis, 432,433

Nicotiana, $137,282,285,286,290,293^{-}$ $295,297,301,302,307,3$ I $6,340,358$, $360,407,409,422$; alata grandiflora, 358 , 420, 423; Forgetiana, 358, 420, 423; paniculata, 423; rustica, 423; Tabacum, 284

Nigredo Medicaginis, 509; proeminens, 509

Nolina, 49I

North America, north of Mexico, The genus Hippochaete in, 461

North American species of Allodus, I 73

North Wales in June, A botanical trip to, I 67

Norton, J. B. S. Variation in Tithymalopsis, 455

Notes on some marine algae from the vicinity of Beaufort, North Carolina, 105

Nunmularia Bulliardi, 508

Nymphaea, 270, 276, 306

Nyssa, 82, 84; sylvatica, 80

Observations on inheritance of sex-ratios in Mercurialis annua, 69
Observations on the flora of Mammoth Cave, Kentucky, 65

Odostemon aquifolium, 482

Oedipodium Griffithianum, I 72

Oedogonium, 258, 537

Oenothera, $134,273,284,306,307,364$; biennis, 129; gigas, I27, I28, I29; Lamarckiana, 127, 335; lata, 127, 335; semilata, 127

Oleander, 509

On the nature of types in Pediastrum, 9I

Oospora rosea, 555

Ophiobolus acuminatus, 509

Opuntia, I4, 49I, 509; arborescens, 49I ; Blakeana, $14,15,18,19,22$; discata, I 1, 22, 26; fragilis, 490; polyacantha, 490

Orbilia chrysocoma, 506

Orcheosanthus, 46, 47

Orchis, 305; Morio, 270

Orchyllium, 53-56, 64; alpinum, 53, 55

Oreoxis humilis, 194

Orthocarpus, I 63

OrToN, C. R. North American species of Allodus, 173

Osmunda, 267, 304

Ostrya virginica, 485,489

Otozamites Macombii, 77

Oxalis Acetosella, I 70

Oxyria digyna, I68

Pachira, 229

Pachystima Myrsinites, 482

Padus, 49I; melanocarpa, 486, 490; valida, 486

Pallavicinia, 266, 304

Palissya, 78

Panaeolus campanulatus, 5 I I

Panicularia obtusa, 81

Panicum, 515; geminatum, 568

Papulospora, 68

Parnassia, 282, 307

Parthenocissus quinquefolia, 8I

Paspalum Helleri, 569

Passiflora, 274, 275, 306, 35I: alata, 351: caerulea, I 26; suberosa, 575

Patellaria atrata, 506

Pecopteris bullata, 76 ; falcatus, 76

Pediastrum, 9I-93, 95, 102-104; Boryanuin, 91, 94, 95, 97-100, 102, 104

Pediastrum. On the nature of types in, 9 I

Pedicularis canadensis, 202 ; centranthera, 202 ; scmibarbatus, 202

Pelargonium, 335

Peliclnia, 42, 50-52, 64; caerulea, 50, 5 I

Pellia, 265, 304

Peltandra, 272, 305

Pemphiginia, 62, 63

Penicillium, 325

Pentstemon, $\mathrm{I}_{3} 3,482$; chionophilus, 202; confertus, 202; Harbourii, 202; humilis, 202; Menziesii, 202; Newberryi, 202; ovatus, 202 ; pinctorum, 202

Periola tomentosa, $55+$ 
Persicaria punctata, 509

Personula, 54

Petradoria, 493

Petunia, 335

Pestalozzia Guepini, 509

Peucedanum foeniculaceum, I90; Grayi, I90; macrocarpum, I90; nevadense, I90; nudicaule, I90; simplex, 190, I9I; Suksdorfii, I90; triternatum, I90

Phabartis cathartica, I96

Phaeostroma, I I0; pusillum, 106; 108-I I I, I I 8, I 2 I ; pustulosum, I IO

Phascum, 267

Phaseolus, 255; vulgaris, 242, 243

Phaseolus vulgaris, A tetracotyledonous race of, 229

Phegopteris Dryopteris, I70; polypodioides, I 70

Phellomyces, 549, 55I-553, 558; sclerotiophorus, 549-552, 554, $55^{8}$

Phellopterus montanus, I9I

Philoxerus vermicularis, $57 \mathrm{I}$

Phlox alyssifolia, I99; depressa, I99; diapensioides, 199; diffusa, 199; divaricata, 200; Douglasii, I99; longifolia, 200; multiflora, 200; speciosa, 200; Stansburyii, 200

Phoma leguminum, 509; Fourcroyae, 509; Musarum, 509

Phormidium, I I 7

Photinia laevis, 246 ; villosa, 246

Phycomyces, 8, 23, 25

Phycophila stellulata, I I0, I I I

Phyllanthus polycladus, 573

Phyllaria, 50

Phyllosticta Ipomoeae, 509; Opuntiae, 509

Physalis angulata, 578

Picea, 269; albertiana, 483; canadensis, 480; Engelmanni, 478, 480, 481, 483; Mariana, 480; Parryana, 478,483

Pictetia aculeata, 567, 573

Pilea tenerrima, 570; trianthemoides, 570

Pilobolus crystallinus, 502, 505

Pimpinella Saxifraga, 170

Pinguicula, 40, 4I, 44, 46, 63, 64; caudata 46; crenatiloba, 46, 47; lusitanica, 46; pumila, 46; vulgaris, 46 , I 72

Pinus, 269, 305 ; albicaulis, $480,481,483$; aristata, $478,480,48 \mathrm{I}, 483$; Banksiana, $48 \mathrm{I}$; edulis, $478,487,493$; flexilis, 478 , 483 ; monophylla, $478,487,493$; montana, 480; monticola, 483, 496; Murrayana, 478,483 ; palustris, $29,3 \mathrm{I}$; ponderosa, 483, 488; resinosa, $48 \mathrm{I}$; scopulorum, $478,481,483,485,486$, 488, 497; Strobus, $48 \mathrm{I}$

Pionophyllum, 46,47

Pisonia subcordata, 57 I, 580

Pisum, 306; sativum, $28 \mathrm{I}$

Pithecolobium Unguis-cati, 572

Pithya Cupressi, 505

Plagiochasma, 266

Planera, I63
Plantago, 427; lanceolata, 73, 427; major halophila, 85; maritima, 85,86

Plant diseases, Cooperation in the investigation and control of, 5 I 7

Plant ecology and the new soil fertility, 319

Plant life, Present status of the problem of the effect of radium rays on, I53

Plectoma, 60

Pleiochasia, 42, 5I-53, 64; dichotoma, $5 \mathrm{I}, 53$

Plesisa, 60

Pleurage anserina, 508; fimiseda, 508; vestita, 508

Pleurotopsis niduliformis, 5 I I

Pluchea purpurascens, 579

Plumiera alba, 576

Poa, 5 I 5

Podophyllum, 280, 306, 307; peltatum, I 78,187

Poinsettia heterophylla, 509

Pollen grain as colloidal systems, The embryo-sac and, 56I

Pollen-mother-cells of certain dicotyledons, Cytokinesis of the, 253

Polygala hectacantha, 573

Polygonum, 5 I 5

Polypodium, 267; vulgare, I29

Polypompholyx, 41, 49; laciniata, 50

Polyporus arcularius, 5 I I ; obliquus, 5I I

Polysiphonia urceolata, I I 2, I I 3

Polytrichum, 294

Populus, $478,483,488$; acuminata, 485 , 487 ; angustifolia, $483,485,487$; aurea, 482; balsamifera, 48r, 483; Fremontii, 478; Sargentii, 485,487 ; tremuloides, $480,481,483$; trichocarpa, 483 ; IVislizeni, 478,487

Poronia Oedipus, 509

Portulaca halimoides, $57 \mathrm{I}$; oleracea, $57 \mathrm{I}$

Potamogeton, 272, 305

Potentilla, I27, 279; canadensis, 172; pumila, I72; Tormentilla, I72

Pourthiaea, 246, 249; villosa, 245, 246, 250

Present status of the problem of the effect of radium rays on plant life, I 53

Primula, 283, 285, 302, 303, 306, 433, 44I, $442,444,445$; kewensis, 129; sinensis, $284,342,444,450$; veris, $169,34^{2}, 444$ Propolis faginea, 506

Prosopis, 494

Prunus, 536; americana, 485 ; melanocarpa, 485

Pseudocymopterus anisatus, I94; bipinnatus, 194

Pseudotsuga mucronata, $478,483-486$

Psilotum, 268, 304

Ptelea, I63

Pteris, 254, 267, 304

Pterospora, I 63

Pteryxia calcarea, I9I; terebinthina, I9I

Puccinia aculeata, I86, I 87; ambigua, 203; anachoreta, I 8I; arabicola, I99; areolata, I86; asperior, I93; aurea, 
I 87; Batesiana, 204; Bouvardiae, 202; Calochorti, I8I; Carnegiana, I82; Chamaesarachae, 20I; Cladii, 504, 509; claytoniata, i 84 ; commutata, 203; consimilis, I87; crassipes, I96; Cryptotaeniae, 192; Cymopteri, 190; deBaryana, I 85; depressa, I99; Desmanthodii, 206; Dichelostemmae, I 83; Dichondrae, 509: difformis, 203; Douglasii, 198; effusa, I88; fragilis, I99; gigantispora, I85; giliicola, I99; graminella, I 80; Holboellii, I\&8; Holwayi, I8I; imperspicua, I89; insignis, I97; intermixta, 204; investita, 205; Ipomoeae, 196; japonica, I 86; Jonesii, I90; Lantanae, 509; Lindrothii, I92; Ludwigjae, I89; Mariae-IVilsoni, I 84; melanconioides, I94; mellifera, 200; microica, 192; Moreniana, I82; Musenii, I93; Nesacae, I89; nocticolor, I97; nodosa, I82, I 83; obtegens, 176 ; opulenta, I95; oregonensis, 193: pagana, I81; Palmeri, 202; plumbaria, I99; plumbaria phlogina, I99; Podophylli, 176, 178, 186, 187; Polygoni-amphibii, 509; purpurea, 5 ro Purpusii, I99; Richardsoni, I98; rufescens, 202; Saniculae. 194; Seymourii, I93; sphalerocondra, I92; subangulata, I 83; subcircinata, 206; subulata, I99; superflua, 198; Swertiae, I95; tenuis, 205; Traversiana, I90; tumamocensis, 183; vertisepta, 201; Wilcoxiana, I99 Pyrola, 48 I

Pyronema omphalodes, 503, 506

Pyrus, 245, 250, 524, 534, 535; Aucuparia, 170; Mlalus, $245,250,519,524,526$; Miyabei, 25I, 252; sinensis, $245^{-247}$, 249 ; spectabilis, 250; Toringo, $25^{\circ}$

Pyrus Malus, The nature of the inflorescence and fruit of, 5 I9

Pyxine Meissneri, 580

Quercus, 493; Gambelii, 478, 487; macrocarpa, 485,489 ; rubra, 80 ; stellata, 84 ; undulata, 478

Quinquelobus, 63

Race of Phaseolus vulgaris, A tetracotyldeonous, 229

Radium rays on plant life, Present status of the problem of the effect of, 153

Rafflesia, 271, 276, 281, 305

Ramalina denticulata, 580

Randia aculeata, 578

Ranunculus Flanmmula, $17 \mathrm{I}$

Reactions in Rhizopus nigricans, Chemotropic, 323

Recent exploration in southern Floricla, 475

Rerluction divisions in certain species of Drosera, Somatic and, 125

Reserla, 350, 358, 402, f04, 407, 417-419, 427; lutea, 339, 340; odoratá, 339-3+1 Reynosia uncinata, 575
Rhacoma crossopetalum, 574

Rhizomorpha molinaris, 67,68

Rhizophora Mangle, 509, 567, 576

Rhizopus, 324-326; nigricans, 325

Rhizopus nigricans, Chemotropic reactions in, 323

Rhododendron, $8 \mathrm{I}, 480$; maximum, 80

Rhus, 49I; copallina, 84 ; trilobata, 485 , 486,490

Ribes, 279, 306, 487; Gordonianum, I27; inebrians, 485,486 ; odoratum, 485

Riccardia, 266

Robinia, I63; neomexicana, 486 ; squamata 567

Rocky Mountain region, Vegetative life zones of the, 477

Roestelia, 246, 250, 252; koreaensis, 245-249; Photiniae, 246,250 ; solenoides, 25I ; solitaria, $25 \mathrm{I}$

Rosa, 487 ; carolina, 84

Rosellinia mammaeformis, 508 ; subiculata, 508

Rozites gongylophora, 222

Rubus hispidus, $8 \mathrm{I}$; saxatilis, I70

Rudbeckia, I 63

Rudbeckia hirta, Inheritable variations in the yellow daisy, 89

RyDBERG, P. A. Vegetative life zones of the Rocky Mountain region, 477

Sabal, 5 I 0, 569; Blackburnianum, 506, 509

Sabbatia stellaris, 86

Sabina occidentalis, 493; monosperma, $478,487,493$; scopulorum, 478, 483, $485,486,488$; utahensis, 478,487

Saccharum officinarum, 510

Saccobolus Kerverni, 506

Salicornia ambigua, 57 I; europaea, 85; perennis, $57 \mathrm{I}$

Salix, $478,483,488$; herbacea, I 70

Salvia ballotaeflora, 20I; mellifera, 200; micrantha, 577 ; serotina, 577 ; Sessei, 201 ; spathacea, 200

Sambucus, 48I; canadensis, 81

Sanguisorba canadensis, 86

Sanicula, 192, I93; marilandica, I94

Saprolegnia, 256

Sarcobatus, 494

Sarcomphalus domingensis, 575

Sarcoscypha minuscula, 503, 506

Sargassum vulgare, I 8

Sarracenia, I63, 307

Sassafras, 80,163

Saxifraga oppositifolia, I68; stellaris, I72

Scaevola Lobelia, 567; Plumicri, 567, 578

Schizandra chinensis, 29, 3 I

Schizoncura Carrerei, 77

Schizophyllum alneus, 5 I I

Schoepfia obovata, 570

Scleropogon brevifolius, 490

Sclerotium, 553; bataticola, 553; durum, 554; Semen, 509

SEAVER, Frei) J. Bermuda fungi, 501

Secale, $3+6,422$; cereale, 346 ; montanum, $34^{6}$ 
Sedum roseum, 168

Segregation of genera in Lentibulariaceae, 39

Self- and cross-pollinations in Cichorium Intybus with reference to sterility, 333

Self, close and cross fertilization of beets, I 49

Senecio atriapiculatus, 207; crassulus, 207; cruentus, 339, 340; dispar, 207; hydrophilus, 207; hydrophilus pacificus, 207; integerrimus, 207; lugens, 207; taraxacoides, 207 ; triangularis, 207

Septoria oleandrina, 509

Sericocarpus, 163

Serjania polyphylla, 575

Setiscapella, $42,57,64$; subulata, $57,5^{8}$

Sex-ratios in Mercurialis annua, Observations on inheritance of, 69

Shaw, Harry B. Self, close and cross fertilization of beets, 149

Sida ciliaris, 575

Silene acaulis, I68, I70

Silphium, I 63

Silver scurf (Spondylocladium atrovirens Harz) of the white potato, A contribution to our knowledge of, 549

Sinnot, Edmund W. Endemism as a criterion of antiquity among plants, $16 \mathrm{I}$

Sisyrinchium, 27 I, 305; linifolium, I 88

SMALL, JOHN K. Recent exploration in southern Florida, 475

Smilax glauca, 8 ; ; rotundifolia, $8 \mathrm{r}$

Soil fertility, Plantecology and the new, 3 I9

Solanum persicifolium, 578; tuberosum, 509,554

Solidago, 163,463 ; sempervirens, 85,86 ; Virgaurea, 169

Somatic and reduction divisions in certain species of Drosera, 125

Some things learned in managing a botanic garden, $5 \mathrm{I}_{3}$

Sonora, Mexico, including a Neocalamites not previously reported from North America, Triassic plants from, 75

Sophera tomentosa, 573

Sorbus, 252; alnifolia, 252; Aria, 252

Southern Florida, Recent exploration in 475

Spartina cynosuroides, 85 ; patens, 85,86

Spathyema foetida, $8 \mathrm{I}$

Species of Allodus, North American, I 73

Species of Drosera, Somatic and reduction divisions in certain, $\mathbf{1} 25$

Species of Gymnosporangium, Japanese, 245

Spermacoce tenuior, 578

Sphacelaria, 259, 260, 264

Sphaerostilbe flammea, 507

Spirogyra, 103, 109, 258-260, 269, 277

Spondylocladium atrovirens, $549-552$, $554-560$

(Spondylocladium atrovirens Harz) of the white potato, A contribution to our knowledge of silver scurf, 549
Sporobolus angustus, 509; argutus, 568; virginicus, 568

Sporormia intermedia, 508; minima, 508 Sporotrichum densum, 68; flavissimum, 68 Stanleya, I63

Status of the problem of the effect of radium rays on plant life, Present, I53

Staysanus Stemonitis fimetarius, 509

Stereum hirsutum, 5I I; radians, 5II

Sterility, Self, and cross-pollinations in

Cichorium Intybus with reference to, 333

Stictis graminum, 506; radiata, 506

Stigmaphyllon lingulatum, 573

Stilbocrea hypocreoides, 507

Stipa, I8I; eminens, I 81

Stomoisia, $44,52,55,64$; cornuta, 54,55

Stout, A. B. Self- and cross-pollinations in Cichorium Intybus with reference to sterility, 333

Streblonema, I08; solitarium, I06, I08I I0, I I 2, I I 5, I 8

Streptotheca, 503

Stropharia a mbigua, 22 I

Strumpfia maritima, 578

Stylosanthes hamata, 573

Suriana maritima, 567,573

Swamp at Merrick, Long Island and its significance, A white-cedar, 79

Swertia, I95; palustris, I95; perennis, I95; scopulina, 195

Swietenia Mahagoni, 29, 31

Symphoricarpos, I63, 48I, 487 ; occidentalis, 485,490

Symplocarpus, 272, 305

Synchytrium, 26r

Syringa, 137, 279, 280, 306, 307; persica, I27; rothomagensis, 127 ; vulgaris, 127

Tabebuia heterophylla, 567,578

Tanacetum, 282

Taonia atomaria, 108

Taraxacum, 281, 282, 306, 363

TAubenhaus, J. J. A contribution to our knowledge of silver scurf (Spondylocladium atrovirens Harz), of the white potato, 549

Taxus brevifolia, 483

TAILOR, Norman. A white-cedar swamp at Merrick, Long Island, and its significance, 79

Temnoceras, 46,47

Tetracentron, 27-3I ; sinense, 29, 3I, 32

Tetracentron, Trochodendron and Drimys specialized or primitive types? Are, 27

Tetracotyledonous race of Phaseolus vul-

Tetradymia, 488,494 garis, A, 229

Tetralobus, 49

Tetramicra elegans, 570

Tetraploa aristata, 509

Tetraspora, 258

Thalictrum alpinum, 169

Thecotheus Pelletieri, 506

Thelypodium, 163 
Thompsox, IV. Gilmax. Address of welcome, I

Thompsox, IT. P., and 1. WT. Bailey. Are Tetracentron, Trochodendron and Drimys specialized or primitive ty pes? 27

Thrinax Morrisii, 569

Thuya plicata, 483 ; occidentalis, 481

Tillandsia utriculata, 569

Tissa marina, 85

Tithymalopsis, 455 ; arundelana, $455^{-}+5^{8}$; corollata, $455,45 \%,+58$; I pecacuanhae, $455^{-}+57$; marylandica, 455,457 ; zinniiflora, $457,45^{8}$

Tithymalopsis, Variation in, 455

Torenia, 562

Townsendia, 163

Toxicodendron radicans, 8I; Rydbergii, 490 ; Vernix, 8 I

Tradescantia, 263,271, 281, 305

Tranzschelia punctata, 5 Io

Tremella koreaensis, 249

Triadenum virginicum, $8 \mathbf{I}$

Triassic plants from Sonora, Mexico, including a Neocalamites not previously reported from North America, 75

Trichoglossum hirsutum, 502, 505; hirsutum Wrightii, 502, 505

Trichomanes, i 70

Trientalis a mericana, $8 \mathbf{I}$

Trifolium, 5I5; pratense, 338

Trillium, 272, 305

Trilobulina, 60

Trip to North Wales in June, A botanical, I 67

Trixapias, 54

Trochodendron, 27, 29-31 ; aralioides, 29, 31,32

Trochodendron, and Drimys specialized or primitive types? Are Tetracentron, 27

Trollius europaeus, 169

Tropaeolum, 275, 28I, 285, 302, 303, 306-308; majus, 275,284 ; minus, 275

Troximon, 163

Trutta, 262

Tsuga heterophylla, $48 \mathrm{I}, 483$

Types in Pediastrum, On the nature of, 91

Tyromyces graminicola, 5 I I

Udotea cyathiformis, 105

Ulmus americana, 485,489

Ulothrix, 259

Ulva, 567

Umbellularia, 16.3

Unifolium canadense, 8 I

Urechites lutea, 576

Uredo nootkatensis, 251

Uromyces Behenis, I77; Glycyrrhizae, I 76; Scrophulariae, 177

Uromycopsis, 173, 175, 177, 178

Ustilago Carbo, 504; Zeac, 504, 509

Utricularia, $39-41,43,50,52,54,56$, 59-62, 64, 538; alpina, 53; bryophila, 5+; cacrulea, $50-52$; capensis, 56 ; cornuta, 54; cucullata, 63 ; denticulata, 56; diclotoma, 53; fimbriata, 49
Glaziuana, 57; hydrocarpa, 6I ; inflata, 6I; macrorhiza, 59, 60; Mannii, 54; minima, 59; minor, 39, 60; minutissima, 52; multifida, 49; neottioides, 56; olivacea, 59; parviflora, 52; pumila, 60; purpurea, 62 ; racemosa, $5 \mathrm{I}$; resupinata, 58 ; reticulata, 52 ; saccata, 62 ; Spruceana, 58 ; striatula, 50 ; subulata, 58 ; tubulata, 63; vulgaris, 39 , 6I

Vaccinium, 84, 48I; atlanticum, 8I; atrococcum, 8I ; Myrtillus, I70

Vagnera racemosa, $8 \mathbf{I}$

Valeriana acutiloba, 204; edulis, 204; occidentalis, 204; officinalis, 204; sitchensis, 204

Valerianaceae, 204

Variation in Tithymalopsis, 455

Variations in the yellow daisy (Rudbeckia hirta), Inheritable, 89

V'arronia bahamensis, 577

Vegetation of Anegada, The, 565

Vegetative life zones of the Rocky Mountain region, 477

Velaea arguta, I92; Hartwegii, 192

Venus mercenaria, 86

Vermicularia, 553-556; atramentaria, 553, 554,558 ; atramentaria sclerotioides, 553

Vesiculina, 42, 44, 6I-64; cucullata, 6I, 63; purpurea, 62

Viburnum dentatum, 81

Vicia, 254, 283, 306

Vicinity of Beaufort, North Carolina, Notes on some marine algae from the, I05

Viola lobata, I 74, I 88 ; ocellata, I74, 188; pallens, $8 \mathrm{I}$; papilionacea, $8 \mathrm{I}$; praemorsa, I 88

Vitis, 335; aestivalis, $8 \mathbf{I}$

Volkameria aculeata, 577

IValchia, 78

Wedelia parviflora, 579

IVelwitschia, 27

White-cedar swanp at Merrick, Long Island, and its significance, A, 79

Woodwardia areolata, $8 \mathrm{I}$; virginica, $8 \mathrm{I}$

Xananthes, 60

Xenoxylon latiporosum, 30

Xylaria arbuscula, 509; filiformis, $\mathbf{5 0 8}$

YAMPOLSKY, CECIL. Observations on inheritance of sex-ratios in Mercurialis annua, 69

lellow daisy (Rudbeckia hirta), Inheritable variations in the, 89

Yucca, 493, 494; glauca, 49 I

Zamia, 268, 305

Zamites (Otozamites?), 77; Powellii, 77

Zasmidium cellare, 68

Zea, 305; Mlays, 273, 509

Zizia, 163

Zones of the Rocky Mountain region Vegetative life, +77

Zostera, 110

Zygogynum, 27 






OK3 New York Botanical Garden Library

QK3 .N4
New York Botanical/Papers presented at t

|| || || || || || || || || || || | || || || || || || || || || || || ||

35185000997146 
